UNIVERSIDADE DE SÃO PAULO

FFCLRP - DEPARTAMENTO DE PSICOLOGIA E EDUCAÇÃO

PROGRAMA DE PÓS-GRADUAÇÃO EM PSICOLOGIA

\title{
A reflexão como método de conhecimento psicológico em Agostinho e Husserl
}

\begin{abstract}
Tese apresentada à Faculdade de Filosofia, Ciências e Letras de Ribeirão Preto da USP, como parte das exigências para a obtenção do título de Doutor em Ciências. Área: Psicologia.

Apoio: CAPES
\end{abstract}

Sávio Passafaro Peres

Orientadora: Professora Doutora Marina Massimi

Co-orientadora: Professora Doutora Angela Ales Bello.

RIBEIRÃO PRETO - SP

2011 
Autorizo a reprodução e divulgação deste trabalho, por qualquer meio convencional ou eletrônico, para fins de estudo e pesquisa, desde que citada a fonte.

FICHA CATALOGRÁFICA

Peres, Sávio Passafaro

A reflexão como método de conhecimento psicológico em Agostinho e Husserl. Ribeirão Preto, 2011.

421 p. :il $29,7 \mathrm{~cm}$.

Tese apresentada à Faculdade de Filosofia, Ciências e Letras de Ribeirão Preto/ USP - Dep. de Psicologia e Educação.

Orientadora: Massimi, Marina

1. Santo Agostinho 2. Fenomenologia. 3. Husserl. 4. História da Psicologia 


\section{FOLHA DE APROVAÇÃO}

Nome: PERES, Savio Peres.

Título: A reflexão como método de conhecimento psicológico em Agostinho e Husserl

Tese apresentada à Faculdade de Filosofia, Ciências e Letras de Ribeirão Preto da USP, como parte das exigências para a obtenção do título de Doutor em Ciências. Área: Psicologia.

Aprovado em:

Banca Examinadora

Prof. Dr. Instituição_

Julgamento: Assinatura:

Prof. Dr. Instituição

Julgamento: Assinatura:

Prof. Dr. Instituição

Julgamento: Assinatura:

Prof. Dr. Instituição

Julgamento: Assinatura:

Prof. Dr. Instituição

Julgamento: Assinatura:

Prof. Dr. Instituição

Julgamento: Assinatura: 

Aos meus avós. 



\section{AGRADECIMENTOS}

Agradeço à Profa. Dra. Marina Massimi, pela presença constante, pela disponibilidade, pelos grandes horizontes culturais, pela sabedoria e honestidade intelectual.

Agradeço à minha mulher, Andrea, que, me amando e sendo por mim amada, fez e faz feliz a minha vida.

Agradeço à Ângela Ales Bello, minha co-orientadora, que me acolheu durante o estágio em Roma e guiou-me no reino da fenomenologia.

Agradeço aos professores Dr. Cerqueira e ao professor Dr. João Madeira pelas preciosas sugestões, que muito contribuíram a esse trabalho.

Agradeço à minha família, pelo imenso amor e carinho.

Agradeço à minha irmã Lúcia, que muito contribuiu na escrita do texto de Agostinho

Aos meus amigos, com quem pude conversar sobre as ideias dessa tese.

Agradeço às minhas primas, Maíra e Fernanda,

Agradeço ao Sandro, pelo forte apoio logístico.

Agradeço ao Paulo José, que muito me ajudou na elaboração do projeto.

Agradeço à Capes, essa respeitável instituição, que proporcionou as condições necessárias para que se tornasse possível esse trabalho. 

Importa primeiro perder o mundo pela epoché, a fim de o reaver na universal auto-reflexão. Noli foras ire, diz Agostinho, in te redi, in interiore homine habitat veritas. (HUSSERL, p.171, 1992) 



\section{RESUMO}

\section{PERES, S.P. A reflexão como método de conhecimento psicológico em Agostinho e}

Husserl. 2011. 420 p. Tese de Doutorado - Faculdade de Filosofia, Ciências e Letras de Ribeirão Preto, Universidade de São Paulo, Ribeirão Preto.

O objetivo desta tese consiste em avaliar, sob um prisma fenomenológico, as concepções presentes na obra de Santo Agostinho referentes ao uso da reflexão como instrumento do conhecimento de si. Para isso, analisamos as obras As confissões (397d.C.) A trindade (416 d.C.) e fragmentos de outras obras em que ele aborda o tema da reflexão. Consideramos dois diferentes níveis em que as ideias se encontram presentes nas obras: nas descrições de estados subjetivos narrados em primeira pessoa por Agostinho nas Confissões e nas exposições feitas por Agostinho em outras de suas obras. Investigamos alguns temas que se mostraram de grande importância para se compreender o papel da reflexão em Agostinho. Em primeiro lugar, o espírito humano entendido como uma realidade íntima, um ser reflexivo e imaterial. Em segundo lugar, analisamos o papel do método reflexivo em suas investigações acerca da memória, da percepção e das inter-relações entre o corpo e a mente. Em terceiro lugar procuramos observar como Agostinho compreende a vida do espírito em suas inter-relações com o mundo e com Deus. Na segunda parte da tese, os temas foram retomados e abordados sob um prisma fenomenológico. Para isso procuramos expor e avaliar, no que tange aos temas abordados por Agostinho, o percurso metodológico traçado por Husserl em Ideias 1 (1913) e Ideias 2 (1952). Na terceira parte da tese, fizemos uma análise comparativa entre as concepções e os métodos adotados pelos dois autores. Observamos que, embora haja diferenças no modo de aplicar a reflexão, muitas das conclusões tiradas por Husserl já haviam sido antecipadas por Agostinho, embora, neste, com um menor nível de rigor. Merecem destaque os seguintes pontos abordados primeiramente por Agostinho e posteriormente desenvolvidos por Husserl: 1) a mente é uma realidade íntima e indubitável; 2) a essência da mente é sua reflexividade, sua capacidade de apreender-se a si mesma; 3) a atenção ou intentio voluntatis é um fator constituinte do ato de percepção e de qualquer ato do cogito; 4) o tempo é abordado por Agostinho não como realidade independente do espírito, mas sim como uma realidade vinculada ao espírito, de modo que o passado, o presente e o futuro são articulados com a memória, a atenção e a expectativa. Em suma, o objetivo das análises e comparações é contribuir para uma visão mais rica e complexa da história do método reflexivo e, ao mesmo tempo, defender sua legitimidade e seu valor cognitivo. A reflexão é instrumento intelectual capaz de fornecer não só conhecimentos seguros sobre a estrutura apodíctica da consciência e dos diferentes estratos da pessoa humana, como também é válida para que cada indivíduo possa conhecer a si mesmo em sua singularidade. E essa individualização é marcada por fatores psíquicos, corpóreos e pelo mundo espiritual do sujeito, isto é, pelo mundo da vida.

Palavras-chaves: Agostinho de Hipona, Husserl, História da Psicologia, reflexão. 



\begin{abstract}
PERES, S.P. Reflection as a method of psychological knowledge in Augustine and

Husserl. 2011. 420p. Dissertação de Mestrado - Faculdade de Filosofia, Ciências e Letras de Ribeirão Preto, Universidade de São Paulo, Ribeirão Preto.

The objective of this thesis is to evaluate, under a phenomenological perspective, the concepts present in the work of St. Augustine regarding the use of reflection as a tool of selfknowledge. We study the works Confessions (397AD) The Trinity (416AD) and fragments of other works in which he addresses the topic of reflection. We consider two different levels at which ideas are in his works: the descriptions of subjective states narrated in first person by Augustine in the Confessions and the presentations made by Augustine in his other works. Some themes have proved of great importance for understanding the role of reflection in the Augustine's works. Firstly, we analyze how Augustine develops the concept of mind understood as an inner reality, self-consciousness, characterized as immaterial substance. Secondly, we examined the role of the reflective method in his researches on memory, on perception and on the strata of the human person. Thirdly we analyzed how Augustine understands the life of the spirit in their interrelations with the world and with God. In the second part of the thesis, the issues addressed in the first part were reexamined under a phenomenological perspective, according to the methodological approach outlined by Husserl in Ideas 1 (1913) and Ideas 2 (1952). In the third part of the thesis, we made a comparative analysis of concepts and methods adopted by the two authors. We observe that although there are differences in the way of applying the reflection, many of the conclusions drawn by Husserl had already been anticipated by Augustine, albeit with a lower level of rigor. In particular the following points addressed first by Augustine and later developed by Husserl: 1) the mind is an intimate and undeniable reality. 2) The essence of mind is its reflexivity, its ability to know herself directly. 3) attention or intentio voluntatis is a constituent factor of the act of perception 4) the time is approached by Augustine not as a reality independent of mind, but as a reality linked to the spirit, so that the past, present and future are articulated with memory, attention and expectation. In short, the purpose of analysis and comparisons is to contribute to a richer and complex history of the reflective method and at the same time maintaining its legitimacy and its cognitive value. Reflection is an intellectual instrument able to provide apodictic knowledge of the structure of consciousness, about the different strata of the human person, and helps individuals to know himself in his uniqueness. And that individualization is marked by psychological factors, by corporal's factors and by his world of life.
\end{abstract}

Key words: Husserl, Augustine, History of Psychology, Reflection 



\section{Sumário}

APRESENTAÇÃO

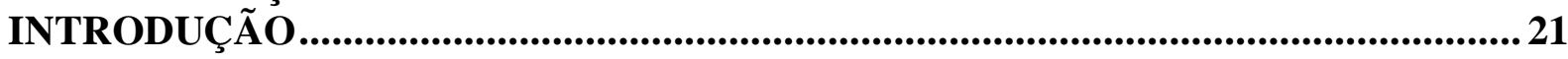

0.1 As Confissões e a importância do pensamento de Agostinho na história da

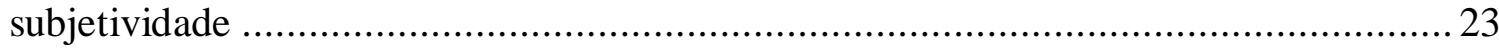

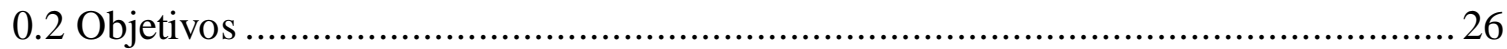

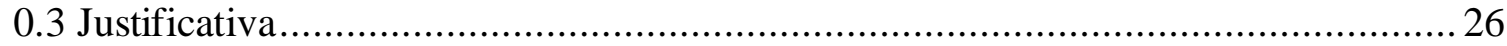

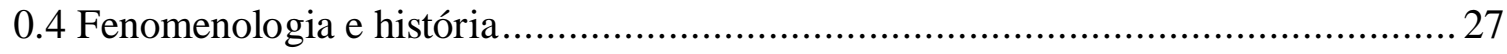

PARTE I: Os atos reflexivos como método de conhecimento em Agostinho.......................31

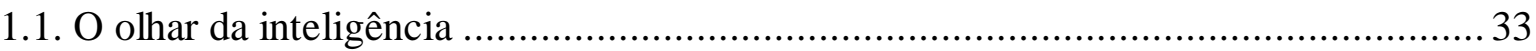

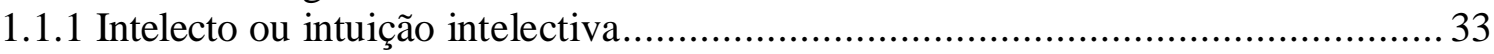

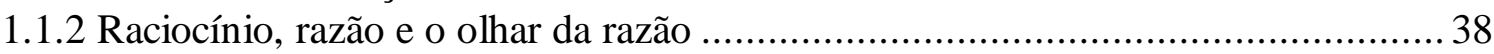

1.2 Os conteúdos da memória e o reino do pensável........................................................ 41

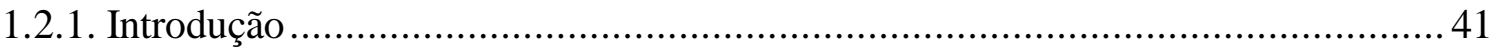

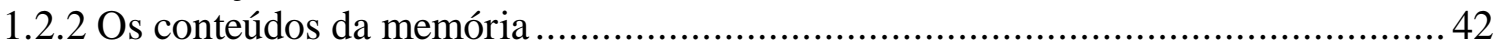

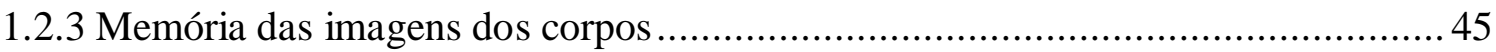

1.2.4 Memória das experiências passadas................................................................... 47

1.2.5 Memória do conhecimento das artes liberais......................................................52

1.2.6 Memória dos números e das formas geométricas .................................................53

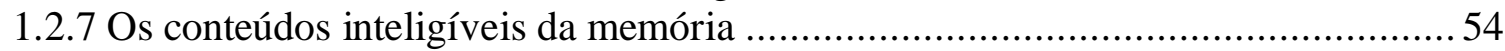

1.2.8 As duas memórias. Memória disponível e memória profunda.................................58

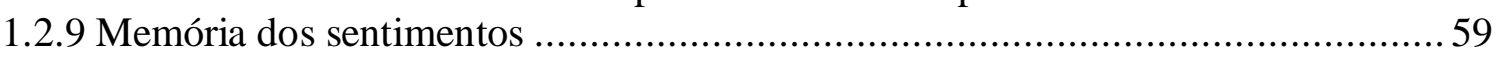

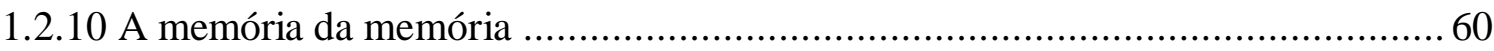

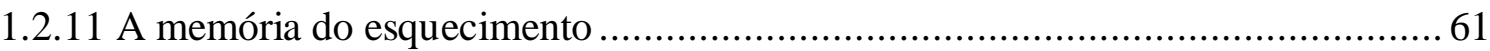

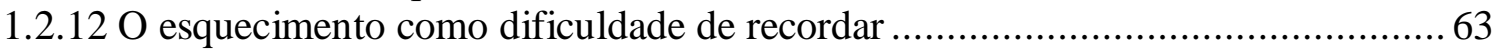

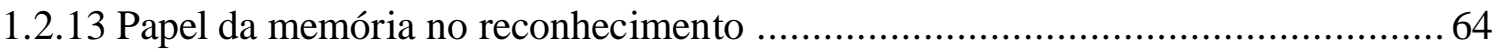

1.2.14 A participação da memória na escuta e na leitura ................................................65

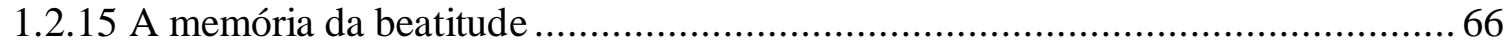

1.3 Uma águia imperial católica apostólica romana bicando o próprio peito ....................... 69

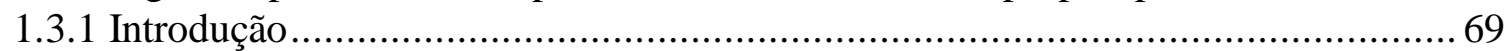

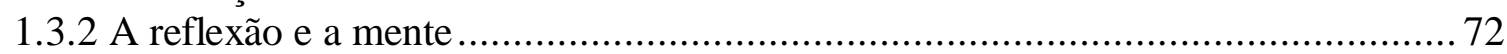

1.3.3 A torção interior da atenção e suas condições ....................................................... 76

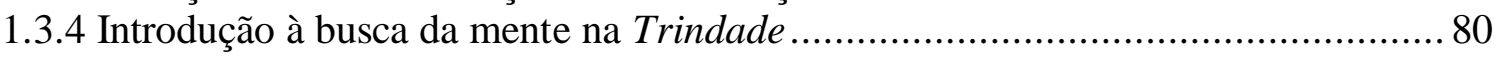

1.3.5 Primeira condição de toda investigação racional: conhecer algo do objeto

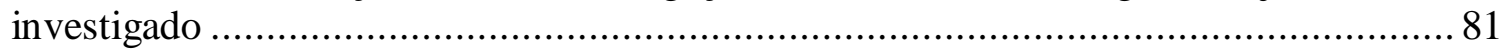

1.3.6 Segunda condição: querer conhecê-lo em função de um "preconceito" relativo ao

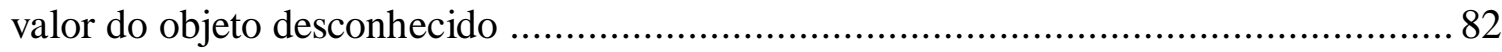

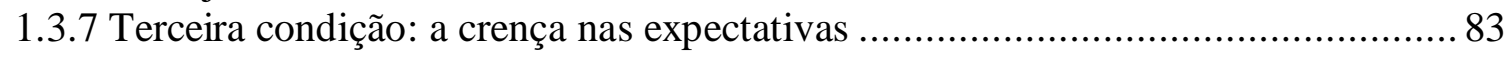

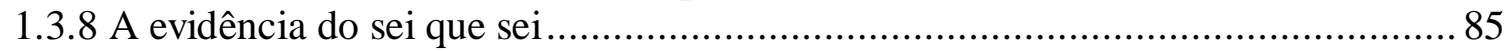

1.3.9 A mente, sujeito do conhecimento, morada do conhecimento ................................ 87

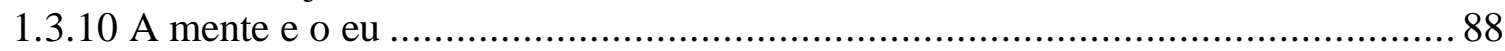

1.3.11 Memória, inteligência e vontade contêm-se mutuamente, formando uma só vida,

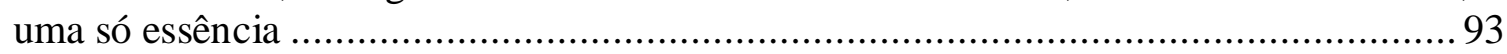

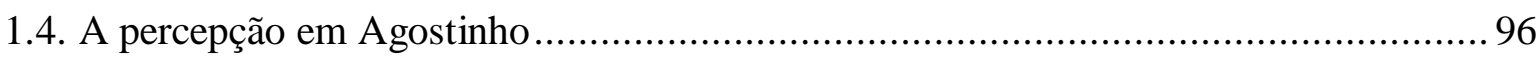

1.4.1 Os sentidos e a vontade: A trindade contida na visão exterior e a intentio ............. 96

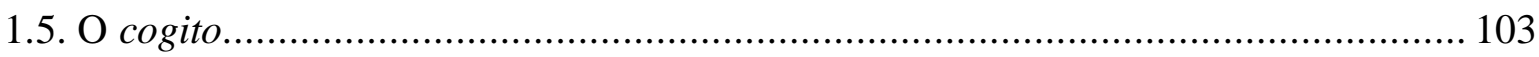

1.5.1 O pensamento das realidades sensíveis: a forma impressa no olhar da mente ..... 103 
1.5.2 O movimento do cogito e o fluxo de consciência ......................................... 104

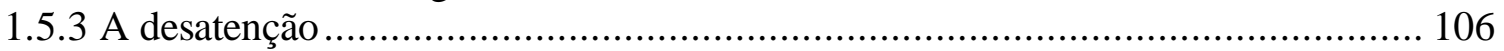

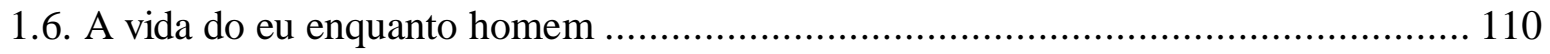

1.6.1 O homem interior e o homem exterior ..................................................... 110

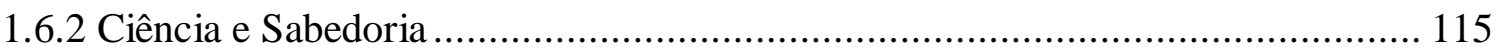

1.6.3 Inteligência das realidades eternas e das realidades sensíveis ........................ 117

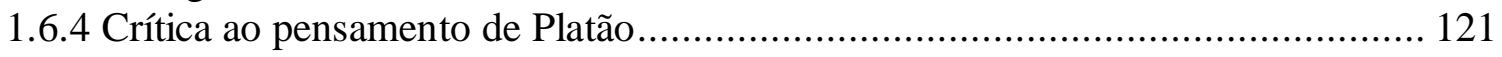

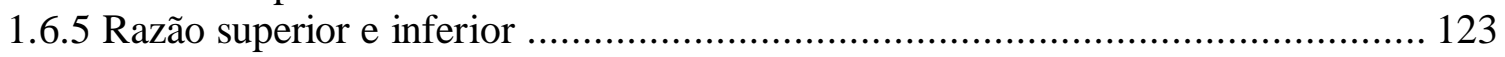

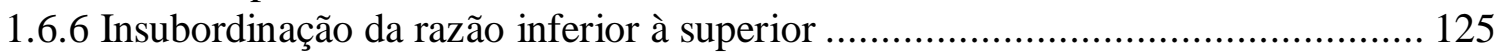

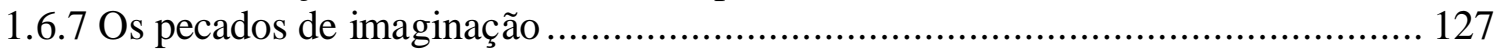

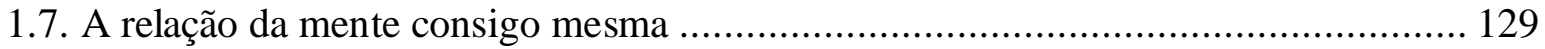

1.7.1 Refutação dos filósofos da Nova Academia ................................................... 129

1.7.2 O conhecimento reflexivo: Scio me scire me vivere ........................................ 131

1.7.3 Distinção entre pensar-se e conhecer-se.................................................... 135

1.7.4 Uma visão em espelho e enigma. ........................................................... 140

1.7.5 Inter-relações entre a mens e os estratos do homem ...................................... 141

1.7.6 A mente lembra-se de si mesma e compreende a si mesma e ama a si mesma .... 143

1.7.7 Distinção entre voluntas e intentio .................................................................... 144

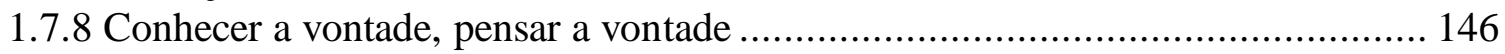

1.7.9 O entrelaçamento das vontades .............................................................. 148

1.7.10 Distinção intelectual entre o puro sujeito e a vida interior do sujeito ................. 156

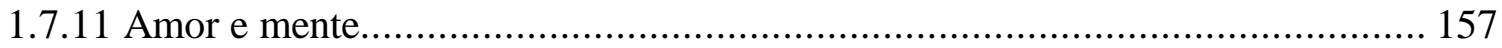

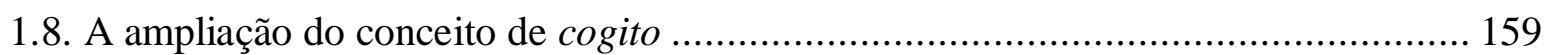

1.8.1 Definição ampla do cogito: o olhar da mente informado pela ação da vontade ... 159

1.8.2 O pensamento e linguagem: locutiones cordis esse cogitationes ....................... 162

1.8.3 O verbo verdadeiro provém da realidade .................................................. 167

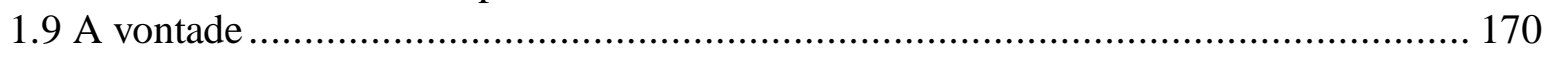

1.9.1 A experiência de Paulo ......................................................................... 170

1.9.2 A experiência paulina de Agostinho: Sic intellegebam me ipso experimento id quod

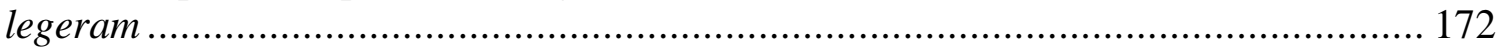

1.9.3 A interpretação Agostiniana da passagem de Paulo........................................ 175

1.9.4 O homem interior, o homem exterior e a vontade ....................................... 180

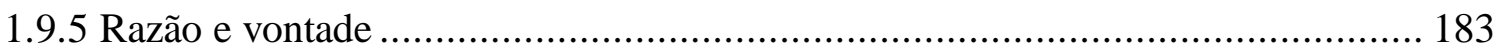

1.9.6 O risco da experiência Maniqueia e o conflito entre as vontades ....................... 184

1.10. O tempo e o espírito ....................................................................................... 188

1.10.1 O pensamento, o olhar do pensamento e o senso de presença .......................... 188

1.10.2 A intentio e o homem como imagem de Deus ................................................. 189

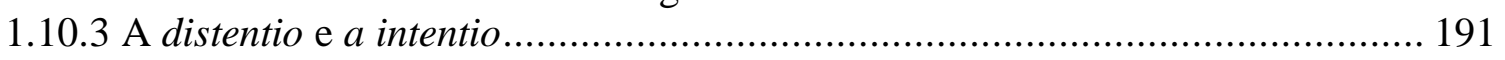

1.11 O homem: imagem de Deus em enigma e espelho ........................................... 198

PARTE II - Os atos reflexivos como método de conhecimento em Husserl ................. 211

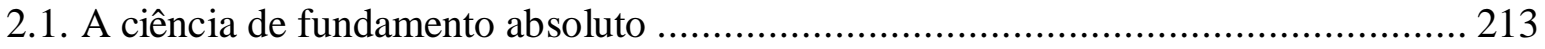

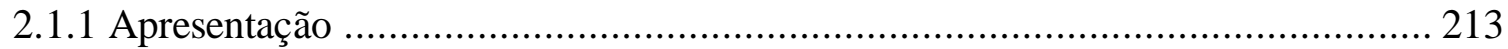

2.1.2 O projeto de Husserl e a psicologia eidética...................................................... 218

2.1.3. Ciência como fenômeno cultural e a noção de verdade.................................... 221

2.1.4 A verdade não é uma crença subjetiva ..................................................... 222

2.1.5 O ato de julgar e o juízo...................................................................... 223

2.1.6 Os dados iniciais e a evidência................................................................... 224

2.1.7 O grau de perfeição da evidência ............................................................... 226

2.1.8 As evidências adequadas ao ataque da crítica cética..................................... 227

2.1.9 Necessidade de se iniciar a ciência absoluta na evidência apodíctica ................. 229 
2.1.10 Solipsismo versus realismo ingênuo .................................................... 230

2.1.11 Solução ao solipsismo. A intencionalidade da consciência. $O$ cogitatum .......... 234

2.1.12 Distinção entre "eu puro" e "eu psicológico" ................................................. 237

2.1.13 Distinção entre objeto real e objeto intencional ........................................ 238

2.1.14 $\mathrm{O}$ ser absoluto da consciência e a contingência do ser real........................... 239

2.1.15 O problema do mundo ....................................................................... 240

2.1.16 Estados psíquicos reais e vivências transcendentalmente reduzidas................. 243

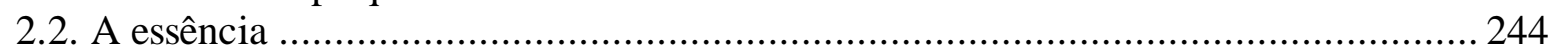

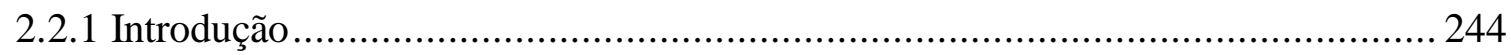

2.2.2 Inseparabilidade entre intuição do individual e intuição de essência .................. 245

2.2.3 Distinção entre essência intrínseca ao fenômeno e existência de um real-

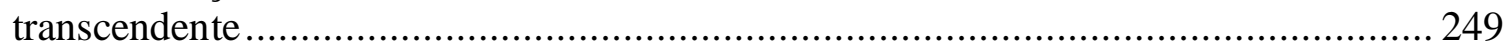

2.2.4. Essência e imaginação. O campo das experiências possíveis ........................... 252

2.3.A reflexão fenomenológica transcendental ................................................... 258

2.3.1 Reflexão natural e reflexão transcendental................................................. 258

2.3.2 O eu puro como condição de possibilidade da reflexão ................................ 261

2.3.3 Objeções à reflexão ............................................................................... 263

2.3.4 Classificação das intuições entre presentificação e apresentação ....................... 267

2.3.5 Atos de consciência atuais e inatuais ........................................................ 269

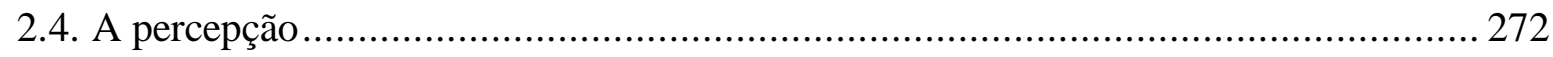

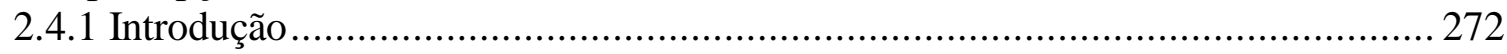

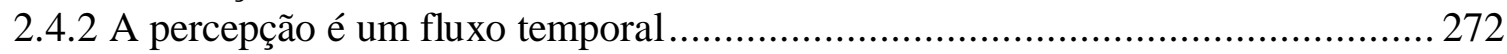

2.4.3 Perfil é vivido de consciência. O que se perfila (perfilado) não........................ 274

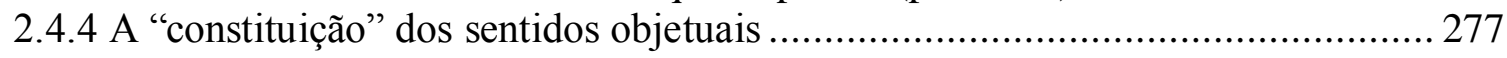

2.4.5 Perceber não é ter sensações ................................................................. 278

2.4.6 Os momentos do ato intencional ............................................................ 280

2.4.7 Generalização dos três momentos na percepção para diferentes vivências .......... 282

2.4.8 A função noética .............................................................................. 283

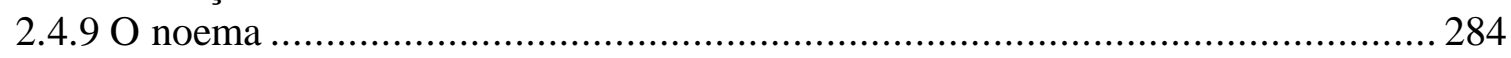

2.4.10 Elementos autênticos e inautênticos da percepção ....................................... 287

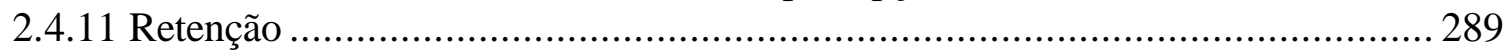

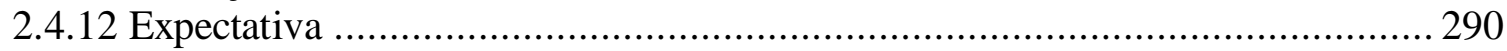

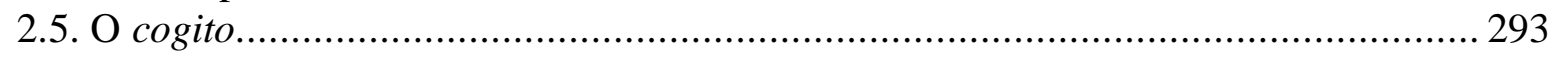

2.5.1 A síntese universal do tempo transcendental .............................................. 293

2.5.2 A verdade como juízo preenchido intuitivamente: a correlação entre a unidade de

sentido no juízo e a unidade de sentido na percepção............................................. 296

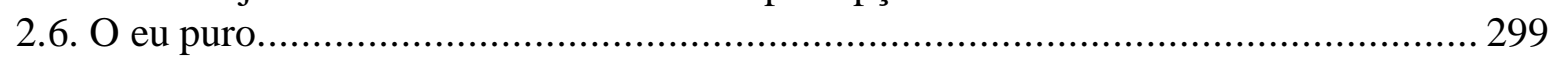

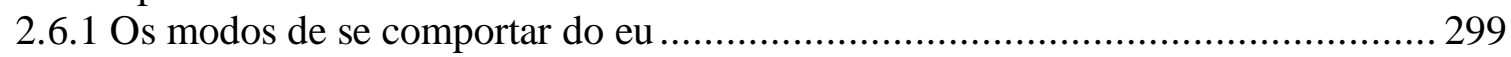

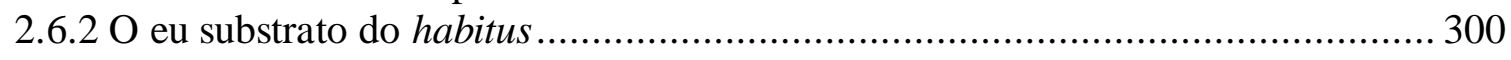

2.7. As experiências concordantes e o sentido do real............................................ 306

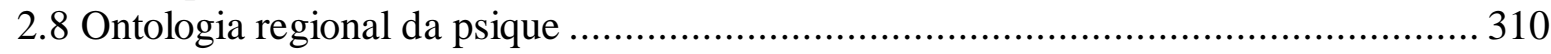

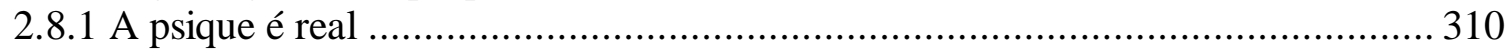

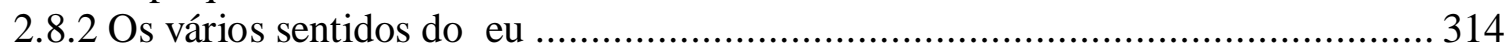

2.8.3 A intuição empática da psique como princípio animador dos corpos .................. 316

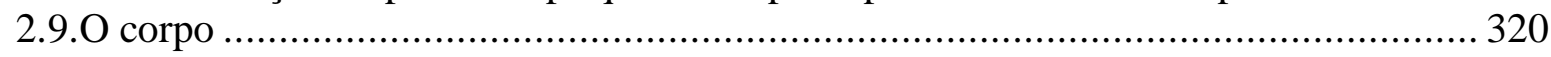

2.9.1 O corpo próprio e seu modo de doação à consciência ....................................... 320

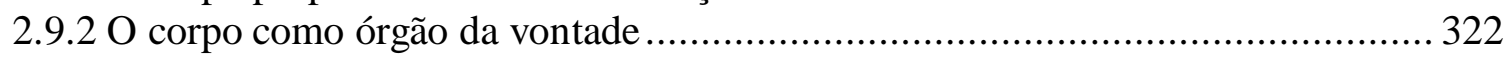

2.9.3 O corpo como órgão de sensações localizadas .............................................. 323

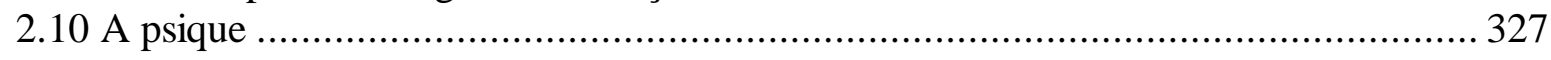

2.10.1 Apresentação das investigações sobre a psique .......................................... 327 
2.10.2 A psique enquanto realidade substancial-real distinta da natureza material ...... 328

2.10.3 Necessidade da reflexão para apreensão das propriedades psíquicas ................ 331

2.10.4 Relação entre propriedades psíquicas e os estados psíquicos ......................... 332

2.10.5 Dependência da psique do real material ................................................... 334

2.10.6 Diferenças entre a substância real psíquica e a substância real material............ 336

2.10.7 Os três níveis de dependência do sujeito psíquico ........................................ 338

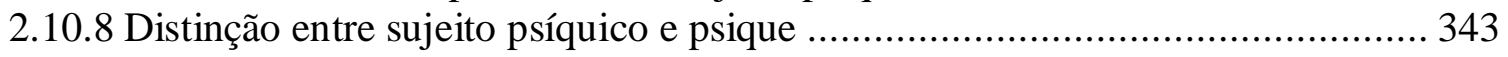

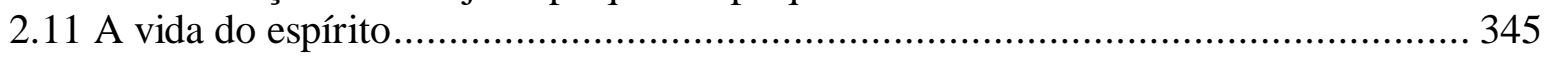

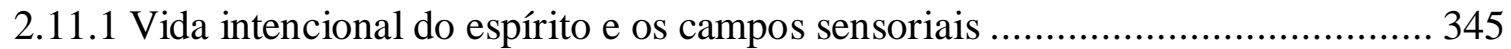

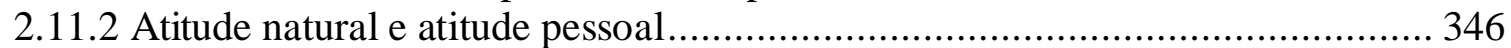

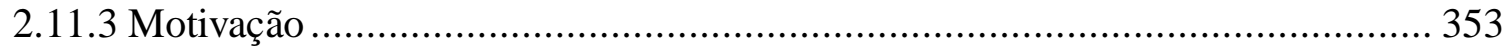

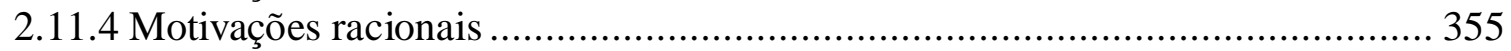

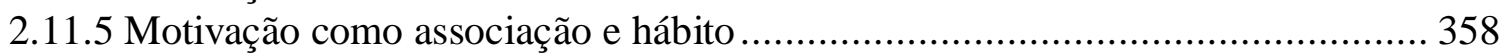

2.11.6 Sensações de sentimento e sentimentos intencionais ................................... 361

2.11.7O valor e a motivação no sujeito moral..................................................... 363

2.11.8 Vivências intencionais autônomas e vivências intencionais executadas pelo eu

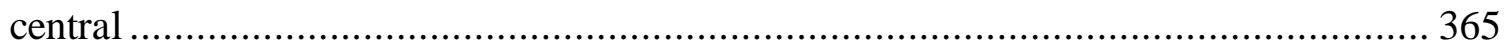

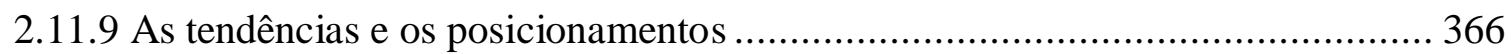

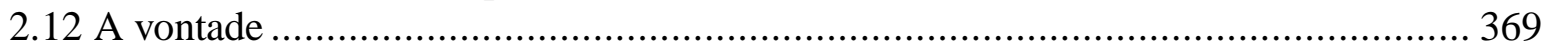

2.12.1 Distinção entre diferentes concepções e momentos da vontade ........................ 369

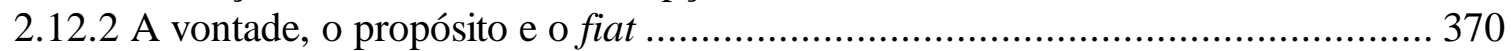

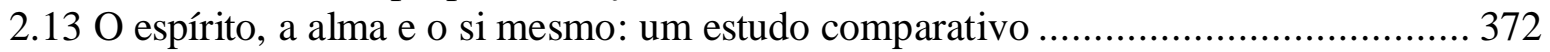

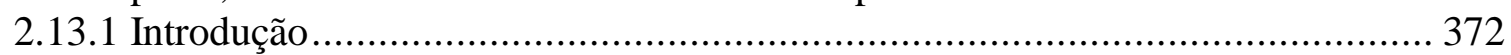

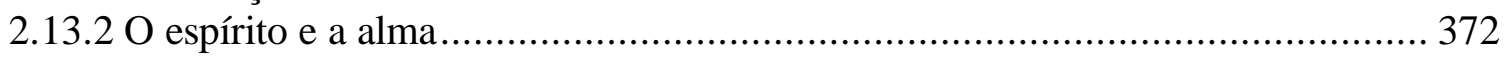

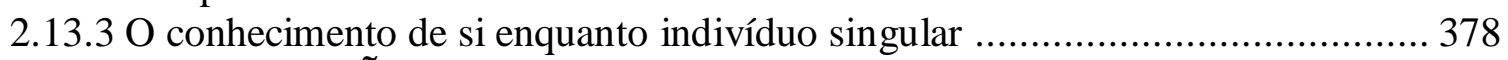

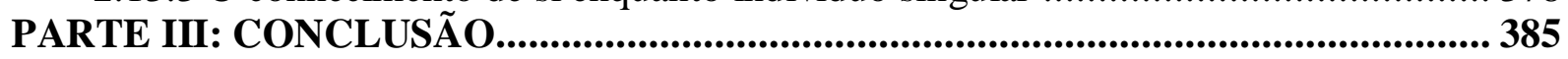

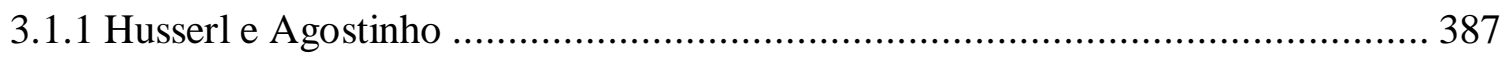

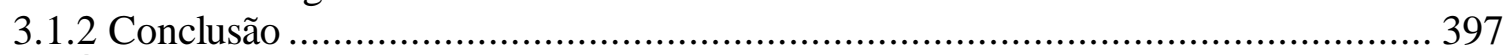

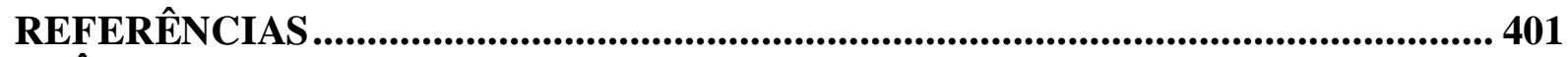

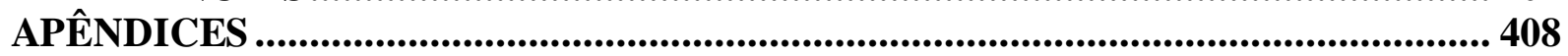

Apêndice A - Dificuldades terminológicos na tradução de Agostinho......................... 408

Apêndice B - Aristóteles e a questão do Nous ...................................................... 411

Apêndice C - Distinção entre psicologia descritiva e fenomenologia ........................ 412

Apêndice D - A atenção e intencionalidade .................................................... 415

Apêndice E - Fenomenologia e as filosofias da suspeita........................................ 416

Apêndice F - Atos motivantes e o "campo de possibilidade" dos atos motivados: O

estímulo como motivo a-racional, porém não irracional.......................................... 417

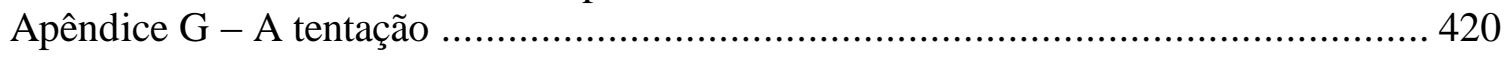




\begin{abstract}
APRESENTAÇÃO
Este trabalho foi construído em três partes. Na primeira parte, focamos o pensamento de Agostinho, fundamentados na fenomenologia, a fim de analisar como ele emprega o método reflexivo e quais os resultados obtidos em suas investigações acerca da vida psíquica humana. Para isso, pesquisamos o modo como Agostinho buscou explorar, coordenar, discernir e conceituar a sua vida interior. Usamos como corpus de análise as obras Confissões e $A$ trindade.

Na segunda parte do trabalho, procuramos observar e analisar como Husserl enfocou os temas abordados por Agostinho, como a consciência, a vida da psique, as articulações entre a psique e o corpo, a memória, a atenção e a vontade. A exposição e a análise do pensamento de Husserl foram fundamentadas especialmente nos volumes 1 e 2 da obra do pensador alemão: Ideias para uma fenomenologia pura e uma filosofia fenomenológica. No primeiro volume, publicado em 1913, que é mais conhecido, Husserl apresenta o método fenomenológico e emprega a reflexão fenomenológica transcendental para o conhecimento da essência da consciência e dos atos de consciência. Já no volume 2, também conhecido como Ideias 2, obra póstuma publicada em 1952 e menos conhecida do público geral, Husserl aplica o método fenomenológico, a fim de explorar a essência do sujeito psíquico e, de modo geral, da pessoa humana.

Em um terceiro momento, procuramos elucidar e analisar brevemente as semelhanças e as diferenças no modo como Husserl empregou a reflexão, em comparação a Agostinho. Os resultados de nossas análises revelam que Agostinho havia antecipado muito do pensamento de Husserl, embora sem o rigor conceitual e metodológico deste último. Isso evidencia, ao lado de outros aspectos que iremos salientar, a importância do pensamento de Agostinho na história da psicologia.

Dentro do âmbito da história da psicologia, o nosso intuito foi o de resgatar e sublinhar a importância dos atos reflexivos como capazes de trazer conhecimentos seguros e rigorosos a respeito do sujeito psíquico. Esses conhecimentos obtidos por autopercepção não podem ser colhidos por outros métodos derivados de experimentação, dentro dos moldes positivistas.
\end{abstract}


INTRODUÇÃO 


\subsection{As Confissões e a importância do pensamento de Agostinho na história da subjetividade}

As Confissões podem ser consideradas a primeira autobiografia "espiritual" do Ocidente, dado que a narrativa tem como foco não apenas a dimensão exterior da vida de Agostinho, mas foca sobretudo a dimensão interior. Nela, encontramos não apenas descrições de ações e atitudes, mas também de como ele experimentou interiormente diversas situações de sua vida. Como aponta Peter Brown, ao se referir às Confissões:

Em termos muito sucintos, são a história do "coração" de Agostinho, ou de seus "sentimentos", de seus affectus. Nelas, um acontecimento intelectual, como a leitura de um novo livro, é registrado como que por dentro, em termos de pura excitação da experiência, de seu impacto no sentimento do autor: sobre o Hortênsio de Cícero, por exemplo, jamais diria que "ele mudou minha opinião", e sim, caracteristicamente, "ele mudou meu modo de sentir" - mutatis affectum meum. (BROWN, 2000, p.206)

Como decorrência deste foco nos aspectos interiores, encontram-se nas obras de Agostinho, implícita ou explicitamente, várias elaborações sobre a memória, a vontade, as paixões, o orgulho, a temporalidade e até mesmo descrições de êxtases místicos. Mas um dos principais pontos de interesse é que, nas Confissões, tais análises são fundamentadas em suas experiências pessoais. É como se o bispo de Hipona, ao olhar para trás, se questionasse: "Por que reagi a tal situação de tal modo?", "Por que fui seduzido pelo mal?", “Quais os motivos que me levaram ao pecado?".

Daí que, nas Confissões, Agostinho procura revelar, em sua história de vida, as diversas experiências interiores e as motivações que alteraram a direção de sua vontade e de seu intelecto. Essa avaliação do passado exige a efetuação de atos reflexivos que visam ao autoconhecimento, tanto em sua generalidade de "ser humano", quanto em sua singularidade de eu-Agostinho. Vemos claramente nas Confissões como o percurso intelectual de um homem está diretamente associado com as experiências afetivas e, portanto, com a história de vida. Segundo Misch:

O que ele alcançou desta forma, analisando os vários estados de sua mente, tendo a unidade da mente em vista, é geralmente reconhecido como um marco na História da Psicologia. Isto se aplica sobretudo às Confissões, embora em seus outros trabalhos se encontrem também observações e reflexões psicológicas. (1950, vol.2, p.636, tradução nossa)

A tendência de voltar-se para o interior, presente em Agostinho, está ligada a questões religiosas. De fato, Agostinho procura mostrar como Deus sempre esteve presente em sua vida e influenciava-o sem mesmo que ele fosse incapaz de perceber. A relação entre o homem e Deus não se dá como se houvesse um Deus "fora", que observa o homem a partir de seu 
exterior. O homem não pode esconder seus pensamentos de Deus; a consciência tem uma testemunha infalível, Deus. Para Misch (1950), estas constantes evocações a Deus nas Confissões revelam um novo modo de o homem estabelecer sua relação com Deus: não é mais entendido de modo objetivo, mas subjetivo. Esta nova forma de relação entre o homem e Deus, no qual se observa um "eu" em relação direta a um "Vós", foi introduzida pelo cristianismo. Encontra-se implicada nesta relação a ideia de "alma profunda", internum aeternum, conceito que o misticismo medieval desenvolveu em direção à ideia de individualidade (cf. Misch, p.643).

Segundo Giovanni Reale, Agostinho não propõe nas Confissões, tal como se tinha feito até então, o problema do homem em abstrato, ou seja, o problema da essência do homem em geral. "O que ele propõe é o problema mais concreto do eu, do homem como indivíduo irrepetível, como pessoa, como indivíduo, poder-se-ia dizer com uma terminologia posterior. Neste sentido, o problema do seu eu e o de sua pessoa tornam-se significativos" (2003, p. 437).

A reflexão de Agostinho a respeito de sua vida interior antecipa muitas das conclusões da fenomenologia. Para Agostinho, o homem conhece o mundo por meio do espírito, portanto, de forma mediata, ao passo que o conhecimento do espírito se dá de forma imediata, pois nada é mais presente ao espírito do que ele mesmo. Não é possível duvidar de sua existência sem se contradizer:

Quem, porém, pode duvidar que a alma vive, recorda, entende, quer, pensa, sabe e julga? Pois, mesmo se duvida, vive; se duvida, lembra-se do motivo de sua dúvida; se duvida, entende que duvida; se duvida, quer estar certo; se duvida, pensa; se duvida, sabe que não sabe; se duvida, julga que não deve consentir temerariamente. Ainda que duvide de outras coisas, não deve duvidar de sua dúvida. Visto que, se não existisse, seria impossível duvidar de alguma outra coisa. $(2009, \text { De Trinitate, } X, 10,14 ; 2005, \text { p.328 })^{1}$

O espírito, por ser substância incorporal, isto é, uma substância cujas partes não são menores do que o todo, pode subsistir enquanto relação consigo próprio. Ademais, o espírito, dotado do olhar da inteligência, tem acesso, devido a sua participação na sabedoria eterna, aos inteligíveis e às regras eternas, imutáveis e indestrutíveis, dadas por evidência (ou intuição ou iluminação). Neste modo de conceber as coisas, podemos notar alguns ecos do pensamento metafísico grego em geral e, mais particularmente, o Neoplatonismo de Plotino. Aliás, é digno de nota que a leitura das obras dos neoplatônicos, como Agostinho aponta no livro VII das

\footnotetext{
${ }^{1}$ Em vista de maior praticidade e universalidade, adotamos o sistema de referência da Patrologia Latina, de Migne, indicando o livro, capítulo e artigo. Trata-se do sistema de referência mais usados pelos especialistas de Santo Agostinho e constam em quase todas as edições. Nas edições latinas, colocaremos apenas as referências da Patrologia de Migne.
} 
Confissões, foi necessária para que ele conseguisse intuir a substância não corporal, referente à mente (mens) e a Deus.

Contudo, segundo Angela Ales Bello, Agostinho não se limita a expor o pensamento grego. A força de seu pensamento, e seu sentido de uma interioridade individual, está justamente no encontro da tradição grega com a hebraico-cristã. É desse encontro que nasce o sentido da subjetividade, tão forte na cultura Ocidental.

No caso da cultura ocidental, há duas matrizes fundamentais: a filosofia grega - que desenvolveu a atividade de reflexão, de tomada de posição consciente acerca da realidade e de onde brotaram todas as filosofias posteriores e a ciência - e a matriz da tradição hebraico-cristã, especialmente o cristianismo onde o chamado divino apela para a singularidade, a responsabilidade individual, com relação ao destino de salvação individual. Esse é um elemento importante que, unido à tradição grega, desenvolveu nos povos do Ocidente a capacidade para a introspecção e o sentido da subjetividade (BELLO, 2004, p.58).

A evidência do espírito, do "eu” como realidade indubitável, é, para Agostinho, a pedra angular sobre a qual irá sustentar diversas concepções posteriores. Esse acento na interioridade também se evidencia na própria estrutura de uma de suas primeiras obras escritas após a sua conversão ao Catolicismo, Solilóquios, texto feito na forma de um diálogo travado entre a alma e a razão. Ademais, como veremos, Agostinho emprega a reflexão em suas análises a respeito da memória (livro X das Confissões) e do tempo (Livro XI das Confissões). O tempo será concebido não como uma realidade objetiva, mas como uma distensão do espírito (distentio animi). Sobre a atualidade e a profundidade das meditações de Agostinho acerca do tempo, Husserl afirma:

Os capítulos 14-28 do Livro XI das Confissões devem ainda hoje ser profundamente estudados por quem se ocupe com o problema do tempo. Porquanto, nestas coisas, a época moderna, orgulhosa de seu saber, nada mais grandioso e mais considerável trouxe do que este grande, e na verdade, incansável pensador. Ainda hoje se pode dizer com Santo Agostinho: si nemo a me quaerat, scio, si quarenti explicare velim, nescio ${ }^{2}$. (HUSSERL, 1994, p.37)

Além de abordar temas antigos por novos ângulos, Agostinho também coloca novos problemas e temas, dentre os quais se destaca a evidência da positividade do mundo enquanto um parecer algo. Concordará com os céticos que os sentidos enganam, razão pela qual não servem como critério último da verdade - mas ao contrário dos céticos, afirma que mesmo que esse "algo" seja mera aparência, ainda assim é um "algo" para o espírito. Pode-se duvidar que aquilo que se percebe é real, mas não se pode duvidar de que ao menos se percebe algo

\footnotetext{
${ }^{2}$ Tal passagem, contida no livro XI, cap. 14, das Confissões, pode ser traduzida como: "Se ninguém me pergunta, sei; porém se quero explicá-lo a quem me pergunta, então não sei” $(2004$, p.342)
} 
que parece real. E esse algo, afirma ele em Contra Acadêmicos, é o que ele denomina de mundo.

Assim, o método agostiniano explora sob um novo viés a relação homem-mundo, pois o mundo e a existência serão analisados a partir da consciência como interioridade, a qual terá um status privilegiado, tanto na ordem do conhecimento quanto na ordem do ser. A partir dessa nova perspectiva, Agostinho retoma velhos problemas (a vontade, as paixões, o orgulho, a relação entre o corpo e a alma, o mal), apresentando-lhes novas respostas e colocando novos problemas, sobretudo do espírito como reflexividade e como uma substância incorporal e individual e da vontade associada à noção de atenção (intentio animi).

\subsection{Objetivos}

Nosso objetivo consiste em elucidar e analisar o modo como a reflexão se faz presente nas obras de Agostinho, sobretudo nas Confissões e na Trindade, e como Husserl aborda o tema em Ideias 1 e Ideias 2.

De modo específico, os objetivos são os seguintes:

1) Mapear os conceitos e os termos empregados por Agostinho para a descrição de sua dinâmica interior e, de modo mais geral, de sua dinâmica vital. E elucidar o modo como estes conceitos se articulam.

2) Identificar quais os domínios da interioridade focados e privilegiados por Agostinho, bem como investigar os pressupostos e as motivações subjacentes à análise reflexiva de si.

3) Elucidar como Agostinho usou a reflexão e os resultados por ele alcançados.

4) Apresentar o pensamento de Husserl sobre os temas abordados por Agostinho, para compará-los e avaliá-los. Este objetivo demandou um aprofundamento do percurso realizado por Husserl, no que diz respeito ao método reflexivo como método de conhecimento.

\subsection{Justificativa}

A base destas investigações é o fato de a capacidade reflexiva fazer parte da essência do ser humano. Mas o como, o porquê e os fins dos atos reflexivos dependem de uma série de fatores: motivações, valores, crenças, opiniões. Como veremos, a prática da confissão implica um certo modo de refletir sobre a vida interior. Esta prática está ligada a um conjunto de valores e crenças. Do mesmo modo, a reflexão fenomenológica transcendental exige atos reflexivos, embora, neste caso, as motivações e o modo de se efetuar os atos reflexivos são 
distintos. Essas diferenças entre os modos de se refletir sobre si serão abordados ao longo do trabalho.

Dentre as principais justificativas para a realização deste projeto destacam-se as seguintes:

1) A descrição agostiniana do eu apresenta uma riqueza e uma sutileza de distinções conceituais que podem ser de especial interesse para os ramos da psicologia que abordam os fenômenos psíquicos sobre um prisma qualitativo.

2) A análise dos atos reflexivos em Agostinho pode contribuir para uma melhor compreensão tanto da história da formação da subjetividade quanto do que está implicado nas motivações que levam o homem a refletir, fornecendo uma base e um parâmetro útil ao debate acerca da subjetividade contemporânea.

3) Poucos trabalhos em história da psicologia abordam o uso do método reflexivo antes do século XIX. Entretanto, procuraremos evidenciar como este método pode servir para a aquisição de saberes psicológicos, e, de modo mais amplo, da pessoa humana.

\subsection{Fenomenologia e história}

A fenomenologia não prega que os homens são idênticos ao longo do tempo. Apenas assume que existem determinadas essências apriorísticas, determinadas condições de possibilidade sem as quais um homem não seria homem, sem as quais a consciência não seria consciência, sem as quais uma percepção não seria percepção etc. Contudo, a essência está vinculada com o ser singular. Para Husserl, não há ser individual sem essência, não há essência sem o ser individual.

Em linha de princípio, a essência dos atos reflexivos, da consciência, da pessoa humana é invariável. A essência da consciência é a mesma, não importa a cultura, não importa o tempo histórico. Por exemplo, faz parte da essência de um pensamento não ter extensão. Essa lei é universalmente válida e independente da história e da cultura. Entretanto, toda riqueza cultural e histórica está no modo de se comportar do homem, nos conteúdos da consciência, nas crenças, nos valores, no modo como os diferentes homens pensaram o mundo e a natureza etc. Por partirmos da fenomenologia clássica de Husserl, procuraremos combater, juntamente com o autor, a hipótese do relativismo cultural e histórico, segundo o qual tudo é cultural, tudo é linguagem. Por outro lado, procuraremos combater igualmente a ideia de que os seres humanos são, em todos os seus aspectos, invariáveis ao longo da história. Trata-se simplesmente de uma questão de não se exagerar para nenhum dos lados. 
Por isso, é preciso sublinhar que o pensamento de Agostinho é influenciado pelas suas crenças, opiniões, valores, pela sua história de vida e seu contexto espiritual. Tudo isso condiciona a visão que ele tem dele mesmo e do que é o ser humano. Mas há, como procuraremos defender, uma essência apriorística da consciência e da pessoa humana. Basta notar que, se não existisse absolutamente nada em comum entre homens, seria impossível compreender não só os homens do passado e de outras culturas, como também seria impossível qualquer forma de compreensão do "outro", pois o outro seria absolutamente diferente $^{3}$. Se há algo em comum entre os diferentes homens, há uma essência em comum. Podemos dizer que determinados predicados são comuns a todo homem ${ }^{4}$.

Husserl afirma, aliás, que existe uma estrutura universal e apodíctica da experiência do eu.

O conteúdo absolutamente certo que nos é fornecido na experiência interna transcendental não se reduz unicamente à identidade do eu sou. Por meio de todos os dados singulares da experiência interna real e possível - ainda que não sejam absolutamente certos no detalhe -, estende-se uma estrutura universal e apodíctica da experiência do eu, como, por exemplo, a forma temporal imanente da consciência. Em virtude dessa estrutura - e este é um dos caracteres próprios - o eu possui um esquema apodíctico de si mesmo, esquema indeterminado que o faz aparecer a si mesmo com eu concreto, que existe com um conteúdo individual de estados vividos, de faculdades e tendências, portanto, como um objeto de experiência interna possível, que pode ser infinitamente ampliada e enriquecida. (HUSSERL, 2001, p.47)

Um dos focos da fenomenologia, com efeito, é conhecer de forma rigorosa e radical as estruturas das vivências, a essência da consciência humana, da psique e do espírito. $\mathrm{O}$ conhecimento dessas essências é fundamental para se elaborar uma abordagem histórica, pois, sem este conhecimento, o historiador pode acabar por confundir fatores psíquicos, espirituais, culturais etc.

A fenomenologia, em sua investigação, busca uma definição rigorosa do domínio psicológico, o qual está ligado a uma certa classe de vivências particulares, diferenciando-se de outras classes de vivências, como as culturais.

\footnotetext{
${ }^{3}$ Tanto um mulçumano quanto um católico possuem a capacidade, por exemplo, da memória. Ter memória e se lembrar faz parte da estrutura apodíctica do eu. Faz parte da essência da psique ter a faculdade da memória e isso independe de fatores históricos e culturais. O que dependerá dos fatores históricos e culturais são os conteúdos da memória.

${ }^{4}$ Para citar alguns exemplos de aspectos essenciais do ser humano: 1) Todo homem, para que tenha consciência de si e para que possa ter uma visão de si, deve ter memória. Ter a capacidade de se lembrar não é algo cultural. Alguém sem absolutamente nenhuma memória não pode se comunicar, não pode querer nada.

2) Toda consciência é consciência de alguma coisa. Uma consciência que não é e não pode ser consciência de nada não é consciência.
} 
A capacidade de se efetuar vivências reflexivas faz parte da essência da consciência. Mas a maneira como ocorrem as vivências reflexivas depende de outros fatores como crenças, opiniões, componentes psíquicos, experiências religiosas etc. Segundo Ales Bello (2004):

Em suma, a fenomenologia tem uma atenção predominante sobre a complexidade do ser humano, sendo essa complexidade estudada estruturalmente pela análise transcendental e, posteriormente, abordada pela fenomenologia das culturas em suas específicas e diversificadas articulações conforme as diversas condições humanas nas diversas culturas. No que se refere à análise das culturas, é pertinente pontuar que a atividade reflexiva que no Ocidente é muito forte e que chamamos atividade do logos - não é própria apenas dos seres humanos do Ocidente, mas é inerente a todo o ser humano, sendo, porém, desenvolvida de formas diferentes em diferentes culturas. (p.59)

O grande mérito da fenomenologia é o de, em certo sentido, propor uma saída entre o dogmatismo e o relativismo. Todos os homens possuem estruturas comuns. E o conhecimento dessas estruturas são válidos independentemente dos fatores históricos. Entretanto o eu concreto muda de pessoa para pessoa, de acordo com suas condições vitais e o seu "mundo da vida".

Dizemos que cada um tem seu mundo: É verdade, mas é verdade no conteúdo, não na estrutura, na forma, todos os seres humanos tem a mesma estrutura. Porém, têm também um mundo circunstante diverso e então percebem coisas diferentes, ou se lembram de coisas diferentes, ou imaginam coisas diferentes. (2004, p.189)

Segundo Husserl, para se entender a História é necessário levar em conta o mundo do espírito. É preciso investigar os valores de uma cultura e as relações intersubjetivas:

Quando o estudioso que se move no âmbito das ciências do espírito fala de "regra", de "leis", que reinam aqueles modos de comportamento ou os modos de formação de certas configurações culturais, as "causalidades", que nestas leis encontram uma expressão geral, são totalmente diversas das causalidades naturais. O problema do histórico é este: que coisa imaginavam, que coisa pensavam, como valoravam, que coisa queriam etc, os membros de sua sociedade na vida em comum? Em quais modos estes homens se determinavam reciprocamente e em que modo se deixavam determinar pelo mundo circunstante das coisas, em que modo, por outro lado, o plasmavam? (HUSSERL, 2008, p.664; tradução nossa) 
PARTE I: Os atos reflexivos como método de conhecimento em Agostinho 


\subsection{O olhar da inteligência}

\subsubsection{Intelecto ou intuição intelectiva}

Para Agostinho, todo conhecimento é de objetos corporais ou de objetos incorporais.

O primeiro tipo de conhecimento advém com a percepção. A condição de possibilidade para o conhecimento do mundo corporal são os sentidos corpóreos; sem eles, homem algum poderia ter consciência do mundo. Para que se conheça o que é um leão é preciso observá-lo ou ser informado por alguém que o viu. O homem, por ser dotado de órgãos sensíveis, está aberto à esfera de manifestação sensível, mas também ao mundo incorporal, pois possui um outro órgão, o olho da inteligência, também denominado o olho da razão. Assim como os objetos sensíveis mostram-se ao olhar sensível de modo que, para conhecê-los, é preciso vêlos, também os objetos incorporais mostram-se ao olhar intelectual e "vê-los" é conhecê-los.

As realidades corporais caracterizam-se pelo fato de as partes serem menores que o todo, de ocuparem lugar no espaço e de poderem afetar o corpo humano, mais especificamente os órgãos corporais. O teste constante que Agostinho faz para saber a natureza de um objeto conhecido é questionar se este possui ao menos algum traço sensível, como cor, peso, cheiro, gosto, e se é passível de ser tocado. Como é possível notar, números, sentimentos, pensamentos, ideias, leis não passam em tal teste.

É preciso distinguir: o próprio conhecimento de uma realidade corporal é incorporal e uma realidade inteligível. A árvore pode ser tocada, o conhecimento da árvore não. Ambos são reais, pois um existe na criação, o outro na mente do criador. A ideia do peso não possui peso. Mas é possível que tenhamos a ideia de peso ou a ideia de árvore sem os sentidos? A resposta a questão é dada pelas observações seguintes. Todo conhecimento, seja lá do que for, é incorporal, mas, como todo conhecimento, é conhecimento de um objeto sensível ou inteligível. Se não tivéssemos visão, não poderíamos conhecer as cores, mas para que se conheça o número, não é necessário nenhum sentido em particular. Tanto o conhecimento do número, quanto o próprio número são incorporais. Já no caso do conhecimento sensível, a relação entre objeto conhecido e conhecimento é menos estreita. A árvore real está fora do corpo e é sensível, o conhecimento da árvore está dentro do espírito e é inteligível, pois podemos olhar com os olhos da inteligência o próprio conhecimento da árvore.

Portanto, todo conhecimento é conhecimento de um objeto e esse objeto é sensível e ocupa um lugar no espaço ou é invisível, incorporal e inteligível.

De fato, a ideia de igualdade, de número, as formas e as regras geométricas e aritméticas não podem ter entrado em nossa mente pelos sentidos, pois tais realidades não são sensíveis, 
entretanto, isso não quer dizer que os sentidos não tenham relação com o conhecimento dos inteligíveis. Há duas razões centrais para essa afirmação.

Primeira: os objetos sensíveis possuem proporções intrínsecas e relações extrínsecas com outros objetos corporais. Embora os corpos sejam sensíveis, as proporções intrínsecas e extrínsecas não são elas mesmas sensíveis. A lua é sensível, mas a proporção entre o número de dias e os ciclos lunares não é sensível. O mundo da manifestação sensível é ordenado, a racionalidade habita o Cosmos. A ordenação do sensível, embora seja captada através do sensível, não é ela mesma sensível: pode apenas ser apenas vista pela inteligência. Depois de intuída com a inteligência, pode tornar-se objeto do pensamento. Deus criou o mundo com número, medida e peso. Por isso, o mundo da manifestação, criado pelo Logos divino, não é um caos sensorial, mas um mundo regulado, no qual as coisas são traduzíveis em verbos interiores, em noções inteligíveis. Um conhecimento, que é inteligível, pode se referir a algo sensível, pois ambos apresentam semelhança formal. A relação entre o nome e as coisas do mundo é explicitada no próprio Gêneses, no qual Deus, ao criar o mundo, primeiro diz o objeto que será criado e posteriormente o cria. ${ }^{5}$

A criação já estava no espírito de Deus "antes" de ser criada. E o espírito humano pode conhecer a criação porque coloca-se, na hierarquia dos seres, acima da criação e abaixo do criador.

Segunda: as realidades sensíveis possuem o poder de se remeter e servir como meio de transporte às realidades inteligíveis. $\mathrm{O}$ geômetra que traça uma linha na areia para ensinar um teorema usa da sensibilidade para indicar algo que só pode ter realidade no espírito. A matéria sensível pode ser usada de modo a incitar o olhar interior a forcar-se na direção correta. Um professor talvez use um quadro negro para mostrar a seus pupilos que a diagonal de um quadrado o divide em dois triângulos isósceles. Mas é a inteligência, em última instância, que percebe ali uma regra eterna, válida para qualquer outro quadrado. Um único exemplo pode ser suficiente para que conheçamos essa regra universal, se nossa inteligência assim o permitir. O objeto sensível dado à percepção serve como um portal através do qual o olho do espírito pode penetrar mais facilmente no reino do inteligível.

Um terceiro aspecto dessa inter-relação entre o sensível e o inteligível mostra-se na comunicação humana. Como o homem não é capaz de telepatia, todo intercambio de ideias e informações é feito mediante o mundo sensível. As palavras ditas, tomadas por si próprias,

\footnotetext{
5 "Deus disse: "Produza a terra seres vivos segundo suas espécies, animais domésticos, répteis e animais selvagens, segundo suas espécies". E assim se fez. Deus fez os animais selvagens segundo suas espécies, os animais domésticos segundo suas espécies e todos os répteis do solo segundo suas espécies. E Deus viu que era bom." (Gên. 1:24,25)
} 
são meros ruídos, mas elas podem servir de indicadores de objetos inteligíveis. Os fonemas que compõem a palavra "número" são sensíveis, mas indicam algo inteligível.

Embora distintos, há intricadas relações entre o mundo da manifestação sensível e o mundo inteligível. Além das relações já mencionadas, Agostinho observou que os objetos incorporais mostravam-se ao olhar do espírito com um grau de perfeição e segurança não comparáveis aos objetos sensíveis. Em Solilóquios, uma de suas primeiras obras, ele se questiona se seria possível conhecer Deus e a alma com a segurança com que se conhece a geometria: "Então, responde-me se te é suficiente conhecer a Deus como conheces a esfera geométrica, isto é, ter conhecimento de Deus de tal modo que não venhas a duvidar" (Sol., I, 14, 9; 1998, p.27). Está ao alcance do espírito humano um conhecimento de si mesmo tão seguro quanto uma verdade matemática? A resposta a essa questão exige um longo caminho. Em certo sentido, Agostinho a investigou ao longo de décadas. O escopo deste nosso trabalho é mostrar a atualidade dessa investigação. E só podemos mostrá-la por uma sucessão de etapas e após efetuar uma série de distinções.

Como íamos dizendo, existem objetos corporais e incorporais. Acresce a isso que os incorporais podem ser mutáveis ou imutáveis. Os números são eternos e imutáveis. O reino da manifestação sensível, em constante devir, não pode afetar, por exemplo, o número três, pois o "três" não está sujeito à temporalidade, permanece sempre o mesmo, idêntico a si. Mesmo que não seja pensado por homem algum, o três continua sendo o mesmo, pois subsiste eternamente no espírito de Deus. Mas se os números são imutáveis e eternos, também o será a relação entre eles. A soma de três e sete sempre será dez. E isso é válido em qualquer mundo possível: sonho ou realidade. A proporção entre a diagonal e o lado de um quadrado será sempre a mesma. Em outras palavras, não apenas existem objetos incorpóreos e eternos, como também existem regras, proporções e relações entre esses objetos que são eternas e imutáveis. Que existam relações imutáveis entre objetos incorpóreos e imutáveis, parece algo trivial. Mas quadro torna-se mais complexo tão logo observemos que objetos mutáveis e corpóreos podem possuir proporções e relações incorpóreas, as quais podem ser mutáveis ou imutáveis. As proporções entre as estrelas fixas, levando em consideração os conhecimentos do tempo de Agostinho, seriam imutáveis. A proporção entre folhas e olivas numa oliveira é mutável.

Todavia o foco de Agostinho não é conhecer as regras inteligíveis do mundo sensível, tarefa essa que feita adequadamente é boa, isto é, com o intuito de evitar o mal. O que importa observar é que o fato do objeto ser inteligível, como a proporção entre as folhas de uma determinada oliveira e o número de olivas, é uma proporção incorporal e mutável com o transcorrer do tempo. 
Observamos até aqui que o mundo sensível e corporal pode ser estruturado e entremeado por relações incorpóreas e estas podem ser mutáveis ou imutáveis. Observamos também como os números são incorporais e possuem relações incorporais e imutáveis. Dentro deste horizonte conceitual, o espírito humano se insere com os seguintes atributos: é uma realidade incorporal e mutável, embora com uma estrutura nuclear trinitária e imutável, como teremos ocasião de ver em detalhes. A relação entre o espírito humano e Deus é mutável, pois o espírito pode, em uma fase da vida, acreditar e amar Deus, em outra, abandonar a fé. Aliás, a própria fé é incorporal, assim como o amor. Entretanto, o espírito humano possui determinadas estruturas invariáveis, sem as quais deixaria de ser o que é. Por vezes pode querer mais a criatura, por vezes mais o criador, mas querer, sempre possui dentro de si uma incansável vontade, cuja extinção faria apagar o rarefeito fogo do espírito. Uma segunda observação merece ser feita a respeito do espírito: por ser incorporal, só pode ser conhecido e investigado pelo olhar da inteligência.

Os animais, por não possuírem inteligência, são incapazes de "ver" e investigar o incorporal. Apenas o homem é capaz de colocar sua própria animus sob seu crivo e investigar os inteligíveis e Deus. Os animais também possuem o conhecimento sensível, mas apenas o homem é capaz de ter os olhos abertos para o mundo inteligível, e, portanto, de conhecer seus próprios conhecimentos ${ }^{6}$.

A mente, que é variável, ao vislumbrar as regras e as ideias eternas, iluminadas pela luz divina, torna-se consciênte de uma esfera de realidade superior ${ }^{7}$, imutável e incorpórea, a qual não é o fruto da fantasia humana - pois o poder imaginativo do homem consiste em compor novas imagens a partir da imagem de coisas corporais contidas na memória, ao passo que os inteligíveis eternos e imutáveis não são imagens de $\operatorname{corpos}^{8}$, mas regras, ideias, verdades.

\footnotetext{
${ }^{6}$ Essa doutrina Agostiniana se insere, em muitos aspectos, na tradição platônica. Para Platão, assim co mo o Sol ilumina os corpos sensíveis para que possamos vê-los, o sumo bem é o sol do mundo das ideias. Em Agostinho Deus é o sol do mundo inteligível, que ilumina as ideias e as regras eternas para que possamos vê-las com o intelecto. É provável que a apropriação de algumas ideias platônicas pelo pensamento agostiniano tenha sido através do Neoplatonismo de Plotino.

${ }^{7}$ Como afirma Gilson(2007), a metáfora tem limites. No caso do Sol, as coisas iluminadas pelo Sol são exteriores ao Sol, mas as regras e as ideias divinas subsistem em Deus e são suas ideias. Daí resulta a imutabilidade, a eternidade, a incorruptibilidade, e identidade das leis da matemática e dos princípios lógicos e a validade universal desses princípios. Quando afirmamos que dado dois juízos contraditórios, apenas um pode ser verdadeiro, o que estamos afirmando não é uma mera convenção humana, mas uma evidência racional, cuja negação destrói a própria racionalidade. Se uma pessoa afirma que o quadrado diferencia-se do círculo por convenção, o mais provável é que ela esteja confundindo os nomes com os conceitos. Não é possível conceber um quadrado redondo. E isso não ocorre porque a sociedade assim convencionou, mas por uma impossibilidade inerente ao próprios inteligíveis.

${ }^{8}$ As ideias estão acima da mente, mas também servem de critério seguro para os nossos julgamentos. A regra formal do silogismo, bem como o princípio de contradição, apenas para citar dois exemplos, seriam, no pensamento de Santo Agostinho, não construções humanas, mas verdades eternas, subsistindo no espírito divino,
} 
Estas entidades inteligíveis e eternas se distinguem dos corpos e mesmo da alma humana, que, embora inteligível, está sujeita à temporalidade.

O homem, embora uno, tem em si duas naturezas distintas e, por isso, é capaz de negociar com o corpóreo e com o inteligível. E está, na hierarquia dos seres, entre o mundo sensível e o inteligível, entre o transitório e o eterno; vive entre as criaturas, mas é capaz de vislumbrar aquilo que há de eterno e imutável. De fato, nesta vida não contemplamos Deus face a face, o bem supremo, o uno, que é absolutamente simples. Intuímos o que Deus é pela contemplação das ideias eternas.

De fato, o intelecto é capaz de ver as ideias e as regras eternas iluminadas pela luz divina. Mas isso não significa que o intelecto veja diretamente a própria luz ou próprio "Sol". Apenas na experiência mística o homem pode ter um certo vislumbre da experiência direta de Deus, embora, ainda assim, não seja propriamente a visão face a face. Por outro lado, para Agostinho, embora seja possível não aceitar, por orgulho, a revelação, só a loucura ou a impiedade ou a cegueira espiritual poderia levar o homem à negação de Deus. Dentro desta perspectiva, notamos que existem graus de aproximação da mente a Deus. Quanto mais o homem o conheça e o contemple, mais se tornará dele a imagem.

Todo esse quadro parece sugerir uma visão demasiadamente intelectualista da relação homem - Deus. Mas não é caso, pois a visão intelectual possui alguns pré-requisitos, dentre os quais o primeiro é crer e amar Deus, sobre todas as coisas. Sem a fé no testemunho, o homem não se dispõe a conhecê-lo, e sem amor, os olhos da inteligência se mantêm obnubilados. Embaçados sim, mas para que estejam cego a Deus, só um orgulho insano; Mas a descrença pode advir de um mau entendimento do que Deus seja, de modo que a pessoa, ao negar sua própria ficção, cria que esteja negando Deus. Todavia, embora os homens possam abandonar Deus, Deus nunca abandona os homens.

Devido a sua fixidez, as evidências inteligíveis servem de âncora ao espírito instável do ser humano. Submetendo-se aos inteligíveis, a mente pode ser regulada pelo que é fixo e superior. Essa submissão é liberdade, pois submeter-se a Deus é amá-lo e amá-lo é o que há de melhor para amar. Quando o espírito age de acordo com Deus e com as evidências racionais, ele age de acordo com sua natureza mais profunda; e renegar as verdades intuídas

e que o homem só as alcança por iluminação. Assim como ocorre com todos axiomas e primeiros princípios, não há como provar. Demonstrar uma tese é justamente conduzi-la logicamente aos princípios que a sustentam. Não há, portanto, como provar que o princípio de não-contradição é verdadeiro, pois ele é justamente o indemonstrado que sustenta qualquer demonstração. Os primeiros princípios são dados à razão intelectiva. O intelecto de um homem que viu com o olho do espírito a regra do silogismo perceberá facilmente que a conexão de proposições tais como "todo sapo é verde, folha é verde, logo folha é sapo" é errônea, sem que seja necessário provar que é errado. 
pelo olhar da inteligência é escravizar-se pelos apetites, pelas opiniões dos manipuladores e enganadores, ou mesmo pelos falsos deuses, que, no fundo, muitas vezes não passam de demônios.

\subsubsection{Raciocínio, razão e o olhar da razão}

O olhar da razão, como observamos, é o órgão receptor da luz divina, pelo qual vemos não a própria luz, mas os inteligíveis e as relações entre eles. O conhecimento do inteligível é uma efetiva visão do inteligível; o raciocínio é o movimento da razão em direção à visão.

Em Sobre a Potencialidade da Alma (De quantitate animae), Agostinho define o raciocínio como uma atividade investigativa, que tem como fim conhecer o desconhecido. Por isso, o fim para onde o raciocínio se movimenta é a visão da realidade inteligível. A analogia com a faculdade visual serve de auxiliar simbólico para entender a distinção entre raciocínio e olhar da razão e a visão efetiva da razão.

Em primeiro lugar, Agostinho estabelece uma sutil distinção entre o ato de dirigir o olhar para algo (aspiciem) e o ato de ver (viseo) esse algo visado. Um exemplo pode esclarecer a diferença: quem está em um quarto com pouca luz e mira um objeto não necessariamente verá distintamente o objeto. Neste caso, dirigimos o olhar para algo, mas não conseguimos ver com nitidez esse algo. Mas como havíamos dito, o raciocínio é uma atividade investigativa e, por isso, define-se como um movimento das direções do olhar em busca do objeto procurado. Alguém que esteja em um quarto com pouca luz procurando uma chave, dirigindo o olhar ora para as estantes, ora para cima da mesa, ora para outro canto qualquer, opera uma atividade investigativa, que pressupõe o movimento da direção do olhar, o que não necessariamente implica que alcance uma visão daquilo que está procurando.

Ao ponto onde você disse recentemente que temos ciência antes da razão, porque, na sua opinião, do conhecido a razão nos leva ao desconhecido. Agora concordamos em que esta passagem do conhecido ao desconhecido não se chama razão, pois assim procede a inteligência normal, de vez que usa a razão a qualquer tempo. A essa maneira de agir chamamos raciocínio, ou indagação racional. Razão é o olhar da mente, e raciocínio é o exercício da inteligência, ou seja, o movimento do olhar da mente sobre aquilo que deve examinar. Essa indagação, ou raciocínio, é necessária para a procura. $\mathrm{O}$ olhar da mente, ou racionalidade, é necessário para ver intelectualmente. Quanto esse olhar da mente, chamado razão, dirigido a algo, é capaz de ver, chamamos ciência. Quando não consegue ver, por mais esforço que empregue, chamamos ignorância. (Quantitate Animae, I, 27; 2005, p.126)

Quia paulo ante dixisti, propterea me tibi debere assentiri scientiaim nos habere ante rationem, quod cognito aliquo nititur, dum nos ratio ad incognitum ducit: nunc autem inuenimus non rationem uocandam esse dum 
hoc agitur; non enim sana mens agit hoc semper, cum semper habeat rationem; sed recte ista fortasse ratiocinatio nominatur; ut ratio sit quidam mentis aspectus, ratiocinatio autem rationis inquisitio, id est, aspectus illius, per ea quae aspicienda sunt, motio. Quare ista opus est ad quaerendum, illa ad uidendum. Itaque cum ille mentis aspectus, quem rationem uocamus, coniectus in rem aliquam, uidet illam, scientia nominatur: cum autem non uidet mens, quamuis intendat aspectum; inscitia uel ignorantia dioitur. Non enim et his corporalibus oculis omnis qui aspicit, uidet; quod in tenebris facillime animaduertimus. Ex quo liquet, ut opinor, aliud esse aspectum, aliud uisionem; quae duo in mente rationem et scientiam nominamus. (2009, Quantitate Animae, I, 27) ${ }^{9}$

Agostinho distingue:

1) O movimento investigativo da razão definido como "rationis inquisitio": o ato de raciocinar.

2): "Mentis aspectus", isto é, o olhar da mente. Portanto, se o olhar da mente, após um movimento investigativo, consegue ter a visão do objeto o qual procura, há o conhecimento.

3) A visão da mente, isto é, quando a mente vê efetivamente um objeto, é denominada conhecimento. Esse conhecimento é a visão da mente.

Diante um problema de matemática, alguém pode raciocinar, raciocinar, sem ver solução alguma. Se a pessoa alcançar a resposta do problema e chegar ao conhecimento significa que o olhar da mente, isto é, a razão, atingiu a visão do objeto inteligível. Mas para que se tenha visão de um objeto determinado, não basta que o objeto esteja iluminado, é preciso movimentar os olhos da mente na direção correta, isto é, raciocinar corretamente. Uma vez que haja a visão, há o conhecimento. Ao contrário do uso atual que se faz do termo inteligência, ter inteligência de algo ou inteligir algo é ter uma intuição intelectual deste algo, processo não muito diferente do que se denomina insight. Como já procuramos mostrar, é

\footnotetext{
${ }^{9}$ As citações latinas desta tese foram tiradas do sítio público http://www.augustinus.it. Neste sítio se encontram as obras completas de Agostinho em latim e italiano. O sítio disponibiliza o conteúdo presente nas edição bilíngue das obras Completas de Agostinho publicada pela editora Città Nuova. Trata-se de uma das mais conceituadas edições das obres completas de Agostinho em italiano. Por se tratar de publicação em site, não foram fornecidos o número de páginas correspondentes na edição Città Nouva. Mas isso não constitui um problema, pois fornecemos o sistema de referência da patrologia de Migne, que consta em quase todas as edições das obras de Agostinho, de modo que o leitor possa encontrar facilmente as referências em quase a totalidade das edições latinas ou bilíngues da obra. Apenas as citações latinas das Confissões foram tiradas da edição portuguesa, isso se justifica pelo fato de que disposmos para o português de uma excelente tradução bilíngue que pode ser usada com fins acadêmicos. Já a edição da Trindade, publicada pela Paulus, consta com muitos problemas de tradução, erros graves ao nosso ver, devido às confusões conceituais. O tradutor não respeita as distintinções conceituais de Agostinho que se expressam em seus termos. Daí que o tradutor usa como sinônimos termos que, atualmente, são tidos como sinônimos. Não se trata de detalhes, mas da essência do pensamento de Agostinho, as distinções entre mens, spiritus, animus, anima, cogito. Esses erros crassos não ocorrem na tradução das Confissões usadas por nós. Os tradutores respeitaram as termos originais e consequentemente o leitor pode penetrar o refinamento nas distinções conceituais agostinianas. Já de início deixamos claro que a má tradução da Trindade constituiu um esforço a mais, pois tivemos que usar, em muitos momenos, notas explicando e corrigindo os erros conceituais nesta tradução.
} 
possível também que haja raciocínio sem que resulte em visão intelectual, como ocorre na investigação estéril $^{10}$.

\footnotetext{
${ }^{10} \mathrm{Na}$ passagem Agostinho não usa o termo intelecto, mas diz que a ratio, que e o ato de mirar; Uma coisa é o raciocínio, que se refere ao movimento do olhar em sua investigação; outra coisa é a visão da mente, que é o conhecimento. Ora, quem traz o conhecimento é o intelecto. Aquilo que é visto com o intelecto torna-se conhecimento. Essa visão da mente é o que, na Trindade, Agostinho denominará intelecto.
} 


\subsection{Os conteúdos da memória e o reino do pensável}

\subsubsection{Introdução}

A memória desempenha uma função central no pensamento de Agostinho. Para ele, o que temos na memória não é apenas aquilo que foi "armazenado" ou gravado nela. O conceito é amplo: todo conteúdo que está no espírito está na memória. É verdade que guardamos na memória a imagem dos corpos sensíveis, mas as realidades inteligíveis, como as regras, as proporções e os números, não possuem imagens. Se o homem não encontra as realidades espirituais e inteligíveis olhando para fora é porque encontra dentro de si próprio. Por isso, a memória contém as imagens de coisas já experienciadas no passado, mas também possui conteúdos que não possuem tempo, como os números e regras eternas. Deus e suas ideias estão, de algum modo, no espírito humano, logo, estão presentes na memória. Mas acresce que a memória do espírito guarda sua própria historicidade, seu próprio passado de experiências. E a memória não diz respeito apenas às realidades passadas, mas também às realidades presentes e mesmo àquelas eternamente presentes. Neste capítulo, iremos avaliar como Agostinho usou da própria reflexão para explorar a memória e as conclusões a que ele chegou.

Para começar, todo pensamento (cogito) tira sua "matéria-prima" da memória. Mesmo quando a mente imagina algo que nunca antes havia imaginado, ela nada mais faz do que compor algo a partir das imagens retidas na memória.

No caso dos números, a mente só é capaz de pensá-los porque os possui dentro de si. Como é capaz de pensar em Deus? Pensa-o porque Deus está, de certo modo, no espírito. Não poderia ser de outro modo; Deus é onipresente e está inteiro em toda parte. Em última instância, todo pensamento só pode ser pensado se as suas partes constituintes estiverem na memória. Alguém que conversa interiormente consigo mesmo também está usando a memória, pois está "evocando" as palavras com seus respectivos significados para compor a conversação interior. Fica claro que essa fala interior só faz sentido porque nela há signos cujo significado conhecemos com um certo grau de determinação. O raciocínio pode combinar os conteúdos presentes na memória. E esses conteúdos são dados seja pelo intelecto ou pela percepção sensível.

Como vínhamos dizendo, todo conteúdo que se encontra na mente, que não é pensado momentaneamente, mas que poderia vir a ser pensado, se encontra na memória. Portanto, a 
memória contém não apenas aquilo que foi experienciado no passado, mas também tudo aquilo que não é passado nem futuro, tal como Deus e as ideias de Deus, ou mesmo os números ${ }^{11}$, além dos próprios significados e conceitos. Mas, se a mente pode ser pensada, é porque a ela possui memória de si mesma. Em outras palavras, todo pensamento tem que ter um conteúdo, o qual emana da memória.

\subsubsection{Os conteúdos da memória}

É a memória que fornece tudo aquilo que pode ser pensado. Se todos os conhecimentos estão na memória, conhecer a memória implica um ato reflexivo pelo qual conhecemos os nossos conhecimentos. Conhecer os conhecimentos envolve classificá-los, analisá-los e investigar sua origem. Mas, se observarmos que só podemos pensar no mundo e nas coisas fundamentadas na memória, fica claro que o alcance do pensamento está vinculado ao conteúdo que a memória pode lhe oferecer.

A investigação da memória parte do princípio da reflexão. Pois é um conhecimento do conhecimento. Embora pareça contrassenso querer conhecer o que há na memória, dado que conhecer o que está na memória é conhecer o que já se conhece, o fato é que só em um primeiro momento isto soa absurdo. Porque uma coisa é conhecer algo, outra coisa é conhecer o conhecimento desse algo. Mas qual a diferença? A diferença faz-se notar tão logo observamos que, muitas vezes, temos conhecimentos, mas somos incapazes de dizer sua origem. Uma coisa é conhecer a origem de uma árvore, que ela vem da semente. Outra coisa é conhecer a origem do conhecimento que temos de árvore, o qual se encontra na percepção e não na semente.

O homem conhece os números. Isso é uma coisa. Outra coisa é conhecer o conhecimento dos números. Como o homem veio a ter conhecimento dos números. Isto é, qual a origem desse conhecimento?

A investigação da memória será uma investigação de caráter epistemológico. Será, com efeito, uma epistemologia sui generis. Isso porque Agostinho toma como ponto de partida o exame dos próprios conhecimentos, para apenas em seguida observar o meio pelo qual os adquiriu. Sua teoria do conhecimento é fundada por aquilo que é dado em evidência pelo exame reflexivo. Algumas vezes, devido a sua honestidade, ele se confessa incapaz de dizer

\footnotetext{
${ }^{11}$ Aquele que pensa no número três, não está pensando em algo que aconteceu no passado. O três é, foi e continua sendo, ele mesmo, imutável, invulnerável à passagem do tempo. Uma vez entendido o que é o número três, já se tem a certeza que ele é o que é, e continuará sendo o que é, quer exista alguém que o pense quer não. No entanto, é necessário que o número três esteja presente em nosso espírito, antes de pensá-lo. Pela mesma razão, no momento em que não pensamos no número três, ele não deixa de existir, não deixa de estar em nossa mente. E não poderia estar em outro lugar que não a memória.
} 
como tal conhecimento foi parar na memória. Por isso, não faz como aqueles que negam os dados para que estes se enquadrem em uma teoria do conhecimento pré-estabelecida. Agostinho, em primeiro lugar, constata a existência do dado, posteriormente investiga sua origem, seu gênero e suas demais características. Primeiro, ele constata que é possível se lembrar de um sentimento e entendê-lo sem senti-lo. Posteriormente se questiona "como isso é possível?”, “O que isto nos diz sobre a memória?” Daí resulta que Agostinho, justamente por investigar a memória partindo daquilo que pode ser pensado ou lembrado, desenvolve descrições minuciosas daquilo que é dado e como é dado ao olhar reflexivo, para, somente então, partir para considerações posteriores.

Ao se propor examinar a memória como um todo, ele se vê obrigado a classificar os conteúdos da memória. Quais as semelhanças e as diferenças entre a memória de um sentimento, de um evento passado, de um número? Ao comparar o conhecimento de realidades tão díspares, algumas estranhas distinções e insuspeitas igualdades vão aparecendo. Uma coisa é se questionar sobre a diferença entre um número e um sentimento. Outra coisa é se questionar acerca da diferença entre o conhecimento do número e conhecimento de um sentimento. Mas esses dois níveis estão articulados: quem se questiona sobre o que é um sentimento, o que é um número, está consciente ou inconscientemente usando sua memória e nela confiando, pois se não tivesse memória do que é um sentimento ou do que é um número, não saberia sequer o que está questionando. Crê que está investigando o "ser" do número e o "ser" do sentimento, mas, em última instância, sua investigação está apoiada na memória que ele tem do número e do sentimento. Mas até que ponto ele está investigando o próprio ser, até que ponto ele está investigando o ser tal qual está em sua memória?

Esta problematicidade constitui uma das condições inerentes de todo questionar, de todo perguntar, de todo investigar. Aquele que se coloca perguntas como: “o que é um animal?", “o que é um sentimento?”, “o que é um buraco negro?” só pode formulá-la por que tem na memória uma noção prévia do que seja um buraco nego e um sentimento. Quando procuramos uma coisa já temos a noção do que a coisa é. $\mathrm{O}$ objeto questionado é limitado por essa noção que temos dele. Ainda que se mostre mais tarde um preconceito, essa noção inicial, a notícia inicial, é essencial como ponto de partida. E o exame do que são essas noções forma um campo de investigação.

Uma coisa é investigar o que é um sentimento, outra coisa é examinar esse conhecimento prévio que temos do que é um sentimento. Aquele que, sem estar triste, decide investigar o que é a tristeza está, sem o saber, confiante que sua memória será capaz de fornecer aquilo que tal sentimento é. Isso só seria possível se, de algum modo, a essência do 
sentimento estivesse guardada na memória. Se investigamos o sentimento é porque o signo "sentimento" possui um sentido. E essa lei pode se estender a qualquer signo. Para que uma pessoa negue que os conceitos de substância ou de átomo refiram-se a coisas reais é preciso, antes, que ela entenda o que é uma substância e um átomo. As noções, em alguns casos, não podem ser ensinadas, pois, em última instância, é preciso que o próprio aluno as veja. $\mathrm{O}$ máximo que o professor pode fazer é tentar guiar o aluno para que ele mesmo perceba com os olhos de sua inteligência tal objeto ou tal relação entre objetos. Por mais que uma pessoa se esforce, ela não conseguirá ensinar a um papagaio o que é o número 100.

Segundo Agostinho, temos associada em nossa memória a "imagem sonora" da palavra com aquilo que ela quer dizer. Para que uma palavra tenha sentido, é preciso ter noção do que ela designa. Isso leva a complexas consequências. Antes de uma pessoa negar ou afirmar Deus, é preciso que ela explicite o que entende pelo termo "Deus" e como veio a ter essa noção. Um homem pode negar Deus, tendo em mente a noção de que Deus é um velho barbudo superpoderoso. Mas um verdadeiro católico também negaria semelhante fantasia, pois um velho barbudo superpoderoso não é Deus.

Toda questão possível é feita pelas pré-noções na memória. A memória serve como uma espécie de solo, sobre o qual podemos nos posicionar de modo a vermos aquilo que ainda não víamos. Antes que a pessoa conheça o teorema de Pitágoras é preciso que ela tenha noção do que é um triângulo retângulo.

Investigar a memória significa tomar conhecimento reflexivo de tudo aquilo que, de algum modo, é para mim. Por outro lado, limitar-se à memória, aparentemente, é limitar-se ao que foi e ao que é. Mas a razão, nutrida pela memória, pode ir além, abrindo ao espírito o campo das possibilidades, imaginando o que poderia ser para mim. Não é a memória exclusivamente que me informa das possibilidades dos cachorros possíveis, mas a inteligência. $\mathrm{O}$ conhecimento das possibilidades individuais de ser de uma essência é dado pela inteligência, pela mente. Para designar essas possibilidades que se exemplificam em objetos individuais apreendidos, lembrados ou mesmo imaginados, Agostinho, por vezes, usa o termo "imagens genéricas". Por ter na memória a imagem genérica suficientemente elástica de uma árvore, o homem ao ver uma árvore que nunca viu, sabe que ela é uma árvore. Procuremos acompanhar Agostinho, usando como base o livro X das Confissões, sobre o que ele diz acerca dos diferentes conteúdos da memória. 


\subsubsection{Memória das imagens dos corpos}

Segundo Agostinho, a primeira espécie de conteúdo que se encontra na memória são as imagens das coisas sensíveis, daquilo que é visto, tocado, cheirado, escutado, saboreado. Assim, o que temos na memória não é a imagem do corpo enquanto corpo, ou do corpo em si, mas a imagem desse corpo tal como foi dada aos sentidos. Aquele que viu, durante toda a sua vida, a imagem de um lado da lua, terá, dentro de si, a imagem deste lado da lua e não do outro lado que nunca viu, embora a razão saiba que existe um outro lado que poderia ser visto. De todo modo, a imagem visual do objeto presente na memória está ligada à visão tida do objeto.

Mas a noção de "imagem" não diz respeito apenas à imagem visível, pois, segundo Agostinho, temos dentro de nós também "imagens sonoras", "imagens táteis", etc. Quem vê um cavalo possui em sua própria visão a imagem visual do cavalo. Mas, se escuta um cavalo relinchar, poderá relembrar posteriormente a "imagem" do relincho do cavalo. Caso nunca tenha escutado um cavalo relinchar, não terá a imagem do relincho do cavalo. Um surdo terá na memória a imagem do que viu, das cores, da luz, mas não terá a imagem dos sons ${ }^{12}$. Com o corpo, não temos apenas sensações táteis, mas também percebemos o frio e o quente. E, por isso, quando lembramos do quente ou do frio, lembramos a "imagem" do quente e a "imagem" do frio.

As imagens sensíveis entram na alma por diferentes portas. Cada sentido é uma "porta de entrada" $" 13$ na alma para o mundo dos sentidos. Por isso, Agostinho divide as imagens presentes na memória, conforme sua via de acesso ${ }^{14}$, de modo que cada via corresponda um sentido. De fato, uma coisa é o objeto sensível, outra coisa a imagem vista perceptivamente desse objeto sensível, outra ainda é a imagem mental, contida na memória, do objeto sensível.

Levando adiante a investigação, um fato se impõe: um mesmo objeto sensível pode ser captado por diferentes sentidos. Quando pensamos no objeto sensível como um todo, isso implica algum trabalho de síntese. Não é possível que esta síntese seja feita nem pela própria visão, nem por qualquer outro sentido em particular. Resta que é alguma faculdade da alma, superior aos sentidos, que sintetiza as diferentes imagens sensíveis relativas a um mesmo

\footnotetext{
${ }^{13}$ Como havíamos frisado anteriormente, a memória é apresentada como um topos, um recesso, isso na medida em que é até mesmo possível existir algo como um "esconderijo secreto". Neste topos são guardadas todas as sensações até aquelas tidas com todo o corpo.

${ }^{14}$ Temos gravado na memória dois tipos de sensações, aquelas que são introduzidas por cada um dos cinco sentidos e aquelas que são aí introduzidas através da sensibilidade difusa por todo o copo, que nos permite perceber o áspero, o pesado, o duro e o mole, o quente e o frio.
} 
objeto. A mesma xícara é amarela e dura. Quem me informa que é dura, é meu tato; quem me informa que é amarela, são meus olhos, mas quem me informa que o mesmo objeto é simultaneamente duro e amarelo é outra função, que está acima dos sentidos. Essa função sintética pela qual a alma liga as imagens fornecidas pelos diferentes sentidos está presente também nos animais; também eles são capazes de se lembrar dos objetos sensíveis como um todo.

Agostinho nota que a recepção do objeto por um dos sentidos não é afetada pelos demais, isto é, cada um deles possui autonomia. Se estivermos em um ambiente barulhento, isso não impede que vejamos com nitidez a imagem visual do objeto e que guardemos dele a imagem visual. ${ }^{15}$

Certo, uma coisa é perceber as coisas com os sentidos, outra é evocar da memória a imagem das coisas sensíveis. Mas o que a própria visão do objeto pode oferecer que a memória não oferece? Qual a diferença e a semelhança entre lembrar algo sensível e perceber algo sensível? Não haveria uma diferença de nitidez? O que Agostinho nos informa a esse respeito no livro $\mathrm{X}$ das Confissões é que as imagens presentes na memória possuem traços suficientes para determiná-las e distingui-las de outras imagens ${ }^{16}$ contidas na memória. “ $\mathrm{Na}$ verdade, quando estou às escuras ou em silêncio, trago à memória as cores, se quiser, e distingo o branco do negro, e outras cores, que eu quiser, umas das outras". (Conf., X, 8, 13; 2004, p.455). O branco visto interiormente com o auxílio da memória é semelhante ao branco visto pelo sentido. Daí resulta que o conteúdo da memória pode, em alguns casos, servir de base para julgamentos tão seguros quanto se estivéssemos vendo, em carne e osso, a realidade julgada “(...) sem nada cheirar, distingo o perfume dos lírios do das violetas e, sem nada

\footnotetext{
15 “Ali estão arquivadas, de forma distinta e classificada, todas as coisas que foram introduzidas cada uma pela sua entrada: a luz e todas as cores e formas pelos corpos, pelos olhos; todas as espécies de sons, pelos ouvidos; todos os odores, pelo nariz (...) Todas estas coisas recebe, para as recordar quando é necessário, e para as retomar, o vasto recôndito da memória e as suas secretas e inefáveis concavidades: todas essas coisas entram nela, cada uma por sua porta, e nela são armazenadas. Contudo, não são as próprias coisas que entram, mas sim as imagens das coisas, percedias pelos sentidos, que ali estão à disposição do pensamento que as recorda" (Conf. $\mathrm{X}, 8,13 ; 2004$, p. 455).

"Haec omnia recipit recolenda, cum opus est, et retractanda grandis memoriae recessus et nescio qui secreti atque ineffabiles sinus eius; Nec ipsa tamen intrant, sed rerum sensarum imagines illic praesto sunt cogitationi reminiscenti eas. Quae quomodo fabricatae sint, quis dicit, cum appareat, quibus sensibus raptae sint interiusque reconditae?" (Conf. Liber X, 8,13).
}

De fato, a expressão "rerum sensarum imagines illic praesto sunt cogitationi reminiscenti eas" deixa nítido o sentido do verbo cogitar, que é trazer as imagens das coisas corporais disponíveis na memória ao olhar da mente.

${ }^{16}$ Seja mais nítida ou não, a essência é a mesma. 
provar, nem tocar, mas apenas recordando, prefiro o mel ao arrobe e o macio ao áspero" 17 (Conf., X, 8, 13; 2004, p.456).

\subsubsection{Memória das experiências passadas}

Na memória não há apenas as imagens dos objetos sensíveis. Sabemos que podemos nos lembrar de nossas experiências passadas, como qualquer um pode confirmar dentro de si mesmo, constatando reflexivamente. Afinal, quem duvidaria disso? Posto esse fato, resta examiná-lo. É o que Agostinho faz, ao descrever e analisar os conteúdos inerentes à memória de uma experiência passada ${ }^{18}$ :

Aí me encontro também comigo mesmo e recordo-me de mim, do que fiz, quando e onde o fiz, e de que modo fui impressionado quando o fazia. Aí estão todas as coisas de que eu me recordo, quer aquelas que experimentei, quer aquelas em que acreditei. (Conf., X, 8, 14; 2004, p. 457).

Intus haec ago, in aula ingenti memoriae meae. ibi enim mihi caelum et terra et mare praesto sunt cum omnibus, quae in eis sentire potui, praeter illa, quae oblitus sum. ibi mihi et ipse occurro, meque recolo, quid, quando et ubi egerim quoque modo, cum agerem, affectus fuerim. ibi sunt omnia, quae sive experta a me sive credita memini. (Conf., X, 8, 14; 2004, p. 456).

Analisando essa experiência passada encontrada na memória, podemos achar os seguintes componentes:

1) O próprio eu que teve a experiência (ibi mihi et ipse occurro). Portanto, aquele que se lembra de uma experiência passada encontra a si mesmo nessa experiência. Mas essa constatação pede esclarecimento, pois há um aparente paradoxo. O "eu mesmo" implicado na experiência lembrada não pode ser o mesmo "eu" que atualmente se lembra. Por outro lado, se não fossem o mesmo, esse eu implicado na experiência lembrada seria um eu de outra pessoa. Portanto, sob determinados aspectos, é o mesmo, sob outros aspectos, não. Por enquanto constatemos apenas o seguinte: esse eu imbricado na experiência evocada é o próprio “eu”, mas é diferente porque é um "eu lembrado" e não um "eu que se lembra". Se analisarmos a diferença entre ambos, fica claro que um dos pontos que os diferencia é que

\footnotetext{
${ }^{17}$ Com isso, Agostinho, simplesmente segue descrevendo o fenômeno tal qual lhe aparece, antecipa uma dos mais importantes ideias da fenomenologia, segundo o qual todo fenômeno possui uma essência. A essência do amarelo está tanto naquele que imagina o amarelo, quanto no amarelo visto. Nos palácios da memória encontrase, portanto, tudo aquilo que o homem colheu com os sentidos, excetuando-se apenas os que foram sepultados pelo esquecimento.

${ }^{18}$ Ora, se por um lado o espírito se recorda das imagens, agora aparecem duas outras categorias de coisas que o eu pode se recordar: o eu mesmo (mihi et ipse) e as experiências (experta) desse eu. A memória das experiências passadas diferencia-se, com efeito, da memória das imagens dos corpos sensíveis ${ }^{18}$. Agostinho mete em evidência o seguinte fenômeno: se podemos recordar das experiências vividas, é porque temos de algum modo essas experiências na memória. Como havíamos observado a exploração da memória não ocorre simplesmente do ponto de vista teórico. Em primeiro lugar, Agostinho descreve o fenômeno em sua evidência.
} 
cada qual está referido a circunstâncias distintas. $\mathrm{O}$ eu lembrado estava em outro tempo e em outro espaço, vivia uma outra experiência. Já o eu que se recorda vive a experiência de recordar-se.

2) Agostinho se diz também capaz de se lembar dos sentimentos que ele sentia no momento da experiência. Suponhamos que alguém se lembre da experiência de alegria que sentiu ao receber a notícia de que um filho nasceu. Tal pessoa não se lembrará da alegria enquanto conceito, mas sim da experiência concreta daquela alegria em particular. Portanto, uma coisa é lembrar-se da alegria de modo genérico, outra coisa é recordar aquela alegria vivida em um momento determinado, com seus traços de singularidade, tal como foi sentida naquele momento.

3) As circunstâncias em que a experiência foi vivida. Essas circunstâncias podem ser circunstâncias espaciais. Por exemplo: aquele que se lembra do nascimento de seu filho lembra que recebeu a notícia quando estava em determinado hospital. Daí resulta que um dos elementos que está implicado na memória da experiência passada são imagens sensíveis. Tal pessoa poder-se-ia recordar da imagem do hospital, de ter sido um dia quente, das pessoas que estavam com ela no momento em que recebeu a notícia.

4) Pode lembrar-se não apenas das circunstâncias sensíveis, mas também dos próprios atos corpóreos. Levando adiante o exemplo supracitado, o homem pode recordar-se do fato que fumou um charuto, tomado de alegria, na porta do hospital.

5) A experiência passada, quando evocada, é vivenciada como possuindo uma certa distância do presente. $\mathrm{O}$ homem sabe, por exemplo, eventos próximos àquela experiência. Pode recordar-se que a data em que seu filho nasceu foi dois dias depois dos atentados de 11 de setembro.

6) É possível, ao analisarmos uma experiência passada, lembrar-nos também dos pensamentos que tivemos na ocasião. Tal homem pode até mesmo lembrar-se de que considerava, com temor, a hipótese de que houvesse complicações médicas.

A memória da experiência passada constitui-se por uma pluralidade de conteúdos, amarrados pelo eu que viveu a experiência. Essa é concebida como uma unidade sintética, composta por muitos conteúdos cujo nó que os liga é justamente o eu. Ao nos lembrarmos de uma experiência passada, temos a consciência de eventos sincrônicos. Além disso, essa experiência é localizada interiormente com uma "distância" do eu atual.

O "eu atual" carrega dentro de sua memória a "vida desse eu", tal qual vivida por dentro e não por fora. Como consequência, a vida do próprio eu não é dada em sentido objetivo, 
como se o eu recordasse a si mesmo vendo-se por um ponto de vista exterior ao corpo ${ }^{19}$. Uma coisa é lembrar-se de um quadro, outra coisa é lembrar-se da experiência com aquele quadro. Aquele que se lembra de um quadro, lembra-se de sua imagem. Já aquele que se lembra da sua experiência de ver um quadro, lembra-se de uma unidade complexa, pois envolve tanto a imagem, como os sentimentos que teve ao vê-lo, as circunstâncias em que o viu, os devaneios que teve em sua presença, as crenças que tinha com relação ao quadro e que foram desfeitas ou confirmadas ao vê-lo.

Mas algo se faz notar: é possível nos lembrarmos de algo sem que nos lembremos da experiência com esse algo. Posso lembrar-me de um brinquedo da minha infância sem que necessite lembrar-me com precisão das experiências e das circunstâncias em que brinquei com ele. Mas o mesmo fenômeno não ocorre com o eu: não podemos pensar o eu do passado em estado puro sem estar referido a nada que não seja ele. Agostinho nota que "o eu do passado" é encontrado imbricado nas memórias de suas próprias experiências, o que exige uma circunstância determinada, algum fator de referência. Isto porque o "eu do passado", fora de suas experiências, revela-se indeterminado, pois ele se determina nas experiências como um sujeito passivo ou ativo. E é justamente por ser o próprio "eu” que sofreu e agiu, que ele é o ponto de ligação não somente entre os conteúdos sincrônicos em uma experiência, como também o que possibilita trazer ao presente o que foi vivido, pois ele "esteve no passado" e ainda "está no presente".

Tais considerações parecem sugerir fortemente que não faz sentido lembrar-se do "eu no passado", sem nenhuma referência desse passado. Mas, como nem tudo que está na memória está no passado, seria possível não exatamente recordar do eu do passado, mas de um "puro eu", fora de qualquer experiência determinada? Ora, tudo o que pode ser pensado, só pode ser pensado porque está na memória, o termo "eu" faz sentido. Ao que parece, a resposta é positiva, mas isso será melhor examinado ao abordarmos a Trindade. Para abordar o eu, serão necessárias algumas distinções sobre os múltiplos sentidos pelo qual se diz: "eu".

Mas já temos dados suficiente para fazer as seguintes constatações: o eu, em sua pureza, é puro sujeito das vivências e não se determina fora de qualquer vivência, não se diferencia de qualquer outro eu. Por outro lado, se ele se determina pelas suas experiências passadas e atuais e nelas se encontra, isso não significa que ele seja suas próprias experiências. As experiências são múltiplas e transcorrem, ao passo que o eu é uno e permanece, embora enriquecendo a si mesmo com as novas experiências. É justamente por ser uma unidade que

\footnotetext{
${ }^{19}$ Devemos observar que esse caso também é possível, pela intuição empática.
} 
se mantém que o "eu" está imbricado em todas suas experiências e é o que pode ligar o presente ao passado. O "eu" está nas suas experiências atuais, mas também esteve em outras experiências, às quais retém em sua memória. Por permanecer, o eu torna-se o denominador comum entre as experiências passadas e presentes. Como consequência, o eu é o ponto de ligação não apenas dos diferentes conteúdos "sincronizados" na experiência passada, como o ponto de ligação entre o seu presente e o seu passado.

Imaginemos que me lembro da alegria que senti em um determinado dia frio. $\mathrm{O}$ sentir frio e o sentir alegria encontram o ponto de ligação no eu. Sei que as duas experiências foram simultâneas. Isso implica que não apenas a imagem do frio foi gravada, nem apenas a imagem da felicidade; também foi gravada a própria simultaneidade das duas experiências.

A bagagem de experiências do eu atual é maior do que a carga de experiências do eu do passado. O que o eu do passado podia recordar diferencia-se do que esse eu atual pode recordar. Mas o que há de mais importante é: as experiências passadas influenciam as experiências atuais do eu, tanto as experiências de si quanto dos demais seres. Por exemplo, a experiência de conversão, em Agostinho, afeta o seu modo de experienciar a si mesmo, os demais homens e criaturas, e até mesmo o próprio passado. Aquilo que antes era motivo de alegria, após sua conversão torna-se motivo de arrependimento. "De fato, em relação às coisas torpes, fui inundado de uma certa alegria que, recordando agora, detesto e abomino (...)" (Conf. X, 21, 31; 2004, p.483)

Agostinho faz questão de marcar a diferença entre o "eu" seguidor do maniqueísmo e o seu "eu" após a conversão. A conversão é uma experiência que abala a estrutura do eu alterando o próprio modo de experienciar a existência. Não por acaso, a conversão era vista como um renascimento espiritual, no qual o homem abandonava sua vida passada, uma vida de morte, para renascer no espírito cristão. O hiato entre a vida anterior e a posterior à conversão era de tal magnitude que, antes de Agostinho, quase a totalidade das biografias dos santos iniciavam a partir da conversão, focando-se nos feitos extraordinários dos santos e a coragem como muitos deles encararam as mais terríveis e cruéis torturas e mesmo o martírio. O que haviam feito antes não parecia objeto de interesse: por que um relato da vida profana haveria de interessar a um Cristão? O que há de instrutivo e exemplar em uma vida entregue ao pecado? Nada há para ser emulado. As Confissões são uma inovação, pois nelas encontramos um relato detalhado da vida de Agostinho antes da conversão. Os erros e os pecados cometidos não oferecem, é verdade, matéria para emulação. Todavia, isso não significa que haja aí algo de instrutivo. Se não servem de exemplo, ao menos valem como 
contraexemplo, no qual o leitor tem a possibilidade de ver escancarada a condição dos homens sem Deus: a futilidade dos fins buscados pelos homens impiedosos, movidos pelas paixões da carne, pelo orgulho, pela vaidade, incapazes de repousar a vontade em algo estável, pois amam o transitório ao invés de amar o eterno. As funestas consequências da ausência da fé devem ser conhecidas por todos. E conhecê-las pode ser útil para aqueles que têm as costas viradas para Deus perceberem que rumam como cegos em direção ao precipício, sempre com o coração atormentado por não encontrarem onde repousar a vontade. A vida profana pode servir para revelar o contraste entre esta e a vida de renascimento cristão.

Mas o contraste não significa uma completa ruptura. Agostinho faz questão de mostrar que há continuidade entre sua vida passada e sua vida presente. Sua conversão ocorre gradualmente, por uma série de experiências, até o momento culminante no jardim de Milão. Essas experiências são as mais diversas, como o encontro com Ambrósio, as insistências de sua mãe, a experiência do luto em decorrência da morte de um amigo, a desilusão com o maniqueísmo, a leitura de Plotino. Tudo isso revela que, além de relatar o passado para mostrar a miséria da vida sem Deus, Agostinho quer mostrar como as experiências profanas podem sutilmente conduzir um homem à conversão. A mão invisível de Deus sempre esteve presente mesmo antes de sua conversão. Por isso querer iniciar a narrativa de sua vida após a conversão é contar uma história de amor já na metade da trama. A providência age por estranhos caminhos e ela já está presente na vida daqueles que irão se converter.

Há ainda um outro aspecto que dá sentido à narrativa de sua vida profana. Mesmo com a conversão, o converso deve assumir e se responsabilizar e estar arrependido dos pecados cometidos. É verdade que a água do batismo lava os pecados, mas ela não exime o homem de se arrepender pelos pecados feitos. Arrepender-se não é chicotear-se, é apenas tornar-se sensível às feridas abertas em nossa consciência pela lâmina do pecado. Pecar não significa apenas agir erroneamente, mas também experienciar erroneamente.

Como pudemos observar, há, antes e depois da conversão, elementos de ruptura e de continuidade. O instante de sua conversão, no jardim de Milão é, com efeito, pontual. Separa, com vívida dramaticidade, o antes do depois: o antes de receber a graça e o depois de tê-la recebido. Mas as próprias tentações não somem com a conversão. A grande diferença é que, com a graça, o coração fica aberto para que uma potência superior possa exercer o seu poder de elevar e tonificar a vontade espiritual. Agostinho procura mostrar que, com o coração aberto à ação da graça, muitas das tentações que antes ele julgava irresistíveis, se tornaram resistíveis. Sob o efeito da graça, os valores superiores são sentidos com mais intensidade, de modo que a vontade espiritual terá mais condições de conduzir a vida com braços firmes. 
Agostinho não se limita a descrever sua vida passada sob uma ótica exterior, mas tal como foi vivida por dentro. Revolve o seu passado com bravura, decidido a iluminar as motivações que, no instante vivido, lhe eram apenas entrevistas, mas que, ainda assim, impulsionaram os seus atos ${ }^{20}$. Com triste amargura, relata algumas das suas alegrias passadas, lamentando-se não em razão delas próprias, mas dos ignóbeis motivos a partir dos quais nasceram. O que antes da conversão the era valoroso, torna-se infame. Os abundantes aplausos que sua afiada e irônica oratória tiravam do público extasiado, antes motivo de efusiva alegria, mostram-se, ao severo olhar do bispo, nada mais do que o gorduroso alimento da vaidade. Sob a ótica do arrependimento, refere-se à oratória esvaziada de conteúdo, tal como ele a concebia e ensinava, em seus devidos termos: a "arte da tagarelice".

Após a conversão, os valores se reestruturam, operando uma transformação nos modos de sentir e de se deixar motivar. Converter é adotar para a própria vida diferentes valores, agindo de acordo com eles. E pela ação da graça esses valores espirituais são profundamente sentidos, de modo que a vontade torna-se capaz de desligar-se dos prazeres rasteiros para se elevar em direção ao céu.

\subsubsection{Memória do conhecimento das artes liberais}

Além dos conteúdos mencionados anteriormente ${ }^{21}$, a memória ainda contém o conhecimento das artes liberais, como a retórica e dialética ${ }^{22}$. Aquele que conhece retórica e a domina é capaz de falar bem, mas poderia, se quisesse, transmitir a arte a outra pessoa, ensinado as figuras de linguagem, os modos de argumentar, de escolher corretamente as

\footnotetext{
${ }^{20}$ As experiências, tais como ocorrem no momento vivido, são estados nos quais a atenção está dirigida ao objeto amado e não ao motivo implícito do amor. Em outras palavras, a atenção era centrífuga no instante da experiência, e as motivações não eram elas mesmas objeto de reflexão. Ao refletir, isto é, ao tornar essas experiências objetos de descrição e análise, as motivações implícitas se manifestam.

${ }^{21}$ Vimos que, em relação aos corpos, a memória retém deles a imagem. De fato, não poderia reter os próprios corpos dentro de si, o que seria absurdo. Deve, por conseguinte, existir uma correlação entre o corpo exterior e o que é retido deste corpo no interior. E essa correlação se dá, na explicação de Agostinho, pela forma ou imagem. No caso das emoções, Agostinho questiona-se em que sentido se poderia falar de uma imagem das emoções. Pode-se, entretanto, falar de impressões que as emoções deixam na alma? O que é certo, é que as emoções, uma vez sentidas, deixam algum vestígio. Sem a noção de vestígio seria impossível pensar em uma emoção passada. Esses vestígios deixados pelos sentidos, Agostinho os denomina de imagem. Um papagaio, por exemplo, guarda em si a imagem dos sons.

22 "Mas essa capacidade da minha memória não encerra apenas essas coisas. Aqui estão também todas aquelas que, tomadas das artes liberais, ainda não se perderam, como que escondidas num lugar interior, que não é lugar. E não levo comigo as suas imagens, mas as próprias coisas” (Conf. X, 9, 16; 2004, p.459).
}

Sed non ea sola gestat immensa ista capacitas memoriae meae. Hic sunt et illa omnia quae de doctrinis liberalibus percepta nondum exciderunt, quasi remota interiore loco, non loco; nec eorum imagines, sed res ipsas gero. Nam quid sit litteratura, quid peritia disputandi, quot genera quaesitionum, quidquid horum scio, sic est in memoria mea, ut non retenta imagine rem foris reliquerim, aut sonuerit aut praeterierit, $($ Conf. $\mathrm{X}, 9,16)$ 
palavras, de seduzir o público e conduzi-lo na direção escolhida. Portanto, a arte possui um lado teórico e um prático. Quem domina a retórica atualiza-a no seu ato de falar ou escrever. Agostinho observa que o mestre de uma arte liberal não a conhece em imagem, como se a imagem estivesse dentro e a própria arte liberal estivesse fora, como se dá com o conhecimento dos corpos, dos quais retemos apenas a imagem e não o próprio ser.

Como havíamos observado, tudo aquilo que pode ser pensado deve estar, de algum modo, no espírito, isto é, na memória. Se podemos pensar numa casa é porque temos algo da casa dentro de nós, isto é, a sua imagem. Mas se podemos pensar na retórica é porque temos algo da retórica dentro de nós? Quando se diz que alguém conhece retórica, se diz de dois modos: o de ter noção do que é a arte e ode conhecê-la no sentido de dominá-la. Portanto, uma coisa é ter, na memória, a noção a respeito da arte, outra é ter a própria arte. Nem todos que sabem o que é a música dominam a arte. Quem domina a arte possui em si não imagem da arte, mas a própria arte.

\subsubsection{Memória dos números e das formas geométricas}

A memória também contém relações e inumeráveis regras da aritmética e da geometria, que não foram impressas por nenhum sentido do corpo. De fato, os números não possuem cor, sabor, peso etc., logo não é possível que tenham entrado por nenhuma das portas carnais. É dentro de si, com o olhar da inteligência, que o homem os conhece. O mesmo ocorre com algumas noções espaciais: por mais fina que seja a teia de aranha, ela será distinta da idéia de linha. Como é possível que o homem pense em uma forma espacial pura? Para Agostinho, as formas espaciais puras estão presentes no espírito e não entraram pelos sentidos. Poderíamos levar adiante o raciocínio e dizer o mesmo da noção de “igual". Nenhum ser sensível é exatamente igual a outro. No entanto, o homem é capaz de pensar a igualdade. De onde tirou essa ideia se não de dentro do próprio espírito? Se o homem tirou tal ideia do espírito, tirou da memória ${ }^{23}$.

\footnotetext{
${ }^{23}$ Item continet memoria numerorum dimensionumque rationes et leges innumerabiles, quarum nullam corporis sensus inpressit, quia nec ipsae coloratae sunt aut sonant aut olent aut gustatae aut contrectatae sunt. Audivi sonos verborum, quibus significantur, cum de his disseritur, sed illi alii, istae autem aliae sunt. nam illi aliter graece, aliter latine sonant, istae vero nec graecae nec latinae sunt nec aliud eloquiorum genus. vidi lineas fabrorum vel etiam tenuissimas, sicut filum araneae; sed illae aliae sunt, non sunt imagines earum, quas mihi nuntiavit carnis oculus: novit eas quisquis sine ulla cogitatione qualiscumque corporis sensibus, quos numeramus; sed illi alii sunt, quibus numeramus, nec imagines istorum sunt et ideo valde sunt. rideat me ista dicentem, qui non eos videt, et ego doleam ridentem me.
}

(Conf., X, 12,19) 
Agostinho ainda define dois tipos de números, os números numeráveis e os números puros. Os números numeráveis se dão através da atividade de contar os objetos sensíveis. Estes são aprendidos através de todos os sentidos do corpo. Já os números puros são usados para se calcular. Estes últimos possuem uma existência própria e estão presentes na memória eles mesmos.

\subsubsection{Os conteúdos inteligíveis da memória}

Para Agostinho toda palavra é um signo e só possui significado caso se refira a alguma coisa. Quando ouvimos o som "pedra", o reconhecemos e sabemos o significado. Mas analisando detidamente, o processo de escutar e reconhecer pressupõe alguns componentes: 1) o som "pedra". 2) a imagem do som "pedra" na memória. 3) a imagem da pedra na memória 4) a própria pedra.

Por termos a imagem do som "pedra" gravada na memória, isto é, da sequência de fonemas, podemos reconhecer o signo. Mas isso de nada adiantaria se não tivéssemos associada na memória a imagem do som "pedra" com a imagem da pedra captada pelos sentidos ${ }^{24}$. Por isso, ao escutarmos o som, a imagem da pedra emerge em nossa mente; mas também sabemos que essa imagem mental não é a pedra real, mas diz respeito a esta. Mas o que dizer quando escutamos o vocábulo "três"? Seria correto considerar que, neste caso, teremos:

1) O som da palavra recebida pelos sentidos.

2) A imagem do som gravada na memória, pela qual reconhecemos o signo.

3) A imagem interior do número três.

4) O próprio número três.

Para Agostinho, não é assim que se passa. Isso porque o significado da palavra "três" não se refere a algo que está fora do espírito, mas algo presente nele próprio. Ora, aquele que conhece o número três, ao pensa-lo, não evoca sua imagem, mas o próprio número. Já aquele que pensa em uma pedra, não possui a própria pedra dentro de si. $\mathrm{O}$ conhecimento da pedra está dentro do espírito, a própria pedra está fora. Já o significado de "três", que está dentro do espírito, é o próprio número três. Quem pensa no três, tem o próprio três diante do olhar do espírito $^{25}$.

\footnotetext{
${ }^{24}$ Se um papagaio dissesse "pedra". Isso significa que o papagaio tem a imagem do som "pedra" gravada em sua alma. No entanto, desconhece o significado.

${ }^{25}$ É fácil apreendermos essa diferença no caso da palavra designar um objeto corporal. O que o som "pedra" significa é a imagem da pedra guardada na memória, acompanhado do juízo de que essa imagem corresponde a
} 
Em certa passagem do livro I das Confissões, Agostinho disserta como um bebê aprende os nomes das coisas. Antes de aprender a linguagem, o bebê já tem dentro de si as imagens das coisas e tem vontades direcionadas para determinados objetos. Toda vontade é vontade de algo: só podemos querer algo se temos dentro de nós a imagem desse algo. Embora o bebê tenha a vontade e vislumbre interiormente a imagem do que quer, falta-lhe o nome do que quer. O bebê vai conhecendo as coisas antes de saber o nome delas. Por isso, embora queira comunicar suas vontades, não possui os meios de fazê-lo, de modo que ele se vê sem outra alternativa senão berrar e chorar, seja para exigir algo, seja para se vingar quando não lhe dão o que quer. Mas essa situação não dura para sempre, pois o bebê, movido por sua vontade de expressar com precisão suas vontades, passa a observar atentamente as pessoas dirigindo-se às coisas com determinados nomes, os quais, paulatinamente, ele vai decorando. A manifestação mais visível deste processo é que cada pessoa usa os signos da língua em que nasceu. Mas os significados são os mesmos para qualquer língua. Uma palavra pode significar a mesma coisa em grego ou em latim, o que não impede que algumas línguas não tenham termos para designar algumas entidades inteligíveis.

Observando exteriormente os homens dirigindo-se às coisas com determinados nomes, o bebê aprende a nomear os objetos corpóreos. Mas como o espírito humano aprende os significados de palavras que dizem respeito às realidades incorpóreas, como no caso dos termos "essência", "tempo", "alma", "número". Aquilo que surge na mente ao se pronunciar essas palavras são realidades que a mente descobre dentro de si mesma, posto que não são dadas por sentido algum. Dizem respeito às realidades inteligíveis, as quais não são transcendentes ao espírito, mas estão elas mesmas presentes no espírito, de modo que o olho da mente, por uma comunhão de natureza, é capaz de vislumbrá-las. Elas são incorporais tais como o olho da inteligência. ${ }^{26}$ São essas observações que Agostinho faz ao constatar que são três espécies de questões:

Mas, porém, quando ouço dizer que há três espécies de questões: "se uma coisa é; o que é; e como é", tenho as imagens dos sons de que se compõem estas palavras e sei que eles passaram pelo ar, com ruído, e já não existem. Mas as próprias coisas que são significadas por esses sons não as atingi por nenhum sentido do corpo. (Conf., X, 10, 17; p.2004, p.461)

uma realidade exterior, a pedra exterior. A imagem interior e a imagem exterior (a visão da pedra) e a própria pedra (a pedra transcendente à consciência) posssuem semelhança de forma.

${ }^{26}$ De modo análogo, a alma só consegue ver os seres corporais porque conta com os sentidos carnais, os quais são da mesma natureza dos corpos:como o olho o ouvido, a pele, etc. Se o olho é danificado, a alma perderá a visão. 
At vero, cum audio tria genera esse quaestionum, an sit, quid sit, quale sit, sonorum quidem, quibus haec verba confecta sunt, imagines teneo, et eos per auras cum strepitu transisse, ac iam non esse scio. res vero ipsas, quae illis significantur sonis, neque ullo sensu corporis attigi neque uspiam vidi praeter animum meum(...).(Conf., X, 10, 17; p.2004, p.460)

Em seguida Agostinho procura explicar como essas coisas entraram em sua memória:

Donde e por onde entraram na minha memória? Não sei como. Pois, quando as aprendi, não dei crédito ao coração de outra pessoa, mas reconheci-as no meu, e admiti que eram verdadeiras e confiei-as no meu, como que depositando-as onde pudesse buscá-las quando quisesse. Portanto, estavam lá, e já antes de as ter aprendido, mas não estavam na memória. Quando pois e porque motivo, ao serem proferidas, as reconheci e disse: "Sim, é verdade"? A não ser que o fizesse porque já estavam na minha memória, mas tão afastadas e escondidas, como que nas concavidades mais recônditas, de tal maneira que, se de lá não fossem arrancadas, por sugestão de alguém, talvez eu não pudesse pensar nelas. (Conf., X, 10, 17; p.2004, p.461)

Unde et qua haec intraverunt in memoriam meam? nescio quomodo; nam cum ea didici, non credidi alieno cordi, sed in meo recognovi, et vera esse approbavi et commendavi ei tamquam reponens, unde proferrem, cum vellem. ibi ergo erant et antequam ea didicissem, sed in memoria non erant. ubi ergo, aut quare, cum dicerentur, agnovi et dixi: ita est, verum est, nisi quia iam erant in memoria, sed tam remota et retrusa quasi in cavis abditioribus, ut, nisi admonente aliquo eruerentur, ea fortasse cogitare non possem? (Conf., X, 10, 17; p.2004, p.460)

Interessante notar o malabarismo dialético antes de Agostinho chegar à sua conclusão de que os inteligíveis estavam na "memória recôndita". Primeiro, ele nega essa hipótese: "Portanto, estavam lá, e já antes de as ter aprendido, mas não estavam na memória." Em seguida, ele nega essa afirmação e, para isso, estende as fronteiras da memória, dando cidadania a essas ideias inteligíveis que habitam em cavidades secretas. Mas essa extensão não é fortuita, pois, quando ele escuta a respeito dessas realidades intelifíveis, é tomado de certeza. E ele sabe que essa certeza não deriva da confiança depositada na autoridade de quem lhe transmitiu as idéias e as regras eternas, mas da visão interior, que as revela tais como são. Todavia, embora essas verdades não se sustentem na autoridade alheia, é preciso observar que o "outro" exerce a importante função de indicá-las para que o ouvinte as encontre dentro de si.

Advertir para que o homem encontre dentro de si próprio as verdades constitui o trabalho do verdadeiro professor, caso o tema seja as realidades inteligíveis. Quando o mestre disserta oralmente aos seus pupilos, os significados das palavras não vão enganchados junto aos sons que saem de sua boca. Cabe aos alunos encontrarem em si mesmos os significados dos sons. O mestre nada mais pode fazer do que apontar os inteligíveis, seja com símbolos, seja com outros termos da língua que seja de conhecimento dos alunos. Processo semelhante a alguém que usa o dedo indicador para apontar uma constelação, que, sozinhos, não seríamos 
capazes de ver, ainda que estivéssemos livres para ver a massa estelar. Caso o olhar da mente do aluno seja bem sucedido e visualize o objeto nas profundezas da memória, restará apenas resgatá-lo, colocando-o à luz, de modo que, a partir de então, ele se torne disponível ao pensamento. Pela indicação, é possível que o homem consiga intuir o conteúdo inteligível, o que não ocorre necessariamente, por exemplo, àqueles que possuem o olhar da inteligência embaçado pelos vapores emanados de um coração vil.

No que diz respeito às realidades inteligíveis, como é possível o erro, se tudo gira em torno de ver ou não ver? É possível porque nem sempre o olhar de nossa mente se detém e avalia adequadamente os contornos da realidade inteligível vista, e, como se não bastasse, os inteligíveis alimentam entre si relações dificilmente percebidas em um primeiro golpe de vista. Percebe-se com relativa clareza o que são os axiomas, que $\mathrm{A}=\mathrm{A}$; mas nem sempre a verdade dos teoremas é facilmente visualizada pelo olhar da inteligência. Sabemos nitidamente o que são os números primos, mas o teorema, segundo o qual não existe um maior número primo, não é facilmente visualizado ${ }^{27}$. E, como havíamos exposto nos primeiros capítulos, pode acontecer de alguém raciocinar e raciocinar sobre essa questão sem que chegue à visão intelectual que lhe daria a resposta, o que não significa que ela não exista. O problema é que a pessoa pode tomar como certo, sem que tenha uma visão clara, que existe o maior número primo. Eis aí o erro: tomar como evidente algo o qual não temos evidência.

Os conhecimentos a respeito das realidades históricas são diferentes dos conhecimentos que versam sobre as realidades inteligíveis. Se um professor diz um disparate sobre uma regra da geometria, o aluno pode, sozinho, refutá-lo. Basta que veja dentro de si que a afirmação não corresponde à realidade. Por isso, um único homem pode negar sozinho mil geômetras que compartilhem do mesmo erro. Isso não ocorre com os fatos históricos. Se escutamos alguém que dizer ter visto um elefante no interior do Brasil, ou confiamos no seu testemunho ou não. Não temos inerentemente na memória a realidade exterior, nem mesmo a história do mundo. Se cremos que nosso pai é nosso pai é porque confiamos no relato de nossa mãe. Se cremos que Cristo existiu e fez milagres é porque cremos no testemunho de quem afirmou ter visto.

Já no caso da aprendizagem das realidades inteligíveis, ao contrário, o que o professor pode fazer é guiar o estudante para que ele tire tais ideias e as relações essenciais entre elas da

\footnotetext{
${ }^{27}$ Poderíamos complexificar e questionar: é possível que, com um número finitos de axiomas e com um número finito de passos, podemos provar todos os teoremas verdadeiros da aritmética? Ora, temos a visão intelectual do que é um axioma, temos a visão intelectual do que é um teorema, mas talvez não tenhamos a visão intelectual da solução da resposta.
} 
profundidade da memória recôndita e, em seguida, deposite-as em outra parte da memória, tornando-as facilmente disponíveis, para que possa lembrá-las facilmente quando quiser.

\subsubsection{As duas memórias. Memória disponível e memória profunda}

Considerando a memória enquanto um lugar ou região, podemos distingui-la em duas: uma memória recôndita e uma memória disponível. Aquilo que está na memória recôndita, ao ser percebido pelo olhar da mente, é depositado na memória disponível. Por exemplo, quando entendemos pela primeira vez o significado do termo qualidade, o significado que estava na memória profunda passa para a memória disponível. Quando isso ocorre, diz-se que a pessoa aprendeu o que significa "qualidade". Portanto, o aprendizado das coisas que não possuem imagem ocorre da seguinte forma:

Por conseguinte, verificamos que aprender essas tais coisas, cujas imagens não absorvemos pelos sentidos, mas vemos, tal como são, dentro de nós mesmos, em si mesmas, sem imagens, não é outra coisa senão como que recolher, pensando, aquilo que a memória, indistinta e desordenadamente, continha, e fazer com que, reparando nelas, as coisas, que estão como que colocadas à disposição na própria memória, onde antes, dispersas e esquecidas, estavam ocultas, ocorram facilmente à atenção já familiar. E quantas coisas desta natureza a memória encerra, coisas que já foram encontradas e tal como disse, colocadas à disposição, e se diz que nós aprendemos e conhecemos! (Conf., X, 11, 18; 2004, p.463)

Quocirca invenimus nihil esse aliud discere ista, quorum non per sensus haurimus imagines, sed sine imaginibus, sicuti sunt, per se ipsa intuscernimus, nisi ea, quae passim atque indisposite memoria continebat, cogitando quasi colligere atque animadvertendo curare, ut tamquam ad manum posita in ipsa memoria, ubi sparsa prius et neglecta latitabant, iam familiari intentioni facile occurrant. Et quam multa huius modi gestat memoria mea, quae iam inventa sunt, et sicut dixi, quasi ad manum posita, quae didicisse et nosse dicimur. (Conf., X, 11, 18; 2004, p. 462)

Podemos dizer que aprender consiste: 1) numa visão interior (intus cernimos). 2) essa visão interior acontece quando o pensamento reúne em um trabalho da alma o que estava desordenadamente disposto na memória; ${ }^{28} 3$ ) após reunir o que estava esparso, o conhecimento deve ser passível de se tornar, com facilidade, presente novamente ao olhar do pensamento $^{29}$. Quando isso ocorre, podemos dizer que aprendemos algo, que temos o conhecimento deste algo inteligível.

\footnotetext{
${ }^{28}$ Em outras palavras, o cogito articula racionalmente esses conteúdos, da uma ordem a eles. Quem apreende uma relação entre um triângulo e um quadrado, reune um elemento com um outro, os organizando mentalmente.

${ }^{29}$ Para Husserl, uma verdade é dita conhecimento, quando temos a liberdade de reproduzi-la e percebê-la em nossa consciência como sendo a mesma verdade.
} 


\subsubsection{Memória dos sentimentos}

Quando nos lembramos de uma coisa corporal, não evocamos a própria coisa, mas a sua imagem. Isso por necessidade. Não poderíamos evocar a própria coisa, pois a alma, que é incorporal, não guarda dentro de si coisas corporais, mas apenas a imagem delas. A memória guarda a imagem da pedra porque não pode guardar a própria pedra. Ao recordarmos de um elefante, não ficamos mais pesados. Ora, mas se os sentimentos são incorporais, não teríamos, por princípio, necessidade de guardar na memória a imagem do sentimento; poderíamos guardá-los eles próprios. Não seria razoável, portanto, considerar que, ao recordar a alegria, trazemos a própria alegria para a superfície do espírito? Mas se assim fosse, questiona Agostinho, por que razão, quando nos lembramos da alegria, não ficamos alegres? Isso parece sugerir que, se não nos alegramos, é porque não trazemos a própria alegria, mas a imagem da alegria.

É neste ponto que Agostinho formula uma interessante teoria para explicar como é possível se lembrar de um sentimento sem senti-lo. Afirma que memória é uma espécie de estômago da alma ${ }^{30}$. A teoria pode ser posta brevemente do seguinte modo: enquanto temos na boca um alimento, percebemos dele o sabor: se é amargo, doce etc. Quando passa ao estômago, ele continua dentro de nós, entretanto, não mais sentimos o sabor. Do mesmo modo, os afetos, após exercerem seus efeitos, passam à memória e ali não mais são sentidos. Ao lembrarmo-nos dos afetos, estes passam do estômago para a boca, como um animal que rumina, mas diferentemente deste, não mais sentimos em nossa boca o sabor. E é justamente neste ponto que Agostinho marca o limite da metáfora.

Talvez, portanto, assim como a comida é tirada do estômago, pela ruminação, assim também estas coisas são tiradas da memória, pela ruminação. Então porque é que quem as discute, isto é, quem as recorda, não sente, na boca do pensamento, a doçura da alegria e a amargura da tristeza? Porventura as duas situações são dissemelhantes por não serem semelhantes em todos os aspectos? $\mathrm{Na}$ verdade, quem, de livre vontade, falaria de tais coisas, se, todas as vezes que nomeamos a tristeza ou o medo, outras tantas fôssemos obrigados a sentir tristeza e medo? (Conf.,X, 14, 22; 2004, p.469)

\footnotetext{
30 “O fato é que a memória é, por assim dizer, o estômago da alma. A alegria e a tristeza são como alimento, que ora é doce, ora é amargo. Quando tais emoções são confiadas à memória, podem ser aí despertadas como num estômago, mas perdem o sabor. Seria ridículo querer comparar sentimentos com alimentos; no entanto não são completamente diferentes". (Conf., X, 14, 21, 2004, p.285)

"Nimirum ergo memoria quasi venter est animi, laetitia vero atque tristitia quasi cibus dulcis et amarus: cum memoriae commendantur, quasi traiecta in ventrem recondi illic possunt, sapere non possunt. ridiculum est haec illis similia putare, nec tamen sunt omni modo dissimilia”. (Conf., X, 14, 21)
} 
Forte ergo sicut de ventre cibus ruminando, sic ista de memoria recordando proferuntur. cur igitur in ore cogitationis non sentitur a disputante, hoc est a reminiscente, laetitiae dulcedo vel amaritudo maestitiae? an in hoc dissimile est, quod non undique simile est? Quis enim talia volens loqueretur, si quotiens tristitiam metumve nominamus, totiens maerere vel timere cogeremur? (Conf.,X, 14, 22; 2004, p.468)

\subsubsection{A memória da memória}

O que é que surge diante do olhar da mente quando pensamos na memória? Temos ela própria ou temos uma imagem dela? Como já havíamos observado, tudo aquilo que pode ser pensado deve estar na memória ou deve ter nela suas partes constituintes. De fato, aquele que pensa na saúde tem a imagem da saúde na memória. A questão que Agostinho coloca é a seguinte: ao nomearmos a palavra, o que nos vem à mente? Se nomeamos o sol, o que temos presente na mente é a imagem do sol e não o próprio sol. Se nomeamos o número, temos presente na mente não a imagem do número, mas o próprio número. Mas retornando à questão inicial: quando nomeamos a memória e entendemos o que isso quer dizer, o que temos presente na mente? A própria memória ou a imagem da memória?

Nomeio os números de que nos servimos para fazer cálculos; e logo estão presentes na minha memória não as suas imagens, mas eles mesmos. Nomeio a imagem do sol e esta está presente na minha memória; não é a imagem da sua imagem que eu recordo, mas a própria imagem. É ela que se me torna presente, quando a relembro. Nomeio a memória e reconheço o que nomeio. E onde a reconheço senão na própria memória? Acaso também ela está presente a si mesma por meio da sua imagem e não por si mesma? (Conf. X, 15, 23; 2004, p.471).

nomino numeros, quibus numeramus; en assunt in memoria mea non imagines eorum, sed ipsi. nomino imaginem solis, et haec adest in memoria mea; neque enim imaginem imaginis eius, sed ipsam recolo: ipsa mihi reminiscenti praesto est. nomino memoriam et agnosco quod nomino. et ubi agnosco nisi in ipsa memoria? num et ipsa per imaginem suam adest ac non per se ipsam? (Conf. X, 15, 23)

Para que continuemos a investigação é necessário observar o seguinte. Tudo aquilo que o espírito pode se lembrar, deve estar no espírito. Tudo o que está no espírito pode ter entrado pelas portas dos sentidos ou são realidades que o espírito encontrou em si mesmo ${ }^{31}$. A dificuldade de Agostinho é que tanto os afetos quanto os números e a própria memória possuem em comum o fato de serem realidades que o espírito encontra dentro de si. Todavia, os números estão eles mesmos na memória. Já os afetos podem estar de dois modos no

\footnotetext{
${ }^{31}$ Mas como sei o que é um ornitorrinco sem nunca ter visto um? Sei o que é um ornitorrinco na medida em que considero verdadeiro o relato de quem o viu. E fundamentado naquilo que conheço, entendo o relato, procurando montar a imaginar do ornitorrinco conforme o que foi relatado. Um cego de nascença pode apenas ter uma noção vaga do que sejam as cores. Em todo caso, é necessário que o cego creia no relato dos outros para que saiba que existam as cores.
} 
espírito: vivos, perturbando a alma, ou enquanto imagem, como ocorre quando uma paixão extinta é recordada. A memória guarda apenas a imagem dos afetos e não os próprios afetos. Mas dentro dessa ordem de classificação, como inserir a memória? ${ }^{32}$ Para Agostinho, nas Confissões, quando nomeamos a memória, não há presente na memória a imagem da memória, mas a própria memória. Se me lembro do significado do termo memória é porque tenho memória da memória.

\subsubsection{A memória do esquecimento}

Se nós aplicarmos a mesma ordem de raciocínios anteriormente feita ao caso esquecimento, chegamos a algumas estranhas conclusões. Ao nomearmos o "esquecimento", sabemos do que se trata. Isso é fato. Mas de que modo aprendemos o que é o esquecimento? Ora, se conhecemos o esquecimento é porque ele já esteve presente ou está presente.

De que forma poderei dizer que a imagem do esquecimento, e não o próprio esquecimento, é conservada na minha memória, quando me lembro dele? $\mathrm{E}$ de que forma direi isto, uma vez que, quando se imprime na memória a imagem de cada coisa, é necessário que antes esteja presente a mesma coisa, a partir da qual se possa gravar aquela imagem? (Conf. X, 16, 24; 2004, p.473).

quo pacto dicam imaginem oblivionis teneri memoria mea, non ipsam oblivionem, cum eam memini? quo pacto et hoc dicam, quandoquidem cum imprimitur rei cuiusque imago in memoria, prius necesse est, ut adsit res ipsa, unde illa imago possit imprimi? (Conf. XVI, 24; 2004, p.472).

Partamos da hipótese de que, ao nomearmos o esquecimento, o que nos vem ao espírito seja a "imagem do esquecimento" e não o próprio esquecimento. Nesse caso, a memória do esquecimento seria comparável à memória do medo. O fato de vivenciarmos o medo deixa no espírito uma marca, a imagem do medo, a qual poderemos evocá-la a qualquer momento. Mas se transportamos esse caso para o esquecimento, um obstáculo logo surge. Como é possível que o esquecimento deixe sua marca na memória? Afinal, se o esquecimento é a ausência da memória, é inconcebível que ele deixe uma marca na memória, pois sua presença implica, por definição, a ausência da memória. Logo, não há como o esquecimento deixar uma marca na memória.

\footnotetext{
${ }^{32}$ Mas esse não é o caso da memória, não preciso crer nos relatos dos outros para saber que tenho uma memória. E de fato, experimento em mim mesmo o ato de recordar. Portanto, ou a memória já esteve presente na mente ou ela está na mente. Se sei o que é a visão, é porque ela está presente ou já esteve presente. Alguém que ficou cego sabe o que é a visão porque se lembra da visão, tem dentro de si a imagem da visão. Mas aquele que tem visão sabe o que é a visão tanto porque ela está presente quanto porque já esteve presente. Ora, a memória está sempre presente ao espírito.
} 
Uma das dificuldades de apreender o pensamento de Agostinho resulta da maneira razoavelmente indeterminada como ele usa nas Confissões o termo memória (memoria). Nesta obra ainda não distinguiu com precisão suficiente os sentidos do termo memória, evitando ambiguidades, pois designa com a mesma expressão ora faculdade retentiva, ora a faculdade de se lembrar, ora o "lugar" onde estão armazenados os conteúdos da memória, e mesmo esse lugar é por vezes distinguido, como vimos em memória recôndita e memória disponível. Além do mais, ele não distingue claramente nas Confissões a relação entre o olhar da mente e os vários aspectos da memória. É bem verdade que ele já usa o conceito de olhar da razão, como já observamos em De quantitate animi. Mas ali, referia-se, sobretudo, à apreensão do inteligível. Posteriormente, Agostinho distinguirá o olhar da mente em sentido amplo e o olhar do intelectual em sentido restrito. O olhar intelectual será concebido como uma possibilidade do olhar da mente, que se atualiza quando vemos as realidades inteligíveis. Na Trindade Agostinho conseguirá expor uma visão mais clara da dinâmica da alma humana, afirmando claramente que pensar algo é ter esse algo diante do olhar da mente.

Também Agostinho refere-se ao "esquecimento" sem levar em consideração que o termo diz respeito a diferentes fenômenos. Afirmar, como ele faz, que o esquecimento é ausência da memória parece mais uma definição lógica do que uma apreensão dos fenômenos ligados ao esquecimento.

Em primeiro lugar, o esquecimento pode ser concebido como um estado no qual nos esforçamos por recordar um conteúdo qualquer, sem que obtenhamos sucesso. Não se trata da ausência da memória, mas da ausência de um conteúdo que cremos que deveria estar em nossa memória.

Em segundo lugar, podemos designar esquecimento o "apagar-se" de um conteúdo da memória. Neste caso, só tomamos consciência do conteúdo apagado quando tentamos dele nos lembrar. Esse esquecimento entendido como extinção de um conteúdo da memória ocorre sem que tenhamos consciência: ninguém vê com os olhos da mente um conteúdo da memória se extinguir. Chegamos ao conhecimento dessa extinção por vias racionais. Sei que comi algo domingo retrasado, mas não me recordo o quê, me esqueci. Sei que esqueci porque deduzo que comi algo domingo retrasado, ainda que não me lembre do quê. Em outras palavras, o esquecimento, entendido como a extinção do conteúdo, ocorreu sem que eu o percebesse. É diferente de quando o ato de recordar falha, isto é, quando tentamos relembrar algo que está na memória, embora temporariamente não consigamos.

Há ainda um terceiro sentido pelo qual se entende o termo "esquecimento". Ocorre quando não nos lembramos de algo determinado no momento em que deveríamos lembrar, 
como quando "esquecemos" de tomar o remédio às oito horas. Neste caso, tomamos consciência do esquecimento justamente no momento em que nos lembramos de que deveríamos ter tomado o remédio.

O que entra em cena na descrição dos três casos é uma distinção entre ter algo na memória e ter algo na consciência. O nosso atual "ter algo na consciência", que Agostinho designa por ter "algo diante do olhar da mente", é justamente um dois eixos de investigação na Trindade. Isso lhe trará novas luzes ao seu pensamento, pois a consciência caracteriza-se pela sua temporalidade, pela corrente de pensamento, e por sua incapacidade de atualizar tudo o que está na memória a um só tempo. É significativo que, após abordar a memória no capítulo X, o capítulo XI das Confissões tenha como tema central o tempo. Estes dois temas aparecem magnificamente articulados na Trindade, como uma poderosa síntese; verá a memória a partir da temporalidade da consciência. Já no capítulo X das Confissões Agostinho retoma o tema do esquecimento e o aborda sob um novo ângulo, mais fenomenológico, por assim dizer. É o que veremos na seção seguinte.

\subsubsection{O esquecimento como dificuldade de recordar}

No capítulo XVIII do livro X das Confissões Agostinho, ao invés de investigar o esquecimento pautando-se em sua definição, "ausência da memória", ele irá observar justamente o fenômeno mental relativo ao esforço de se lembrar de algo sem sucesso. ${ }^{33}$ Partirá da seguinte questão: como é possível que queiramos lembrar de algo? Para que queiramos lembrar de algo, é preciso antes que saibamos do que estamos tentando nos lembrar. Mas como sabemos o que estamos tentando nos lembrar, se é justamente o que esquecemos? Ora, tal fato parece impossível. Se esquecêssemos por completo algo, nem poderíamos nos esforçar para lembrar desse algo, pois não saberíamos sequer o que procurar. Parece absurdo querer se lembrar de uma coisa da qual não se tem a mínima noção do que seja, assim como não é possível amar o que é absolutamente desconhecido em todos os seus aspectos.

Agostinho clareia o problema com um exemplo, o de uma mulher procurando um dracma com uma lanterna. Ela tem dentro de si, em sua memória, a imagem do objeto que procura, condição necessária para que ela possa procurar o dracma perdido. Se ela encontrar uma outra moeda, ela saberá que não é aquilo que procura. Do mesmo modo, só é possível querer lembrar de algo se somos capazes de recordar uma parte daquilo que procuramos

\footnotetext{
${ }^{33}$ Pelo fato de o pensamento se dar como em um fluxo, como já observamos, a presença da vontade não é facilmente discernida. É de se supor que Agostinho tenha inferido a presença da vontade no pensamento a partir do fenômeno do esquecimento. De fato, a vontade de se lembrar coloca em evidência a existência de uma vontade que tem como alvo o próprio espírito, mais particularmente, a memória.
} 
lembrar. É partindo da parte lembrada que nos esforçamos para lembrar a parte esquecida. A título de ilustração, tomemos o exemplo de uma pessoa que procura se lembrar do nome de um ator. Ela se lembra, por exemplo, da face do ator, lembra-se de alguns filmes de que ele participou, que o ator tem um nome e lembra até mesmo que já soube o nome dele. E mais, quando sugerimos a essa pessoa nomes que não correspondem ao nome do ator, ela sabe que não são o nome que procura. Mesmo quando emergem ao olhar do seu espírito outros nomes que não são o do ator, a pessoa igualmente os recusa, como a mulher que, ao encontrar outras moedas, sabia que não eram o dracma procurado. Mas se em um lampejo lhe ocorre o nome do ator, ela saberá que encontrou o que estava procurando.

Para Agostinho, esse fenômeno só pode ocorrer porque o homem lembra-se de certos aspectos do todo, que remetem a outros aspectos que não lhe vêm facilmente à mente. Por isso, o objeto se encontrava "mutilado na memória". No exemplo supracitado, quando o nome do ator é lembrado, o objeto volta a se integrar, para ser novamente guardado na memória. E se tal pessoa quiser se lembrar do nome do ator depois de pouco tempo, mais facilmente ela irá conseguir.

\subsubsection{Papel da memória no reconhecimento}

O exemplo da mulher que procura o dracma coloca em relevo o papel da memória em qualquer ato de reconhecimento. Aquele que reconhece algo é porque tem a imagem desse algo dentro de si. "Não dizemos que encontramos o que estava perdido, se não o reconhecemos, nem o podemos reconhecer, se não o lembrarmos: mas aquilo que, de fato, estava perdido para os olhos, conserva-se na memória." (Conf. X, 19, 28; 2004, p.477) ${ }^{34}$.

A condição de todo procurar é ter em mente o procurado. E encontrá-lo é reconhecê-lo. Mas não seria possível generalizar isso e dizer que toda percepção, em certa medida, é um reconhecimento? De fato, tudo aquilo que percebemos, reconhecemos como sendo algo. Mesmo quando vemos algo que nunca havíamos visto, esse algo é reconhecido como pertencente a alguma classe de coisas. Imaginemos o caso de um homem que certo dia viu seu amigo morrer vítima da mordida de uma cobra venenosa. Se anos depois, ao andar pela floresta, ele encontrar uma outra cobra, é de se esperar que ele sentirá medo. Sentirá medo porque reconheceu como sendo uma cobra, como pertencente à classe das cobras.

Todavia, essa investigação nos leva a observar um outro aspecto aqui envolvido. Por que sentirá medo se não a conhece? Afinal aquela cobra não é a mesma cobra que outrora

\footnotetext{
${ }^{34}$ nec invenisse nos dicimus quod perierat, si non agnoscimus, nec agnoscere possumus, si non meminimus: sed hoc perierat quidem oculis, memoria tenebatur. (Conf. X, 19, 28; 2004, p.477).
} 
havia matado seu amigo. Como ele associa aquele objeto a esse? Isso ocorre, devido à semelhança entre ambas. Portanto, o que ele guarda da cobra não é apenas a imagem da cobra singular, mas uma imagem genérica da cobra, suficientemente elástica para abarcar outras cobras. Mas essa descrição não basta: tal homem só sente medo porque guardou não apenas a pura imagem visual, mas também uma imagem mental do que a cobra pode fazer. Ele tem a imagem mental da cobra atacando seu amigo. Mas por que aquela cobra não haveria de querer apenas atacar o seu amigo? A imagem mental que ele tem da cobra atacando seu amigo deve ser de algum modo também generalizada e "transferida" para ele. A pura imagem mental não pode fornecer o raciocínio: "se a cobra atacou o meu amigo, isso significa que a cobra pode me atacar, porque, para a cobra, eu sou tão nutritivo quanto meu amigo". Em virtude disso, dessas generalizações, que envolvem algum tipo de operação não sensível da alma, ele crê que ela é um animal que oferece perigo.

O que ocorreu é que a imagem interna da cobra não é exatamente a cópia da imagem daquela cobra que ele viu, mas uma imagem genérica. Trata-se do problema entre o singular, dado à percepção, e o "conceito" que abarca toda uma classe de seres individuais. Uma coisa é aquela cobra singular observada em um instante datado, outra é aquilo que Agostinho denomina imagem genérica.

\subsubsection{A participação da memória na escuta e na leitura}

O processo pelo qual o homem chega aos conceitos das coisas corporais não é explicado por Agostinho. Ele limita-se a afirmar a respeito de "imagens genéricas". Aquele que escuta uma fala só consegue entender o que escutou porque conhece os significados das palavras ditas. Escutando atentamente alguém falar, o que ocorre no ouvinte é que os significados das palavras escutadas são trazidos incessantemente da memória para o olhar da mente. Sem isso, ele escutaria apenas o som que sai da boca de alguém e não entenderia o sentido. Aquele que escuta não só está trazendo os significados ao olhar da mente, mas também está compondo imagens, está com a imaginação ativada. Se escuto algo como "cisne preto na montanha verde", sou capaz de compor a imagem mental desta cena tendo como matéria-prima as imagens genéricas que tenho dentro de mim.

O que me represento são as imagens dos corpos que o narrador quer significar com suas palavras e sons. Ora, penso nessas imagens, não recordando, mas ouvindo.

Mas se observarmos atentamente nem mesmo assim se esgota a capacidade da memória. Pois eu não poderia entender o narrador e não me teria lembrado de cada uma de suas frases - mesmo supondo que o que diz eu o 
estivesse ouvindo pela primeira vez -, nada deixaria de corresponder a alguma recordação genérica guardada por ela. (De trinit. XI, 14, 8; 2005, $357)$.

- Non ipsas uoces loquentis dico ne quisquam putet in illam me exisse trinitatem quae foris in sensibilibus et in sensibus agitur, sed eas cogito corporum species quas narrans uerbis sonisque significat, quas utique non reminiscens sed audiens cogito. Sed si diligentius consideremus, nec tunc exceditur memoriae modus. Neque enim uel intellegere possem narrantem si ea quae dicit et si contexta tunc primum audirem, non tamen generaliter singula meminissem. (2009, De trinit. XI, 14, 8).

\subsubsection{A memória da beatitude}

Ao tratar da memória da felicidade, Agostinho inicia com a seguinte sentença: "Todos querem ser felizes (beatitude)". Se ninguém duvida disso é porque todos sabem o que é a felicidade. E, se sabem é porque ela está na memória. Mas se ela está na memória, como ela foi parar ali? Por experiência? Ou por ser a felicidade uma noção que está dentro da memória de todo homem, quer ele tenha experienciado quer não.

O primeiro procedimento de Agostinho para resolver o problema é investigar qual a natureza de seu conteúdo. A memória da felicidade seria do mesmo gênero da memória de um objeto exterior, tal como a memória que ele tem de Cartago? A resposta é negativa, pois a vida feliz não se vê com os olhos do corpo. Posto que a vida feliz é algo que não provém dos sentidos, haveria o homem de conhecê-la tal como conhece os números, já que ambas são realidades incorporais? Agostinho também refuta essa hipótese. Quem tem os números na memória disponível não precisa se esforçar em alcançá-los. Já aquele que tem na memória o significado da vida feliz procura alcançá-la. Ora, se alguém a deseja é porque não a possui dentro de si. Seria, portanto, equivalente ao caso da eloquência? Afinal, algumas pessoas sabem o significado do termo eloquência, mas ainda assim procuram alcançá-la. Agostinho, também refuta essa hipótese. Quem tem noção do que tal arte significa é porque já ouviu, com prazer, uma pessoa falar eloquentemente. Em outras palavras, o conhecimento desta arte exige observação exterior aliada a um sentimento íntimo de prazer estético. No entanto, não é o caso da felicidade, pois “(...) não é por nenhum sentido do corpo que experimentamos nos outros a vida feliz" (Conf., X, 21, 30; 2004, p.483).

Em seguida Agostinho questiona-se se conhecemos a felicidade (beatitude) do mesmo modo como conhecemos a alegria (laetitia). Ora, mesmo estando tristes é possível que lembremos da alegria, a qual é incorporal, pois não podemos tocá-la, cheirá-la etc. Ademais, todos já experimentaram a alegria e, portanto, todos têm dentro de si a noção da alegria. Mas, 
afinal, qual a diferença entre a vida feliz e a alegria? A distinção entre laetitia e beatitude se dá, segundo Agostinho, pelas razões seguintes.

Toda alegria tem um motivo. Antes de sua conversão, como já havíamos observado, Agostinho sentia alegria em relação a coisas torpes. Sentia alegria, por exemplo, em ganhar concursos de retórica, sentia alegria em se tornar uma celebridade. O que diferencia a alegria da felicidade são os motivos. Para sermos mais exatos, a alegria é o gênero do qual a felicidade é espécie. $\mathrm{O}$ traço distintivo da felicidade com relação às demais alegrias é que a felicidade é motivada pela contemplação da verdade. Agostinho diz que esse é o sentido das palavras escritas no Evangelho de João: "É uma alegria que vem de ti, que és a Verdade,(...)" (João, 14, 16). Mas a afirmação "todos os homens querem ser felizes" continua sendo válida, se definimos a felicidade desta maneira? Mas como é possível que seja válida, se alguns homens se recusam a amar a verdade? Não seria mais correto dizer que todos os homens querem alegria, mas nem todos querem a felicidade? Porém, não seria um absurdo dizer que alguns homens não amam a verdade?

O fato é que todos os homens amam a verdade sob determinado aspecto. Tome-se, como exemplo, os mentirosos. Agostinho faz notar que mesmo eles amam a verdade, pois ainda que eles amem enganar os outros, odeiam quando são enganados, isto é, odeiam quando os outros lhes faltam com a verdade.

Todavia, há um segundo sentido pelo qual os homens amam a verdade. Ninguém gosta de descobrir que está enganado. E quando tentamos tirar os homens do engano, expondo-lhes a verdade, ocorre que a "verdade gera ódio" (João, 3:20). Gera o ódio porque os homens enganados muitas vezes acreditam, sem que tenham consciência, que seu engano é a verdade. Eis aí um estranho modo pelo qual a verdade é amada. Sem que o saibam, amam o próprio engano como se fosse verdadeiro. "E assim odeiam a verdade por causa daquilo que amam no lugar da verdade. Com efeito, uma vez que não querem ser enganados e querem enganar, amam-na quando ela se anuncia e odeiam-na quando ela os denuncia" (Conf., X, 23, 34; 2004, p.487) ${ }^{35}$.

Portanto, a verdade gera o ódio quando denuncia a mentira, seja a mentira intencional, seja a mentira que os enganados tomam por verdadeira. Estes últimos, por crerem que é verdadeira, amam-na mais ainda. E, por amá-la, querem-na verdadeira. Esse ciclo vicioso do homem enganado frequentemente ocorre por lhe faltar a coragem de examinar criticamente a ilusão amada. Os homens simplesmente acatam falsas opiniões recebidas de enganadores, os

\footnotetext{
35 “amant eam lucentem, oderunt eam redarguentem. quia enim falli nolunt et fallere volunt, amant eam, cum se ipsa indicat, et oderunt eam, cum eos ipsos indicat". (Conf. X, 23, 34; 2004, p.487) $)^{35}$.
} 
quais, em muitos casos, não estão conscientes do engano, tal como Agostinho define a si mesmo quando maniqueísta: "enganado e enganador".

Uma vez que o homem passa a depositar sua fé na falsa opinião, tomando-a como verdadeira, ele tem dificuldade de abandoná-la. A falsa opinião é tratada como um pertence, como um objeto de amor. O homem, ao ver o seu engano denunciado, sente como se o seu objeto amado fosse atacado, sente-se igualmente atacado em sua inteligência e em seu orgulho. Todos os homens, mesmos os ímpios, amam, de algum modo, a verdade. Amam-na quando ela se anuncia, odeiam-na quando ela os denuncia. 


\subsection{Uma águia imperial católica apostólica romana bicando o próprio peito}

\subsubsection{Introdução}

Até o momento, observamos, em linhas gerais, que a distinção ontológica entre realidades inteligíveis e realidades sensíveis é estrutural no pensamento de Agostinho. Esse critério, como vimos, é explicitamente usado para a análise dos conteúdos da memória. A percepção das realidades sensíveis nos fornece a base para o conhecimento dos objetos sensíveis; por outro lado, a percepção das realidades inteligíveis, com o olhar da mente, nos fornece o conhecimento das realidades inteligíveis. Esta última função é exclusiva da alma humana (animus), mais especificamente, da mens, que, como define Agostinho, é o estrato da alma humana(animus) dotado de intelecto. A mente, por ser uma realidade inteligível, sempre presente a si mesma, é conhecida pela reflexão, que é um dobrar-se da mente, de modo que o olho da mente apreenda a própria mente e seus processos. Nestas considerações já está implícita uma concepção de espírito humano, distinta da tradição clássica segundo a qual a anima ou a psique é o princípio animador dos corpos. Aliás, Agostinho, mesmo em suas obras de maturidade, continua empregando o termo anima de acordo com esse sentido. Não há em Agostinho uma revolução do conceito de anima, entendido como princípio vital, presente nos homens e animais. O ponto central é que, ao lado do conceito clássico de alma, Agostinho insere e circunscreve um outro ser, uma outra realidade, vinculada com a alma (anima), mas não redutível a ela: a mens. E a característica marcante desta realidade ou desta esfera do ser é que ela é dada exclusivamente por reflexão e pela intuição intelectiva. Não vem confundida, portanto, com a alma, entendida enquanto puro princípio vital animador dos corpos, ou mesmo com o conceito de pneuma usado pelos estoicos para designar uma matéria sutil. Por isso, se for para utilizarmos o termo "alma", uma ressalva dever feita, um pequeno acréscimo: "alma reflexiva". Esta sim tem um modo de ser diferente daquilo que a antiguidade clássica denomina psique ou pneuma. A esse respeito, escreve Ortega y Gasset.

Assim, o animal consiste numa matéria organizada e movida por uma coisa que há dentro, oculta na matéria: é a alma. Mas esta alma não tem nada de íntima: é interior apenas no sentido de que está oculta no corpo, submersa nele e, portanto, invisível. É um sopro, um ar leve, - psyché -spiritus - ou então uma umidade como em Tales, um fogo como em Heráclito. Não obstante o moderno ter conservado o termo "espírito" para designar sua descoberta da intimidade, convém lembrar que o grego e o latino entendiam por ela uma realidade não menos externa do que os corpos, vinculadas aos corpos, um poder alojado no cosmos. (1971, p.129) 
A noção de uma alma reflexiva, como um espaço de intimidade, como espírito, raiz histórica do conceito atual de consciência, é algo que surge após o advento do cristianismo. Embora o espírito tenha como pressuposto a sua incorporeidade, não é a incorporeidade mesma que o define. Platão e outros filósofos gregos já insistiam na incorporeidade da psique. Argumentavam que, se a psique era capaz de pensar ideias que não poderiam provir dos sentidos, tal como a de igualdade, de número, de círculo, isso se devia ao fato de que ela era incorporal. Mas o que está em jogo para Agostinho não é apenas a incorporeidade da "alma", é justamente o fato de que o "espírito" forma um espaço interior, uma presença constante de si para si, uma realidade íntima, que se mostra a si mesma de modo absolutamente privilegiado, pois nada é mais presente ao espírito do que ele mesmo.

Além disso, essa "alma reflexiva", ou o "homem interior", embora possua muitas semelhanças com o nous Aristotélico não vem confundida com este. Pois o espírito caracteriza-se pela sua história pessoal, pelos pecados que carrega, pela sua singularidade, pela carga pessoal de experiências passadas e atuais, pelos modos de se deixar motivar. É verdade, como veremos, que a racionalidade e a inteligência estão na mente (mens) ou no espírito (spiritus), mas a racionalidade não singulariza o homem. A razão é comum a todos, bem como o olhar da inteligência. $\mathrm{O}$ fato de eu ter o poder de ver racionalmente a verdade de um axioma ou a demonstração de um teorema não me singulariza, apenas me coloca em igualdade com qualquer outro homem dotado de razão, isto é, qualquer homem normal. Mas minha história, a história de minhas experiências, o fato de eu me seguir "acompanhando" dentro mim mesmo, o fato de eu observo interiormente os meus próprios pensamentos - tudo isso coloca esse espírito como realidade íntima.

A fim de se evitar confusões, é preciso frisar que os termos spiritus, pneuma, psyché, anima não designavam, na antiguidade clássica, aquilo que atualmente se designa com o termo "consciência" e que os modernos, como Descartes, designaram com o termo "espírito". É digno de nota que o próprio Descartes não empregou o termo espírito fortuitamente, mas deu voz a uma tradição. Como já havíamos dito, Agostinho também irá usar o termo spiritus, ou mais exclusivamente mens, para designar o "ser reflexivo". A própria noção de consciência, enquanto realidade íntima e reflexiva, inicia-se com o Neo-platonismo e com o cristianismo.

cristianismo e Neo-Platonismo elaboraram pari passu a noção da relação puramente privada do homem consigo mesmo, na qual o homem se desliga das coisas e dos outros e "retorna para si mesmo", dando testemunho de si para si e criando uma indagação puramente "interior", na qual possa conhecer-se com absoluta verdade e certeza. (...) Ora, não parece que a filosofia clássica da Grécia tenha reconhecido a realidade privilegiada da 
interioridade espiritual. A noção que, na teoria de Platão, mais se aproxima da relação da alma consigo mesma é a definição de opinião (ou pensamento em geral) como "diálogo da alma consigo mesma"(Teet., 189; Sof., 263e), porém o mais notável nessa definição é o fato de utilizar a linguagem para definir o pensamento, mais precisamente a linguagem para perguntar e responder, portanto, como diálogo ou comunicação. (ABBAGNANO, 2007, p.217)

São vários os fatores levantados para justificar por que o cristianismo foi o descobridor dessa realidade íntima. O maior deles é a fusão da doutrina judaico-cristã com a filosofia grega. Mas outras razões são igualmente importantes. O cristianismo, por ser uma doutrina cujo centro é a salvação pessoal, embora não negue a racionalidade da alma humana (animus), faz dela não uma pura substância racional, mas do "eu individual" o núcleo da alma. Já a partir de Agostinho, o termo spiritus ou mens passou a ser empregado para designar essa parte superior e racional da alma. E essa tradição segue até os tempos de Descartes, e, de pois dele, consciência.

O nome que depois de Descartes se dá ao pensamento como ser para si, como dar-se conta de si, é ...consciência. Não alma, anima, - psyche - que significa ar, sopro - porque anima o corpo, insufla-lhe vida, move-o - como o vento marinho empurra a vela curvando-a - mas a consciência, isto é, darse conta de si. Neste termo aparece à intempérie o atributo constituinte do pensamento - que é saber-se, ter-se a si mesmo, refletir-se entrar em si, ser intimidade. (1971, p.121)

Essa noção de alma reflexiva afasta-se da tradição clássica, dentre outros aspectos, por ser entendida realidade interior e individual. Segundo Giovanni Reale (2003), Agostinho não propõe, nas Confissões, tal como se tinha feito até então, o problema do homem em abstrato, ou seja, o problema da essência do homem em geral, mas do indivíduo como homem irrepetível.

Segundo Ortega, a noção de uma alma individual causava uma certa repulsa à mentalidade grega. Para Platão, as realidades individuais eram apenas as sombras de uma outra dimensão do ser, mais perfeita e mesmo mais real: as ideias, caracterizadas pela sua universalidade e eternidade. O homem singular é o que é porque participa da ideia universal de homem. O que individualiza cada um dos homens são suas imperfeições, os desvios, as rebarbas do molde. Se todos os homens fossem perfeitos, seriam iguais, do contrário, existiriam inúmeros modelos de perfeição de homem, o que é um absurdo.

Mesmo Aristóteles, que apresenta o ser individual como a verdadeira substância (ousia), a substância primeira, enquanto a forma, o universal, é a substância segunda, também tem para si a ideia de que o que individualiza o ser real são os acidentes de sua substância, que ocorrem pela fusão entre forma e matéria. Lógico que, para Aristóteles, é possível estudar os 
diferentes tipos de homens e classificá-los conforme seus vícios e virtudes, em suas disposições, mas isso não significa fazer da intimidade uma realidade reflexiva e individual e marcar, a ferro e fogo, essa individualidade ${ }^{36}$.

Um levantamento e uma análise precisa da ideia de "eu-espírito" como realidade íntima, pessoal, racional, responsável e incorporal, é operação urgente. Compreender o sentido, entender com o máximo respeito possível o que é essa alma-reflexiva, que tanta influência teve ao longo dos séculos, é um exercício quase terapêutico. Entender a história de nossa mentalidade é um exercício de autoconhecimento, é procurar, ainda que humildemente, esboçar a resposta à pergunta: “como viemos parar aqui?”. Um povo que esquece seu passado cultural está condenado a voltar à barbárie, por mais técnica que tenha conquistado.

O que iremos observar, nos próximos capítulos, é como Agostinho chegou à noção de espírito reflexivo. Para isso, procuraremos traçar em poucas linhas, e selecionando algumas obras exemplares, o percurso intelectual de Agostinho, acompanhando as experiências que o levaram a tomar a descoberta da "mente reflexiva", a consciência como uma esfera privilegiada do ser.

\subsubsection{A reflexão e a mente}

Em poucas palavras, o que faz de Agostinho um gigante, do ponto de vista não só teológico, mas também na história do pensamento ocidental, não são apenas suas complexas

\footnotetext{
${ }^{36}$ Todavia, a ideia cristã de espírito reflexivo e individual não vem confundida com o culto da individualidade, o culto do indivíduo singular, que desponta no renascimento e atinge seu zênite no romantismo. Uma coisa é cultivar e cultuar a individualidade, outra coisa é compreender-se como uma espírito individual. É sob esta base de ideias que o culto romântico à individualidade se constituiu, embora com os sinais trocados, por uma espécie de inversão da hierarquia dos seres, em quel, levando em consideração o duplo sentido que isso pode suscitar, a criatura revoltou-se contra o criador. É significativo que Rousseau, esse precursor do romantismo, escreveu suas Confissões para os homens; ao passo que Agostinho, o inventor do gênero, confessa-se para Deus e apenas em segundo plano para os homens; Nesta ordem de ideias, não nos espanta que Nietzsche, em Ecce Homo, tenha escrito sua autobiografia como uma autoglorificação desesperada de si mesmo; que Schopenhauer tenha buscado no extremo Oriente o ópio filosófico para nadificar o eu individual; A alma individual, fruto do cristianismo, revolta-se contra seu "criador", o cristianismo. Atualmente, entretanto, se tem consciência da profundidade da raiz cristã. Tentando arrancar em si mesmo essa raiz, Gilles Deleuze declara-se que ele não é uma "pessoa". E já está na moda "desconstruir" o conceito de indivíduo, subjetividade, pessoa. A contraposição não termina aí. $\mathrm{O}$ delicado equilíbrio entre o livre arbítrio, a graça e as prisões do hábito e do apetite, traçado por Agostinho, que faz do homem individualmente responsável pelos seus atos, é revirado. Sobretudo nos últimos três séculos encontraremos pensadores que irão colocar o homem como um ser determinado, pela cultura, pela matéria, pela biologia, pela física, pela química, pelo inconsciente. O espírito torna-se epifenômeno. A verdade torna-se relativa. A razão torna-se um subproduto do instinto a serviço da sobrevivência dos genes. A lógica torna-se psicologia. A ideia de uma estrutura ontológica e universal do ser, presente Platão, Aristóteles, no cristianismo, em inúmeros filósofos e ainda em Husserl, vem substituída por ilhas de ser, cada qual isolada e surdas e mudas com relações às demais. No fundo, o que parece unir todos esses pontos sem nós presentes no século XX e XI é uma espécie de horror, nos círculos intelectuais, a tudo que é cristão ou a tudo que o cristianismo encostou o dedo.
} 
descrições da alma humana (animus), mas a própria descoberta da "consciência", ou do espírito como ser reflexivo. Agostinho, de fato, foi um homem dotado de uma afiada capacidade de por a si mesmo problemas que ninguém via. E qual é o grande problema de Agostinho? O próprio eu. E o eu desdobra-se em três problemas fundamentais: sua relação com a criação, com o criador e consigo mesmo. Estes três problemas relativos, como veremos, estão articulados. Agostinho leva ao paroxismo aquela antiga exortação gravada sobre o templo de Apolo em Delfos: "Conhece-te a ti mesmo". Ele faz de si mesmo o seu maior problema. "Eu, pela minha parte, senhor, inquieto-me com isto, inquieto-me em mim mesmo: tornei-me uma terra de dificuldades e de muito suor ${ }^{37, '(C o n f ., ~ X, ~ 16, ~ 25 ; ~ 2004, ~}$ p.473).

Antes de examinar qual a ideia de Agostinho a respeito da alma humana, é preciso investigar as condições que o conduziram, gradualmente, a formular os problemas pelos quais ele alcançou uma apreensão da mente reflexiva. E, como veremos, a formulação adequada do problema será metade do caminho para sua resposta. O primeiro problema, pelo qual inicia a série de problemas que o levam ao método introspectivo, diz respeito à possibilidade do homem de alcançar a verdade ${ }^{38}$. Quando, com cerca de 30 anos, ele tomou conhecimento das doutrinas céticas, seu coração sofreu um terremoto interior. Dois foram os principais argumentos usados pelos céticos a fim de se provar que não era possível ao homem conhecimentos absolutamente seguros.

O primeiro argumento usado pelos céticos é que aquilo que nos vem pelos sentidos está sujeito ao engano. O bastão parcialmente submerso na água parece torto à visão, ao passo que, quando o tiramos da água, nos parece reto. Portanto, não há uma verdade última sobre se o bastão é reto ou não; fora da água ele se mostra reto, dentro, se mostra torto. Por que confiar em um dos casos e não no outro?

A segunda objeção levantada pelos céticos reside no argumento, conexo ao primeiro embora mais radical, de que o mundo é um sonho ou uma ilusão. Não podemos ter certeza absoluta, quando vemos algo, de que não estamos tendo uma ilusão. Levado às últimas

\footnotetext{
37 "Ego certe, domine, laboro hic et laboro in me ipso: factus sum mihi terra difficultatis et sudoris nimii". (Conf. $\mathrm{X}, 16,25)$

${ }^{38}$ Agostinho admite que, em muitos casos, os sentidos podem gerar conhecimentos enganosos. Entretanto, muitos dos conhecimentos obtidos pela alma humana na investigação de si mesma, são dotados de uma certeza inabalável. Neste sentido, por tomar a introspecção como o instrumento fundamental para obtenção de conhecimentos, Agostinho se insere em uma longa tradição da introspecção. Agostinho é o primeiro a expor de forma clara o fato de que o conhecimento que o eu tem a respeito de sua própria existência não poderia ser posto, em hipótese alguma, em dúvida.
} 
consequências, o mundo poderia ser um sonho. Como nos relata nas Confissões, Agostinho se instruiu de tais argumentos defendidos pela Nova Academia com os textos de Cícero(106-46 a.C). De fato, Cícero estudou com Filo de Larissa (145-79 a.C.), o último condutor reconhecido da Academia de Platão. Embora seja possível traçar uma linha sucessória dos condutores da Academia, partindo de Platão até chegar aos tempos de Filo, o fato é que houve, no desenrolar das gerações, um distanciamento cada vez maior das ideias defendidas pelos seus sucessores com relação a seu fundador. Em virtude dessas divergências, a antiga Academia de Platão ficou conhecida como Nova Academia. Esse afastamento se deu no sentido de um crescente ceticismo, um ceticismo às vezes radical, como o Carnéades (214129 a.C.), outras vezes moderado, como o professado por Metrodoro (330-278 a.C), ou mesmo um probabilismo, defendido pelo próprio Cícero. De todo modo, a Academia se desenvolveu em polêmica aberta com o estoicismo, cuja filosofia sustentava-se na noção de evidência sensível. Ao contrário dos estoicos, os acadêmicos julgavam que as impressões sensoriais não eram capazes de fornecer conhecimentos suficientemente seguros, pois estavam sujeitas ao engano.

O que sabemos é que o pensamento ciceroniano influenciou enormemente o pensamento de Agostinho, já quando este era apenas mais um estudante numa escola africana. É sob a inspiração tirada da leitura de Hortensius, de Cícero, que o jovem Agostinho passa a se dedicar, com fervorosa paixão, à busca da verdade. E ironicamente, é com a posterior leitura de outras obras de Cícero, pelas quais se instruiu acerca do pensamento dos acadêmicos, que ele vê sua convicção, de um dia encontrar a verdade, abalada. A argumentação a favor do ceticismo parecia-lhe insuperável, razão pela qual ele sente estremecer sua esperança de encontrar, algum dia, a verdade. O mais dramático é que Agostinho vem a se instruir com mais profundidade do ceticismo acadêmico logo após sua desilusão com o Maniqueísmo, cujos seguidores diziam sustentar suas ideias a respeito de Deus sobre uma base estritamente racional, ao contrário dos católicos, seres ingênuos e incultos. A propaganda racionalista e cientificista dos maniqueus havia sido, para Agostinho, um dos fatores decisivos à sua adesão e, posteriormente, de seu abandono, após reconhecer que ninguém dentro da doutrina era capaz de solucionar suas dúvidas. Assim, desiludido com a promessa maniqueísta de uma religião científica e incapaz de refutar os argumentos propostos pelos céticos, sua ânsia juvenil de encontrar a verdade começa a esmorecer. Todo esforço racional parecia-lhe destinado ao fracasso. Talvez o ceticismo fosse mesmo o único pensamento possível para um homem culto e letrado, ciente dos limites da razão e de sua impotência para alcançar qualquer tipo de verdade absolutamente segura. Mas essa sugestão 
não convencia inteiramente seu coração. No fundo, alimentava ainda o fogo da esperança de encontrar uma saída às objeções céticas, embora ainda não soubesse por onde.

Parte da relutância de Agostinho em aceitar o ceticismo provinha do fato de que ele, embora abandonasse o catolicismo de sua infância, bem como o maniqueísmo, ainda assim acreditava em Deus. Configura-se aí um confronto entre sua razão, que lhe convidava ao ceticismo, e seu coração, que lhe convidava para Deus, fosse ele alcançável racionalmente ou não. Mas todos os caminhos que sua razão, até então, havia trilhado para chegar a Deus terminaram em enormes abismos. Dessa crise oriunda do conflito entre a crença em Deus e o ceticismo, resultará uma espécie de situação ideal, pela qual Agostinho fará a atitude "insuspeita" de voltar sua atenção do exterior para o interior, chegando às verdades reflexivas e à compreensão da consciência como realidade indubitável. Eis aí o núcleo irradiador do pensamento de Agostinho. O que surpreende, segundo Ortega y Gasset, é a "torção do eu" implicada na descoberta da alma como intimidade.

O surpreendente, o que intriga e pede esclarecimento é o fato inverso. Como a atenção, que primitivamente é centrífuga e vai para a periferia, executa essa inverossímil torção sobre si mesma e o "eu", dando as costas ao contorno, se põe a olhar para dentro de si mesmo? (...) Esse fenômeno de conversão pressupõe duas coisas: uma que incite o sujeito a despreocupar-se do exterior e outra que lhe chame atenção em seu interior (1961, p.132).

Em seguida, Gasset aponta a raiz histórica positiva e a negativa implicadas na noção de espírito como autoconsciência: "A descoberta da subjetividade tem duas fundas raízes históricas: uma negativa e outra positiva. A negativa é o ceticismo; a positiva é o cristianismo. Nem aquela sem esta, nem esta sem aquela houveram podido dar tal resultado" (Gasset, 1961, p.131). Isso porque o Deus cristão, ao contrário de outras concepções de divindade com as quais Agostinho havia tomado contato, é um deus transcendente ${ }^{39}$ à criação.

Essa crença em um Deus transcendente, aliada ao empenho em refutar racionalmente o ceticismo, levou Agostinho, como veremos detalhadamente, à evidência da alma como realidade da qual não se pode duvidar e sobre a qual não se pode estar enganado.

De fato, alimentado pela fé, ele sabia que o único modo de demolir o ceticismo era contrapor-lhe verdades irrefutáveis. Isso o levou a trilhar os caminhos intelectuais que o conduziram a conclusão de que não há como colocar em questão a existência de um eu que pensa, quer, entende e possui memória. É esse caminho que iremos procurar expor.

\footnotetext{
${ }^{39}$ No Gênese de São João, o Logos (o Verbum na tradução latina da Vulgata) é o criador do Cosmos, e, portanto, é anterior e superior a este.
} 


\subsubsection{A torção interior da atenção e suas condições}

A noção de "alma reflexiva" se origina não de uma torção repentina do eu. Aliás, a própria distinção entre mente espiritual e reflexiva (mens) e alma (anima) só adquire clareza e contornos nítidos nas obras de Agostinho depois de anos de desenvolvimento intelectual. Em virtude disso, nos capítulos seguintes deste trabalho, usaremos indistintamente o termos "alma humana", "mente" e "espírito" em concordância com os textos apresentados, pois o que está em questão é justamente mostrar como Agostinho, partindo da noção clássica de alma, como princípio vital, vai, aos poucos, distinguindo uma outra esfera do ser, a consciência, ou mais propriamente a mens. Quando as diferenças estiverem suficientemente claras, usaremos os termos adequados para designar cada uma dessas realidades. Por isso, usaremos, por enquanto, o termo "mente" de modo intercambiável com "alma reflexiva" ou "alma humana".

Cada novo livro publicado por Agostinho após sua conversão revela a maturação gradativa do conceito de "mente reflexiva". Algumas vezes ele apenas abre a porta que levaria a ela, mas não entra. Outras vezes, a apalpa, mas não a vê. Outras vezes, parece a formular, mas não reconhece o alcance. Outras vezes a formula, mas com termos ambíguos. De alguma forma, não é exagero dizer que tal questão do conhecimento absoluto que o eu tem de si mesmo já aparece em seus primeiros escritos. A evidência implicada no "sei que sou" vai como que aparecendo paulatinamente, à medida que ele vai retirando os resíduos, até sobrar a ossatura. Trata-se, como veremos, de um dos temas centrais de seu pensamento, a chave de leitura da relação entre o homem, a criatura e o criador.

Agostinho sentirá, inclusive, em seu percurso intelectual, a necessidade de precisar seu vocabulário e afinar os conceitos até encontrar sua melhor forma de exprimir o espírito, que vem oferecida em sua monumental $A$ trindade (416 d.C) onde oferece o mapa e o itinerário espiritual capaz de conduzir o homem para o núcleo de seu ser e dali elevar-se em direção a Deus. É nessa obra que o conceito de mente (mens) adquire todo seu contorno. Todavia, mesmo nos quinze livros que compõem a Trindade, podemos sentir essa vitalidade do

pensamento de Agostinho, que, em seus movimentos espiralados, não raro retoma o livro anterior para aprofundar um tema ainda pouco trabalhado para ajustar os nós ainda frouxos, ou para seguir adiante em suas investigações.

Segundo Gilson(2007), a primeira indicação do argumento que levaria ao cogito agostiniano encontra-se em Contra Acadêmicos. Trata-se de um elegante diálogo tirado de suas conversas com seus amigos, no ano de 386, no vilarejo de Cassicíaco, pouco tempo depois de sua conversão, quando ainda era catecúmeno e se preparava para o batismo. $\mathrm{O}$ 
diálogo, como o próprio nome nos alerta, tem como objetivo derrubar a doutrina cética dos neoacadêmicos. $\mathrm{O}$ ataque se faz em duas frentes. Por um lado, Agostinho procura mostrar a inconsistência da teoria, por outro, procura contrapor a ela conhecimentos invulneráveis ao ceticismo.

O primeiro argumento contra os acadêmicos é um argumento do tipo ad hominem: se não é possível ao homem o conhecimento, logo Carneades e quem quer que seja que defenda tal teoria deve, por força, deixar de ensinar, pois, em última instância, não tem nada mais o que dizer.

O segundo argumento contra o ceticismo provém da indubitabilidade dos juízos disjuntivos. Se alguém afirma: "o mundo ou é criado ou é incriado", tal afirmação é verdade, pois é construída de tal modo que, qualquer que seja a possibilidade, ela continua sendo verdadeira.

O terceiro argumento, que o próprio Agostinho aprofundará ao longo de sua vida, é aquele que se fundamenta na evidência que a mente tem de si mesma. Agostinho afirma que ele não pode duvidar do fato de que ele quer encontrar a verdade. Poderíamos expor o raciocínio da seguinte forma. 1)“É possível a verdade?” 2) Eis uma questão que quero saber a resposta. 3) Tenho certeza de que quero saber a resposta. 4) Logo, alguma verdade existe: "quero saber a resposta".

Já se vê aí uma indicação desse estranho ato de girar o olho espiritual 180 graus para encontrar dentro de si próprio um conhecimento que pudesse ser absolutamente seguro e verdadeiro. Temos uma verdade interior, a de que o próprio eu tem a respeito de si mesmo, e, portanto, dada por reflexão: um juízo individual, mas de alcance universal, já que cada homem possui um eu. Agostinho não diz "todos os homens querem encontrar a verdade, logo é verdade que existe alguma verdade". Mas sim "eu quero encontrar a verdade e tenho certeza de que quero". A certeza introspectiva encontra sua prova no próprio eu e é referente ao eu. De fato, o objeto que é alvo do juízo verdadeiro é a própria vontade. "Eu tenho certeza de que quero conhecer a verdade".

Isso revela uma diferença essencial entre o modo como o eu relaciona-se com os objetos corporais exteriores e do modo como o eu se relaciona com realidades interiores, no caso, a vontade, quando esta é feita objeto de seu pensamento. Quando o objeto julgado é a própria vontade, o eu não pode, como acontece com os sentidos, se enganar. Não apenas a vontade tem existência certa, como também o objeto da vontade não é passível de engano. Seria absurda uma afirmação como: "tenho vontade de conhecer a verdade, mas me enganei, pois queria mesmo era comer chocolate". A "vontade", posta sob reflexão, revela um estado 
interior àquele que julga. Em Contra acadêmicos, Agostinho não explicita tais conclusões que, nesta obra, já estavam em germe. Será apenas na Trindade, escrita mais de duas décadas depois, entre os anos 400 e 416, que Agostinho se dará conta de todo alcance implicado na percepção interior da vontade própria. Agostinho, em Contra Acadêmicos, limita-se a constatar de que não pode duvidar de sua vontade de conhecer a verdade. Trata-se de um argumento a mais contra o ceticismo. Mas nesse argumento se esconde o germe que de concepção de "consciência" entendida como uma realidade interior.

Um novo esforço no sentido de se alcançar verdades indestrutíveis encontra-se em outro livro, De Beata Vita, escrito também no período em que morava na agradável Vila de Cassicíaco, em 386 D.C. O tema central é a vida feliz ou vida beata. Em determinada passagem, logo no início da obra, Agostinho se dirige a seus interlocutores, questionando-os se eles são compostos de corpo e de alma. Todos foram concordes, exceto Navígio, que, em sua sinceridade, declarou não saber. Para que Navígio encontre por si só a resposta, Agostinho lhe pergunta:

“- Ao menos você sabe que vive e que possui um corpo?

- Sim, sei - responde Navígio.

- Portanto - argumenta Agostinho - não resta dúvida que o homem é composto de corpo e de alma (anima) $)^{40}$." (De Beata Vita, I, 2,7; tradução nossa ${ }^{41}$ )

A ideia implícita nesta passagem é que aquele que vive apenas vive porque possui alma. Em outras palavras, em De Beata Vita, Agostinho simplesmente equipara vida e alma. O que há é a explicitação de que todo homem possui a evidência de estar vivo; a verdade está enlaçada com o próprio eu. Contudo, a evidência de estar vivo não é explorada. Agostinho se limita a fazer Navígio dirigir seu olhar para a certeza de que ele está vivo, mas o "eu estou vivo" não é, ele mesmo, justificado, devido à própria força da evidência dada na constatação de si para si. Agostinho não fornece aquilo que poderíamos chamar de argumento apodíctico, cuja característica é a impossibilidade de se rejeitá-lo em razão de qualquer hipótese contrária se mostrar absurda.

Em De Beata Vita, a ordem de seus raciocínios não leva à distinção entre a alma reflexiva e alma entendida como princípio vital. A ordem se coloca da seguinte maneira: 1) Constatação do eu vivo. 2) A alma é o princípio vital. 3) Logo tenho alma. 4) A alma humana

\footnotetext{
40، Et cum dubitaret: Scisne, inquam, saltem te vivere? Scio, inquit. Scis ergo habere te vitam, siquidem vivere nemo nisi vita potest. Et hoc, inquit, scio. Scis etiam corpus te habere? Assentiebatur. Ergo iam scis te constare ex corpore et vita. Scio interim; sed utrum haec sola sint, incertus sum. Ergo duo ista, inquam, esse non dubitas, corpus et animam. "(De Beata Vita, I, 2,7)

${ }^{41}$ Nós mesmos traduzimos a passagem em vista da má tradução das edições consultadas.
} 
é também racional. 5) Portanto, a alma humana é um princípio vital dotado de razão. Em outras palavras, o "eu vivo", nesta passagem, serve para fundamentar o conceito que remonta à visão clássica da alma. Não está presente a noção da alma reflexiva ou, em termos modernos, "autoconsciência", intima scientia.

É em Libero Arbitrio, escrito em 388, alguns anos depois de De Beata Vita, que Agostinho encontrará uma fórmula mais potente para a elucidação da essência da alma humana. Os três livros que o compõem condensam o diálogo que travou com seu amigo Evódio. No segundo livro deste diálogo, o que está em pauta é a demonstração da existência de Deus. A cadeia demonstrativa tem início quando Agostinho propõe a Evódio partir de uma verdade evidente e indestrutível: “Assim, pois, para partirmos de uma verdade evidente, eu te perguntaria, primeiramente, se existes. Ou, talvez, temas ser vítima de engano ao responder a questão? Todavia, não te poderias enganar de modo algum, se não existisses." ${ }^{42}$ (Lib. Arb. II, 3,7; 2008, p.80). Não é possível se enganar diante de tal questão, pois quem se engana é porque existe. Existir é condição a priori para se enganar. Gilson (2007) aponta a grande semelhança desta linha de raciocínio com o de Descartes.

O parentesco que une o pensamento de Agostinho e de Descartes é aqui dos mais impressionantes; nas duas doutrinas é sublinhada a necessidade de pensar "por ordem", a existência do pensamento é apresentada como a primeira e mais evidente de todas as certezas. Tal certeza é a primeira de todas porque ela continua evidente mesmo no caso de o pensamento que se conhece ser um erro. (p.91)

O que Agostinho coloca em evidência é a indestrutibilidade de um eu que não pode se enganar a respeito de sua existência. A certeza que tem de existir está acima de qualquer dúvida possível. Não pode sequer conceber sua não existência: ao colocar para si a hipótese de não existir, a hipótese mesma é destruída, pois se o eu não existisse, não teria colocado a hipótese. Tal eu, que por força existe, mostra-se, portanto, como um eu que possui uma atividade pensante. Ora, é igualmente indubitável que este eu pensante está vivo, ao menos enquanto atividade pensante. Há, com efeito, uma inversão do pensamento de Agostinho, se compararmos com o procedimento pelo qual ele justificava a alma em De Beata Vita. Se neste livro ele questionava Navígio sobre o fato de ele estar vivo, para daí concluir a existência da alma, em Libero Arbitrio, Agostinho parte da indubitabilidade da existência do "eu";

Em Libero Arbitrio, no entanto, a descoberta do conhecimento absoluto que o "eu" tem a respeito de si mesmo, dado que não pode se enganar a respeito de si, não é detalhada em sua dinâmica temporal, apesar de ele mostrar as camadas do eu, subindo gradualmente, até chegar

\footnotetext{
${ }^{42}$ Quare prius abs te quaero, ut de manifestissimis capiamus exordium; utrum tu ipse sis. An fortasse tu metuis, ne in hac interrogatione fallaris, cum utique si non esses, falli omnino non posses? (Lib. Arb. II, 3,7;)
} 
à prova de Deus. ${ }^{43} \mathrm{O}$ conhecimento que lhe servirá de sustentáculo para sua escalada em direção a Deus, posto numa sentença, é: “eu existo". Mas que eu é esse que não se pode enganar de sua existência? A que ponto que ele é aquilo que a antiguidade clássica denominava anima ou spiritus, psyche ou nous?

Aquele que é questionado, em um primeiro momento, teme se enganar, mas logo em seguida dá-se conta de que um engano implicaria na existência de um eu que se engana. Por isso, o temor do engano torna-se desprovido de sentido. No entanto, para que se tenha consciência desta certeza, é necessário, antes, ter esse temor de se enganar. É considerando a hipótese do engano que se observa nitidamente que se trata de uma impossibilidade. A existência do sujeito é garantida pelo próprio problema, cuja única função é ser refutado. Caso análogo ocorre com a dúvida hiperbólica de Descartes; para se ter certeza da própria existência é primeiro necessário duvidar do mundo e de si, para em, um segundo momento, observar que a dúvida a respeito de si é impossível, pois ela pressupõe, como condição de sua possibilidade, o sujeito que duvida. A certeza nasce de uma atitude existencial da dúvida, cuja função é revelar-se desprovida de sentido. Plagiando Wittgenstein, a dúvida em Descartes ou o medo do engano em Agostinho servem como uma escada, que após ser usada, deve ser abandonada.

\subsubsection{Introdução à busca da mente na Trindade}

O que devemos observar agora é como essa certeza reflexiva do "eu existo" vem explorada em sua obra de maturidade, a Trindade, e como torna-se não uma simples certeza do "eu sou", mas da própria existência da mente (mens) ou do espírito (spiritus). A evidência do "eu existo" vem articulada não com a existência de um princípio vital presente também nos animais, a anima, mas exclusivamente com a existência daquilo que há de superior no eu, isto é, sua mente. Essa distinção resultará em complexas articulações entre alma humana em sua globalidade vital e espiritual (animus), a mente (mens) e a alma (anima) como princípio vital, presente nos homens e animais.

Agostinho começa sua abordagem do espírito humano por vias indiretas, procurando não propriamente responder o que ele é, mas as condições implicadas na própria formulação da questão e em sua subsequente investigação.

\footnotetext{
${ }^{43}$ A pergunta que ele faz a Evódio é: "Você existe?". Ao que se obtém como resposta: "sim, sou, pois se me enganasse, também teria que ser. Se me engano é porque sou, logo não posso estar enganado.". De fato, não é possível estar enganado da existência do eu.
} 
A primeira condição é de ordem prática. Para que o homem investigue o que é algo, uma das condições é que ele queira conhecer esse algo. Portanto, a investigação inicia-se com a vontade de saber.

A segunda é uma condição de possibilidade de qualquer investigação racional. Quem quer conhecer algo é porque tem uma noção prévia e relativamente determinada do que é esse algo. Essa noção prévia pode ser o conhecimento de algum aspecto do objeto ou uma noção hipotética a respeito dele. Se alguém desconhece plenamente aquilo que quer conhecer e não tem nenhuma referência a respeito do que está buscando, como sabe o que quer conhecer? Portanto, se não tivermos alguma noção daquilo que procuramos, não sabemos sequer o que procurar.

A terceira condição para a investigação do espírito, de certo modo, já diz algo a respeito do que ele é. O homem que procura investigá-lo deve refletir, deve observar-se a si próprio, pois não tem acesso direto aos outros espíritos, pois o espírito não é algo que possa ser visto, tocado, cheirado etc.

Iremos observar agora cuidadosamente estas três condições para, fundamentando-se nelas, compreender o conceito de espírito.

\subsubsection{Primeira condição de toda investigação racional: conhecer algo do objeto investigado}

No livro X da Trindade Agostinho, seguindo seu estilo de investigação, coloca a seguinte questão: “É possível amar o que se desconhece?” Se uma pessoa quer aprender retórica é porque não a desconhece por completo. Tem notícia do que seja: a arte de bem falar. Do mesmo modo, alguém que, ao ler um texto antigo, encontra uma palavra cujo significado não conhece, no fundo já sabe algo a respeito do objeto: sabe que é uma palavra e sabe que as palavras possuem significados e sabe que ama conhecê-las.

Portanto, o que ama? Não será porque conhece e intui nas razões dos seres qual seja a beleza de um saber no qual se encerram as noções de todos os sinais? E qual seja a vantagem desse saber, o qual torna possível a comunicação mútua das ideias na sociedade humana e impede desse modo que a vida em sociedade não seja prejudicada pela solidão, como o seria se faltasse a comunicação de pensamentos mediante a linguagem? É pois a beleza e a utilidade desse ideal, que a alma percebe, conhece e ama. E é esse ideal que se esforça por aperfeiçoar em si, o quanto possível, todo aquele que investiga o significado das palavras que ignora. (De trinit., X, 1, 2; 2005, p.311)

Quid ergo amat, nisi quia novit atque intuetur in rationibus rerum quae sit pulchritudo doctrinae, qua continentur notitiae signorum omnium; et quae sit 
utilitas in ea peritia, qua inter se humana societas sensa communicat, ne sibi hominum coetus deteriores sint quavis solitudine, si cogitationes suas colloquendo non misceant? Hanc ergo speciem decoram et utilem cernit anima, et novit, et amat; eamque in se perfici studet, quantum potest, quisquis vocum significantium quaecumque ignorat, inquirit. (De trinit. $\mathrm{X}, 1$, 2)

Temos, portanto, a primeira condição de toda investigação consciente: toda busca por conhecer algo já pressupõe o conhecimento parcial deste algo a ser conhecido:

Por isso, todo aquele que se dedica ao estudo, ou seja, todo espírito que deseja saber o que ignora, ama não o que desconhece, mas aquilo que sabe, e em vista desse conhecimento deseja saber o que ainda não sabe. (De trinit. $\mathrm{X}, 1,3 ; 2005, \mathrm{p} .313)$

Quamobrem omnis amor studentis animi, hoc est volentis scire quod nescit, non est amor eius rei quam nescit, sed eius quam scit, propter quam vult scire quod nescit. (De trinit., $\mathrm{X}, 1,3$ )

\subsubsection{Segunda condição: querer conhecê-lo em função de um "preconceito" relativo ao valor do objeto desconhecido}

Essa noção prévia daquilo que a pessoa quer conhecer não basta para que ela realize a investigação. É preciso que ela queira conhecer ${ }^{44}$ o objeto "desconhecido", partindo de uma expectativa de que o conhecimento do objeto lhe trará algum bem. Contudo, nada impede que a pessoa creia que conhecer o objeto seja um bem, mas, ainda assim, estime que não valha a pena o esforço necessário para sua aquisição. É possível, por exemplo, que alguém tenha uma certa noção do que seja o grego arcaico, creia que seu conhecimento lhe trará algum bem, mas não se disponha a ir adiante na empreitada. De fato, para que o homem conheça algo, é preciso que se empenhe e, portanto, que o queira suficientemente, a ponto de enfrentar as dificuldades exigidas para a sua realização. O querer, para que se converta em ação, exige esforço, o qual nem sempre é bem-vindo.

Portanto, a expectativa do bem que trará o conhecimento serve de motivação. Mas, se observarmos de perto, fica claro que, muitas vezes, o "querer conhecer" sustenta-se numa

\footnotetext{
${ }^{44} \mathrm{O}$ significado levado por um ideal geral. O ideal é conhecer as línguas. E por que tal ideal apresenta-se como um fim digno de amor? Porque conhecendo as línguas, o homem torna-se capaz de se fazer entendido, que é algo que todos almejam. A própria fama da beleza de um objeto pode gerar a vontade de conhecê-lo.
} 
crença: que o conhecimento do objeto possui alguma espécie de valor, seja um valor de utilidade ou de beleza. E quanto a isso, podemos estar enganados. ${ }^{45} \mathrm{Um}$ homem, enganado por um "guru" que diz apoiar suas ideias na física quântica, pode resolver dedicar longos anos ao estudo dessa disciplina, com o intuito de nela encontrar a prova da transmigração das almas, constatando, para sua infelicidade, que fora feito de trouxa.

Todo conhecimento exige alguma dose de esforço. E como não podemos conhecer tudo, temos que escolher, dentre as possibilidades, a que dedicar nosso esforço. Para isso, cremos que o conhecimento do objeto irá nos propiciar algum bem. Contudo, todo esse processo envolve crença: nem sempre é possível ter certeza que o conhecimento do objeto corresponderá a nossas expectativas. É o que iremos observar detalhadamente na próxima seção.

\subsubsection{Terceira condição: a crença nas expectativas}

Muitas são as razões que nos levam a acreditar que o conhecimento de determinada disciplina, assunto ou objeto, nós trará os frutos prometidos. Aquele que se propõe a conhecer engenharia civil acredita que poderá projetar um edifício. Os motivos para se crer nisso são tantos, que seria risível que alguém não cresse. Basta o simples conhecimento visual de que existem muitos prédios no mundo, bem como o conhecimento de que foram os engenheiros que o projetaram. O mesmo se dá com a oratória; é suficiente observar um grande orador para saber que a oratória é realizável. Contudo, com relação aos conhecimentos que prometem resultados invisíveis, a coisa se complica. Aquele que escolhe fazer psicologia clínica deve crer na eficácia do método terapêutico. Talvez tenha "observado" o benefício que algumas sessões clínicas trouxeram a um de seus amigos. Talvez tenha admiração por um amigo que seja psicólogo e creia na autoridade de sua palavra, quando este afirma que se trata de um método que possui eficácia. Muitas vezes, acreditamos nos bens que um conhecimento nos trará, fiando-nos na opinião daqueles que dizem ter o conhecimento e nos dão notícia de sua utilidade e beleza.

Assim acontece quando o espírito se inflama pelo desejo de ter e gozar de certas coisas, levado pela fama da beleza delas. Isso é porque já tem um

\footnotetext{
${ }^{45}$ Em muitos casos, queremos conhecer algo em particular não em razão da própria coisa, mas em razão de um ideal genérico. Aquele que procura conhecer o significado de uma palavra tem como ideal, por exemplo, o desejo de bem se comunicar. Em toda vontade autêntica de se conhecer aquilo que se desconhece está implícito uma vontade ligada a um ideal útil ou belo, ou ambas as coisas. Essa vontade, enquanto não atinge seu fim, carrega em si uma esperança, a de realizar em si o ideal. E tanto a esperança quanto a vontade são enfraquecidas de acordo com o nosso julgamento a respeito do grau de dificuldade de se alcançar esse ideal.
} 
conhecimento geral das belezas corporais, pelo fato de as ter visto bem numerosas (De trinit. X, 1, 1; 2005, p.309).

Et in his quippe rebus in quibus non usitate dicitur studium, solent exsistere amores ex auditu, dum cuiusque pulchritudinis fama ad videndum ac fruendum animus accenditur, quia generaliter novit corporum pulchritudines, ex eo quod plurimas vidit (...) (De trinit. X, 1, 1)

Não basta a fama da beleza para que o homem vá atrás de conhecer o que desconhece. É necessário também que conheça com antecedência o que é a beleza. É igualmente necessário que acredite não só que a fama faz jus à própria beleza do objeto, mas que creia também na autoridade daqueles que dizem que o alcançaram e, em virtude disso, o louvam e o exaltam. São "preconceitos" deste gênero que levam alguém a estudar, por conta própria, Husserl, Tomás de Aquino, Heidegger ou qualquer outro filósofo.

Alguns componentes, portanto, estão presentes naquele que busca conhecer uma doutrina: a confiança na autoridade dos que a louvam e se dizem aptos a ensinar, uma certa noção do que a doutrina ou o objeto de estudo irá propiciar, bem como sua finalidade. De fato, a confiança na autoridade dos que louvam a doutrina ou a disciplina é extremamente importante quando não temos uma comprovação visível dos frutos daquele conhecimento ${ }^{46}$.

Imaginemos a situação hipotética de um homem o qual nunca teve notícia a respeito da escrita. Para que possamos comunicar-lhe o que é a escrita seria necessário expressá-la dentro de seu universo conceitual, oferecendo-lhe uma definição como: um jeito de aprisionar no papel as falas de um homem por meio de desenhos, ou algo assim. Talvez tal "bárbaro" compreenda de modo genérico o que seja a escrita, sinta-a como desejável, mas, ainda assim, duvide da possibilidade de sua realização. Caso não creia que o fim prometido seja realizável, dificilmente este "bárbaro" iniciará o estudo. Não tomaríamos a mesma postura se alguém nos afirmasse que a telepatia é a arte de transmitir as palavras apenas pela força do pensamento? Poderíamos até considerar a finalidade útil, no entanto, o simples fato de a considerarmos impossível faz com que nem sequer busquemos a "arte telepática". E mesmo se víssemos um espetáculo de telepatia, tenderíamos a considerar um truque, do mesmo modo como o analfabeto poderia igualmente considerar a arte da escrita e da leitura como um "truque".

Antes de aprendermos uma coisa, temos que crer. Processo semelhante ocorre, por exemplo, com quem pretende aprender o teorema de Pitágoras. Talvez, no começo, o

\footnotetext{
${ }^{46}$ Tome-se por exemplo, a hipnose. Por que razão muitas universidades de psicologia não coloca essa disciplina nos currículos? Talvez porque não creiam na eficácia. Mas por que alguns historiadores iniciam a história da psicologia no século XIX, com o nascimento da psicologia experimental? Talvez porque, embora creiam que seja possível conhecer Aristóteles, Platão, Agostinho, não creiam, entretanto, que aqueles conhecimentos sejam tão úteis e válidos quanto o conhecimento experimental.
} 
estudante considere aquilo um bando de relações numéricas confusas, em seguida talvez aprenda a efetuar o cálculo, sem, no entanto, entender o que está fazendo. Mas, se o estudante se esforçar, ele pode, em um instante de lampejo intelectual, ter um insight e então aqueles cálculos passarão a lhe fazer sentido. Tendo obtido a inteligência do teorema, não mais terá necessidade de crer, já que o vê na luz eterna e imutável da verdade. Portanto, antes de aprender, é necessário crer na possibilidade de se atingir o ideal amado ${ }^{47}$. Não é outro o sentido do credo ut intelligam "creio para que possa entender".

Mas poderia o homem buscar conhecer apenas por conhecer? Isto é, sem ser movido por ideal algum? Sim, responde Agostinho, trata-se do curioso, o qual se diferencia do estudioso. Pois enquanto este busca conhecer fundamentando-se em um ideal conhecido, por amor a esse ideal, o curioso é movido não pelo amor ao ideal, mas pelo ódio ao desconhecido.

\subsubsection{A evidência do sei que sei}

Como observamos, o estudioso, quando procura conhecer um determinado objeto que lhe é "desconhecido", parte de uma noção a respeito do objeto, bem como em um conjunto de crenças a respeito do que irá encontrar. Ocorre que o "objeto desconhecido" não é plenamente desconhecido, pois se fosse, se não tivéssemos referência alguma a respeito dele, a pesquisa sequer iria começar. Esses conhecimentos prévios são o que Agostinho coloca em cena para investigar o que é o espírito. Pois, a ideia é justamente observar que aquele que se coloca a questão a respeito do que é a mente, o faz porque já sabe algo a respeito dela. O que interessa é clarear "algo" que já sabemos de antemão.

Para que tenhamos ilustrar o que são esses conhecimentos, tomemos o seguinte caso. Ao perguntarmos a uma pessoa "Você sabe ler?", podemos obter como resposta "sim, eu sei ler". Neste caso a pessoa sabe que ela sabe ler. Imaginemos que, em seguida, perguntamos a essa mesma pessoa: "E você sabe o que é o saber?" Se a resposta for negativa, poderíamos afirmar que tal pessoa não poderia afirmar que sabia ler, pois como ela pode assegurar que sabe ler se ela não sabe o que é saber? Entramos assim em uma estranha situação. Como é possível que a pessoa saiba o que sabe, sem que saiba o que é o saber? Lógico que isso não é

\footnotetext{
${ }^{47}$ É preciso diferenciar dois aspectos implícitos no ideal em virtude do qual o homem visa atingir pelo conhecimento de algo desconhecido. Uma coisa é contemplar a beleza do ideal, e outra coisa é desejar realizar essa beleza em suas faculdades, afinal não é apenas a beleza do ideal aquilo capaz de atrair, mas também a utilidade do ideal, que são contemplados na luz da verdade.
} 
possível. Alguém que não tenha noção alguma do que seja o conhecimento não terá como saber que tem conhecimentos.

Uma situação como essa revela a diferença entre dois modos de conhecimento: o dado intuitivamente, numa visão interior. E outro que é o conhecimento a respeito do qual sabemos exprimir com palavras e conceitos. De fato, se conseguimos diferenciar em nós mesmos o que sabemos do que não sabemos é porque, de algum modo, sabemos o que é o saber, ainda que eventualmente não saibamos expressá-lo. É notável o método pelo qual Agostinho examina o que seja o saber: não parte da investigação do que seja o saber em si mesmo, parte do fato de consciência "do saber que sabe" para extrair daí a essência do saber.

Deve saber o que seja o saber, não somente o que diz: "Sei" e diz a verdade, mas também aquele que diz: "Não sei", e o afirma com certeza e na verdade, e sabe que diz a verdade, e sabe o que seja saber. Mostra que sabe a diferença entre o que sabe e o que não sabe, quando, intuindo a si mesmo com sinceridade, diz "Não sei". Pois, ao afirmar que diz a verdade, como o saberia se ignorasse o que seja saber?" (De trinit. X, 1, 3; 2005, p.314).

Non solum enim qui dicit: "Scio", et verum dicit, necesse est ut quid sit scire sciat; sed etiam qui dicit: "Nescio", idque fidenter et verum dicit, et scit verum se dicere, scit utique quid sit scire; quia et discernit ab sciente nescientem, cum veraciter se intuens dicit: "Nescio". Et cum id se scit verum dicere, unde sciret, si quid sit scire nesciret? (De trinit. X, 1, 3)

Sabemos o que sabemos porque temos evidência daquilo que sabemos ou, como ele diz, quando intuímos a nós mesmos com sinceridade cum veraciter se intuens. Alguém que sabe que "dois mais três é cinco" não tem necessidade de justificá-lo, simplesmente porque vê, dentro de si, com evidência, a verdade deste juízo. E mais, sabemos com certeza que o conhecimento é nossa posse. ${ }^{48}$.

\footnotetext{
${ }^{48} \mathrm{O}$ problema consiste em analisar o que é essa evidência, a qual não é tida como um simples fenômeno subjetivo, assim como a "certeza" não é um fenômeno subjetivo, pois implica em veracidade. Trazendo a questão para o nosso tempo, poderíamos afirmar, com Husserl, que esse é justamente o ponto cego do psicologismo, que toma a evidência como fenômeno de um ser psicofísico, sem considerar que pela intuição o homem tem a consciência imanente do próprio objeto.
} 


\subsubsection{A mente, sujeito do conhecimento, morada do conhecimento}

Observamos que quando o homem intui a si mesmo com sinceridade é capaz de saber o que sabe e o que não sabe ${ }^{49}$. Mas quem é este ser capaz de discernir o que sabe e o que não sabe? Não pode ser outro ser que não a alma humana (animus). Logo ela não se desconhece completamente, pois tem algumas certezas a respeito de si mesma:

1) Que ela conhece algumas coisas e outras não.

2) Que ela conhece os seus conhecimentos.

3) Que ela ama conhecer.

4) Que ela sabe que os conhecimentos estão nela própria.

Temos, portanto, algo certo sobre a alma humana:

Como, porém, conhece o seu saber, se não se conhece a si mesma? Com efeito, sabe que conhece outras coisas, embora não se conheça a si mesma. Portanto, é em si que ela sabe o que é conhecer. De que modo, porém, sabe o que seja conhecer, quem não se conhece? Pois não conhece outra alma (mentem: n.d.r) capaz de conhecer, mas a si mesma. Portanto, conhece a si mesma. (De trinit. X, 3, 5; 2005, p.317).

Novit autem quid sit nosse, et dum hoc amat quod novit, etiam se cupit nosse. Ubi ergo nosse suum novit, si se non novit? Nam novit quod alia noverit, se autem non noverit; hinc enim novit et quid sit nosse. Quo pacto igitur se aliquid scientem scit, quae se ipsam nescit? Neque enim alteram mentem scientem scit, sed se ipsam. Scit igitur se ipsam. Deinde cum se quaerit ut noverit, quaerentem se iam novit. Iam se ergo novit. (De trinit. X, $3,5)$

O que Agostinho faz é expor aquilo a respeito da alma humana que não pode ser negado. Definindo a alma humana como ser pensante, os argumentos anteriormente citados fornecem a prova apodíctica de sua existência. Algo semelhante foi encontrado em Libero Arbitrio, em que o autor usa da justificação apodíctica para demonstrar a existência do "eu" que não pode estar enganado acerca de sua própria existência. Mas naquela obra, a certeza apodíctica de um eu pensante servia a outros propósitos. Observamos também como, em Contra acadêmicos, Agostinho ao tratar o tema da verdade, afirmava, en passant, que tinha certeza de que ele queria conhecer a verdade, logo, não poderia duvidar a respeito da existência de suas vontades. Nesta passagem da Trindade, a certeza interior é mais uma vez retomada, neste caso a certeza de ser o sujeito do conhecimento, pois conhece com absoluta certeza os próprios conhecimentos.

\footnotetext{
${ }^{49}$ Tratemos agora de juntar as condições para o conhecimento da alma. Em primeiro lugar, uma vez que o homem se questione: “O que é a alma humana?", ele já tem noção do que está procurando. Em segundo lugar, o homem quer conhecer a alma, porque crê que o conhecimento da alma lhe será valioso. Em terceiro lugar, crê que será valioso porque muitas autoridades louvam o conhecimento da alma.
} 
Mas como já havíamos antecipado, a precisão conceitual toma novas dimensões. Para se referir a este "ser" que conhece a si próprio, Agostinho não usa o termo alma (anima), mas sim o termo mente (mens), como fica claro na passagem "Neque enim alteram mentem scientem scit, sed se ipsam”. Reservando o termo mente para referir-se ao ser que conhece a si mesmo, ele pode manter a definição clássica de anima como princípio vital, presente também nos animais, os quais, embora tenham o princípio vital que lhes dão o movimento, não possuem um "eu" capaz de operações reflexivas: limitam-se a conhecer os corpos sensíveis, distinguindo o útil do nocivo. Não são capazes de refletir de modo a conhecer os próprios conhecimentos e reconhecerem a si mesmos como o ser que conhece.

O homem, dotado de mente, não apenas conhece seus conhecimentos, mas também suas vontades e, por isso, pode julgá-las. Essas operações pressupõem uma criatura dotada do olhar da inteligência, capaz de apreender as realidades inteligíveis. Os animais conhecem os sensíveis, mas não conhecem seus próprios conhecimentos porque lhes falta o intellectus, que é aquilo que permite a abertura para os vastos domínios das realidades espirituais e não apenas às "coisas". A alma animal, como a alma humana, possui um certo conhecimento das coisas. Mas apenas a mente (mens) sabe do conhecimento que tem das coisas. Por isso Agostinho usa, com muita precisão, o termo mens ${ }^{50}$, para se referir a essa parte superior da alma humana (animus). ${ }^{51}$

Ao se procurar, a mente se encontra, revelando a si mesma como o ser que se procura, o ser que se sabe sendo, que sabe que é em si que estão seus conhecimentos. Todo esforço posterior é elucidar conceitualmente essa noção preconceitual que a mente tem de si.

\subsubsection{A mente e o eu}

Vejamos agora a relação entre a mente e o "eu". Eu não tenho como negar que exista um ser que é capaz de conhecer, conhece os próprios conhecimentos, sabe que tem vontade de conhecer e sabe que é em si que estão esses conhecimentos que ele conhece. Aparentemente esse ser sou eu mesmo. Mas por que dar o nome de mente (mens) a esse ser, já que este ser sou eu? É preciso ir com calma para não escorregar. A questão aqui é que tais aspectos acima

\footnotetext{
${ }^{50}$ Observa-se que na tradução, o autor usa o termo alma, o que pode dificultar o entendimento do leitor. Em virtude de não termos explicitado esta distinção, nós, para facilitar a leitura, usamos no lugar do termo "mens" o termo "alma reflexiva". As distinções serão feitas posteriormente.

${ }^{51}$ Ver apêndice A.
} 
descritos referem-se apenas a uma parcela do meu "eu"52. O sapo é animal, mas animal não é sapo. A mente é uma parcela do meu eu, uma parcela absolutamente necessária para que eu seja eu, mas é evidente que eu não me reduzo à minha mente. Eu não apenas penso, tenho conhecimento e vontades, mas tenho também tenho um corpo vivo, emoções; eu percebo o mundo com os meus sentidos, sinto fome e sede, tal como qualquer outro animal. No entanto, posso, com o auxílio do intelecto, discernir em mim as faculdades do meu eu que me permitem conhecer o conhecimento, conhecer meu querer, e circunscrevê-las e dizer que essas faculdades pertencem à mente. Posso, sem maiores problemas, dizer que eu tenho um corpo, como as pedras, uma alma, tal como os animais, e uma mente, tal como os demais homens. Portanto, a mente nada mais é do que o nome que dou a esse núcleo do meu eu com o qual conheço a mim mesmo e sem o qual eu não poderia ser eu. Esse é o sentido Agostiniano de mente.

Sem minha mente, deixo de ser o que sou. Mas sem um braço, sem a visão, sem um dos sentidos, continuo sendo eu mesmo. Continuo capaz de entender os números, capaz de querer, de pensar, de me lembrar, de "ver" dentro de mim mesmo minhas vontades, meus conhecimentos, meus pensamentos. Continuo dotado de razão, com a qual posso raciocinar, dotado de inteligência, com a qual continuo aberto às realidades espirituais e inteligíveis.

A mente se define pela sua abertura aos inteligíveis e às realidades espirituais, pela reflexão, pela inteligência. Em suma, ela se define pelo incorporal. Já a alma (anima) vem definida como vitalidade, pelos sentidos, pelos batimentos cardíacos, pelos sangue que circula nas veias, pelos movimentos involuntários do corpo. Em outras palavras, não é possível definir a anima sem o corpo. É o que anima os corpos dos animais.

Até o momento, sabemos que o corpo não é essencial à definição de mente. Mas isso não significa, pelo menos à princípio, que a mente seja incorpórea. É preciso investigar isso com cuidado.

Retomemos. Já havíamos observado que Agostinho afirma que a mente, ao procurar-se, já conhece algo de si, pois, do contrário, não poderia procurar-se. Posteriormente, ele começa a explorar essa evidência que o espírito possui a respeito de si mesmo, isto é, essa noção, esse conhecimento prévio que a mente possui de si mesma. Com isso, encontra alguns atributos essenciais a respeito da mente. Entretanto, existem ainda outros aspectos da mente que não

\footnotetext{
${ }^{52} \mathrm{O}$ problema é que o eu não define a mente, pois eu sou mais do que uma mente. Portanto, a essa realidade de mim, que também sou eu, embora eu seja mais que isso, da mesma forma como alguém diz eu sou médico, mas sou mais do que isso. Por isso o nome mente é justo para designar que o eu é e que não pode negar que seja, embora o eu creia ser mais que isso. Portanto, a conclusão de Agostinho, observar a impossibilidade do eu negar a sua mente, isto é, de ser um ser que conhece e sabe que tem vontade e que é em si que conhece.
} 
foram elucidados, pois a mente poderia ter outros atributos que ainda não conhecemos. É preciso, portanto, um método para se separar o que é a mente daquilo que ela não é. Por exemplo, a grande maioria dos filósofos da tradição clássica considerava o espírito uma matéria constituída de algum tipo de substância sensível ou corporal, como o fogo, os átomos, ou até mesmo uma matéria sutil, uma quintessência. $O$ fato de os conhecimentos estarem na mente e de ela poder conhecê-los não diz nada, pelo menos a princípio, sobre a matéria de que é feita a própria mente. Sêneca e os estoicos, por exemplo, acreditavam a um só tempo que o pneuma era uma matéria sutil e também a sede do pensamento. E não viam aí contradição alguma.

O procedimento de Agostinho, que irá de uma vez por todas estabelecer as fronteiras da mente, separando-a do conceito de alma da tradição clássica, consiste em subtrair desse eu reflexivo tudo aquilo que ele não pode ter certeza de ser. Agostinho parte da ideia de que o que é absolutamente verdadeiro deve, absolutamente, ser. $\mathrm{O}$ eu reflexivo tem certeza absoluta de ser, e essa certeza já é garantia suficiente da sua existência. Resta apenas retirar todos os preconceitos, tudo aquilo que não podemos ter certeza a respeito de nós mesmos, para encontrarmos a ossatura da mente, o seu verdadeiro ser, a sua substância.

Não se pode dizer com lógica, que se tenha conhecimento de alguma coisa da qual se desconhece a substância. Se ela se conhece é porque ela conhece a sua substância. Se ela se conhece com certeza é porque ela conhece com certeza a sua substância. Ora, ela se conhece com certeza, como prova o que acima foi dito. Pelo contrário, ela não tem certeza alguma de ser ar, fogo, ou algo de corporal. Não é, portanto, nenhuma dessas coisas. Toda força do preceito de se conhecer reside na certeza de que não é nada daquilo que ela não está certa. (De trinit. X, 10, 16; 2005, p.329)

Nullo modo autem recte dicitur sciri aliqua res, dum eius ignoratur substantia. Quapropter, dum se mens novit, substantiam suam novit; et cum de se certa est, de substantia sua certa est. Certa est autem de se, sicut convincunt ea quae supra dicta sunt. Nec omnino certa est, utrum aer, an ignis sit, an aliquod corpus, vel aliquid corporis. Non est igitur aliquid eorum. Totumque illud quod se iubetur ut noverit, ad hoc pertinet ut certa sit non se esse aliquid eorum de quibus incerta est, idque solum esse se certa sit, quod solum esse se certa est. (...) (De trinit. X, 10, 16)

A passagem suscita algumas questões de ordem epistemológica ${ }^{53}$. Agostinho parte do princípio de que tudo que conhecemos com certeza é porque conhecemos sua substância ${ }^{54}$, tal

\footnotetext{
53، A evidência apodíctica não é a evidência de coisas ou fatos evidentes. Ela se revela como uma impossibilidade absoluta de que se conceba a sua não-existência. Nela, 'toda dúvida imaginável torna-se desprovida de sentido' “ (HUSSERL, 2001, p.33) As verdades apodícticas são geralmente atribuída aos princípios. Às vezes o estudioso busca justificar num plano mais alto verdades já evidentes em si, quando procura justificá-las em princípios apodícticos.

${ }^{54}$ Conheço com certeza um computador, logo tenho certeza a respeito do que é um computador? Mas a questão é: tenho certeza absoluta que conheço o que é um computador? O segundo passo é pura decorrência do primeiro.
} 
como afirma: Nullo modo autem recte dicitur sciri aliqua res, dum eius ignoratur substantia. Os atributos da substância são aqueles sem os quais a coisa deixa de ser o que é. Ser músico ou pedreiro não é um atributo da substância homem, mas apenas um acidente. Alguém pode deixar de ser músico e se tornar pedreiro sem que deixe de ser homem. Ora, os atributos sem os quais o eu reflexivo deixa de ser o que é não coincidem com os atributos sem os quais o corpo deixa de ser um corpo vivo. Portanto, o ser da mente não corresponde ao ser da alma, entendida como princípio vital animador do corpo. Tomamos consciência da substância da anima comparando o corpo vivo com o cadáver. Dentre os atributos sem os quais não se pode dizer que um corpo está vivo estão justamente: o movimento espontâneo, a forma do corpo pela qual ele permanece sem se desmembrar, a respiração, o calor etc. Agostinho, por explorar a pura presença reflexiva do homem consigo mesmo, delimita o conceito de mente, entendida como o núcleo do eu ${ }^{55}$, que é justamente a parte superior do homem em sua totalidade. Sem o corpo, a alma não pode ser alma, mas sem a inteligência, sem a vontade, sem a memória, o eu não pode ser.

Muito se critica a noção de mente substancial usada por Agostinho. Mas antes de qualquer crítica, é necessário observar o que ele entende por substância. Se, por substância, Agostinho entende o suporte de certos atributos sem os quais a coisa deixa de ser o que é, não há o que se criticar. Pois ninguém duvidaria dos atributos levantados por Agostinho, que definem a mens enquanto aquilo que pensa, quer, tem memória e é presente a si mesma, dado que ninguém pode duvidar que pensa.

De todo modo, devemos observar que Agostinho não apenas diz o que a mente é, como também a delimita, excluindo dela todo e qualquer atributo que não seja dado por reflexão. Ora, o que o eu encontra ao refletir sobre si e ao procurar as faculdades implicadas na própria reflexão são justamente as faculdades superiores, exclusivas da mente. De fato, não seria possível a reflexão sem que existisse a capacidade de discernir aquilo que se sabe daquilo que não se sabe, sem a capacidade de querer, sem a capacidade de pensar, sem a capacidade de pensar os próprios atos interiores, o que exige o poder de apreender o inteligível. $\mathrm{O}$ eu, enquanto sujeito capaz de reflexão, é o espírito, é a mente. Tudo o que não é essencial à reflexão é riscado da mente. Eis aí por que os sentidos, a dor, o corpo, as sensações corpóreas, a faculdade de perceber não são faculdades essenciais à mente, embora esta esteja também

\footnotetext{
${ }^{55}$ Como já observamos, ao contrário do que parece sugerir a tradução, Agostinho está se referindo a mens e não à anima. Um conceito não se confunde com o outro. Os animais possuem alma (anima), mas não possuem mente(mens). A mente, por seu turno, é aquilo que há de superior da alma, e é dotada de intelligentia ou razão. Quanto a tradução, resta apenas lamentar pelo fato do tradutor ter usado alma para traduzir mente, carregando o termo para a má-interpretação moderna.
} 
envolvida com a percepção, com a dor, com o corpo, como iremos ver mais adiante. Eis aí também por que a mente não é o ar, fogo, átomos, corpúsculos.

Mas há ainda uma outra razão pela qual a mente não é o ar, fogo, átomos: a de que o espírito deve fazer representações imaginárias de si mesmo. Ora, a mente, quando se crê sendo fogo, ar ou qualquer outra coisa corporal, identifica-se erroneamente com o imaginado. A mente não pode ser algo imaginado, pois tudo aquilo que é imaginado provém dos sentidos, e os sentidos remetem ao exterior e, portanto, às realidades corpóreas. A mente não pode ter nenhuma certeza de ser essas coisas, embora possa equivocadamente acreditar ou pensar que as seja. Trata-se, no entanto, de uma crença desprovida de razão. A mente não é nada que possa ser imaginado, mas é, isto sim, o ser que possui a faculdade de imaginar. ${ }^{56}$ De fato, a mente não tem certeza de ser o que imagina, mas tem certeza absoluta de que é ela que imagina e não outra mente. Assim, a mente, ao se despir de tudo aquilo que não tem certeza de ser, acaba por revelar-se a si mesma, como uma pura presença constante de si para si.

Pensaria, porém, por meio de uma presença interior, real e não imaginária pois nada lhe é mais presente do que ela mesma - assim como entende que está viva, que recorda, que entende ou quer. Pois ela tem ciência de todos esses atos em si mesma. Portanto, não é algo que imagina, como se tivesse sido influenciada exteriormente, mediante os sentidos, como acontece com as realidades corporais. Se ela não se apegar arbitrariamente a esses pensamentos, de modo a não pensar que ela mesma seja algum desses elementos, tudo o mais que lhe restar em si mesma é isso, que é ela mesma. (De trinit. X, 10, 16; 2005, p.330).

Si quid autem horum esset, aliter id quam cetera cogitaret, non scilicet per imaginale figmentum, sicut cogitantur absentia, quae sensu corporis tacta sunt, sive omnino ipsa, sive eiusdem generis aliqua; sed quadam interiore, non simulata, sed vera praesentia (non enim quidquam illi est se ipsa praesentius); sicut cogitat vivere se, et meminisse, et intellegere, et velle se. Novit enim haec in se, nec imaginatur quasi extra se illa sensu tetigerit, sicut corporalia quaeque tanguntur. Ex quorum cogitationibus si nihil sibi affingat, ut tale aliquid esse se putet, quidquid ei de se remanet, hoc solum ipsa est. (De trinit. $\mathrm{X}, 10,16)$

Eu, ao observar a mim mesmo, e descartar dessa auto-observação tudo aquilo que não tenho certeza de ser, encontro-me a mim, naquilo que indubitavelmente sou. O que encontrarei indubitavelmente são as puras certezas que tenho de mim: que eu sou, que penso, que me investigo, que quero me conhecer, que me lembro de mim; pois se não lembrasse de mim, não poderia iniciar minha investigação a respeito de mim mesmo. Também me dou

\footnotetext{
${ }^{56}$ Interessante notar que Hume usa argumento muito semelhante para tentar provar o oposto, a inexistência da alma, entendendo o eu como um feixe de sensações. Para Hume, tudo o que existe são impressões fortes (sentidos) ou fracas (memória das impressões), e o resto se resumiria em associações das últimas segundo a semelhança ou a contiguidade, no tempo e no espaço. A diferença é que Hume desconsidera a intuição e a autoevidência que a mente tem de si mesma.
} 
conta que só sou capaz de conhecer meus próprios pensamentos, meu próprio querer e meus conhecimentos porque tenho uma inteligência, por meio da qual vejo essas realidades inteligíveis. Tudo isso descubro por reflexão, com um conhecimento absolutamente seguro. Esses aspectos absolutamente seguros que descubro de mim e sem os quais não conseguiria descobrir constituem a substância da mente. Definida deste modo, posso dizer que tenho certeza de ter uma mente ${ }^{57}$.

Mas há ainda outro aspecto que deve ser sublinhando e a que pouco fizemos referência até aqui. As faculdades implicadas na reflexão estão presentes mesmo quando não estou refletindo sobre mim mesmo. A mente é constantemente presente a si mesma. O homem que considerava sua alma fogo ou ar, tão logo pensava em ser o fogo, tão logo aparecia na tela de sua mente a imagem do fogo. E quando pensava em outra coisa, a imagem do fogo deixava de ser presente na mente. Em outras palavras, ora imaginava o fogo, ora não. A mente, por seu turno, é sempre presente a si mesma. Sed quadam interiore, non simulata, sed vera praesentia (non enim quidquam illi est se ipsa praesentius).

As imagens evocadas e os pensamentos passam, mas a mente continua sempre presente a si mesma, por isso, é presença real e não simulada. Não importa o que o eu esteja imaginando, o objeto imaginado durará apenas enquanto ele imagina. Poderíamos generalizar isso: tudo aquilo que está presente diante do olhar da mente passa, mas a vontade, o intelecto e a lembrança sempre estão presentes. A mente está presente a si mesma, ainda que esteja lembrando de outras coisas que não a si mesma, imaginando coisas que não a si mesma, julgando coisas que não a si mesma. Portanto, a mente não é apenas um ser que possui faculdades, mas um ser que está presente na atualização de suas faculdades.

\subsubsection{Memória, inteligência e vontade contêm-se mutuamente, formando uma só vida, uma só essência}

Até o momento observamos alguns traços básicos da mente e o modo como ela se mostra a si mesma. Mas algumas questões ainda pairam no ar. Para isso, temos que confrontar duas teses. 1) A mente é dotada de razão e é aquilo que distingue o homem dos animais. 2) A mente é o eu naquilo que o eu conhece de si pela reflexão, após descartar tudo aquilo que não

\footnotetext{
${ }^{57}$ Há uma diferença que mais tarde será esclarecida. Uma coisa são os aspectos que a mente tem certeza de ser; mas dentre esses aspectos existem aqueles que, subtraídos, ela não seria. A mente tem certeza que percebe, mas, ainda que não percebesse, ela não seria subtraída em sua substância. Isso critério distingue o animus da mente. Mas essa distinção será feita posteriormente.
} 
está implicado na reflexão ${ }^{58}$. A mente é o eu em suas atividades superiores. Essas atividades superiores provêm daquelas mesmas capacidades que permitem a reflexão sobre si. Seria possível resumir essas faculdades? É o que Agostinho faz na Trindade, quando aponta que as três faculdades fundamentais da mente são a memória, a vontade, a inteligência, que são justamente as três faculdades sem as quais a reflexão seria impossível.

Mas se considerarmos que a mente é um conjunto de falculdades, um outro problema advém: em que sentido podemos dizer que a mente é una. Dizer que a mente é una é dizer que o núcleo do eu é uno. Se a mente é uma substância, ela não pode ser uma coleção fortuita de faculdades; deve haver aí uma unidade. Ora, o que Agostinho percebeu, com espantosa penetração intelectual, é que as faculdades da inteligência, da memória e vontade constituem uma unidade.

Estas três capacidades estão, isso sim, entrelaçadas e imbricadas umas nas outras. Podem ser apenas distinguidas intelectualmente, pois a atualização de uma implica a atualização das demais. Não é possível querer algo se não se compreende esse algo e não se lembre desse algo. Nem entender algo se esse algo não esteja dentro do espírito, isto é, na memória. Nem se lembrar de algo caso não se queira lembrar esse algo, e sem que se entenda aquilo de que se lembra.

Pois eu me lembro de que tenho memória, inteligência e vontade; compreendo que entendo, quero e recordo; quero querer, lembrar-me e entender; e me lembro ao mesmo tempo de toda minha memória, minha inteligência e minha vontade, toda inteira. O que não me lembro de minha memória, não está em minha memória. Nada porém, existe tão presente na memória como a própria memória.(De trinit. X, 11, 18; 2005, p.332)

Neque enim tantum a singulis singula, verum etiam a singulis omnia capiuntur. Memini enim me habere memoriam, et intellegentiam, et voluntatem; et intellego me intellegere, et velle, atque meminisse; et volo me velle, et meminisse, et intellegere, totamque meam memoriam, et intellegentiam, et voluntatem simul memin. Quod enim memoriae meae non memini, non est in memoria mea. Nihil autem tam in memoria, quam ipsa memoria est. (De trinit. $\mathrm{X}, 11,18$ )

\footnotetext{
${ }^{58}$ Essas duas teses podem entrar em conflito. Os animais também se lembram e possuem visão. O eu tem certeza que percebe, o eu tem certeza que se lembra, o eu tem certeza que entende. Mas perceber e se lembrar é algo comum aos animais, ver realidades inteligíveis é específico do homem. Os animais, por seu turno, não são capazes de refletir, lembram, mas não pensam no fato de que lembram. Percebem, mas não pensam na sua própria percepção. Ora, somos capazes de pensar no lembrar, de pensar no perceber porque temos inteligência, que é a capacidade de ver o incorpóreo e reconhecê-lo em sua incorporeidade. Como já alertamos, os animais, por terem memória, são capazes de retornar a suas tocas. Mas apenas o homem é capaz de entender o que seja a memória e entender a percepção. Só a mente é capaz de fazer seus próprios atos se tornarem objeto de entendimento. Daí resulta que a mente não é o eu naquilo que o próprio eu tem certeza absoluta de ser.
} 
Por isso, são três faculdades humanas relativas, interdependentes; cada uma delas não pode subsistir por si só. As três faculdades relativas formam uma só substância, pois, juntas, formam uma só vida mental, de tal sorte que a anulação de uma acarretaria a anulação das demais. Segundo Agostinho, isso não seria assim se elas não tivessem igualdade de substância. Não é possível, por exemplo, uma "memória pura" sem que haja a vontade e a inteligência.

Concluindo: como todas e cada uma das faculdades se contêm reciprocamente, existe igualdade entre cada uma e cada uma das outras, e cada uma com todas juntas em sua totalidade. E as três formam uma só unidade: uma só vida, uma só alma e uma só substância. (De trinit. X, 11, $18 ; 2005$ p.333)

Quapropter quando invicem a singulis et tota et omnia capiuntur, aequalia sunt tota singula totis singulis, et tota singula simul omnibus totis; et haec tria unum, una vita, una mens, una essentia. (De trinit. X, 11, 18)

Mas lembremos: o homem não é uma pura mente. O próprio homem também é uma substância e uma unidade, constituído de anima, corpo e mente. Isso coloca uma complexa questão: como a mente se articula com a alma e com o corpo? Existem algumas faculdades que estão entre o corpo e a mente? A visão, por exemplo, não é exclusiva do corpo, nem da alma, nem da mente. Se os olhos estão danificados, não há visão. Sem o princípio vital da anima, não teríamos sensações, pois o corpo não estaria vivo, mas sem a mente, não haveria percepção. Pois perceber exige o foco da atenção dirigido para o exterior. A percepção, quando nossa atenção está voltada ao objeto sensível, envolve o corpo, a alma e a mente.

Como iremos observar nos capítulos subsequentes desta tese, a atividade da mente não se limita à visualização das realidades inteligíveis. Há situações em que a mente se volta para o sensível. E a mente participa inclusive dos movimentos corpóreos, pela ação da vontade. Todas essas complexas articulações serão examinadas no desenrolar das análises. No capítulo que se segue, iremos investigar as explicações de Agostinho a respeito da percepção. Essa explanação nos fornecerá os elementos para a compreensão mais ampla e complexa da mente e do cogito. 


\subsection{A percepção em Agostinho}

\subsubsection{Os sentidos e a vontade: A trindade contida na visão exterior e a intentio}

No livro XI da Trindade, Agostinho investiga como captamos as realidades exteriores pela percepção. Toma como base de suas análises o sentido da visão, argumentando que o que vale para um dos sentidos será igualmente válido para os demais, uma vez que se busque na visão aquilo que é estruturalmente comum aos demais sentidos.

São três realidades presentes em toda a visão e sem as quais a visão não seria possível.

1) Realidade vista (rem quam uidemus) a qual possui uma forma.

2) O sentido da vista (sensus oculorum), que existia antes de o sentido ter percebido o objeto. O sentido da vista pode assumir a forma do objeto, isto é, ser informado pelo objeto.

3) O elemento "copulativo", que une ou fixa o sentido no objeto. Este elemento é, por vezes, designado por "atenção do alma humana", intentio animi ${ }^{59}$, outras vezes vontade (voluntas), outras vezes ainda intentio voluntatis ${ }^{60}$, o que poderia ser traduzido por "intenção da vontade", "atenção da vontade" ou ainda "intencionalidade da vontade". É este terceiro elemento que mantém o sentido dirigido ao objeto para ser informado ${ }^{61}$ pela forma do objeto.

Assim sendo, recordemos como as referidas três realidades: a figura do objeto visto, sua imagem impressa em nosso sentido, e a vontade da alma que aplica o sentido ao objeto sensível e nele mantém a visão -, repito, como essas três realidades, embora sejam de naturezas diferentes, amalgamam-se em certa unidade. (De trinit., XI, 2, 5; 2005, p.342)

Quae cum ita sint, tria haec quamuis diuersa natura quemadmodum in quandam unitatem contemperentur meminerimus, id est species corporis quae uidetur et imago eius impressa sensui quod est uisio sensusue formatus et uoluntas animi quae rei sensibili sensum admouet, in eoque ipsam uisionem tenet.. (De trinit. XI, 2, 5)

A visão é, portanto, definida como o sentido informado pelo objeto sensível, pela ação da vontade. O objeto, dotado de forma, exerce uma ação sobre o sentido dos olhos,

\footnotetext{
59 Termo que às vezes vem traduzido como vontade, às vezes por atenção, e mais raramente, por intenção. Consideremos aqui como sendo atenção. Os problemas relativos aos termos ficarão mais claros logo adiante.

${ }^{60}$ Em outras passagens, Agostinho descreve a mesma trindadade, usando no lugar do termo intentio, tal como citado anteriormente, o termo voluntas.E no livro XIV, da Trindade, Agostinho usa o termo intentione voluntatis, ao dizer aqui que é por meio dela que se conjuga o objeto que se vê e o olhar do vidente: "uoluntatis intentione quae utrumque coniungit". Com isso Agostinho parece dizer que a atenção pertence à vontade. Isso resolveria porque em uma passagem ele usa voluntas como o elemento conjugador e em outra usa intentio.

61، Todavia, não possuem a mesma substância: o objeto que informa o sentido da vista para a percepção; e a forma que esse objeto imprime no sentido da vista". (De trinit., XI, 2, 2; 2006, p.337).

“(...) nullo modo tamen eiusdem substantiae est corpus quo formatur sensus oculorum cum idem corpus uidetur et ipsa forma quae ab eodem imprimitur sensui, quae uisio uocatur.” (De trinit.,, XI, 2, 2).
} 
imprimindo sua forma. Sob este aspecto o sentido é passivo com relação à forma do objeto. ${ }^{62}$ Por outro lado, a atenção (intentio), que pertence à mente, será responsável pelo caráter ativo da visão: dentro do horizonte de objetos possíveis a serem vistos, sempre há um no qual a atenção se aplica. Quando não prestamos atenção no mundo exterior, embora tenhamos os sentidos informados, não "vemos", isto é, não percebemos o objeto no modo da atenção.

A visão de um corpo, por ser composta de três elementos, pode ser compreendida como uma espécie de trindade, dado que é composta por três elementos distintos que formam uma só visão. No entanto, diferencia-se da Trindade divina por não comportar igualdade de substância entre os termos componentes. Dos elementos presentes na visão, o objeto visto pertence ao mundo corporal, ao passo que a intentio pertence à mente, que usa o sentido dos olhos como quem se serve de um instrumento corporal para a captação das formas exteriores que ficam impressas nos olhos.

Esse esquema para a compreensão da visão trouxe para Agostinho um problema a ser enfrentado: "Na visão, o que está fora, o que está dentro"? O que é exterior, o que é interior? Quando vejo algo, tenho a impressão que vejo algo no espaço, que vejo algo que está fora de mim. Mas como isso é possível, já que a visão pertence à alma, que é algo interior? Afinal, a visão não é definida como os sentidos informados pelo objeto? Agostinho responde que pertencem ao vidente: os sentidos, a atenção (intentio) e a própria visão. Entretanto, o objeto real para o qual a visão se dirige está fora.

O primeiro desses três elementos, ou seja, o objeto visível, não pertence à natureza do vivente, dotado de alma, a não ser quando olhamos o nosso próprio corpo. A segunda pertence-lhe de tal modo que se produz no corpo e por meio do corpo também na alma. Com efeito, atua no sentido que não pode operar sem o corpo e sem a alma. Quanto ao terceiro elemento, referese tão-somente à alma, porque é a própria vontade (voluntas). (De trinit.,, XI, 2, 5; 2005, p.342)

Quae cum ita sint, tria haec quamuis diuersa natura quemadmodum in quandam unitatem contemperentur meminerimus, id est species corporis quae uidetur et imago eius impressa sensui quod est uisio sensusue formatus et uoluntas animi quae rei sensibili sensum admouet, in eoque ipsam

\footnotetext{
62، Atenção da alma, que retém o sentido no objeto percebido e enlaça a ambos”, não é apenas diferente desse objeto em sua natureza ( pois a atenção é espiritual e o objeto corporal). A atenção também é diversa do próprio sentido da visão. Pois a atenção é função apenas da alma, enquanto o sentido dos olhos recebe o nome de sentido corporal precisamente porque os olhos são partes do corpo. E embora um corpo sem vida não tenha sensações, alma, no então, unida ao corpo sente através de um instrumento corporal, instrumento esse chamado de sentido" (De trinit., , XI, 2, 2; 2005, p. 338)

"Itemque illa animi intentio quae in ea re quam uidemus sensum tenet atque utrumque coniungit non tantum ab ea re uisibili natura differt quandoquidem iste animus, illud corpus est, sed ab ipso quoque sensu atque uisione quoniam solius animi est haec intentio. Sensus autem oculorum non ob aliud sensus corporis dicitur nisi quia et ipsi oculi membra sunt corporis, et quamuis non sentiat corpus exanime, anima tamen commixta corpori per instrumentum sentit corporeum et idem instrumentum sensus uocatur”. (De trinit., XI, 2, 2)
} 
uisionem tenet. Horum primum, id est res ipsa uisibilis, non pertinet ad animantis naturam nisi cum corpus nostrum cernimus. Alterum autem ita pertinet ut et in corpore fiat et per corpus in anima; fit enim in sensu qui neque sine corpore est neque sine anima. Tertium uero solius animae est quia uoluntas est. (De trinit., XI, 2, 5)

Mas como é possível que o objeto visto esteja fora e esteja simultaneamente na visão? Pois se não tivesse de algum modo na visão, não o veríamos.

Agostinho observa que a visão do objeto não é o objeto corporal exterior, mas a forma ou a imagem do objeto. O objeto real imprime sua forma no sentido, formando na visão sua forma. Interessante notar que Agostinho se vê obrigado a se estender sobre o fato da visão estar no vidente. O problema é que aquele que vê não tem a "impressão" de que a imagem está dentro de si. Pelo contrário, tem a "impressão" de que a visão se estende para o exterior, se alongando até o objeto. A evidência natural nos mostra os olhos como janelas, como uma abertura pela qual vemos as próprias coisas nos espaço.

Todavia, quem realmente vê não é o sentido, mas a alma humana (animus), e esta não pode sair de si mesma. O que a alma vê é a forma ou a imagem do corpo, que está impressa no sentido. É de se supor que Agostinho encontrou grandes dificuldades para explicar isso, dado o tanto que se alonga sobre esse tema.

Agostinho procura raciocinar tomando como base os seguintes exemplos. Imaginemos um anel que carimba um pedaço de cera. Neste caso, é fácil diferenciar a forma impressa na cera da forma do próprio anel, a despeito da similaridade das duas formas. Na alma ocorre algo semelhante, mas, para usarmos um exemplo adequado, teríamos que imaginar um anel imerso na água em vez de um anel cravado na cera. Enquanto o anel permanece mergulhado na água, ele deixa nela sua forma, mas tão logo é retirado do líquido, sua forma deixa de estar no líquido. Assim é com os sentidos. Assim que o objeto deixa o campo visual, ele para de imprimir sua forma no sentido.

O mesmo acontece em relação à água, que guarda o vestígio do corpo, enquanto esse nela permanece. Retirando tal corpo, todo vestígio desaparece, ficando somente a água que existia antes de receber a forma daquele corpo. Por isso, não podemos dizer que é o objeto visível que gera a visão. Gera, no entanto, essa forma que é como uma semelhança sua, que atua no sentido da vista ao termos a sensação. (De trinit., XI, 2, 3; 2005, p.339).

Por isso o homem tende a confundir a forma do próprio objeto com a forma do objeto impressa no sentido. No entanto, são duas formas. A forma do objeto pré-existe no próprio corpo e é a partir dela que a forma se imprime no sentido, formando a visão.

O que pode causar confusão, diz Agostinho, é que o homem, ainda que "saiba" que uma coisa é o corpo e outra, a visão do corpo, não consegue distinguir, com os próprios olhos, a 
"forma do próprio corpo" da forma impressa em seu sentido, dada a estreita união entre ambas. A alma tem do objeto sensível apenas sua forma tal qual impressa nos sentidos. ${ }^{63}$

É digno de nota que Agostinho demonstra ter consciência de que o fenômeno da visão, tal como ele a expõe, não garante a existência de uma "exterioridade", da forma do próprio objeto corporal. Isso porque a visão não tem acesso à forma do próprio objeto real, mas apenas à forma que está impressa nos sentidos. Aliás, a ideia de que exista uma forma impressa no sentido já pressupõe a existência de uma forma fora e que exerce a ação sobre os sentidos. Mas como é possível que o homem se certifique de que a visão é a forma do próprio objeto impressa no sentido? Afinal, todo acesso que o homem tem do mundo exterior é pelos sentidos, portanto não tem como confirmar pelos sentidos mesmo a existência de algo que está realmente fora dos sentidos? A alma não tem como sair de si mesma para confirmar que há um objeto fora dela, já que a visão está nela. Agostinho, com efeito, percebe o risco do solipsismo, afinal, tudo que a alma humana possui do mundo exterior corpóreo são imagens que estão nela própria. O que há são imagens interiores de um "suposto" mundo exterior. Agostinho procura sair desse dilema recorrendo àquilo que poderíamos denominar "teoria das formas".

A forma é o denominador comum entre o corpo exterior e a imagem interior, é o que faz a ponte entre o fora e o dentro. Lógico que com isso ele não responde a questão. Pois se é verdade que a imagem interior possui uma forma, como certificar que essa forma corresponde à forma do objeto exterior, já que o único acesso imediato é a forma no sentido e não a forma do próprio objeto corporal? Evidentemente, não é a própria visão que pode saber a respeito da forma exterior. Agostinho resolve esta questão afirmando que é pela racionalidade, e não pela visão, que sabemos que existem corpos exteriores dotados de forma. Trata-se de uma hipótese

\footnotetext{
63 "É por isso difícil convencer as pessoas de pouca capacidade, que se forma no nosso sentido uma imagem do objeto visível, enquanto o vemos, e que essa forma ou imagem é a visão." (De trinit.,, XI, 2, 3; 2005, p.339) “Ac per hoc tardioribus ingeniis difficillime persuaderi potest formari in sensu nostro imaginem rei uisibilis cum eam uidemus, et eandem formam esse uisionem" (De trinit., XI, 2, 3)

Para ilustrar a realidade de sua afirmação, Agostinho vale-se dos exemplos de pessoas que após olhar durante certo tempo para algumas barras bem iluminadas e em seguida fecha os olhos, vê as barras como borrão. $\mathrm{O}$ próximo passo nesta trindade consiste em considerar as naturezas dos três aspectos contidos na visão:

"Com efeito, suponhamos que se imprima um anel na cera: não se pode dizer que a figura não tenha ficado gravada, pelo fato de somente a percebermos depois de se destacar o anel. Mas como depois de separado da cera permanece tal gravação e pode ser vista, deduz-se facilmente que a figura do anel já estava impressa na cera, antes mesmo da separação." Ora, do mesmo modo como deve-se deduzir que a figura do anel estava na cera antes mesmo de se separaram, deve-se deduzir que a forma do objeto estava na visão quando não olhamos mais para ele." (De trinit., XI, 3, 4; 2005, p.338)
} 
que não pode, como já demonstramos, ser provada empiricamente ${ }^{64}$. Não é pelo sentido que afirmamos a existência e distinguimos a forma do próprio corpo da forma impressa no sentido. É pelo juízo da razão (iudice ratione) ${ }^{65}$ que podemos discernir a existência de duas realidades, de duas formas, uma interior impressa no sentido, e outra exterior, a forma do objeto real.

Para Agostinho a pura evidência de que existe um mundo exterior é suficiente. Ninguém seria louco de duvidar. O seu trabalho é tentar resolver a aporia oriunda do fato de que a alma só tem acesso ao mundo por meio de imagens imanentes, pois a visão dos objetos está no vidente. Sua solução foi dada pela "teoria das formas", a qual remonta Aristóteles.

Em De anima, Aristóteles afirma que os objetos imprimem suas formas na alma, e essas formas impressas permanecem na memória. Daí resultaria que os objetos exercem ação na alma. Segundo Gilson (2007), Agostinho não aceita essa concepção, pois no pensamento agostiniano o inferior não pode exercer ação sobre o superior.

O dilema anteriormente apresentado pode ser posto nas seguintes palavras: a visão é uma ação ou uma paixão da alma? Em Aristóteles, a visão é uma paixão, e é provável que Agostinho conhecesse sua teoria, seja pelo uso do conceito de forma, seja porque afirma que os sentidos carnais são passivos perante a realidade. É notável que também Aristóteles, em De Anima, usa o exemplo do anel na cera para elucidar sobre a visão. Mas a teoria de Agostinho vai além, porque os sentidos, por si só, não determinam e afetam o animus, o qual possui um papel ativo. É possível que Agostinho também tenha conhecido a teoria de Plotino acerca da visão e tenha buscado encontrar uma síntese confrontando-a com a teoria de Aristóteles.

Para Plotino, a visão não pode ser uma paixão. A percepção ocorre quando um objeto é agarrado, pelo espírito, lá onde ele se encontra. O espírito projeta-se, em linha direta, para fora de si, até chegar ao objeto visto, de modo que acontece a visão. Por isso não há impressão do objeto sobre sentido, de modo análogo ao anel na cera. Se vejo a lua é porque a mente,

\footnotetext{
${ }^{64}$ Para sermos mais exatos Agostinho dá um argumento empírico. O homem que olha para um objeto luminoso e em seguida, fecha os olhos, vê os borrões de tal objeto. Mas essa dedução não leva à prova indubitável que exista uma exterioridade.

65 “Ora, sendo essas três realidades de substâncias diferentes, amalgamam-se contudo em uma unidade tal que as duas primeiras, ou seja, a figura do objeto que se vê e sua imagem no sentido, denominada visão, podem apenas ser distinguidas pela intervenção da razão". (De trinit., XI, 2, 5; 2005, p.342)

"Cum igitur horum trium tam diuersae substantiae sint, tamen in tantam coeunt unitatem ut duo priora uix intercedente iudice ratione discerni ualeant, species uidelicet corporis quod uidetur et imago eius quae fit in sensu, id est uisio." (De trinit., XI, 2, 5)
} 
seguindo a direção que aponta o olhar, foi até a lua, embora o corpo permaneça na terra. Os argumenta levantados por Plotino a fim de justificar sua teoria são os seguintes: ${ }^{66}$

1) $\mathrm{O}$ primeiro ponto diz respeito à distância. Se a visão fosse resultado de uma impressão, não saberíamos a distância que o objeto está de nós. Como a alma poderia ver que o objeto está distante dela, se não há intervalo entre ela e a imagem do objeto?

2) Se a visão não passa de impressões, como a alma poderia definir a magnitude dos objetos percebidos, como saberíamos, por exemplo, o tamanho do céu? Haveria de ser uma impressão grande como o céu?

3) Se aceitássemos a hipótese de que vemos apenas as impressões das coisas, isso significa que nós nunca vemos os próprios objetos, mas apenas os vestígios que estes objetos deixam em nós, apenas sombras. Neste caso, as coisas mesmas poderiam ser muito diferentes da visão que temos delas.

4) Além disso, nós nunca poderíamos ver se os objetos estão em contato com nossos olhos. A visão necessariamente só pode haver se existe uma dualidade, um agente que vê e o objeto visto. Se a visão é uma impressão, não há, para quem vê, objeto visto, mas apenas o próprio agente que vê: a visão se resumiria em uma simples alteração da alma. Portanto, seria correto considerar que a alma sofra "alterações involuntárias" e estas alterações sejam aquilo que se chama visão de objetos?

Ora, é de se supor que Agostinho conhecia direta ou indiretamente os argumentos de Plotino e Aristóteles. No entanto, Agostinho não aceita, por completo, nenhum dos dois. A teoria de Agostinho acerca da visão é, em certo sentido, uma síntese dialética entre as teses opostas de Aristóteles e de Plotino. O sentido da vista, da audição etc. são passivos em sua

\footnotetext{
66 Perceptions are no imprints, we have said, arte not to be thought of as seal-impressions on soul or mind. (...) In any perception we attain by sight, the object is grasped there where it lies in the direct line of vision; it is there that we attack it; there, then, the perception is formed; the mind looks outward; this is ample proof that it has taken and takes no inner imprint, and does not see in virtue of some mark made upon it like that of the ring on the wax; it need not look outward at all if, even as it looked, it already held the image of the object, seeing by virtue of an impression made upon itself. It includes with the object the interval, for it tells at what distance the vision takes place: how could it see as outlying an impression within itself, separated by no interval from itself? Then, the point of magnitude: how could the mind, on this hypothesis, define the external size of the object or perceive that it has any-the magnitude of the sky, for instance, whose stamped imprint would be too vast for it to contain? And, most convincing of all, if to see is to accept imprints of the objects of our vision, we can never see these objects themselves; we see only vestiges they leave within us, shadows: the things themselves would be very different from our vision of them. And, for a conclusive consideration, we cannot see if the living object is in contact with the eye; we must look from a certain distance; this must be more applicable to the mind; supposing the mind to be stamped with an imprint of the object, it could not grasp as an object of vision what is stamped upon itself. For vision demands a duality, of seen and seeing: the seeing agent must be distinct and act upon an impression outside it, not upon one occupying the same point with it: sight can deal only with an object not inset but outlying. (Enneads, IV, 6, 1; PLOTINUS, 1952; p.189)
} 
relação com os objetos, posto que estes lhes imprimem a forma. No entanto, a mente é ativa com relação ao sentido, pois, para que a percepção ocorra efetivamente, é necessário um trabalho da mente, um trabalho da atenção, que aplica os sentidos aos objetos. Esse conceito de atenção, ou intentio animi, será, de certo modo, o germe, em Brentano, do conceito de intencionalidade do qual Husserl se apropriará, fazendo dele um dos conceitos chaves da fenomenologia. A intencionalidade é, tanto em Agostinho quanto em Husserl, justamente o que distingue a percepção do simplesmente ter sensações. Quando Agostinho diz que a intenção aplica o sentido ao objeto, ele está usando a noção de "estar com o olhar do espírito voltado para um objeto" como elemento inseparável da percepção. Em Husserl, perceber é uma vivência intencional e, portanto, um ato da consciência, no qual a sensação é "interpretada", ou "animada" de modo que se dê a percepção de um objeto intencional. 


\subsection{O cogito}

\subsubsection{O pensamento das realidades sensíveis: a forma impressa no olhar da mente}

Observamos como Agostinho, para compreender o problema dos objetos exteriores à alma humana, recorre a uma "teoria das formas". A forma que está impressa no sentido é uma similitude da forma do próprio objeto corporal. Contudo, não são idênticas, pois a forma no sentido é gerada pela forma do objeto corporal. E aquilo que é gerado é distinto daquilo que gera, embora possuam uma relação de similitude formal. Essa forma gerada no sentido ocorre porque a vontade aplicou e direcionou o sentido da visão ao objeto visto.

Uma vez que o homem tenha a visão de um objeto, ele é capaz de guardar na memória a imagem do objeto. Este processo de retenção, segundo a explicação agostiniana é semelhante ao processo da visão, pois memorizamos algo quando a forma impressa nos sentidos imprime sua forma na memória, processo que também aqui ocorre em virtude da ação da vontade, como elemento copulador. Em outras palavras, a vontade "pega" a forma presente na visão e "carimba" essa forma na "cera" da memória.

Finalizado o processo de retenção de uma imagem na memória, a mente pode pensá-la ou recordá-la. Ainda aqui, o processo de se pensar (cogito) os objetos ausentes é semelhante ao processo da visão. Se a visão era ter a forma do objeto exterior impressa no sentido dos olhos (sensus oculorum), em virtude de uma ação da vontade ou atenção:

(...) desaparecida a figura corporal que atuava sobre o sentido corporal, permanece na memória uma imagem desse objeto, imagem essa que pode levar a vontade a voltar-se novamente a ela com o olhar da alma. A informação passa-se assim ao interior, tal como do exterior o sentido era informado mediante o objeto sensível. Produz-se desse modo uma nova trindade produzida pela memória, pela visão interna e pela vontade que a ambas enlaça. Quando essas três coisas estão reunidas em um só todo, essa reunião é dita ser o pensamento - palavras cuja raiz lembra essa união. (De trinit., XI, 3,6; 2005, p.343)

(...) detracta specie corporis quae corporaliter sentiebatur remanet in memoria similitudo eius quo rursus uoluntas conuertat aciem ut inde formetur intrinsecus sicut ex corpore obiecto sensibili sensus extrinsecus formabatur. Atque ita fit illa trinitas ex memoria et interna uisione et quae utrumque copulat uoluntate, quae tria cum in unum coguntur ab ipso coactu cogitatio dicitur. Nec iam in his tribus diuersa substantia est. (De trinit., XI, 3,6 ; os negritos são nossos)

O pensamento, por sua vez, ocorre quando a forma do objeto corpóreo, armazenada na memória, imprime sua forma no olhar da mente, pela ação da vontade, que une ambos. Na 
passagem abaixo Agostinho resume todo o processo, desde quando vemos um objeto até o momento em que o pensamos.

No decorrer desta análise das diversas formas ou imagens, tendo começado pela imagem corporal e chegado àquela gerada pelo olhar da alma, encontramos quatro imagens que foram nascendo gradualmente, uma da outra: a segunda, da primeira; a terceira, da segunda. E a quarta, da terceira. Da figurra corporal observada nasce a imagem produzida no sentido do observador. Desta se origina outra: a que é produzida na memória. E desta nasce a que se forma no olhar mental daquele que pensa. (De trinit., XI, 9,$16 ; 2005$, p.359)

In hac igitur distributione cum incipimus ab specie corporis et peruenimus usque ad speciem quae fit in contuitu cogitantis, quattuor species reperiuntur quasi gradatim natae altera ex altera, secunda de prima, tertia de secunda, quarta de tertia. Ab specie quippe corporis quod cernitur exoritur ea quae fit in sensu cernentis, et ab hac ea quae fit in memoria, et ab hac ea quae fit in acie cogitantis. (De trinit., XI, 9,16)

O que ocorre é que uma forma vai gerando a outra, devido à ação da vontade. Daí resulta que a forma, ou imagem (speciem) no olhar da mente, é uma forma de "quarto grau", por assim dizer, dado que temos as seguintes formas: 1) a forma do próprio objeto, que gera a forma do objeto nos sentidos corporais; 2) a forma do objeto impressa no sentido, que gera a forma do objeto na memória; 3) a forma do objeto na memória, que gera a forma no olhar do espírito.

\subsubsection{O movimento do cogito e o fluxo de consciência}

O verbo latino cogitare, tal como empregado por Agostinho e que traduzimos como pensar, engloba o ato de lembrar. O ato de lembrar é uma espécie de pensamento. Como já havíamos observado anteriormente, todo ato de pensar implica a memória. Agostinho, de fato, define "cogito" como ter o olhar da mente informado por um objeto, pela ação da memória. Portanto, o ato de recordar é uma espécie de cogito, pois é ter o olhar da mente informado por um conteúdo da memória ${ }^{67}$, assim como imaginar e, como veremos mais adiante, até mesmo perceber. Usaremos o termo pensamento em sentido amplo, para corresponder àquilo que Agostinho entende por cogito.

No momento em que pensamos algo, temos esse algo diante do olhar da mente devido à vontade. Mas se é a vontade que "põe" um conteúdo da memória diante do olhar da mente é também a vontade que o "retira". Trata-se de um trabalho incessante da vontade, no qual ela

\footnotetext{
${ }^{67}$ A investigação do que é a mente atinge agora um maior nível de complexidade. Havíamos observado que a mente é incorporal, uma presença a si mesma, que quer, entende, conhece, pensa.
} 
põe e tira os conteúdos diante do olhar da mente, sucessivamente. Fica claro, portanto, que uma coisa é ter algo diante do olhar da mente, outra é ter algo na memória. Mas como a memória pertence à mente, somos forçados a constatar que nem tudo aquilo que está nela contido está diante do olhar da mente, ou do olhar do animus (acies animi). De fato, Agostinho nas Confissões alerta que ter algo no espírito (animus) equivale a ter algo na memória, afinal, a memória pertence ao espírito (animus).

Portanto, embora o espírito ou a mente possua um olhar (acies animi), não se deve confundir o olhar do espírito com o próprio espírito. Pois podemos ter algo no espírito sem que esteja diante do olhar do espírito. Não é difícil perceber que essa distinção revela algo muito próximo do que hoje se entende por consciência enquanto dados imediatos ao eu, e de inconsciente ou pré-consciente, enquanto dados que podem vir a se tornar imediatos. Basta considerar que aquilo que está na memória é, em certo sentido, "inconsciente" ou "preconsciente", sem que isso signifique nada de psicanalítico, apenas que existem conteúdos na memória que não estão diante do olhar da mente, mas que poderiam vir a se tornar conscientes, caso se queira ${ }^{68}$. E isso é condição necessária da mente humana, que não possui a capacidade de vislumbrar, em um único instante temporal, tudo quanto há na memória ${ }^{69}$. A temporalidade, aqui, é essencial à mente humana: para que tenhamos o olhar da mente informado por uma coisa, é necessário deixar de pensar em outra.

Neste processo incessante através dos quais os pensamentos vão passando, o olhar da mente não possui um caráter móvel, ao contrário da vontade, que está em constante mobilidade, em seu trabalho de unir os conteúdos da memória ao olhar da mente, colocandoos e retirando-os diante do olhar da mente para informá-lo. Em virtude desse movimento contínuo da vontade, forma-se aquilo que poderíamos chamar de fluxo do pensamento ou sucessão de cogitatones.

Mas como a visão da alma não pode abranger com um só olhar tudo o que está retido na memória, as trindades do pensamento se revezam, aproximando-se e retirando-se, alternadamente. Isso faz resultar trindades numerosíssimas, contudo não em número infinito, pois não superam o número das imagens conservadas na memória. (De trinit., XI, 8, 12b; 2005, p.355).

Sed quoniam non potest acies animi simul omnia quae memoria tenet uno aspectu contueri, alternant uicissim cedendo ac succedendo trinitates cogitationum, atque ita fit ista innumerabiliter numerosissima trinitas, nec tamen infinita si numerus in memoria reconditarum rerum non excedatur. (De trinit., XI, 8, 12b).

\footnotetext{
${ }^{68}$ Não é o caso, como já observamos, da memória recôndita; para se encontrar algo nela envolve um processo de "descoberta", ainda que esta descoberta seja guiada por outros homens.

${ }^{69} \mathrm{E}$ mais, por que a vontade traria ao espírito uma recordação que lhe cause, por exemplo, a dor da vergonha?
} 
Devemos observar que, dentro desta perspectiva, o uso do termo "fluxo de pensamento" pode dar uma impressão equivocada. A ideia de fluxo pode transmitir a noção de continuidade indivisível, ao passo que o que há, para Agostinho, são sucessões discretas de trindades do pensamento, cedendo ac succedendo trinitates cogitationum. Outro fato que devemos notar é que o cogito, por ser o fruto da reunião de três elementos formando uma trindade, não implica necessariamente a sucessão de trindades. Podemos imaginar uma situação hipotética em que a vontade permanece fixa em um único objeto, mantendo-o presente diante do olhar da mente, como um monge que contempla concentrada e fixamente um único objeto. Neste caso, teríamos, por assim dizer, um único pensamento, um pensamento que não passaria para que outro pensamento viesse, e poderíamos nos manter neste estado contemplativo por toda eternidade.

\subsubsection{A desatenção}

Aquele que deixa de prestar atenção em uma coisa é porque está prestando atenção em outra. Se a atenção está fixada em algo, significa que temos esse algo diante do olhar da mente. Não é possível prestar atenção em algo, sem que tenhamos con sciência deste algo, sem que este algo esteja, portanto, diante do olhar da mente.

Algumas vezes se diz que o fenômeno da distração ocorre quando a pessoa deixa de prestar atenção em algo. Mas, por outro lado, se deixou de prestar atenção em uma coisa é porque está prestando atenção em outra coisa. Em suma, ela nada mais fez do que substituir o objeto de atenção. Se assim é, em que sentido devemos compreender o termo desatento?

A primeira hipótese seria dizer que o desatento é aquele que troca muito rapidamente o objeto da atenção. Mas essa hipótese revela-se falsa: para um vigia de uma loja, seu estado de atenção caracteriza-se por uma atenção ágil e móvel, no qual ele troca rapidamente o foco de atenção sem que se detenha por razões fortuitas a única pessoa, de modo que possa detectar caso alguma delas esteja furtando um produto. Se o segurança entrar em um devaneio, ou se entreter com a beleza de uma mulher que entra na loja, diz-se que é desatento. Na verdade, está atento à beleza da mulher, está com o olhar da mente dirigido para a mulher. Mas ficar atento à beleza da mulher não é fim da função do vigia, pelo contrário, pode atrapalhar o bom desempenho de sua função. Algo semelhante pode ocorrer com quem está lendo um livro, mas com a cabeça em outra coisa. Quando "cai em si”, dá-se conta de que estava pensando em um assunto alheio à leitura e constata que não sabe o que leu. 
Tais exemplos sugerem que a desatenção se define por um desvio despercebido daquilo que a pessoa previamente determinou, por um ato da vontade, como sendo seu fim, seu objetivo. O desatento deixa de se ocupar com aquilo que previamente havia se determinado a fazer. É como se a pessoa temporariamente se esquecesse da tarefa que ela mesma se colocou e se impôs.

Um dos traços básicos da atenção, segundo Agostinho, é que ela é estreitamente vinculada com a vontade. A atenção pertence à vontade, razão pela qual ele usa o termo intentio voluntatis (atenção da vontade). Colocar para si um projeto e se determinar a realizálo são atos dos quais a vontade participa ${ }^{70}$. Afinal, aquele que se determina a fazer um projeto possui, por definição, vontade de realizá-lo.

No entanto, uma coisa é a decisão, outra a realização. Entre a decisão da vontade e realização pode haver intervalos pequenos ou grandes de tempo. Como consequência, para que a decisão se realize, é necessário que a vontade não se perca nesse ínterim. Mas como a decisão se separa da realização por incontáveis circunstâncias e cada uma delas exige nossa atenção, atraindo-nos ou repelindo-nos, resulta que a vontade sempre pode se desviar daquilo que ela havia se imposto a si mesma.

De fato, a atenção, a todo instante, pode se voltar a uma enorme gama de objetos possíveis, presentes aos sentidos ou imaginados. Trata-se de uma possibilidade constante, de um risco constante, pois a atenção é escrava da vontade. E esta, por seu turno, é atraída pelo prazeroso e repelida pelo doloroso.

E cada circunstância possui sua "tentação", entendida como aquilo que pode nos fazer desviar de nossa meta, levando-nos a trair a nós mesmos, como um ex-alcoólatra pode sentirse tentado a beber quando está em uma festa cujos participantes estão bêbados e felizes. Neste momento é crucial para ele lembrar-se dos motivos pelos quais parou de beber, das consequências que terá ao beber, em suma, ele deve se lembrar da própria vontade e dos motivos que o levaram a ter a vontade de não beber. Do mesmo modo, o vigia desatento não é desatento em si, ele é desatento com relação à vontade ${ }^{71}$.

Por outro lado, não apenas as circunstâncias imediatas têm o poder de roubar atenção de modo que nos desviemos de nossa meta. O espírito pode também deixar de prestar atenção naquilo que é dado aos sentidos, para mergulhar dentro de si mesmo e vice-versa. Agostinho coloca da seguinte forma a questão:

\footnotetext{
${ }^{70}$ Quanto a esse ponto, há grande semelhança com o pensamento de Aristóteles, para o qual, como já observamos, a escolha é um desejo raciocinado. A escolha é união entre razão e desejo.

${ }^{71}$ Do mesmo modo, quem está lendo um livro e se afunda em um devaneio é desatento com relação à vontade de ler o livro.
} 
Em relação à memória, a vontade desvia-a dos sentidos fazendo-a atenta a outras coisas e não lhe permitindo fixar-se nos objetos presentes no momento. Constata-se isso facilmente, por exemplo, quando parecemos não escutar quem nos dirige a palavra, por estarmos com o pensamento ocupado com outra coisa. Mas tal não é verdade, pois escutamos, e se não recordamos, é porque a atenção, que fixa as impressões em nossa memória, estava desviada por um movimento diferente da vontade perante as palavras que apenas resvalaram pelo sentido da audição. (De trinit., XI, 8, 15; 2005, p.358).

Memoriam uero a sensu uoluntas auertit cum in aliud intenta non ei sinit inhaerere praesentia. Quod animaduertere facile est cum saepe coram loquentem nobis aliquem aliud cogitando non audisse nobis uidemur. Falsum est autem; audiuimus enim sed non meminimus subinde per aurium sensum labentibus uocibus alienato nutu uoluntatis per quem solent infigi memoriae. (De trinit., XI, 8, 15).

Atenção possui uma direção centrífuga e uma centrípeta. Pode retirar-se do mundo presente aos sentidos para voltar-se aos conteúdos da memória, ou o contrário. Mesmo que a atenção esteja voltada para dentro, o mundo exterior não deixa de atuar nos sentidos, se bem que esta atuação é, por assim dizer, invalidada. Para que a forma no sentido seja impressa na memória é necessário que a vontade una ambas, o que exige que prestemos atenção ao "mundo dos sentidos",72. Caso não o façamos, é como se existisse uma "visão inconsciente", ou uma visão periférica, de segundo plano.

Um outro exemplo usado por Agostinho, o qual já expomos, é o de alguém que está lendo um texto e subitamente se dá conta que apenas passava os olhos pelas páginas sem assimilar nada. Não assimilou, pois pensava em outras coisas. Os sentidos não deixaram de ser informados pelas letras, no entanto, a atenção do espírito não estava direcionada para o conteúdo do texto, o qual, portanto, não foi retido na memória.

Em outro exemplo, Agostinho comenta a respeito de um caminhante que vai andando tão absorto em seus pensamentos, que, quando "cai em si”, não sabe sequer o percurso que fez. Neste caso, aquele que caminhava, em certo sentido, via o caminho, dado que não trombava em nada. Mas, por outro lado, não via o caminho, posto que sua atenção estava

\footnotetext{
${ }^{72}$ Em Ética a Nicômaco, Aristóteles aborda problema bem semelhante ao de Agostinho. Depois de comentar que toda atividade pode ter um prazer próprio, comenta que o prazer intensifica as atividades, logo tem afinidades com as atividades.

"Essa asserção torna-se ainda mais evidente pelo fato de que algumas atividades são impedidas por prazeres provenientes de outras. Efetivamente, as pessoas que gostam muito de tocar flauta são incapazes de acompanhar um argumento filosófico se ouvem um flautista, já que o som desse instrumento lhes dá mais prazer do que a outra atividade a qual se dedicam no momento. E desse modo, o prazer proveniente da música é um obstáculo relacionado ao raciocínio filosófico. (...) É por isso que, quando comprazemos de modo excepcional com alguma coisa não a dedicamos a mais nenhuma, e só fazemos uma coisa quando a outra não nos causa grande prazer (por exemplo, as pessoas que gostam de doces no teatro os comem em maior quantidade quando os atores são ruins)". (1175 b 5; ARISTÓTELES, 2007, p.224).
} 
dirigida a outra coisa ${ }^{73}$. Ao observar esse estranho fenômeno, Agostinho coloca-se a seguinte questão: Por que aquele que caminhava, quando "cai em si”, isto é, quando verte sua atenção novamente ao mundo dos sentidos, não consegue lembrar-se por onde andou? Agostinho explica o fenômeno da seguinte forma. Aquele que pensa está requisitando sua memória, pois enquanto está pensando, a vontade está ocupada na atividade de trazer os conteúdos da memória para diante do olhar da mente. Por isso, a vontade não poderia estar exercendo com zelo a função copulativa de imprimir as imagens dadas aos sentidos na memória, aí as retendo, pois tanto a memória quanto a vontade estavam ocupadas na atividade de pensar coisas alheias aos sentidos. A vontade desligou-se do mundo circundante imediato e afundouse no pensamento. Daí, a conclusão final de Agostinho: "Portanto, querer desviar o olhar da alma de um conteúdo da memória é o mesmo que não pensar". (De trinit., XI, 8, 15; 2005, p.359) $)^{74}$.

Essas situações observadas por Agostinho revelam como a experiência do pensar implica uma espécie de abstenção do mundo imediato das presenças corporais, donde resulta inversamente que aquele que tem a atenção voltada para o mundo circundante e não para os conteúdos da memória não está necessariamente pensando ou, quando muito, está em outro nível de pensamento. O que "existe" para a mente em um dado momento é justamente aquilo para o qual o olho da mente está voltado. Enquanto a alma está voltada para algo e percebe esse algo, ela pode "esquecer" até mesmo de si mesma e dos objetivos que outrora impôs a si mesma e que ela deveria estar seguindo.

A análise dos fenômenos supracitados coloca em evidência o fato de que não só existem conteúdos no espírito, mas também atividades do eu que não se passam diante do olhar da mente. Com efeito, o ato de caminhar em direção a um lugar exige algum tipo de atividade da alma humana, isto é, do princípio vital. A questão que fica é: existe uma atividade da anima paralela à atividade da mens? Qual a relação entre a anima e a mens?

\footnotetext{
${ }^{73}$ Agostinho não fala em algo como um "automatismo da carne", isto é, que o corpo vivo, animado, tem uma vida que ultrapassa a apreensão do olhar da mente. Certo, ele não explicita isso, mas a ideia está implícita.

${ }^{74}$ Iam porro ab eo quod in memoria est animi aciem uelle auertere nihil est aliud quam non inde cogitare.( $D e$ trinit., XI, 8, 15)
} 


\subsection{A vida do eu enquanto homem}

\subsubsection{O homem interior e o homem exterior}

Para compreender as relações entre mens, corpus e anima é necessário em primeiro lugar observar que esses diferentes estratos estão referidos àquilo que entendemos por "eu". O termo "eu" é um tanto escorregadio, pois dependendo de como é empregado, pode referir-se a realidades específicas presentes no homem. Se digo: "sou moreno", estou me referindo ao corpo, pois ser moreno é um atributo corporal, o qual não pode predicar um pensamento ou um sentimento, mas quando digo: “tenho a compreensão do teorema de Pitágoras", estou me referindo a um atributo não-corporal, isto é, um predicado do espírito.

$\mathrm{O}$ eu entendido como um homem em sua totalidade, enquanto ser dotado de mente, alma e corpo, que se relaciona com o mundo, com Deus e consigo mesmo, também é o que poderíamos denominar de eu-pessoa, ou eu-homem. Se considero apenas a mim mesmo naquilo que possuo de superior em mim, em minhas faculdades ligadas à contemplação das ideias eternas, refiro-me à minha própria mente, que é o que há de superior no eu-homem. Mas, como já vínhamos observando, o "eu” não necessariamente exige o corpo para que seja eu. Por exemplo, se eu digo: "eu sonhei que eu estava em um castelo", - o pronome "eu" não se refere ao eu-homem real vivendo num mundo real. Entretanto, não deixou de ser eu que, embora num mundo de sonhos, estava em um castelo. Essa distinção, como veremos, é de suma importância, pois ela será, em Agostinho, a chave para a compreensão da permanência do eu após a morte do corpo carnal.

Com a morte do corpo, não posso mais ser um eu-homem, tal qual sou enquanto vivo. Não poderei dizer "tenho fome", "sou moreno" etc. No entanto, de algum modo deverei permanecer sendo eu. E, evidentemente, só poderia continuar a ser eu se existir algo em mim que possa subsistir sem um corpo. Se é verdade que, após a morte, não poderei mais ver as criaturas e não terei mais sensações, poderei, entretanto, contemplar o bem supremo e viver o gozo da verdade, pois estamos falando aqui de realidades inteligíveis e espirituais.

O que iremos expor neste capítulo são justamente as distinções que Agostinho faz nesse eu-homem, observar como seus diferentes estratos estão articulados e finalmente circunscrever o que no homem há de eterno, separando daquilo que nele há de transitório e corruptível. Essa investigação, embora possua evidente inspiração religiosa, não se limita ao âmbito religioso, mas também ao racional e intelectual. $O$ foco de nosso interesse não é a prova da imortalidade do espírito humano, mas o fato de que, Agostinho, partindo da 
"hipótese" da imortalidade, procura entender sob que condições isso seria possível. E, ao avaliar as condições de possibilidade, consegue distinguir intelectualmente no "eu" aquilo que "poderia", ao menos enquanto possibilidade de essência, ser imortal. Esses estudos das condições de possibilidade são válidos mesmo para quem é cético a respeito da imortalidade do espírito; assim como não é necessário ser religioso para acreditar na existência da consciência.

Justamente por partir da crença da imortalidade do espírito, e procurando compreender como isso é possível, Agostinho acaba chegando a uma refinada compreensão daquilo que poderíamos denominar "consciência humana", aproximando-se muito dos resultados encontrados pelo método fenomenológico. Nada impede que ideias religiosas sirvam de inspiração à racionalidade, resultando em conhecimentos científicos.

$* * *$

Para encontrar o que há de eterno no homem é preciso subtrair do eu tudo aquilo que não é necessário para que o "eu" continue reconhecendo a si mesmo como um "eu”. Como já observamos, as sensações estão vinculadas com corpo, embora seja concebível um eu que tenha pensamentos sem que tenha sensações. O que parece necessário para que o eu possa ter pensamentos é que tenha tido sensações antes de perdê-las. Mas depois de tê-las e, a partir delas, desenvolver sua capacidade pensante, poderia muito bem perdê-las e continuar a ser um eu. Quem perde um dos sentidos não perde a capacidade de querer, de pensar, de se lembrar, de entender. Portanto, a visão e os demais sentidos são inessenciais à vida do eu. De fato, com a morte do corpo, vão-se as sensações. Daí resulta que nem o corpo, nem as sensações do corpo dizem respeito ao que há de eterno no homem.

É dentro desta ótica que Agostinho interpreta as palavras do apóstolo Paulo: "Embora em nós, o homem exterior vá caminhando para a sua ruína, o homem interior se renova dia a dia” $(2$ cor 4,16$)$. O que no homem caminha para a ruína é aquilo que nele há de transitório, o que corresponde a tudo aquilo que possui em comum com os animais.

Ao homem exterior, portanto, estão referidos não apenas o próprio corpo carnal, mas também a capacidade de mover os membros, os sentidos corporais, as sensações, os apetites sensíveis e ainda:“(...) perceber através dos sentidos do corpo os objetos materiais colocados no mundo exterior, lembrar-se deles, depois de impressos na sua memória, desejar entre eles os que the são úteis e fugir dos que the são nocivos." ${ }^{75}$ (De trinit. XII, 2,2; 2005, p.366). No

\footnotetext{
$75 ،$ Verum ea notare ac non solum naturaliter rapta sed etiam de industria memoriae commendata retinere et in obliuionem iamiamque labentia recordando atque cogitando rursus imprimere ut quemadmodum ex eo quod gerit memoria cogitatio formatur, sic et hoc ipsum quod in memoria est cogitatione firmetur, fictas etiam uisiones hinc
} 
que se refere ao homem exterior, a única diferença significativa em relação aos animais é que o corpo humano é ereto, razão pela qual pode olhar para o céu, símbolo da advertência de Deus para que o homem não se assemelhe aos animais naquilo que nele há de superior: sua mente.

Ao homem interior pertencem a racionalidade e a inteligência, atributos, como já sabemos, da mente ${ }^{76}$. Mas por que Agostinho usa o termo "homem interior" e não o próprio termo "mente"? Trata-se, provavelmente, de uma grande sutileza do autor. O uso do termo "homem interior" é, em certo sentido, sinônimo de mente. Entretanto, refere-se à mente em sua condição de estrato superior do eu enquanto esse eu vive sua condição humana. Enquanto vivemos essa vida, nossa mente está entremeada com o homem em sua globalidade, vinculada às atividades concretas não propriamente "mentais". Isso torna-se patente pelo fato de que a vontade da mente possui uma dupla direção, ora voltando-se ao transitório, ora ao eterno, ora dirigindo-se para o interior e o superior, ora para o exterior.

Já observamos alguns conceitos fundamentais sobre o que é a mente humana: uma presença constante, que conhece a si, sabe que seus conhecimentos estão em si, capaz de pensar, dotada de vontade, inteligência e memória, sendo estas três faculdades imbricadas uma na outra embora distintas ${ }^{77}$. Por ter inteligência, a mente é capaz de apreender a si mesma, os números, as regras eternas e Deus, dado que tais realidades são incorpóreas e inteligíveis. Todavia, uma coisa é definir a faculdade da inteligência e da razão, outra é detalhar essas faculdades em suas atividades concretas e elucidar como elas participam da vida do homem, partindo de uma concepção de vida suficientemente ampla para abarcar a vida cotidiana do homem.

atque inde recordata quaelibet sumendo et quasi assuendo componere, inspicere quemadmodum in hoc rerum genere quae uerisimilia sunt discernantur a ueris, non spiritalibus sed ipsis corporalibus, haec atque huiusmodi, quamuis in sensibilibus atque in eis quae inde animus per sensum corporis traxit agantur atque uersentur, non sunt tamen rationis expertia nec hominibus pecoribusque communia". (De trinit., XII, 2,2; 2005, p.366).

76، (...) por certa manifestação de vida que confere vigor a todas as articulações e sentidos corporais, instrumentos esses da percepção do mundo exterior. E quando as imagens percebidas pelos sentidos e fixadas na memória são revistas mediante a recordação, elas também referem-se ao homem exterior.” ( De trinit. XII, 1, 1; 2005, p.365).

"Quidquid enim habemus in animo commune cum pecore recte adhuc dicitur ad exterior deputabitur sed adiuncta quadam uita sua qua exterior deputabitur sed adiuncta quadam uita sua qua compages corporis et omnes sensus uigent quibus instructus est ad exteriora sentienda. Quorum sensorum imagines infixae in memoria cum recordando reuisuntur res adhuc agitur ad exteriorem hominem pertinens." (De trinit., XII, 1, 1).

77 Os animais não possuem vontade, mas apenas a cupiditas. A distinção entre vontade e cupiditas será investigada posteriormente. Por ora, basta reconhecermos que um animal só poderá querer voltar para a toca, porque tem memória da toca e sabe que a toca é útil. Contudo, falta-lhe a comprensão de seu próprio desejo. A vontade implica inteligência, a cupiditas não. De fato, o homem pode ter a cupiditas e não se deixar levar por ela. Mesmo tendo comida a sua disposição, o homem pode se abster de comê-la, ainda que a desejando. E pode querer comer, ainda que não desejando, como o doente que come a sopa, sem apetite. 
Havíamos dito que a distinção fundamental do homem frente aos outros animais é a inteligência e a razão com as quais ele relaciona-se com as realidades invisíveis e inteligíveis. O ponto que Agostinho irá deixar claro no livro XII da Trindade é que o poder da mente não se limita à sua capacidade de lidar com as realidades inteligíveis: a própria mente pode se voltar para o mundo sensível. É verdade que também a alma animal se relaciona com o mundo corporal sensível, mas o homem é capaz de se relacionar com as imagens sensíveis de um modo próprio, isto é, de lidar racionalmente com os seres sensíveis, o que significa também que ele pode lidar racionalmente com as imagens sensíveis que estão na memória. ${ }^{78}$ Portanto, é possível encontrar alguns elementos fundamentais da mente que dizem respeito à relação da mente com o mundo sensível e das imagens sensíveis na memória.

1) $\mathrm{O}$ primeiro poder diferencial do homem diz respeito ao modo como usa a imaginação. O homem pode não apenas lembrar-se das imagens dos corpos, mas pode usar estas imagens contidas na memória para compor racionalmente novas imagens. De fato, se nunca fomos à Cartago, mas lemos ou escutamos a respeito desta cidade, podemos dela formar uma imagem mental. Não se trata, evidentemente, de uma criação ex nihil, mas de uma composição que se faz usando, como matéria-prima, as imagens contidas na memória. $\mathrm{O}$ homem pode, se quiser, imaginar duas luas, um sol quadrado, ou até mesmo criaturas estapafúrdias, como um animal cujos olhos se encontrem nas patas.

2) Um segundo aspecto que diferencia o homem dos animais diz respeito à capacidade de avaliar e compor suas imaginações conforme um senso de verossimilhança. Ao escutarmos uma descrição de Cartago, imaginamos a cidade apoiados no que é dito, mas também no não dito. De certo modo, completamos a imagem mental com elementos não presentes na própria descrição. Por exemplo, se imagino Cartago tal como era no tempo de Agostinho, não a

\footnotetext{
78 "Verum ea notare ac non solum naturaliter rapta sed etiam de industria memoriae commendata retinere et in obliuionem iamiamque labentia recordando atque cogitando rursus imprimere ut quemadmodum ex eo quod gerit memoria cogitatio formatur, sic et hoc ipsum quod in memoria est cogitatione firmetur, fictas etiam uisiones hinc atque inde recordata quaelibet sumendo et quasi assuendo componere, inspicere quemadmodum in hoc rerum genere quae uerisimilia sunt discernantur a ueris, non spiritalibus sed ipsis corporalibus, haec atque huiusmodi, quamuis in sensibilibus atque in eis quae inde animus per sensum corporis traxit agantur atque uersentur, non sunt tamen rationis expertia nec hominibus pecoribusque communia". (De trinit., XII, 2, 2)

"Ao contrário, fixar a atenção, reter, além das lembranças captadas espontaneamente na natureza, como ainda as que foram confiadas intencionalmente à memória, e quando essas lembranças estão parqa cair no esquecimento, lembrá-las e representá-las (pois assim como o pensamento forma-se pelo que está contido na memória do mesmo modo o que já está gravado na memória consolida-se pelo pensamento); além disso, construir visões imaginárias, recolhendo e como que tecendo tais e tais lembranças tomadas aqui e ali; ver como nesse gênero de coisas se distingue o verossímil do verdadeiro, não só no domínio espiritual, mas até no material; todas essas e outras operações do gênero, ainda que tenham relação com o sensível e com os conhecimentos que a alma adquire mediante os sentidos, não são estranhas à razão, nem são comuns a homens e animais". (De trinit., XII, 2,$2 ; 2005$, p.366)
} 
imaginarei com luz elétrica, nem com asfalto nas ruas, mas posso imaginar que dentro das casas havia mesas e camas de palha. Nunca encontrei uma descrição antiga afirmando explicitamente que havia em Cartago camas de palha. Não sei com absoluta certeza se realmente havia mesas em Cartago e camas de palhas, mas considero verossimilhante. No entanto, outras imagens, embora compostas pela imaginação, podem muito bem não ser apenas verossímeis, mas verdadeiras ${ }^{79}$.

3) Um terceiro elemento, levantado por Agostinho, diz respeito à capacidade de guardar e recordar intencionalmente determinadas lembranças. Apenas o homem sabe que deve guardar algo na memória e, em virtude disso, não apenas guarda propositadamente, mas também pode propositadamente recordar várias vezes daquilo que é guardado com o único intuito de melhor fixar o que está na memória. Portanto, se é verdade que tanto os homens quanto os animais possuem memória das realidades sensíveis, o homem usa a faculdade de modo proposital. Tal operação, como se pode observar, não diz respeito diretamente ao conhecimento das realidades inteligíveis, embora esteja implícita nesta atividade, pois exige que o homem tenha conhecimento do fato de que tem uma memória e de que sabe que pode se esquecer. Isso pressupõe que ele conheça e entenda tanto a memória quanto o esquecimento, o que só ocorre porque possui o olhar da inteligência.

Esses primeiros elementos considerados por Agostinho como exclusivos do "homem interior" revelam que este não apenas possui a capacidade contemplativa do inteligível, mas a capacidade de articular racionalmente e intencionalmente as imagens das coisas sensíveis que ele possui na memória. Com isso revela-se que a mente não negocia exclusivamente com as realidades inteligíveis, mas também com seres transitórios, sensíveis e corporais. Como já havíamos mencionado, embora una, ela possui duas funções distintas, que correspondem a duas direções possíveis. A primeira é contemplar as regras eternas, imutáveis, inteligíveis e suprassensíveis. A segunda serve para auxiliar o homem exterior em sua vida prática. Agostinho define a primeira de razão superior, a segunda de razão inferior.

O jogo entre vida contemplativa e vida prática constituem, para Agostinho, um dos maiores dramas do ser humano. Se é verdade que nem só de pão vive o homem, também é verdade que não só de contemplação vive o homem. O homem interior, embora seja capaz de contemplar os inteligíveis, deve, por força, se ocupar da vida prática. Não é possível emitir a

\footnotetext{
${ }^{79} \mathrm{O}$ modo como se distinguem as imaginações verossímeis da verdadeiras não é explicado por Agostinho.
} 
luz da atenção apenas para o alto, é preciso também que a vontade e a racionalidade se apliquem ao inferior e ao exterior ${ }^{80}$.

Em resumo, o homem interior também tem a função de auxiliar e guiar, com a razão inferior, o homem exterior, tal como o cavaleiro conduz um cavalo. Por isso, a criatura humana, em sua vida prática, não age como um animal. Mesmo quando está satisfazendo suas necessidades animais, o espírito está ali. Trata-se da condição insuprimível: a mente deve também se ocupar com o temporal, com o variável, com o contingente, deve planejar seu futuro, decidir suas ações, se precaver contra o mal, conhecer os corpos sensíveis, dominar a natureza; mas deve também saber se comportar adequadamente com outros homens e resistir às tentações que o mundo the oferece. Em suma, o homem deve lidar com o transitório, mas tudo isso seria vão se o homem interior não estivesse também com os olhos abertos à estrela guia à qual toda vida prática deve estar referida: o sumo bem.

\subsubsection{Ciência e Sabedoria}

Todo esse conhecimento relacionado à vida prática e aos seres transitórios Agostinho define de "ciência". Todo conhecimento relacionado à pura vida contemplativa Agostinho chama de "sabedoria". A contemplação de Deus é o fim último do ser humano, o porquê de ser e existir, pois a fonte da beatitude ou felicidade. Durante essa vida, essa contemplação é parcial, após a morte, para os bem-aventurados, essa contemplação será completa: o espírito verá Deus face a face. Já a ciência se distingue da sabedoria, dentre outros aspectos, porque esta não é um fim em si mesma, é apenas um meio, uma necessidade inerente à condição humana. De fato, temos um corpo, que está irremediavelmente lançado no mundo, e temos nossa vida entrelaçada com os demais homens. Tanto o corpo quanto o nosso mundo circunstante exigem constantes cuidados.

\footnotetext{
80 "apparet tamen cum secundum deum uiuimus, mentem nostram in inuisibilia eius intentam ex eius aeternitate, ueritate, caritate proficienter debere formari, quiddam uero rationalis intentionis nostrae, hoc est eiusdem mentis, in usum mutabilium corporaliumque rerum sine quo haec uita non agitur dirigendum, non ut conformetur huic saeculo finem constituendo in bonis talibus et in ea detorquendo beatitudinis appetitum, sed ut quidquid in usu temporalium rationabiliter facimus aeternorum adipiscendorum contemplatione faciamus per ista transeuntes, illis inhaerentes" (De trinit., XII, 13, 21)

"Quando vivemos em conformidade com Deus, nossa alma tende para as suas perfeições invisíveis e deve modelar-se progressivamente em contato com a eternidade, a verdade e a caridade divinas. Entretanto, sempre certa parte de nossa atenção racional, ou seja, da própria alma, há de se dirigir à lida com as coisas mutáveis e corporais, isso por necessidade, sem o que não se conseguiria viver. Não, porém, no sentido de nos conformamos com esse mundo (Rm, 12, 2), fixando nosso fim nesses bens sensíveis e distorcendo para esse lado nosso anseio de felicidade. Mas a fim de que em tudo o que fizermos, sem cessar de contemplar os bens eternos a serem atingidos, caminhemos por meio daqueles, não nos apegando senão a estes últimos". (De trinit., XII, 13, 21; 2005, p. 387)
} 
Em nossa vida prática é preciso ciência, e ciência é saber agir adequadamente com o transitório, incluindo aí o saber se comportar com os demais homens segundo as regras estabelecidas por Deus, amando-nos fraternalmente e agindo com justiça, com a vontade reta. Mas colocar em prática esses princípios nem sempre é fácil, pois exige aplicar as leis gerais e eternas às diversas situações particulares, sempre variáveis. Querer fazer o bem é justo, mas, para bem realizá-lo, é conveniente, em muitos casos, que sejamos dotados de outros conhecimentos "científicos". Se quisermos transmitir a palavra de Deus a um outro povo, é preciso que tenhamos ciência do idioma deste povo; e se conhecemos retórica e oratória, a transmissão da palavra de Deus pode ter mais eficácia. Se quisermos cuidar de nosso corpo, é importante conhecer a respeito dos alimentos bons para a saúde, conhecer a medicina, saber construir casas, assim como domesticar os animais.

No entanto, as ciências não se limitam às disciplinas práticas, incluem também o conhecimento de si. Aquele que planeja fazer algo precisa estimar a circunstância na qual a ação será realizada, as possíveis tentações que nela estarão presentes e avaliar sua capacidade de resistir a elas. Um homem, logo após o tratamento de um vício em álcool, deve avaliar corretamente sua capacidade de resistir à tentação de beber antes de ir para uma festa de arromba. Portanto, até mesmo o conhecimento de nossas próprias fraquezas entra no grande domínio da ciência, pois todos esses conhecimentos estão relacionados à nossa vida prática.

Isso revela uma noção de "ciência" extremamente ampla. Engloba conhecimentos tão díspares quanto a medicina, a astronomia, a retórica, a arte de domesticar os animais, o domínio do fogo, da natureza em geral, o conhecimento das virtudes, o conhecimento de nossas capacidades e fraquezas. Nenhum desses conhecimentos constitui um fim em si mesmo, mas diz respeito aos meios para se atingir um único fim, que é felicidade oriunda da contemplação de Deus. É apenas dentro deste fim que todos os conhecimentos podem adquirir uma estrutura unitária.

Sabedoria e ciência podem ser resumidas em uma única sentença do livro de Jó: "Piedade é sabedoria; apartar-se do mal é ciência". Agostinho observa que nesta sentença o termo "piedade" é tradução do termo grego theosebeia, que também poderia ser traduzido por "culto de Deus". Em outras palavras, sabedoria é contemplar Deus; a ciência é o conhecimento de como se apartar do mal, seja do mal físico, seja do mal espiritual.

Posto que o objetivo das ciências é evitar o mal, tanto físico, quanto espiritual, segue daí que as ciências não dizem respeito apenas ao conhecimento da criação, mas também das virtudes, como a temperança, a fortaleza, a prudência e a justiça. No que concerne a essas virtudes, Cícero argumenta em Hortensius, conforme relata Agostinho (Trinit, XIV, 9,12; 
2005, p.456), que se fôssemos desta vida para a ilha dos venturosos, não necessitaríamos da fortaleza, já que não haveria mal algum a suportar; não necessitaríamos da temperança, pois não haveria paixões imoderadas; nem da justiça, posto que não haveria a ambição de tomar as posses alheias injustamente; e muito menos da prudência, que se define como a ciência de se escolher o bem e não o mal, já que não haveria mal. Tal argumentação é correta? Isto é, tais virtudes subsistirão no Paraíso? Agostinho não dá uma resposta definitiva, apenas diz que a justiça, com certeza, continuará, pois ser justo nada mais é do que estar subordinado a Deus.

A ciência tem sua origem quando a mente se aplica ao mundo da multiplicidade a fim de evitar o mal. A sabedoria é resultado da aplicação da mente à contemplação do eterno, da verdade imutável, que é Deus e as ideias de Deus. Mas esse quadro pode se tornar ainda mais complexo. Agostinho acresce que a condição de possibilidade do mal é a temporalidade:

Por outro lado, abster-se do mal - o que Jó considera ciência -, pertence sem dúvida ao campo das coisas temporais. Pois é no tempo que estamos sujeitos ao mal do qual nos devemos abster, para chegarmos aos bens eternos" ( $D e$ trinit., 14, 22; 2005, p.388).

O mal não é uma substância, mas está nas relações que estabelecemos com as substâncias corruptíveis e temporais. Essas relações não são más em si mesmas, o que é mal é o modo como são feitas, bem como os propósitos subjacentes a elas. Se o homem limita-se a se ocupar com o transitório, ele leva uma vida má.

Agostinho sempre faz questão de frisar que a temporalidade está ligada à multiplicidade, constituindo sua condição de possibilidade. Embora Deus seja uno, a criação é múltipla. Mas, essa situação, vista pela ótica da mente em sua vida concreta, coloca-se do seguinte modo: dirigir a atenção para Deus é uma dentre múltiplas possibilidades. A vontade, por estar na mente do homem, pode ligar-se ora nisso, ora naquilo, ora no corruptível, ora no incorruptível, mas nunca apenas exclusivamente em Deus. Embora uno, Deus é um dentre múltiplos objetos possíveis sobre o qual a consciência pode lançar o raio de seu olhar. Isso é inerente à condição humana.

\subsubsection{Inteligência das realidades eternas e das realidades sensíveis}

O intellectus é intrínseco à mente; devido a essa faculdade podemos ter inteligência das realidades inteligíveis. Havíamos observado já nos primeiros capítulos desra tese que o inteligível pode ser variável ou invariável. O três é um inteligível e invariável, já a fé se trata de uma realidade inteligível, que pode tanto nascer quanto se extinguir do coração. 
Por outro lado, uma realidade corporal variável pode conter ela mesma algo de inteligível e invariável. Cabe também à inteligência captar a estrutura ou as formas inteligíveis intrínsecas ao mundo sensível.

Já observamos que a razão inferior é capaz de operar racionalmente sobre as imagens dos corpos sensíveis. Quando planejamos o futuro, devemos imaginar o que iremos fazer e qual serão as circunstâncias. Ao imaginar algo, estamos lidando com o variável, com aquilo que poderia ser diferente do que planejamos, razão pela qual também procuramos imaginar os eventos imprevistos que podem ocorrer. Contudo, por mais elaborado e por mais pensado que seja nosso plano, algo de imprevisto pode acontecer, além de que podemos morrer a qualquer instante. A mente, quando planeja suas ações futuras, está operando na esfera do possível, provável e do variável. O máximo que pode fazer, ao planejar o futuro, é bem calcular e elaborar, dentro do possível, um plano que provavelmente se realizará. Ninguém gastaria seu suor para plantar se soubesse com antecedência que uma terrível seca está pela frente. Se resolve plantar é porque crê que as chances de ser bem sucedido compensam o risco da seca. O que vale observar é que aquele que bem planejou o plantio, embora esteja lidando com o possível, também está lidando com o provável e está se movendo dentro de um âmbito de conhecimento. Conhece a terra e sabe o tipo de frutos que aquela terra pode proporcionar. Conhece igualmente a estação do ano mais adequada para o plantio. Embora as estações do ano sejam variáveis, elas variam de acordo com determinado padrão, o qual pode ser apreendido. Mas essa ordem é ela mesma sensível? Sem os sentidos, não saberíamos o que é o verão nem o inverno. Contudo, a ordem segundo a qual as estações do ano variam não é uma realidade sensível. Embora alguns invernos sejam mais rigorosos, outros menos, há uma espécie de proporção entre as durações do verão e do inverno. E esta proporção pode ser apreendida pelo olho da razão.

No exemplo supracitado usamos como exemplo proporções entre durações de tempo. Mas essas realidades inteligíveis e invariáveis também estão nos próprios corpos, os quais possuem proporções intrínsecas, as quais são incorpóreas. Em virtude disso, a razão humana pode julgar os corpos tomando como critério as próprias regras intrínsecas aos corpos ${ }^{81}$.

Contudo, é a uma função mais alta da inteligência (razão) que pertence a possibilidade de fazer juízo a respeito dessas realidades corporais, segundo razões incorpóreas e eternas. Essas razões, se não estivessem acima da mente humana não seriam imutáveis. Entretanto, se elas não tivessem nenhuma ligação com nosso ser, que lhes é submisso, não poderíamos emitir juízo

\footnotetext{
${ }^{81}$ Do mesmo modo como o homem julga seus atos, tomando como critério as leis imutáveis escritas no livro da verdade, ele capaz de julgar os corpos sensíveis fundamentando-se nas medidas imutáveis.
} 
algum a respeito daquelas realidades corporais. Ora, fazemos juízos sobre tais realidades baseados na razão de suas dimensões e figuras, e cuja razão nossa mente reconhece como imutável. (De trinit., XII, 2, 2; 2005, p.367)

Sed sublimioris rationis est iudicare de istis corporalibus secundum rationes incorporales et sempiternas quae nisi supra mentem humanam essent, incommutabiles profecto non essent, atque his nisi subiungeretur aliquid nostrum, non secundum eas possemus de corporalibus iudicare. Iudicamus autem de corporalibus ex ratione dimensionum atque figurarum quam incommutabiliter manere mens nouit. (De trinit., XII, 2, 2)

Trata-se de uma passagem complexa. Enumeremos as proposições para analisá-las.

1) O homem julga os corpos fundamentando-se em razões incorpóreas e eternas.

2) Essas razões incorpóreas e eternas estão acima da mente. Estão acima da mente porque esta é variável, enquanto aquelas são invariáveis.

3) Contudo, os juízos que ele faz dos corpos, segundo as razões eternas, dependem da apreensão das razões das dimensões e figuras dos próprios corpos, as quais são imutáveis.

As proposições pedem um esclarecimento. As razões eternas e incorpóreas são intrínsecas aos corpos ou estão acima da mente? Ou ambas se identificam, de modo são, a um só tempo, intrínsecas aos corpos e superiores à mente?

As respostas a essas perguntas que o texto suscita devem ser articuladas com outra questão. O que Agostinho entende, nesta passagem, por julgar? Afinal, julgar pode ter dois sentidos.

1) O primeiro é quando julgamos a coisa segundo algum critério ou modelo ideal. Por exemplo, quando dizemos "este texto deveria ser mais direto". Neste caso, o que está em jogo é o grau de adequação entre a coisa e critério ideal adotado, o qual é, aparentemente, extrínseco à coisa, pois se fosse intrínseco, não haveria distinção entre o critério e o que é julgado.

2) Pode-se entender a faculdade de julgar como emitir juízos no qual se afirma o que a coisa é e não o que ela deveria ser. Quando dizemos "Os astros possuem órbitas circulares", estamos simplesmente tentando dizer o ser do objeto em questão, o que se distingue de dizer os "os astros deveriam ter órbitas circulares". Assim, emitir juízos sobre o que uma coisa é não é o mesmo que emitir um juízo sobre o que ela deveria ser.

O que parece é que Agostinho refere-se ao julgamento das coisas tomando como critério o que elas deveriam ser, os seus modelos ideais. Mas como a mente é capaz de saber o que algo deveria ser? Isso só seria possível distinguido o ser singular, - dado à percepção ou à imaginação - da razão implicada na ideia geral da coisa. Investiguemos esta hipótese interpretativa. 
Agostinho afirma que estas razões incorpóreas intrínsecas aos corpos são razões imutáveis de suas dimensões e figura ${ }^{82}$. A mente humana é capaz de captar essas "razões". Mas em que sentido o homem julga o corpo com as razões que ele consegue perceber nos corpos?

Como já observamos, essas proporções pelas quais o homem julga as formas sensíveis são imutáveis, estão acima da mente. Podemos usar, como exemplo, a roda. A roda não é o círculo, mas a roda possui forma circular. Ora, a circularidade da roda está, em certo sentido, na própria roda. Mas é apenas o homem que, por ter inteligência, é capaz de julgar as rodas reais fundamentado na razão intuída do círculo perfeito, cuja proporção é imutável e eterna. Se alguém vê a roda de um carro e observa que há irregularidades, logo percebe ali um defeito. Portanto, julga a roda real baseando-se em uma proporção inteligível, a qual apenas a inteligência é capaz de alcançar. Em outras palavras, a razão intrínseca daquele objeto singular é, sob determinada perspectiva e em sua concretude, mutável, mas não é mutável ao sabor do acaso e não pode assumir qualquer proporção sem que deixe de ser o que é. A roda também tem uma razão ideal, imutável. O espírito vê através da proporção real e variável uma proporção ideal e invariável, esta sim acima da mente.

Dentro desta perspectiva, o objeto singular pode não estar em consonância com a razão ideal que a mente entrevê naquele objeto. Mas será esse o modo correto de entender essa passagem de Agostinho? Ao que tudo indica, sim e essa interpretação se reforça no livro IX da Trindade. Aí Agostinho afirma que se ele viu um arco curvado de forma bela e exata em Cartago, ele pode, caso tal arco esteja ausente, lembrá-lo e ver a imagem desse arco em sua mente. No entanto, a mente possui o poder de julgar a imagem do arco imaginado e até mesmo "corrigi-lo", se assim quisesse. Afirma em seguida que esse poder de corrigir a imaginação é um poder distinto do puro imaginar ${ }^{83}$. Uma coisa é, portanto, fazer figurar no espírito (animus) a imagem do corpo visto, outra coisa é ver com a inteligência, acima do olhar da mente, as tais razões com as quais julgamos ${ }^{84}$ as imagens e o mundo sensível.

\footnotetext{
${ }^{82}$ Nas Confissões, também ali ele se refere, como pertencente à memória, essas razões. Não fala das razões das figuras, mas fala das razões dimensões e dos números. "Item continet memoria numerorum dimensionumque rationes et leges innumerabiles, quarum nullam corporis sensus inpressit, quia nec ipsae coloratae sunt aut sonant aut olent aut gustatae aut contrectatae sunt". (Conf., X, 12,19)

83 "Item cum arcum pulchre et aequabiliter intortum, quem vidi, verbi gratia, Carthagine, animo revolvo, res quaedam menti nuntiata per oculos, memoriaeque transfusa, imaginarium conspectum facit. Sed aliud mente conspicio, secundum quod mihi opus illud placet; unde etiam si displiceret corrigerem". (De trinit. IX, 6,9)

${ }^{84}$ Itaque de istis secundum illam iudicamus, et illam cernimus rationalis mentis intuitu. Ista vero aut praesentia sensu corporis tangimus, aut imagines absentium fixas in memoria recordamur, aut ex earum similitudine talia fingimus, qualia nos ipsi, si vellemus atque possemus, etiam opere moliremur; aliter figurantes animo imagines
} 
Não é possível ir muito além dessas considerações para explorar o que Agostinho quer dizer nesta passagem, pois isso implicaria em colocar questões que, nesta passagem, Agostinho não colocou. O que podemos afirmar com certeza é que a mente tem o poder de encontrar razões e formas ideais das coisas corporais e transitórias e elas estão acima da mente porque estas razões e ideias subsistem em Deus e com elas Deus criou o universo. De modo análogo, é na verdade eterna que podemos encontrar a forma segundo a qual somos feitos. Essa forma do homem já existia no espírito de Deus desde toda eternidade e quando levamos a vida de acordo com a forma com a qual fomos criados, nós agimos de acordo com a reta razão. Agir bem é ser verdadeiramente homem.

\subsubsection{Crítica ao pensamento de Platão}

É bem possível que tais concepções de Agostinho sobre as realidades inteligíveis sejam inspiradas em concepções platônicas, que lhe foram transmitidas pelo Neoplatonismo. $\mathrm{O}$ próprio Agostinho estava ciente da proximidade de seu pensamento com o de Platão e faz questão de marcar, em determinados domínios, a distância de seu pensamento em relação ao mestre grego. No livro XII da Trindade, Agostinho afirma que Platão, por ter compreendido que a alma é capaz de atingir o reino das ideias, erigiu sua teoria da reminiscência, a fim de explicar como isso era possível. "Eis por que Platão, aquele ilustre filósofo, esforçou-se em fazer-nos acreditar que as almas humanas já viviam neste mundo, inclusive antes do nascimento dos corpos". (Trinit, XII, 15, 24; 2005, p.390) ${ }^{85}$. Logo em seguida, Agostinho alude ao diálogo Menon, de Platão, no qual um jovem escravo, espremido pela maiêutica socrática, chega "por si só" ao teorema de Pitágoras:

Conta ele que certo jovem, interrogado não sei sobre que assunto de geometria, respondeu como se tivesse invejável competência nessa disciplina. Tendo-se feito perguntas sucessivas e artificiosas, via ele o que devia ver e dizia o que via. (Trinit, XII, 15, 24; 2005, p.390).

Retulit enim puerum quendam nescio quae de geometrica interrogatum sic respondisse tamquam esset illius peritissimusdisciplinae. Gradatim quippe atque artificiose interrogatus uidebat quod uidendum erat dicebatque quod uiderat. (Trinit, XII, 15, 24)

corporum, aut per corpus corpora videntes; aliter autem rationes artemque ineffabiliter pulchram talium figurarum super aciem mentis simplici intellegentia capientes. (De trinit. IX, 6,9)

${ }^{85}$ Vnde Plato ille philosophus nobilis persuadere conatus est uixisse hic animas hominum et antequam ista corpora gererent, et hinc esse quod ea quae discuntur reminiscuntur potius cognita quam cognoscuntur noua. ( $D e$ trinit., XII, 15, 24;) 
Agostinho assume que é possível que alguém, questionado com arte, encontre dentro de si as respostas às perguntas a respeito de geometria ou de matemática. Contudo, esse fato não prova, de modo algum, a teoria da reminiscência. Prova simplesmente que o homem é capaz de encontrar dentro de si realidades inteligíveis, como as da geometria. Platão estava certo em dizer que algumas verdades inteligíveis a mente encontra dentro de si, entretanto o mestre grego erra ao considerar que essas verdades estão no espírito pelo homem tê-las visto em uma vida anterior a essa.

As ideias geométricas estão dentro do homem não porque ele as conheceu em uma vida anterior; se isso fosse verdade, seria necessário que todos os homens tivessem sido geômetras em outra vida.

Ora, se fossem apenas recordações de conhecimentos anteriores, nem todos, nem mesmo uma maioria que fosse, poderia se lembrar ao serem interrogados sobre esse determinado assunto. Pois nem todos devem ter sido geômetras na vida anterior, visto que esses são tão poucos entre os homens que dificilmente se encontra alguém. Assim, é preferível acreditar que a natureza da alma intelectiva foi criada de tal modo que, aplicada ao inteligível segundo sua natureza, e tendo assim disposto o Criador, possa ver esses conhecimentos em certa luz incorpórea de sua própria natureza. Assim acontece com o olho do corpo que vê os objetos que o cercam na luz natural, pois pode-se acomodar a essa luz, já que para ela foi feito. (De trinit., XII, 15,$24 ; 2005$, p.390)

Sed si recordatio haec esset rerum antea cognitarum, non utique omnes uel pene omnes cum illo modo interrogarentur hoc possent; non enim omnes in priore uita geometrae fuerunt cum tam rari sint in genere humano ut uix possit aliquis inueniri. Sed potius credendum est mentis intellectualis ita conditam esse naturam ut rebus intellegibilibus naturali ordine disponente conditore subiuncta sic ista uideat in quadam luce sui generis incorporea quemadmodum oculus carnis uidet quae in hac corporea luce circumadiacent, cuius lucis capax eique congruens est creatus. (De trinit., XII, 15, 24).

Para Agostinho, as verdades estão dentro do homem porque Deus está dentro do espírito, o qual, por conseguinte, participa da sabedoria de Deus. Todavia esse afastamento do pensamento de Agostinho com relação a Platão também ocorre com relação ao conhecimento das coisas sensíveis. Por mais habilidoso que um homem possa ser "na arte de fazer perguntas", não é possível extrair de dentro do espírito do homem questionado conhecimentos a respeito das coisas sensíveis que ele nunca viu. Quem nunca viu um elefante nem ouviu falar de tal animal não poderá encontrar, dentro de si, a ideia do elefante. O conhecimento das realidades sensíveis tem origem na percepção. Todavia, é preciso não esquecer, como já observamos, que uma vez que conhecemos as coisas corporais, podemos, com o olhar da inteligência, captar as razões incorporais intrínsecas aos objetos vistos. 


\subsubsection{Razão superior e inferior}

Como já observamos, razão superior e razão inferior referem-se a duas funções distintas de uma única mente, posto que esta deve ora se aplicar à vida prática e portanto ao reino do transitório, ora à vida contemplativa, ao reino do eterno. Isso revela que o tipo de atividade da mente conforma-se com a natureza do objeto ao qual ela se ocupa. A atividade da razão superior traz a Sabedoria, a da razão inferior traz a Ciência.

O homem é imagem de Deus, segundo a mente, pois é nela que pode residir o conhecimento de Deus e é com ela que o homem pode contemplá-lo e não com os sentidos. Há, portanto, uma espécie de comunhão de naturezas entre a mente e Deus, assim como o olho e as coisas corporais. Em virtude dessa comunhão de naturezas a imagem de Deus deverá ser buscada na própria mente, no homem interior: "Assim, vê-se que a imagem de Deus se radica tão-somente na parte da mente que se entrega à contemplação e à consideração das razões eternas." (Trinit, XII, 7,12; 2005, p.378) ${ }^{86}$.

O homem exterior caminha para a sua ruína, enquanto o homem interior se renova dia a dia, na contemplação de Deus. E o homem interior, em suas atividades ligadas à razão prática, não subsistirá após a morte. Os próprios conhecimentos adquiridos pela razão inferior, todos eles ligados ao transitório e prático, perderão sua função após a morte. Ora, para encontrar o eterno no homem é preciso abstrair da mente tudo aquilo que é corruptível em sua natureza ou que está vinculado ao transitório.

Fica claro que a mente é a imagem de Deus apenas naquilo que ela possui de superior, isto é, na sua capacidade contemplativa. Se assim é, então podemos fazer a pergunta: o que está implicado na contemplação do eterno? Quais são as condições de possibilidade da contemplação? Quais as faculdades envolvidas? Se a contemplação, tem como alvo, o que há de eterno, tudo o que for condição de possibilidade da contemplação deve também ser eterno.

A primeira condição é a memória, pois não há como contemplar o que não temos conhecimento do que seja; e sem memória de si, não distinguiríamos o eu de Deus, o sujeito que contempla e do ser contemplado. Em segundo lugar, a inteligência, pois sem ela sequer poderíamos contemplar Deus, vê-lo face a face. Em terceiro lugar, amor, pois sem amor não ficaríamos felizes em sua presença, seríamos como máquinas e não haveria o gozo da verdade

\footnotetext{
${ }^{86}$ Sed quia sexu corporis distat a uiro, rite potuit in eius corporali uelamento figurari pars illa rationis quae ad temporalia gubernanda deflectitur ut non maneat imago dei nisi ex qua parte mens hominis aeternis rationibus conspiciendis uel consulendis adhaerescit, quam non solum masculos sed etiam feminas habere manifestum est. (Trinit, XII, 7,12)
} 
contemplada. Não é por acaso que amor, inteligência e memória formam uma unidade, uma só vida, a mente.

A imagem de Deus no homem é a mente, mas não enquanto pura potência, mas sim quando atualiza essas faculdades na contemplação da Verdade. Por outro lado, no que se refere às atividades da mente implicadas em suas funções correlacionadas ao homem exterior, a mente não é propriamente imagem de Deus:

(...) contempla a verdade toda e inteira. Mas quando alguma parte dela é desviada e sua atenção se afasta para agir nas coisas temporais, ainda que pela parte direcionada para a verdade, ela permaneça imagem de Deus, todavia pela parte que se ocupa na ação em coisas inferiores ela não é imagem de Deus. E quanto mais se elevar para as coisas eternas tanto mais vai se formando à imagem de Deus. (Trinit, XII, 7,9; 2005, p.375)

Sicut de natura humanae mentis diximus quia et si tota contempletur ueritatem, imago dei est, et cum ex ea distribuitur aliquid et quadam intentione deriuatur ad actionem rerum temporalium, nihilominus ex qua parte conspectam consulit ueritatem imago dei est; ex qua uero intenditur in agenda inferiora non est imago dei. Et quoniam quantumcumque se extenderit in id quod aeternum est tanto magis inde formatur ad imaginem dei, et propterea non est cohibenda ut se inde contineat ac temperet, ideo uir non debet uelare caput. (Trinit, XII, 7,9)

O que essa passagem parece sugerir é que a mente não é, por si só, imagem de Deus, mas sim a mente em sua função e atividade mais elevada. Por isso, quando o homem dirige a atenção de sua mente à Verdade imutável, amando-a, ele é imagem de Deus. Mas quando volta sua atenção para as coisas temporais e corruptíveis, ele não é imagem de Deus em ato, mas apenas em potência. A contemplação, assim como a ação no temporal, dizem respeito a dois estados possíveis da mente, os quais estão em referência com a direção da atenção, a direção da própria vontade, a direção do próprio amor. À atenção, entretanto, não se aplica a distinção entre razão inferior e razão superior. Ao contrário, a atenção é uma espécie de comutador existencial da mente, que pode curvar-se para o que há de mais excelente, ou pode se curvar para o mundo.

Dirigido para o alto, o homem atualiza essa potência mais elevada e suprema e, pela sua atualização, vai perfeccionado sua imagem, aproximando-a de Deus. "E quanto mais se elevar às coisas eternas tanto mais vai se formando a imagem de Deus" (De trinit., XII, 7,9; 2005, p.375). 


\subsubsection{Insubordinação da razão inferior à superior}

O fim último desta vida é a contemplação da Verdade. Essa é, aliás, a própria definição de felicidade proposta por Agostinho: o gozo da verdade. "Entretanto, sempre certa parte de nossa atenção racional, ou seja, da própria alma, há de se dirigir à lida com as coisas mutáveis e corporais, isso por necessidade, sem o que não se conseguiria viver." (De Trinit, 13, 21a; 2005 , p.386) ${ }^{87}$. Mas se por força, o homem deve se ocupar com o temporal, ele não pode, entretanto, fazê-lo mais do que deve, pois tal atividade é apenas um meio ou um fim parcial, mas não o fim último. O homem deve estar sempre atento ao direcionar-se para o exterior, pois é esta atividade vizinha das tentações. Em virtude da perversão natural do gênero humano, a alma humana tem propensão a se resvalar demasiadamente para o exterior, colocando-se no nível do homem exterior, deixando-se "escravizar" por este. E assim, homem interior pode envelhecer entre os seus inimigos, os demônios e o diabo, o príncipe dos demônios.

Como já havíamos observado, a distinção entre o homem interior e o homem exterior relaciona-se com duas possíveis direções para as quais a mente tende ou põe a sua atenção racional (intentionem rationalis). Ao voltar sua atenção ao temporal, o homem pode se esquecer das realidades mais altas, tomando a vida temporal como um fim em si mesmo, e assim, ao invés de lidar com o temporal apenas para evitar o mal, acaba indo ao seu encontro. Tal quadro é simbolizado no próprio livro do Gêneses, na narrativa do primeiro casal humano.

Dentro deste quadro, a serpente simboliza, para Agostinho, os sentidos corporais do homem exterior. Eva, por seu turno, simboliza a razão inferior, sempre vizinha do mundo dos sentidos, representado pela serpente. Tal interpretação se sustenta no fato de que Deus, a fim de encontrar uma auxiliar para Adão, retirou deste uma de suas costelas para formá-la. Por isso, são dois numa só carne. Analogamente, a razão inferior foi formada para auxiliar a razão superior. E ambas funções formam uma só essência. A boa relação se dá quando a razão inferior está subordinada à razão superior. Adão, tentado por Eva, equivale à queda da razão superior, desviada de seu verdadeiro fim, que é a contemplação do eterno, para chafurdar no mundo sensível. Com efeito, Adão havia recebido de Deus a ordem para não comer do fruto

\footnotetext{
87 "Sed siue isto siue illo siue aliquo alio modo accipiendum sit quod apostolus uirum dixit imaginem et gloriam dei, mulierem autem gloriam uiri, apparet tamen cum secundum deum uiuimus, mentem nostram in inuisibilia eius intentam ex eius aeternitate, ueritate, caritate proficienter debere formari, quiddam uero rationalis intentionis nostrae, hoc est eiusdem mentis, in usum mutabilium corporaliumque rerum sine quo haec uita non agitur dirigendum, non ut conformetur huic saeculo finem constituendo in bonis talibus et in ea detorquendo beatitudinis appetitum, sed ut quidquid in usu temporalium rationabiliter facimus aeternorum adipiscendorum contemplatione faciamus per ista transeuntes, illis inhaerentes". (De Trinit, 13, 21a)
} 
proibido, assim como a razão superior recebe de Deus as regras divinas e deve, em vista destas regras, regular tanto a razão inferior quanto o homem exterior. Ao comer do fruto proibido, desobedecendo a Deus, a justa hierarquia das coisas é rompida: o homem interior subordina-se ao homem exterior, abdicando de sua razão superior para se arrastar pela inferior, que está ligada à serpente. Ao fazê-lo, o homem conhece o mal e, ao conhecê-lo, torna-se consciente do bem que perdeu.

Segundo Agostinho, quando Paulo nos exorta para que não nos conformemos com esse mundo, trata-se de uma advertência para que não vivamos achatados ao nível do homem exterior. Eis uma questão dramática: a mente humana é obrigada a lidar com o mundo prático das coisas corruptíveis, mas, ao fazê-lo, está se expondo à tentação.

Trata-se de um equilíbrio delicado. Tanto a contemplação quanto a vida prática são necessárias ao cristão. Entretanto as duas possibilidades dizem respeito a dois estados mentais distintos. A contemplação do eterno exige que a mente coloque a si mesma em um determinado estado, exige que nossa atenção racional (intentione rationalis) subtraia-se do mundo para mergulhar na luz divina que emana dentro e acima da mente. Já a ação no temporal exige um direcionamento centrífugo da atenção para a superfície, para um mundo criado e suas criaturas. O homem não pode pensar em tudo ao mesmo tempo. O foco da atenção ou está em Deus ou em outra coisa, por exemplo, na conta que se tem para pagar. Mas isso não impede que, quando pensa em uma coisa, a pessoa esqueça-se por completo de Deus. Para que o homem aja justamente e de acordo com o homem interior é preciso que ele tenha sempre Deus presente em sua mente, ainda que, no pano de fundo, como uma criancinha que, embora esteja ocupada com esse ou aquele brinquedo no parque, ainda assim sente o conforto de estar sob os olhos amorosos de sua mãe. É preciso que Deus sempre esteja presente, ainda que no canto da mente, de modo que, em vista de uma tentação, possamos nele nos agarrar e nos sustentar antes que seja tarde demais.

Para Agostinho a vida prática deve ser sempre subordinada à vida contemplativa, pois esta é o fim último. E o perigo reside muitas vezes na própria distração. O homem, ao ocupar todo seu espírito com o transitório, acaba distraindo-se daquilo que é a verdadeira vida, a vida pela qual se renova o homem interior. 


\subsubsection{Os pecados de imaginação}

Seguindo essa ordem de raciocínios, Agostinho continua buscando mapear a mente humana e os labirintos que ela forja para si mesma. O puro direcionamento interior da atenção não significa contato com o superior. Em alguns casos, o homem volta-se para o interior e vê apenas um espelho no qual o exterior se reflete. Trata-se do perigo do pecado de imaginação, ou "fornicação da imaginação", quando o homem delicia-se em pura imaginação, com os prazeres do mundo. Já está implícita aí uma refinada noção da imaginação. Não são apenas pelos sentidos corporais que o homem desfruta do mundo corporal. Existe uma espécie de usufruto mediado pela imaginação do mundo sensível, de tal modo que, quando a atenção se volta com muita intensidade para aprazíveis fantasias, há um certo gozo oriundo dessas imagens fantasiadas. Tudo se passa como se a mente se deliciasse com as próprias imagens, tomando a imagem das coisas pelas próprias coisas. No livro XI da Trindade, Agostinho comenta acerca de um curioso caso, o de um sujeito que via com o olhar do pensamento uma imagem tão nítida de um corpo feminino que chegava a ter ejaculação. (cf. De trinit., XI, 4, 7) ${ }^{88}$.

Essa passagem apenas revela a organicidade do pensamento de Agostinho. No início do livro XII da Trindade afirma que pertence ao homem interior a capacidade de imaginar, combinando as imagens contidas na memória. Mas, se bem observarmos, aquele que imagina a mulher nua, excitando-se com a fantasia criada, assim o faz em virtude de sua vontade. No entanto, o homem, projetando seu animus no objeto imaginado, não tem a própria vontade sob sua atenção. O animus, imerso em sua vontade, não se retira dela para refletir a respeito dela, colocando-a sobre julgamento. Imerso inteiramente na vontade, totalmente distraído de seu fim último, vive uma orgia da imaginação. O próprio fato de que ele se deleita com a imagem já prova a perversão de sua vontade. Pois gozar é usufruir o objeto da vontade, que, no caso, é a imagem da coisa substituindo aquilo de que é imagem. Aquele que imagina uma vingança pode sentir prazer com a imagem da vingança, ainda que sua razão superior lhe proíba de realizá-la.

Por existir um tênue fio que separa a imagem das coisas e próprias coisas, a vontade corrompida usa da tinta da memória para compor, com o pincel da imaginação, o quadro de seu sucesso, como alguém que, em um momento de fúria, imagina seu inimigo perfurado por sua espada, deleitando-se com a imagem do sangue ainda fresco no cortante metal. A cena do

\footnotetext{
${ }^{88}$ Et memini me audisse a quodam quod tam expressam et quasi solidam speciem feminei corporis in cogitando cernere soleret ut ei se quasi misceri sentiens etiam genitalibus flueret. (De trinit.,, XI, 4, 7)
} 
assassinato pode surgir mesmo que o homem não esteja determinado a realizá-lo. Neste caso, o que ocorre é o seguinte: a vontade de realizar o mal atua na imaginação, mas retira-se da esfera da ação. Portanto, o homem, mesmo quando pensa em algo mau e com isso sente prazer, ainda que não esteja determinado a realizá-lo, peca. Essa situação encontra seu símbolo com Eva seduzida pela serpente, porém incapaz de seduzir Adão.

Um terceiro nível de pecado puramente interior e ainda mais grave é quando a mente pensa no mau e se determina a realizá-lo. Isso equivale a Adão seduzido por Eva. Mesmo que não consiga realizá-lo, pecou de forma ainda mais grave do que o puro pecado de imaginação. Uma representação para essa situação seria o de Adão tentado por Eva, decidido a comer da maçã, tentando colhê-la, mas incapaz de alcançá-la por ela estar na parte mais alta da árvore. É o homem decidido ao pecado, embora impedido de cometê-lo por fatores exteriores a sua vontade. 


\subsection{A relação da mente consigo mesma}

\subsubsection{Refutação dos filósofos da Nova Academia}

Um dos pontos mais importantes do pensamento de Agostinho reside na sua investigação a respeito da reflexão. Ela abre todo um novo campo de investigação. $\mathrm{O}$ eu e sua atividade tornam-se não apenas objeto de investigação possível, mas também uma região privilegiada epistemologicamente, pois nada mais próximo à mente do que ela própria. Agostinho, como já observamos, sempre fala de duas espécies de conhecimentos: um, referente ao mundo corporal, outro, das coisas que a mente percebe por si mesma ${ }^{89}$. O erro dos neoacadêmicos consiste em considerar que o conhecimento sensível é o único tipo de conhecimento, como se não existissem verdades que a mente encontra em si mesma ${ }^{90}$.

No capítulo 12 do livro XV da Trindade, Agostinho assume que os neoacadêmicos possuem uma certa razão em afirmarem que o conhecimento das coisas sensíveis está sujeito ao erro. Muitas vezes, no que se refere aos sentidos, o homem se deixa levar por "falsas aparências", como um remo parece quebrado quando é em parte submerso na água. Trata-se de uma "falsa aparência", pois a aparência não corresponde à realidade do objeto real. Há, neste caso, há uma distinção entre o que a coisa é e seu modo de aparecer. Mas, como já observamos, existem muitas outras espécies de verdade.

Repito que, excetuadas as coisas que chegam a nós pelos sentidos, quantas outras restam que conhecemos com certeza, como, por exemplo, o fato de sabermos que estamos vivos. Neste pormenor, não tememos absolutamente ser enganados por falsa verossimilhança, pois aquele mesmo que se engana, vive, e também tem certeza disso (De trinit., XV, 12, 21b; 2005, p.510).

Exceptis enim quae in animum veniunt a sensibus corporis, in quibus tam multa aliter sunt quam videntur, ut eorum verisimilitudine nimium constipatus, sanus sibi esse videatur qui insanit; unde Academica philosophia sic invaluit, ut de omnibus dubitans multo miserius insaniret; his ergo exceptis quae a corporis sensibus in animum veniunt, quantum rerum remanet quod ita sciamus, sicut nos vivere scimus?" (De trinit., $\mathrm{XV}, 12$, 21b)

\footnotetext{
${ }^{89}$ É bem verdade que Agostinho aceita que fazia sentido a crítica cética aos sentidos, posto que os sentidos não forneciam verdade indubitável. Entretanto, afirma que não se poderia levar ao radicalismo a crítica aos sentidos: "Longe de nós, ainda, negarmos que sabemos o que foi adquirido pelo testemunho dos outros. Pois de outra maneira desconheceríamos, por exemplo, do oceano, de terras e cidades que se recomendam por sua celebridade. Ignoraríamos a existência dos homens e das obras de que nos fala a história. Não teríamos conhecimen to do que acontece em todas as partes do mundo e que se apoia em indícios unânimes e dignos de crédito. Finalmente, não saberíamos o lugar e o nome das pessoas das quais descendemos". (De trinit., XV, 12, 21b; 2005, p.512).

90 "Cum enim duo sint genera rerum quae sciuntur,unum earum quae per sensus corporis percipit animus, alterum earum quae per se ipsum : multa illi philosophi garrierunt contra corporis sensus; animi autem quasdam firmissimas per se ipsum perceptiones rerum verarum, quale illud est quod dixi: Scio me vivere, nequaquam in dubium vocare potuerunt." (De trinit., $\mathrm{XV}, 12,21 \mathrm{~b})$.
} 
Agostinho, nesta passagem, faz uma sutil variação do argumento já exposto em Livre Arbítrio, quando afirma a impossibilidade de enganar-se ao afirmar "eu existo". Quanto a isso, o homem não pode errar, pois não se trata de conhecimentos acerca de realidades exteriores, percebidas pelo olho carnal, mas sim de realidades interiores, percebidas com o olhar da mente. Mas, se em Livre Arbítrio o que é posto como impossibilidade de engano é o $\mathrm{eu}^{91}$, na Trindade, Agostinho varia a fórmula: o homem não pode estar enganado a respeito do fato de que ele vive, "Intima scientia est qua nos vivere scimus." (De trinit., XV, 12, 21b; 2005, p.510). Em relação a essa verdade, não se pode sequer objetar que estejamos dormindo e sonhando, pois quem sonha vive. De fato, Agostinho argumenta que o que se afirma não é "sei que estou desperto" - quanto a isso, de fato poderíamos estar enganados - mas sim "sei que estou vivo" e quanto a isso não se pode estar enganado. Agostinho continua advogando que em relação à verdade de sabermo-nos vivos não se pode nem mesmo contra-argumentar algo como: "Deliras, está enganado", pois quem delira vive ${ }^{92}$.

Interessante notar que, nesta passagem, Agostinho rearticula o conceito de vida. Não entende estar vivo do ponto de vista orgânico, mas sim possuir um eu em atividade. O que garante a vida não é propriamente o batimento cardíaco, mas o próprio ato de pensar, de ser capaz de refletir.

Certo, o homem que reflete tem certeza absoluta de viver, descobre olhando dentro de si que está vivo e não pode se enganar, pois quem se engana é porque está vivo. Mas essa é a única verdade? Agostinho afirma que se este fosse o único conhecimento seguro possível ao homem, a ciência teria um campo muito reduzido.

\footnotetext{
${ }^{91}$ Como fica claro na pergunta que ele faz a Evódio: "Quare prius abs te quaero, ut de manifestissimis capiamus exordium; utrum tu ipse sis. An fortasse tu metuis, ne in hac interrogatione fallaris, cum utique si non esses, falli omnino non posses?" (Lib. Arb. II, 3,7;)

92 Trata-se, sem dúvida, daquilo que se chama cogito agostiniano. Trata-se de uma certeza irrefutável, apodíctica. Descartes também chega a essa mesma certeza. O diferencia talvez Agostinho, de Descartes, é como cada um dos pensadores fizeram uso dessa verdade, isto é, a exploraram e tiraram consequências delas. Husserl, por seu turno, também parte dessa verdade em investigações cartesianas, mas o modo como o pensador alemão explora essa verdade é distinto de ambos os pensadores. E é isso que deve ser observado detalhadamente.
} 


\subsubsection{O conhecimento reflexivo: Scio me scire me vivere}

É preciso ir adiante, examinar esse núcleo inquebrantável de certeza para saber se é possível extrair daí outras verdades. O que a astúcia de Agostinho irá logo observar é que a verdade do "sei que vivo" pode ela mesma ser refletida: "Com efeito, aquele que diz: 'Sei que vivo', diz saber uma coisa. Mas se disser: 'sei que sei que vivo', já são dois conhecimentos." (De trinit., XV, 12, 21b; 2005, p.510) ${ }^{93}$.

Agostinho nota que, dando continuidade a este procedimento, a série pode se multiplicar ao infinito: "Sei que sei que sei que vivo", e assim por diante. Em seguida, Agostinho procura investigar se existem outras verdades do mesmo gênero, indubitáveis a princípio e que podem ser multiplicadas infinitamente por reflexão. Encontra algo semelhante com a vontade.

De modo semelhante, pode-se também perceber certezas na própria vontade. Quem poderá responder com razão: "Talvez tu te enganes", ao que diz "Quero ser feliz"? E se disser: "Sei que eu quero, e sei que o sei” poderá acrescentar uma terceira verdade às duas anteriores, ou seja: que sabe as duas coisas, e uma quarta, ou seja: que sabe saber as duas, e assim por diante, podendo chegar a um número infinito. (De trinit., XV, 12, 21b; 2005, p.510).

Hoc et in voluntate certa similiter adverti potest. Quis est enim cui non impudenter respondeatur, Forte falleris, dicenti, Volo beatus esse? Et si dicat, Scio me hoc velle, et hoc me scire scio; iam his duobus et tertium potest addere, quod haec duo sciat; et quartum, quod haec duo scire se sciat, et similiter in infinitum numerum pergere. (De trinit., XV, 12, 21b).

Se alguém me pergunta se quero ser feliz, não tenho como me enganar. Se respondo a pergunta: "sim quero ser feliz"-, como poderei estar enganado? Será que alguém poderia duvidar sobre a legitimidade da própria vontade de ser feliz? Não é concebível. Aquele que vê a própria vontade não tem como se enganar a respeito dela, pois, ao contrário dos corpos sensíveis, não há uma diferença entre o seu ser e o seu aparecer. Ela é, para mim, exatamente o que parece ser para mim e tal qual aparece. E mais, além de termos certeza do querer e do objeto do querer, podemos, como já havíamos observado em outros casos, refletir sobre essa verdade. A sentença "Sim, quero ser feliz" exprime uma coisa. Já a sentença "Sei que quero ser feliz" exprime outra. No primeiro caso, nós exprimimos um estado mental referente à nossa vontade "Quero ser feliz"; no segundo, exprimimos o conhecimento que temos do estado "Sei que quero ser feliz". Esses estados mentais são sempre passíveis de serem refletidos e postos como objeto de conhecimento. Mas isso sugere o seguinte fenômeno:

93 "Qui enim dicit: "Scio me vivere", unum aliquid scire se dicit. Proinde si dicat: "Scio me scire me vivere";" (De trinit., $\mathrm{XV}, 12,21 \mathrm{~b})$. 
quando o homem vive uma vontade, o olhar de sua mente não está voltado para a própria vontade, mas sim ao objeto da vontade. Mas se exprimimos o estado, estamos com a atenção direcionada para o próprio estado. Refletindo, percebemos o estado, de modo que podemos exprimi-lo.

Ao dizer: "sei que sei que quero ser feliz", a afirmação pode ser dividida em um estado direcionado para um objeto. O primeiro "sei" da sentença é estado, o segundo "sei” é objeto para o qual se volta o primeiro "sei". Para sermos mais precisos, o segundo "sei" da sentença é um estado objetificado pela própria mente. E o que faz com que a série possa ser infinita advém de que é sempre possível que o estado seja ele mesmo objetificado por um novo ato reflexivo. Agostinho procura mostrar isso usando como exemplo a sentença "não quero errar"

Além disso, se alguém disser: "Não quero errar", errando ou não, não seria verdade que não quer errar? E se afirma saber isso, está acrescentando um número qualquer de coisas conhecidas, e percebe que o número é infinito. Pois quem diz "Não quero me enganar, e sei que não o quero e sei que o sei”, pode seguir até um número infinito, embora de expressão difícil. Existem ainda outras razões válidas contra os neo-acadêmicos, esses filósofos que propugnam a ignorância absoluta do homem. (De trinit., XV, $12,21 b ; 2005$, p.512).

Item si quispiam dicat, Errare nolo; nonne sive erret sive non erret, errare tamen eum nolle verum erit? Quis est qui huic non impudentissime dicat, Forsitan falleris? cum profecto ubicumque fallatur, falli se tamen nolle non fallitur. Et si hoc scire se dicat, addit quantum vult rerum numerum cognitarum, et numerum esse perspicit infinitum. Qui enim dicit: Nolo me falli et hoc me nolle scio, et hoc me scire scio; iam et si non commoda elocutione, potest hinc infinitum numerum ostendere: et alia reperiuntur, quae adversus Academicos valeant, qui nihil ab homine sciri posse contendunt. (De trinit., XV, 12, 21b)

No livro XV, da Trindade, Agostinho retoma e desenvolve uma série de argumentos já presentes em outras obras, como Vita Beata. Naquele livro Agostinho constatava que ele não podia duvidar de sua própria vontade de conhecer se a verdade era possível, levando-o a concluir que era verdade que ele queria conhecer a verdade. $\mathrm{O}$ argumento, naquela ocasião, não é mais desenvolvido, como se ele não tivesse percebido a extensão do reino cuja porta ele abrira. Já em Libero Arbitrio, ele toma como verdade garantida que o eu não pode se enganar a respeito de sua existência. Neste capítulo do livro XV da Trindade, Agostinho mostra que essas duas verdades possuem um parentesco em comum. Tanto o conhecimento da própria vontade quanto o conhecimento de que se está vivo dizem respeito à própria mente, não dizem respeito a exterioridades. Ao refletir-se sobre si mesma, a mente tem acesso a 
realidades interiores, nas quais essência e aparência não se distinguem ${ }^{94}$, e, portanto, o conhecimento a respeito dessas realidades não é suscetível ao engano e é absolutamente verdadeiro.

Já havíamos observado anteriormente que Agostinho dizia que a mente não pode duvidar que tem vontades, pensamentos, inteligência. Mas é preciso distinguir. Uma coisa é saber possuir faculdades, outra é conhecer como se atualizam essas potências. É o que acontece com a vontade. Uma coisa é sabermos que possuímos a faculdade da vontade; outra é conhecermos o que há de individual em cada uma de nossas vontades em sua concretude. Para uma melhor visualização do quadro, analisemos o que o animus pode descobrir a respeito das vontades:

1) Sabe o que é a vontade (sei que a vontade é diferente da percepção).

2) Sabe que é aquele que tem vontade. (a vontade é minha, provém de mim).

3) Sabe que possui a faculdade da vontade (se tenho vontades que são minhas e sei que posso ter outras vontades é porque sei que possuo a faculdade, que sou um ser dotado do poder volitivo).

4) Conhece também as suas próprias vontades (tenho várias vontades e sou capaz de distinguir uma vontade de outra).

Portanto, a mente conhece não apenas o que é a essência da vontade, mas conhece cada uma de suas vontades singulares, isto é, cada uma de suas vontades em ato. Ora, a vontade, em ato, possui uma força e possui um fim para onde se dirige, e este fim está ligado a um objeto ou a um estado de coisas a ser realizado pelo sujeito ${ }^{95}$.

Esse objeto da vontade varia conforme grau de determinação ${ }^{96}$. Um homem pode querer desde coisas pontuais como um fogão, até aspirar por algo mais genérico como uma ascensão

\footnotetext{
${ }^{94}$ Quando o olhar do animus, ao girar sua atenção, coloca em foco a própria vontade, ele pode conhecê-la absolutamente. Aquele que percebe dentro de si sua vontade, não pode se enganado nem sobre a existência, nem sobre sua essência. O parecer fornece o próprio ser. Aparência e essência coincidem. A vontade mostra-se aos olhos da mente sem disfarces, tal como é. Não é possível o fenômeno da "falsa aparência", tal como pode acontecer com aquilo que é dado aos sentidos, como quando alguém observa o remo submerso na água, o qual aparenta estar quebrado, embora não esteja. A aparência do remo não corresponde ao que ele é. O remo é reto, mas, quando submerso parcialmente na água, aparenta ser torto.

${ }^{95}$ Se alguém quer um carro, o objeto da vontade é o carro, mas o fim é usufruir o carro, gozar o prazer de seu uso. Pode ocorrer também, talvez com frequência menor, o homem querê-lo apenas para tê-lo. Poderia querer também por outros fins, entrevistos pela mente e que servem de motivo ao eu, direcionando a vontade para conduzir o corpo naquela direção.

${ }^{96} \mathrm{Nem}$ sempre, entretanto, o objeto da vontade coincide com o fim. Um homem na presença de algo perigoso e que the amedronta, tem a vontade direcionada para um abrigo seguro. Colocando de forma mais precisa: o fim da vontade é justamente se livrar do objeto do qual temos consciência que é perigoso. O traço que singulariza esse gênero de vontades é a negatividade, a repulsão e não a atração, o estado de coisas querido é definido em oposição um determinado objeto. Se sei que um furacão está vindo para a cidade, o estado de coisas desejado é estar longe do furacão, o que não significa um lugar determinado. O que é determinado é o objeto a se afastar.
} 
social, poder político ou sentir-se importante. Mas todos esses fins compartilham, como Agostinho incessantemente faz lembrar, da transitoriedade. A vontade está condenada a se extirpar, seja por um corromper físico do objeto da vontade, seja porque o usufruto do objeto já não mais fornece prazer.

Examinando cada uma dessas vontades transitórias percebe-se que elas estão apontadas ao transitório e nasceram por sugestão do corpo ou do orgulho espírito. As vontades transitórias só podem ser reguladas por vontades cujo objeto não seja transitório. Daí a necessidade de uma vontade dirigida à eternidade ${ }^{97}$.

Cada vontade mostra-se em sua singularidade, Agostinho não diz apenas: "tenho certeza de ter vontades", mas tenho certeza de que "não quero errar", que "quero ser feliz". O que fica explícito é que ele tem certeza de que tem determinadas vontades, as quais se distinguem pelo estado de coisas querido.

Estabelecido que cada uma das vontades é conhecida pela mente, podemos analisar um outro aspecto. A vontade voltada para um objeto determinado tem uma duração e, enquanto dura, sua força pode ser variável, ora mais forte, ora mais fraca. O término da vontade pode ocorrer por várias formas, umas morrem quando alcançam seu fim, outras morrem antes de atingir o seu fim. Outras, como a vontade de ser feliz, duram enquanto durar a vida do homem. Existem vontades cujo fim não consiste em adquirir algo que não se tem, mas em não perder o que se tem ${ }^{98}$.

Todavia, o que tudo isso parece sugerir é que a mente tem uma espécie de conhecimento a respeito de si que é um conhecimento que acompanha o nascer e o morrer das vontades, um conhecimento que não é um conhecimento apenas da essência de suas faculdades, mas um conhecimento que acompanha seu ser em sua concretude, um conhecimento de sua própria atividade, um conhecimento que só emerge aos olhos da mente quando é pensado.

Esse conhecimento que a mente tem de si é distinto do conhecimento obtido mediante o poder reflexivo. Podemos ter uma vontade, "conhecermos" essa vontade e, ainda assim, não colocá-la sob reflexão. O conhecimento pré-reflexivo é, por essência, anterior ao reflexivo. Essa distinção, nos termos de Agostinho, entre "o pensar em si" e "o conhecer a si" trouxe-lhe

\footnotetext{
${ }^{97}$ Existe, entretanto, uma vontade em estado bruto, simplesmente querendo, instaurando a tirania no corpo e persuadindo o olhar da mente a não olhar para ela. Pensá-la é refleti-la, colocá-la à luz para melhor examiná-la e pedir para ela a certidão de nascimento, sua origem, sua proveniência e estirpe. Pensá-la é objetificá-la, é petrificá-la com os raios do olhar da mente, como um veterinário africano que paralisa o leão para poder examiná-lo.

${ }^{98}$ Mesmo o homem que alcança uma alegria terrena, teme perdê-la, o que significa que ele não quer perdê-la, tem vontade de não perdê-la.
} 
a clareza necessária para resolver as peças do quebra-cabeça já anunciado nas Confissões, quando ele, sem distinguir as duas instâncias, perguntava: como é possível a monstruosidade de nada ser mais próximo do espírito do que ele mesmo e ainda assim ele não se conhecer? Agora, o quadro se inverte: conhecer a si ultrapassa o pensar em si. Conhecer a si não significa estar consciente deste conhecimento.

\subsubsection{Distinção entre pensar-se e conhecer-se}

Alguns capítulos atrás nós pudemos examinar como Agostinho chega à conclusão de que, para que a mente conheça sua substância, basta que ela descarte tudo aquilo que ela não tem certeza de ser. Despida de todo engano possível, restará ainda o círculo espiritual, sua incansável circularidade reflexiva, a presença a si mesma, inquebrantável, incólume a todo ceticismo. Essa presença, indubitavelmente segura, indubitavelmente é algo, ainda que para isso necessitemos reformular ou ampliar a noção clássica de substância. Dado este modo surpreendente de ser, o espíririto não é comparável a nada que chegue pelos sentidos, embora ela possa, caso não se pense, identificar-se ilusoriamente com as coisas sensíveis. Mas a verdade é que nada do que é corporal, como os átomos, o fogo, o ar, revela sua essência. Tudo isso, aliás, está dentro dela apenas em imagens que desfilam diante de seu olhar interior. A mente tem, por outro lado, certeza de que é, no palácio da memória, que estas imagens estão guardadas. É da memória que a vontade tira as imagens para coloca-las diante do olhar da mente. Não tem certeza de ser nada do que vê pela imaginação, mas tem certeza de ser o sujeito que imagina, pensa, lembra, quer, tem certeza que seus conhecimentos estão em si e que ela está sempre presente a si mesma, ao contrário de uma imagem evocada determinada, que ora está presente, ora está ausente, pois as trindades do cogito sucedem-se, num jorrar sem fim. Tudo isso o espírito sabe de si porque é capaz de ver-se a si, de pensar em si.

Mas se bem observarmos, chegamos a uma estranha constatação. Se é verdade que a mente é capaz de observar-se e conhecer a si com certeza, por que então tantas pessoas erraram ao dizer que a mente era átomos, fogo, ar, uma estrutura ou uma matéria sutil? Como é possível que a mente conheça a si com certeza absoluta e, ao mesmo tempo, creia ser o que não é? Ora, havíamos dito que a mente, ao subtrair de si tudo aquilo que ela não tem certeza de ser, descobre o que realmente é. Mas, antes de descobrir-se, ela se conhecia ou não? Como 
é possível que ela não se conhecesse se ela estava presente a si mesma? ${ }^{99}$ São estas as questões que Agostinho irá enfrentar no livro XIV da Trindade. Nele Agostinho procura demonstrar a seguinte tese: "Não há nada que a alma (mens: n.d.r) conheça tão bem como aquilo que lhe está presente; e nada mais presente do que ela, a si mesma." (De trinit., XIV, 4, $6 ; 2005$, p.)" ${ }^{100}$

Essa tese, aparentemente simples, esconde uma grande complexidade e suscita uma série de questões. Basta pensarmos na mente de um bebê ou de uma criança que aprendeu as primeiras palavras e nem sequer sabe o significado dos termos "mente", "espírito". Seria correto dizer que a mente de uma criancinha conhece a si mesma, apenas porque está presente a si mesma? Poderíamos estender a questão: imaginemos um indivíduo, nascido em uma cultura bárbara na qual o termo mente ou espírito ou outros termos análogos estão ausentes. Seria correto afirmar que este indivíduo teria conhecimento de sua mente apenas porque sua mente está presente a si mesma? Tais questões, sem dúvida, pedem esclarecimentos. Segundo Agostinho, o primeiro ponto a ser fixado é que ninguém negaria que tanto a mente de uma criança, quanto a de um bárbaro estão presentes a si mesmas. Mas seria decorrência necessária que, por estar presente a si mesma, a mente necessariamente se conhece? ${ }^{101} \mathrm{O}$ problema começa a ganhar novos contornos se distinguirmos o "conhecer a si" e o "pensar em si”: a distinção entre a mente e o olhar da mente. Para Agostinho é condição de todo pensar que o objeto pensado esteja diante do olhar da mente. O homem só pode ter o olhar da mente informado por algo se sua atenção estiver aplicada a esse algo. As crianças têm a atenção quase que inteiramente voltada para os sentidos. Portanto, será que a mente da criança se conhece mas não volta sua atenção para si, de tal modo que possa se pensar? É essa a questão que Agostinho se coloca:

Ou dever-se-á crer que a alma da criança se conhece, mas atenta em demasia ao que começa a sentir por meio dos sentidos corporais, com um prazer tanto maior, quanto mais recente, ela pode não se ignorar, mas não ter a possibilidade de se pensar? (De trinit., XIV, 4, 6; 2005, p.446).

\footnotetext{
${ }^{99}$ Diante de seus próprios olhos? Como veremos, está justamente aí o problema, ela estava presente, mas não diante de seus próprios olhos

100 "Nihil enim tam nouit mens quam id quod sibi praesto est, nec menti magis quidquam praesto est quam ipsa sibi." (De trinit., XIV, 4, 6).

${ }^{101}$ Observemos, para isso, o nosso olhar. Nada mais presente ao olhar do que o próprio olho. Mas o olho vê a si mesmo, embora imbricado no olhar? Sabemos que, o único modo de se ver o olho é por reflexo em algum espelho ou em alguma superfície refletora. Seria assim com a mente? São essas as dificuldades que Agostinho decide enfrentar.
} 
An etiam ipsa se nosse credenda est, sed intenta nimis in eas res quas per corporis sensus tanto maiore quanto nouiore coepit delectatione sentire, non ignorare se potest sed cogitare se non potest? (De trinit., XIV, 4, 6)

A atenção, como já havíamos observado, pode se voltar tanto para o interior quanto para o exterior. Na criança, a atenção está voltada justamente para o exterior. "A alma da criança como que se fecha em sua atenção de tal modo que somente aborrece ou deseja o que a ofende ou atrai fisicamente, com vivo impulso" (De trinit., XIV, 4, 6; 2005, p.446) ${ }^{102}$. De fato, os objetos sensíveis possuem um poder imenso de atrair as crianças. Basta observar o quanto elas são atraídas pela luz. Se alguém "colocar à noite uma luz no quarto onde uma criança está deitada, e em um ângulo onde esse pequeno possa torcer o olhar, ainda que sem poder virar o pescoço, seus olhos não se desviarão desse clarão.” (De trinit., XIV, 4, 6; 2005, p.446) $)^{103}$.

Analisando a mente infantil, Agostinho sutilmente estabelece uma distinção fundamental entre pensar em si e o conhecer a si. Uma coisa é não conhecer a si mesmo, outra coisa é não pensar em si mesmo. Essa distinção já havia sido discutida por ele no livro X, mas é aprofundada no livro XIV da Trindade. O fato a ser observado é que a criança não é capaz de pensar em sua interioridade, pois a atenção dela está voltada para o exterior. E mais, é impossível a alguém adverti-la para que o faça, já que ela não conhece os signos linguísticos através dos quais alguém poderia aconselhá-la para que o fizesse.

Ela não reflete em seu interior e nem podemos aconselhá-la que o faça, porque ainda não conhece os sinais de quem a adverte. Ora, entre esses sinais têm primazia as palavras, que ela desconhece totalmente, aliás, como a tudo o mais. Já demonstramos naquele mesmo livro que uma coisa é não se conhecer a si mesmo, outra coisa é não pensar em si mesmo. (De trinit., XIV, 5, 7; 2005, p.446).

sua uero interiora non cogitent nec possint admoneri ut hoc faciant quia nondum admonentis signa nouerunt ubi praecipuum locum uerba obtinent quae sicut alia prorsus nesciunt. Quod autem aliud sit non se nosse, aliud non se cogitare iam in eodem uolumine ostendimus. (De trinit., XIV, 5, 7).

Agostinho afirmava no livro XI que o cogito é composto por um conteúdo da memória, unido ao olhar da mente pela vontade. A vontade da criança está inteiramente aplicada ao mundo. Eis porque a criança não pensa em si mesma, porque a atenção da alma, pertencente à

\footnotetext{
102 "Ita et in alios corporis sensus quantum sinit illa aetas intentione se quasi coartant animae paruulorum ut quidquid per carnem offendit aut allicit hoc solum abhorreant uehementer aut appetant" (De trinit.,, XIV, 5, 7).

103 Agostinho chega até mesmo a comentar que algumas delas se tornaram estrábicas devido a isso, "conservando seus olhos a forma que o hábito imprimiu-lhes, quando ainda eram tenros e delicados" (De trinit., XIV, 4, 6; 2005, p.446).
} 
vontade, se estreita apenas para aquilo que ofende ou que deleita a carne ${ }^{104}$. No entanto, o fato de que as crianças não voltem o pensamento para o interior, uero interiora non cogitent, não implica que elas não se conheçam (nosse). Assim, Agostinho acaba por distinguir duas espécies de conhecimento, um conhecimento que temos, mas que nele não pensamos, e um conhecimento que sabemos que temos, conhecimento pensado, refletido. Ora, o espírito que se crê sendo fogo, ar, ou qualquer outra coisa do gênero, embora enganado, no fundo não deixa de conhecer-se verdadeiramente, embora não tome conhecimento do conhecimento que tem de si, pois não reflete sobre si mesmo.

Delineada a distinção entre pensar em si e conhecer a si, convém observar um outro aspecto, implicado no conhecimento de si, que é a memória de si. A base do argumento é: se a mente conhece a si mesma é porque ela tem memória de si. O que devemos observar é em que sentido ela tem memória de si.

Ao examinarmos a memória nas Confissões, observamos que a mente só pode guardar aquilo que de algum modo esteve presente ou está nela presente. Trata-se de uma condição sine qua non: só aquilo que é presente ou já foi presente na mente pode ser conservado. Ora, a mente está sempre presente a si mesma. Logo, ela não deixaria a marca de si mesma em si mesma? Sem dúvida, se a mente está constantemente presente a si mesma, ela deixa marcas de sua atividade sobre si mesma. Se ela vê algo, ela sabe, momentos depois, que viu algo; se ela quer algo, ela saberá instantes depois, que quis algo. Os atos que ela constantemente executa ficam marcados nela mesma, isto é, na memória. $\mathrm{E}$, enquanto não forem sepultados pelo esquecimento, podem ser lembrados. Isso só ocorre porque a mente conhece aquilo que faz e, sem dúvida, ela sabe que quem fez não é outra mente, que quem pensou não é outra mente. Portanto, a mente se conhece também no sentido de que ela tem memória de sua própria atividade. Se não houvesse nenhuma lembrança de seus próprios atos, a mente não poderia nem se conhecer, nem se pensar. Ora, essa característica está nas crianças, nos bárbaros, e em qualquer ser que não pense na mente. Mas ainda aqui podem ocorrer confusões, pois o fato de a mente saber sua atividade passada não significa que ela tenha conhecimento de que ela é o sujeito dos atos mentais e que, no seu núcleo, é um ser dotado de memória, vontade e intelecto.

O que acontece quando a mente, pela primeira vez, pensa em si mesma e descobre o que ela realmente é? Ora, como já havíamos observado, não se pode pensar em algo cujos

\footnotetext{
104 “intentione se quasi coartant animae paruulorum ut quidquid per carnem offendit aut allicit hoc solum abhorreant uehementer aut appetent”. (De trinit.,, XIV, 5, 7)
} 
componentes não tenham sido presentes ou que não estejam presentes na mente. A mente foi e é presente a si mesma.

De tudo isso, basta-nos ter certeza de que, quando o ser humano puder pensar sobre a natureza de sua alma e encontrar a verdade, não a encontrará em outro lugar, a não ser em si mesmo. Encontrará, porém, não o que ignorava, mas aquilo em que não pensava. (De trinit., XIV, 5, 8a; 2005, p.447).

Hinc tantum certos nos esse suffecerit quod cum homo de animi sui natura cogitare potuerit atque inuenire quod uerum est, alibi non inueniet quam penes se ipsum. Inueniet autem non quod nesciebat sed unde non cogitabat. (De trinit., XIV, 5, 8a).

O que sucede no caso das crianças é que, se elas crescerem e um dia pensarem em si, encontrarão não aquilo que ignoravam, mas aquilo que elas já conheciam mas que, até então, nunca tinham pensado ${ }^{105}$.

Se sabemos qualquer coisa, o que quer que seja, esse saber está em nossa mente e foi conhecido por nossa mente. "Pois, o que sabemos nós, se não sabemos o que é a nossa mente? Visto que tudo o que sabemos, só podemos conhecê-lo por meio de nossa mente?" (De trinit., XIV , 5, 8a; 2005, p.447). Quid enim scimus si quod est in nostra mente nescimus cum omnia quae scimus non nisi mente scire possimus? (De trinit., XIV, 5, 8a) ${ }^{106}$.

O pensar em si (cogito) e o conhecimento de si (nosse) ${ }^{107}$ possuem modos distintos de ser. O ato de pensar em si é temporal, tem uma duração e dura enquanto a própria mente estiver informando o olhar da mente. Já o conhecimento, por seu turno, não deixa de existir quando não é pensado.

\footnotetext{
${ }^{105}$ A mente pensar em si implica um ato reflexivo, no qual o sujeito que pensa é o mesmo que o objeto pensado. Ao pensar-se, a mente coloca a si mesma como objeto. Portanto, há uma diferença entre o conhecimento que a mente tem de si após pensar em si pela primeira vez e o conhecimento que ela tinha de si antes de pensar-se. $\mathrm{O}$ conhecimento que a a mente tinha de si antes de pensar-se era um conhecimento puramente potencial pensado, ainda não objetificado. Ao pensar-se o olho da mente vê pela primeira a própria mente.

106 Ora, através dessa argumentação, a tese que Agostinho procura desenvolver e provar vai ganhando cada vez mais luzes e sentido. "Não há nada que a alma conheça tão bem como aquilo que lhe está presente; e nada mais presente do que ela, a si mesma". (De trinit., XIV, 5, 7; 2005, p.446). Portanto, o argumento é o seguinte. A mente conhece os conhecimentos porque seus conhecimentos estão presentes nela. Se os conhecimentos não estivessem nela, ela não os conheceria. Mas os conhecimentos tem, comparados com a própria mente, um estatuto inferior à própria mente. Pois os conhecimentos podem estar presentes de duas formas, ou presentes na memória ou presentes no olhar da mente. Contudo, mente é sempre presente a si mesma de tal modo que basta que volte a si a atenção corretamente, para que perceba a si dos seguintes modos: 1) O ser onde estão presente os conhecimentos. 2) O ser por meio do qual conhecemos o que conhecemos. Portanto, o que deve ser observado é que a mente é definida em relação aos conhecimentos, é o ser que adquire conhecimentos e que tem em si os conhecimentos.

${ }^{107} \mathrm{O}$ pensamento é um ato da consciência que possui um conteúdo. O conhecimento, por seu turno tem algumas características básicas. 1) O conhecimento está numa mente. 2) O conhecimento é conhecimento de algo. 3) o conhecimento tem sua origem no algo do qual é conhecimento. 4) O conhecimento é vinculado com a experiência que a mente teve desse algo. 5) Experimentar algo é ter esse algo presente na mente, seja em imagem, seja ele próprio. 6) O conhecimento só é conhecimento na medida em que possa vir a ser pensado.
} 
Todavia, a força do pensamento é de tal maneira que nem a própria mente coloca-se, de certo modo, em sua própria presença, a não ser quando se pensa. Em consequência, nada há presente na mente, senão quando nisso ela pensa, a ponto que nem mesmo a própria mente, - que é condição de todo pensamento -, pode estar presente a si mesma, a não ser pensando-se em si mesma. (De trinit., XIV, 5, 8b; 2005, p.447).

Tanta est tamen cogitationis uis ut nec ipsa mens quodam modo se in conspectu suo ponat nisi quando se cogitat, ac per hoc ita nihil in conspectu mentis est nisi unde cogitatur ut nec ipsa mens qua cogitatur quidquid cogitatur aliter possit esse in conspectu suo nisi se ipsam cogitando. Quomodo autem quando se non cogitat (De trinit., XIV, 5, 8b).

A passagem supracitada é surpreendente: a tese aqui defendida, segundo a qual a mente não pode estar presente a si mesma a não ser pensando a si mesma, parece a própria negação da tese inicialmente defendida: "Não há nada que a alma conheça tão bem como aquilo que lhe está presente; e nada mais presente do que ela, a si mesma." (De trinit., XIV, 4, 6; 2005, p.446). ${ }^{108}$

O fato é que o pensador está ciente de sua contradição e sua honestidade é estarrecedora. "Não consigo compreender, porém, como a alma, quando não pensa em si mesma, não esteja presente a si, pois nunca pode ela estar separada de si mesma, como se uma coisa fosse ela e outra a vista de sua presença." (De trinit., XIV, 5, 8b; 2005, p.447).

\subsubsection{Uma visão em espelho e enigma.}

Em certa passagem, Agostinho, aprofundando sua discussão do modo pelo qual o homem é a imagem de Deus, investiga as palavras do Apóstolo: “Agora, vemos Deus em espelho e em enigma, mas depois o veremos face a face.” (De trinit., XV, 25, 45). Agostinho interpreta da seguinte forma: quem olha para o espelho, o que vê não é outra coisa senão a imagem. Significa que se é verdade que o homem vê Deus é porque vê Deus em imagem. Por outro lado, vê Deus em enigma. Que enigma é esse? Antes de mais nada, é necessário compreender a definição de enigma, usando para isso o gênero próximo e a diferença específica. Pelo gênero próximo, enigma é uma figura de retórica ou um tropo. O tropo está para o enigma, assim como o gênero animal está para homem ${ }^{109}$. O tropo é quando o significado natural de uma palavra é substituído por outro, devido a uma relação de

\footnotetext{
108 "Nihil enim tam nouit mens quam id quod sibi praesto est, nec menti magis quidquam praesto est quam ipsa sibi”. (De trinit., XIV, 4, 6).

109 “Assim, por exemplo, como todo cavalo é animal, e nem todo animal é cavalo, também todo enigma é um tropo, mas nem todo tropo é um enigma”.(De trinit., $\mathrm{XV}, 9,15 ; \mathrm{p} .500)$.
} 
semelhança no sentido de ambas. Já a diferença específica que caracteriza o enigma é que, neste caso, a analogia é obscura, de difícil percepção.

Portanto, o que a passagem de Paulo quer dizer é que o homem vê Deus em espelho, pois a mente do homem é imagem de Deus, mas também vê em enigma, pois não é fácil perceber a sua relação de semelhança com Deus. É uma semelhança obscura. O problema é: nada é mais presente à mente do que ela própria: ela se conhece e, ainda assim, pode ocorrer que ela não tome consciência do fato que ela se conhece. O enigma está na própria autorreflexão: a mente não vê aquilo que ela não poderia deixar de ver.

Pois quem não vê o próprio pensamento? E contudo, quem vê o seu pensamento, não digo mediante os olhos carnais, mas com o olhar interior? Quem não vê e quem vê o próprio pensamento" (De trinit., XV, 9,16; 2005, p.502)

Nomen quippe hic non sonaret aenigmatis, si esset facilitas visionis. Et hoc est grandius aenigma, ut non videamus quod non videre non possumus. Quis enim non videt cogitationem suam? et quis videt cogitationem suam, non oculis carnalibus dico, sed ipso interiore conspectu? Quis non eam videt, et quis eam videt? (De trinit., XV, 9,16).

O pensamento, embora seja sempre presente, ainda assim, não é notado, isto é, não é objetificado. Quando o pensamento pensa em si mesmo, ele se revela. O pensamento (cogitatio) é uma espécie de visão da alma (visio animi). Do mesmo modo como costumamos atentar ao objeto visto, e não à visão do objeto, o mesmo ocorre com a cogitatio, que, numa torção espiritual, pode apreender a si mesma.

\subsubsection{Inter-relações entre a mens e os estratos do homem}

A fim de compreender como a alma observa a si mesma, Agostinho levanta três hipóteses, todas tiradas do mundo sensível.

A primeira é que a alma humana, para que contemple a si, deve retirar-se de si mesma para se observar. "Será que ela como que se desdobra, de modo a poder estar ali e aqui, ou seja, lá onde possa ver e aqui onde possa ser vista? Está em si para ver e diante de si para ser vista?" (De trinit., XIV, 5, 8b; 2005, p.449). Mas isso é um contrassenso, pois a mente não pode ausentar-se de si mesma para se observar.

A segunda hipótese é feita por analogia com o fenômeno do olhar. O olho está no corpo, mas o "olhar estende-se ao que está fora, e alonga-se mesmo até os astros" (De trinit., XIV, 5, 8b). O olho, portanto, não é presente ao olhar. Embora o olho seja essencial para que haja o olhar, o próprio olho não está presente no olhar, pois vemos as coisas com os olhos, embora 
não vejamos os próprios olhos. Os raios do olhar não conseguem dobrar-se 180 graus de modo que se possa ver o próprio olho. ${ }^{110} \mathrm{O}$ olho pode ver-se apenas com auxílio de um espelho.

A terceira hipótese seria que, ao contrário do olhar físico, a mente não use nada exterior a ela. Seria, portanto, como quando olhamos para as nossas mãos ou para os pés: uma parte do corpo é capaz de observar uma outra parte. Mas neste caso, é preciso observar que a parte que observa distingue-se da parte observada. Ocorreria o mesmo com a mente? Não pode ser o caso, pois isso implicaria que parte da mente observasse uma outra parte da mente, contudo, a mente não é divisível como os corpos, os quais se definem pelas partes serem menores do que o todo. Ora, a mente está toda inteira ao se observar. Dizer que parte de minha consciência está presente a si mesma e parte de minha consciência não está presente a si mesma é negar a própria definição de consciência. Uma consciência que não está presente a si mesma não é consciência, é inconsciência.

Só há uma solução: a mente, enquanto ser que observa, está inteira no ato de observar e também está inteira enquanto objeto observado. Para que possamos compreender isso, é necessário deixar de lado as analogias com o mundo dos sentidos. De fato, nas três hipóteses supracitadas a mente está pensando com a imaginação. O segredo é pensar com a inteligência. Tanto a hipótese segundo a qual a mente se desdobra para que uma parte veja a outra, quanto a da mente retirar-se de si mesma para ver-se nascem de um equívoco: o de confundir as realidades incorporais-espirituais com as corporais ${ }^{111}$. Em outras palavras, todo esforço de se tentar compreender a mente por meio de imagens mostra-se infrutífero. Não é possível colocar em imagens o modo como a alma encontra-se presente a si mesma.

Tal constatação é de grande importância no pensamento de Agostinho. Anos e anos no treinamento da retórica fizeram desta mente incansável um mestre nas imagens, nas metáforas e nas analogias, de tal modo que lhe parecia natural que os fenômenos fossem todos eles passíveis de serem elucidados com imagens. Esse poder imaginativo, que foi uma de suas grandes armas quando professor de retórica, foi durante anos também sua prisão, quando esforçava-se em compreender por meio da imaginação o problema da onipresença de Deus. Em certa passagem ele comenta como, ao pensar nas coisas incorporais, as imagens vinham a sua mente, como que voando e embaçando o olhar da inteligência. Ora, é preciso que deixemos de procurar imagens que ilustrem como a mente pode observar a si mesma e

\footnotetext{
110 Poderíamos dizer, em outras palavras, que o olho é em si, mas não é para si.

111 O que caracteriza os corpos é que neles, as partes são menores do que o todo. No espírito, as partes não são menores que o todo.
} 
simplesmente constatemos que: 1) sou eu que penso; 2) os pensamentos estão em mim; 3) os pensamentos são incorporais; 4) logo estão no meu eu incorporal. Como havíamos observado, ao buscar-se, a mente se conhece, pois não poderia buscar a si se não se conhecesse:

Consequentemente, só resta admitir que na mente a presença a si é algo pertinente à sua própria natureza; e quando pensa em si mesma, ela volta-se para si mesma, em movimento incorpóreo, não em movimento espacial. (De trinit., XIV, 5, 8b; 2005, p.448).

Proinde restat ut aliquid pertinens ad eius naturam sit conspectus eius, et in eam quando se cogitat non quasi per loci spatium sed incorporea conuersione reuocetur. (De trinit., XIV, 5, 8b).

É por um dobrar imaterial (incorporea conversione) sobre si mesma que a mente se pensa. Isso deve ficar claro: para se conhecer a mente não precisa realizar esse movimento incorporal de dobrar sobre si. Mas é preciso para pensar-se, para conhecer esse conhecimento que ela tem de si. Este pensar-se pode ser entendido como uma espécie de movimento ou em outras palavras, de uma ação realizada pela mente.

\subsubsection{A mente lembra-se de si mesma e compreende a si mesma e ama a si mesma}

Há um segundo aspecto ressaltado por Agostinho na trindade composta pela autocontemplação da mente. Trata-se do amor que a mente tem em relação a si mesma. Antes mesmo da mente pensar em si, ela já se amava? Só poderia se amar caso se conhecesse. Sabemos que a mente sempre se conhece, ainda que não se pense. Essa exigência está, portanto, satisfeita. Mas esse amor permanece mesmo que a mente não se pense? Seria como um amor ${ }^{112}$ inconsciente que a mente tem de si mesma? Esta pergunta articula-se com outra pergunta: compreendemos (intelligimus) aquilo que está na memória apenas no momento em que pensamos? Para se desembaraçar destas dificuldades, Agostinho usa o seguinte exemplo:

112

Não é possível amar a si nem se lembrar de si, sem compreender a si; Mas Agostinho em certos momentos diz que a trindade da alma é composta por vontade, memória, intelecto. Por que então Agostinho diz da trindade de "amor a si", "compreensão de si", "memória de si"? Basta observar que Agostinho usa, em alguns casos: "amor" em outro "vontade" para tratar do elemento copulativo. "Decorre daí o modo como apresentávamos a trindade da alma. - a memória, - onde colocávamos o que informa o olhar do pensamento;

- a forma, que reproduz a imagem impressa na memória; - o amor ou vontade, que enlaça um a outro;" (De trinit., XIV, 5, 8b; 2005, p.449; grifos são nossos).

Ideo trinitatem sic commendabamus ut illud unde formatur cogitantis obtutus in memoria poneremus, ipsam uero conformationem tamquam imaginem quae inde imprimitur, at illud quo utrumque coniungitur amorem seu uoluntatem. (De trinit., XIV, 5, 8b; 2005, p.449). Ao que parece, é que não queremos aquilo que, de alguma forma, não amamos. Amar algo é querer esse algo. A vontade corrompida do homem, após a queda, nada mais é do que um amor corrompido, no qual o homem ama o múltiplo, as realidades sensíveis, ao invés de amar o Uno, a realidade inteligível, a Sabedoria. Portanto, não é de se espantar que nessa passagem Agostinho use amor como intercambiável com o termo vontade, para referir-se ao elemento de conjunção entre o que estava na memória e o olhar da mente. 
alguém que conhece duas ou mais disciplinas, quando pensa em uma delas, não deixa de conhecer, nem de compreender, nem de amar as demais.

Será que podemos dizer com razão: "Este músico conhece realmente a música, mas no momento não compreende, porque não pensa na música, pois atualmente compreende geometria, já que agora está pensando na geometria". Tal afirmação é absurda, o quanto me parece. E o que dizer desta outra: "Este músico conhece de fato música, mas no momento não a ama, pois não pensa em música." Não é igualmente uma afirmação absurda? (De trinit., XIV, 7, 9; 2005, p.450).

Duarum ergo uel plurium disciplinarum peritus quando unam cogitat, aliam uel alias etiam si non cogitat nouit tamen. Sed numquid recte possumus dicere: 'Iste musicus nouit quidem musicam sed nunc eam non intellegit quia non eam cogitat; intellegit autem nunc geometricam, hanc enim nunc cogitat'? Absurda est quantum apparet ista sententia. (De trinit., XIV, 7, 9; 2005, p.450).

Ilustrando com tais exemplos, Agostinho conclui que, mesmo quando não estamos pensando em algo que conhecemos, isso não significa que deixamos de amá-lo nem de compreendê-lo. Com essa sutileza, Agostinho distingue uma trindade composta por entendimento (intelligentia), memória e amor a si. Com efeito, a mente ama, compreende a si e tem memória de si. Trata-se de uma trindade que permanece, ainda que nela não pensemos.

\subsubsection{Distinção entre voluntas e intentio}

Havíamos observado que a mente é uma unidade composta por vontade ou amor, memória e inteligência e, no capítulo anterior, observamos como estas três potências formam uma circularidade, pois, por um lado, a mente é simultaneamente o sujeito e o objeto das três faculdades. Sem uma memória de si, um amor a si e inteligência de si, a mente não poderia ser mente. Essa estrutura é constitutiva da mente, está sempre presente, ainda que a mente não esteja pensando em si mesma, ainda que não esteja com a atenção voltada para si.

Nesse cenário torna-se patente que há uma sutil distinção entre vontade e atenção (intentio). Tanto o olhar da mente, quanto a atenção (intentio) são essenciais à trindade do cogito. Agostinho, algumas vezes usa a expressão intentio voluntatis para se referir ao elemento que une o conteúdo da memória com o olhar da mente, de tal modo a formar o pensamento. Já na trindade constituída por memória de si, amor a si, entendimento de si não há, necessariamente, a participação do olhar da mente e intentio voluntatis. A mente ama a si mesma, quer esteja pensando em si, quer não, quer esteja com a atenção voltada para si, quer não. 
Seria correto admitir, portanto, que ter atenção (intentio) dirigida a algo implica pensar esse algo? O que podemos dizer com certeza é que ter o olhar da mente informado por esse algo exige que a atenção da vontade esteja aplicada a esse algo. Aquele que pensa na trindade da mente tem sua intentio voltada para ela. Mas isso não significa que a trindade da mente não estará existindo quando sua intentio para não estiver dirigida à própria mente. A consequência disso é que a mente nunca deixa de se amar, de se entender e de se lembrar, ainda que ela não esteja pensando nela própria. Trata-se de uma trindade sempre presente, em certa medida estável, ao contrário da trindade do pensamento, que caracteriza-se pelo fluxo, por um eterno desfilar de objetos diante do olhar da mente. Não deixamos nem de nos amar, nem de nos entender porque não estamos pensando em nós mesmos. Contudo, é possível sempre que quisermos, dirigindo adequadamente a atenção, ver, com o olhar da mente, o nosso amor, o qual está presente, embora não refletido conscientemente, o que implicaria a participação do olhar da mente e da intentio voluntatis.

Portanto, uma coisa é haver um conteúdo presente na mente e outra é ter algo presente diante do olhar da mente ${ }^{113}$. Embora Agostinho não explicite, os textos deixam claro que há quatro níveis nos quais algo está presente no animus.

1) $\mathrm{Na}$ memória recôndita.

2) Na memória disponível.

3) Presentes ativa e atualmente na própria mente, sem que sejam notados com o olhar da mente. Assim, quando a mente pensa em si mesma "percebe então o que recordava, compreendia e amava, mesmo que não pensasse ou pensasse em outras coisas" (De trinit., XIV, 5, 9; 2005, p.450).

4) Presentes diante do olhar da mente ${ }^{114}$.

${ }^{113}$ A mente é sempre presente a si mesma quando não é presente ao seu próprio olhar. Existem dois tipos de presenças para a alma, uma presença que é apreendida, isto é, pensada, e uma presença que, embora presente, não é pensada, não é objeto de atenção. Aquele que usa óculos nem sempre vê os próprios óculos, ou melhor dizendo, sempre vê os próprios óculos, mas são notados apenas quando dirige sua atenção a eles é que os vê com o olho da mente.

Mas se quisermos também considerar que os conhecimentos (sem ser o conhecimento que a mente tem de si mesma) estão presentes na memória, logo notamos que eles estão presentes de um modo distinto de como a mente está presente a si mesma sem se pensar. E para complexificar ainda mais as coisas, os próprios conhecimentos que estão na memória estão ou na memória recôndita ou na memória disponível.

Agostinho parece sugerir em algumas passagens que trata de gradações de luminosidade. O máximo de luminosidade é o objeto que está diante do olhar da mente:

"Isso chama nossa atenção para o fato de possuirmos nos refolhos da alma conhecimentos de certas realidades que de algum modo vêm à superfície da mente e se põem como que mais abertamente à luz, na presença da mente, quando nelas ela pensa" (De trinit., XIV, 5, 9; 2005, p.450).

"Hinc admonemur esse nobis in abdito mentis quarundam rerum quasdam notitias, et tunc quodam modo procedere in medium atque in conspectu mentis uelut apertius constitui quando cogitantur". (De trinit., XIV, 5, 9) 
Possuímos dados para observar mais de perto como é possível que existam vontades sem que estejam elas mesmas diante do olho da mente ${ }^{115}$ e o modo como isso se dá.

O amor, ainda que não pensado, está presente, está vivo. E estar presente, aqui, significa se fazer presente: afetar e participar de modo ativo da vida da mente. Se isso for verdade, somos forçados a admitir que Agostinho possui uma visão extremamente moderna da mente, pois o inconsciente, o não notado, o irrefletido ultrapassa o refletido conscientemente. Colocando a pergunta mais precisamente: "Seria correto considerar que o olhar da mente, pela sua estrutura, é informado apenas de uma parcela da vida da mente?" O que sabemos com segurança é que o olhar da mente não pode abarcar num só relance tudo o que a mente possui na memória, pois é informado por um número limitado de conteúdos. Mas o olhar da mente pode abarcar num só relance todas as atividades da mente. Qual a relação entre a vida irrefletida da mente e a vida refletida? Em que sentido a vida da mente ultrapassa o olhar da mente e a cogitatio?

\subsubsection{Conhecer a vontade, pensar a vontade}

Para respondermos as questões levantadas é necessário afiar ainda mais os conceitos. O que significa pensar na vontade? Já observamos que, em alguns casos, aquele que tem a vontade diante do olhar da mente pode compreender essa vontade de modo indubitável. Por exemplo, a vontade de não errar, de querer ser feliz, de querer conhecer a verdade. Contudo, essas vontades podem estar presentes e ativas mesmo que nelas não estejamos pensando?

Aquele que está concentrado na resolução de um problema matemático não quer errar. O fato notável é que essa vontade de não errar não está, ela mesma, sob o olhar da mente. Ele está imerso no problema, com o olhar da mente dentro do problema, e não pensará propriamente em sua vontade de não errar. Mas podemos extrapolar e dizer que, enquanto está pensando no problema matemático, não apenas não quer errar, mas também não perdeu sua vontade de ser feliz, de fazer uma viagem no fim do ano, de ir ao cinema à noite. $\mathrm{E}$, do mesmo modo, não deixou de amar sua esposa e amar Deus.

Contudo, mesmo que o amor não deixe de existir quando o homem não pensa no objeto amado, não decorre daí que nunca mais irá pensá-lo. O objeto amado atrai gravitacionalmente o olhar da mente. Aquele que ama Deus, embora não possa contemplá-lo a todo instante, tem

\footnotetext{
${ }^{115}$ A mente pode amar sem que tenha o seu amor diante de seu olhar. Pode até mesmo pensar no objeto amado com amor, sem que pense no próprio amor. Uma coisa é, em virtude do amor, ter a atenção dirigida ao objeto amado, outra coisa é ter atenção dirigida para o amor do objeto. O fato de não termos o amor diante do olhar da mente, não significa que este amor esteja congelado, cristalizado, inerte, esperando ser pensado para que ganhe vida.
} 
uma tendência a contemplá-lo e, para isso, é preciso que a intentio voluntatis una o que está na memória ao olhar da mente.

Portanto, aquele que durante determinado momento tem o olhar da mente concentrado em um problema matemático não deixa de estar também amando Deus, nem mesmo deixa de saber que ama Deus. De fato, uma vez que o homem encontre a solução do problema de matemática, ele pode dirigir uma prece a Deus, agradecendo-lhe pela resposta encontrada. Enquanto tal homem resolvia o problema matemático, o amor por Deus e sua vontade de contemplá-lo estavam ali presentes, apenas esperando a ocasião propícia para dirigir o holofote da atenção para Deus. Mas, mesmo quando ele está rezando, ele pode estar pensando em Deus e não no amor que sente por Deus. Todavia, se voltasse sua atenção para este amor, pensando no seu amor, ele não se surpreenderia, apenas constataria o amor que já estava ali. De modo análogo, quando prestamos atenção nos sons que nos circundam, apenas constatamos que eles já estavam presentes e que já tínhamos uma certa consciência deles.

Há, portanto, em Agostinho uma intricada relação entre vontade, pensamento e atenção ${ }^{116}$. Suponhamos o caso de uma pessoa que acabe de almoçar e lembre-se que precisa resolver uma pendência no banco, que já há algum tempo está adiando. Digamos que ela está adiando o problema porque ele exige uma boa dose de esforço. Trata-se de duas vontades antagônicas: querer resolver o problema, mas, ao mesmo tempo, não querer se esforçar. Contudo, ela está determinada a enfrentá-lo em algum momento, apesar de todo esforço que o esforço exige. Certo dia, entretanto, essa pessoa, acabando de almoçar, lembra-se da conta que tem para pagar. Se fôssemos entender esse exemplo dentro do esquema agostiniano, diríamos: o lembrar-se da conta está conectado com a vontade de pagá-la. O segundo ponto a se observar é que essa vontade existia e estava presente em seu animus, mesmo quando ele comia e estava pensando em outras coisas. Tal vontade apenas esperava por trás do olhar da mente, ansiosamente, a ocasião de roubar a atenção para ela. A vontade está presente antes de o homem pensá-la, em uma espécie de memória "inconsciente", mas ativa. Em um segundo momento, a vontade informa o olhar da mente: a vontade é refletida pelo pensamento, é pensada. Mas pensar a vontade implica, na maior parte dos casos, uma avaliação da vontade $^{117}$. O produto dessa avaliação é a decisão. Em termos simples: a vontade põe-se à luz

\footnotetext{
${ }^{116}$ Aquele que quer resolver um problema tem sua atenção no próprio problema. Quer resolver o problema, o que não significa que necessariamente pensa na vontade que tem de resolver o problema.

${ }^{117}$ A vontade pode ser avaliada de diferentes formas. Julgamento se a vontade é justa, se ela merece o esforço, julgamento a respeito de quando realizá-la. Neste momento, o homem começa a ponderar se vai agora mesmo ao banco. Mas então se lembra de que hoje é um dia no qual o banco está lotado, é decide que é melhor deixar para outro dia.
} 
para ser avaliada quanto ao seu valor, o esforço exigido, os meios para sua realização. E quando o homem decide por executá-la, ele não mais pensará propriamente na vontade, pois esta não será o objeto de juízo. O que ocorrerá é que a própria vontade irá direcionar seu pensamento e seu corpo para a realização ${ }^{118}$.

\subsubsection{O entrelaçamento das vontades}

No homem existem inúmeras vontades entrelaçadas e não é possível que todas as vontades existentes no animus estejam, a um só tempo, informando o olhar do animus. No momento em que decido ir ao banco e começo a pensar sobre qual o melhor caminho para chegar até lá, meu raciocínio e o olhar de minha mente estão focados em analisar e estimar, dentre as possibilidades, qual a melhor. E, enquanto penso isso, embora o olhar de minha mente não esteja sendo informado pela vontade de pagar a conta no banco, esta vontade está implícita e presente no ato de pensar no melhor caminho para se chegar ao banco. Mas, além disso, se eu decido ir por tal caminho é porque também tenho vontade de ir por aquele determinado caminho e não por outro. Esta vontade só faz sentido em virtude da vontade geral de ir ao banco pagar a conta. E de certo modo, podemos dizer que a vontade de ir por tal caminho nasce da vontade de pagar a conta no banco, assim como um galho nasce do tronco. $\mathrm{E}$, se levarmos adiante essas considerações, a vontade de ir ao banco nasce de outra vontade, a vontade de ter o benefício da luz elétrica em casa, supondo que a conta que irei pagar no banco é a conta de luz. Seguindo essa ordem de raciocínio, podemos dizer que a vontade que está na base e da qual emanam todas as outras é a vontade de ser feliz.

Já observamos que o homem pode ter muitas vontades: vontade de querer ser feliz, vontade de querer conhecer a verdade, vontade de não errar, vontade de querer extinguir um mal corporal. Observamos também que um homem, quando quer resolver um problema, não deixa de querer não errar, não deixa de querer ser feliz, não deixa de querer contemplar Deus. Cada vontade possui um grau de generalidade. Basta observarmos que, de um lado, existem

\footnotetext{
${ }^{118} \mathrm{O}$ homem espontaneamente volta sua atenção para a vontade quando quer decidir se vai realizá-la ou não. Em outras palavras, ele irá pensar se empenhará no problema ou não. Não se pode negar que ele tenha vontade de resolver o problema e que não esteja pensando nesta sua vontade. Uma vez que se decida se empenhar, sua atenção volta-se para o problema. Caso o problema esteja muito difícil, sua atenção pode novamente voltar-se para a vontade, isso porque uma outra vontade, a vontade de querer conforto, pode colocar aquela vontade sob exame. Será que é tão importante para mim resolver tal problema, ele vale o esforço? Qual o valor que resolver o problema tem para mim. Em outras palavras, o homem, após se deixar levar pela vontade, percebe que aquela vontade, para ser realizada, conduz ele para a dor do esforço. Aquilo que causa dor torna-se objeto do olhar da mente, e, por isso, é posto à luz. E então o homem irá avaliar a vontade.
} 
vontades que abarcam todas as outras, como a vontade de estar alegre (laetitia) e, em alguns, a vontade de ser realmente feliz (beatitude). De outro lado, o ato quase pontual de perceber algo só ocorre em virtude da vontade. Afinal, quem vê algo só vê esse algo quando sua intentio voluntatis está dirigida a esse algo. É necessário que a vontade se aplique na xícara para que o homem veja a xícara. Contudo, se ele resolve pegar a xícara, dirigindo sua mão até ela, assim o faz porque sua vontade moveu seus membros. É possível distinguir as vontades: uma é a simples vontade de ver a xícara, outra a vontade de pegar a xícara e levá-la até a boca para beber o café. Mas ambas as vontades estão entrelaçadas. E essas duas vontades estão ligadas com uma terceira: a vontade de beber o café.

No livro XI da Trindade, logo após observar que a vontade é o que aplica os sentidos ao objeto visto para que ocorra a visão, Agostinho desenvolve a noção que o fim de toda vontade é o repouso. Isso é válido mesmo para a visão. "Talvez possamos chamar, com propriedade, a visão de fim e de repouso da vontade, em certo caso concreto. A vontade, pelo fato de ver o que queria não deixará de ter outros desejos (voluntas: n.d.r) a mais". (De trinit. XI, 6, 10; 2005, p.350) ${ }^{119}$.

O repouso de uma vontade específica não implica o repouso da vontade que a gerou. De fato, a vontade especifica que se aplica à visão, para que percebamos o objeto, tem seu fim na própria visão do objeto. Aquele que dirige o olhar para algo quer, sem dúvida, ver esse algo, mas quer vê-lo em virtude de um outro querer, o qual também está presente. Agostinho usa como exemplo o caso de alguém que quer ver uma cicatriz a fim de confirmar se houve ali um ferimento. Neste caso estão presentes duas vontades: a vontade de se certificar que houve um ferimento e, como vontade derivada, a vontade de ver o ferimento.

Assim, a vontade de ver uma cicatriz tende a seu fim: o de ver a cicatriz e nada mais. Pois a vontade de comprovar que houve um ferimento é outro querer, embora ligado ao primeiro, e seu fim específico é a comprovação do ferimento." (De trinit. XI, 6, 10, 2005, p.352)

Voluntas itaque uidendi cicatricem finem suum expetit, hoc est uisionem cicatricis, et ad eam ultra non pertinet; uoluntas enim probandi uulnus fuisse alia uoluntas est, quamuis ex illa religetur, cuius item finis est probatio uulneris. (De trinit. XI, 6, 10, 2005, p.352)

Em suma, a vontade de ver a cicatriz é decorrência da vontade de se certificar que houve um ferimento. Poderíamos dizer que se a pessoa escutasse de outra que não houve um ferimento, ela perderia a vontade de ver a cicatriz.

119 ، Finem fortasse uoluntatis et requiem possumus recte dicere uisionem ad hoc dumtaxat unum; neque enim propterea nihil aliud uolet quia uidet aliquid quod uolebat". (De trinit. XI, 6, 10) 
O exemplo citado, embora aparentemente banal, deixa entever toda estrutura a qual deve se submeter o querer humano. O homem tem obrigação de refletir a respeito de suas vontades para ordená-las, estruturando-as de modo que todo o querer humano em suas múltiplas variedades seja decorrência da vontade de querer fazer o bem. Cada uma das vontades será reta se deriva da vontade de fazer o bem. Se, ao invés disso, a vontade de base é má, será má toda a cadeia subsequente de vontades. Se um homem impiedoso tem uma vontade desmedida de enriquecer, todas as vontades específicas referidas a essa vontade serão más. Por outro lado, quando as vontades são retas, todas elas formam uma espécie de itinerário que tem como fim último a felicidade. Com isso, Agostinho compara a vida humana a uma longa jornada, cujo fim último é o repouso da vontade, da vontade de base. O homem é como um Odisseu retornando a Ítaca, com inúmeros perigos no caminho. Em determinados momentos o homem sofrerá, em outros terá que enfrentar ventos contrários, mas um dos maiores perigos encontra-se dentro do próprio homem, a possibilidade de ele distrair-se e esquecer o seu destino, tal como poderia ter ocorrerrido com Odisseu, quando na ilha da ninfa Calipso.

A vontade da beatitude é um fim último e o mais geral. Mas cada uma dessas vontades específicas que dela emanam possui um fim específico. Estes fins, caso sejam retos, são etapas de um único caminho. E ao alcançar cada um desses fins específicos, a vontade específica encontra seu repouso, o que lhe traz prazer, pois, para Agostinho, o prazer é o repouso da vontade. Agostinho compara as vontades específicas com o andar. Cada passo consiste no movimento de uma das pernas que segue até pousar os pés no chão logo a sua frente, dando início o próximo passo com a outra perna.

O prazer que encontramos com alguma coisa, pode incitar a vontade a descansar aí com agrado. Contudo, essa não é a meta definitiva. É preciso que tenha relação com outro fim, o definitivo, e esse interesse momentâneo seja considerado não como a pátria, mas como descanso ou abrigo do peregrino" (De trinit. XI, 6, 10, 2005, p.352)

$\mathrm{Si}$ autem aliquid ita placet ut in eo cum aliqua delectatione uoluntats adquiescat, nondum est tamen illud quo tenditur, sed et hoc refertur ad aliud; deputetur non tamquam patria ciuis sed tamquam refectio uel etiam mansio uiatoris. (De trinit. XI, 6, 10)

Portanto, a vontade específica é reta quando conectada à vontade suprema. A vontade de um Cristão de ir ao Afeganistão para evangelizar os mulçumanos só será reta se estiver conectada a uma outra vontade, superior a esta, que é a vontade de repousar a vontade em Deus. Não faz sentido que a vontade de ir ao Afeganistão evangelizar os mulçumanos seja um fim último. Mas essa pessoa também precisará querer pegar um avião e, por isso, comprar um 
bilhete aéreo. Enquanto ela está indo comprar o bilhete aéreo, o fim específico dessa vontade é comprar o bilhete aéreo, mas este fim está ligado ao fim específico de ir ao Afeganistão e assim por diante, de tal modo que o fim específico conecta-se com outro fim, com a cadeia terminando no fim último que é a felicidade.

Todo o problema ganha novas luzes se compreendermos esse quadro dentro de uma escala de tempo. Se formos para a última ponta dessa cadeia de fins, encontraremos a felicidade, cuja duração se estende pela vida inteira do sujeito, mas, se formos para a outra ponta da cadeia, encontraremos o homem no seu presente atual, com suas vontades instantâneas, com aquilo que ocupa, no determinado instante, o olhar de sua mente. Afinal, o que está no olhar da mente é posto pela vontade ${ }^{120}$.

$* * *$

Tal descrição tem um cheiro de artificialidade. O primeiro ponto pelo qual tal descrição soa artificial, advém do fato de que nem todas as vontades que levam o homem a agir são pensadas interiormente, numa fala íntima, em um diálogo interior. Ninguém pensa consigo mesmo, formando um diálogo interior consigo do tipo: "vou pegar a xícara, vou ver a xícara, vou mexer meus braços" e assim por diante. O segundo ponto é que, factualmente, a noção de referir todas as vontades específicas à vontade suprema trata-se um ideal a ser seguido, mesmo que ele não seja plenamente factível. Trata-se de um "ideal” porque para que o realizássemos teríamos que pensar e avaliar reflexivamente cada uma das vontades. De fato, ao lado de um querer planejado e avaliado em um diálogo interior pelo pensamento, reside também um querer implícito e um querer espontâneo, que poderia ser refletido mas nem sempre o é. E esse querer implícito e espontâneo é muitas vezes desviante em relação ao “querer fazer o bem”, que é o querer que deveria estar na base ${ }^{121}$ de todos os quereres. Se observarmos que essas vontades desviantes ocorrem sempre, logo percebemos que a atitude Cristã pede uma constante reflexão sobre as vontades, para avaliá-las. A confissão diária, o exame de consciência têm como uma de suas consequências o fortalecimento do eu

\footnotetext{
${ }^{120} \mathrm{O}$ homem que está indo comprar o bilhete aéreo, está buscando realizar o fim específico de comprar o bilhete. Contudo, dentro desse fim, encontramos outras vontades específicas ligadas a essa vontade. Se o homem quer comprar o bilhete, ele deve querer ir à agência de turismo, para isso, deve querer sair de sua casa e deve querer levantar-se da cadeira, deve querer olhar para a estante para saber onde está a chave de casa. Para o próprio querer olhar a estante é, segundo o modo de compreensão de Agostinho, distinto do querer pegar a chave. No fundo, o simples ato de ver a estante está conectado com sua viagem ao Afeganistão, a qual está conectado com o seu querer ser feliz.

${ }^{121}$ Um homem vai viaja para outra cidade em vista de uma conferência científica. Chegando a cidade, sente espontaneamente a vontade de fazer turismo, o que nada mais é do que um desvio de sua vontade de base. Ora, é preciso que o homem avalie essa vontade e a reconheça como uma vontade desviante e, em um segundo momento, decida se cederá ou não.
} 
reflexivo $^{122}$. Pensar em si, avaliar-se a sí, tornar explícito os quereres implícitos fazem parte da moral cristã. Trata-se de uma avaliação proposital de si mesmo e implica em um modo próprio de efetuá-la. Isso porque essa avaliação da vontade, processo que implica em reflexão, pode se dar por outros fatores e ser feita de outro modo. $O$ homem pode refletir espontaneamente sobre suas vontades, como ocorre, por exemplo, com quem está avaliando se tal vontade vale o esforço ou não. Neste caso não avalia o fim da vontade, mas o esforço.

Agostinho, no momento em que diz que todos os quereres devem estar conectados com a vontade última, está exortando algo implícito em todo cristianismo, que é a avaliação do próprio querer espontâneo. Uma avaliação cujo sentido não é pensar no querer para medir o esforço implicado em sua realização, mas pensar se ele é justo ou injusto, se esse querer se coloca de acordo com a vida cristã ou não.

A mente conhece a sua vontade e o seu fim sem que necessite pensá-la, isto é, sem que a avalie em um diálogo interior, bem como a mente tem por si só noção do objeto da vontade ${ }^{123}$. Agostinho, de fato, afirma que a mente tem um conhecimento que acompanha o nascer e o morrer das vontades, e esse conhecimento não necessariamente é refletido diante do olhar da mente $^{124}$.

Portanto, essa vontade que está fora do olhar da mente está presente, pois ela, embora não se coloque na luz do holofote da consciência, está dirigindo o holofote. Eu simplesmente quero fumar, vejo o cigarro, levo minha mão até ele e fumo. Tudo isso foi dirigido pela vontade, mas eu não refleti sobre a própria vontade que me levou até isso. E só consegui fazer isso devido ao fato de que eu compreendo pré-reflexivamente e tenho memória do objeto da vontade.

Mas, quando Agostinho exorta para referir todas as vontades à vontade de base, o quadro se muda. Essa vontade irreflexiva de fumar um cigarro deveria se tornar reflexiva,

\footnotetext{
${ }^{122}$ Voltemos ao exemplo do homem que diz "quero não errar". Quando ele afirma isso, ele diz algo que tem certeza. Em outras palavras, ele coloca seu querer diante do olhar da mente. Contudo, como afirma Agostinho, outra coisa é dizer "sei que não quero errar". O fato, portanto, é que aquele que quer algo sabe de seu querer e no momento em que afirma "quero tal coisa" nada mais faz do pensar no seu querer, um querer o qual não precisou de pensá-lo para sabê-lo. Quando explicitamos para nós mesmos "não quero errar", apenas explicitamos o que já sabemos. Mas uma coisa é pensar o querer, outra é pensar no conhecimento que se tem desse querer. Por que haveria do homem pensar no conhecimento que ele tem de seu querer? Pode parece uma resposta escapista, mas uma das razões é ele fazer filosofia, isto estar questionando aquilo que conhece e desconhece. Aquele que pensa no conhecimento desse querer pode avaliar esse próprio conhecimento e descobrirá que ele é um conhecimento seguro.

${ }^{123}$ E mais uma coisa é pensar no objeto da vontade, outra coisa é pensar na própria vontade. Mesmo quando não é refletida, ela é, ainda assim, conhecida. Se pego um cigarro para fumá-lo, não preciso pensar no ato, não preciso avaliá-lo, simplesmente sei que quero pegar um cigarro para fumá-lo, sem precisar formular um diálogo interior na minha mente.

${ }^{124}$ Mas não é porque não é refletida em uma anunciação interior: "tenho vontade de fumar e vou pegar um cigarro" que não temos uma consciência pré-reflexiva de sua presença. Se enunciássemos para nós mesmos, apenas enunciaríamos interiormente o que já sabíamos.
} 
pois deve ser avaliada. Essa vontade de fumar está ligada à vontade de ser feliz? Se não estiver, devo abandoná-la. Trata-se, com efeito, de um modo próprio de reflexão, pois também existe uma reflexão espontânea. Nesses casos, o homem avalia a vontade não em relação à vontade suprema, mas em relação ao custo: "Será que vale a pena tal vontade?", “Será que vale a pena o esforço?". Quero comprar um bom carro, mas será que vale a pena gastar tanto dinheiro?" Neste último caso, como se pode notar, o homem não avalia sua vontade fundamentado na vontade última, que é a vontade de fazer o bem, mas apenas pelo esforço, pelo custo para realizá-la.

$* * *$

Agora que os conceitos foram precisados mais nitidamente, podemos melhor distinguir qual a diferença entre:

1) amar, compreender e ter memória de algo exterior à própria mente;

2) amar, compreender e ter memória da própria mente.

No primeiro caso, podemos usar o exemplo de um homem que ama carros, tem memória de carros e entende o que um carro é. Nem sempre, no entanto, pensa no fato que os ama, entende e deles tem memória. A primeira distinção é que nesse caso o amor pode deixar de existir: digamos, o homem se entedia de seu hobby. Continuará a ter memória dos carros e compreendê-los, mas não amá-los. Mas pode acontecer uma outra situação: se ele perde a memória de todos os carros que já viu e inclusive do conceito de carro, ele não mais compreenderá o que é um carro e nem terá como amá-los. Isso não pode ocorrer com a mente. Mas a mente não tem como deixar de amar a si mesma, de entender a si mesma, de lembrar-se de si mesma, pois em qualquer um dos casos, ela deixa de ser mente. Como já havíamos observado atrás, encontra-se justamente aí o núcleo essencial da mente. A mente pode se esquecer de tudo aquilo que entrou nela pelos sentidos. Contudo, a mente não pode se esquecer de si.

Com efeito, conhecemos muitas coisas que de certo modo vivem na memória e de certo modo morrem pelo esquecimento. Mas mesmo quando deixam de existir em nossa memória, nós continuamos a viver. E mesmo quando nossa ciência desaparecer com a separação da alma do corpo, continuaremos a viver. (De trinit., XV, 15, 24; 2005, p. 518).

Multa quippe novimus quae per memoriam quodam modo vivunt, ita et oblivione quodam modo moriuntur: atque ideo cum illa iam non sint in notitia nostra, nos tamen sumus; et cum scientia nostra animo lapsa perierit a nobis, nos tamen vivimus. (De trinit., $\mathrm{XV}, 15,24$ ). 
De fato, com a morte do corpo, a ciência do mundo transitório abandonará a mente, mas esta não pode abandonar a si mesma. Se os conhecimentos do transitório podem nascer e morrer na alma, o conhecimento que a mente tem de si jamais cessa de ser. Agostinho percebe que sem uma memória de si, sem inteligência de si e sem querer a si o próprio eu não pode subsistir. Eliminado esse núcleo de atividade circular-reflexivo, a distinção entre "eu" e "nãoeu" torna-se impossível sob qualquer hipótese, pois a consciência de si, seja refletida pelo pensamento ou não, o exige; não há consciência de alteridade sem a consciência de si. $\mathrm{Na}$ vida terrena, a relação é entre o "eu” e um "não-eu”, que é múltiplo. Após a morte, a relação torna-se dual: é entre esse eu e o não-eu, que é o Uno. Mas enquanto o eu está na terra e se relaciona com o múltiplo, subsistem na mente, mais especificamente na memória, conteúdos inessenciais à própria mente. Esses conteúdos provém da multiplicidade das relações entre o eu e a criação. Já o amor de si, a inteligência de si, a lembrança de si estão não apenas imbricados um no outro, como também constituem as próprias condições de possibilidade (e portanto, essenciais) do eu espiritual ${ }^{125}$ e a relação possível e posterior entre o eu e o criador.

$* * *$

Até o momento, o que nossas análises deixam claro é que, para Agostinho, a mente conhece a si mesma sob diversos aspectos. Essas distinções são difíceis, mas necessárias. As intuições de Agostinho parecem mais poderosas do que seu poder de sistematização. Tratemos, portanto, de colocar ordem ao conjunto:

1) Há conhecimento que a mente tem de si referente às suas faculdades, como a capacidade de querer, entender (intelectus) e a memória.

2) Há o conhecimento prereflexivo da mente em seus atos específicos, isto é um conhecimento não exatamente das faculdades da mente, mas de sua atividade, de sua vida interior. Ela sabe o que está pensando, o que está imaginando, o que está se lembrando. Mas também é capaz de conhecer essas atividades não apenas no instante atual, mas também, em certa medida, até onde a memória permite, os pensamentos que teve, as imaginações que teve, as crenças que teve. Por ser uma presença constante a si mesma, a mente conhece as suas vontades específicas em seus fins específicos, cujos objetos relativos são dados pela memória. Há um conhecimento prereflexivo da vida atual do eu. Prereflexivo porque ela os conhece sem que necessite parar para pensá-los, para lembrá-los.

125 É por isso que é nessa trindade da mente que Agostinho procurará a imagem da trindade divina, na qual há uma só essência e três pessoas. Mas a alma não ama apenas a si, ela deve amar o criador, os demais homens e as criaturas, segundo uma hierarquia, a qual quando quebrada advém o mal. 
A mente retem em si mesma os seus próprios atos realizados em sua especificidade. Estes atos retidos formam a história de vida do eu, isto é, a história das próprias experiências. Essas experiências, em sua maior parte, são irrefletidas ou parcialmente refletidas. A diferença entre refletir as experiências e simplesmente vivê-las se dá, para usarmos um exemplo, como alguém que em um primeiro momento é o ator de um filme e, no segundo momento, vê o filme.

3) O conhecimento reflexivo da atividade do eu. Este conhecimento reflexivo acerca da vida do eu sustenta-se sobre o pré-reflexivo ou sobre o parcialmente refletido. Este é de outra espécie, pois nele, o olhar da mente volta-se para as atividades atuais ou passadas da mente. Se eu tenho uma vontade, eu conheço minha vontade sem que tenha necessidade de refletir sobre ela, mas se eu reflito sobre minha vontade, tenho aí um outro conhecimento. Como já havíamos observado, uma coisa é não querer errar, outra coisa é saber que sabemos que não queremos errar. No caso acima, entretanto, o que ocorre é a reflexão sobre a vida irrefletida e atual do eu. E esta deve ser distinguida da reflexão sobre a vida passada do eu.

Um exemplo formidável de reflexão sobre a vida passada do eu é encontrado nos primeiros nove livros das Confissões. Evidentemente, ele já conhecia seu passado antes mesmo de refletir, antes mesmo de pensar sobre ele. Mas, no momento em que o pensa, o conhecimento da vida passada do eu ganha novos contornos. Isso porque há uma distância entre as experiências vividas em determinado momento e o eu que organiza as experiências passadas. Este eu irá organizá-las, narrá-las, interpretá-las, dar um sentido ao conhecimento bruto que tem de si. E esse sentido implícito na organização do passado será feito pelas crenças, valores e conhecimentos atuais do eu. Mas isso não significa que o passado é simplesmente interpretação. As experiências passadas, quando examinadas, oferecem sentidos que estavam nelas próprias, mas que o homem, imerso em vivê-las, não pode apreendê-las.

4) Conhecimento pré-reflexivo da mente enquanto o ser que vive, enquanto puro sujeito, enquanto presença de si para si. Intima scientia est qua nos vivere scimus. Trata-se de um puro conhecer pré-reflexivo de si para si mesmo como um ser que vive, como uma presença de si para si (esse é o núcleo do eu). E esse puro conhecimento que a mente tem de si mesma pode ser conhecido reflexivamente. Uma mente que ama a si, lembra-se de si, compreende a si enquanto um puro eu que vive, independentemente da especificidade de suas vivências, independentemente de tudo aquilo que seja contingente a ela. 


\subsubsection{Distinção intelectual entre o puro sujeito e a vida interior do sujeito}

Dentro dessa perspectiva, a memória de si, a lembrança constante de si e o amor constante de si não dizem respeito ao conteúdo de suas experiências. $\mathrm{O}$ amor que a mente tem de si como puro eu que vive é um amor que só secundariamente depende de sua história de vida. Com a morte, toda ciência humana das coisas transitórias se estinguem, enquanto o amor a si, a inteligência de si, a lembrança de si permanecem. Fica claro que esse conhecimento diz respeito à mente enquanto um puro ser que vive, que se entende e sabe ser o que é. E esse puro conhecimento e amor a si não dizem respeito às experiências de vida. Uma coisa é amar a si mesmo em virtude do que se fez, outra é amar a si mesmo independentemente do que se fez. O problema é que, durante a vida, o amor puro que a mente tem de si encontra-se posicionado com relação ao amor pelo que a mente fez, amor pela história de vida, amor pela vida que tem. Apenas num nível nuclear subsiste esse puro amor que gira no espaço e recai sobre si mesmo. Enquanto vive, todos os estratos do amor, desde esse mais central até o mais periférico, estão formando uma unidade. O espirito está articulado e emaranhado com seus atos e com sua circunstância.

O homem que pensa coisas más, possui vontades sórdidas e vive na mesquinharia não terá como amar a si pelo que sua mente faz, mas, ainda assim, mesmo que de forma muito débil, irá, neste nível nuclear, amar a si mesmo. Mas o núcleo se define pela periferia e por sua ligação ao sentido vertical da existência, ao uno, ao eterno, ao infinito. A periferia apenas reflete Deus, pois é sua criação, mas o próprio criador está acima da mente, internum aeternum. De todo modo, enquanto vivemos essa vida, o amor que o espírito tem por si mesmo é modulado pela boa ou má condução de sua vida atual e pretérita. .

A salvação da mente depende da história das experiências do eu e do modo como o espírito relaciona-se com seu passado que vive em seu coração. Quando se arrepende, o eu estabelece uma postura reflexiva com seu passado. $\mathrm{O}$ aspecto mais profundo do ato de se confessar não é referente ao passado. O passado já passou e não pode ser mudado, mas a relação do homem com o seu passado está no presente e é no presente que ele se arrepende diante da face de Deus. Confessar-se não é arrepender-se de modo genérico do passado, é esmiuçar na tela da consciência o que fez e colocar em plena luz do meio dia aqueles motivos torpes, vividos de modo implícito e irrefletido, motivos esses enterrados dentro de si mesmo, pelos quais resolveu fazer o que fez. Confessar é também dar os justos nomes aos próprios atos, sem eufemismos, sem perfumaria. 
Este ato de nomear o que foi vivido está intimamente associado com o fato de que o ato de confessar-se é sempre dirigido para alguém, seja para Deus, seja para o padre, seja para o leitor, seja até mesmo para o "eu do presente", que em certo sentido é um outro com relação ao "eu do passado". Esse processo exige que os pecados feitos sejam anunciados, para que sejam entendidos pelo receptor. Esse processo implica pensá-los com palavras. A confissão é transformar o conhecimento do passado, que existe na consciência em estado bruto, em narrativa pensada e refletida.

O mal feito, o ato vergonhoso, deve ser lembrado, deve ser descrito com suficiente nitidez e detalhes para que o receptor o compreenda. E esse processo implica uma escolha de termos e conceitos que narrem apropriadamente a experiência vivida, a qual, no momento vivido não era vivida na forma de palavras, era simplesmente vivida em estado bruto. Ao trazê-la à consciência na forma de fala interior ou mesmo fala expressa, o homem sente na boca da mente um amargor semelhante ao de um animal que rumina um alimento amargo. Mas, ao mesmo tempo, sente a doçura do perdão divino.

A história das experiências passadas não pode ser avaliada por fora, mas por dentro. É uma responsabilidade absolutamente pessoal. Força exterior alguma pode coagir a pessoa humana a assumir sua culpa a si mesma e a Deus, que habita no íntimo, é onisciente e julga o homem desde dentro, quer ele assuma sua culpa, quer não.

\subsubsection{Amor e mente}

Havíamos observado que existe uma vida de experiências passadas e atuais da mente e existe a própria mente. Mas ainda falta comentar suficientemente a visão de Agostinho sobre $\mathrm{o}$ assunto. Uma das leis que se pode tirar é que a mente não se manifesta fora de seus atos, o que não significa que ela seja seus atos. Quando se diz que a mente ama a si mesma, o que é que estamos dizendo? Em primeiro lugar que o ser que ama e o ser amado são um só. Contudo, ambos se distinguem do próprio amor. Mas embora distintos, tanto o amado quanto o amante não existiriam se não fosse o amor. Não faz sentido um amor sem um sujeito que ame, sem objeto amado e sem um sujeito que ame. Portanto, amor, amado e amante são termos relativos. A existência de um exige a existência dos demais, assim como não é possível um filho sem que haja o pai. Se é filho, é filho de alguém. O sujeito que ama, o ato de amar, e o objeto do amor formam uma estrutura essencial a qualquer amor, de modo que, retirando um dos componentes, os demais caem por água abaixo. Seguindo essa lógica, tornase claro que no homem corpo e espírito não são termos relativos, pois: 
Retirai do homem o que o constitui, isto é, sua união a um corpo. Tirai pois o corpo, permanecem a alma e o espírito. Retirando, porém o sujeito que ama, não há mais amor. Retirai o amor e não há mais quem ama. Logo, como termos relativos, ele são dois. Mas considerados em si, de modo absoluto, cada um é espírito e os dois juntos são uma só e única mente. (De trinit. IX, 2,$2 ; 2005$, p.289)

Esse modo de raciocinar é válido não apenas no caso do amor, mas se estende a todos os atos do eu: não há pensar sem que haja um sujeito pensante e um objeto pensado, o mesmo ocorre com o caso do imaginar, do perceber etc. ${ }^{126}$. Por isso Agostinho diz que "A mente, quando ama a si mesma, manifesta duas realidades: a própria mente e o amor" (De trinit. IX, 2, 2; 2005, p.288). Portanto, é impossível que o amor se manifeste sem que a mente se manifeste, isto é, o sujeito que ama e o objeto amado ${ }^{127}$.

Certo, amante, amor e amado são termos relativos. Mas até aí não haveria muita inovação. Aristóteles já fala dos termos relativos. Mas o que se destaca em Agostinho é a constatação de que a essência da mente é dada pelos relativos. Os termos relativos são essenciais para a definição da substância da mente. Isso não ocorre, por exemplo, com os relativos em geral. Para Aristóteles o relativo predica a substância, mas nunca é um atributo da substância. $\mathrm{O}$ amado e o amante dizem respeito à relação entre dois seres humanos. Caso o amante deixe de amar o amado, o amado deixa de ser amado, no entanto, continua sendo um homem. A substância do ser amado era "ser humano". Mas não é assim que se passa com a mente. Se retirarmos os atos da mente, a própria mente deixa de ser. A mente não é o amor, mas sem amor, não há mente.

Mas, como observamos, todo objeto amado é também o objeto conhecido e só o conhecemos porque compreendemos o que a coisa é. Daí que o amor tem como sua condição de possibilidade a memória, sem a qual não haveria conhecimento do objeto ${ }^{128}$.

\footnotetext{
126 E por objeto pensado, entenda-se objeto determinado. Mesmo o indeterminado é, em certo sentido determinado, pois o indeterminado vai até onde vai o determinado.

${ }^{127}$ A distinção entre ato e sujeito do ato só se dá intelectualmente, quando se percebe as realidades que estão presentes, isto é, o sujeito que ama, o objeto amado, e o próprio amor. No caso do amor que a mente tem de si, o sujeito que ama e o objeto amado coincidem.

${ }^{128}$ Vontade e conhecimento se relacionam de outro modo. No conhecimento do objeto está contido também a vontade. Aquele que conhece uma vaca, sabe que, se quiser, pode vê-la. Esse saber que pode ver uma vaca, isto é, um saber do tipo "posso ver, se quiser, uma vaca" não é algo inerente à vaca, mas é um conhecimento que o homem tem a respeito da vaca.
} 


\subsection{A ampliação do conceito de cogito}

\subsubsection{Definição ampla do cogito: o olhar da mente informado pela ação da vontade}

No capítulo anterior procuramos notar os vários aspectos envolvidos no conhecimento que a mente tem de si mesma. Um deles provém da reflexão sobre suas próprias experiências e pelas quais apreende a si mesma como o sujeito de suas experiências. Vimos também que a vida de experiências do eu desdobra-se em experiências pretéritas e experiências atuais. E, evidentemente, as experiências atuais são condicionadas pelas experiências passadas. A mente tem uma historicidade: ela é hoje distinta do que foi, não propriamente enquanto sujeito de experiências, mas pelo modo de experienciar o mundo e a si mesma e pelas próprias circunstâncias em que está imersa. $\mathrm{O}$ eu, quando observa suas experiências passadas, irá analisá-las e avaliá-las conforme sua situação atual. Isso, como já observamos, é patente nas Confissões, em que os olhos do bispo de Hipona encontram e analisam dentro de si as experiências do jovem herege que havia sido. $\mathrm{O}$ eu do passado é em certo sentido um outro eu que deu origem a esse eu. Enquanto puro sujeito das vivências, Agostinho sempre foi o mesmo. Mas se tomarmos o eu, enquanto eu atual, com seus próprios modos de experienciar o mundo e a si mesmo, este "eu atual" se distingue do "eu do passado". Ou seja, a maneira pela qual ele experiencia o mundo e a si mesmo atualmente é dista do eu do passdo.

Mas havíamos dito, confessar é um modo peculiar de pensar no passado, em que se organizam, por assim dizer, os dados brutos das experiências vividas sob uma determinada ótica e com determinados propósitos. Havíamos dito que se conhecer a si mesmo é distinto de pensar-se e o pensar gera uma nova espécie de conhecimento de si, um conhecimento reflexivo. Posteriormente, fizemos uma série de investigações e distinções sobre o conhecimento de si. Uma coisa é conhecer-se enquanto puro sujeito, outra é conhecer a vida do eu. A mente conhece a si mesma sem precisar refletir sobre si. Sei o que quero sem precisar refletir sobre a vontade que tenho. E mais, a mente de uma criança que não conhece os termos "mente", "alma", "espírito" e outros correlatos, conhece a si mesma. Não se pensa, mas se conhece.

O problema até o momento é que não ficaram suficientemente claras todas as questões envolvidas e a própria abrangência do cogito. O essencial a respeito já foi dito, o cogito ocorrre quando a vontade coloca diante do olhar da mente um objeto da memória para informá-lo. Mas essa definição deve ser mais detalhada, pois é nela que está a chave para aprofundarmos o significado da reflexão em Agostinho. 
Em certa passagem, Agostinho esclarece melhor o que é o pensamento, ao afirmar que o pensamento (cogitatio), como já insistimos, é uma espécie de visão da alma (visio animi):

Pois o pensamento é uma certa visão da alma - esteja presente o que é percebido pelos próprios olhos corporais ou capte pelos outros sentidos; - já não esteja presente e vejamos suas imagens pelo pensamento; - já nada disso existia, mas o que é pensando não tenha semelhança com o corporal, como, por exemplo, são pensadas as virtudes e vícios, e finalmente, o próprio pensamento; - já sejam as causas e razões últimas de todas as coisas pensadas na natureza imutável; - já, finalmente, pensemos em coisas más, inúteis e falsas, sem o consentimento da vontade, ou devido a um consentimento equivocado. (De trinit., XV, 9,16; 2005, p.502).

Quandoquidem cogitatio visio est animi quaedam, sive adsint ea quae oculis quoque corporalibus videantur, vel ceteris sentiantur sensibus, sive non adsint, et eorum similitudines cogitatione cernantur; sive nihil eorum, sed ea cogitentur quae nec corporalia sunt, nec corporalium similitudines, sicut virtutes et vitia, sicut ipsa denique cogitatio cogitatur; sive illa quae per disciplinas traduntur liberalesque doctrinas; sive istorum omnium causae superiores atque rationes in natura immutabili cogitentur; sive etiam mala et vana, ac falsa cogitemus, vel non consentiente sensu, vel errante consensu. (De trinit., $\mathrm{XV}, 9,16)$.

A passagem é extremamente rica e mostra a abrangência do que Agostinho entende por cogito. A riqueza desta passagem se revela pelos objetos possíveis que o olhar do animus ou o olhar da mente pode ver.

1) Os objetos que estão presentes aos olhos do corpo. Com isso, fica claro que o termo cogito é estendido para abarcar também a percepção. E devemos distinguir entre ter sensações e percepção. Perceber é mais do que ter sensações, é ter o olhar da mente informado pelo objeto presente na percepção, o que exige a atenção do espírito (intentio animis) dirigida ao objeto. Mas pensar não é ter o olhar da mente informado por um conteúdo da memória? Há alguma participação da memória no ato de percepção? Nesta passagem Agostinho não explicita, mas tanto em De musica quanto no livro XI das Confissões Agostinho deixa claro que sem memória não há percepção. Se em um instante percebo um objeto, no instante seguinte a imagem que estava no sentido estará também na memória, de modo que a percepção envolve uma composição entre o que está na memória e o que é dado, no instante, ao sentido. Se assim não fosse não conseguiríamos perceber diferentes durações. Sei que uma sílaba que foi pronunciada agora possui um intervalo de tempo duas vezes maior que a anterior porque retenho na memória a duração da sílaba anterior. Só entendo uma palavra, entendida como sucessão de fonemas, porque as sílabas que sucederam permanecem na minha memória. Quem vê algo com atenção tem o olhar da mente simultaneamente informado pelos 
sentidos e pela memória do que acabou de ver ou ouvir. Por isso eu nunca escuto em um único instante uma palavra composta por mais de um fonema: a cada instante eu escuto um fonema e os "componho internamente" de modo que "escuto" palavras e frases. Do mesmo modo, sem memória não poderia escutar uma música.

2) O olhar do espírito pode ser informado pelas imagens dos objetos corporais que estão ausentes, isto é, as imagens dos objetos que estão na memória. Neste sentido, imaginar também é cogitar, pois quem imagina tem o olhar do espírito informado pelo objeto imaginado.

3) Pode ver coisas que não são corpóreas e que não são imagens de nada, como os vícios, as virtudes, a fé ou os conhecimentos das artes liberais e os conhecimentos científicos, que os outros nos transmitem. Neste caso, o olhar da mente mostra um outro aspecto, que é o fato de coincidir, no homem, com o olhar da inteligência. $\mathrm{O}$ olhar do espírito pode ver o visível, mas também o mundo incorporal e espiritual. Pode observar-se inclusive a si mesmo só porque tem inteligência. É por ter inteligência que o homem pode pensar-se, isto é, ver-se a si mesmo.

4) Mas também pode ver um outro gênero de coisas invisíveis, superiores às mencionadas: a regras eternas. Ver as causas superiores de todas as coisas na natureza imutável $^{129}$.

5) Pode até mesmo pensar em coisas más, inúteis e falsas.

Não parece haver muitas dúvidas de que, fazendo um levantamento sobre os objetos possíveis de lhe informar, o cogito mostra-se bastante amplo. Trazendo para os nossos tempos, o cogito é muito semelhante ao "ter consciência de algo." Entretanto, algo ainda parece faltar. Isso se dá porque pensar, embora exija ter um olhar da mente informado, não parece se limitar a isso, pois é também articular, associar e ligar e coordenar o que está na memória. Mas isso já foi parcialmente resolvido, quando Agostinho diz que a corrente de cogitationes ocorre pelo fato de que a vontade informa a mente com determinado conteúdo, para em seguida retirá-lo e informá-lo com outro conteúdo, dando, assim, a sequência de pensamentos. Todavia, há ainda um segundo aspecto, envolvido no pensar. O homem conversa interiormente consigo mesmo. Quem o faz, está pensando. O pensamento também assume a forma de uma fala interior. E é justamente com esse conceito de fala interior que

129 "Sed nunc de is loquamur quae nota cogitamus, et habemus in notitia etiam si non cogitemus, sive ad contemplativam scientiam pertineant, quam proprie sapientiam, sive ad activam, quam proprie scientiam nuncupandam esse disserui. Simul enim utrumque mentis est unius, et imago Dei una. Cum vero de inferiore distinctius et seorsum agitur, tunc non est vocanda imago Dei, quamvis et tunc in ea nonnulla reperiatur similitudo illius Trinitatis". (De trinit., XV, 10,17). 
ficará claro o que é a mentira. Como seria possível pensar intencionalmente em algo mentiroso se o pensar se resumisse a trazer à luz da consciência algo que está na memória? É preciso, portanto, ir além e investigar a relação entre ter o olhar da mente informado e a fala interior.

\subsubsection{O pensamento e linguagem: locutiones cordis esse cogitationes}

Observarmos até aqui que uma coisa é a mente pensar em si outra é ela conhecer-se a si. Ela pode conhecer-se sem se pensar, sem se refletir com o pensamento, sem colocar seus próprios atos ou a si mesma sob seu próprio olhar. Refletir é ter o olhar da mente informado pela própria vida mental, como se a mente desse um passo para trás e observasse a si própria. Mas algo deve ser notado. Uma coisa é simplesmente trazer à consciência as experiências passadas e observá-las, outra coisa é trabalhar esse material, avaliá-lo e organizá-lo. A pura auto-observação, para Agostinho, entra na categoria do pensar-se, pois pensar é ter o olhar da mente informado por um dado. Mas o pensar em si não consiste apenas em observar-se, em ver-se interiormente, seja a vida atual, seja a vida pretérita. Pensar-se se estende também a se julgar, se analisar, se avaliar, travar consigo mesmo um diálogo interior, um diálogo que tem como matéria-prima o conteúdo, ainda mudo, das experiências interiores observadas. Trabalhar essas experiências mudas e dar a elas uma voz, dar-lhes os nomes e uma narrativa aproriada é também um modo de pensar-se. Isso coloca em evidência um outro aspecto do pensamento, entendido como fala interior. Conhecer-se é falar para si mesmo verdadeiramente a respeito de si mesmo.

Estes últimos aspectos serão um dos temas desenvolvidos por Agostinho no livro XV da Trindade. Neles, o bispo de Hipona entra em mais detalhes na descrição do fenômeno, incluindo aí, como componente essencial do pensamento, a fala interior. Nam etsi verba non sonent, in corde suo dicit utique qui cogitat. E ele encontrará na própria Bíblia fragmentos que elucidam esse aspecto da cogitatio. Agostinho aponta que no Livro da sabedoria vem explicitada a noção de que quem pensa é porque fala interiormente em seu coração:

Pois aquele que pensa, embora não soem as palavras, ele as diz e seu coração. Daí as palavras do livro da Sabedoria: Disseram (os ímpios) em seu interior, pensando distorcidamente (Sb 2, 1). E o autor declarou o que seja: "disserem em seu interior" ao acrescentar "pensando". (De trinit. XV, 10, $17 ; 2005$, p.503)

Nam etsi verba non sonent, in corde suo dicit utique qui cogitat. Unde illud est in libro Sapientiae: Dixerunt apud se cogitantes non recte. Exposuit enim quid sit: Dixerunt apud se, cum addidit, cogitantes. (De trinit. XV, 10, 17) 
Agostinho declara que nos Evangelhos, há algo semelhante:

Há algo parecido no Evangelho, quando os escribas ouviram o que o Senhor dissera ao paralítico: Tem ânimo, meu filho, os teus pecados te são perdoados, eles diziam consigo mesmo: Está blasfemando. E o que vem a significar: diziam consigo mesmo, senão: diziam pensando? E continua a passagem: Mas Jesus, conhecendo os seus pensamentos, disse: Por que tendes esses maus pensamentos em vossos corações. (Mt 9, 2-4) (De trinit., $\mathrm{XV}, 10,17 ; 2005$, p.503)

Huic simile est in Evangelio, quod quidam Scribae cum audissent a Domino dictum paralytico: Confide, fili, remittuntur tibi peccata tua; dixerunt intra se, Hic blasphemat. Quid est enim, dixerunt intra se, nisi cogitando? Denique sequitur: Et cum vidisset Iesus cogitationes eorum, dixit: Utquid cogitatis mala in cordibus vestris? (De trinit. XV, 10, 17).

Agostinho, não contente em demonstrar essa equivalência no texto de Mateus, procura a mesma passagem no texto de Lucas.

Lucas narra o mesmo episódio: Os escribas e fariseus começaram a raciocinar (cogitare dicentes: n.d.r): Quem é este que diz blasfêmia? Não é só Deus que pode perdoar os pecados? Jesus, porém, percebeu os seus raciocínios e respondeu-lhes: Porque raciocinais em vossos corações? Nas duas passagens declara-se que dizer em seu interior e em seu coração é o mesmo que dizer em seu pensamento. (Lc, 5, 21-22) . (De trinit. XV, 10, 17; 2005, p.504).

Lucas autem hoc idem ita narrat: Coeperunt cogitare Scribae et Pharisaei, dicentes: Quis est hic qui loquitur blasphemias? Quis potest dimittere peccata, nisi solus Deus? Ut cognovit autem cogitationes eorum Iesus, respondens dixit ad illos: Quid cogitatis in cordibus vestris? (Lc, 5, 21-22) (De trinit. XV, 10, 17).

Ao comparar a passagem no Evangelho de Mateus e no de Lucas, Agostinho conclui: "Nas duas passagens declara-se que dizer em seu coração é o mesmo que dizer em seu pensamento" (De trinit., XV, 10, 17; 2005, p.504) ${ }^{130}$. Por meio deste e de outros exemplos, Agostinho começa a desenvolver a ideia do pensamento entendido como uma "fala interior" ou uma "fala do coração", chegando assim à definição: locutiones cordis esse cogitationes.

Portanto, alguns ${ }^{131}$ pensamentos são palavras do coração, no qual existe uma boca, no dizer do senhor: Não é o que entra pela boca que torna o homem impuro; mas o que sai da boca procede do coração e é isso que torna o homem impuro. Uma só sentença abrangeu as duas espécies de bocas de boca do homem, a do corpo e a outra, do coração. (De trinit., XV, 10, 18; 2005, p.504).

\footnotetext{
130 "Quale est in libro Sapientiae: Dixerunt cogitantes; tale hic est: Cogitaverunt dicentes". (De trinit. XV, 10, 17);

131 A tradução incorreta. Nada justifica ser traduzido por alguns pensamentos. Mais correto seria "os pensamentos".
} 
Quaedam ergo cogitationes locutiones sunt cordis, ubi et os esse Dominus ostendit, cum ait: Non quod intrat in os coinquinat hominem; sed quod procedit ex ore, hoc coinquinat hominem. Una sententia duo quaedam hominis ora complexus est, unum corporis, alterum cordis. (De trinit., $\mathrm{XV}$, $10,18)$.

Os pensamentos são palavras que saem da boca do coração. A impureza do homem não está no que entra pela boca exterior, mas no que sai da boca interior, que é a fonte de onde saem as palavras da boca do corpo.

Mas se o pensamento é uma fala interior, como é possível que o pensamento também seja uma visão interior (animi visio), tal como Agostinho sustentava anteriormente? O que acontece, diz Agostinho, é que uma coisa não exclui a outra.

Contudo, pelo fato de termos asseverado que os pensamentos são palavras do coração não queremos dizer que eles não sejam também visões originadas pelo olhar do conhecimento implícito, quando verdadeiro. Assim, também, audição e a visão são duas realidades separadas entre si, nos nossos sentidos corporais. Na alma, porém, não é uma coisa ver e outra ouvir. (De trinit., $\mathrm{XV}, 10,18 ; 2005$, p.505) ${ }^{132}$.

Nec tamen quia dicimus locutiones cordis esse cogitationes, ideo non sunt etiam visiones exortae de notitiae visionibus, quando verae sunt. Foris enim cum per corpus haec fiunt, aliud est locutio, aliud visio: intus autem cum cogitamus, utrumque unum est. (De trinit., XV, 10, 18).

A articulação destes dois aspectos do cogito, como fala interior e como visão interior, provém do conteúdo da memória (notitia). Visio e locutio formam uma unidade em virtude da origem comum de ambas. E fica marcada aqui a distinção entre o gerado e aquilo que gera. $\mathrm{O}$ pensamento, tanto em seu aspecto de visão interior, quanto em seu aspecto de fala interior, é gerado e não se confunde com a fonte geradora, isto é, o próprio conteúdo da memória, a notitia, a partir do qual é gerado. Na visão exterior de um objeto, isso é fácil de constatar. A visão de um objeto não é a própria coisa exterior vista, mas é gerada a partir desta, assim como a visão da notitia ou o verbo interior não são a própria notitia. Assim, ele distingue o verbo e a imagem sonora:

Logo, todo aquele que puder perceber a palavra (verbum), antes de ser pronunciada, e mesmo antes de se formar pelo pensamento a imagem de seus sons, (palavra esta que não pertence a nenhuma das línguas chamadas dos povos, entre os quais o latim, todo aquele, digo eu, que puder conhecê-la, poderá também ver através desse espelho e nesse enigma, alguma semelhança daquele Verbo, do qual está escrito: No princípio era o Verbo e o Verbo estava com Deus, e o Verbo era Deus (Jo 1,1). (De trinit., XV, 10, $18 ; 2005$, p.505)

\footnotetext{
${ }^{132}$ A tradução da Paulus do trecho supracitado é incapaz de transmitir o sentido do original, conforme a explicação abaixo.
} 
Quisquis igitur potest intellegere verbum, non solum antequam sonet, verum etiam antequam sonorum eius imagines cogitatione volvantur: hoc enim est quod ad nullam pertinet linguam, earum scilicet quae linguae appellantur gentium, quarum nostra latina est: quisquis, inquam, hoc intellegere potest, iam potest videre per hoc speculum atque in hoc aenigmate aliquam Verbi illius similitudinem, de quo dictum est: In principio erat Verbum, et Verbum erat apud Deum, et Deus erat Verbum (De trinit., XV, 10, 18)

O que merece destaque é a ideia de Agostinho de um "verbo puro", independente do idioma. O idioma apenas servirá como uma espécie de roupagem deste verbo puro, revestindo-o com uma "imagem sonora". E por esse motivo cada idioma terá as suas próprias roupagens, mas o verbo puro não tem idioma. Não importa se a palavra de Deus é dita em latim ou grego, desde que o verbo, que não tem pátria, seja transmitido. E a inteligência pode apreender que este verbo interior é anterior não apenas ao som emitido que lhe corresponde, mas também ao aparecimento de sua imagem sonora na mente. Aquele que fala nada mais faz do que dar um corpo a esta entidade inteligível que é o verbo puro, para que este possa ser transmitido e comunicado, posto que o homem não consegue apreender telepaticamente o que o outro está pensando.

O pensamento informado pelo que sabemos é o verbo pronunciado no coração. Verbo que não é palavra grega, nem latina ou de qualquer idioma. Entretanto, como é preciso fazer ao conhecimento daqueles com que falamos, assumimos algum sinal que o signifique. (De trinit., XV, 10, 19; 2005, p. 505).

Formata quippe cogitatio ab ea re quam scimus, verbum est quod in corde dicimus: quod nec graecum est, nec latinum, nec linguae alicuius alterius; sed cum id opus est in eorum quibus loquimur perferre notitiam, aliquod signum quo significetur assumitur. (De trinit., XV, 10, 19).

Mas esses signos devem ser entendidos em sentido amplo, abrangendo, além dos idiomas, todo e qualquer sinal capaz de indicar o conteúdo inteligível. Um surdo de nascença, com efeito, não tem a imagem sonora das palavras. No entanto, é capaz de se comunicar usando outros signos, como os gestos. Do mesmo modo, se uma pessoa está muito distante de outra, elas podem se comunicar usando como signo sinal de fumaça. O que caracteriza o signo é o fato de que ele é uma realidade sensível que indica algo inteligível ou sensível ${ }^{133}$. O signo é:

Muitas vezes é um som. Outras vezes, um gesto. Aquele som dirige-se ao ouvido e este gesto aos olhos. Assim o verbo de nossa mente será conhecido por meio de sinais sensíveis corporais. E o que é acenar, senão dizer de algum modo, de maneira sensível? (...) Para haver possibilidade de nos

133 "Sed haec atque huiusmodi corporalia sive auribus sive oculis praesentibus quibus loquimur exhibemus: inventae sunt autem litterae, per quas possemus et cum absentibus colloqui: sed ista signa sunt vocum, cum ipsae voces in sermone nostro earum quas cogitamus signa sint rerum. (De trinit.,, XV, 10, 19). 
comunicarmos mesmo com ausentes, inventaram-se as letras escritas. São elas sinais que representam as vozes; tal como as palavras, em nossa comunicação oral, são sinais do que pensamos. (De trinit., XV, 10, 19; 2005, p. 506).

Et plerumque sonus, aliquando etiam nutus, ille auribus, ille oculis exhibetur, ut per signa corporalia etiam corporis sensibus verbum quod mente gerimus innotescat. (...) inventae sunt autem litterae, per quas possemus et cum absentibus colloqui: sed ista signa sunt vocum, cum ipsae voces in sermone nostro earum quas cogitamus signa sint rerum (De trinit, $\mathrm{XV}, 10,19)$.

A palavra exteriorizada é veículo sensível que porta a palavra interior, para que haja comunicação entre os espíritos. Eis aí mais um outro modo como vemos Deus em espelho e enigma $^{134}$. Da mesma forma como o verbo interior se manifesta exteriormente para se fazer percebido pelos sentidos, assim o Verbo se fez carne para se fazer conhecido pelos homens.

Assim, nossa palavra torna-se voz do corpo ao assumir essa voz para se revelar aos homens de modo sensível - tal como o Verbo de Deus se fez carne, assumindo-a para se manifestar aos sentidos dos homens, de modo sensível. E tal como nosso verbo torna-se voz, sem se transformar em voz, assim o Verbo de Deus fez-se carne. Longe de nós, porém, de pensarmos que ele transformou-se em carne. (De trinit., XV, 11, 20; 2005, p.507).

Ita enim verbum nostrum vox quodam modo corporis fit, assumendo eam in qua manifestetur sensibus hominum; sicut Verbum Dei caro factum est, assumendo eam in qua et ipsum manifestaretur sensibus hominum. Et sicut verbum nostrum fit vox, nec mutatur in vocem; ita Verbum Dei caro quidem factum est, sed absit ut mutaretur in carnem. (De trinit., XV, 11, 20).

\footnotetext{
134 "Perveniendum est ergo ad illud verbum hominis, ad verbum rationalis animantis, ad verbum non de Deo natae, sed a Deo factae imaginis Dei, quod neque prolativum est in sono, neque cogitativum in similitudine soni, quod alicuius linguae esse necesse sit, sed quod omnia quibus significatur signa praecedit, et gignitur de scientia quae manet in animo, quando eadem scientia intus dicitur, sicuti est”. (De trinit., XV, 11, 20).

“É pois necessário chegarmos a esse verbo do homem, a esse verbo do ser dotado de alma racional, a esse verbo da imagem de Deus - não da Imagem nascida de Deus, mas a imagem criada por Deus. Esse verbo que não é pronunciado por meio de sons, nem pensado à maneira de um som, o qual está necessariamente implicado em toda linguagem, mas que, anterior a todos os signos nos quais se traduz, nasce de um saber imanente à alma, quando esse saber se exprime numa palavra interior." (De trinit., XV, 11, 20; 2005, p.507).
} 


\subsubsection{O verbo verdadeiro provém da realidade}

É dentro desta matriz conceitual que Agostinho irá procurar e desenvolver a concepção de verdade e falsidade, honestidade e mentira. A expressão é verdadeira quando ela tem sua origem no verbo verdadeiro. E o conhecimento só é verdadeiro quando é gerado por uma percepção sensível ou por uma visão intelectual.

Nem sempre é possível que tenhamos a experiência sensível e por isso confiamos no testemunho dos que tiveram a experiência sensível. Creio que meu pai é meu pai porque confio no testemunho de minha mãe. Os testemunhos podem apoiar-se apenas em uma experiência sensível distante, chegando de terceira, quarta mão. Por exemplo, leio numa apostila que houve um incêndio em Roma em 18 de julho do ano 64 d.C. O escritor da apostila leu isso em um livro de História, cujo autor leu e confiou no autor de outro livro, que confiou no relato de um outro autor. No final, é preciso encontrar os primeiros autores que descreveram o incêndio e saber se algum deles o viu pessoalmente ou tenha escutado de uma pessoa ou de um grupo de pessoas que o presenciaram. No momento em que digo que houve um incêndio em Roma em tal data, isso é verdadeiro se a minha fala provém das próprias coisas, dos próprios fatos, da própria realidade. Se o que digo hoje, quase dois milênios depois, provém do próprio fato ocorrido dois milênios atrás, por uma corrente de testemunhos que terminam com os sujeitos que viram e presenciaram o incêndio, o que digo é verdadeiro.

Mas quando a realidade não é uma realidade sensível, mas uma realidade inteligível, o quadro se torna distinto. Pois, para me assegurar que um teorema matemático é verdadeiro não preciso confiar no testemunho de ninguém, basta que eu mesmo veja, com os olhos da minha inteligência, na luz da verdade, que o que foi dito é verdadeiro. A opinião de uma multidão de homens não abala a convicção de quem vê a verdade dentro de si.

O dizer verdadeiro ocorre quando o verbo, anterior a qualquer som e a todo projeto de som, se origina das próprias realidades conhecidas e possui uma relação de semelhança com estas:

Tal verbo é totalmente semelhante a coisa conhecida, da qual nasce a imagem, pois a visão do que penso é gerada pela visão do que sei. Esse verbo não pertence a nenhum idioma, é um verbo verdadeiro provindo de uma realidade verdadeira, nada tem de próprio, mas nasce inteiramente do conhecimento do qual se origina. (De trinit., XV, 12, 22a; 2005, p.512).

Tunc enim est verbum simillimum rei notae, de qua gignitur et imago eius, quoniam de visione scientiae visio cogitationis exoritur, quod est verbum linguae nullius; verbum verum de re vera, nihil de suo habens, sed totum de illa scientia de qua nascitur. (De trinit., XV, 12, 22a). 
Assim, a verdade do verbo está no fato de que ele é gerado pela realidade: dum tamen verbum sit verum, id est, de notis rebus exortum. (De trinit., XV, 12, 22a). O fato de que o verbo é gerado pelo conhecimento leva Agostinho a fazer uma importante distinção do conhecimento humano com relação ao conhecimento de Deus. Muitos dos conhecimentos humanos, incluindo todos os conhecimentos sensíveis, surgem na mente do homem de forma datada e o homem pode esquecê-lo. Já em Deus, isso não ocorre, pois a ordem se inverte: não é Deus que conhece o ser, mas as coisas são porque Deus já as conhecia antes de criá-las. Em Deus, a sabedoria é sua essência. No homem a sabedoria é uma propriedade, uma posse que ele adquiriu e que pode perder. A sabedoria de Deus é imutável, nada lhe acontece de novo. Deus sabe desde toda a eternidade tudo o que acontecerá no futuro, tudo o que vamos pedir em nossas orações, bem como os pedidos que ouvirá ou não. Em Deus, uma coisa não é o ser e outra o saber; saber e ser são uma única e mesma coisa. Longe est igitur huic scientiae scientia nostra dissimilis. Quae autem scientia Dei est, ipsa et sapientia; et quae sapientia, ipsa essentia sive substantia. (De trinit., XV, 12, 22b).

A verdade do discurso não é definida como uma adequação entre o pensamento e a realidade, mas quando o pensamento origina-se do real. Entretanto, muitas vezes os homens dizem aquilo que não sabem direito como se fosse verdadeiro, emitindo opiniões infundadas, sem se dar conta de que não sabem a respeito do assunto. Outros estão conscientes do limite de seus próprios conhecimentos. Estes, assumindo não saberem se o que dizem provém ou não da realidade, em alguns casos expressam sua dúvida a respeito do assunto, ou assumem juízos não como verdadeiros, mas apenas como prováveis. Em que sentido alguém que expressa uma dúvida está expressando uma verdade?

As questões levantadas não alteram o fato de que a fala verdadeira provém da realidade; o que importa é observar que, por realidade, pode-se pensar tanto uma realidade interior quanto uma realidade exterior. Um homem diz, sem o saber, que existem cisnes negros. Se ele disse isso sem saber, o seu verbo, isto é, o verbo gerado em seu interior, é mentiroso, ainda que haja uma correspondência entre o que foi dito e a realidade. Por outro lado, pode acontecer de alguém ter um falso conhecimento, como aconteceria com alguém que desse crédito a um testemunho falso e o tomasse como verdadeiro. Nesse caso, o verbo também não é verdadeiro, pois o verbo não provém da realidade conhecida. Por outro lado, se dissermos que temos dúvida a respeito da existência de cisnes negros, o verbo aí é verdadeiro. Cum autem dubitamus, nondum est verbum de re de qua dubitamus, sed de ipsa dubitatione 
verbum est. ${ }^{135}$ A verdade deste verbo não provém da realidade da qual duvidamos, mas provém da realidade interior da dúvida.

Como já observamos, aquele que possui dúvida e se encontra no estado de dúvida não pode duvidar de sua dúvida. Tem certeza que tem dúvida. Havíamos observado que Agostinho já havia dito que não podemos estar enganados sobre uma vontade que temos, nem sobre o fato de estarmos vivos; um terceiro ponto que conhecemos com certeza é de que temos dúvida sobre isso ou aquilo.

Um outro tipo de verbo que pode ser expresso provém da mentira intencional. $\mathrm{O}$ verbo da mentira nasce da má intenção do indivíduo, que conscientemente quer enganar. Todavia, quem mente conscientemente tem, dentro de si, a verdade. Poderia não exprimi-la, poderia expressar a sua dúvida, mas não o faz, preferindo enganar por algum motivo torpe. Sem a consciência de sua intenção e da verdade que omite, não saberia que está mentindo ${ }^{136}$.

Agora, o que pensar do fato de que podemos mentir? Quando o fazemos voluntariamente e de modo consciente, nosso verbo é falso. Há aí um verbo verdadeiro que está em que mentimos e sabemos. E quando confessamos ter mentido, dizemos a verdade, pois dizemos algo que sabemos, ou seja, que mentimos. (De trinit., XV, 15, 24; 2005, p.517).

Quid, quod etiam mentiri possumus? Quod cum facimus, utique volentes et scientes falsum verbum habemus: ubi verum verbum est mentiri nos; hoc enim scimus. Et cum mentitos nos esse confitemur, verum dicimus: quod scimus enim dicimus. Scimus namque nos esse mentitos. (De trinit., $\mathrm{XV}$, $15,24)$.

\footnotetext{
135“Numquid verbum nostrum de sola scientia nostra nascitur? Nonne multa dicimus etiam quae nescimus? Nec dubitantes ea dicimus, sed vera esse arbitrantes: quae forte si vera sunt, in ipsis rebus de quibus loquimur, non in verbo nostro vera sunt; quia verbum verum non est, nisi quod de re quae scitur, gignitur. Falsum est ergo isto modo verbum nostrum, non cum mentimur, sed cum fallimur. Cum autem dubitamus, nondum est verbum de re de qua dubitamus, sed de ipsa dubitatione verbum est. Quamvis enim non noverimus an verum sit unde dubitamus, tamen dubitare nos novimus: ac per hoc cum hoc dicimus, verum verbum est; quoniam quod novimus dicimus." (De trinit., $\mathrm{XV}, 15,24)$.

${ }^{136}$ Por exemplo, afirmo para outra pessoa que Maria está na escola sem eu saiba. É possível que Maria esteja na escola, e caso esteja, o que disse correspondeu aos fatos. Mas ainda aqui eu menti, pois minha realidade interior era a da dúvida e eu afirmei algo de que tinha dúvida como se fosse verdadeiro
} 


\subsection{A vontade}

\subsubsection{A experiência de Paulo}

Paulo, em carta aos Romanos, procurou descrever suas experiências interiores relativas ao conflito entre a carne e o espírito.

Sabemos, de fato, que a lei é espiritual, mas eu sou carnal, vendido ao pecado. Não entendo, absolutamente, o que faço, pois não faço o que quero; faço o que aborreço.

$\mathrm{E}$, se faço o que não quero, reconheço que a lei é boa. Mas, então, não sou eu que o faço, mas o pecado que em mim habita. Eu sei que em mim, isto é, na minha carne, não habita o bem, porque o querer o bem está em mim, mas não sou capaz de efetuá-lo. Não faço o bem que quereria, mas o mal que não quero. Ora, se faço o que não quero, já não sou eu que faço, mas sim o pecado que em mim habita. Encontro, pois, em mim esta lei: quando quero fazer o bem, o que se me depara é o mal.

Deleito-me na lei de Deus, no íntimo do meu ser. Sinto, porém, nos meus membros outra lei, que luta contra a lei do meu espírito e me prende à lei do pecado, que está nos meus membros. Homem infeliz que sou! Quem me livrará deste corpo que me acarreta a morte?...

Graças sejam dadas a Deus por Jesus Cristo, nosso Senhor! Assim, pois, de um lado, pelo meu espírito, sou submisso à lei de Deus; de outro lado, por minha carne, sou escravo da lei do pecado. (Rm, 7.14-25)

Vemos nitidamente que Paulo não apresenta o conflito entre carne e espírito de um ponto de vista puramente teórico, mas observa e analisa sua própria experiência a respeito do conflito das duas vontades. O apóstolo faz notar que a reflexão não porta à plena luz o refletido. A vida interior não se revela facilmente, parece sempre esconder algo; seus contornos são difíceis de serem apreendidos. Daí sua afirmação: "não entendo o que faço". Com efeito: como é possível "querer o bem" e, ainda assim, não efetuá-lo? Que monstruosa impotência é essa?

Descrever a experiência interior não parece uma tarefa trivial. Exige que as experiências, ainda mudas, encontrem seus nomes e sejam fixadas em conceitos. E sem conceitos e palavras, não podem se tornar inteligíveis nem ao próprio sujeito da reflexão, nem mesmo ao próprio leitor. Para piorar, os sentidos pré-reflexivos parecem arredios aos nomes. A linguagem cotidiana, com suas ambiguidades, parece fixar apenas em parte o que está ali, enquanto a outra escapa, como quem tenta agarrar o ar com as mãos para the dar forma e consistência. Há ainda uma outra dificuldade na narrativa em primeira pessoa das experiências interiores: ao colocá-las sob a mira do pensamento investigativo, a fim de descrevê-las, o próprio eu deve encontrar seu lugar frente a elas, articular-se e traçar a distância com relação às suas próprias experiências. Podemos dizer que o eu descrito por Paulo identifica-se com duas camadas ou estratos do homem: a carne, com suas leis, e o 
espírito, com suas próprias leis. Mas qual o grau de identificação? Existe um grau de identificação?

Um fator central e complexo embutido na descrição de uma experiência interior é que todos os elementos interiores se dão em referência ao eu. De fato, uma coisa é dizer "O homem é composto de carne e espírito, cada qual possui a sua lei”, outra coisa, muito distinta e bem mais complexa, é descrever a própria experiência interior, porque, ao descrevê-la, o "eu" não pode se limitar a uma apresentação teórica do que é, mas deve ver e discernir dentro de si, em sua concretude, as experiências ligadas à carne, bem como as ligadas ao espírito. Deve compreender em que sentido ele se encontra naquilo que se oferece ao olhar interior, distinguindo o modo como está referido à carne e ao espírito. Paulo não diz simplesmente que a carne é contrária ao espírito, mas afirma: "Sinto, porém, nos meus membros outra lei, que luta contra a lei do meu espírito". E dessa ferrenha luta, nem sempre o espírito sai vitorioso.

A constatação de sua impotência espiritual de fazer o bem que quer não permanece em uma atmosfera abstrata, mas faz vibrar e estremecer os seus sentimentos. A reflexão escancara a si mesmo sua impotência. E o conhecimento da impotência deve ser assumido, como quem, com espanto e terror, vê sua face no espelho. O homem deve assumir a existência de uma carne cujas leis, em muitos momentos, sobrepujam as leis do espírito. Mas assumir isso é aceitar que somos pecadores, e assumir que somos pecadores é aceitar que não somos Deus. Por outro lado, por não sermos Deus, pecamos, e pecando, colocamos em jogo a salvação, ou a condenação eterna de nosso espírito. E tudo isso tem o sabor de um doce e amargo peso de ser humano: "Homem infeliz que sou! Quem me livrará deste corpo que me acarreta a morte?..."

A experiência interior mostra-se escorregadia e parece escapar dos conceitos. Colocando-se como elemento coordenador de toda descrição, o eu, quando bem investigado, parece guardar dentro de si uma multiplicidade de sentidos e um certo estilo de ser tão diverso do resto do mundo, que, quando começamos a descrevê-lo, logo nos damos conta que a linguagem cotidiana parece não ter sido construída para lidar com um ser tão sutil.

Se analisarmos bem, encontramos na passagem de Paulo o seguinte quadro. Em certos momentos, há uma identificação entre o "eu" e o "espírito", quando, por exemplo, ele diz: "eu quero apenas o bem”. A incapacidade de realizá-lo parece que se dá a fatores exteriores ao eu-espírito, tasi como "a lei dos membros" ou "a carne". É devido a esses fatores que o "euespírito" faz o que não quer. Com efeito, quando Paulo afirma "faço o que não quero", "faço o que aborreço" ele está se referindo e se identificando ao seu espírito e a sua vontade 
espiritual. É a vontade espiritual que não quer fazer o que ele acaba fazendo; é o espírito que se aborrece pelo fato de ele acabar fazendo o que não queria fazer.

Ele sente no espírito leis distintas da lei da carne. Ele quer fazer o bem, mas é incapaz de realizá-lo. Mas seria correto concluir daí que essa misteriosa carne é exterior ao eu? Se tomássemos isoladamente como base de todas as conclusões a sentença "já não sou eu que faço, mas sim o pecado que em mim habita", a impressão que fica é que sim. No entanto, como conciliar essa passagem com aquela afirmação explícita e aberta: "eu sou carnal”? A relação entre o "eu" e a "carne", assim como a relação entre o "eu" e o "espírito", é descrita em alguns momentos na ordem do ser, outras na ordem do ter. "Tenho em meus membros uma outra lei”.

\subsubsection{A experiência paulina de Agostinho: Sic intellegebam me ipso experimento id quod legeram}

No livro VIII das Confissões, Agostinho afirma explicitamente ter experimentado em si a mesma experiência do Apóstolo: a luta entre a lei dos membros e a lei do corpo. "Portanto, eu compreendia por experiência própria o que havia lido: que a carne tem vontades contrárias ao espírito, e o espírito tem vontades contrárias à carne". (Conf., VIII, 5, 11; 2006, p.215).

Se quiséssemos resumir em uma única linha toda interpretação de Agostinho da passagem de Paulo, ela se encontra no acréscimo de uma única palavra: ao "faço o que não quero" do apóstolo, Agostinho emenda "faço querendo aquilo que não quero". “(...) volens quo nollem perveneram”. Observamos, em Paulo, que nem toda vontade espiritual leva o homem a praticá-la, mesmo que esteja materialmente ao alcance sua realização. Existe um entrave interno, originado das leis dos membros, que leva o homem a fazer não só o que quer, mas também a realizar o que "não quer". Agostinho concorda inteiramente com isso. O único aspecto observado por Agostinho é que toda ação consciente provém da vontade. Quando o homem faz o que não quer, ele faz o que não quer sob a ótica da vontade espiritual. Mas, do ponto de vista da vontade carnal, ele faz sim o que quer. Em outras palavras, toda ação consciente provém do eu volitivo.

Semelhantes discussões podem parecer, a uma primeira vista, um detalhismo irrelevante. Mas, se examinarmos a vida de Agostinho, selecionando as experiências que repercutiram mais profundamente em seu espírito, e tomarmos ciência de seu contexto cultural, fica claro que cada palavra foi escolhida com penetrante rigor, que cada sentença foi 
cuidadosamente elaborada, para não dar margem ao equívoco. A experiência de ser maniqueu, a sutileza da heresia de Pelágio exigiam uma aguda precisão nos conceitos.

Um dos aspectos culturais a ser sublinhado é que a contradição exposta por Paulo entre a lei da carne e as do espírito também estava presente no maniqueísmo ${ }^{137}$. A própria experiência de Agostinho nos tempos de maniqueísmo havia lhe ensinado que, se esta distinção não fosse cuidadosamente articulada, ela poderia resultar em uma má interpretação de si, cujo resultado seria uma identificação exclusiva do "eu" apenas com o espírito, tomado como essencialmente bom. Em virtude dessa identificação, o eu retiraria de suas costas o peso do pecado, atribuído ao corpo. $\mathrm{O}$ "eu" espiritual em sua guerra eterna com o corpo, quando derrotado em uma batalha, não pode responder moralmente pela ação de seu inimigo.

Por outro lado, enquanto Agostinho escreve as Confissões, parte de suas preocupações se concentram nas ideias teológicas de um monge inglês, Pelágio (350-423) $)^{138}$, para quem a noção da "carne ser mais forte" não passava de uma desculpa esfarrapada. As ideias deste monge a respeito do livre arbítrio e sua relação com a graça pareciam conformar-se totalmente com as escrituras. O homem deve responsabilizar-se pelo mal. Todavia, se a vontade não é livre, como pode o homem se responsabilizar sobre o mal? A resposta de Pelágio era categórica: "a vontade é livre", ela não está condicionada a nada, apenas ao espírito. A doutrina de Pelágio se disseminava como o fogo na palha, chegando até mesmo a dividir os altos escalões da Igreja. Agostinho sabia que sua polêmica com o monge era perigosa e delicada, pois tocava um dos pontos mais complexos da doutrina cristã. Segundo Gilson:

Reduzida a seus elementos essenciais, e tal como santo Agostinho a compreendeu, a doutrina de Pelágio define o pecado como sendo apenas um mal uso do livre-arbítrio; não diminuem nem sua liberdade nem sua bondade

\footnotetext{
${ }^{137}$ A ideia de que a lei da carne são contrárias às leis do espírito provém de tradições muito antigas. Sabe-se que os órficos desenvolveram a ascese espiritual por meio de técnicas de purificação e que, Platão, herdeiro da tradição,, deu-lhe uma poderosa forma filosófica, que chegou à Agostinho pelo Neo-Platonismo. Contudo, essa mesma distinção entre a carne e espírito havia chegado para Agostinho antes mesmo que ele conhecesse o Neoplatonismo, sobre um outro formato, cuja raiz não se encontrava na tradição órfica, mas no Zoroastrismo dos indo-europeus da região da Persia, em sua versão maniqueísta. Por outro Agostinho sabia que também os estóicos faziam essa distinção, e como se não bastasse, Agostinho conhecia ao menos os rudimentos da noção da alma como forma do corpo de Aristóteles. É lógico que movendo-se dentro deste complexo campo de referências, qualquer escorregada podia ser fatal.

138 Pelágio foi o fundador de uma doutrina posteriormente considerada herética, que ficou conhecido como "pelagianismo". As três teses principais do monge inglês que foram condenadas são: 1) Negação da graça para a salvação. Um homem plenamente virtuoso como Sócrates, poderia ser salvo. 2) A ideia de que não há o pecado original. 3) Superestimar o poder do livre arbítrio. Suas ideias foram duramente combatidas por Agostinho. Dentre outras questões, para Agostinho era impossível que o homem, mesmo os santos, fossem isentos de pecado. E o poder da graça é redimir o homem dos pecados passados e fortalecer a vontade para que esta se deixasse motivar pelo bem. Após várias controvérsias, Pelágio foi condenado no Sínodo de Cartago no ano de 418 da era cristã.
} 
natural, nem consequentente, seu poder de fazer o bem. Se é assim, o socorro da graça não tem que se aplicar à vontade, que não estando corrompida, não tem essa necessidade; ele se reduz, consequentemente, ao perdão da ofensa feita a Deus pela realização do ato mau. (2007, p.299)

A graça, segundo Pelágio, não atua na vontade, mas no perdão dos pecados, os quais o homem comete voluntariamente. Para ele, mesmo um pagão pode levar uma vida irrepreensível moralmente, pois a vontade é livre, seja para pagãos, seja para cristãos. Mesmo quando guiada pelos princípios clássicos da virtude, a vontade tem o poder de suprimir tudo aquilo que se encontra em seu caminho. Portanto, ainda segundo Pelágio, não há uma impotência natural da vontade: está ao alcance do homem se determinar a fazer algo e levar seu querer até o fim. Não poderia ser de outra forma, argumenta Pelágio: se existisse algo capaz de escravizar a vontade, isso significaria simplesmente que ela não é livre. E se ela não é livre, o homem não pode ser responsabilizado pelos seus pecados, pois não estaria ao alcance de suas forças resisti-lo e, consequentemente, estaria condenado a cometê-lo.

Segundo Gilson (2007), o que levou Agostinho a contrapor-se à doutrina de Pelágio não se limita a discordâncias de ordem hermenêutica. A raiz mais profunda da controvérsia com o monge inglês reside no fato de que a doutrina deste último contrapunha a uma experiência profundamente vivida por Agostinho. A história de sua conversão o refutava.

Tendo em vista o pelagianismo de um lado e o maniqueísmo do outro, Agostinho sabia que a discussão da vontade exigia refinadíssimas articulações. As relações entre a vontade e a carne, o espírito e o eu, formavam um terreno minado e cada passo deveria ser delicadamente executado.

Todavia, para complexificar ainda mais a questão, dentro do panorama cultural de Agostinho, não havia apenas a doutrina de Pelágio e a doutrina Maniqueísta a se combater. Agostinho refuta também a visão "clássica" a respeito da vontade, definida como apetite racional em oposição ao apetite sensível. Se levarmos em consideração tudo isso, não é motivo de espanto que os termos empregados por Agostinho sejam profundamente pensados já nas Confissões e serão ainda mais aprofundados na Trindade, como veremos. Segundo Gilson (2007), os próprios termos de Agostinho se modificam, antes e depois de ele tomar conhecimento da doutrina pelagiana. 


\subsubsection{A interpretação Agostiniana da passagem de Paulo}

Qual é a experiência pessoal que, na história de vida de Agostinho, negava o Pelagianismo? Encontramo-la no livro VIII das Confissões. Já nas primeiras páginas deste livro, Agostinho já está convencido acerca da verdade da doutrina Cristã. Sob influência de Ambrósio, o grande bispo de Milão, da leitura de Plotino, e de outras fontes, os olhos de seu intelecto haviam se aberto para o espírito imutável e um novo tipo de amor penetrava seu coração. Mas o fato é que mesmo com o intelecto convertido ao cristianismo e mesmo tendo vontade de seguir a doutrina, ainda assim Agostinho mostrava-se relutante à adesão total.

Para que haja a verdadeira conversão cristã, não basta vislumbrar Deus com o intelecto e amá-lo; é necessário mudar a própria vida, e para mudá-la é necessário auxílio divino. A vida conforme o Catolicismo exige uma mudança de hábitos. No caso de Agostinho, dos hábitos sexuais. Parecia-lhe, com efeito, insuportável levar a vida nas grades da continência sexual, sem o perfume e os abraços de uma mulher, sem os aplausos do auditório, sem o conforto do luxo. Todavia, em virtude de nascente fé no Deus Cristão, começava-lhe a operar a transformação. Despontava no íntimo de seu "eu" uma nova vontade, que lhe ordenava o abandono da concupiscência. Mas essa vontade não era forte o suficiente para fazê-lo mudar de vida. A vontade carnal, fortalecida pelo hábito, lhe acorrentava aos prazeres sensuais. Assim, na honestidade de si consigo mesmo, via-se incapaz de abdicar de seus hábitos e, mesmo querendo seguir a vida cristã, acabava cedendo ao mal, como um marujo incapaz de resistir ao canto das sereias, ou como alguém que, após se jogar de um arranha-céu, resolve, no meio da queda, mudar de ideia. De todo modo, o que Agostinho viveu foi uma experiência dilacerante, a vivência de acreditar em Deus, amá-lo, querer fazer o bem e, ainda assim, sofrer profundamente em virtude de sua incapacidade de resistir ao mal. Compara-se a si mesmo a alguém que quer acordar de um sono profundo, mas nota que é incapaz de mover os membros.

Nada tinha para te responder quando me dizias: Levanta-te, tu que dormes, e ergue-te de entre os mortos, e Cristo te iluminará, e a ti, que mostravas de todos os lados que dizias a verdade, não havia absolutamente nada que eu te pudesse responder, convencido da verdade, a não ser apenas umas palavras arrastadas e sonolentas: "Já vou, vou já, só mais um bocadinho". Mas o “já vou" não tinham fim, e só mais um bocadinho prolongava-se em muito. Em vão me deleitava na tua Lei, segundo o homem interior, uma vez que outra lei lutava nos meus membros contra a lei do meu espírito e me levava cativo na lei do pecado, que estava nos meus membros. (Conf. VIII, 5, 12; 2004, p.343)

non enim erat quod tibi responderem dicenti mihi: Surge qui dormis, et exsurge a mortuis, et inluminabit te Christus; et undique ostendenti vera te 
dicere, non erat omnino, quid responderem veritate convictus, nisi tantum verba lenta et somnolenta: modo, ecce modo sine paululum. sed modo et modo non habebat modum et sine paululum in longum ibat. frustra condelectabatur legi tuae secundum interiorem hominem, cum alia lex in membris meis repugnaret legi mentis meae, et captivum me duceret in lege peccati, quae in membris meis erat. (Conf. VIII, 5, 12; 2004, p.342)

Como podemos observar, Agostinho já estava convencido da verdade, e mais, era capaz de se deleitar na lei de Deus, segundo o "homem interior". Mas a força da vontade corrompida, fortalecida pelo hábito, era tamanha que ele não tinha "forças espirituais" para abandoná-las. Como ele nos conta, seu quadro se agrava após ouvir da boca de Simpliciano a narrativa da conversão de Vitorino, um grande orador romano, que viveu nos tempos de Juliano, imperador que proibiu os Cristãos de ensinarem literatura e retórica. Em virtude do decreto, Vitorino, forte na fé, abdicou, sem demora, daquele ofício mundano pelo qual se tornara célebre. Incendiado pela vontade de imitá-lo, seu quadro se agravava, pois quanto maior fosse a vontade espiritual, maior o conflito e maior o sofrimento de ver a vontade carnal prevalecer.

Em suma, Agostinho conhecia a lei espiritual, deleitava-se com ela segundo o homem interior, queria segui-la, mas era incapaz de seguir o exemplo de Vitorino, devido aos seus próprios grilhões: "Por tal circunstância suspirava eu, acorrentado, não por ferro alheio, mas pela minha vontade de ferro. $\mathrm{O}$ inimigo dominava o meu querer, e dele para mim fizera uma cadeia, e amarrava-me com ela" (Conf. VIII, 5, 10; 2004, p.339) ${ }^{139}$. Que cadeia era essa? E qual era a origem dessa vontade férrea? A resposta dele é: "Porque da vontade pervertida nasce o desejo, e quando se obedece, nasce o hábito, e, quando se não resiste ao hábito, nasce a necessidade" (Conf. VIII, 5, 10; 2004, p.339) ${ }^{140}$. E ainda: "Com estes como que pequenos elos ligados entre si - daí eu chamar-lhe "cadeia" - mantinha-me preso a dura servidão". (Conf., VIII, 5, 10; 2004, p.339) ${ }^{141}$.

Escravidão sim, pois sua vontade de seguir Deus era uma vontade nova que despontava, sem que fosse suficiente para vencer a vontade antiga, já que esta havia sido fortalecida pelo tempo. Não basta uma simples resolução para que o homem aja conforme o cristianismo. Afinal, a realização da vontade envolve a mudança de todo viver humano, com hábitos

\footnotetext{
139 “cui rei ego suspirabam, ligatus non ferro alieno, sed mea ferrea voluntate. velle meum tenebat inimicus; et inde mihi catenam fecerat et constrinxerat me". (Conf. VIII, 5, 10; 2004, p.338)

140 "quippe voluntate perversa facta est libido, et dum servitur libidini, facta est consuetudo, et dum consuetudini non resistur, facta est necessitas". (Conf. VIII, 5, 10; 2004, p.338)

141 "quibus quasi ansulis sibimet innexis -- unde catenam appellavi -- tenebat me obstrictum dura servitus". (Conf. VIII, 5, 10; 2004, p.338)
} 
arraigados e vontades férreas. É, de fato, após escutar a narrativa de Vitorino que Agostinho afirma ter vivido a mesma experiência do apóstolo Paulo:

Assim, compreendia, por experiência própria, aquilo que lera - de que modo a carne tem desejos contra o espírito e o espírito contra a carne - e eu, na verdade, estava em ambos, mas estava mais naquilo que em mim aprovava do que naquilo que em mim desaprovava. Pois já aí havia mais de não eu, porque, em grande parte, mais o sofria, contra a vontade, do que o fazia, querendo. Mas todavia o hábito, de dentro de mim mesmo, tornara-se mais obstinado contra mim, porque, querendo, eu tinha chegado aonde não queria. (Conf., VIII, 5, 11; 2004, p.341)

Sic intellegebam me ipso experimento id quod legeram, quomodo caro concupisceret adversus spiritum et spiritus adversus carnem, ego quidem in utroque, sed magis ego in eo, quod in me approbabam, quam in eo, quod in me improbabam. Ibi enim magis iam non ego, quia ex magna parte id patiebar invitus quam faciebam volens. Sed tamen consuetudo adversus me pugnacior ex me facta erat, quoniam volens quo nollem perveneram. (Conf., VIII, 5, 11. Negritos são nossos)

Nesta passagem podemos entrever todas as articulações centrais que revelam a teoria agostiniana da vontade. Agostinho faz questão de esclarecer que, embora a carne se oponha ao espírito, o "eu” está em ambos, se bem que, em dosagens e em modos diferentes. De fato, o eu está mais presente na vontade que ele aprovava do que na que desaprovava, "magis ego in eo, quod in me approbabam". A diferença entre ambas é que uma conta com o juízo de aprovação e a outra não. Mas tal constatação suscita uma questão: quem é esse eu que aprova a vontade nova e rejeita a antiga e sob que critérios a aprova?

Em primeiro lugar, é preciso observar que esse "eu quero" não agir conforme a concupiscência está em consonância com o "eu que julga", isto é, com o eu capaz de julgar. O eu que é capaz de julgar está correlacionado com o eu que pensa. De fato, pensar é ter algo diante do olhar do espírito. $\mathrm{O}$ е и que julga tem na mira de sua mente não apenas o objeto da vontade, mas também a própria vontade carnal, que surge espontaneamente e sempre está direcionada para algo. O "eu", movido por aspirações espirituais, põe-se em alerta ao nascer das vontades, colocando-as sob julgamento. Esse eu que julga suas vontades, aprovando-as ou desaprovando-as, é, essencialmente, um eu dotado do poder da reflexão. É o eu reflexivo que pode colocar sua vida espontânea sob julgamento, objetificando com o olhar de sua mente, sua atividade interior. Já observamos que o eu reflexivo circunscreve as faculdades e as atividades daquilo que poderíamos denominar "eu-mente". É exclusiva da mente a capacidade de observar e conhecer e julgar as realidades inteligíveis, dentre as quais a própria vontade. Os animais apenas seguem seus apetites, o homem, por seu turno, por ser dotado de mente, pode conhecer suas vontades, analisá-las e julgá-las. 
Como já analisamos na Trindade, o eu é composto por estratos: o homem exterior e o homem interior. Este último é a mente do homem enquanto o homem vive essa vida. No homem interior há duas funções: razão superior e razão inferior. $\mathrm{O}$ eu, enquanto vive na Terra, é tudo isso. A mente é parte superior desse eu em suas atividades e estados superiores, isto é, em sua razão superior. E é o que perdurará após a morte, quando o homem verá, com a inteligência, Deus face a face.

$\mathrm{O}$ "eu” é, como um todo, um homem, de tal modo que pode dizer sem se enganar: "eu sou carnal". Por outro lado, o eu é, acima de tudo, sua própria mente, seja em sua função da razão inferior, quanto em sua função da razão superior, sempre presente a si mesma em virtude de suas atividades e de seu poder reflexivo vinculado com a inteligência, memória e vontade. Trata-se daquilo que poderíamos chamar de "eu central", pois é o "eu-mente" que define a essência do "eu" do homem.

O eu vive em diversos níveis. Quando sentimos uma dor de dente, quem sente é o eu. Contudo, o sentir uma dor de dente não diz respeito às atividades superiores da mente. De fato, o homem pode, enquanto sente uma dor de dente, estar pensando em Deus, o que significa ter Deus diante do olhar da mente, ou ter a atenção dirigida para Deus. Mas, se a dor de dente for muito forte, ela roubará, de tempos em tempos, senão a todo instante, a atenção da mente. Os níveis inferiores do eu se relacionam com os níveis superiores do eu. De fato, se a dor de dentes for insuportável, o homem mal conseguirá se concentrar para aprender novos conhecimentos. É o que mostra Agostinho, em uma interessante passagem dos Solilóquios, na qual se lamenta pelo fato de que, em virtude de sua dor de dente, ele não consegue aprender nada de novo:

Tenho muito medo da dor não por outra razão senão porque me impede a investigação. Nesses dias tenho sido atormentado por uma fortíssima dor de dentes, que não me permitia pensar senão nas coisas que já havia aprendido, mas me impedia completamente de aprender novas coisas, pois para isso é necessária toda atenção. (Solil; I, 12, 21; 1998, p.42)

Et ipsum non ob aliud vehementer formido, nisi quia me impedit a quaerendo. Quamquam enim acerrimo his diebus dentium dolore torquerer, non quidem sinebar animo volvere, nisi ea quae iam forte didiceram; a discendo autem penitus impediebar, ad quod mihi tota intentione animi opus erat: tamen mihi videbatur, si se ille mentibus meis veritatis fulgor aperiret, aut me non sensurum fuisse illum dolorem, aut certe pro nihilo toleraturum. (Solil; I, 12, 21)

Ora, a dor de dente rouba a atenção, coloca-se diante do olhar da mente. Portanto, devido à intensidade da dor que o eu sente, o eu volta seu pensamento para ela. Por que o eu volta seu pensamento para ela? Porque é o eu pensante e racional que pode deliberar sobre os 
meios de extingui-la. As funções racionais da mente entrarão em ação, com o intuito de extinguir um mal corporal. Temos aí a mente ocupando-se, com sua racionalidade, na resolução deste mal corporal. É a razão inferior, ou razão prática, fazendo seu serviço.

O que convém observar é que quem sente a dor é o animus, que é composto por anima $e$ mens. Portanto, tudo aquilo que pertence à mente também pertence ao animus. A atenção, o pensar, o avaliar, o julgar e o referir a existência ao que há de mais elevado são atributos e propriedades do animus. O animus vê, dentro de si, o grito da carne, enquanto sua atenção sempre está prestes a escapulir para o exterior e se projetar inocentemente no mundo. Esquecido de si mesmo, o homem passa a viver uma vida disforme e sem estrutura: um agir sem aquilo que Agostinho denomina ordo amoris. A desestruturação do amor é a desestruturação da vida, é a perda do sentido vertical do espírito e a decadência para o horizontal, para o que há de mais rasteiro, para o que há de mais transitório, para aquilo que, tão logo nasce, já míngua e se evapora.

Tudo aquilo que pertence à mens, enquanto a mens está ligada a um corpo, é, por definição, do animus. Por isso, Agostinho não raro usa de modo intercambiável a expressão aciem animi e aciem mentis, outras vezes usa intentio mentis, outras intentio animi. Por outro lado, nem tudo que é do animus diz respeito exclusivamente à mens, como se nota pela ausência de expressões como affectione mentis. O que ele usa é affectione animi. O animus possui afecções, com as quais deve negociar.

O homem, ao ver sua imagem no espelho exterior, vê uma figura colorida em um espaço. Olha para dentro de si, vê os pensamentos, vê os números e as grandes racionalidades, mas também sente, no plano de fundo, escorrendo como lava o sangue nas veias. $\mathrm{O}$ que convém observar é que enquanto vivemos essa vida, ninguém é uma pura mens enfiada na carne. $\mathrm{O}$ eu é um animus dotado de carne, com a qual alimenta uma relação de amor, que pode ser, em diferentes medidas, desordenada. O bom animus sabe ceder, mas sabe impor os limites e a frequência da relação. Sabe quando contemplar a beleza suprema da criação e sabe quando construir, quando plantar, sentido o prazer carnal na medida da hierarquia ontológica. Esse é o papel que Deus confiou ao varão, à razão superior: mandar e ceder com limites. Mas ceder não é ceder ao mal, pois a carne não é má, é boa, é força vital, pulsante, todavia cega, sempre querendo extrapolar os limites, pular de cabeça no prazer, viver inconsequentemente o imediato, dissolver-se na dança dionisíaca. É preciso o espírito para que a vida se torne reta e adquira estrutura, estruturando o amor, amando cada ser em sua justa medida.

O homem em sua globalidade é anima, animus e corpo, homem exterior e homem interior. Mas o homem, em sua vida terrena, é tudo isso, englobando essas realidades todas. 


\subsubsection{O homem interior, o homem exterior e a vontade}

Para entender o que é a vontade em Agostinho, essas distinções são necessárias. Quando Agostinho, nas Confissões, procura descrever a experiência que teve da oposição entre carne e espírito, ele compreende implicitamente aquela experiência dentro dessa estratificação do eu. Já observamos que Agostinho diz que experienciava duas vontades lutando entre si e aprovava uma delas, enquanto a outra desaprovava. Aquela faculdade que aprova ou desaprova pertence à mente. $\mathrm{Na}$ Trindade, ele será mais específico: essa faculdade que aprova e desaprova é razão superior, pois é ela que possui a inteligência das regras eternas. O conflito entre as duas vontades, narrado no livro VIII das Confissões, tem início justamente quando Agostinho, inteirado do verdadeiro sentido vertical da vida, se convence, com os olhos da inteligência, a respeito da verdade da fé cristã, processo esse narrado com precisão no livro VII das Confissões. Mas essa transformação intelectual encontra seus limites: mesmo com seu "eu" estando mais na vontade espiritual e mesmo aprovando-a, Agostinho sente em si mesmo a terrível impotência narrada por Paulo, incapaz de vencer a vontade que o arrastava aos prazeres carnais, condenado a trair-se a si mesmo pelo homem exterior, deixando-se escravizar pela sedução irresistível da cupiditas. Cupidita ou libido, aliás, são os termos preferidos por Agostinho para referir a esse poder carnal que, nos fracos de espírito, põe seu jugo sobre a vontade, arrastando-a para a realização dos bens carnais. Essa vontade carnal, vontade decaída, não se confunde com a libido ou a cupiditas ou ainda apetite sensível pertencentes ao homem exterior. A voluntas, decaída ou não, promana da mente, do homem interior. Mas haveria outras diferenças? É conveniente buscarmos na Trindade os detalhes apenas implícitos ou pouco trabalhados nas Confissões. O que no livro VIII das Confissões pode suscitar dúvidas, o livro XII da Trindade pode respondê-las.

O apetite sensível pertence ao homem exterior e é simbolizado, como já mencionamos nesta tese, pela serpente, cujo destino é seduzir a razão inferior, simbolizada por Eva. O apetite sensível é vizinho da razão inferior, já que ambos negociam com o que há de transitório. “Ora, o apetite sensível é vizinho da razão que se aplica à ciência, visto que é sobre os próprios objetos temporais percebidos pelos sentidos do corpo que a ciência - dita ciência da ação - raciocina. Esse conhecimento é reto quando refere seu conhecimento ao sumo bem." (De trinit. XII, 12, 17; 2005, p.383)

Quando o olhar da mente lança seus raios sobre o mundo, o que entra em cena são as funções da mente ligadas às atividades práticas e, imbricadas com elas, os apetites. Daí o risco da razão inferior escorregar e deixar-se seduzir pelo apetite, colocando-se docilmente ao 
serviço deste. No exemplo supracitado, em que a dor de dentes furtivamente atrai a atenção do espírito, o que ocorre é apenas um exemplo de uma estrutura geral: o apetite sensível tenta constantemente roubar a atenção para si, de modo a colocar a mente a seu serviço, prometendo prazeres. Uma vez que os olhos da mente sejam seduzidos e a função pensante se volte para o objeto apetecível, contemplando-o e degustando-o interiormente pela imaginação, a execução do pecado está na metade do caminho. Resta apenas apenas saber se a razão inferior irá obter sucesso em tentar a razão superior e se esta cederá, tal qual Adão cedeu às sugestões de Eva.

Observando a vida do homem dentro desta estratificação, o significado do pecado ganha novas luzes, caso a seguinte questão seja respondida: “O que, no homem, comanda o corpo, o que dá movimento aos membros?"

Em determinada passagem da Trindade Agostinho diz que o homem domina o corpo apenas parcialmente: "Tudo o que o orgulho pretende fazer, levado pelo seu próprio interesse, é contra as leis que governam o mundo, e é feito por meio do corpo, ao qual o homem domina apenas parcialmente." (De trinit. XII, 9, 14; 2005, p.379). A afirmação pode parecer estranha, mas bem examinada fica clara. Basta observar que o corpo também é dominado pelas leis da gravidade e que possui movimentos involuntários, o pulsar o do coração, ora compassado, ora violento, o roncar do estômago etc. Chega até mesmo ser desnecessário que alguém diga: "eu controlo o corpo parcialmente" 142 . É esse "eu" que, dentro do possível, ordena seus membros para que façam isso ou aquilo. É uma realidade espiritual, é a própria mente, mais especificamente, é a intentio mentis. É ela que tem o sumo poder de mover os membros.

Com efeito, pode-se dar o pecado, não apenas quando se pensa em algo mau, com agrado, mas também quando se determina na mente a realizá-lo - e isso tão somente se realiza quando a inteção da mente que tem o poder de mover os membros corporais à ação ou de impedi-lo, venha ceder e sujeitar-se à ação pecaminosa. (De trinit. XII, 12,17; 2005, p.383).

Neque enim potest peccatum non solum cogitandum suauiter uerum etiam efficaciter perpetrandum mente decerni nisi et illa mentis intentio penes quam summa potestas est membra in opus mouendi uel ab opere cohibendi malae actioni cedat et seruiat. (De trinit. XII, 12,17).

Sublinha-se que Agostinho, nesta passagem, não se refere ao corpo, mas aos membros. Deve ser descartada a ideia de que os membros são movidos pelo homem exterior, pelos

\footnotetext{
${ }^{142}$ Fica claro que, em tal afirmação, o "eu” não vem equiparado ao corpo. O corpo é meu. Contudo, poderíamos dizer, "eu não controlo a mim mesmo". Neste caso, estamos identificando esse mim mesmo com eu-homem, assim como dizemos "eu sou alto". De todo modo, o que é certo é que há um eu posto como um "eu" que controla o "mim mesmo" como o que é controlado. Colocando o problema seja de um jeito seja de outro, o ponto é que existe um eu que controla e algo relativo ao eu que não é totalmente controlado.
} 
apetites, ou pela cupiditas. É sempre a voluntas ou, mais especificamente, a intentio mentis que move os membros. Daí resulta que não há ação pecaminosa sem que haja participação da mente e da racionalidade. A distinção clássica entre apetite sensível e apetite racional, ambos digladiando entre si pelo controle do corpo, torna-se inadequada. Quando o homem faz uma ação pecaminosa, quem faz, em última instância, é a mente, o homem interior.

Quando o homem pensa, imagina, calcula uma ação, ele assim o faz com sua mente racional em sua função prática. Mas desse processo também participa a razão superior, embora ao seu modo, como juiz que faz valer a lei divina, como o imperador que só tem que prestar contas a Deus. A razão superior pode tomar medidas em relação ao projeto de ação pecaminoso, coibindo-o, moderando-o. Mas a razão superior também pode ser conivente, não se importando com a imaginação do ato mau que está sendo concebido na mente. Esta conivência pode advir de um monstruoso orgulho, pelo qual a criatura, num gesto de loucura, quer igualar-se a Deus e se deleita com o mal que sabe realizar. Ao fazê-lo, sente os pruridos de uma liberdade demoníaca de infringir as leis divinas e eternas. Mas, existe ainda uma outra possibilidade, trágica ao seu modo, em que a razão superior simplesmente não tem forças para conter a razão inferior ${ }^{143}$. O mais trágico desta última situação é que, quando o homem faz o que não quer, ele também faz o que quer.

A lei da contradição não se aplica à vontade. Duas vontades opostas convivem numa única e mesma mente ${ }^{144}$. O eu animus, dotado de anima e mens, sente as duas vontades, pensa a respeito das duas. $\mathrm{O}$ resultado final é um eu despedaçado.

Mas, quando a vontade cede ao apetite sensível, seria correto dizer que o inferior sobrepujou o superior? Mas como o inferior pode dominar o superior, se o homem não pode mandar em Deus? Não seria uma monstruosidade considerar que o homem exterior, a quem pertence o apetite sensível, possa mandar no homem interior, a quem pertence a voluntas? A questão aqui é que o homem interior pode, por um livre ato da vontade, se rebaixar ao homem exterior, invertendo a hierarquia estabelecida por Deus. Isso não significa que o homem exterior o escravizou, o que ocorre é que o homem interior deixa-se escravizar pelo homem exterior. Poderia, se quisesse, manter-se longe do jugo. Mas não o faz, sua vontade é corrompida. Entrega-se de bom grado a cupiditas, e quando cai em si e tenta fugir, toma

\footnotetext{
${ }^{143}$ Portanto, a ação pecaminosa não é o resultado da mente perder temporariamente as rédeas do corpo, de modo que o apetite sensível do homem exterior passe a conduzi-lo.

144 E mais, a lei da soma dos vetores também não se aplica, como se apenas a vontade mais forte prevalecesse havendo uma única resultante. É certo, O homem, de fato, irá agir de acordo com a vontade mais forte, mas isso não significa que ele apenas tenha a experiência da resultante.
} 
consciência que já está acorrentado pelas duras correntes do hábito ${ }^{145}$. O homem poderia não ter caído no posso, mas, uma vez ali dentro, só lhe resta rezar para ser resgatado pela ação da graça.

\subsubsection{Razão e vontade}

O conflito humano mais profundo em Agostinho não é aquele entre razão e apetite sensível. Toda ação humana que envolve o pensamento e deliberação é efeito da vontade da mente. A razão não necessariamente entra em conflito direto com o apetite, pois ambos podem ser comparsas no mal. Mesmo quando o homem faz o mal, ele não deixa nem de ser racional, nem de empregar sua razão para fazê-lo. A razão torna-se mero instrumento da vontade pervertida, servil ao homem exterior. Mas, com a vontade decaída ainda viva, pode surgir, ao lado desta, uma vontade de elevação, de contemplar, com consciência limpa, o eterno. Mas ainda que essa vontade espiritual se esforce por erguer o homem dos pântanos, sozinha, ela está condenada ao fracasso. Esse é o conflito mais profundo: duas vontades, ambas em guerra, ambas dilacerando a mente, a imaginação, o raciocínio, a atenção. Mas esse conflito das vontades não implica um conflito entre razão e emoção, ou entre razão e apetite sensível, ou mesmo entre apetite racional e apetite sensível, ou entre razão inferior e libido.

Se um homem se exime, ainda que sentindo desejo, de beber em excesso, a fim de que possa ter tempo de trabalhar e conseguir dinheiro, ele nada mais foi do que racional. É possível que algum conflito tenha existido aí. Mas o conflito da vontade é um conflito de amor; é preciso amar Deus e a Verdade com mais intensidade do que se ama o transitório. E nem sempre é fácil, em todas as circunstâncias, amar Deus e os seres em sua justa medida.

\footnotetext{
${ }^{145}$ Contudo, ao aplicar desordenadamente sua vontade ao mundo, esta vontade corrompida se fortalece. O homem, por assim dizer, cria a sua própria mansão de prazeres carnais e entra dentro dela. Mas, depois de determinado tempo, se ele descobre o bem supremo, por mais convencido que esteja, ele não descobre que não é capaz de abandoná-la. Contudo, enquanto ele não descobre o bem supremo, ele não se dá conta que estava preso. A consciência da prisão advém com a consciência da liberdade. Mas, ao dar-se conta que ele trancou-se a si mesmo, sem que percebesse e que a verdadeira vida está lá fora, o desespero começa a vir, ele se lança contra as grades. Descobre, de fato, que o futuro daqueles que se encontram dentro das grades é a morte, e fora dela a vida eterna.
} 


\subsubsection{O risco da experiência Maniqueia e o conflito entre as vontades}

O conflito mais profundo do homem e mais essencial ocorre entre duas vontades pertencentes à mente. Não se trata de um conflito entre corpo e alma. Agostinho insiste neste aspecto porque sabe, por experiência própria, que entender o conflito entre duas vontades como uma guerra entre corpo e espírito é dar razão ao Maniqueísmo. É provável que Agostinho tenha observado que a descrição que Paulo faz de sua experiência interior dava abertura para um falso entendimento da vontade e do eu, acarretando uma interpretação maniqueia. Paulo afirma: "faço o mal que não quero". E de onde vem o mal? "Ora, se faço o que não quero, já não sou eu que faço, mas sim o pecado que em mim habita". E onde habita o pecado? Nos membros. Afinal, ele sente nos membros uma lei distinta da lei do espírito. Teríamos aí uma sugestão para entender o conflito estrutural do ser humano como sendo entre corpo e espírito. Corpo e espírito existem e dizem respeito ao homem, mas deve-se ter claro o que é do corpo e o que é do espírito.

O problema é que o modo como vem compreendida ou mal compreendida a interrelação entre os estratos humanos reflete diretamente na questão da responsabilidade. Agostinho sabia que o eu possui uma certa inclinação natural para tirar de suas costas o peso da responsabilidade, depositando a culpa em algo exterior a si: no corpo tomado como coisa exterior, nos astros, nos deuses e demônios, e no próprio Deus. Segundo o maniqueísmo, o espírito é uma fagulha divina, uma parcela de Deus.

Eles, querendo ser luz, não no Senhor, mas em si mesmos, julgando que a natureza da alma é aquilo que Deus é, deste modo se tornam trevas mais densas, porque se afastaram para mais longe de ti, com abominável arrogância, de ti, verdadeira luz, que ilumina todo o homem que vem a este mundo. (Conf. VIII, 10, 22; 2004, p.359) ${ }^{146}$

A consequência direta desse modo de entender-se é que o eu, identificado apenas com o espírito, crê que só pode querer o bem. O corpo, por seu turno, é um pedaço do Mal. Daí resulta o ponto mais grave: como alguém que se julga uma parcela de Deus, um ser perfeitamente bom, pode tomar para si o peso dos atos vis? Como o espírito em sua pureza imaculada poderia se responsabilizar por algo o qual ele não controla? Para eles, a "vontade carnal" não diz respeito ao espírito, ela brota diretamente do corpo, como um inimigo que invade o eu. As técnicas de purificação maniqueístas são feitas com o objetivo de extrair de si impurezas alheias, como se o mal fosse "algo outro", como bactérias incrustradas no espírito.

\footnotetext{
146، Illi enim dum volunt esse lux non domino, sed in se ipsis, putando animae naturam hoc esse, quod deus est, ita facti sunt densiores tenebrae". (Conf. VIII, 10, 22)
} 
O corpo é um "outro". Por isso, os Maniqueus chegam ao cúmulo de afirmar que existem duas mentes dentro de um mesmo homem, uma má e outra boa.

Pereçam diante de ti, ó Deus, como realmente perecem, os que dizem palavras vãs e os sedutores da mente, os quais, como consideram duas vontades no acto de deliberar, afirmam que há duas naturezas próprias de duas mentes: uma boa e uma má.

(Conf. VIII, 10, 22; 2004, p.357).

Pereant a facie tua, deus, sicuti pereunt, vaniloqui et mentis seductores, qui cum duas voluntates in deliberando animadverterint, duas naturas duarum mentium esse asseverant, unam bonam, alteram malam. (Conf. VIII, 10, 22; 2004, p.357)

A fim de eliminar semelhante modo de se interpretar o homem, Agostinho insiste em intercalar o relato de suas experiências com as palavras do Apóstolo, de modo a fechar qualquer dúvida.

Agostinho, ao contrário dos maniqueístas, traz para o "eu" o nolle e o velle, o querer e o não querer. O conflito não se resume entre o um eu espiritual e um corpo material alheio ao eu. Afinal o eu está em ambas as vontades ${ }^{147}$. “(...) ego eram, qui volebam, ego, quo nolebam; ego eram" (Conf. VIII, 10, 22). Note-se a insistência com que Agostinho usa o pronome ego. O problema é a luta no próprio animus entre duas vontades antagônicas: o nolle e o velle . É um único eu que quer abandonar os prazeres carnais e é esse mesmo eu que não quer abandoná-los. O animus engloba dentro de si a anima. Adão e Eva formam uma só carne, assim como razão inferior e razão superior formam um só espírito. Dentro deste quadro, talvez não fosse inteiramente errôneo dizer que a cupiditas ou libido, simbolizada pela serpente, é uma alteridade. É involuntária. Mas essa involuntariedade da libido não implica necessariamente em conflito. Também Cristo sentia, em si, a força da carne ${ }^{148}$.

Agostinho deixa claro: é o "eu" que deve ser responsabilizado pelos próprios atos. Mas quem é esse "eu" que deve ser responsabilizado? Ora, já sabemos que é tanto o animus, com sua mens e sua anima, ou melhor ainda, o homem como um todo.

Tratemos, portanto, de analisar mais detidamente como ocorre aquilo que Agostinho denomina "monstruosidade": o animus ordena o querer, só ordena porque quer e, no entanto, não executa o que ele mesmo quer?

\footnotetext{
${ }^{147}$ Em outras palavras fenomenológicas, o eu está nas duas vivências intencionais.

${ }^{148}$ Certo, mesmo o homem que resiste à libido, ainda assim sente dentro de si o prurido incômodo da carne. Mas o conflito entre vontades pertence ao nível existencial, espiritual. Este conflito reflete para o homem como um todo e tem sua origem no fato de que a vontade férrea, chumbada pelo hábito, não mais consegue elevar-se mesmo com o surgimento de vontade ascendente, exclusivamente espiritual, oriunda do amor que se tem por Deus.
} 
O problema, como esclarece Agostinho, é que todo "querer querer", toda vontade de ter vontade exige, como sua condição de existência, o "não querer". A luta de ambas as vontades residia na falta de plenitude de cada uma das vontades. Uma vontade plena é isenta de conflitos internos. O mal não deve ser imputado a uma segunda mente dentro do homem, (naturam mentis alienae) mas à pena do pecado "poenam meae" (Conf. VIII, 10, 22). O homem, portanto, é dividido contra a vontade.

Quando deliberava pôr-me de imediato ao serviço do Senhor meu Deus, tal como já há muito decidira, era eu quem queria, era eu quem não queria; era eu. Nem queria plenamente, nem plenamente não queria. E por isso lutava comigo mesmo e derrotava-me a mim próprio, e a própria derrota acontecia realmente contra a minha vontade, e todavia não mostrava a natureza de uma mente alheia, mas o sofrimento da minha mente. E por isso já não era eu o autor dessa derrota, mas sim o pecado que em mim habitava, por castigo de um pecado mais livre, porque eu era filho de Adão. (Conf. VIII, 10, 22; 2004, p.359)

ego cum deliberabam, ut servirem domino deo meo, sicut diu disposueram, ego eram, qui volebam, ego, quo nolebam; ego eram. nec plene volebam nec plene nolebam. ideo mecum contendebam et dissipabar a me ipso, et ipsa dissipatio me invito quidem fiebat, nec tamen ostendebat naturam mentis alienae, sed poenam meae. et ideo non iam ego operabar illam, sed quod habitat in me peccatum, de supplicio liberioris peccati, quia eram filius Adam. (Conf. VIII, 10, 22; 2004, p.358)

Aquele que quer ter determinada vontade, só a quer, porque não a possui por completo. Ninguém quer querer algo se já quisesse plenamente este algo ${ }^{149}$ Mas como não quer plenamente, o conflito surge, dissipando e dilacerando a alma humana: dissipabant animam meam e, a própria mens e mais globalmente, do próprio eu: "dissipabar a me ipso". 150

A verdadeira luta interior não é entre o corpo e a alma, mas entre a vontade pervertida e a vontade espiritual. Essa cisão original da vontade, essa incompletude da vontade, é o peso do pecado de Adão. A continência, com a qual a vontade espiritual supera a vontade

\footnotetext{
149 “ ego autem adhuc terra obligatus, militare tibi recusabam; et inpedimentis omnibus sic timebam expediri, quemadmodum inpediri timendum est. Ita sarcina saeculi, velut somno assolet, dulciter premebar;" (Conf. X, 10, $22 ; 2004$, p.357)

${ }^{150}$ Então, naquela intensa luta da minha morada interior, luta que eu intensamente desencadeara com a minha alma no nosso quarto, que é o meu coração, perturbado tanto no rosto como no espírito, dirijo-me intempestivamente a Alípio, exclamo: "Porque padecemos?” (Conf. VIII, 8, 19; 2004, p.353)

"Tum in illa grandi rixa interioris domus meae, quam fortiter excitaveram cum anima mea in cubiculo nostro, corde meo, tam vultu quam mente turbatus invado Alypium, exclamo: quid patimur? (Conf., VIII, 8, 19; 2004, p.352)
}

"frustra condelectabatur legi tuae secundum interiorem hominem, cum alia lex in membris meis repugnaret legi mentis meae, et captivum me duceret in lege peccati, quae in membris meis erat". (Conf. VIII, 5, 12; 2004, p.343) 
pervertida, só pode ser obtida através da graça ${ }^{151}$. A continência é a unificação do eu. "Efetivamente, pela continência saímos da dispersão e somos reconduzidos à unidade, da qual nos dissipamos em muitas coisas. Na verdade, ama-te menos aquele que, ao mesmo tempo que ama a ti, ama alguma coisa que não ama por causa de ti” (Conf. VII, 30, 41; 2004, p. $495)^{152}$.

\footnotetext{
151، Cuidava que havia de ser extremamente infeliz, se me privasse dos abraços de uma mulher, e não pensava no remédio de tua misericórdia para curar a mesma enfermidade, porque não o tinha experimentado, e estava convencido de que a continência dependia de minhas próprias forças, das quais não estava consciente, sendo tão estulto que ignorava, como está escrito, que ninguém pode ser continente, se tu não lho concederes. (Conf. VI, 6, 2004, p.253).

"putabam enim me miserum fore nimis, si feminae privarer amplexibus, et medicinam misericordiae tuae ad eandem infirmitatem sanandam non cogitabam, quia expertus non eram; et propriarum virium credebam esse continentiam, quarum mihi non eram conscius, cum tam stultus essem, ut nescirem, sicut scriptum est, neminem posse esse continentem, nisi tu dederis." (Conf. VI, 6, 20, p.252).

${ }^{152}$ Per continentiam quippe colligimur et redigimur in unum, a quo in multa defluximus. minus enim te amat qui tecum aliquid amat, quod non propter te amat. (Conf. VII, 30, 41; 2004, p. 494)
} 


\subsection{O tempo e o espírito}

\subsubsection{O pensamento, o olhar do pensamento e o senso de presença}

Como já observamos, há uma diferença fundamental entre o pensar e ter $\mathrm{o}$ conhecimento na memória. O cogito é atividade, é sempre presente. Os conteúdos da memória permanecem como potência, como notitia, a partir da qual o pensamento é gerado. Ao lembrarmos de um conteúdo da memória, esse conteúdo, embora referente ao passado, torna-se presente ao eu, informando o olhar da mente. Assim como pelo olhar exterior só é possível ver o que está presente, o mesmo ocorre com olhar da mente (aciem mentis). Tudo o que ouvimos, ouvimos no presente. Ninguém vê, com os olhos do corpo, um objeto exterior que está no passado ${ }^{153}$. Em certo sentido, dizemos que vemos o passado na memória. Mas esse modo de dizer não é exato. Imaginemos a situação de um homem que evoca a imagem de um cachorro que viu no dia anterior. O que ocorre é que, no instante em que ele evoca a imagem, a imagem do cachorro está presente ao olhar da mente, assim como os objetos vistos estão presentes ao olhar corporal. No entanto, no que se refere a essa visão interior, a mente é capaz de julgar, na luz da evidência, que esta imagem que está presente diante do olhar da mente pertence a um passado: no exemplo citado, o homem sabe que aquele cachorro vislumbrado na mente é uma similitude de um cachorro que já esteve presente ao seu olhar exterior. O mesmo se dá com o futuro. Ninguém vê com os olhos do corpo aquilo que está no futuro e ninguém vê, dentro da mente, o próprio futuro. $\mathrm{O}$ que o homem faz é imaginar uma situação acompanhada da expectativa e da presunção de que aquilo que é imaginado irá se realizar de forma semelhante ao imaginado. O imaginado esboça o que será efetivamente presente aos sentidos e ao homem como um todo ${ }^{154}$.

O que foi exposto acima coloca em evidência a necessidade de uma faculdade cujo papel é discernir as diferentes classes de imagens mentais: a memória, a percepção, a ilusão, a pura fantasia, a imaginação verossímil do futuro. Trata-se da razão judicante. Sem ela não poderíamos distinguir a modalidade daquilo que está presente ao olhar da mente. Se eu tenho

\footnotetext{
${ }^{153}$ Levando em consideração os conhecimentos atuais, poder-se-ia dizer que isto não é verdadeiro. Quem vê uma estrela no céu, talvez esteja vendo uma estrela que, na realidade, já se extinguiu, dado o tempo necessário a um raio de luz emanado pela estrela chegar até a retina do observador. De todo modo, o que está em jogo não é a própria realidade corporal exterior que está presente, é o objeto visto tal como visto e não o objeto real. A imagem do objeto visto é uma imagem presente, pois ser presente é estar atualmente na consciência, como veremos.

154 Aliás, os sentidos além de estarem mergulhados no presente, estão igualmente mergulhados no particular. Ninguém "o cavalo", vê este cavalo ou aquele cavalo. Apenas o olhar do espírito pode compreender o que seja "o cavalo". Por essa razão Aristóteles faz a distinção nas Categorias entre substância primeira e substância segunda. O "homem" é substância segunda, Sócrates é a substância primeira. Os sentidos veem o singular e o conhecimento do particular é dado por intuição. O pensamento, no entanto, pode lidar com geral.
} 
no olhar da mente um cachorro que vi ontem, como poderei saber que esta imagem que está presente refere-se ao cachorro que vi ontem? Como sei que não se trata apenas de uma simples fantasia? A própria imagem, em si mesma, traz poucas pistas acerca de ser imagem de algo que foi outrora presente aos sentidos. É necessário algo exterior à própria imagem e que me informe que se trata de algo que vi. Um outro exemplo: imagino um plano de ação a ser realizado e creio provável que irei realizá-lo. Como podemos julgar que este algo imaginado é provável e não é uma mera fantasia estapafúrdia? Já observamos em alguns capítulos atrás dessa tese que é a razão inferior que nos permite distinguir o verossimilhante e o verdadeiro nestas imagens. É a razão judicante que consegue discernir a modalidade daquilo que está presente ao olhar da mente. Aquele que perde a razão judicante, ou parte da razão judicante, e não mais distingue a memória da fantasia ${ }^{155}$ enlouquecerá.

\subsubsection{A intentio e o homem como imagem de Deus}

Observamos que a atenção (intentio) se volta tanto para os objetos presentes aos sentidos quanto aos conteúdos da memória, imprimindo a forma deles no olhar da mente, formando assim o pensamento (cogito). Quando a vontade conjuga o olhar da mente com a imagem de um objeto sensível contido na memória, ocorre aí uma trindade. Os três elementos, olhar da mente, conteúdo na memória e vontade não são seres corporais e os três juntos formam o pensamento. Mas essa trindade não é a imagem divina, pois, neste caso, a forma que está na mente, ainda que não seja corporal, tem sua origem nos sentidos. Há, portanto, algo de impuro nesta trindade, donde resulta que não basta que a atenção (intentio) se dirija ao interior para que o espírito recolha-se ao homem interior, em sua função e atividade mais alta, pela qual é imagem de Deus.

De fato, quando o espírito se dirige aos objetos ausentes, isto é, à forma de um objeto contido na memória, o que o espírito faz é ainda pensar no mundo, embora de maneira mediata. Há, contudo, uma outra região do espírito, na qual estão os inteligíveis eternos, que não são imagens de coisas ausentes, mas coisas em si mesmas no espírito. Enquanto o homem negocia com o mundo, sua razão inferior estará imbricada com o homem exterior. Quando contempla a Sabedoria, ele se torna imagem de Deus. Mas como aquilo para onde a atenção tende é determinado pela vontade, e por ser a vontade humana pervertida, a atenção se projeta

155 A fantasia, pela qual fantasiamos o futuro, implica em um trabalho do espírito de composição de novas imagens a partir da matéria prima da memória. 
para fora, "foras se nostra proicit intentio" voltando-se, impropriamente, para as criaturas e não para o criador: Deus e os inteligíveis eternos.

Em conseqüência de nossa condição humana, que nos converte em seres mortais e carnais, lidamos mais fácil e familiarmente com as realidades visíveis do que com as inteligíveis. Ainda que aquelas sejam exteriores e estas interiores; e que percebamos aquelas pelos sentidos do corpo, e estas as compreendamos pela mente. $E$ isso embora sejamos almas não sensíveis, isto é, corporais, mas sim inteligíveis, já que somos vida. Contudo, como disse anteriormente, estamos tão familiarizados com o que é corporal e de tal modo nossa atenção (intentio: n.d.r) resvala para o mundo exterior, que ao ser arrastada da incerteza do mundo corporal para se fixar no espiritual, com conhecimento muito mais certo e estável, a nossa atenção retorna ao que é sensível e deseja aí repousar - justamente de onde vem a sua fraqueza. (De trinit., XI, 1, 1; 2005, p.336. Negritos nossos)

Neque enim frustra et iste homo dicitur nisi quia inest ei nonnulla interioris similitudo, et illo ipso ordine conditionis nostrae quo mortales atque carnales effecti sumus facilius et quasi familiarius uisibilia quam intellegibilia pertractamus cum ista sint exterius, illa interius, et ista sensu corporis sentiamus, illa mente intellegamus; nosque ipsi animi non sensibiles simus, id est corpora, sed intellegibiles quoniam uita sumus; tamen, ut dixi, tanta facta est in corporibus consuetudo et ita in hae miro modo relabens foras se nostra proicit intentio ut cum ab incerto corporum ablata fuerit, ut in spiritu multo certiores ac stabiliore cognitione figatur, refugiat ad ista et ibi appetat requiem unde traxit infirmitatem. (De trinit., XI, 1, 1. Negritos nossos)

No momento em que a vontade tende para um objeto, o olhar do espírito toma a forma do objeto contemplado. Em certos casos, a atenção da alma se projeta com tanta força em um único objeto que, para ela, naquele momento, não há outra realidade que não o objeto contemplado. A violência de tal processo pode ser tamanha que até mesmo a razão judicante se silencie, de modo que o espírito se torne incapaz de distinguir a forma vista da forma impressa no olhar, confundindo-as, incapaz de julgar a diferença entre o eu e o outro.

Assim é com o homem, que, no instante em que contempla Deus e tem, por assim dizer, Deus na "retina da mente", é imagem de Deus. E é justamente por Agostinho ter uma noção temporal do espírito que o homem é a imagem de Deus enquanto sua intentio mentis verte o olhar da mente para Deus. Nesse momento o homem participa da sabedoria de Deus: ama a Deus, intelige Deus (que é ter Deus no olhar do pensamento), o Deus que está presente em nosso espírito porque subsistimos Nele. 


\subsubsection{A distentio e a intentio}

Ter atenção em algo é fazer com que este algo se torne presente para o animus. Examinemos, à luz desse conceito, a célebre definição agostiniana, de que o tempo é a distentio animi.

Daí que me tenha parecido que o tempo não é outra coisa senão distensão; mas distinção de que coisa, não sei, e será surpreendente se não for uma distensão do próprio espírito. (Conf. XI, 26, 33; 2004, p.591)

Inde mihi visum est nihil esse aliud tempus quam distentionem: sed cuius rei, nescio, et mirum, si non ipsius animi. (Conf. XI, 26,33)

Em primeiro lugar, como é possível medir o tempo, ou durações de tempo? O passado não está aí para medi-lo, o futuro ainda não chegou, tem-se apenas o presente, mas este não possui duração. Tampouco o tempo é o movimento dos corpos, ou o movimento dos astros. O que faz o dia ter a duração de um dia não é necessariamente o movimento do sol. O sol poderia, se Deus quisesse, girar muito mais rápido ou mesmo parar. Se o sol completasse mil giros em torno da Terra enquanto comemos um prato de comida, o tempo que nós demoraríamos para comer um prato de comida seria o mesmo ${ }^{156}$.

A atenção está focada na memória, o conteúdo da memória lhe está presente. Lembrarse de algo é tornar mais uma vez presente, embora de outro modo, o que já lhe foi presente. Mas aquilo que foi presente para o animus, foi presente enquanto sua atenção e o olhar de sua mente estavam voltados para ela. Quando o olhar da mente volta-se para outro conteúdo, este conteúdo não mais será presente para o animus. É a intentio voluntatis que fixa o olhar do espírito em algo e é, simultaneamente, também a voluntas que grava o que foi visto na memória. A atenção pode permanecer mais tempo ou menos tempo fixa em um mesmo objeto. Enquanto a atenção perdura em um objeto, esse objeto impresso no olhar da mente vai se estendendo para dentro do espirito, para as regiões da memória.

Mas como diminui ou se extingue o futuro que ainda não existe, ou como cresce o passado que já não existe, senão porque no espírito, que faz isso, há três operações: a expectativa, a atenção e a memória? Desta forma, aquilo

\footnotetext{
156 "Nemo ergo mihi dicat caelestium corporum motus esse tempora, quia et cuiusdam voto cum sol stetisset, ut victoriosum proelium perageret, sol stabat, sed tempus ibat: per suum quippe spatium temporis, quod ei sufficeret, illa pugna gesta atque finita est. Video igitur quandam esse distentionem. Sed video? An videre mihi videor? Tu demonstrabis, lux, veritas". (Conf. XI, 24, 30; 2004, p. 587)

"Portanto, ninguém me diga que os tempos são os movimentos dos corpos celestes, porque, tendo o tempo parado a pedido de um homem, para que pudesse levar a seu termo uma batalha vitoriosa, o sol estava parado, mas o tempo ia avançando. Com efeito, o combate travou-se e terminou durante o espaço de tempo que lhe era suficiente. Vejo, pois, que o tempo é uma certa extensão. Mas vejo? Ou parece-me que vejo? Tu mo mostrará, ó luz, ó Verdade. ( Conf. XI, 24, 30; 2004, p. 587)
} 
que é objecto da expectativa passa, através daquilo que é objeto da atenção, para aquilo que é objeto da memória. Por conseguinte, quem nega que as coisas futuras ainda não existem? E, todavia, já existe no espírito a expectativa das coisas futuras. E quem nega que as coisas passadas já não existem? E, todavia, ainda existe no espírito a memória das coisas passadas. E quem nega que o tempo presente não tem extensão, porque passa num instante? E, todavia, perdura a atenção através da qual tende a estar ausente aquilo que estará presente. Portanto, não é longo o tempo futuro, porque não existe, nem é longo o passado, porque não existe, mas um passado longo é uma longa memória do passado. (Conf. XI, 28, 37; 2004, 597. Negritos nossos).

Sed quomodo minuitur aut consumitur futurum, quod nondum est, aut quomodo crescit praeteritum, quod iam non est, nisi quia in animo, qui illud agit, tria sunt? Nam et expectat per id quod adtendit transeat in id quod meminerit. Quis igitur negat futura nondum esse? Sed tamen iam est in animo expectatio futurorum. Et quis negat praeterita iam non esse? Sed tamen est adhuc in animo memoria praeteritorum. Et quis negat praesens tempus carere spatio, quia in puncto praeterit? Sed tamen perdurat attentio, per quam pergat abesse quod aderit. Non igitur longum tempus futurum, quod non est, sed longum futurum longa expectatio futuri est, neque longum praeteritum tempus, quod non est, sed longum praeteritum longa memoria praeteriti est. (Conf., XI, 28, 37; 596. Negritos nossos)

A atenção do espírito sempre está no presente, assim como o olhar da mente, e por isso todo perdurar, toda duração é relativa ao perdurar da atenção. Se a atenção perdura por muito tempo numa expectativa, ela será longa. Mas como entender algo como: "sed longum praeteritum longa memoria praeteriti est"?. O que viria a ser uma memória longa? E uma longa expectativa do futuro? A dificuldade, sem dúvida, advém do fato de Agostinho procurar compreender em termos espaciais o tempo, e daí a ideia de distentio animi. O termo distentio, aliás, pode ser compreendido' tanto como “extensão", "distensão" ou mesmo "distração", ou “dispersão”. O mais difícil é que, por vezes, Agostinho compreende a distentio em articulação com a intentio, como aquela contraposta a esta. Levando adiante esta articulação, o termo distentio possui o sentido de "distração", ou "desatenção". Em outros momentos, o termo distentio é usado explicitamente no sentido de "estender", “distender" e, portanto, o conceito assume uma conotação espacial. Mas o mais importante disso é que Agostinho articula o sentido de distração com o sentido de extensão, o que torna mais difícil a compreensão.

Podemos dizer, em linhas gerais, que nas Confissões Agostinho emprega o termo distentio para falar sobre o tempo, sempre o articulando com o termo intentio. Essas articulações infelizmente se perdem na tradução:

Mas, porque a tua misericórdia é mais preciosa do que a vida, eis que a minha vida é uma dispersão (distentio: n.d.r.), e a tua dextra acolheu-me no meu Senhor, Filho do Homem, mediador entre ti, que és uno, e nós, que somos muitos, em muitas coisas e através de muitas coisas, a fim de que eu alcance por meio daquele no qual também fui alcançado, e seja reconstituído 
a partir dos meus dias velhos, seguindo-te só a ti, esquecido do passado e não distraído (distentus: n.d.r), mas atraído (extentus: n.d.r.), não para aquelas coisas que hão-de vir e passar, mas para aquelas coisas que estão adiante de mim, não com dispersão (distentionem: n.d.r.), mas com atenção (intentionem: n.d.r.), encaminho-me para a palma da celestial vocação, onde ouvirei um cântico de louvor e contemplarei as tuas delícias, que não vêm nem passam. (Conf., XI, 29, 39; 2004, p. 599) ${ }^{157}$

Sed quondam melior est misericordia tua super vitas, ecce distentio est vita mea, et me suscepit dextera tua in domino meo, mediatore filio hominis inter te unum et nos multos, in multis per multa, ut per eum adprehendam, in quo et adprehensus sum, et a veteribus diebus colligar sequens unum, praeterita oblitus, non in ea quae futura et transitura sunt, sed in ea quae ante sunt non distentus, sed extentus, non secundum distentionem, sed secundum intentionem sequor ad palmam supernae vocationis, ubi audiam vocem laudis et contempler delectationem tuam nec venientem nec praetereuntem. (Conf., XI, 29, 39; 2004, p. 598) $)^{158}$

Se a atenção é o que faz a alma se voltar para algo e se fixar neste algo, a distensão é o que faz a alma "desfixar", "distensionar", o que é necessário para que haja o fluxo de pensamento, para que haja o transcorrer do tempo, para que aquilo que é presente se torne passado. A distentio está ligada à multiplicidade, ao movimento e ao transitório. Estar na distentio é estar dispersado no múltiplo. Deus é uno, as criaturas são múltiplas. E se chega à unidade pela intentio, sem a distentio.

Seguindo a leitura do texto supracitado, observamos como o termo intentio, em sua segunda aparição (na forma do acusativo intentionem), vem traduzido por atenção, "dirigir-se a", "voltar-se para", "tender para"159 "ocupar-se com". O que também é ter aquilo "no olhar

${ }^{157}$ Observamos mais uma vez que o termo oferece enorme dificuldade quanto à tradução: o tradutor para o português usa, na primeira vez em que o termo distentio aparece no texto supracitado o termo "dispersão". Algumas traduções italianas usam aqui "distração", dado que Agostinho faz questão de opor a distentio a intentio, que na maior parte dos casos possui o sentido de atenção, ou tender para algo.

${ }^{158}$ A Edição para o português da Paulus nos oferece a seguinte tradução da passagem:

Mas porque a tua misericórdia é melhor que todas as vidas", a minha vida nada mais é que uma distensão (distentio), "e tua destra me sustentou" no meu Senhor, o filho do homem, mediador entre ti, que és único, e nós, que somos muitos e que vivemos divididos por paixões diversas e objetos vários. Assim é, para que eu "alcance aquele por quem já fui alcançado" e me desprenda da dissipação dos dias antigos, seguindo a Deus uno. Assim, "esquecendo o passado", sem a preocupação das coisas futuras que passarão, e inteiramente "voltado para o que é" eterno, "poderei caminhar para o prêmio da vocação do alto", não na distenção (distentionem: n.d.r), mas com desejo pleno(intentionem: n.d.r); lá "ouvirei o cântico de teus louvores" e "comtemplarei a tua beleza", que não tem começo nem fim. (Conf., XI, 29, 39; 2006, p.360)

159 A descoberta da intentio corresponde, portanto, à descoberta da alma enquanto substância espiritual. No entanto, no livro VII, Agostinho apenas aponta para a existência dessa intentionem, fornecendo poucos indícios acerca da essência dela, embora deixe claro que está vinculada com o fato da alma se projetar naturalmente para fora de si. De fato, primeiramente ele afirma: "per quales enim formas ire solent oculi mei, per tales imagines ibat cor meum (...)”. E logo na sequência como que fazendo um paralelo entre o coração à intentio, afirma: “(...) nec videbam hanc eandem intentionem, qua illas ipsas imagines formabam, non esse tale aliquid: quae tamen ipsas non formaret, nisi esset magnum aliquid". A intentio, portanto, fica associada à função de formação das imagens. E de fato, observamos na Trindade que a intentio é de natureza distinta dos corpos e que é pela intentio - que é um modo de ser da vontade - que a alma conflui para esse ou aquele objeto. 
da mente”. Está aí implícito o termo intentio em seu senso de tempo presente, em oposição ao passado e ao futuro. Pois se o termo intentio tem também o sentido de vontade, ou encontra-se ligado a esta (observamos o uso de intentio voluntatis), tem também o caráter do tempo presente e de perduração do presente. A intentio não pode ser guardada na memória. Qualquer ato de consciência que tem como base uma representação, como desejo, a imaginação, a lembrança etc, passado o tempo, torna-se passado. Lembro-me de algo e no instante depois já estou com a cabeça em outra coisa; mas a atenção não passa, perdura e está sempre no presente, e não podia ser diferente, pois é ela que coloca diante do olhar da mente aquilo que está na memória para informá-lo.

O que é presente, portanto, para o espírito, não é nem mesmo o próprio tempo. O que é presente para o espírito é o próprio espírito e o objeto para o qual a intentio se aplica, informando o olhar da mente - quando a intentio conflui a outro objeto (interior ou exterior), este novo objeto será presente ao olhar da mente, ao passo que o objeto deixado de lado pela intentio se tornará passado (será impresso na memória).

Assim, a intentio tem a capacidade de presentificar isso ou aquilo, pois é a intentio que colocará esta ou aquela coisa ao olhar da mente. Tudo aquilo para o qual a intentio está voltada está em algum plano, presente ao olhar da mente. Quando lemos, temos tanto as palavras, quanto o conteúdo da leitura diante do olhar da mente, embora o foco para o qual o próprio olhar da mente se dirige é o conteúdo ${ }^{160}$.

Dissemos, pouco antes, que os cinco sentidos só nos pode fornecer o que é presente e que não vemos com os olhos do corpo uma coisa que está no futuro ou que está no passado. Contudo, como Agostinho afirma, a vontade pode confluir inteiramente para uma imagem interior, perdendo o sentido da temporalidade presente imanente aos sentidos voltados ao exterior, isto é, aos corpos que estão diante de nós. De fato, quando a alma fixa inteiramente em seu interior, o que é presente, nesse momento, para ela, é o objeto interior, enquanto os objetos do mundo circunstante estão presentes em um sentido mais fraco, porque o olho da mente não está direcionado para eles. O modo como o tempo passa para quem está com o olhar da mente dirigido para dentro de si distingue-se do modo como o tempo passa para quem está voltado para o mundo exterior.

\footnotetext{
${ }^{160}$ Já observamos que as vontades podem estar entrelaçadas e ocorrerem simultaneamente. Aquele que lê, vê, se se vê é porque tem a atenção aplicada à visão, contudo, também quer conhecer o conteúdo, e, portanto, tem a vontade, simultaneamente informando o olhar de sua mente com os significados do texto. Embora o olhar da mente esteja sendo informado pelos significados, as palavras visuais também estão, de certo modo, presentes na mente.
} 
Aquilo que é presente só o é em virtude de algo alheio às próprias coisas em si mesmas, o que é presente só é presente em relação ao espírito. Por isso o tempo, compreendido nas três dimensões - passado, presente e futuro - só existe para o espírito, para um ser que tem memória, inteligência e atenção, imaginação e expectativa ${ }^{161}$.

Vimos atrás que o fluxo do tempo ocorre devido ao fato de haver uma sucessão de objetos sobre os quais a intentio aplicou o olhar do espírito. Em virtude dessa mobilidade da intentiovoluntatis sucedem-se várias trindades dentro de nossa mente ${ }^{162}$. Na passagem que se segue, Agostinho procura mostrar como é a intentio que está associada com este processo do futuro tornar-se passado:

Alguém que tenha querido emitir um som um pouquinho mais alongado e que tenha decidido mentalmente qual há de ser a sua duração, esse, na verdade, delimitou a duração do tempo em silêncio e, confiando-o à memória, começa a emitir esse som que soa até atingir o limite fixado: mais ainda tal som soou e soará, pois a parte que se extinguiu sem dúvida soou, enquanto o que resta soará, e assim se prolonga, enquanto a atenção presente arrasta o futuro para o passado, crescendo o passado com a diminuição do futuro, até ao momento em que, com a extinção do futuro, tudo é passado. (Conf., XI, 27, 36; 2004, p. 597)

si voluerit aliquis edere longiusculam vocem, et constituerit praemeditando, quam longa futura sit, egit utique iste spatium temporis in silentio, memoriaeque commendans coepit edere illam vocem, quae sonat, donec ad propositum terminum perducatur: immo sonuit et sonabit; nam quod eius iam peractum est, utique sonuit, quod autem restat, sonabit, atque ita peragitur, dum praesens intentio futurum in praeteritum traicit, deminutione futuri crescente praeterito, donec consumptione futuri sit totum praeteritum. (Conf., XI, 28, 37; 2004, p.596)

Se conseguimos medir o tempo é porque, como vínhamos observando, temos algo em nós mesmos que perdura. "Sed tamen perdurat attentio, per quam pergat abesse quod aderit". Toda medida de uma duração temporal exige atenção e memória. Por isso o espírito não mede o tempo exteriormente, mas é em si mesmo que o espírito mede o tempo. In te anime meus, tempora metior. Se não tivéssemos nenhuma capacidade de retenção, não poderíamos mensurar as durações de tempo. A consciência do tempo e das durações tem como condição a existência da memória. Quando afirmamos que uma sílaba foi pronunciada com uma duração duas vezes maior do que a que foi pronunciada agora é porque podemos comprar a memória que temos de ambas as sílabas; a memória de uma é mais extensa do que a de outra e

\footnotetext{
${ }^{161}$ Mesmo o futuro e o passado só o são em relação à mente e ao sentido de presença imanente a intentio e ao olhar da mente. Por isso o futuro é uma expectativa associada à imaginação presente de algo que julgamos que poderá ou deverá se tornar presente, assim como o passado se revela igualmente a apresentação de um conteúdo da memória ao olhar do pensamento, devido ao fato da intentio mover o olhar do espírito a esse objeto.

${ }^{162}$ Devemos notar que o termo distentio não é usado por Agostinho na Trindade. Na Trindade ele fala apenas de intentio.
} 
podemos até mesmo dizer que o intervalo de silêncio entre duas notas durou mais do que outro intervalo de silêncio.

Partindo dessas mesmas considerações, podemos compreender porque Agostinho considera que a eternidade não é um tempo que nunca tem fim, isto é, que dura para sempre. Mesmo que uma pessoa viva para sempre, ela não seria eterna, pois a concepção de eternidade não coincide com a de imortalidade. A situação da morte, na qual o homem pode atingir a eternidade, trata-se da intentio sem a distentio. Ora, mas isso não implicaria a existência apenas do presente, sem passado e sem o futuro? Ao que parece é justamente isso:

Aqueles que isto dizem ainda não te compreenderam, ó sabedoria de Deus, ó luz das mentes, ainda não compreenderam como são feitas as coisas que por meio de ti em em ti são feitas, e esforçam-se por saborear as realidades eternas, mas o seu coração esvoaça ainda nos movimentos passados e futuros das coisas, continuando vazio. Quem poderá detê-lo e fixá-lo, a fim de que ele pare e por um momento capte o esplendor da eterninadae sempre fixa, e a compare com os tempos nunca fixos, e veja que ela é incomparável, e veja que um longo tempo não é longo senão a partir de muitos momentos que passam e não podem alongar-se simultaneamente; veja, pelo contrário, que, no que é eterno, nada é passado, tudo é presente: e veja que todo passado é obrigado a recuar a partir do futuro e que todo futuro se segue a partir de um passado, e que todo o passado e futuro são criados e derivam daquilo que é sempre presente. (Conf., XI, 13, 15; 2004, p.340)

Et conantur aeterna sapere, sed adhuc in praeteritis et futuris rerum motibus cor eorum volitat et adhuc vanum est. quis tenebit illud et figet illud, ut paululum stet, et paululum rapiat splendorem semper stantis aeternitatis, et comparet cum temporibus numquam stantibus, et videat esse incomparabilem: et videat longum tempus nisi ex multis praetereuntibus motibus, qui siuml extendi non possunt, longum non fieri; non autem praeterire quicquam in aeterno, sed totum esse praesens; (Conf., XI, 13, 15). ${ }^{163}$

É por isso que no dia em que a mente vir Deus face a face, ela o verá "non secundum distentionem, sed secundum intentionem". Neste dia haverá o repouso da vontade, que é verdadeira felicidade. O repouso da vontade implica, como vínhamos argumentando, a paralisação, para o espírito, daquilo que chamamos fluxo do pensamento, resultado de uma movimentação incessante da vontade, que fixa ora nisso, ora naquilo, traz esse conteúdo da memória para o olhar da mente e, sem descansar, já traz outro. Isto é, ela está mergulhada no

\footnotetext{
${ }^{163}$ Eis a tradução da Paulus, que pode servir também como referência: "Eles se esforçam para conhecer as coisas eternas, mas o pensamento deles vagueia ainda na agitação das realidades passadas e futuras. Quem poderá deter esse pensamento e fixá-lo um instante, afim de que colha por um momento o esplendor da tua sempre imutável eternidade, e veja como não se pode estabelecer um confronto com o tempo sempre móvel. Compreenderá então que a duração do tempo só será longa porque consta de muitos movimentos passageiros que não podem alongarse simultaneamente. Na eternidade nada passa, tudo é presente, ao passo que o tempo nunca é todo presente." (Conf., XI, 13, 15; 2006, p.340).
} 
múltiplo. O repouso da vontade é a imobilização da vontade, a meta final, o laço final com o uno, razão pela qual o múltiplo fica para trás, mas junto com o reino da multiplicidade, perdem-se também o passado e o futuro, pois sem multiplicidade não há passagem, o agora não se distingue do depois.

Contudo, este estado de repouso da vontade não implica a ausência do tempo. A eternidade, se não tem futuro, nem passado, possui, entretanto, o tempo presente. Sabiamente, Agostinho percebeu que se o retirasse, de certo modo, não haveria diferença entre a morte plena, isto é, o nada, e a eternidade, o eterno presente. Assim, a morte dos escolhidos é um estado de repouso da vontade, no qual apenas o amor perdura em plena contemplação ao ser amado, a unidade suprema. O espírito, entretanto, não se funde com Deus, formando uma única unidade, pois embora contemplando, a mente continua amando a si, tendo memória de si, e entendendo a si, de modo que, em virtude desta circularidade reflexiva, o espírito mantém sua individualidade, de modo que objeto contemplado e sujeito que contempla possam se distinguir. O homem verá Deus face a face, mas não será Deus. A vontade não mais saltará de um objeto a outro, na distensão, e assim deixará o reino da multiplicidade para permanecer na unidade, e então a mente viverá o gozo da contemplação da verdade. 


\subsection{O homem: imagem de Deus em enigma e espelho}

A ênfase nos estados de consciência e o estudo desta por meio de atos reflexivos constituem um dos principais denominadores comuns entre Husserl e Agostinho. No caso de Agostinho (embora não convenha discutir sobre questões pontuais de pioneirismo), é preciso ressaltar que o seu pensamento é um marco de capital importância na história do pensamento Ocidental. Marcou profundamente toda a Idade Média e ainda hoje apresenta grande interesse, pelo valor para a compreensão da história da subjetividade Ocidental, devido especialmente ao acento à individualidade, ao filosofar em primeira pessoa, ao seu estilo de pensar o homem sempre fundamentado em suas experiências pessoais e a suas explorações dos atos reflexivos. Suas investigações possuem não apenas um valor histórico, mas um valor intrínseco, ainda hoje Agostinho tem algo a nós dizer. Parte desse valor advém do cuidado e precisão com que o bispo de Hipona procurou descrever suas próprias experiências. Esse valor se revela tanto em âmbito teológico, mas também filosófico e psicológico.

Um dos aspectos que não pode ser descartado, pois representa a chave para uma compreensão global do pensamento de Agostinho, encontra justamente no fato de que o homem, em Agostinho, nunca é pensado isoladamente, mas é sempre pensado em sua relação com o Cosmos e com Deus. Em certo sentido, isto representa um problema para se elaborar uma justa apresentação e a compreensão da "psicologia" de Agostinho.

Para Agostinho, o ser supremo, o sumo bem, unidade perfeita e eterna, é quem criou o reino da multiplicidade da manifestação temporal. Essa concepção já havia sido expressa por Plotino (205-207), o qual, um século antes do bispo de Hipona, já professava que tudo quanto há provém de uma série de emanações divinas, até chegar à matéria sensível ${ }^{164}$. No livro sete das Confissões, Agostinho confessa abertamente que seu espírito sofreu uma transformação intelectual, quando, nos tempos de retórico em Milão, chegou-lhe às mãos uma tradução latina das Enneidas de Plotino.

Segundo Abbagnano (2009), no pensamento de Plotino: "Elementos pitagóricos, aristotélicos, estoicos, são fundidos com o Platonismo em uma vasta síntese que iria influenciar todo o curso do pensamento cristão e medieval, e, através deste, também o pensamento moderno". (ABBAGNANO, 2009).

\footnotetext{
${ }^{164}$ A consciência humana pertence a uma hierarquia do ser acima da matéria. O homem está, segundo Plotino, entre o Nous e a matéria. Está ligado à matéria pelo seu corpo, está ligado ao Nous pelo seu espírito. Daí a presença em Plotino da antiga ideia de ascetismo: a purificação do espírito de suas manchas carnais.
} 
Dentro do sistema de emanações de Plotino, encontra-se, como ser supremo, em primeiro lugar, o Uno, que se define negativamente em relação à multiplicidade. É absolutamente transcendente, está além do próprio Ser e por isso não pode ser predicado, já que todo predicado implica dizer o que o sujeito é, em determiná-lo e, portanto, em separá-lo do que ele não é, o que exige multiplicidade. Do Uno emana o Nous, ou Intelecto, o qual pressupõe, em sua própria essência, a multiplicidade, pois seu ser implica a distinção entre sujeito que pensa e objeto pensado ${ }^{165}$. Este Nous não é, todavia, o criador absoluto, posto que a hylé não foi criada por ele.

Agostinho se apropria desta forma de se pensar Deus em sua abordagem acerca da Trindade. Identifica Deus também com o Uno. Nossa vida é dispersão no múltiplo, após a morte, haverá, para os espíritos puros, a contemplação face a face de Deus. A vida terrena é caracterizada pela distentio, o movimento centrífugo da atenção no qual a vontade projeta-se para fora; já o movimento de ascensão espiritual é caracterizada pela intentio em direção ao interior, ao que há de eterno no homem, em direção à contemplação do Uno. Deus é que o há de mais longe, transcendente à Criação e anterior a ela; ainda assim, Deus, que é Espírito, habita no íntimo do espírito humano, mas, por outro lado, sua marca está na criação. O Ser perfeito não poderia fazer algo que não era bom. Se a natureza tem forma, medida, estabilidade, ordem é porque é criação do Logos. Deus nomeia a espécie, que é uma enquanto espécie, depois faz os membros individuais de carne e osso, que são múltiplos. O logos contem a dualidade de palavra e conceito. O conceito também é real, embora dotado de outro tipo de realidade. Subsiste no espírito do homem, mas antes dele já subsistia no espírito de Deus.

A ideia de que uma inteligência suprema é a coordenadora e a causa de tudo foi defendida por longa tradição. Já Anaxágoras (500-428 a.C) defendia o Nous como coordenador do Cosmos. Platão guarda para si a ideia de mente divina (Nous), reformulando-a no Timeu, embora distancie dos demais aspectos da teoria de Anaxágoras, que lhe pareciam insatisfatórios. Platão nos narra que, ao ouvir falar de Anaxágoras, esperava encontrar nos escritos dele uma solução definitiva sobre o problema se a terra era esférica ou plana. Platão raciocinava que, se uma mente perfeita e infinitamente inteligente regesse o mundo e fosse causa de tudo, ela haveria feito o mundo da melhor modo possível. Para que o homem obtivesse a resposta à questão de a Terra ser plana ou esférica não seria necessário experimento algum, bastaria o esforço de elevar sua mente à Mente coordenadora e imaginar

${ }^{165}$ Corresponde, segundo alguns estudiosos, ao Demiurgo de Platão, o qual deu forma ao mundo, constituindo, com a hylé primordial, os múltiplos seres, cada qual com uma forma que já preexistia em seu espírito. 
qual a forma mais inteligente, mais bela, pela qual ela haveria modelado a Terra. A ideia por trás do argumento é que a estrutura do Cosmos é racional e, por isso, torna-se objeto de compreensão e contemplação, dada à sua perfeição e beleza. O esforço em conhecer a natureza nada mais é do que um movimento do espírito em direção ao espírito do demiurgo

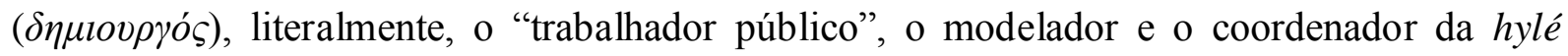
primordial. O centro da questão é a comunhão de naturezas entre Deus e o intelecto humano.

Plotino move-se neste âmbito metafísico, retomando, ao seu modo, o Nous de Anaxágoras. Entretanto, como vimos, Plotino retoma a tradição pitagórica e coloca o Uno como sendo anterior, do ponto de vista ontológico, ao Nous. Do Nous emana a "alma do mundo", que é verbo e o ato do Nous. Essas ideias pareceram a Agostinho mais verdadeiras e sutis do que aquelas que vira no Maniqueísmo.

O pensamento de Plotino oferece à Agostinho o plano conceitual para a compreensão de Deus e da relação entre Deus, o espírito humano e a criação. A importância do pensamento de Plotino em Agostinho consistiu fundamentalmente em dois pontos. Em primeiro lugar, Agostinho abriu os olhos para a ideia de que Deus é transcendente ao Cosmos. Em segundo lugar, Deus é espírito, assim como o animus também é espírito e a base do espírito é sua reflexividade. Daí que a compreensão de Deus encontra-se profundamente ligada com a compreensão do próprio espírito. Compreender o modo em que se dá o ser do próprio espírito auxilia a compreender Deus e vice-versa. Portanto, há por assim um movimento dialético entre teologia e "psicologia" em Agostinho. Deus é transcendente à criação, mas está presente no fundo do espírito. Internum aeternum.

Quando jovem, movendo seu pensamento dentro das grades conceituais do Maniqueísmo, do estoicismo, e de uma visão ingênua do cristianismo, herdada do “cristianismo popular" do interior da África, faltavam a Agostinho as intuições que ele encontrará na obra de Plotino. O misticismo de Plotino era, com efeito, muito apreciado pelos intelectuais cristãos de Milão, como Ambrósio. Já o Maniqueísmo, mais pobre do ponto de vista filosófico e metafísico, reduzia tudo a dois princípios cósmicos contrapostos e, por isso, participantes e formadores do Cosmos, sem qualquer espécie de transcendência. Aliás, bem e mal, eram entendidos em termos materiais. Constituíam as duas substâncias a partir das quais se compõem as demais. Tudo quanto há está no Cosmos, está na natureza. Cosmologia e Teologia estão fundidas no maniqueísmo. 
Agostinho também conhecia o Deus dos estoicos, que era imanente ao Cosmos. A esse respeito é interessante observar a visão de Sêneca, autor o qual Agostinho não só conhecia, como o apreciava ${ }^{166}$ :

À nossa liberdade importa imenso investigar as questões acima referidas, porquando tudo no mundo consta de matéria e espírito divino. A divindade é que regula tudo, e tudo a rodeia e segue como a um guia ou um chefe. $\mathrm{O}$ agente, ou seja, a divindade, é mais poderoso e válido que a matéria submetida à ação da divindade. Ora lugar idêntido ao que a divindade ocupa no universo, ocupa lugar no homem o espírito; o que no universo é matéria, em nós é corpo. Sirva, portanto, o inferior ao superior. (SÊNECA, 2004, p.235)

Vemos nitidamente aí o conceito de Deus como "alma do mundo". Deus é a alma da matéria cósmica. O sistema de Plotino abarca essa concepção, contudo, para Plotino, a alma do mundo vem posta, dentro do sistema de emanações, em um nível inferior ao Uno Supremo, princípio transcendente ao Cosmos. Segundo Guenon (1990), os Estoicos perderam de vista o Princípio transcendente, de que falavam os Pitagóricos, e consideram "apenas um "Deus" imanente que, para eles, se assemelhava pura e simplesmente ao "spiritus mundi"'(p.71)

A discussão entre a transcendência e a imanência de Deus ao Cosmos é de suma importância, pois está diretamente vinculada com as concepções de Agostinho acerca do espírito. Trata-se de um tópico que não poderia faltar nesta tese.

O maniqueísmo também defendia a ideia de um Deus imanente, não apenas entremeado com a matéria, mas ele mesmo feito de matéria, uma matéria mais sutil. O abandono do maniqueísmo começa com as aporias decorrentes de tal concepção, com a percepção de que ela desrespeitava a noção segundo a qual Deus é inviolável.

Inicialmente Agostinho diz que o maniqueísmo havia satisfeito seu intelecto ao explicar o porquê do mal. Ao contrapor o mal com o bem, como substâncias distintas e eternas, o bem aparentemente se salvava, pois não havia criado o Mal. Mas, melhor examinada, a ideia feria sua intuição, pois o Mal era explicado em detrimento do Bem. Se Deus é o bem e ele se relaciona com o Mal, com este guerreando, é porque um age no outro e outro age no um. Cada qual possui uma dose de poder sobre o outro. O Mal exerce efeitos no bem e o Bem no Mal. Tal concepção não poderia ser aceita, afinal Agostinho tinha como certo que Deus é o ser supremo, onipotente e inviolável. Por outro lado, partindo da "hipótese" de que Deus é o criador de tudo, consequentemente, Deus também deve ser o criador do Mal.

Portanto, teríamos o seguinte paradoxo: se Deus não criou o mal e se contrapõe ao mal é porque não é onipotente e inviolável. Se Deus criou o mal, não é plenamente bom ou é

\footnotetext{
${ }^{166}$ Agostinho aprecia Sêneca não pelas suas idéias teológicas, mas sobretudo por suas idéias morais.
} 
incompetente. Como resolver a contradição? Fausto, a suma autoridade maniquéia de seu tempo, sua última esperança, de quem espera ouvir a resposta à questão, apenas lhe diz: "não sei”.

Esse paradoxo intelectual atormenta profundamente Agostinho. Aliás, a capacidade de se atormentar é uma de suas marcas mais fortes. Sua impotência para dar uma respostas a esta questão, leva-o a uma outra: "Deveria ele ter uma fé cega e lançar-se de cabeça na doutrina religiosa, abandonando a razão?'

Agostinho ainda não via que o espírito está sempre presente a si mesmo, de modo mais indubitável e seguro do que o conhecimento sensível. Ao ver a si mesmo, Agostinho descobre o que é o espírito e o seu modo peculiar de ser. Entendendo-o, conseguirá dar um passo na compreensão de Deus, que é espirito e não matéria.

O pensamento de Plotino é absorvido por Agostinho a ponto de servir-lhe quase de uma gramática para entender a relação entre o homem, Deus e a Natureza segundo uma interpretação consonans do Evangelho. Com Plotino, Agostinho abre os olhos do intelecto, de modo que ele compreende o estranho modo de ser da substância espiritual. Até Plotino, Agostinho só sabia pensar em Deus a partir dos cânones maniqueístas e estóicos, isto é, ao pensar a infinitude de Deus, ele usava de raciocínio imagético, o qual é válido apenas para se raciocinar sobre as coisas sensíveis.

Deste modo, embora não te concebesse soba forma de um corpo humano, era todavia levado a conceber alguma coisa de corpóreo espalhado pelos espaços, quer imanente ao mundo, quer difuso além do mundo, pelo infinito, e que fosse justamente isso o infinito, e que fosse justamente isso o incorruptível, e o inviolável, e o imutável que eu antepunha ao corruptível, e o violável, e o mutável. (Conf. VII, 1, 2; 2004, p.267)

Em suma, Deus seria onipresente em virtude de ser uma espécie de éter difuso infinitamente pelos espaços. Esse "éter sutil", permaneceria imutável, pervadindo e abarcando todas as coisas, embora sempre imutável. Por isso, seria onipresente.

Mas logo essa ideia pareceu violar sua visão divina, pois, partindo dessa imagem, que ele visualizava em sua mente, um elefante teria em si uma maior parcela de Deus maior do que um rouxinou, assim como ocorreria caso duas esponjas de tamanhos distintos fossem mergulhadas na água: a maior seria preenchida por uma maior quantia de água.

Inviolável, incorruptível, imutável. Agostinho já sabia que estes eram os predicados de Deus. Entretanto, não conseguia formar uma imagem clara sobre isso. Pelo contrário, vinham à visão de seu espírito apenas fantasmas (phantasmata), os quais obnubilavam o olhar da mente (acie mentis). Toda vez que ele se empenhava em compreender Deus, as imagens 
apareciam esvoaçando e ele logo se esforçava em afugentar essas imundícies. Mas como compreender a onipresença divina sem o modelo do éter? Como explicar o problema do mal?

Agostinho só encontrará a resposta quando ele se esvair do mundo dos sentidos e afundar-se em seu próprio espírito. É então que ele descobre um modo de ser distinto do modo de ser do mundo sensível. Percebe que as idéias de ser coisal-espacial não se aplicam ao espírito. O espírito não pode ser dividido em partes maiores e menores, ele está sempre inteiro em si mesmo. Quando reflete sobre si mesmo, ele se "duplica" em um sujeito que pensa e, ao mesmo tempo, objeto do pensamento e, ainda assim, continua sendo o mesmo. E, ao pensarse, ele se ama. O espírito tem como essência sua reflexividade, sua presença de si para si, autoconsciência, dotado de um amor que dirige a si mesmo em um giro imaterial. Veja por exemplo, a distância entre essa concepção e a ideia estoica de espírito proposto por Sêneca (aliás, Sêneca nem mesmo distingue alma e espírito). Ainda assim, Sêneca(2004) julgava sua concepção de alma mais refinada do que a de outros estoicos:

Imaginas que faço minhas as palavras daqueles estoicos para quem a alma de um homem esmagado sob massa de grande peso não poderia permanecer uma, mas sim, privada de sair livremente do corpo, imediatamente ficaria reduzida a fragmentos? Não, não faço, porque me parece laborar em erro quem faz uma afirmação destas. Tal como o ar não é afectado por golpes ou estocadas, não se deixa sequer cortar, antes imediatamente rodeia o objecto que tenta repeli-lo; assim também a alma, que é feita de matéria extremamente tênue, não pode ser coagida nem esmagada dentro do corpo: graças a sua subtileza, consegue escapar-se através da massa que a comprime. (...) ( p.197)

Para Sêneca e o Etoicismo em geral, o animus era sempre uma matéria sutil, racional, pensante e dotada de vontade, esta última entendida como apetite racional. Já pela concepção agostiniana e plotiniana, a mens ${ }^{167}$ não se limita a ser a sede da razão, do pensamento e da vontade. O que a caracteriza e a define é sua presença a si mesma, auto-consciência, intimidade consigo mesma, pela sua capacidade de amar-se a si mesma. Essa estrutura reflexiva, essa coincidência entre o sujeito do ato e o objeto do ato, é o que faz do espírito do homem imagem de Deus. O homem não é imagem de Deus pelo seu corpo, mas pelo seu espírito. Mas há distinções. No espírito do homem, uma coisa é o ser, outra o conhecer. Em Deus, ser e conhecer, se identificam. O Uno, ao pensar em si mesmo, torna-se dois. Por um lado o puro ser; por outro lado o conhecimento que o ser tem de si mesmo. Mas esta distinção é puramente relacional, não é uma distinção de substância ou de essência. Porque, em Deus, o conhecimento que ele tem de si não é menor ou maior a si - é idêntico a si. Por isso, o Uno

\footnotetext{
${ }^{167}$ Para Plotino, nous.
} 
e sua primeira emanação se distinguem apenas do ponto de vista relacional, mas não do substancial:

Pois em Deus o conhecer e o ser se identificam. E assim como o Pai não recebeu o ser do Filho, tampouco recebeu o saber. O Pai, como que dizendo a si mesmo, gera o verbo que lhe é em tudo igual. (...) Por isso, o Verbo é a verdade, pois o que existe na ciência que o gerou existe nele. (De trinit., $\mathrm{XV}$, 14,$23 ; 2005$, p.516)

É o pai que, ao dizer a si mesmo, gera o filho, que é seu próprio conhecimento a respeito de si mesmo, o que não lhe é distinto. O amor, que é o Espírito Santo, do mesmo modo, procede entre pai e o filho e pede a reflexividade, pois não é possível amar-se a si sem conhecer-se a si. Por isso o amor procede principalmente do pai, mas também do filho. Portanto, o filho é gerado; o amor procede do pai. É preciso notar: o filho é gerado; é o conhecimento do pai sobre si mesmo; é logos do pai. O amor procede do pai e do filho; pois Deus ama a si mesmo. De forma simples, porém menos exata: do ser emana o conhecimento que o ser tem de si mesmo; e ao conhecer-se, ele se ama. Contudo, amor, ser e conhecer só se distinguem relacionalmente, pois diz respeito a uma única substância.

O sistema de emanações de Plotino fornece para Agostinho o suporte a partir da qual ele irá pensar a Trindade divina em analogia com a trindade humana, constituída de inteligência, vontade e memória, formando uma só vida, uma só mente.

Deus é o uno e também é trindade. Três pessoas, uma única essência. Ou, no grego,

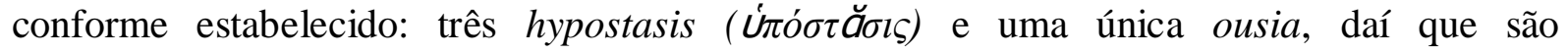
consubstânciais (homoousios) relativos, que constituem uma trindade. Interessante notar que os gregos usam o termo hypotasis em vez de pessoa, que, em grego, seria prosopon. Agostinho bem notou essa diferença: "Os gregos, se quisessem, poderiam dizer três pessoas, "três prosopa", assim como falam em três substâncias ou três hipóstases. Preferiram, no entanto, a segunda designação por corresponder melhor à índole do seu idioma." (De trinit. VII, 6, 11; 2005, p.252). Entretanto, Agostinho argumenta que em Deus se indentificam o ser o e o subsistir. Tanto o termo essentia, quanto o termo substantia, provém de esse. Substantia é aquilo que subsiste por si só. Daí que não se pode dizer que Deus possui três substâncias, assim como não se pode dizer que possui três essências. O termo pessoa, por seu turno, mostra-se mais adequado. Abbagnano (2007) comenta que o termo pessoa, possui um sentido distinto atualmente empregado: o de homem em suas relações consigo e com o mundo. $\mathrm{O}$ termo proveio isto sim do termo latino usado para designar máscara, no sentido de personagem. E máscara simboliza o que aparece, o que se manifesta 
As concepções místicas de Plotino, na qual vem sintetizadas as tradição platônica (arquétipos com os quais o demiurgo modela a hylé primordial), aristotélica ${ }^{168}$, estoicas (spiritu mundi) e Pitagórica (o uno transcendente) fornecem à Agostinho conceitos chaves para se compreender a Trindade Divina. Mas não demora para que Agostinho perceba os limites do pensamento de Plotino. Embora seja verdadeiro que o pensamento intelectual é capaz de se elevar até Deus, não é capaz, entretanto, de chegar, por si próprio, a Cristo. É apenas a revelação e o testemunho que nos informa acerca de Cristo, que foi um homem, mas também é Deus.

Com Cristo, a dimensão da verdade revela-se em outro nível, de digestão difícil aos homens orgulhosos de sua racionalidade. Cristo não é o simples portador e o transmissor da verdade, não é um profeta, não é um representante de Deus, mas o próprio Deus, a própria verdade. E a verdade é expressa não apenas pela fala, mas também pelos atos, pelo próprio modo de viver de Cristo. Chega-se à verdade não apenas subindo os degraus do intelecto, como queriam os gnósticos, mas também imitando a vida daquele homem. $\mathrm{O}$ advento de Cristo sobre a terra, em sua especificidade, não pertence ao mundo das ideias, mas à história. A história do mundo é marcada, para sempre, pelo fato de que se Deus fez, nos tempos do império romano, homem. Sacrificado no altar da injustiça, o sangue do inocente libertou e redimiu a humanidade.

Segundo Agostinho, embora Plotino tenha visto que no "início era o Logos e ele estava com Deus e ele era Deus", faltava-lhe Cristo. Faltando Cristo, faltava ao ilustre filósofo uma visão clara sobre o que seja o amor.

Partindo das ideias expostas por Sócrates no Banquete, Plotino entenderá o amor (Eros) como um daimon, um ser que se coloca entre a esfera divina e o espírito transitório do homem. Este daimon, ou demônio, é o responsável pelo comércio entre a esfera divina e a humana. É a ponte entre o transitório e o eterno. Isso ocorre porque o amor é filho da Pobreza (penia) e da Abundância (poros), e sendo filho de ambos, possui um pouco de cada um. Movimenta-se em direção à plenitude e ao eterno, mas sempre tem algo que lhe falta. $\mathrm{O}$ amor é uma potência que abre um canal entre o espírito e beleza suprema.

Bela visão. Mas, para Agostinho, não capta a essência do amor, no sentido de agape. $\mathrm{O}$ amor é derramado em nossos corações pelo Espírito Santo. É o dom de Deus aos homens, presente gratuito com o qual Deus agracia os homens. $\mathrm{O}$ amor não é uma falta, mas um transbordar. Apenas o desejo é falta, já o amor só irradia quando transborda.

\footnotetext{
${ }^{168}$ Sobre a questão do nous em Aristóteles, ver apêndice B.
} 
Se compreende a novidade de tal "salto", referindo-o ao mundo grego. O deus grego não pode amar. Não pode porque o amor grego é uma busca daquilo que se falta. É agarrar o que se é privado e que se tem necessidade. Mas Deus possui tudo e não pode faltar-lhe nada; portanto, o Deus grego não pode amar. De fato, Eros platônico é um demônio, e não um deus. (REALE; SINI, 2006, p.26, tradução nossa)

Baseado no Evangelho de João e focalizado na frase "Deus é amor", Agostinho, comenta. Deus é amor, logo todo aquele que ama o amor, ama a Deus. E junto com essa frase Agostinho também exorta: “Ame e faça aquilo que quer". Para Reale e Sini (2006), essa última sentença:

Se trata de um pensamento que pode causar estupor, e que alguns a banalizam, mas é ao contrário, muito profundo. Que coisa quer dizer "ama?". Significa: doe ao outro aquilo que esteja ao grau de doar, e faça aquilo que quer... Isto é claro na dimensão do amor como ágape ou seja do amor como absoluta "doação". Se escreve em uma mensagem de fundo fortíssima: "Deus quis ser filho do homem, porque o homem se tornasse filho de Deus". Isto eu chamo de "amor absoluto", e constitui um das mais belas mensagens que nos há deixado Agostinho. (p.26)

Os cristãos não amam apenas o Uno, mas também rezam pelos pecadores e esforçam em amar os próprios inimigos.

Como conciliar o princípio transcendente, eterno, uno, indivisível e a vida de Cristo, dotado simultaneamente de carne, alma e mente humana e, simultaneamente, Deus? A resposta mais profunda de Agostinho é que Deus, quando se esvazia a si mesmo para se fazer homem, a transcendência entra na imanência para se anunciar, assim como o inteligível, para que seja comunicado, deve encarnar-se no signo sensível. Daí a identificação entre o Logos e Cristo, nas palavras de João. O Logos estava com Deus e o Logos era Deus. Segundo Guenon:

Não é sem razão que se podem lembrar, a propósito do simbolismo, as primeiras palavras do Evangelho de São João: "No princípio era o Verbo". O Verbo, o Logos, é ao mesmo tempo, Pensamento e Palavra: Em si, Ele é o intelecto divino, "o lugar dos possíveis". Em relação a nós, Ele se manifesta e se exprime na Criação, na qual se realizam, na existência atual, alguns desses possíveis que, enquanto essências, estão contidas Nele desde toda eternidade. A Criação é obra do Verbo. Ela é também, por isso, sua afirmação, sua manifestação exterior. (GUENON, 1993, p.17)

Evidentemente, o verbo divino não coincide, como Agostinho faz questão de frisar, com o verbo humano. No entanto, o Logos torna-se o símbolo supremo, pelo qual o intelecto chega a uma esfera superior de realidade. Para Guenon, "o simbolismo é meio melhor adaptado ao ensino das verdades de ordem superior, religiosas e metafísicas, ou seja, tudo o que é repelido e descuidado pelo espírito moderno." (GUENON, 1993, p.14). 
Para darmos continuidade às articulações entre pensamento teológico e "psicológico", é preciso investigar as diferentes articulações entre a temporalidade do espírito e de Deus. O movimento Cósmico, tal como captado pela alma, possui um futuro, um passado e um presente. Mas todo passado, todo futuro, todo presente está em Deus. A eternidade de Deus não é um tempo infinito, no sentido de que nunca tem termo, nunca tem fim. O tempo da eternidade é absoluto e não possui início, nem fim, não há transcorrer. É eternamente presente. E isso se dá pela sua transcendência ao Cosmos, ou melhor dizendo, à sua criação.

A mente é sempre presente a si mesma, conhece a si mesma, mas nem sempre pensa em si mesma. O conhecimento que ela tem de si permanece como pura potência que pode ser atualizada, ao pensar-se. No espírito humano, o pensar-se em si é eventual, o sujeito que pensa é instável, de modo que o cogito está ligado ao múltiplo e move-se no múltiplo, pensando ora nisso, ora naquilo. Por isso, o pensar em si é sempre instável, o conhecimento de si, por sua vez, é estável. Assim, o pensamento torna-se mais estreito que o conhecimento.

A maravilhosa capacidade do espírito é a de superar o dado sensível e penetrar o sensível e apreender as ideias inteligíveis, com as quais o homem chega vislumbrar Deus, embora, nesta vida, não seja uma visão face a face. A intuição do espírito e de seu modo de ser, distinto do modo "coisal", fez com que Agostinho superasse uma noção puramente corporal de substância. O espantoso é que o mundo sensível existe em imagem dentro do espírito:

Grande é essa força da memória, imensamente grande, é meu Deus, santuário amplo e sem limites. Quem lhe chegou ao fundo? E esta é a força do meu espírito e pertence à minha natureza, e nem eu consigo captar o todo que eu sou. Logo, o espírito é estreito para abarcar a si mesmo: então onde poderá estar o que de si mesmo ele não abarca? Acaso fora de si mesmo e não dentro de si? Como é que, então, o não abarca? Muita admiração me causa isto, a estupefacção apodera-se de mim. Deslocam-se os homens para admirar as alturas dos montes, e as ondas alterosas do mar, e os curso larguíssimos dos rios, e a imensidão do oceano, e as órbitas dos astros, e não prestam atenção a si mesmos nem se admira de que, quando eu dizia todas essas coisas, não as via com os olhos, e todavia não as diria, se interiormente não visse na minha memória, em espaços tão vastos, como se os visse fora de mim, os montes, e as ondas, e os rios, e os astros que vi, e o oceano a que dei crédito. E, todavia, vendo essas coisas, não as absorvi, quando as vi com os olhos, e não são essas coisas que estão em mim, mas sim as suas imagens, e sei a partir de que sentido do corpo cada coisa foi impressa em mim. (Conf. $\mathrm{X}, 9,12 ; 2004, \mathrm{p} .459)$

Mas observando essas imagens, o espírito nada encontra que sirva para representar sua própria imagem. É preciso superar as imagens para ver a si mesmo. O puro poder de formar imagens não tem uma imagem. O espírito sabe de seu poder de guardar em si as imagens e 
posteriormente reproduzi-las ao pensá-las. Por isso, o espírito humano, embora seja limitado, é capaz de reter parcialmente o Cosmos de dentro de si.

Mas seu espírito humano nunca é pura atualidade e seu ser, ainda que inteligível, está em constante movimentação, pois a vontade não se apega e não repousa em nada.

Ao investigar o tempo, Agostinho nota que o tempo só existe para um ser que tem memória, atenção e expectativa. A medida do tempo é um certo modo de se medir a memória. Localizo na memória uma experiência vivida faz muitos anos e diferencio-a de uma experiência que vivi ontem. Sempre estou no presente e é a partir do presente que meço o tempo. O passado é o reino do que já foi, não é mais. O passado deixa de ser no plano do Cosmos; mas pode permanecer no espírito. O que aconteceu ontem não é mais. Mas o acontecimento permanece em meu espírito. O futuro mostra-se não como a esfera do que é, mas como a esfera do possível, mas também do provável e, em alguns casos, até mesmo como certo. O que é presente não é apenas as circunstâncias sensíveis que envolvem e formam a casca do animus, mas o próprio espírito a si mesmo. Mas, assim como o Cosmos está em constante mutação, a vida do espírito também está em constante devir, em virtude da mobilidade da intentio voluntatis, pois ela nunca fixa o olhar do espírito em um único objeto.

Os homens conhecem o passado; A vinda de Cristo faz parte do passado, mas Cristo não se tornou realidade passada, algo que foi e não é mais. Pois Cristo permanece vivo no espírito dos homens, pois Cristo é o Logos. O próprio simbolismo do verbo deixa entrever essa relação entre o eterno e o passageiro. O verbo é Pensamento no interior e Palavra no exterior. A palavra expressa, pelo seu corpo material, é algo que nasce, tem uma duração e morre, mas a palavra, o verbo interior, permanece no espírito. Sua exteriorização não afeta o seu ser, assim como quem transmite os próprios conhecimentos não perde os seus próprios conhecimentos. O número um está em todos os espíritos e, ainda assim, continua sendo o mesmo número um. Mas como é possível que o mesmo um esteja em múltiplos espíritos sem que se subdivida em partes? Para que uma quantia de vinho esteja em vários lugares ao mesmo tempo é necessário dividi-lo em partes. Mas um ser inteligível pode habitar vários espíritos e ainda assim ser o mesmo, exatamente o mesmo.

A onipresença e a onisciência poderia ser concebida levando em conta o modo de ser do espírito. Assim, Agostinho pode abandonar a noção segundo a qual Deus é uma espécie de éter imóvel que abarca o espaço; noção essa tirada, como já observamos, do pensamento imagético.

A onisciência só é adequadamente concebida em termos espirituais. Outra vez é preciso partir do ponto de apoio de que a mente pode, como afirmarmos, ter o passado dentro de si. 
Embora o tempo seja fluxo, a mente sustenta em si, no presente, pela memória, o passado. Mas o que dizer do futuro, que é o reino da possibilidade? O futuro é o reino do possível, do imprevisível, mas também do provável. Mas o que dizer dos profetas e dos astrônomos, que possuem o dom de prever o futuro? O antigo astrônomo, durante séculos, foi tido como uma espécie de mago, pois ele era capaz de prever os eclipses. Tales de Mileto previu o eclipse de 28 de maio de 585 A.C. Mas na Babilônia, dois séculos antes, já existem relatos de previsões de eclipses. Não é de se espantar, nas tradições antigas, uma forte correlação entre o movimento dos astros e a previsão do futuro, entre a fusão da figura do profeta e do astrônomo.

Mas o ponto que queremos alcançar é que o homem que anunciava um eclipse havia, de algum modo, visto o futuro dentro de si. O intelecto humano, ao se aplicar aos dados sensíveis, é capaz, em certa medida, de prever o futuro. Daí que chegamos à conclusão que o espírito humano é capaz de conter, dentro de si, não só a "imagem do mundo atual", como também em certa medida, a imagem do mundo que foi e não mais é, mas também do mundo que será e ainda não é. Por isso, o ser do espírito supera o ser do Cosmos. O Cosmos é um puro acontecer, de modo que está sempre no presente, o que aconteceu não é mais e o que irá acontecer não é. Já o espírito humano, por essência, transcende o tempo presente, pode ter e ver dentro de si, apesar de certas limitações, o passado e o futuro do Cosmos. Mas passado e futuro não existem efetivamente e realmente no Cosmos, pois este é puro devir, sempre está no presente. Passado e futuro são duas dimensões do espírito. O espírito é capaz de ter uma parcela do Cosmos dentro de si e trazer para o presente tanto o passado como o futuro. E isso revela algo do espírito, válido para o homem e para Deus. Se o homem não conseguisse prever absolutamente nada com um grau relativo de sucesso, a vida do homem não seria possível. Mas ainda que o homem conhecesse todo o passado e todo o presente, ainda assim o seu espírito não se assemelharia a Deus. Porque, no homem, o pensar é distinto de conhecer. Seu conhecimento é potência, o pensamento é ato. Como o homem não é capaz de atualizar toda a potência, o fluxo de pensamento permanece. Mas se tudo, incluindo passado o presente e o futuro, permanecessem presente ao olhar do espírito, não haveria a consciência da passagem, não haveria corrupção, não haveria o movimento. Mas isso, como já foi observado atrás, não quer dizer que Deus se limite a isso. Pois Deus não se limita a onisciência de sua criação. Deus também se relaciona consigo mesmo, embora esse relacionar-se não seja um relacionar-se temporal. Por isso, segundo Agostinho, Deus se conhece e se ama, mas não se pensa, pois o pensamento envolve fluxo, movimento do espírito e Deus é imutável. 
Por esses fatores mencionados, a consideração de que Deus é o Todo, o Cosmos ou é simplesmente a alma do Cosmos, não é bem vinda ao entender de Agostinho. Pois tudo que está no Cosmos e é imanente ao Cosmos e é mutação, é um constante deixar de ser o que é. Deus, por seu turno, é aquele que é. A única forma de se compreender isso, como dissemos, é explorando o que Agostinho denomina substância espiritual, desvinculando o pensamento do estilo pelo qual se pensa a matéria.

Com isso, a investigação teológica está incrivelmente articulada com a investigação do espírito e do homem. O homem é a imagem de Deus "em enigma e espelho". 
PARTE II - Os atos reflexivos como método de conhecimento em Husserl 


\subsection{A ciência de fundamento absoluto}

\subsubsection{Apresentação}

Algumas observações e advertências nos parecem convenientes para que o leitor seja capaz de se nortear e entender o espírito e os critérios selecionados na confecção desta segunda parte do trabalho.

Os primeiros capítulos se pautam em uma discussão sobre princípios ${ }^{169}$. Os princípios encontrados constituirão os pilares na construção e investigações posteriores.

Essa discussão, embora um tanto quanto árida e difícil, é necessária, dado a discrepância entre os métodos e os pressupostos aqui adotados e os que atualmente norteiam a psicologia ${ }^{170}$. Entretanto, os princípios que regem as ciências deve ser posto sobre exame, quando seus princípios começam a tornar-se insuficientes para abarcar e dar conta dos fenômenos investigados. Torna-se preciso retomar a questão: “o que é o conhecimento?"171.

Essa discussão merece importância, se estudarmos as raízes da psicologia científica. Muitos dos filósofos do século XVIII e XIX viram na física de Newton um modelo de ciências, na qual se fundiam os princípios da dedução e da indução, pois, por um lado, tinha o rigor da matemática, por outro lado, não era puramente ideal, mas uma ciência da natureza ${ }^{172}$. A mecânica de Newton e, de modo geral, a ideia o experimentalismo de Galileu pareciam sugerir as bases sobre as quais deveria se apoiar todo conhecimento sobre a natureza, incluindo aí o próprio homem. Essa tendência deixou marcas profundas na psicologia e encontra-se na base da "psicologia científica" do século XIX. A consequência de tal posicionamento é que os conhecimentos acerca da psique, do espírito, e da alma, antes do século XIX não eram mais entendidos como "conhecimentos científicos”. Essa concepção se

\footnotetext{
${ }^{169}$ Quem não tem claro para si mesmo os próprios princípios e porque os colocou, nem sabe como justifica-los, carece de uma dose de consciência intelectual.

${ }^{170}$ Norteiam a psicologia de um modo até mesmo psicológico, atuam no inconsciente do investigador. Esse quantum de inconsciência acerca dos princípios elementares do pensamento científico não impede, entretanto, o cientista de continuar seu trabalho diário cotidiano e de enriquecer sua ciência. O cientista, muitas vezes, tem como incorporados em si os princípios vigentes, que já se mostraram sólidos pela tradição. Por serem consolidados, usa-os como que naturalmente, movendo com destreza dentro deles, como a criança que, aos poucos vai falando na gramática correta da língua, apenas pela imitação de seus pais. Possui a seu favor os frutos práticos, técnicos e previsão e a descrição de fenômenos.

${ }^{171}$ Einstein só conseguiu superar Newton em virtude de seu poder teórico, ao colocar em revisão o suporte conceitual empregado por Newton No que concerne propriamente à relatividade geral, Einstein observou que as leis mecânicas só tinham validade em referenciais inerciais, mas não se sabia onde encontrar no universo, um deles. A terra não servia, devido aos movimentos de rotação, nem mesmo o sol. O referencial inercial mostravase, entretanto, uma "ficção útil", como um princípio útil para construção da mecânica. (c.f EINSTEIN; LEOPOLD INFELD; 1988; p.172).
}

${ }^{172}$ Kant mesmo se deixou fascinar, e construiu uma filosofia para mostrar que são possíveis juízos sintéticos $a$ priori. 
reflete em muitos manuais de História da Psicologia, nos quais vem distinguindo o conhecimento científico e pré-científico. O pressuposto é que por "ciência" deve se entender ciência experimental. Aliás, a natureza, inclusive o homem só revelam experimentalmente. Como veremos, a fenomenologia é uma ciência. E não há razão alguma para não denominar os conhecimentos alcançados por este método de científicos. Todavia, não há, na fenomenologia, experimentalismo algum, pois não se trata de uma ciência de fatos, mas uma ciência de essências, cujo método central, por assim dizer é a reflexão.

Ao que parece, a variedade de sistemas psicológicos existentes e ausência de um diálogo entre eles, como se cada qual falasse uma língua, é sintomático. A ideia de Husserl é, de certo modo, encontrar a "pedra de roseta", que permitisse um diálogo e uma contribuição recíproca entre as psicologias. Ao parecer de Husserl, faltava aos psicólogos clareza não só do objeto, quanto dos métodos para investigá-lo.

Antes de se fazer psicologia, deve-se ter muito claro: o que é o sujeito psíquico? Essa questão simples: “O que é?" e não o "como é?” constitui a base da fenomenologia. Mas antes de se questionar o que é o sujeito psíquico, era preciso dar um passo atrás e se questionar: $\mathrm{O}$ que é o conhecimento? O que é possível conhecer? Quais os domínios do ser? Qual a interrelação entre esses diferentes domínios? Segundo Husserl, são estas as autenticas questões filosóficas, pois o filósofo não está interessado nas ciências particulares, tem como objeto supremo o ser, a razão e a verdade, os quais são correlatos inseparáveis.

Husserl observou que o significado de conhecimento havia sido estreitado de forma insuportável. Foi um defensor fervoroso da razão e do conhecimento. Isto, ao ver de Husserl era tarefa de grande importância, pois, para ele, a filosofia estava sendo tomada, de um lado, por correntes irracionalistas e relativistas, e por outro lado, por outro lado, pelo positivismo, cuja característica é a orientação naturalística, que é, por essência, reducionista, dado sua cegueira à determinadas regiões ontológicas. Positivismo de um lado; relativismo de outro. É contra estas duas correntes que Husserl trava uma guerra aberta.

Retomando a tradição socrática, Husserl afirma que é a fundamentação o que distingue a doxa da episteme. O homem que não sabe justificar e fundamentar coerentemente seus juízos, não possui conhecimento, mas opinião. A doxa pode ser verdadeira, mas na mente do homem que não sabe justificá-la, ela tem uma estabilidade instável, pois tal homem crê em uma opinião como poderia crer em qualquer outra; crê, muitas vezes, por razões fortuitas, por motivos psíquicos e não racionais. O filósofo, tanto quanto o cientista, busca a episteme, o conhecimento dado com garantias; já os sofistas ensinam não o conhecimento, mas a arte de 
esmaltar as opiniões de modo que elas pareçam conhecimento, convencendo os outros em virtude de interesses pessoais.

Em primeiro lugar, quem quiser realmente tornar-se filósofo deverá "uma vez na vida" voltar-se para si mesmo e, dentro de si, procurar inverter todas as ciências admitidas até aqui e tentar reconstruí-las. A filosofia - a sabedoria - é um assunto pessoal do filósofo. Ela deve constituir-se como algo dele, ser a sua sabedoria, seu saber, que, embora se volte para o universal, seja adquirida por ele e a qual ele possa ter condições de justificar desde a origem e em cada uma de suas etapas, apoiando-se em suas intuições absolutas. (HUSSERL, 2001, p.20).

Saber pensar é algo distinto de ter a cabeça cheia de informações cujas garantias ou fundamentos não são conhecidos. O filósofo, acima de tudo, luta com bravura para discernir fantasmas e visões reais, e alimenta, com incansável insistência, seu o incômodo hábito de pedir pelos princípios, desenterrar os fundamentos, lançar luz nos pressupostos implícitos, e investigar o processo e a origem do que é dito.

A formação intelectual de Husserl já é reveladora de seu estilo de pensamento. Husserl inicia sua vida acadêmica, graduando-se em matemática, no de 1883, com uma tese em cálculo de variações. Perdidas as chances de se tornar assistente de Weierstrass (1815-1897) em Berlin, Husserl se estabelece em Viena, onde conhece Brentano (1838-1917) e lê sua famosa Psicologia como ciência empírica. De Brentano, Husserl tira a ideia de intencionalidade da consciência. E Brentano havia convencido Husserl a ler Doutrina da Ciência, cujo autor, Bolzano (1781-1848), era um lógico que sustentava a hipótese de se ter um conhecimento em si, independente de fatores subjetivos. Por essa razão, a verdade é eterna, pois é objetiva, não depende da psique do sujeito. Uma verdade continua sendo verdadeira ainda que ninguém pense nela.

Já decido neste caminho investigativo, Husserl se deparará com o pensamento de Lotze (1817-1881), que retomava a tradição platônica das ideias, embora as reformando. Para Lotze, as ideias nada mais são do que possibilidades apriorísticas.

Lotze tinha de fato elaborado uma ideia de verdade que retomava a teoria platônica das ideias atrás de uma bem precisa noção de apriori, que ele distingue claramente daquela de inato. A priori não é aquilo que está na mente, não alude a uma impossibilidade psicológica de pensar diversamente. O essencial daquilo que Platão chamava de ideia deve ser colhido distinguindo entre a mera afeição dos sentidos, que passam e repassam, e aquilo eles significam. (...) E isso significa que os conceitos através dos quais as coisas são pensáveis não tomam parte em sua modificabilidade. (COSTA, p.70).

Em outras palavras, se na realidade uma coisa deixa de ser doce vai se tornando, aos poucos, azeda, isso não significa que o próprio azedo tenha se tornado doce. Existe uma 
noção apriorística de doce e de azedo. Daí que o significado de doce será eternamente distinto do significado de azedo.

Já se vê aí que este modo de compreender não pode ser negado por qualquer forma de ceticismo, pois o fundamento do ceticismo reside nas dificuldades em se confirmar a relação entre o pensamento e o real. Mas a distinção entre as noções apriorísticas não dizem respeito à sua concordância com o real. Ao se afirmar que "o azedo não é doce" não se está afirmando que aquela determinada coisa real é azeda e por isso não é doce. Pode ser azedo para uns, doce para outros; algo que antes eu sentia como doce pode parecer-me azeda quando meu fígado está atacado. De todo modo isso não altera o significado, a essência do azedo. ${ }^{173}$

Este modo de se compreender o conhecimento será aceito por Husserl, o qual retomará em Ideias 1, o termo grego eidos para designar as essências, retomando, aos moldes de Lotze, a tradição platônica. Mas as diferenças com o pensamento platônico são cruciais. Os eidos não são entendidos como algo inato e não constituem os arquétipos com os quais o demiurgo criou mundo. O eidos é apenas algo dado em intuição. Se uma pessoa me diz que sua casa pegou fogo, eu o entendo e torno-me consciente do que aconteceu. Não vi sua casa, mas sei o que é uma casa. Não sei se sua casa era de madeira ou de tijolo. Mas sei a essência do objeto do qual ele está falando. O eidos casa refere-se a um conjunto de possibilidades e impossibilidades apriorísticas. Por isso, possui uma elasticidade, pois inúmeras casas individuais poderiam representar o eidos. Se eu vejo uma casa que nunca antes vi, sem ninguém me dizer nada, sei que é uma casa.

Dotado do gosto demonstrativo dos matemáticos, tendo as ideias de Bolzano e Lotze vivas em seu espírito e, por outro lado, conhecendo a psicologia de Brentano e sua ideia de intencionalidade, Husserl dedicará dez anos de trabalho concentrado na escrita de Investigações Lógicas. Esta obra que tem como escopo derrubar o psicologismo, defendido por muitos autores, dentre eles Stuart Mill, para os quais a ciência lógica seria um ramo da psicologia. Husserl procura demonstrar que as leis lógicas não são decorrências do aparato psíquico do sujeito. É preciso separar os domínios, a psicologia não tem o direito de legislar sobre a lógica.

\footnotetext{
${ }^{173}$ No âmbito da matemática, é fácil perceber que um quadrado não é um círculo e não pode sê-lo; Mas apenas quem intuiu o que é um quadrado e o que é um triângulo sabe que eles não podem ser o mesmo. Mas, a coisa não se modifica no caso do vermelho e do verde. O significado de verde é distinto do significado de vermelho para quem os intuiu.
} 
Tudo isso será exposto na segunda nesta segunda parte do trabalho. Devido à extensão do trabalho de Husserl, tivemos que excluir muitas das discussões feitas pelo autor para apenas nos deter apenas aos conceitos sem os quais não teríamos condições de justificar os resultados das análises do sujeito psíquico e do método reflexivo. Devido à dificuldade do texto de Husserl, optamos por usar o mínimo possível os termos técnicos ${ }^{174}$.

Procuramos focar no essencial, dando especial ênfase nos temas que na primeira parte já havíamos abordado. De todo modo, a exposição do método e dos princípios da fenomenologia são etapas necessárias. Pois elas fornecerão os fundamentos e as justificativas da psicologia apriorística. Ademais, se apresentássemos as conclusões de Husserl acerca do sujeito psíquico, sem expor os fundamentos, estaríamos no terreno da doxa, da opinião. Nada mais fora do espírito husserliano dar crédito a um discurso apenas pela "autoridade do autor" ou por "motivos psíquicos". O conhecimento só é conhecimento quando fundamentado em bases racionais.

Tendo estabelecido as bases do método e organizando as ferramentas conceituais, iremos então abordar o sujeito psíquico. O problema básico foi o de esclarecer o que é a psique, o espírito, a consciência e o corpo e o conceito de "mundo circunstante", ou "mundo da vida"175. Não foi possível omitir nenhuma destas questões, dado que estão intimamente correlacionadas. E para coordená-las é necessário partir daquilo que Husserl denomina o princípio de todos os princípios: a intuição.

As discussões sobre o sujeito psíquico e a psicologia apriorística foram inteiramente sustentados fundamentalmente em Ideias 2. Complementamos as análises com algumas obras de Edith Stein, sobretudo Psicologia e Ciências Humanas, Introdução à Filosofia e A Estrutura da Pessoa Humana e alguns ensaios de Ortega y Gasset. Contudo, recortamos de tais autores apenas as ideias que nos serviriam para clarear e ilustrar os fenômenos descritos por Husserl em Ideias 2.

\footnotetext{
${ }^{174}$ Seu estilo é seco e seu conteúdo só entra no espírito com muita dificuldade. O texto de Husserl é árido, dotado de muitos termos técnicos, pouquíssimos exemplos e raríssimas referências a outros autores. Não se trata de dizer que os termos técnicos empregados por Husserl não seja necessários, o são, pois, como ele afirma, muitos dos termos tradicionais induzem equívocos, razão pela qual, por exemplo, em Ideias 1 ele afirma que ele evitará de usar o termo "ideia" e "objeto ideal", dado o tanto de leituras equivocadas de sua obra anterior. Dirá que usará o termo grego eidos.

${ }_{175}$ Termo empregado por Husserl em Crise das Ciências Europeias
} 


\subsubsection{O projeto de Husserl e a psicologia eidética}

O projeto de Husserl é nada menos que o de construir uma ciência universal de fundamentos absolutos. Uma ciência de essências puras, que servisse de fundamento racional às diversas ciências de fatos particulares. Trata-se de uma ciência eidética (ou "ciência de essências" e "ciência apriorística"). Seu método é a redução eidética e a redução transcendental. Pela primeira chega-se à essência dos fenômenos; pela segunda chega-se à essência da consciência.

As "ciências de fatos" se sustentariam nesta "ciência de essências", absolutamente rigorosa e radical, assim como a física, que é ciência da natureza, tem como um de seus suportes a matemática. Observa-se, nitidamente, neste caso, que a física, que é ciência empírica, encontra seu sustentáculo em uma ciência não-empírica. Não se confirma um teorema matemático pela observação natural, mas se demonstra um teorema matemático pela via racional. A matemática, a lógica, a teoria dos conjuntos, e outras ciências do gênero, não são "ciências de fatos", "ciências experimentais". Tais ciências se desenvolvem pelo puro esforço intelectual do pesquisador em explorar o eidos ou essência ou formas apriorísticas. O eidos não é fruto do capricho humano. São simplesmente possibilidades e impossibilidades apriorísticas que se representam em objetos singulares. Faz parte, por exemplo, da essência do sentimento não ter extensão.

O projeto fenomenológico visa à elaboração de uma ciência de essências que, colocada na base, serviria para coordenar as ciências particulares existentes em uma unidade sistemática. Em certo sentido, a ideia fim coincide com aquela proposta por Descartes, o de construir uma filosofia de fundamentos absolutos:

Ela objetiva uma reforma total da filosofia, para fazer dela uma ciência com fundamentos absolutos, o que implica, para Descartes, uma reforma paralela de todas as ciências, pois, ao seu ver, essas ciências não passavam de componentes de uma ciência universal, que não é outra coisa senão a filosofia. (HUSSERL, 2001, p.20)

No horizonte de Husserl está a ideia de ordem sistemática do saber em correspondência com a ordem de estratificação do ser. Em seu artigo para a Enciclopédia Britânica, Husserl compara a fenomenologia com Organon de Aristóteles. Para tanto, é preciso estudar a essência das diferentes regiões do ser:

De um lado, estão as essências materiais, e estas são, num certo sentido, as essências "propriamente ditas". De outro, porém, está algo eidético, mas fundamentalmente distinto: uma mera forma eidética, que é uma essência, mas completamente "vazia", uma essência que, no modo de uma forma vazia, convém a todas as essências possíveis, que, em sua generalidade formal, contém todas as generalidades, inclusive as mais altamente 
materiais, e lhes prescreve leis mediante as verdades formais a elas inerentes. (HUSSERL, 2006, p.46).

O primeiro nível do edifício teórico seria o estudo do objeto enquanto objeto e suas leis apriorísticas. Uma ciência apriorística válida para um "objeto em geral” será válida para qualquer objeto determinado de uma ciência particular. Sua função seria a elucidação das regras sobre as quais todas as ciências objetivas poderiam se mover de modo racional. Esta ciência que estuda o objeto esvaziado de qualquer conteúdo material é o que Husserl denomina, valendo-se da terminologia Leibniz, Mathesis Universalis, ou Ontologia formal. Tomando o objeto entendido como correlato da consciência, Husserl observa que, por objetos, não se entende apenas objetos reais. Toda ciência objetiva trata de determinados objetos, sejam reais, ideais, psíquicos, ou fantasiados, objetos da cultura. Aliás, por isso mesmo, a lógica é uma ciência objetiva, pois trata de objetos ideais, como conceitos e juízos. O conceito, como iremos posteriormente examinar, não é um objeto psíquico, pois os objetos psíquicos são a-espaciais, porém temporais. Um sentimento tem uma duração e some, um pensamento dura um instante; o conceito "livro", por seu turno, é a-temporal, a-espacial, em suma, é "objeto ideal" e "irreal", pois o conceito de livro não ocupa um lugar no espaço e não envelhece. Mas devemos observar que a ontologia formal não é o estudo estritamente dos objetos ideais, mas de todo e qualquer objeto em sua estrutura formal de objeto, inclusive "objetos reais" "176, ou seja do objeto esvaziado de matéria intuitiva, e por isso, abarca também os "objetos reais", os quais apenas representam possibilidades de ser do objeto.

A ontologia formal não compreende apenas a lógica, mas a teoria dos conjuntos, a teoria das variedades, e outras teorias formais. Por ser uma investigação formal do objeto enquanto objeto e das possibilidades apriorísticas de relações possíveis entre eles, esta ciência abriria ao investigador das ciências particulares o reino do possível, ao mesmo tempo limitando-o ${ }^{177}$, afinal qualquer ciência objetiva trata de certos objetos.

A segunda parte do sistema consiste em delimitar as "ontologias materiais" ou ontologias regionais. Husserl procura provar que as ciências empíricas estão sujeitas não apenas as leis formais-ontológicas, mas também às leis próprias, inerentes ao eidos da região. A tarefa é estabelecer as regiões ontológicas, investigando, para cada uma delas, suas

\footnotetext{
${ }^{176}$ As aspas são necessárias, pois o verdadeiro sentido de objeto real ainda precisa ser elucidado.

${ }^{177}$ Esse aspecto observa-se claramente pela necessidade de consistência lógica que mesmo uma teoria biológica deve ter. Se digamos que uma teoria biológica dissesse que "todos os mamíferos possuem sangue quente", que "baleia possua sangue frio" e que "baleias são mamíferos". Essa contradição interna, puramente lógica, do corpo teórico pede algum tipo de resolução.
} 
condições apriorísticas. Husserl procura mostrar que as ciências empíricas estão sujeitas não apenas as leis formais-ontológicas, mas também às leis próprias inerentes ao eidos da região.

Pois é inteiramente manifesto (caso a postulação feita seja acertada) que a investigação dos fatos empíricos não pode prescindir da rica reserva de conhecimento referente, de maneira pura, incondicionadamente válida, a todos os objetos possíveis da região - uma vez que estes em parte pertencem à forma vazia da objetividade em geral, em parte ao eidos da região, o qual exibe, por assim dizer, uma forma material necessária de todos os objetos regionais (HUSSERL, 2006, p.44).

Evidenciar os domínios próprios de cada uma das ciências particulares e iluminar os limites intrínsecos ao seu objeto é uma tarefa de grande importância. É legítimo tratar o ser humano como um objeto físico? É legítimo tratar uma obra de arte como um produto psicológico? É legítimo tratar uma crise econômica por um viés biológico? Para se responder tais questões seria necessário um exame acurado do que é um ser biológico, um objeto físico, uma crise econômica, uma obra de arte, em outras palavras, é preciso saber a essência de cada um desses objetos ou região de objetos. Nesse sentido, a fenomenologia pauta-se por um respeito extremo pelo próprio objeto, como ficou expresso no famoso lema "voltar às coisas mesmas"

Dentro desta perspectiva Husserl coloca as seguintes questões: Seria possível coordenar, com rigor, as várias ontologias regionais? Quais os modos de relações possíveis entre diferentes regiões ontológicas?? ${ }^{178}$

O problema das ciências particulares, como alerta Husserl, reside na falta de clareza dos princípios filosóficos que as sustentam. Como já foi mencionado, isso é especialmente válido para a psicologia, que é uma ciência de fatos. Ao parecer de Husserl, faltava-lhe uma ciência apriorística que lhe desse suporte. Daí que, não raro, encontramos psicólogos abordando o objeto de seu estudo de modo inapropriado, contrabandeando métodos de determinadas regiões ontológicas para ela. O resultado é que, por vezes, acabam desfigurando o objeto, como alguém que procura interpretar e esgotar o significado de uma obra de arte usando apenas conceitos químicos. Talvez diga alguma verdade sobre os pigmentos da tela, o que não deixa de ter sua importância, mas para que fale do valor e o significado da obra é preciso sair da química.

A matemática é uma ciência de essências. A física, por seu turno, é uma ciência de fatos. Entretanto, esta só tornou-se magnificamente frutífera porque foi construída, a partir de

\footnotetext{
${ }^{178}$ Quando falamos em tais assuntos, estamos falando de possibilidades e impossibilidades, como fez Godel, ao demonstrar a impossibilidade de se construir uma lógica completa e consistente, que, aplica à aritmética, faria com um número finito de axiomas, e com um número finito de passo, se demonstraria todo e qualquer teorema verdadeiro possível.
} 
Galileu, sobre uma base racional, a geometria, que é uma ciência que estuda a essência do espaço. Neste caso, nota-se como uma ciência apriorística ou "ciência ideal" serve de suporte a uma "ciência de fatos"

Isso é confirmado pelo desenvolvimento das ciências racionais da natureza, as ciências, físicas. Sua grande época se inicia justamente na modernidade, quando a geometria, já altamente aprimorada como eidética pura na antiguidade (e, no essencial, pela escola platônica) torna-se repentina e largamente fecunda para o método da física. (HUSSERL, 2006, p.45)

Assim como os geômetras fizeram uma ciência que investiga a essência do espaço, e esta serviu às "ciências de fatos" feitas pelos físicos, o fenomenólogo tem em mira construir um método rigoroso para se elaborar uma ontologia regional da psique e da consciência ${ }^{179}$. A ciência que estuda a essência da psique poderia fornecer os alicerces para a investigação dos fatos psíquicos. Por isso, Husserl afirma (2006) que a fenomenologia permite "Elevação da psicologia a um nível científico mais alto e uma ampliação extraordinária de seu campo de trabalho" (Ibid, p.26). Mas, é preciso ressaltar, o fenomenólogo não está interessado em fazer 'psicologia de fatos', pois os fatos, como veremos, são contingentes, ao passo que as ciências de essências são apriorísticas.

Por maior que seja a importância metodológica que a fenomenologia possa reivindicar no caso da psicologia, por mais "fundamentos" essenciais que ponha à disposição desta, ela (como ciência de ideias) é tão pouco psicologia quanto a geometria é ciência da natureza (Ibid, p.27).

\subsubsection{Ciência como fenômeno cultural e a noção de verdade}

O primeiro passo desta ciência absolutamente fundamentada é encontrar seus princípios. Não pode partir cegamente e aceitar qualquer outra ciência como modelo, nem mesmo a geometria ou a física.

Mas partindo da ideia de construir uma ciência absoluta e rigorosa, fica a questão: onde encontrar uma norma reguladora inerente à ciência para a usarmos na elaboração dessa ciência primeira? Onde encontrar os dados iniciais com os quais se elaborar esta ciência? Uma coisa é certa, não podemos tomar como dado inicial nenhum modelo particular de ciência, sem antes submetê-lo a uma crítica rigorosa.

Em Meditações Cartesianas, Husserl observa que, ainda que coloquemos em suspensão o valor, a exatidão e a veracidade das ciências, nada nos impede, entretanto, de tomar essas ciências como fenômenos culturais. E mesmo duvidando de sua veracidade, viver esse fenômeno cultural: "o fazer ciência". Ao fazermos ciência (tomada como fenômeno cultural)

\footnotetext{
${ }^{179}$ Como se verá adiante, consciência não se identifica com a psique.
} 
podemos, aos poucos, captar a "intenção" da tendência científica. E se examinarmos cuidadosamente o que está pressuposto nesta "intenção" científica, encontramos aquilo que poderíamos chamar de "ideia-fim" da ciência, que é ser verdadeira, isto é, que seja uma ciência "válida de uma vez por todas e para todos".

Mas trata-se de um objetivo alcançável? É possível a verdade ${ }^{180}$ O que é a verdade?

\subsubsection{A verdade não é uma crença subjetiva}

Investigar o sentido ou a essência do termo "verdade" não significa investigar se a verdade é factível. Antes de saber se a verdade é possível ou não, é preciso ter claro o que é a verdade.

Husserl critica a posição do psicologismo, pois este procura sustentar que a verdade se resume a uma "crença subjetiva". Com isso, argumenta Husserl, o psicologismo destrói o próprio sentido do termo, pois, entendido como crença subjetiva, o sentido de "verdadeiro" é posto na relação entre enunciado e sujeito que enuncia. Isso é um erro, pois o sentido de ser verdadeiro está na relação entre o juízo enunciado e o objeto a respeito do qual o juízo enuncia. De fato, a afirmação: “o número de grãos de areia na terra é menor que o número de cabelos humanos que existem em um dado instante" é ou verdadeira ou falsa, ainda que seja anunciado por alguém incapaz de contá-los e, que, ao anunciar, se mantenha no estado subjetivo da dúvida. Segundo Husserl, o ceticismo nega o sentido original do conceito de verdade e ao fazê-lo cai necessariamente em contrassenso.

Cai em contrassenso pelo modo como entende os princípios lógicos. Tomemos, como exemplo, o princípio de não-contradição. O psicologismo entende-o como uma impossibilidade psicológica de se acreditar simultaneamente em duas afirmações excludentes. Ao reduzir o princípio de não contradição ao nível psicológico, o psicologismo faz com que essa lei seja contingente e não uma impossibilidade apriorística. Levado as últimas consequências, nada descarta a possibilidade de imaginarmos uma criatura dotada de um outro aparato psicológico, capaz de acreditar em dois juízos contraditórios. Mas, nesse caso, o fato de ela acreditar simultaneamente em ambos, não significa que ambos os juízos contraditórios sejam verdadeiros, pois para que isso ocorra, seria preciso que houvesse duas realidades, ambas contraditórias. Uma que corresponda a um juízo e outra que corresponda ao juízo contraditório. Evidentemente, isso é um contrassenso. O princípio de não-contradição é necessário, é uma verdade apriorística e se sustenta na própria estrutura ontológica. Seu

\footnotetext{
${ }^{180}$ A ciência, mesmo que matemática, é um conjunto sistemático de juízos, não meros juízos, mas juízos fundamentados.
} 
oposto é inconcebível. Uma teoria que vise a descrever determinado domínio de fatos só pode ser verdadeira ou falsa se possuir consistência lógica. Uma teoria que contradiz si própria é absurda e não pode ser falsa ou verdadeira.

\subsubsection{O ato de julgar e o juízo}

O que constitui o ponto cego do psicologismo é a confusão entre o ato de pensar e o conteúdo do pensamento, ou mais pontualmente, entre o ato de julgar e o juízo. O ato de pensar pertence aos domínios psicológicos e possui seu campo próprio de investigação. $\mathrm{O}$ juízo, por seu turno, é objeto das ciências lógicas e as leis que o regem não são psicológicas, mas leis lógicas. $\mathrm{O}$ ato de pensar é algo real, isto é, tem uma duração no tempo; pensamos em uma coisa e depois pensamos em outra, em constante fluxo. Já o juízo não possui duração no tempo, é um objeto ideal, atemporal. Por essa razão, posso pensar, quantas vezes quiser, na segunda lei de Newton, sem que esta se altere - esta continuará sendo idealmente a mesma. $\mathrm{O}$ ato de pensar na lei dura enquanto penso, é um evento psíquico real. Se depois de vinte minutos penso outra vez na mesma lei, ocorre um novo ato de pensar na lei, um novo evento psíquico; no entanto, a lei continua sendo a mesma, tanto antes quanto depois. As ciências apriorísticas não se reduzem à leis de fato e os domínios de investigação do psicólogo são distintos dos domínios de investigação do lógico e do matemático.

Um juízo, por ser um objeto ideal, permanece sempre o mesmo, não envelhece e não se altera, esteja eu pensando nele ou não, seja ele verdadeiro ou não. Meu estado psíquico, no momento em que penso o juízo, não é falso nem verdadeiro. O que pode ser falso ou verdadeiro é o juízo: se está em conformidade ou não com o estado de coisas julgado. O juízo: “agora não está chovendo" será verdadeiro não em virtude de uma crença subjetiva, mas será verdadeiro se, efetivamente, não estiver chovendo. Esse é o sentido de ser verdadeiro. E se eu digo que "dois mais dois é igual a cinco" isso não é falso porque tenho um sentimento de “mal estar subjetivo", razão pela qual decido não acreditar nisso, mas sim porque a intuição intelectual vê que tal juízo não corresponde aos próprios objetos ideais, às essências em questão.

O que convém observar é que a lógica, a matemática, e as demais ciências não tiram suas leis de mecanismos psicológicos. As leis psicológicas que ligam os pensamentos em seu fluxo real são distintas das leis lógicas para se encadear um juízo a outro de modo correto. Em um fluxo de pensamento real, o homem pensa em uma coisa, lembra-se de outra, imagina o que vai fazer, vê algo que está fora, associa isso àquilo, lembra de um desafeto, de uma obrigação, sente vontade de fazer outra coisa, etc. Os escritores do século XX exploraram o 
fluxo de pensamento. As leis desse fluxo não são as leis do pensamento lógico. O estudo desse fluxo real do pensamento e suas leis de associação pertencem à psicologia.

\subsubsection{Os dados iniciais e a evidência}

Uma vez que tenhamos claro a essência do ser verdadeiro, é necessário agora verificarmos se a verdade é possível. É possível conhecer as próprias coisas para saber se o juízo corresponde a elas?

Há dois tipos de juízos, os mediatos e os imediatos. O julgamento ${ }^{181}$ mediato é aquele no qual acreditamos não devido a ele próprio, mas devido à nossa crença em outro julgamento o qual cremos que o fundamenta. Cremos em um julgamento não por si próprio, mas porque cremos em outro julgamento.

Ao captarmos ainda a tendência científica, fica claro que os juízos científicos necessitam de ser demonstrados, provados. O cientista não quer afirmar coisas por que tem sentimento pelo que disse, não quer afirmar juízos fortuitos, mas almeja que seus juízos sejam fundamentados. Mas se o juízo for verdadeiro e conhecemos sua justificação, ele se torna para nós um conhecimento.

Podemos "voltar" a vontade, a uma justificação uma vez estabelecida, ou à "verdade", uma vez "demonstrada". Essa liberdade de que temos de reproduzir e de perceber novamente em nossa consciência uma verdade concebida, como sendo identicamente "a mesma", faz com que essa verdade seja para nós um bem definitivamente adquirido, chamado então de conhecimento. (HUSSERL, 2001, p.28)

Poderíamos dizer que um juízo mediato se fundamenta em outro juízo. Mas esses mesmos juízos deveriam ser apoiados em outros para que sejam fundamentados. Mas deve-se chegar a um termo, para que a série tenha fim ou não seja circular. Ou seja no final da série, deve-se ter um juízo imediato, o qual não se demonstra por meio de outro juízo. Não pode ser demonstrado, mas apenas mostrado, tal como os axiomas matemáticos.

O que é, afinal, um juízo imediato e verdadeiro? Husserl oferece a seguinte resposta: "Na justificação verdadeira, os julgamentos demonstram sua "exatidão" ou seu "acordo", ou seja, o acordo de nosso julgamento com a própria coisa julgada.” (HUSSERL, 2001, p.28). Portanto, o único modo de sabermos se um juízo é verdadeiro seria conhecer a própria coisa julgada. Mas é possível que a consciência tenha acesso às próprias coisas? O único modo

\footnotetext{
${ }^{181}$ Usamos aqui, julgamento e juízo como sinônimos, diferenciando-os do ato de julgar.
} 
possível de se ter acesso às próprias coisas seria se as próprias coisas se mostrassem à consciência. O que se mostra à consciência será o dado fundamental que procuramos.

Esse "mostrar-se" das coisas à consciência é o que Husserl denomina evidência ou intuição. "Na evidência, a coisa ou o fato não é somente "vista", de maneira distante inadequada; ela própria está presente diante de nós, e o sujeito que julga tem dela uma consciência imanente." (HUSSERL, 2001, p.28).

Portanto, o julgamento, sem a evidência, nada mais é do que uma presunção de que a coisa seja tal como se julga. Se o juízo revela-se verdadeiro, em virtude de uma evidência, ele deixa de ser uma mera presunção, pois o estado de coisas antes presumido é agora estado de coisas "visto", o estado de coisas está presente diante da consciência. Em termos técnicos, a intenção significativa, antes distanciada, se preenche intuitivamente. A evidência é uma experiência que o sujeito tem com o próprio objeto. "Na evidência, no sentido mais amplo deste termo, temos a experiência de um ser e de sua maneira de ser." (HUSSERL, 2001, p.29). A noção de verdade está intimamente relacionada à noção de intuição, evidência ou experiência.

Intuir algo "em carne e osso", ter a evidência de algo, ter a experiência de algo são usados como sinônimos por Husserl. Quando a experiência desmente um juízo, o juízo mostra-se falso. Em certo sentido, o próprio empirismo procura tomar, por princípio, que todo conhecimento deve se sustentar na experiência, o que para Husserl equivale a dizer que ele quer se sustentar na evidência empírica, na intuição empírica. Intuição, evidência, experiência é o que fornece os dados à consciência. Não tenho o poder subjetivo de mudar as evidências. E uma das evidências mais básica, para nós, que vivemos o cotidiano, é a evidência perceptiva ou empírica. Se alguém me diz: "Há uma xícara em cima da mesa” e logo depois vejo a uma xícara em cima mesa, o juízo enunciado revela-se verdadeiro, posto que, pela evidência empírica, ele mostrou seu acordo com o estado de coisas julgado. A percepção, como veremos, é o estado cognitivo fundante.

A fenomenologia fundamenta-se na evidência, o que nada mais significa que ela só pode afirmar a respeito do que é dado à consciência. "Em consequência, não poderia evidentemente nem emitir nem admitir como válido nenhum julgamento, se não tenho a partir da evidência, ou seja, em experiências em que as "coisas" ou os "fatos" em questão me são apresentados “em si”.(HUSSERL, 2001, p.31). 


\subsubsection{O grau de perfeição da evidência}

Para que o juízo seja verdadeiro ele deve corresponder à própria coisa. Mas o único modo de verificar o juízo é que a própria coisa se mostre à consciência, isto é, que se tenha evidência, experiência, intuição do objeto.

Se o problema parasse aí, tudo estaria resolvido. Todavia, a evidência empírica, melhor analisada, mostra-se problemática. As evidências empíricas muitas vezes são insuficientes, muitas vezes não sabemos até que ponto as coisas são mostradas em si mesmas. "A evidência - que abrange na realidade qualquer experiência no sentido comum, mais restrito do termo pode ser mais ou menos perfeita" (HUSSERL, 2001, p.29). Eis o velho problema do bastão submerso parcialmente na água, que se mostra curvado à visão e reto ao tato.

Se alguém me afirma "há um gato branco na sala", e eu percebo ali um gato branco, a própria percepção, na minha atitude natural, já é suficiente para confirmar o juízo. Mas até que ponto o gato mostrou-se "ele mesmo" à minha consciência? Não poderia ser uma ilusão? A intuição perceptiva não está sujeita ao erro? Talvez, aproximando e "vendo melhor" descubra que não era um gato que havia na sala, mas um brinquedo, um boneco com a forma de um gato. Tudo isso leva à seguinte pergunta: "até que ponto os objetos, pela intuição empírica, se mostram à consciência?"

Ampliando a questão e aceitando o princípio da evidência como critério da validade ${ }^{182}$, é preciso passar para a etapa seguinte e questionar:

1) Quais os tipos de intuições? A intuição perceptiva é válida na vida cotidiana, sabemos que é a base das ciências naturais, mas não existem outros tipos de intuições, no qual o objetos não sensíveis se mostram à consciência? Se sinto um sentimento, isso não seria uma experiência de algo? De algo que se mostra? Do mesmo modo, os números, o tempo, o espaço, uma obra de arte, o espaço são dados em intuição?

\footnotetext{
${ }^{182}$ Mas seria correto sustentar as ciências na evidência, na intuição? Alguns críticos af irmam que não é possível. A ideia de se sustentar a lógica sobre o conceito intuitivo de conjunto, um conceito que parece tão claro, mostrou-se deficiente. Bertrand Russel provou que o uso do conceito de conjunto como conceito primitivo conduzia à contradição, decorrente do conjunto que contém todos os conjuntos. A contradição foi representada pelo paradoxo do barbeiro. Estabelecendo o conceito de conjunto como fundamento da lógica, o princípio de não-contradição o acusava e o derrubava. Mas, devemos concluir daí: que não as evidências não são confiáveis? Pelo contrário, refuta-se o conceito de conjunto como fundamento da lógica devido a uma a lei cuja evidência é ainda mais forte: a de não-contradição. Em certo sentido, o lógico não parece fazer mais do que mostrar. Mas o que ele mostra para os outros é o que se mostra para ele. As ideias possuem um poder de se mostrarem-se para quem é capaz de vê-las. O princípio metodológico de Husserl é a evidência, a intuição. O filósofo que inicia sua busca pela ciência verdadeira é sempre juiz de si mesmo, sabe que não pode entregar a preciosa faculdade do seu juízo para outro, que julgue por ele. Nada mais odioso do que obedecer a alguém, a uma autoridade que imponha sua opinião sem mostrar argumento outro que não uma vontade caprichosa. Mas se o que é dito é justificado e satisfazem-lhe as exigências de seu juízo, o filósofo as acatara dentro de si e só terá a agradecer.
} 
2) Qual o alcance da evidência, o grau de perfeição e o limite de cada uma dessas intuições. Em palavras simples: "Até que ponto as coisas mostram-se à consciência elas mesmas?" 183 .

\subsubsection{As evidências adequadas ao ataque da crítica cética}

Em nossa vida cotidiana vivemos e nos orientamos no mundo segundo evidências relativas. No entanto, tais evidências relativas estão sujeitas à crítica cética. Como havíamos comentado, a evidência fundamental da vida cotidiana é a percepção. O fato de eu ver esse computador e com ele escrever, já é, para mim, evidência suficiente de que este computador é um objeto real. Mas uma filosofia que se proponha ser uma ciência radical não deve aceitar nada; nem mesmo a evidência da realidade dos objetos dados pela percepção, sem um exame crítico. Um filósofo cético poderia levantar a objeção de que não há garantias absolutas de que os sentidos não enganam ou ainda que a realidade em sua globalidade não seja outra coisa do que um sonho coerente.

Husserl aceita, por razões metodológicas, a crítica cética, que coloca em dúvida a existência real do mundo. A ciência absolutamente radical deve aceitá-la. Superá-la é o desafio.

O homem natural não vê átomos, mas objetos coloridos, pesados, rugosos, etc. O “cientista natural" 184 , por seu turno, afirma que a cor é um fenômeno subjetivo: o que há, na realidade, são ondas eletromagnéticas, cujos diferentes comprimentos são interpretados subjetivamente como cor. Ambos, entretanto, possuem algo em comum. Ambos compartilham a crença de que existe um mundo real fora da consciência.

Por razões práticas e por razões vitais, tem-se a crença na existência real do mundo. Aceita-se a percepção como um meio de se ter informações a respeito do mundo real. Entretanto, a evidência de que há um mundo real não é apodíctica. Trata-se, sem dúvida, de

\footnotetext{
${ }^{183}$ As evidências seguintes corrigem as evidências anteriores, e então sabemos que era um gato de brinquedo. Algumas vezes, temos a evidência, mas uma evidência não tão precisa. Por exemplo, vemos ao longe um carro vindo em nossa direção, não sabemos que modelo de carro é, o carro se aproxima e agora temos a evidência de que se trata de tal tipo de carro. Ora, no que concerne ao objeto percebido, podemos aumentar dele o grau de evidência, dele aproximando, examinando-o por vários ângulos e assim por diante. Por essa razão que Husserl afirma, por exemplo, que: "A vida cotidiana, para seus fins variáveis e relativos, pode contentar-se com evidências e verdades relativas. Já a ciência quer verdades válidas de uma vez por todas e para todos" (HUSSERL, 2001, p.30).

${ }_{184}$ Consideremos o "cientista natural" uma figura um tanto quanto estereotipada apenas para facilitar nossas análises. Referimos quase, um cientista natural positivista aos moldes de Simão Bacamarte, do conto "O alienista" de Machado de Assis. Isso não significa de modo algum que todos os cientistas naturais sejam tal como figuramos aqui e ao longo do doutorado.
} 
uma evidência, uma evidência extremamente forte, tão forte que parece loucura negá-la. Husserl não a nega, sabe da força da evidência. Apenas considera que, por não ser apodíctica, não pode servir como princípio último da ciência absolutamente rigorosa.

Por isso, a evidência de que o mundo real existe será posta entre parênteses. Embora a crença na realidade do mundo seja válida para o eu natural; o eu filosófico não encontra aí um ponto de apoio absoluto. Não se trata, é preciso enfatizar, que Husserl esteja negando a hipótese de que o mundo real exista. O ponto é: se encontrarmos um princípio apodíctico ${ }^{185}$, absolutamente garantido, um princípio que calasse a boca de todo relativista e de todo ceticismo, poderíamos, em um segundo momento, tentar fundamentar nestes princípios todas as outras formas de evidências.

Distingue-se, portanto, duas classes de evidências: as evidências adequadas; as evidências apodícticas. As ciências de fatos apoiam-se nas evidências adequadas: a evidência empírica e a evidência de que o mundo real existe. A ciência radical, pelo seu turno, deve apoiar-se numa evidência que seja absolutamente indestrutível, de tal modo que seja impossível negada, mesmo pelos céticos. Esta evidência apodíctica será necessária para derrubar o ceticismo e o relativismo, para em seguida, partindo deste princípio supremo, dar o fundamento à intuição empírica e constituir as ontologias regionais e formais.

$* * *$

$\mathrm{O}$ argumento segundo o qual o mundo poderia ser um sonho coerente é suficiente mostrar a contingência do real. Mas é preciso insistir, pois isso gerou muita má-interpretação da fenomenologia. A questão não é negar a realidade do mundo, nem mesmo as evidências perceptivas, a questão é examiná-las, mas, para isso, é preciso conseguir um ponto de apoio, um crivo, uma base apodíctica que não seja abalada pelo pensamento cético. É preciso que saiamos da posição de "eu natural" que aceita passivamente as evidências cotidianas e até mesmo sair da "posição naturalística", que aceita passivamente a tese de existência do real. Não há outro modo de fazer uma ciência absolutamente fundamentada. Só será possível analisar as evidências adequadas apoiando-nos em uma evidência absoluta.

${ }^{185}$ O termo apodíctico é usado por Husserl no sentido de necessidade absoluta. Uma evidência apodícitca é impossível de ser refutada, pois é absolutamente necessária, certa e evidente. 


\subsubsection{Necessidade de se iniciar a ciência absoluta na evidência apodíctica}

É preciso que o filósofo que busque a filosofia radical encontre uma evidência que permaneça incólume ao corrosivo ácido do ceticismo. De fato, o ceticismo assume, dentro da fenomenologia, uma etapa metodológica. Ao contrário da grande maioria dos filósofos de sua época, Husserl não considerou como dado inicial que a física, a lógica, a geometria, e as demais ciências já consolidadas possuíam fundamentos absolutos. Nem mesmo que a realidade existe em si. Pelo contrário, era preciso encontrar um método e um princípio através do qual fosse possível superar o ceticismo e examinar os fundamentos de tais ciências. Em sua busca pela "ciência universal", Husserl usa como método a epoché, a "suspensão" da tese de existência da realidade do mundo e da veracidade de todas as ciências. A inspiração de tal método é tirada das meditações de Descartes. A ciência absoluta deve começar do ponto zero e sua primeira tarefa é encontrar os primeiros dados, o dado conquistado por uma evidência apodíctica, absolutamente segura.

A colocação entre parênteses da tese de existência do mundo, bem como de todas as ciências que a pressupõem, e até mesmo de outras ciências como a lógica, a matemática, não significa que ele as esteja negando. Significa apenas que não assumirá, pelo menos por enquanto, que elas são verdadeiras.

Husserl propõe a argumentação cartesiana. É possível duvidar que o mundo seja real, pois poderia ser um sonho coerente, mas não se pode duvidar de que se está duvidando, e, quem duvida, pensa. Desse mesmo modo, Descartes chega ao famoso ego cogito. Nenhum ceticismo, mesmo o mais radical pode refutar essa evidência. Está totalmente fora de dúvida que eu percebo, que eu imagino e que eu penso. No entanto, segundo Husserl, Descartes não soube explorar essa verdade indestrutível.

O próprio Descartes inicialmente se propusera um ideal científico, o da geometria, ou mais exatamente, o da física matemática. Esse ideal exerceu durante séculos uma influência nefasta. Também suas meditações se ressentem do fato de ele ter sido adotado sem uma crítica prévia. Parecia natural a Descartes que a ciência universal devesse ter a forma de um sistema dedutivo, sistema do qual toda a construção repousaria ordine geometrico num fundamento axiomático que serviria de base absoluta para a construção. (HUSSERL, 2001, p.26)

O pensador francês tira da geometria a "estrutura e a sua norma reguladora" para sua filosofia. A filosofia de Descartes constitui um "sistema dedutivo" que parte, ordine geometrico, do axioma indubitável: "eu sou”. Em Husserl, a verdade contida no "eu sou" não será concebida como um axioma, posto que a certeza intrínseca ao eu sou não garante, pelo menos a princípio, sequer a validade do método dedutivo. 
Não se pode confiar nem mesmo na lógica, como avançar? Como dar um passo em um terreno vazio cujo único tijolo é este "eu sou", "ego cogito". E como prosseguir, se não podemos dele deduzir nada, pois a dedução pressupõe a lógica e esta não pode ser aceita sem um exame crítico, pois esta, ao menos por enquanto, está dentro dos parênteses da epoché? Neste ponto, Husserl confessa que se chegou a um monte escarpado, e que andar com cuidado, será vital para a filosofia ${ }^{186}$.

O que sabemos com certeza absoluta, portanto, é que temos uma consciência e que temos "atos de consciência": percepções, pensamentos, imaginações, recordações. Ora, então só temos certeza da consciência? Mas e a realidade do mundo? O pensamento de Descartes não acaba levando o homem justamente à negação do mundo? Queríamos encontrar uma evidência apodíctica, para depois reconquistar o mundo e as ciências do mundo. Mas, ao que parecer, o princípio apodíctico que encontramos fechou o ser dentro da consciência. Sou uma consciência que tem "percepções”, “imaginações", "lembranças", "pensamentos". Mas tudo isso, ao que parece, está em mim. A via cartesiana parece absolutamente segura, mas, aparentemente, não é capaz de sustentar a objetividade das ciências particulares. Se parássemos aí, o projeto de sustentar as "ciências do mundo" na consciência parece condenado ao fracasso. É preciso avançar.

\subsubsection{Solipsismo versus realismo ingênuo}

Até o momento, chegamos a um aparente paradoxo. Por um lado, a filosofia racionalista de Descartes, que vê na consciência, na autoconsciência, o fundamento absoluto, o princípio absoluto para se erguer uma filosofia. Não é possível refutar essa verdade, nem mesmo o mais virulento ceticismo é capaz. Por outro lado, a conquista do ego cogito colocou o homem dentro de uma espécie de bolha solipsista ${ }^{187}$. Nada está fora da consciência, tudo o que há são representações e atos de consciência. Uma tal filosofia, incapaz de ir além da consciência parece condenada ao fracasso típico de um subjetivismo idealista. Em outras palavras, parece haver um abismo entre a evidência apodíctica da consciência e a evidência extremamente

\footnotetext{
${ }^{186}$ Husserl e Descartes andam de mãos dadas ao usar ao partir do argumento intrínseco ao ceticismo até atingirem a impossibilidade de duvidar do ego cogito. Mas aqui ambos pensadores se bifurcam, Descartes 1) faz do ego cogito um axioma, para deduzir sua filosofia; para Husserl, o primeiro procedimento, frente ao ego cogito, é descrevê-lo. 3) A epoché não se confundo com a dúvida hiperbólica, pois apenas põe em "suspensão" a tese de existência da realidade, mas sobra como resíduo o mundo como fenômeno. 4) Descartes não usa do conceito de intencionalidade.

${ }^{187}$ O solipsísmo é a tese de que apenas o eu existe de modo que todas as outras entidades estão no eu. Como diz a raiz do termo: "solus ipse"
} 
forte, embora não apodíctica, de que existe uma realidade. Tudo isso leva a crer que a descoberta de Descartes revela que a consciência é absoluta, indubitável, mas o método serve apenas para encontrar uma única pedra, um alicerce cercado por abismos. O método parece se mostrar poderoso, não fosse o fato de ele ser incapaz de avançar.

Detalhemos os problemas.

Tomando a consciência como o ser e o dado absoluto, a realidade parece faltar. Afinal a "realidade" está fora da consciência. Com isso, torna-se inviável a noção de verdade. Afinal a consciência não tem acesso ao que está fora dela. Como garantir, pela consciência, a existência real dos objetos que lhe são transcendentes? Como certificar de que existe uma realidade por trás das "imagens mentais" presentes na própria consciência? Aquilo que se chama "coisa real", para o psicologismo, não passa de um conjunto de sensações, às quais estão no próprio sujeito. Costa (2010) expõe da seguinte forma o raciocínio solipsista: "Se o conhecimento depende do sujeito que conhece, e é um evento que acontece no interior de uma mente entendida como teatro ou uma caixa onde estão presentes as imagens das coisas, então se pode questionar que coisa garante que a estas imagens correspondam qualquer coisa de real?” (p.23, tradução nossa). Para Husserl, dentre os primeiros filósofos a formularem esse problema estão os Sofistas gregos, em especial Górgias:

Contra a tese de Parmênides da "identidade" do pensamento (noein) e o ser, cujo sentido era claramente que aquilo que vem pensado no pensamento racional e aquilo que existe verdadeiramente são correlatos inseparáveis, Gorgias objeta, entendendo o ser no sentido natural de ser objetivo (que está além da consciência), que pensar é representar, mas o representar não é aquilo que é representado. Se assim fosse, uma batalha de carros no meio do mar deve existir, se eu represento uma. (2004, p.89, tradução nossa)

Diz-se que um juízo é verdadeiro quando há um acordo entre este e a realidade. Mas a realidade está "fora" da consciência. Ela não pode estar "dentro" da consciência. Ora, a visão, a memória, o pensamento, estão sempre dentro da consciência. Ver é ter um conglomerado de sensações e é loucura dizer que as sensações estão fora do sujeito.

Qual a relação entre a imagem mental ou a representação mental que está em nossa consciência e uma suposta coisa real?

Uma primeira hipótese seria que haveria uma relação de similitude entre a imagem na consciência e a coisa real. Agostinho, como já observamos, diz que há uma relação de forma. A forma nos sentidos é uma similitude da forma do objeto exterior. A imagem que eu tenho em minha consciência de uma coisa quando a percebo possui algum grau de semelhança com a coisa real. Esta hipótese foi destruída por inúmeros argumentos levantados por Berkeley (1685-1753), dentre os quais o seguinte: o único modo de confirmarmos se realmente nossa 
imagem mental é similar ou não ao suposto objeto real correspondente seria se pudéssemos confrontá-los: mas isso seria possível apenas se eu tivesse alguma imagem mental do próprio objeto real, caso contrário como compará-los? Berkeley ainda insiste:

When we do our utmost to conceive the existence of external bodies, we are all the while only contemplating our own ideas. But the mind taking no notice of itself, is deluded to think it can and does conceive bodies existing unthought of or without the mind, though at the same time they are apprehended by or exist in itself. A little attention will discover to any one the truth and evidence of what is here said, and make it unnecessary to insist on any other proofs against the existence of material substance. (BERKELEY, 1952, p.416).

Poder-se-ia talvez argumentar que podemos ter sim acesso ao objeto real que reside por trás de sua imagem, pelo pensamento teórico. No entanto, o que é o pensamento de um objeto real se não uma representação? A ideia teórica que formamos desse "objeto real" que se esconde por trás das sensações subjetivas também é uma representação do objeto real e não próprio objeto real. Um cético voltaria a responder que nossa consciência tem acesso apenas às representações e às sensações. E não ao real ${ }^{188}$.

O objetivo de Husserl é encontrar a saída da bolha solipsista e investigar se há uma porta de acesso ao real ${ }^{189}$ e as objetividades. Se o homem tem acesso apenas às suas representações e às sensações, como é possível que a evidência revele as próprias coisas? Se, como Husserl sustenta, aquilo que pode validar o juízo é a evidência, posto que por ela temos a experiência de um ser e de seu modo de ser, como é possível tal experiência se estamos trancados dentro de nós mesmos. Daí resultaria que temos acesso apenas aos conteúdos de consciência e a não à realidade em si, a qual não passa de uma hipótese a ser aceita, ou mais precisamente, de uma suposta representação que tem para nós o sentido de coisa real. O que podemos afirmar com certeza é que não é possível que a consciência fuja de si mesma, para conhecer o real tal como ele é em si. Para Husserl, tudo aquilo que consideramos existente remete à subjetividade, porque é nela que se realiza todo tipo de fundação e de refutação, cada distinção entre conhecimento, opinião e falso conhecimento.

\footnotetext{
${ }^{188}$ É interessante notar que Hume, o único filósofo empirista que levou às últimas consequências essa doutrina, acabou conduzindo sua doutrina ao solipsismo. Para ele, todo conteúdo mental, tudo aquilo que pode ser pensado, encontra sua matéria prima nas sensações. Tudo o que há são percepções e suas impressões deixadas por essas percepções, as quais podem ser associadas por contiguidade no tempo e no espaço e por semelhança. Não há como o eu sair de si mesmo para ter acesso a algo outro que isso. Aliás, a própria palavra "eu", caso se refira a algo, deve se referir a algo que obtemos pelas sensações, como não é o caso, o eu é não passa de um feixe de sensações.

${ }^{189}$ Contudo, como veremos, o sentido de ser real deverá ser modificado, com relação a atitude natural, que se caracteriza pelo realismo ingênuo.
} 
Como as ciências naturais enfrentam o ceticismo e a crítica cética, segundo a qual o mundo poderia ser um sonho coerente ou que temos acesso direto apenas às imagens mentais? Para Husserl, o homem natural não enfrenta filosoficamente tal crítica, apenas parte da evidência de que o mundo real existe, sem um exame mais acurado dos fatores aí envolvidos. Essa crença natural na realidade e na existência não é apenas exclusiva do "homem cotidiano", mas também do cientista natural. Também ele parte da crença irrefletida de que existe uma realidade exterior à consciência e é essa realidade que ele se propõe a estudar.

No entanto, o que tanto as pessoas no seu dia a dia quanto os cientistas fazem ao tomar como certa a tese de existência da realidade é que, por assim dizer, refutam as objeções filosóficas levantadas pelo ceticismo e pelo psicologismo apenas "atropelando-as", e não as resolvendo filosoficamente.

Como havíamos observado no início de nosso trabalho, o projeto de Husserl é que a fenomenologia seja uma ciência de fundamentos absolutos, que serviria de fundamento às ciências particulares, as ciências de fatos. Para isso é necessário resolver as objeções levantadas pelos solipsismo, salvando o sentido da verdade como adequação dos juízos às próprias coisas e o sentido da evidência, como acesso às próprias coisas.

A atitude natural cotidiana não resolve o problema do ceticismo, mas apenas toma como certa a tese segundo a qual as coisas não são meras representações, meras imagens dentro da consciência, mas existe um exterior real à consciência. E estas coisas existem e continuariam a existir independente do sujeito que as conhece.

No entanto, há muitas confusões e obscuridades no modo pelo qual as ciências naturais estabelecem a relação entre a consciência e a suposta realidade objetiva. Esta última é concebida como exterior à consciência. De fato, para o pensamento científico em geral é necessário estudar não como as coisas aparecem à nossa consciência, mas aquilo que elas são na realidade. Eis o que Husserl chama a realismo ingênuo. Sua objeção é simples e já foi feita por Berkeley. Se o cientista é um homem dotado de consciência, não pode sair de sua própria consciência para ter acesso ao mundo que existe por trás dela, um mundo absolutamente transcendente a ela. Diríamos que o mundo real possui matéria. Mas onde é que vimos a matéria? A matéria não são sensações. Então só pode ser com o pensamento que vemos a matéria? Portanto, seria a matéria apenas um pensamento? Mas se a matéria é pensamento, não é matéria. O mesmo raciocínio vale para átomos, ondas eletromagnéticas, qualquer modelo teórico que se proponha explicar o real. Como ele pode fazer uma ciência sobre uma realidade que transcenda plenamente à sua consciência e seja independente dele? Se as 
ciências naturais procuram investigar o real, deve-se compreender como a consciência alcançou esse sentido: "coisa real".

A ideia não é negar as "ciências de fatos", mas fornecer a cada uma delas uma ciência apriorística, sustentadas em princípios apodícticos. Segundo Husserl, a filosofia do empirismo é incapaz de sustentar as ciências, pois sofre de um estrutural contrassenso de princípios ${ }^{190}$.

\subsubsection{Solução ao solipsismo. A intencionalidade da consciência. $O$ cogitatum}

Como superar o solipsismo que parece inerente ao ego cogito? Em primeiro lugar, é preciso antes explorá-lo ao máximo. Partindo desse princípio, tudo quanto há de indubitável são percepções, lembranças, imaginações, desejos, vontades ${ }^{191}$ Sou capaz de diferenciar diferentes atos de consciência. No entanto, toda vez que penso, penso em algo; toda vez que percebo, percebo algo; toda vez que imagino, imagino algo. Não há uma imaginação que não imagina coisa alguma, uma percepção que não percebe coisa alguma.

O resíduo da epoché não é apenas o ego cogito, mas também o cogitatum. A tese de existência real do mundo está entre parênteses, mas ela não abala as puras aparências das coisas. Esse computador que vejo é algo que aparece à minha consciência, não tenho como duvidar da existência, para mim, dessa aparência.

Se eu tenho a percepção de um homem, posso, sem dúvida, duvidar que esse homem que eu percebo seja real, mas não posso duvidar que percebo algo que me parece um homem. Mas, e se eu me aproximar e descobrir que não era um homem, mas um manequim? Nesse caso, não posso duvidar que percebo agora algo que me parece um manequim. A exploração do ego cogito revela que todo cogito tem um cogitatum. Todo ato de consciência é dirigido a um objeto. Neste ponto uma distinção importantíssima deve ser feita. Não é porque algo aparece a mim que tenho a garantia que essa aparência seja necessariamente real. Nisso se entrevê a distinção sutil, entre "objeto intencional” e "objeto real”. O objeto intencional é o

\footnotetext{
${ }^{190}$ Segundo Husserl (2006), o empirismo é uma filosofia que tenta eliminar a metafísica ao considerar que todo conhecimento deve se fundar em dados empíricos. Contudo, tal princípio cai em contrassenso filosófico, quando aplicado a si mesmo. A proposição: "Todo conhecimento deve ser fundamentado na experiência empírica" exprime um juízo que não pode ser provado empiricamente. Daí resulta que o empirismo funda-se em um contrassenso de princípio, aniquila-se a si mesmo enquanto filosofia. A tese supracitada só poderia ser provada recorrendo a argumentos não empíricos, mas isso continuaria caindo no contrassenso, pois se ela fosse provada por argumentos não-empíricos, ela continuaria contradizendo a si mesma, a não ser se a tese defendida fosse "todo conhecimento provém da experiência, exceto este, que é provado sem o uso da experiência", o que é, convenhamos, um pouco absurdo.

${ }^{191}$ Contudo, Husserl nota que os termos "pensamento", "imaginações”, "percepções” são ambíguos. Isso porque toda vez que percebo, eu percebo algo; toda vez que imagino, imagino algo. São ambíguos porque condensam "o ato de imaginar" e o "objeto imaginado"; o "ato de perceber" e "o percebido", em suma, o cogito e o cogitatum.
} 
que aparece e tal como aparece. E eu não tenho como duvidar que essa pura aparência seja algo para mim.

(...) Em consequência, será necessário ampliar o conteúdo do ego cogito transcendental, acrescentar-lhe um novo elemento e dizer que todo cogito, ou ainda que todo estado de consciência, "assume" algo, e que ele carrega em si mesmo, como "assumido" (como objeto de uma intenção) seu cogitatum respectivo. Cada cogito, de resto, o faz a sua maneira. A percepção da "casa" "assume" uma casa - ou mais exatamente, determinada casa individual - da maneira perceptiva; a lembrança da casa "assume" a casa como lembrança; a imaginação, como imagem (...) Esses estados de consciência são chamados de estados intencionais. A palavra intencionalidade não significa nada mais que essa particularidade fundamental e geral que consciência tem de ser consciência de alguma coisa, de conter, em sua qualidade de cogito, seu cogitatum em si mesma. (HUSSERL, 2001, p.51)

A evidência apodíctica do eu sou, que me coloca como ser cuja realidade está garantida por mim mesmo, leva-me também à constatação de que existe, para mim, aparências, ou melhor dizendo, fenômenos.

Posso duvidar que este computador que eu percebo seja computador real, mas não posso duvidar que percebo isto como algo que se mostra de tal modo que me leva a entendê-lo como computador. Se "no fundo", essa aparência é um holograma materializado de computador, ainda assim não deixa de ser, para mim, um fenômeno de computador, uma aparência de computador. Reconheço-o como sendo um computador em virtude do próprio modo como me aparece, isto é, possui todas as características necessárias que fazem com que um computador seja um computador ${ }^{192}$. Isso ocorre não apenas pelas aparências táteis, visuais, auditivas e demais características sensíveis de um computador, mas também por determinado "padrão" implicado neste manifestar; por exemplo, quando aperto a tecla "p" e vejo escrito na tela a letra "p". Se o que percebo é uma ilusão de computador, essa ilusão deve ser uma ilusão tátil, visual, auditiva e deve, além disso, manifestar-se dentro de determinado padrão. Mas se isso que eu vejo, toco, escuto, e interajo exista na "realidade", isto é, fora de minha consciência, quanto a isso não tenho certeza absoluta. Talvez isso que esteja vivendo seja um sonho coerente (posto que segue um padrão e por isso coerente) ou o computado seja um holograma materializado criado por um gênio maligno, ou qualquer outra coisa, quanto a isso, ao que ele é fora de seu manifestar, eu não tenho nenhuma evidência apodíctica. Mas estou

\footnotetext{
${ }^{192}$ A epoché opera uma modificação no mundo, sobrando como resíduo o eu e os fenômenos purificados, invulneráveis aos ataques céticos. Uma coisa é o ser do fenômeno, outra é o ser real. Um dos erros mais comum do ceticismo é não perceber a indubitabilidade deste ser fenômeno enquanto fenômeno. Esse algo que aparece a mim tal como aparece precede ontologicamente o juízo que se faz a seu respeito. Considerá-lo mera aparência, considerá-lo o próprio ser, considerá-lo um epifenômeno, são atos judicativos que se referem a algo que não é abalado: o próprio fenômeno.
} 
seguro que isso que se mostra à minha consciência é algo que se parece com um computador porque ele se manifesta exatamente como um computador deve se manifestar. ${ }^{193}$.

Em outras palavras, mesmo colocando entre parênteses a tese de existência real do mundo, ainda sobra o "mundo das aparências". Para sermos mais precisos é necessário substituir o nome aparência por fenômeno, que é o termo grego que designa aparência. Investigar as puras aparências, limitando-se ao que é dado, sem levar em consideração se essas aparências são aparências de coisas reais ou não é justamente olhar o mundo na atitude transcendental, pela qual os fenômenos são purificados transcendentalmente. Isto é, tais aparências, dentro da redução transcendental, são entendidas como irrealidades. Tomar essas aparências como irrealidades não significam que elas não sejam para mim, que elas não existam para mim. Não se posicionar sobre a realidade ou irrealidades é imensamente vantajoso. Pois, ainda que o mundo for, no fundo, um sonho coerente, isso não afetará em nada a fenomenologia e análise das aparências. Que eu esteja consciente de algo que se parece um computador é tão indubitável quanto o fato de que eu existo.

Chegamos, portanto, as seguintes conclusões apodícticas:

1)Tenho evidência apodíctica que percebo; que percebo objetos e que esses objetos se parecem algo.

2) Tenho evidência apodíctica que estes objetos existem para mim. Não tenho evidência apodíctica que esses objetos são reais. Não sei, por enquanto, se existem outros "eus" que os percebam. Embora não possa dizer, por enquanto, que o percebido (ou objeto intencional) não seja real, é importante notar que não tenho também a evidência apodíctica de que esses objetos-fenômenos e o "mundo da aparência" (ou mundo fenomênico) foram criados pelo meu inconsciente ou pela minha consciência.

3)Esses objetos percebidos estão, de algum modo, na minha consciência. Todavia, uma coisa é certa: eu diferencio, com absoluta precisão, o "eu" da "aparência". Se vejo uma pedra,

\footnotetext{
${ }^{193}$ Caso o exemplo não seja suficiente. Esse livro que eu percebo poderia ser uma ilusão? Sim, poderia. Esse livro eu vejo, abro e folheio pode ser real? Sim, nada impede. Mas seja ele ilusão ou realidade, isso não elimina o fenômeno enquanto fenômeno. A evidência que eu percebo "algo" e que esse algo se mostra a mim de tal forma que ele que me faz compreendê-lo como sendo um livro, seja um holograma seja ele real. E mais, nada elimina a certeza absoluta que vejo algo que me parece um livro cuja capa é azul. $\mathrm{O}$ fato de que percebo algo como sendo um livro cuja capa é azul possui para mim uma certeza apodíctica. Não tenho como, enquanto percebo o livro azul, duvidar que percebo algo que se mostra como sendo um livro azul. Posso, talvez duvidar quanto ao fato desse livro azul ser real, mas a dúvida quanto à realidade ou não deste livro azul não altera a manifestação enquanto manifestação, o fenômeno enquanto fenômeno, a aparência enquanto aparência. Poderia se objetar que talvez para um daltônico de cor, esse livro seja cinza. Mas o que está em discussão no momento não é se esse livro é, em si, azul nem se ele é real. Ademais, sequer sabemos, por enquanto, se existem outros "eus". A evidência cotidiana de que existem outros eus também está em parênteses. O que está fora de qualquer dúvida é que, para mim, esse algo que eu percebo é percebido e reconhecido como sendo um livro azul.
} 
não digo: "eu sou a pedra". A pedra, de algum modo, está na minha consciência; mas eu não sou ela. Eu sou o sujeito que percebe a pedra. O sujeito que percebe não é o objeto percebido. Ter consciência de uma "pedra" não é ser uma pedra. Do mesmo modo, se imagino o sol, não sou o sou.

\subsubsection{Distinção entre "eu puro" e "eu psicológico"}

Segundo Husserl o maior problema é Descartes é que ele abriu a porta que daria acesso ao sujeito transcendental $e$ ao mundo dos fenômenos, mas não soube explorá-los adequadamente. A falha de Descartes é considerar o eu puro, resíduo da epoché, como uma parte do mundo real, como um espírito. $\mathrm{O}$ eu penso é entendido como uma substância real contraposta ao corpo. Vejamos nas palavras de Descartes na quarta parte de "Discurso do Método":

Em seguida, examinando com atenção o que eu era, e vendo que podia fingir que não tinha nenhum corpo e que não havia nenhum mundo nem lugar onde eu existisse, mas que não podia fingir, apesar disso, que eu não existia, e que pelo contrário, por isso mesmo que pensava ao duvidar da verdade das outras coisas, se seguia com muita evidência e segurança que eu existia; ao passo que bastava que eu tivesse cessado de pensar, ainda que tudo o mais que tivesse imaginado fosse verdadeiro, para não ter nenhuma razão de acreditar que eu existia. Reconheci daí que eu era uma substância cuja essência ou natureza toda não é senão pensar, e que para existir não necessita de nenhum lugar nem depende de nenhuma coisa material. De maneira que esse eu, isto é, a alma, pela qual sou o que sou, é inteiramente distinta do corpo, mesmo mais fácil de conhecer do que ele, e que mesmo que este não existisse, ela não deixaria de ser o que é. (DESCARTES, 1975, p.60).

Mas porque esse "eu" do qual não se pode duvidar, do qual temos evidência apodíctica, não é uma psique, ou uma alma real? A resposta é simples. Porque os termos "psique", "alma" ou "mente", "espírito" designa uma substância real.

Esse eu e sua vida psíquica, que mantenho necessariamente apesar da epoché, não são uma parte do mundo; e se esse eu diz: "Eu sou, ego cogito", isso não mais quer dizer: "Eu, como esse homem, sou. "Eu" não é mais o homem que se percebe na intuição natural de si considerado como homem natural, nem tampouco o homem que, limitado pela abstração aos dados puros da experiência "interna" e puramente psicológica, capta seu próprio mens sive animus sive intellectus, nem mesmo a alma, ela própria, tomada separadamente. (HUSSERL, 2001, p.42)

Descartes observa que o corpo não necessariamente existe. Mas de certo modo assume a existência do corpo, considerando a alma como algo essencialmente separada dele. Todavia, devemos manter fiéis à epoché e não aceitar, até termos dados suficientes, o que é o corpo e a 
psique entendidos como substâncias reais. Em outras palavras, a consciência é ser absoluto; a psique é contingente, pois ela, pelo seu sentido, pertence ao mundo real.

O que a epoché, portanto, não alterou? A vida da consciência, a minha vida "psíquica". Da mesma forma como não posso duvidar desse eu, não posso duvidar da vida desse eu, isto é, de ser um eu dotado de atenção, e que distingue em si o ato de pensar, o ato de perceber e imaginar, etc, bem como o objeto pensado, o objeto percebido, o objeto imaginado. Segundo Husserl, Descartes conseguiu isolar a esfera das cogitationes puras, no entanto, não soube examiná-la corretamente. Para o pensador francês o ego do ego cogito foi tomado como um pedaço do mundo, um pedaço de realidade, uma substância que fazia parte do mundo real. Mas o ego cogito não permite tão ousado salto sem que antes examinemos, passo a passo, como isso é possível. O eu que atingimos pela epoché não é o "eu empírico", nem uma psique, nem uma alma, nem mesmo uma "interioridade", posto que não encontramos ainda nenhuma "exterioridade". Encontramos o objeto intencional, mas este está de algum modo na consciência.

Devemos nos limitar. A evidência apodíctica que temos até agora é de que existe um "eu puro", "atos de consciência" e "objetos intencionais" e uma corrente de cogitationes, um fluxo de consciência. E nessa estrutura indubitável se distingue sujeito e objeto. Se vejo algo que parece um computar, esse "algo" é um objeto, o que não necessariamente signifique que seja real. Se vejo uma vaca voando, a vaca voando não tem o sentido de coisa real mas de "coisa alucinada" que, entretanto, é objeto de minha percepção. Mantendo-nos na epoché, o objeto percebido não mais significa objeto real, mas sim objeto intencional. Mas uma coisa é certa: esse algo que eu vejo e que é aparência não sou eu: o fenômeno simplesmente se mostra ao sujeito e se mostra tal como se mostra.

\subsubsection{Distinção entre objeto real e objeto intencional}

O fenômeno precede o nosso posicionamento perante ele, isto é, nossa decisão de considerá-lo real ou ilusão. Se ao colocar um bastão na água vejo o bastão torto, não posso duvidar que vejo algo que me parece um bastão torto; aquilo se mostra para mim com a aparência de um bastão torto. O fenômeno não é algo que existe em si; só existe para a consciência que o "assume" como objeto intencional, como correlato. A existência do fenômeno é indubitável: que este fenômeno ou a aparência corresponda ou represente uma realidade transcendente à minha consciência, isso é dubitável. O fato do fenomenólogo não 
fazer uso da tese de realidade força-o a descrever o "mundo da aparência", o "mundo fenomênico" sem apelar para atitude natural, o que não é, como Husserl alerta, tarefa fácil ${ }^{194}$.

\subsubsection{O ser absoluto da consciência e a contingência do ser real}

Já observamos que Husserl parte da via cartesiana, pela qual atingimos a apodicticidade da estrutura ego-cogito-cogitatum. Contudo, a garantia absoluta de que eu existo não implica que esse eu que existe seja real. Para que algo seja real, não basta que seja para mim. A evidência absolutamente garantida da existência de um eu, dos atos de consciência e dos correlatos desses atos, isto é, daquilo que se mostra à consciência, não fornece garantia nenhuma de que este eu seja real, de que estes atos sejam reais, de que os objetos visados pelo eu sejam reais.

Se eu vejo uma mesa, a mesa se mostra à consciência, mas nada garante que esse percebido, esse fenômeno seja fenômeno de uma mesa real. Não possuo uma garantia apodíctica, indubitável, que esta mesa que se mostra para mim não seja uma ilusão perfeita ou um holograma materializado, o sonho de Vishnu, o véu de maia. Em suma, não tenho garantias indestrutíveis de que seja real. No entanto, o que as coisas são no "fundo", para além de seu puro mostrar-se à consciência, pouco importa para o fenomenólogo, afinal ele está "protegido" do ceticismo ao abster-se fazer de uso da tese de realidade do mundo. E justamente por isso, ele só pode falar sobre o que, para ele, é indubitável, os fenômenos purificados transcendentalmente.

Esse é justamente o sentido metodológico da epoché. Se "no fundo" sou uma borboleta sonhando que sou um homem isso não afetará a descrição fenomenológica, pois não muda o fato de que esse algo me mostra me parece, por exemplo, uma mesa. Isso não afetará o fato de que, ao olhar-me no espelho, vejo um corpo que me parece ser o corpo de um homem. Aquele que diz que os fenômenos que se oferecem à consciência são fenômenos de coisas reais, que a visão é uma interpretação de fótons, é porque saiu da epoché, é porque está levando em consideração a tese de existência real do mundo.

À tese do mundo, que é uma tese "contingente", contrapõe-se, portanto, a tese de meu eu puro e da vida do eu, que é uma tese "necessária", pura e simplesmente indubitável. Toda coisa dada em "carne e osso" pode não ser,

\footnotetext{
${ }^{194}$ Diante de um fenômeno musical, o fenomenólogo analisará apenas o fenômeno, e mantendo-se, na epoché, (que é a colocação entre parênteses da tese de realidade) não abordará a música como "sensações originadas de ondas que se propagam no ar". Este modo de entender a aparência leva em consideração atitude naturalista, a qual é considerada demasiadamente subjetiva serve apenas como uma ponte provisória para chegar à realidade material ou física que é a verdadeira realidade objetiva que se manifesta subjetivamente para o sujeito. Isso implica estudar o fenômeno não apenas naquilo que é dado, pois o que é dado, na atitude científico-objetivista, torna-se a maneira como a subjetividade interpreta o real.
} 
mas não um vivido dado em carne e osso: tal é a lei de essência que define essa necessidade e aquela contingência. (HUSSERL, 2006, p.109).

O ser "real" é contingente, não é necessário. Não é necessário que essa mesa percebida seja real, pois pode ser ilusão. Ademais, eu poderia ser uma borboleta sonhando que sou um homem percebendo uma mesa, mas que o vivido "percepção de mesa" exista, isso é absolutamente seguro, pois eu não tenho como duvidar de que tenho uma percepção dirigida a um objeto determinado e que entendo como sendo uma mesa. Entretanto, determinadas aparências, isto é, determinados objetos intencionais, possuem o "sentido" de pertencerem ao mundo.

"Mundo" e "consciência" tornam-se correlatos. Não posso estudar um outro mundo que não um mundo que é para mim. Com isso, inverte-se, para Husserl, a ordem habitual pela qual o homem, durante milênios, considerou o ser. $\mathrm{O}$ ser real, que é usualmente compreendido como o ser primeiro, torna-se o ser segundo, pois ele só é em "referência" à consciência. A hipótese de um mundo totalmente irrelacionado, sem nenhuma referência possível à minha consciência, é descartada.

Temos as seguintes conclusões:

1) As considerações que fizemos até aqui não leva à conclusão que o real não exista, significa apenas que ele é contingente e está em referência à consciência. 2) Isso não significa dizer que o real está dentro da consciência. 3) Não significa que a consciência criou o mundo. 4) Não significa que não haja o sentido de ser real. Mas um real absoluto, sem nenhuma referência à consciência. Este sim é contrassenso.

\subsubsection{O problema do mundo}

Não existe um mundo fora da minha consciência? Ora, a única forma de eu saber, com certeza, que existe um mundo fora da minha consciência, um mundo que não se mostra para mim, seria saindo de minha consciência e tendo algum tipo de experiência do mundo. Mas outra vez caio no contrassenso. Se eu digo que creio com todas as minhas forças que o mundo existe independente de mim, creio nisso porque tenho boas razões para acreditar que o mundo existe em si. Contudo, é de mim que eu tiro essas razões. "O mundo objetivo, que existe para mim, que existiu o que existirá para mim, esse mundo objetivo com todos os seus objetos encontra em mim mesmo, como disse acima, todo o sentido e todo o valor existencial que tem para mim.” (HUSSERL, 2001, p.43) 
Como já observamos, epoché não nos fornece um ego cogito, que é um pedaço do mundo real. Se, para mim, o mundo existe realmente, eu preciso encontrar, na minha vida de consciência, as vivências que justificam a minha crença no mundo real. Não é porque tenho pensamentos, visões, crenças que o mundo é real. O mundo não está contido "realmente" na consciência, pois tem o sentido de transcendente. "Essa transcendência é inerente no sentido específico de tudo o que faz parte do mundo, ainda que não possamos dar a esse "mundo" e a suas determinações nenhum outro sentido senão aquele que extraímos de nossas experiências, representações, pensamentos, julgamentos de valor e ações" (...) (Ibid, p.43)

Todo objeto possível para mim é objeto de minha consciência. Não posso sequer conceber um objeto que não seja, de algum modo, para minha consciência, pois se o concebesse seria “objeto concebido". Em outras palavras, todo cogitatum é cogitatum de um cogito.

De saída tomamos a consciência num sentido forte, aquele que acorre de imediato, e que é designado de maneira mais simples como cogito cartesiano, como "eu penso". Como se sabe, ele foi entendido por Descartes como abrangendo todo "eu percebo", "recordo", "imagino", "julgo", "desejo", "quero" e todos os vividos semelhantes do eu em inúmeras e fluidas particularidades. O eu mesmo, ao qual são referidos, ou que "neles vive" de maneiras bem distintas, que é ativo, passivo, espontâneo, que se "comporta" receptivamente ou de um outro modo qualquer" (HUSSERL, 2006, p.86)

Trata-se da grande descoberta de Brentano: toda consciência é consciência de alguma coisa, isto é, o caráter intencional da consciência. Portanto, o julgamento tem um julgado, o pensamento tem um pensado, a percepção um percebido ${ }^{195}$.

A descoberta de Brentano de que toda consciência é consciência de algo é um conhecimento não apenas válido para a fenomenologia, mas é válida também para qualquer psicologia. Uma consciência que não é consciência de nada, não existe. Se eu penso, penso em alguma coisa, se eu quero, eu quero alguma coisa. Isso não significa que o objeto

\footnotetext{
${ }^{195}$ Em primeiro lugar, há um sujeito que percebe, um eu percebe. Seria um erro dizer que na percepção alguém percebe, pois "alguém" implicaria uma pessoa, um homem, etc e tal, implicaria a tese natural. No entanto, não podemos negar que a percepção é percepção de um sujeito. Trata-se do eu puro. Em segundo lugar, há os atos de consciência: $o$ ato da consciência, o ato de perceber, o ato de julgar, o ato de refletir. Em terceiro lugar, há o conteúdo, isto é, o objeto intencional, o objeto percebido, o objeto refletido. O objeto percebido enquanto percebido, isto é, purificado transcendentalmente, não entendido como algo real, ele é correlato de minha consciência. Digo, com certeza apodíctica que tenho percepções. E digo que tenho certeza apodíctica que a vivência intencional perceptiva de uma xícara é diferente da de uma mesa. Não digo com certeza apodíctica que a percepção de uma xícara é percepção de uma xícara real, pois a xícara percebida pode ser o fruto de um sonho coerente, pode ser uma ilusão. Mas mesmo que seja ilusão a percepção de uma xícara (seja uma xícara alucinada ou real) é diferente da percepção de uma mesa. Se eu consigo distinguir uma percepção de outra percepção, por exemplo, a percepção de uma casa é diferente de uma percepção de uma pessoa, o que distingue as duas percepções são seus conteúdos. Em uma das percepções o objeto visado, ou o objeto intencionado é uma mesa, na outra é uma xícara. Cada uma possui um objeto intencional distinto.
} 
intencional se mostre com plena nitidez. Posso querer alguma coisa que nem sei bem ao certo. As vivências intencionais são atos da consciência que se voltam para um objeto, seja lá o que for esse objeto intencional:

Há uma coisa que a epoché concernente à existência do mundo não poderia mudar: é que as múltiplas cogitationes que se relacionam com o "mundo" contêm, nelas mesmas, essa relação; assim, por exemplo, a percepção dessa mesa é, tanto antes quanto depois, percepção desta mesa. Dessa forma, todo estado de consciência em geral é, em si mesmo, consciência de alguma coisa, qualquer que seja a existência real desse objeto e seja qual for a abstenção que eu faça, na atitude transcendental que é minha, da posição dessa existência e de todos os atos da atitude natural.(HUSSERL, 2001, p.50)

Temos aqui uma passagem estranha. Husserl antes afirmava que a tese da existência do mundo deve ser colocada fora de circuito. Trata-se de um ponto de partida. Pois uma das ideias é reconquistar o mundo, chegar ao mundo a partir do ego cogito. Teríamos que sair da bolha solipsista e chegar no "mundo". Tenho apenas meu eu e minhas cogitationes, cada qual com seu cogitatum. No entanto, essas cogitationes se relacionam com mundo? No texto, o termo "mundo" vem posto entre aspas porque não vem compreendido, aqui, pela atitude natural, como um mundo real, mas sim como um "mundo de fenômenos". Se determinados objetos intencionais tem, para mim, um "sentido" de coisa real, isso não significa que sejam absolutamente reais, significa que, para mim, possuem esse sentido e não por razões fortuitas. A fenomenologia, portanto, não nos faz perder o mundo enquanto objeto fenomenológico, enquanto objeto intencional, enquanto correlato de minha consciência. Aliás, não posso falar de outro mundo que não seja um mundo que é para mim.

Isso não significa que todo objeto intencional seja posto pela minha consciência como pertencente ao mundo. Se eu imagino um centauro, esse objeto imaginado não possui o sentido de pertencer ao mundo natural. O objeto percebido, de modo geral, possui esse sentido. Se nos mantivermos na epoché, o "mundo" é um cogitatum. O eu é a condição de existência do mundo, ou melhor dizendo, desse mundo que é para mim. Mas um mundo que não seja para mim, isto é, um mundo que eu não posso pensá-lo, conhecê-lo, percebê-lo, tal mundo não interessa.

Portanto, o que há, para mim, é minha vida de consciência, os vividos intencionais e os objetos implicados em cada uma dessas vivências e nada mais ${ }^{196}$.

\footnotetext{
196 “Portanto, ao efetuar rigorosamente a redução fenomenológica, mantemos em caráter noético o campo livre e limitado da vida pura da consciência, da parte de seu correlato noemático, o mundo-fenômeno como seu objeto intencional." (2001, p.55).
} 


\subsubsection{Estados psíquicos reais e vivências transcendentalmente reduzidas}

A epoché fenomenológica limitou um campo de investigação, o ego cogito: o eu e suas vivências. Trata-se do mesmo domínio de investigação do psicólogo. No entanto, o psicólogo, por se mover na atitude natural, compreenderá esse mesmo domínio "a vida psíquica" de uma maneira diferente do fenomenólogo, pois o primeiro entenderá a vida psíquica, como a vida psíquica de um homem real no mundo, o segundo estudara a "vida psíquica" transcendentalmente reduzida. $\mathrm{O}$ foco de sua investigação será como essa vida de consciência constituiu intuitivamente o sentido mundo real, psique real, homem real. Portanto, embora o tanto o psicólogo quanto o fenomenólogo tratem do mesmo objeto, a direção das pesquisas, como já afirmamos, são extremamente diversas. O primeiro estudará o que se passa na “cabeça de um homem", o segundo estudará o ser primeiro, o sujeito transcendental, a relação ego-cogito-cogitatum. O mundo, o homem, qualquer outro objeto possível são reduzidos transcendentalmente a cogitatum, a um correlato desse cogito. Já os "estados psíquicos" não serão apercebidos como estados psíquicos reais ${ }^{197}$.. Pois isso não é dado em evidência absoluta. Apenas para facilitar, consideremos que, do mesmo modo como não posso ter certeza absoluta que esse computador é real, eu também não posso ter certeza absoluta que minha percepção é uma "percepção real". Para que minha percepção seja real, minha psique deve ser real. Percebo uma dor no estômago. Já sabemos, não tenho certeza absoluta que meu estômago é real, afinal tudo poderia ser uma ilusão de estômago, uma dor fictícia. Entretanto, se, "no fundo" eu sou uma borboleta sonhando que sou um homem percebendo uma dor no estômago, fica claro que minha percepção, neste caso, não é uma percepção real. Contudo, tenho certeza absoluta que percebo uma dor em algo que me parece ser um pé. Tenho certeza absoluta que percebo, mas não tenho certeza absoluta que minha percepção é real.

\footnotetext{
${ }^{197}$ As vivências transcendentalmente purificadas não se confundem com os estados psíquicos, pois estes últimos são reais. Trata-se da um dos fundamentos que distingue a fenomenologia da psicologia descritiva. A esse respeito, ver apêndice $C$.
} 


\subsection{A essência}

\subsubsection{Introdução}

A base da fenomenologia, sem a qual essa descrição seria um trabalho exaustivo e sem grandes proveitos, é que ela não visa descrever os fenômenos em suas singularidades, mas em sua essência. O que aparece carrega no seu próprio aparecer a sua essência. Não há fenômeno que não haja essência. Por isso o trabalho do fenomenólogo não é a descrição da aparência pura e simplesmente, em seus inumeráveis detalhes. O trabalho é elucidar e esclarecer as essências dos fenômenos. Para dar um exemplo simples: todo corpo material se mostra por perfis, de modo que, quando vemos um lado, não vemos o outro. Mas podemos ir além e dizer que todo corpo material possui uma extensão. Mas e se um corpo material não tiver extensão? Se ele não tiver extensão, não aparecerá como um corpo material. O que importa é o seguinte: para que uma aparência seja aparência de um corpo material é preciso que tenha os predicados essenciais acima mencionados. Se os retirarmos, explodimos a própria aparência de um corpo material. Não é possível que algo nos pareça um objeto corporal, material, sem que este objeto se mostre por perfis. Trata-se de uma condição de possibilidade apriorística para que um objeto se pareça um objeto material. Em outras palavras, se os objetos materiais não se mostrassem por perfis não teríamos a noção de objeto material. Já o "aparecer por perfis" não é condição de possibilidade da aparência do sentimento. Pelo contrário, um sentimento não pode mostrar-se por perfis.

A essência é o conjunto de possibilidade e impossibilidades e, por isso mesmo, apriorísticas, necessárias para que uma aparência seja reconhecida como algo determinado.

Mas devemos observar um ponto importante. Havíamos dito que a descrição das aparências não exige que se faça uso da tese de existência real do mundo. Por isso, os fenômenos transcendentalmente purificados são classificados como irrealidades puras. Mas se eles são assim classificados e, ainda assim, possuem uma essência, o que dizer dessas essências? Ora, as essências são "objetos ideais", atemporais e, por isso, irreais. A essência "livro" não envelhece. Continua a "mesma" quer o indivíduo pense nela ou não. 


\subsubsection{Inseparabilidade entre intuição do individual e intuição de essência}

Para se erigir a ontologia regional da psique é preciso que tenhamos afiadas as ferramentas conceituais. É preciso dizer, antes de mais nada, para não gerar confusões, que Husserl distingue psique de consciência. Em outras palavras, a essência da psique é distinta da essência da consciência. Antes de abordarmos essas diferenças é preciso compreender com precisão o que Husserl entende por essência.

Neste capítulo, iremos aprofundar o conceito de essência ou eidos. Havíamos dito que todo fenômeno tem um eidos. Faltou dizer que existe, ao lado de uma intuição do individual, uma intuição eidética, pela qual apreendemos o eidos do próprio do fenômeno.

Segundo Husserl, a percepção é o ato cognitivo fundante. A percepção é uma intuição originária pela qual apreendemos os "fatos", os quais são sempre individuais, embora juntamente com a intuição do fato, temos a intuição de essência.

Um objeto individual não é meramente individual, um este aí!, que não se repete; sendo "em si mesmo" de tal e tal índole, ele possui sua especificidade, ele é composto de predicáveis essenciais que têm de lhe ser atribuídos ("enquanto ele é como é em si mesmo"), a fim de que outras determinações secundárias, relativas, lhe possam ser atribuídas. (HUSSERL, 2006, p.35).

Os fatos, enquanto fatos, não repetem, são individuais, um “este aí". Todavia, são, por sua essência, contingentes. O que Husserl quer dizer com isso? O fato não é contingente em $s i$, afirmação essa descabida de sentido. O contingente só pode ser contingente em relação àquilo que ele é. $\mathrm{O}$ fato contingente só é contingente em relação à sua essência.

Mas de que modo podemos dizer que todo fato tem uma essência? Isso não significaria cair no Platonismo, na noção de que existe um mundo das ideias?

Não existe nada de místico nisso. Já havíamos observado que todo fenômeno, por ser fenômeno de algo, possui uma essência. A essência não é real. Se eu percebo algo que me parece um gato, esse "ser gato" não é desvinculado de sua aparência, é justamente, em virtude de sua aparência, que sei que se trata de um gato. Se parecesse outra coisa, não seria gato. O que a coisa é está vinculado com sua aparência. Mais precisamente: não existe um eidos em si, que não esteja vinculado a objeto individual que o exemplifique, ainda que seja exemplificado em imaginação.

No caso, não estamos discutindo o "fato em si", mas o fato dado à consciência por uma percepção. Para que se compreenda em que sentido todo fato possui uma essência, devemos recorrer à simples constatação de que todo fato singular percebido pode ser predicado do seguinte modo: "isso que percebo me parece ser tal coisa e me parece ser tal coisa não por 
razões fortuitas". Se se admite isso, se aceita que todo fato possui uma essência. Dizer que o "fato percebido" possui uma essência significa afirmar que, embora irrepetível e singular, esse "fato percebido" pode ser alvo de predicados e, dentre esses predicados, existem alguns que lhe são necessários. Se o retirássemos, a coisa deixaria de ser o que é. Por isso, Husserl afirma que um objeto individual não é "meramente individual”, pois possui predicados essenciais.

Se eu percebo um som individual, digamos a nota dó emitida por um violino, posso dizer o que se mostrou para mim é; posso dizer sua essência. Poderia dizer, caso assim se parece para mim: "que é agradável”, mas posso dizer: "é um som de violino" ou pura e simplesmente: "é um som". Que o que estou percebendo seja um som é algo intrínseco àquele fenômeno dado em sua individualidade em "carne e osso". É um predicado essencial deste fenômeno. Posso não saber se é uma nota lá, ou se é uma nota dó. Mas tenho a evidência sobre algo que ele necessariamente é. $\mathrm{O}$ que se ofereceu à minha consciência é um som e não tenho como confundi-lo com uma cor ${ }^{198}$.

Escuto uma segunda vez o violinista tocando uma nota do violino. Sei que o som que foi tocado antes não é o mesmíssimo som que é tocado agora. Ainda que eu não seja capaz de distinguir a diferenças no timbre, volume, altura, sei que não é idêntico ao som anterior, pois aquele som foi tocado antes, este foi tocado agora. Contudo, a diferenciação entre ambos tem limites. Se todo objeto fosse absolutamente único, absolutamente irrepetível e absolutamente diferente de qualquer outro em todos os aspectos, não poderia dizer que agora escutei "um som" e que antes havia tocado outro "som". O ser individual, que se ofereceu a minha consciência antes, era um som, e o que se oferece agora também é um som. Se tudo fosse absolutamente único, absolutamente diferente em todos os aspectos, não poderíamos sequer dar nomes às coisas. Os dois sons percebidos, embora únicos, embora tenham durações distintas e não sejam exatamente os mesmos, possuem em comum algo, isto é, ambos são sons ${ }^{199}$. Logo, ambos os sons possuem uma essência em comum e, em virtude de eu conhecer a essência som, se tocar um som que nunca antes havia escutado, saberei reconhecê-lo como

\footnotetext{
198 Aristóteles estava consciente disso e, por isso considera a intuição a forma pela qual conhecemos o individual. O simples fato de ver uma coisa permite dizer o que ela é. Para Aristóteles não existe ciência do individual, pois o individual é sempre contingente, acidental. o conhecimento do qual se pode dizer "ciência" é sempre um conhecimento de uma espécie. O que é válido para a espécie, ou para a forma, é válido para o individual.

${ }^{199}$ Platão notou isso formou a teoria da ideias para tentar resolver o problema. Tanto um barulho que escuto na rua, quanto a voz suave de mulher são sons, isto, tanto uma coisa, quanto outra, embora diferentes participam da mesma ideia. Essa teoria, apresentada em Parmênides. Nessa obra o Eleata usa contra o jovem Sócrates o famoso argumento do terceiro homem. Parmênides destrói várias ilusões de Sócrates, em primeiro lugar Sócrates quer considerar as ideias como uma realidade mais nobre e bela. Parmênides mostra que as coisas mais abjetas também terão existência abjeta.
} 
som. Simplesmente somos capazes de escutar um som e reconhecer como tal e afirmar: "isso é um som". Ao dizer isso, digo algo sobre o que aquele fenômeno individual é. Por isso, cada uma das intuições singulares "tem sua duração e seu conteúdo de realidade"200. No entanto, "por sua essência", "poderia igualmente estar em qualquer outro momento do tempo". Tanto o fato que se mostrou antes quanto o fato que se mostra agora possuem a mesma essência “som”. E cada som individual percebido, em relação à sua essência, poderia ser diferente, é contingente.

Dizer a essência de uma coisa individual é dizer o que ela é para mim. É dizer um predicado o qual intuímos. Mas essa intuição, pela qual percebemos o eidos, não é uma pura intuição empírica, é uma intuição de essência, ou intuição eidética (o termo grego eidos é usado por Husserl para designar essência). A intuição empírica, pela qual tomamos consciência do objeto singular, é acompanhada por uma intuição de essência, que nos diz o que o objeto é. Quanto a isso, não parece que possamos fazer grandes objeções. Quem poderia negar que é possível predicar os fenômenos percebidos? Mas Husserl dá um passo adiante: predicados essenciais podem ser eles mesmos "postos em ideias"201.

"Essência" designou, antes de mais nada, aquilo que se encontra no ser próprio de um indivíduo como o que ele é. Mas cada um desses "o quê" ele é, pode ser "posto em ideia". A intuição empírica ou individual pode ser convertida em visão de essência (ideação) - possibilidade que também não deve ser entendida como possibilidade empírica, mas como possibilidade de essência. (HUSSERL, 2006, p.35)

O predicado essencial que atribuí àquele som individual pode ser ele mesmo posto em ideia. "Som" não apenas predicará o fato singular. Transformo, pelo processo de ideação, o som que era predicado, em um objeto ideal. Pela intuição eidética eu faço daquele predicado essencial uma nova espécie de objeto, um objeto lógico, ideal, irreal, uma pura possibilidade apriorística, mas também um objeto passível de ser predicado verdadeiramente.

Se eu enuncio o juízo: "um som não é uma cor”, não estou fazendo um juízo sobre um objeto singular dado em intuição empírica. Estou predicando o objeto ideal "som". Acresce, neste caso, que o juízo anunciado é verdadeiro. Mas onde encontro a garantia de que "um som não é uma cor"? Por vias empíricas? Por indução? Ora, não seria esdrúxulo que alguém fizesse um experimento para provar "cientificamente" que uma cor não é um som? Sem

\footnotetext{
${ }^{200}$ Nesta passagem citada, o fato individual é tomado como coisa real, posto que foi tirada do começo de Ideias 1, no qual o autor ainda não praticou a epoché. De todo modo, que todo fato tenha uma essência é uma lei válida tanto para a percepção, na qual inclui a tese de realidade, quanto para a percepção examinada sob a epoché.

${ }^{201}$ Essa noção de que os predicados de coisas singulares podem ser posto em ideia, por ideação, causou e ainda é motivo de polêmica e indignação. Husserl, por isto, foi taxado injustamente de platônico, no sentido pejorativo do termo, como se ele acreditasse em arquétipos com os quais o mundo foi formado, como se Husserl estivesse dizendo que a ideia de "mico leão dourado" e "ventilador" fossem realidades no hiperurânio.
} 
dúvida que um experimento desse gênero é desprovido de sentido: uma cor nunca será um som. Basta que a pessoa tenha uma intuição do que é um som e que tenha uma intuição do que é cor para que se tenha uma certeza absoluta de que um som é um som, uma cor é uma cor, e que cor não é som. Esta intuição eidética oferece o eidos em "carne e osso", ela é originalmente doadora: temos do eidos uma consciência direta.

O mesmo vale se anuncio: "a cor verde é distinta da vermelha". Ora, experimento algum poderia provar, para mim, que sei a distinção entre as duas cores, que o verde e o vermelho são a mesma cor. Basta que eu tenha em mim a ideia de vermelho e a ideia de verde para ver que este juízo anuncia uma verdade essencial. Certo, para que eu tenha tido a visão de essência é necessário que eu tenha outrora visto a cor vermelha e a cor verde. Mas uma única visão da cor vermelha e uma única visão da cor verde são suficientes para que eu tenha para o resto de minha vida, mesmo que me torne cego, a capacidade de saber a verdade do juízo "o verde é distinto do vermelho". Como já havíamos observado, o juízo é verdadeiro quando o próprio objeto sobre o qual dirige o juízo se mostra "ele mesmo" à consciência. De fato, o eidos "verde" e "vermelho" dados em intuição eidética preenchem a intenção significante inerente ao juízo.

Esses exemplos, embora banais, revelam fatores epistemológicos extremamente relevantes. Um juízo, tal como: "uma cor não é um som" não pode nem ser provado indutivamente (Seria risível, como já mencionamos, um suposto cientista elaborar um experimento e empregar métodos estatísticos para saber qual a probabilidade da cor não ser um som), seria tão útil quanto querer provar empiricamente o teorema de Godel. Mas algo ainda deve ser observado: a afirmação "uma cor não é um som", não pode ser falseada empiricamente. Todavia, é uma afirmação verdadeira e necessária para quem intuiu os dois eidos.

“O som é uma sensação". Trata-se de algo que sei que é verdadeiro. Estou agora pensando sobre a essência som, predicando-a verdadeiramente. Posso, pelo fato de ter intuído essa essência, descrevê-la e analisá-la, posso fantasiar sons individuais

Em suma, a intuição originária do individual é sempre acompanhada por uma intuição de essência, a qual é vista com o olhar espiritual. E o predicado essencial da coisa singular pode se tornar, por ideação, um objeto ideal, uma "essência pura". Esses predicados essenciais possuem diversos graus de generalidade. Por exemplo, vejo um aspirador de pó e digo: "é um aspirador de pó", em seguida, “é um utensílio", “é um objeto material”. Aspirador de pó, utensílio, objeto material, e por último um simples "objeto". Tudo isso faz parte da essência do objeto percebido enquanto percebido, na medida em que ele é percebido como um 
aspirador de pó. Cada uma dessas essências possui graus de generalidade. Faz parte, portanto, da essência desse objeto singular que está na minha frente - este aspirador de pó - todas essas essências. É nesse sentido que Husserl afirma: "O apreendido intuitivamente é então a essência pura correspondente ou eidos, seja este a categoria suprema, seja uma particularização dela, daí descendo até a plena concreção.” (HUSSERL, 2006, p.36)

\subsubsection{Distinção entre essência intrínseca ao fenômeno e existência de um real- transcendente}

Devemos distinguir, portanto, entre a "essência" ou "eidos" e a existência realtranscendente. A essência da coisa, isto é, aquilo que ela é, como havíamos dito, não é algo que se esconde por trás da aparência. A essência da coisa é dada pelo modo como a coisa se mostra à minha consciência.

Se percebo um homem, significa que algo aparece para mim de modo tal que eu o entendo como sendo um homem. Se aparecesse de outro modo, se aparecesse tal como uma vaca, com a aparência de uma vaca, eu não compreenderia aquilo como homem. Mas como posso ter "certeza absoluta" de aquilo que vejo é um homem? Como poderei saber se que o que vejo tem a essência homem? O fato é: sabemos que é um homem porque temos evidência de que é um homem. Mas como havíamos dito já no começo, as evidências empíricas podem ser imperfeitas.

O fenômeno não é um “ser em si”. Mas sim o que aquele ser é para mim. E o que ele é para mim é resultado do modo pelo qual ele aparece para mim. Já o "homem real transcendente" à minha consciência não é o próprio fenômeno. Pode ocorrer que, pelas experiências subsequentes, eu me dê conta de que aquilo que eu tinha entendido ser um homem se revele ser um androide. Mas isso só é possível em virtude de novas evidências. Percebo, por exemplo, uma ferida aberta no seu braço e vejo que ele não tem sangue, mas circuitos. Dou-me conta do engano: não é um homem, mas um androide, pois ele está se manifestando para mim tal como um androide se manifesta. Mas isso não significa que ele é "em si" e "na realidade" um androide. Significa apenas que aquilo que, para mim, manifestava-se como sendo homem, por meio de evidências imperfeitas e insuficientes, revelou-se, devido às novas evidências, isto é, devido a novas percepções, como sendo androide. Mas devemos repetir, isso não significa que seja um androide real. Talvez aquilo que aparente ser um androide seja uma ilusão materializada por um gênio maligno. No entanto, mesmo que eu aceite as possibilidades daquilo ser "no fundo" uma ilusão, isso não 
altera em nada o fato de que aquilo tem aparência de um androide. Se é ilusão de alguma coisa, é ilusão de um androide. Seja ilusão de androide, seja holograma de androide, seja androide real, tem a essência androide, pois se mostra com todos os traços e aspectos daquilo que entendo por androide. E não tem a aparência de androide por razões fortuitas, mas porque satisfaz uma série imensa de exigências no seu modo de aparecer. É por satisfazer essas exigências que aparece como um androide e não um leão.

Dizer que o fenômeno tem uma essência não implica necessariamente na existência real e transcendente do objeto, "fora" de minha consciência. Aliás, nada impede que eu esteja enganado acerca da essência do objeto intuído em carne e osso, tal como ocorre quando uma nova evidência corrige uma evidência anterior. ${ }^{202}$

Quem imagina, imagina algo. Se eu imagino um centauro, é possível distinguir o conteúdo da imaginação: o centauro imaginado e o ato de imaginar. Sei que não estou percebendo, mas imaginando. Sei que não estou imaginando uma vaca, mas um centauro. Não posso imaginar um centauro e me enganar sobre o conteúdo. Não faz sentido dizer: "Imagino um centauro, mas me enganei quanto ao conteúdo, pois na verdade imaginei uma mesa". Se imagino um centauro, tenho certeza absoluta que imaginei um centauro. Imaginei algo que é, para mim, um centauro. Portanto, o imaginado tem a essência centauro.

Como havíamos observado, todo ato de perceber tem um percebido, todo ato de pensar tem como correlato um pensado, o ato de julgar tem como correlato um juízo. Trata-se da estrutura da consciência. Em suma, o ego cogito traz em si mesma, como correlato, o seu cogitatum, ou, de outro modo, todo ato intencional tem seu objeto intencional.

Mas algo deve ser esclarecido. Husserl afirma que a consciência, devido ao seu caráter intencional, "assume" o objeto intencional. Outras vezes, toda consciência é consciência de algo. Esse algo, o noema, na atitude transcendental, como já observamos, não é real. Seria correto, portanto, dizer que esse algo que percebemos está na consciência? Aqui é preciso notar a sutileza do autor. De alguma coisa temos certeza: esse "algo" não está plenamente fora da consciência, pois, se o tivesse, não teríamos consciência dele. Mas isso não significa que esse algo esteja completamente "dentro" da consciência ${ }^{203}$. Husserl afirma que consciência e objeto intencional são, isto sim, correlatos. O termo "correlato" é de importância capital,

\footnotetext{
${ }^{202}$ Portanto, se vejo uma xícara, não posso duvidar que esse objeto que percebo, no momento em que percebo, não só parece, mas evidentemente é uma xícara, isto é, tem a essência xícara. Se vejo uma xícara que está na minha frente, em cima da minha mesa, não posso duvidar que tal objeto se manifesta a mim como sendo uma xícara.

${ }^{203}$ Antecipando o capítulo sobre percepção, podemos dizer que apenas um dos perfis está realmente na consciência, os demais perfis do objeto não. Vejo uma pessoa de perfil, não direi que ela tem um único olho.
} 
como ser verá mais adiante. O que importa notar é que o objeto intencional não se confunde com o "objeto real". Uma coisa é o percebido enquanto tal, outra coisa é o "objeto real", que está fora da consciência. Ao ver um elefante, não digo que o elefante real está na minha consciência, mas o elefante percebido enquanto percebido, este sim está, de algum modo, na consciência. Berkeley afirmava que o ser do objeto "é ser percebido". Não podemos ainda afirmar sobre a existência de um objeto real e plenamente transcendente à consciência. Mas podemos afirmar, com segurança que o percebido enquanto tal existe para mim. Isto é, que o objeto intencional existe para o sujeito. E “existir” para não significa ser real ${ }^{204}$.

Toda essa discussão nos coloca numa linha tênue, muito sutil, pois estamos beirando o idealismo, termo que causa horror imediato. Se o mundo inteiro está na consciência, parece que Husserl é idealista. Entretanto Husserl afirma que o seu idealismo é um realismo. É isso que cabe entender. Havíamos dito, entretanto, que o objeto intencional percebido está apenas, em certo sentido, na consciência; está como correlato. Para melhor distinção, fixemos as ideias até aqui alcançadas:

1) Se o objeto real não pode ser pensado, visto, imaginado etc., resulta daí que o próprio termo "objeto real" não faz sentido. Afinal, quando falo do objeto real, nele estou pensando, o que significa que ele é objeto do pensamento e objeto da linguagem.

2) Todo objeto possível de ser alvo de ciência, de discurso, deve estar, de algum modo, na consciência.

3) Todo objeto intencional possui uma essência. Essa essência é intuída. A essência não é algo "em si" do objeto. A intuição eidética não suga a essência no coração do ser, no "em si” do objeto. A essência está na relação entre sujeito e objeto. A essência está implica na vivência intencional. Isso não significa que a essência seja fortuita. Não há "fenômeno em si" e, sua essência, do mesmo modo, não é uma "essência em si", independente do fenômeno e do sujeito. Mas um detalhe deve ser observado. Uma coisa é a essência do fenômeno particular, quando este fenômeno é um objeto percebido. Havíamos dito que, em alguns casos, podemos nos enganar: vejo algo que creio ser um homem, aproximo, vejo melhor, e descubro que é uma manequim. Então quer dizer que o eidos manequim se confunde com o eidos homem? A resposta é negativa. O erro está no reconhecimento da essência do objeto. É aí que está a confusão. A confusão não está no próprio eidos. Para quem é capaz de intuir o eidos coelho e o eidos gato, tem certeza absoluta que um gato não é um coelho. O homem é capaz

\footnotetext{
${ }^{204}$ Uma alucinação existe para mim é parece ser algo e, por isso, pode ser alucinação de uma vaca ou de um peixe. Embora exista para mim é ainda assim caracterizada irreal, tal como são todos os fenômenos transcendentalmente purificados.
} 
de ver, com o olho do espírito, a diferença e sabe a diferença entre ambos. Mas "vendo de longe" é possível confundir-se e pensar que o que se está vendo é coelho; ao aproximar e "vendo melhor", a nova aparência do "mesmo objeto dado em carne e osso" se mostrará como aparência de um gato. Conhecer a essência não é conhecer o "em si" do objeto, é conhecer o que é "para mim".

\subsubsection{Essência e imaginação. O campo das experiências possíveis}

O percebido enquanto percebido possui um eidos. E este eidos, pode ser "posto em ideia”, tornando-se objeto lógico e tornando-se possível objeto de predicados verdadeiros. Havíamos dito que a sentença "uma cor não é um som" é absolutamente verdadeira para quem intuiu a essência som e a essência cor. Da mesma maneira, o juízo "um sentimento não possui extensão" é uma verdade essencial. E mesmo “toda percepção é percepção de alguma coisa".

Mas falta algo de grande importância, que ainda não foi observado:

(...)Nenhuma intuição de essência é possível sem a livre possibilidade de voltar o olhar para algo individual "correspondente" e de formar uma consciência exemplar. - assim como também de modo inverso, nenhuma intuição individual é possível sem a livre possibilidade formar uma ideação e de nela direcionar o olhar para as essências correspondentes, que se exemplificam no visível individual; (HUSSERL, 2006, p.38)

Assim, se tenho uma intuição de essência, por necessidade essencial devo ser capaz de voltar o olhar para um ser individual que corresponda a essa essência. Um dos pontos que faz a genialidade de Husserl é a simples observação de que "esse individual não é necessariamente apreendido pela intuição empírica"

Como já havíamos notado, o eidos pode se exemplificar intuitivamente não apenas em dados de experiência perceptiva, mas também em outras espécies de intuições, como recordação, mas também em dados de imaginação.

Havíamos visto que se eu tenho uma "alucinação de uma vaca" essa alucinação não é uma alucinação de nada, mas é alucinação de uma vaca. A alucinação da vaca representa uma vaca individual. A vaca alucinada pode ser uma vaca malhada ou branca. Mas se ela é malhada, não é branca. A alucinação que tenho é desta vaca individual (ainda que alucinada), tem características que a individualizam, diferenciando-a de outras alucinações possíveis de vacas. O mesmo ocorre quando me lembro de uma vaca. Se me lembro de uma vaca é porque não estou me lembrando de uma xícara. Tenho certeza que estou me lembrando de uma vaca e não de uma xícara. 
Ora, algo semelhante ocorre quando eu imagino uma vaca. Uma coisa é imaginar uma vaca preta, outra uma vaca amarela. Posso imaginar uma vaca da raça angus ou nelore. Esse ato intuitivo, pelo qual eu imagino uma vaca, acaba exemplificando uma possibilidade do eidos vaca. Por outro lado, se eu quero imaginar uma vaca, sou obrigado a pintar na tela de minha consciência algo que tenha a aparência correspondente a uma vaca. Ou seja, não imagino a essência da vaca, mas uma vaca individual.

Posso também imaginar diferentes centauros. Imagino um centauro cuja parte humana é tem a face barbada, imagino outro centauro cuja parte humana não possui barba; imagino um o qual a parte cavalo é parda, outro que é alazã. Entretanto, se um unicórnio aparece na tela da minha consciência, saberei que aquilo não é um centauro. Isso nos leva a uma estranha, mas importantíssima observação. Sem entendê-la não se entende a fenomenologia.

Apreensão intuitiva de essência não implica minimamente a posição de um existente individual; puras verdades de essência não contêm a mínima afirmação sobre fatos, portanto, delas tampouco se pode inferir a mais ínfima verdade factual (HUSSERL, 2006, p.39).

Eu não preciso ver um centauro para ter dentro de mim a essência centauro. E ainda assim, a lei eidética segundo a qual "Nenhuma intuição de essência é possível sem a livre possibilidade de voltar o olhar para algo individual "correspondente" e de formar uma consciência exemplar", mantém-se respeitada. Mantém-se respeitada porque vejo na imaginação um centauro tocando flauta ${ }^{205}$.

Posso imaginar um centauro quantas vezes eu quiser, todos esses diferentes atos com os quais eu o represento são atos psicológicos; mas o centauro não é esses atos; A essência centauro é uma essência, que, pelo seu sentido, para mim, não existe na natureza real, mas existe em uma natureza possível. A essência de um centauro limita as possibilidades de eu representá-lo intuitivamente em livre fantasia. Se imagino um cubo de aço, sei que não imaginei um centauro, isso, por sua própria essência.

Como vimos, toda essência, para que seja uma essência, deve contar com a possibilidade de intuição de algo individual que a represente, seja essa intuição uma intuição

\footnotetext{
${ }^{205}$ Ainda aqui é preciso distinguir o vivido de imaginação e o imaginado enquanto tal. A imaginação é um ato de consciência no qual eu represento o centauro, mas, com Husserl alerta, a representação pode ser entendida em dois sentidos:

"Representação" pode ser compreendida aqui em dois sentidos. O centauro é representação no sentido que se chama o representado de representação, mas não no sentido de que representação é um vivido psíquico. $\mathrm{O}$ centauro mesmo não é, naturalmente, nada de psíquico, não existe, nem na alma, nem na consciência, nem onde quer que seja, ele não é "nada", é imaginação; dito com mais precisão: o vivido-de-imaginação é vivido de um centauro". (HUSSERL, 2006, p.68)
} 
originária ou não. Por outro lado, há a situação invertida, toda visão individual possui uma essência correspondente. Em virtude disso, Husserl escreve:

Se em imaginação livre produzimos figuras no espaço, melodias, processos sociais, ou fingimos atos de experiência, de prazer ou desprazer, querer, etc. podemos, por "ideação" neles aprender, em intuição originária e eventualmente adequada, diversas essências puras, tais como a essência da figura, da melodia, etc. do tipo particular em questão. É indiferente, neste caso, se algo assim já tenha sido dado ou não numa experiência atual. Se a livre ficção, não importa por que milagres psicológicos, levasse à imaginação de dados que, por princípio, fossem de uma nova espécie, por exemplo, dados sensíveis que jamais tivessem ocorrido em experiência alguma, isso em nada modificaria o dado originário da essência correspondente: os dados imaginados, no entanto, jamais serão dados efetivos. (HUSSERL, 2006, p.38)

Justamente por isso, a fenomenologia é fundamentada sobre a experiência possível. Não é necessário ao fenomenólogo fazer uma "ciência de fatos" para que faça uma "ciência de essências", assim como não é necessário ao matemático faça experimentação para provar suas teorias. Sem dúvida, é preciso que tenha a intuição de essência, para que possa explorá-la, e, em muitos casos, essa intuição de essência só é obtida pela experiência atual, pela intuição perceptiva. Um cego de nascença não terá a essência "cor" e não vê cor alguma individual. Mas se por um milagre psicológico, ele visse, em sua imaginação, a cor vermelha, e a cor verde, o dado de sensação imaginado já lhe serviria para obter a essência. Dificilmente uma pessoa que tenha nascido surda terá o eidos "som" (a não ser por um milagre psicológico). Mas um homem que se torne surdo, o eidos som permanecerá em sua memória. A surdez de Beethoven, (1770-1827) ao final de sua vida, não o impediu de compor obras que estão entre suas melhores.

Segundo, Husserl, pela livre fantasia, podemos fantasiar experiências possíveis.

Psicologia eidética, como ciência eidética da natureza em geral, é uma pesquisa voltada sobre o terreno estavelmente dado de uma natureza idealmente possível, ou na verdade, o que dá no mesmo, é uma pesquisa dirigida na constante efetuação de experiências possíveis em geral. Que significa esta última coisa? A "experiência possível" é uma consciência paralela à experiência real, de tal modo que, se aquela nos dá a realidade, esta dá a possibilidade? A resposta é clara. Aquilo que aqui significa "experiência possível" é antes de tudo um "imaginar experienciar", em certo sentido, um viver a experiência, sem que se tenha a experiência de verdade. Em termos correlativos, é um livre fantasiar acerca da natureza e aos objetos da natureza. A natureza fantasiada não é a natureza da experiência atual; (...) Apesar da natureza não ser real, ou mesmo (em termos correlativos) não seja objeto de experiência atual, essa é, todavia, uma natureza quaseexperienciada: o fantasiar tem, de fato, em si mesmo um caráter de um certomodo-experienciar, "como se percebesse" ou "como se recordasse", mas também, um livre plasmar. (HUSSERL, 2004, p.147. Tradução nossa.) 
O ponto que merece atenção é justamente o fato de que a livre fantasia está limitada pela essência correspondente. Fantasiar melodias possíveis é diferente de fantasiar ruídos possíveis, que é diferente de fantasiar figuras geométricas possíveis. A fantasia está limitada a condições apriorísticas:

Isso significa que as possibilidades, ainda que livres, são vinculadas a leis, e em particular, leis a priori, e que este a priori vem formulado e determinado cientificamente, ou seja, em evidência. Um estrato da natureza possível em geral é o espaço possível com suas figuras espaciais idealmente possíveis: objeto da geometria, a qual é, portanto, um terreno essencial da eidética da natureza, uma das suas disciplinas fundamentais. (HUSSERL, 2004, p.149. Tradução nossa.).

Com essas considerações, torna-se nítida a distinção entre o estudo das experiências possíveis e os estudos das experiências reais; entre as experiências simplesmente concebíveis e as experiências de fatos. Questionemo-nos: É possível fantasiar um sentimento dotado de extensão? Uma vaca que tenha um aspecto de um número? Não da representação do número, mas do próprio número? É concebível que haja uma consciência que não seja consciência de nada? É possível que dois acontecimentos simultâneos em um referencial não sejam simultâneos em outro referencial? É possível que as leis do espaço físico, em determinados referenciais, não sigam a geometria euclidiana? É possível pensar um espaço no qual a relação entre o perímetro e o diâmetro não seja $\pi$ ? É possível que um objeto material não ocupe lugar no espaço?

É difícil estabelecer, por enquanto, todo alcance da livre fantasia e do método pelo qual estudamos as essências puras. Isso se tornará mais claro com o decorrer das análises. O que vale notar é que os terrenos da experiência possível formam um terreno do ser, aquele de uma possibilidade de uma natureza. Os estudos das essências visam clarear o possível e o impossível, indicando as possibilidades de qualquer experiência possível.

Einstein, embora não tenha formulado uma teoria do conhecimento, reconhece o papel da experiência idealizada a respeito do movimento. Afirma que reside aí o gênio de Galileu.

Imaginem uma estrada uma estrada perfeitamente lisa e rodas sem atrito algum. Então, nada haveria para deter o carrinho e ele continuaria deslocando-se para sempre. Chega-se a essa conclusão somente imaginandose uma experiência idealizada que jamais poderá ser realmente realizada, porquanto é impossível eliminar todas as influências externas. A experiência idealizada mostra a pista que realmente formou o fundamento da mecânica do movimento. (EINSTEIN; INFELD, 1988, p. 16).

Isso significaria que o experimento idealizado de Galileu e suas conclusões sobre o movimento são verdadeiras? Não é esse o caso. O que interessa é que Galileu raciocinou tendo como base experiências possíveis, ainda que não factíveis; e justamente por isso, se 
contrapôs à ideia de Aristóteles. A noção de movimento, tal como compreendida por Galileu está no plano do concebível, mas outras ideias de movimento também são concebíveis. Uma outra teoria pode, muito bem, fazer do modelo teórico de Galileu apenas uma possibilidade de uma generalidade maior ${ }^{206}$. O pensamento conceitual exige a capacidade de se pensar o possível, o que implica explorar as essências e a relação entre as essências, a essência do espaço, do movimento, do tempo etc. Mas também podemos explorar as condições apriorísticas de essências como um computador, um serrote, um sapo, um animal. O método é realizar em livre fantasia, experimentos possíveis. Trata-se de uma exploração da própria intuição, das noções que temos. Em certo sentido, foi o que Agostinho fez ao explorar a mente. Troquemos o termo substância por essência, que para Agostinho, são sinônimos.

Não se pode dizer com lógica, que se tenha conhecimento de alguma coisa da qual se desconhece a substância. Se ela se conhece é porque ela conhece a sua substância. Se ela se conhece com certeza é porque ela conhece com certeza a sua substância. Ora, ela se conhece com certeza, como prova o que acima foi dito. Pelo contrário, ela não tem certeza alguma de ser ar, fogo, ou algo de corporal. Não é, portanto, nenhuma dessas coisas. Toda força do preceito de se conhecer reside na certeza de que não é nada daquilo que ela não está certa. (De trinit. X, 10, 16; 2005, p.329)

Nullo modo autem recte dicitur sciri aliqua res, dum eius ignoratur substantia. Quapropter, dum se mens novit, substantiam suam novit; et cum de se certa est, de substantia sua certa est. Certa est autem de se, sicut convincunt ea quae supra dicta sunt. Nec omnino certa est, utrum aer, an ignis sit, an aliquod corpus, vel aliquid corporis. Non est igitur aliquid eorum. Totumque illud quod se iubetur ut noverit, ad hoc pertinet ut certa sit non se esse aliquid eorum de quibus incerta est, idque solum esse se certa sit, quod solum esse se certa est. (...) (De trinit. X, 10, 16)

Não é uma necessidade apriorística que a mente seja átomos, ar, fogo. Por outro lado, é inconcebível uma mente que não tenha inteligência, memória e vontade. Em outras palavras, trata-se de subtrair da mente tudo aquilo que é contingente, tudo aquilo que não necessariamente faz parte da mente.

Pensaria, porém, por meio de uma presença interior, real e não imaginária pois nada lhe é mais presente do que ela mesma - assim como entende que está viva, que recorda, que entende ou quer. Pois ela tem ciência de todos esses atos em si mesma. Portanto, não é algo que imagina, como se tivesse sido influenciada exteriormente, mediante os sentidos, como acontece com as realidades corporais. Se ela não se apegar arbitrariamente a esses pensamentos, de modo a não pensar que ela mesma seja algum desses elementos, tudo o mais que lhe restar em si mesma é isso, que é ela mesma. (De trinit. X, 10, 16; 2005, p.330).

\footnotetext{
206 Nós não queremos concluir, daí, dizer que Einstein corrobora ou não com Husserl a respeito da fenomenologia. Einstein foi um grande físico, soube observar, o papel do puro pensamento conceitual na física, soube que este pensamento conceitual não era um derivado imediato dos números tirados dos experimentos.
} 
Si quid autem horum esset, aliter id quam cetera cogitaret, non scilicet per imaginale figmentum, sicut cogitantur absentia, quae sensu corporis tacta sunt, sive omnino ipsa, sive eiusdem generis aliqua; sed quadam interiore, non simulata, sed vera praesentia (non enim quidquam illi est se ipsa praesentius); sicut cogitat vivere se, et meminisse, et intellegere, et velle se. Novit enim haec in se, nec imaginatur quasi extra se illa sensu tetigerit, sicut corporalia quaeque tanguntur. Ex quorum cogitationibus si nihil sibi affingat, ut tale aliquid esse se putet, quidquid ei de se remanet, hoc solum ipsa est. (De trinit. X, 10, 16)

Em outras palavras, Agostinho, ao investigar a substância da mente, o que faz, no fundo, é investigar as condições apriorísticas da mente, a essência da mente. Contudo, comparando com Husserl a uma diferença fundamental. Substância não se confunde com essência. O estudo da essência não implica em existência. Posso estudar a essência de um espaço não significa que esse espaço que estudo seja real. Posso estudar a essência de um centauro, o que não significa que o centauro seja real. Na atitude transcendental, estudamos a essência, sem efetuar a tese de existência. É justamente aí que reside a força da fenomenologia. Posso estudar a essência de uma cadeira, da psique, do corpo, de um objeto da cultura, abstendo-me da tese de existência real de tais objetos. Trata-se, como já dissemos, do estudo das condições sem as quais eu não teria a noção de cadeira, de psique, de corpo. Este estudo esse que é válido ainda que o mundo que eu esteja vivendo agora seja um sonho coerente, ou o véu de Maia. Mais adiante, o que estudaremos, usando sobretudo da livre fantasia, é justamente a essência do sujeito psíquico. 


\subsection{A reflexão fenomenológica transcendental}

\subsubsection{Reflexão natural e reflexão transcendental}

Para estudarmos a essência das vivências intencionais transcendentalmente reduzidas, é preciso familiarizar com o método da reflexão fenomenológica transcendental. Trata-se de reflexão, pois o objeto será justamente os atos de consciência.

Adotamos a definição de ato reflexivo conforme definido por Husserl. Trata-se de um ato de consciência que tem como objeto outro ato de consciência. $\mathrm{O}$ ato reflexivo básico é a percepção imanente. Husserl distingue dois tipos de percepções. Percepções dirigidas à imanência e percepções dirigidas à transcendência.

Por atos dirigidos à imanência ou, de maneira mais geral, por vividos intencionais referidos a imanência, entendemos aqueles da essência dos quais faz parte que os seus objetos intencionais, no caso de existirem, pertencerem ao mesmo fluxo de vividos que eles mesmos. Isso é, portanto, correto, por exemplo, em toda parte onde um ato seja referido a um ato (uma cogitatio a uma cogitatio) do mesmo eu, ou, igualmente, um ato a um dado sentimento sensível do mesmo eu etc. A consciência e seu objeto formam uma unidade individual constituída puramente por vividos. (HUSSERL, 2006, p.93)

A percepção imanente tem por objeto um vivido de consciência. Em outras palavras, a percepção imanente é uma vivência cujo objeto é outra vivência ${ }^{207}$. Toda vez que um vivido de consciência é apreendido em uma percepção imanente, efetuamos uma reflexão. Assim, na vida cotidiana, quando afirmamos: "Eu estou percebendo que você estava com o cabelo cortado", nosso juízo coloca em evidência tanto o cabelo cortado da pessoa quanto nosso próprio ato de percebê-lo. Isto é distinto de dizer: "você ficou bem com esse corte de cabelo". $\mathrm{O}$ ato do juízo, neste último caso, tem como correlato um objeto percebido e não o ato da percepção, como no exemplo anterior.

$\mathrm{Na}$ percepção dirigida para a transcendência o "objeto visado" não é um vivido de consciência. Ao ver um filme no cinema, não fico percebendo que percebo um filme. Em outras, palavras, o meu eu está imerso na vivência da percepção dirigida para a transcendência, está mergulhado no filme, o olhar do espírito está direcionado para a transcendência, trata-se de um vivido irrefletido. Mas esse vivido irrefletido pode ser, por princípio, refletido. Tudo se passa como se o eu, que está com o olho do espírito voltado para o filme, desse como que um passo para trás, para prestar atenção também no fato que está

\footnotetext{
${ }^{207}$ Vivência intencional e atos de consciência são sinônimos para Husserl. (cf. livro V das Investigações lógicas)
} 
percebendo o filme. $\mathrm{O}$ eu percebe sua percepção do filme. Isso implica um direcionar da atenção, no qual apreendo minha vida de consciência.

A percepção irrefletida é um estado de consciência dirigida a alguma coisa. Este estado irrefletido pode tornar-se objeto de uma percepção. Ou seja, o estado irrefletido pode se tornar refletido, por meio de um ato reflexivo. Mas, a vivência apreendida por um ato reflexivo é um estado ou um objeto? Husserl explica isso da seguinte forma: $\mathrm{O}$ ato de percepção imanente, no qual a atenção apreensiva volta-se pra o estado irrefletido é um ato objetificante. O estado de consciência torna-se, pela atenção apreensiva, um objeto, o qual pode ser examinado ${ }^{208}$.

Para se compreender a reflexão é preciso distinguir. Uma coisa são as vivências intencionais; outra é o próprio eu que vive as vivências intencionais. ${ }^{209}$ Ora, o ato reflexivo tem como objeto não o próprio eu, mas sim as vivências do eu. Percebo, em uma percepção imanente, a vivência da imaginação, da percepção, da lembrança etc. O eu nada mais é do que o sujeito da vivência.

Todo eu vive seus vividos, e nestes está realmente e intencionalmente uma variedade de coisas. Ele os vive, o que não quer dizer que os tenha sob "sob o olhar", a eles e àquilo que está incluso neles, nem que os apreenda no modo da experiência imanente ou de uma intuição e representação imanente qualquer. Todo vivido que não se tem "sob o olhar" pode, por possibilidade ideal, passar a ser "notado", uma reflexão se dirige a ele, ele se torna então objeto para o eu. Igualmente assim se passa com os possíveis olhares do eu para os componentes do vivido e para suas intencionalidades (para aquilo de que elas eventualmente são consciência). As reflexões são, mais uma vez, vividos que podem, como tais, tornar-se substrato de novas reflexões e assim in infinitum, em generalidade de princípio. (HUSSERL, 2006, p.168)

$\mathrm{O}$ eu que vive as vivências intencionais tem como característica o fato de que ele lança um raio de consciência para o objeto intencional. $\mathrm{O}$ ato pelo qual percebemos uma casa, por exemplo, é uma intuição que tem como objeto a casa. É um estado e não um objeto. Contudo, como já observamos, o eu pode a qualquer momento, direcionar o olhar para a própria percepção da casa, o que poderia ser colocado da seguinte forma: "percebo que percebo uma casa". O estado de consciência, no qual a casa era percebida, torna-se ele mesmo objeto de uma nova percepção - a "percepção da casa" é o objeto de um novo ato intencional efetuado pelo eu: o ato reflexivo. Poderíamos assim dizer que na percepção da casa, o eu estava dirigido para a transcendência: o objeto visado era a casa. No ato reflexivo, o objeto

\footnotetext{
${ }^{208}$ Estamos assistirmos ao filme e estamos tão envolvidos com a trama, que a morte de um personagem gera em nós um sofrimento desmedido. Nessa hora, como quem acorda de um sonho, a reflexão pode surgir: "esse filme que estou vendo é apenas um filme, uma ficção." Sem dúvida que em casos extremos tal processo pode ser compreendido como uma doença psíquica, pela qual o eu nunca quer mergulhar em uma situação e está sempre com sua atenção dirigida para os próprios atos.
}

${ }^{209}$ Como o ato de perceber alguma coisa, imaginar algo, pensar em algo, etc. 
apreendido é o próprio vivido: "a percepção de casa". Todo vivido ${ }^{210}$ tem a potencialidade de se tornar "notado", isto é, de ser refletido.

É importante observar que os atos reflexivos não se resumem puramente a "percepções imanentes". Isso porque existem outros atos de consciência que também possuem como objetos vivências intencionais, por exemplo, a valoração reflexiva. "Noutras palavras, toda cogitatio pode se tornar objeto de uma assim chamada "percepção interna" e então, posteriormente, objeto de uma valoração reflexiva, de uma aprovação ou reprovação etc". (HUSSERL, 2006, p.91). Mas, em todo caso, todos os atos reflexivos são fundados em percepções imanentes. Em termos simples, para que eu julgue o vivido tenho, antes de julgálo, que percebê-lo.

Por exemplo, sou tomado por um desejo de algo; mas posso, em um momento seguinte, perceber o próprio desejo, apreendê-lo, voltar o olhar do espírito para o próprio desejo. Uma vez que o desejo seja apreendido pela atenção, ele pode ser objeto de um ato de julgamento de valor. Por exemplo, sinto desejo de abrir a geladeira e pegar uma cerveja. O desejo simplesmente me vem. Mas no momento seguinte posso pensar: "mas que desejo inconveniente esse, ainda tenho muito a escrever". O próprio desejo, que anteriormente era estado, tornou-se objeto de uma "percepção interior"; posteriormente esse desejo específico tornou-se objeto de um ato valorativo e foi reprovado por mim. Essa reflexão, pela qual objetificamos estados de consciência trata-se de algo que, segundo Husserl, é especificamente humano. Segundo Husserl, os eus-sujeitos animais não são capazes de trazer os vividos às expressões predicativas, o que ocorre, por exemplo, quando eu digo: "eu percebo uma folha de papel aqui na minha frente"

Husserl distingue a reflexão fenomenológica transcendental da reflexão natural. Em primeiro lugar, é preciso observar é que os atos reflexivos constituem a base do método fenomenológico.

Entre as peculiaridades eidéticas mais gerais da pura esfera dos vividos, trataremos em primeiro lugar da reflexão. Faremos isso em virtude de sua função metodológica universal: o método fenomenológico se move inteiramente em atos de reflexão. (HUSSERL, 2006, p.167).

A reflexão transcendental diferencia-se da reflexão natural. Esta última ocorre naturalmente, em nossa vida cotidiana, toda vez que avaliamos os desejos, que expressamos nossas emoções, nossas dúvidas, isto é, nossos estados interiores. Essa reflexão natural não

${ }^{210}$ Cremos, conforme nota Bello (2004), que o termo "vivência" é mais adequado do que o termo "vivido". Entretanto, o termo vivido tornou-se mais consagrado e é usado na maioria das traduções para o português. Por isso, usamos, conforme a contexto, em alguns momentos, o termo "vivido", em outros o termo "vivência" como sinônimos. 
necessariamente é feita tendo em mira a aquisição de conhecimentos teóricos. Já a reflexão fenomenológica transcendental constitui um método rigoroso de investigação das vivências $^{211}$.

Todavia, embora Husserl tenha desenvolvido um método rigoroso para a análise das vivências, Agostinho e outros pensadores consciente ou inconscientemente empregam de atos reflexivos para o conhecimento da vida interior. A ideia de reflexão, aliás, é uma das bases do pensamento de Agostinho.

A reflexão fenomenológica transcendental visa estudar a estrutura das vivências intencionais. Busca analisar a essência das vivências. A essência da percepção, da imaginação, da vontade. Há outro aspecto importante. O próprio vivido intencional analisado pela reflexão transcendental não é posto como estado psíquico real, pois qualquer posição de realidade, inclusive das próprias vivências, está fora de circuito. Um último aspecto a ser mencionado é que a reflexão transcendental não tem como escopo a análise do vivido em sua individualidade factual, mas, como dissemos, em sua essência.

\subsubsection{O eu puro como condição de possibilidade da reflexão}

O eu puro foi introduzido por Husserl a partir de Ideias 1 e exerce um importante papel na estrutura do pensamento fenomenológico. De um lado ele faz a ligação entre as diversas vivências, pois é um mesmo eu puro que vive as diferentes vivências, fazendo com que com que o fluxo de vividos tenha uma unidade. Todas as vivências, por terem em comum um eu idêntico que as vive, estão ligadas entre si, formando um "todo bem ligado". Embora haja uma corrente de cogitationes, o eu puro permanece o mesmo. É um mesmo eu que vive as vivências, polo estrutural ao qual todas as vivências estão referidas. Ele não possui um conteúdo particular, embora possua, como veremos, posições perante objetos intencionais, tenha modos de se comportar e seja o substrato do habitus. Vejamos o seguinte exemplo. Percebo um cinzeiro, volto meus olhos para outra coisa e agora vejo um gato. Embora a percepção do cinzeiro tenha terminado, posso agora "reproduzi-la" Em outras palavras, posso lembrar-me da percepção do cinzeiro a fim de examiná-la. Ao reproduzi-la, a vivência de percepção antes irrefletida passa a ser objeto. Mas aqui entra um problema: quando a vivência irrefletida é reproduzida, tornando-se objeto de reflexão, não ocorre uma alteração da

\footnotetext{
${ }^{211}$ A reflexão fenomenológica não investiga as vivências em sua singularidade, mas em suas essência.
} 
vivência? Segundo Husserl, de fato há uma alteração que faz com o que antes era estado de consciência torne-se objeto. Entretanto, isso não altera a essência da vivência.

Mas isso é verdade em relação a toda a reflexão, portanto também em relação à reflexão natural. A alteração é essencial, pois o estado vivido, ingênuo de início, perde sua "espontaneidade" primitiva precisamente pelo fato de que a reflexão toma por escopo o que de início era estado e não objeto. A tarefa da reprodução não é reproduzir uma segunda vez o estado primitivo, mas sim explicá-la e observar o seu conteúdo. (HUSSERL, 2001, p.52)

Se não houvesse a possibilidade de um ato reflexivo se dirigir aos estados primitivos irrefletidos, qualquer conhecimento da vida de consciência seria impossível. Se eu afirmo que tenho percepções é porque posso perceber minhas percepções. No entanto, é necessário concordarmos que há sim uma alteração quando reproduzimos um vivido para examiná-lo. $\mathrm{O}$ que era estado torna-se objeto. Mas se assim não fosse, como iríamos examiná-lo? Como percebê-los.

O que importa é que essa alteração do vivido que deixa de ser estado para se tornar objeto, não altera a essência do vivido. Se vi um cachorro ontem na rua e me lembro da percepção do cachorro, já estou refletindo, pois esta recordação é um estado de consciência que tem como objeto a percepção que tive do cachorro - diante do olhar do espírito está uma reprodução do vivido original. Ao lembrar-me da percepção que tive não viverei originalmente a percepção do cachorro, se assim fosse, não seria reflexão, seria um puro voltar no tempo e viver outra vez o que já vivi.

É verdade que não consigo me recordar exatamente de todas as fases perceptivas daquela percepção que tive, mas consigo lembrar-me do essencial, para analisá-la. Entretanto, não estou interessado em analisar este vivido em sua singularidade, em sua individualidade, mas sim, a sua essência, isto é, o que um vivido de percepção tem em comum com qualquer outro vivido de percepção. Mas não preciso, necessariamente, para executar a reflexão reproduzir uma vivência que outrora vivi. Posso simplesmente fantasiar uma percepção possível qualquer. Por exemplo, fantasiando a percepção de um alienígena imaginado, doume conta que essa "percepção" também deve possuir fases perceptivas, que o alienígena deve ser mostrar por perfis, etc. Que deve haver nesta percepção dados de sensação. 


\subsubsection{Objeções à reflexão}

No final do século XIX houve uma proliferação de métodos para se abordar a psique. Dentre esses métodos se encontrava a "introspecção". Wundt, James, Brentano, Fechner e outros psicólogos do fim do século dezenove defenderam a introspecção, como um método para obtenção de conhecimentos psicológicos. Em linhas gerais, esta pode ser concebida como um método pelo qual indivíduo pode conhecer sua própria vida mental. Entretanto, existem certas diferenças no modo como cada um desses psicólogos entenderam a introspecção. Alguns tinham que ela poderia ser usada para se fazer uma ciência quantitativa, outros que poderia ser empregada para uma ciência qualitativa. Brentano diferenciava autoobservação da auto-percepção. Não é possível fazermos uma discussão detalhada sobre as diferentes posições dos psicólogos acerca do que é a introspecção, como cada um deles fez uso e a concebeu. O que importa observar é que Husserl, em Ideias 1, evita o termo introspecção. Husserl, usando o termo "reflexão", a qual é a base metodológica da fenomenologia. São muitos os aspectos pelos quais Husserl usa o termo reflexão e não introspecção. Pela epoché, a tese de existência real do mundo transcendente à consciência é posta fora de circuito. Daí que não faz sentido dizer que o método da fenomenologia é a "introspecção fenomenológica transcendental”, pois o próprio termo carrega o sentido de dirigir-se à interioridade, o que é absurdo, pois é a própria noção de exterioridade que está entre parênteses $^{212}$. E, por outro lado, talvez seja a reflexão que possa revelar o sentido de exterioridade. Até o momento tudo o que temos são atos intencionais, consciência de alguma coisa. Não temos nenhum objeto que não seja para a consciência. O objeto intencional é justamente isso, ele é para a consciência. Não é objeto em si.

O fenomenólogo parte da consciência, que é ser absoluto. Seu objetivo é estudar os atos de consciência. Mas, para estudar estes atos, ele deverá efetuar atos de consciência dirigidos aos atos que ele quer estudar. Com atos reflexivos, estudará os diversos tipos de atos de consciência, dentre os quais a percepção dirigida à transcendência.

A reflexão fenomenológica é uma forma segura de obtenção de conhecimentos sobre si. Isso não significa, entretanto, que o sentido de um conteúdo de consciência seja manifesto, tal

\footnotetext{
${ }^{212}$ Como havíamos citado atrás: "Esse eu e sua vida psíquica, que mantenho necessariamente apesar da epoché, não são uma parte do mundo; e se esse eu diz: "Eu sou, ego cogito", isso não mais quer dizer: "Eu, como esse homem, sou. "Eu" não é mais o homem que se percebe na intuição natural de si considerado como homem natural, nem tampouco o homem que, limitado pela abstração aos dados puros da experiência "interna" e puramente psicológica, capta seu próprio mens sive animus sive intellectus, nem mesmo a alma, ela própria, tomada separadamente". (HUSSERL, 2001, p.42)
} 
como, segundo Lyotard, concebia a psicologia espiritualista do fim do séc. XIX. De fato, Lyotard (1986), ao se referir à relação entre psicologia e a fenomenologia, comenta:

Acontece que a fenomenologia está de acordo com o objectivismo para criticar certas teses introspectivistas. Que o sentido dum conteúdo de consciência seja imediatamente manifesto e captável enquanto tal, isso é desmentido pela própria empresa psicológica: se sentimos necessidade duma ciência psicológica, é precisamente porque sabemos que não sabemos o que seja o psiquismo. É verdade que, estando assustado, eu sinto medo; mas não sei por isso o que seja o medo, sei somente que tenho medo. (p.53).

Assim, é necessário diferenciar a "introspecção" da "reflexão", e, em especial a reflexão fenomenológica, pois esta pode trazer ao sujeito conteúdos confiáveis:

Compreende-se porque razão Husserl, a partir de Ideen 1, procurava fundar a validade da reflexão na retenção, função que não deve confundir-se com a memória, pois é, ao contrário, sua condição. Pela retenção, o vivido continua ele próprio e em pessoa a ser-me dado, afectado de um estilo diferente, isto é, sob a forma do já não. Esta cólera que ontem se apoderou de mim, ainda existe implicitamente para mim, pois posso apreendê-la de novo pela memória, datá-la, localizá-la, encontrar as suas motivações, as suas desculpas. E é de fato esta mesma cólera que assim se encontra retida no seio do meu presente vivo, pois, mesmo que afirme, de acordo com as leis experimentais da degradação da recordação, que o vivido de cólera presente está modificado, esta afirmação implica em profundidade que tenho ainda, de certo modo, a cólera não modificada, para poder compará-la com a cólera passada, da qual presentemente me informa a minha memória. O Gegenstand cólera é o mesmo, ao longo das evocações sucessivas que dele posso fazer, pois falo sempre da mesma cólera. É por isso que toda a reflexão é possível e em especial a reflexão fenomenológica, a qual tenta precisamente restituir o vivido em questão (a cólera), descrevendo-o o mais adequadamente possível. (LYOTARD, 1986, p.54).

Procuraremos a seguir mostrar que algumas das objeções feitas à introspecção não são válidas para o método da reflexão fenomenológica transcendental.

A mais clássica das objeções à introspecção foi feita por Comte. Esta coloca-se nos seguintes termos: "o indivíduo pensante não pode dividir-se em dois, um que raciocina e outro que vê raciocinar. Nesse caso, sendo idênticos o órgão observado e o órgão observador, como poderá ocorrer a observação" (Cour de phil. Positive, 1830, seç.1, 8 apud ABBAGNANO, 2007, p.669). A resposta fenomenológica a essa objeção coloca-se da seguinte forma. De fato, o sujeito que raciocina vive um estado de consciência, de modo que o eu não pode viver simultaneamente atos de raciocínio e raciocinar sobre esses raciocínios. Contudo, devemos observar, como já afirmamos atrás, que a percepção imanente é um estado de consciência que tem como objeto não esse mesmo estado, mas uma vivência intencional reproduzida. Todo ato reflexivo é, também ele, um estado de consciência dirigido a um objeto; Um estado de consciência não é uma reflexão sobre este próprio estado, mas sobre outro ato de consciência 
pertencente ao mesmo fluxo. Comte tem razão em dizer que os vividos, ao se tornarem objeto de um ato reflexivo se alteram, deixando de ser um estado para se tornarem objetos, de modo que seu estado primitivo irreflexo é alterado. Entretanto, mantém a essência.

Um outro ponto a ser observado é que, muitas vezes, as próprias objeções à reflexão já a pressupõem implicitamente. No momento em que a pessoa diz "não é possível estudar os vividos irrefletidos pela reflexão", ela está partindo da tese de que existem vividos irrefletidos, mas se os vividos irrefletidos não podem se tornar objeto de conhecimento, qual a forma milagrosa pelo qual ele descobriu a existência deles? Segundo Husserl, todo ceticismo, qualquer que seja sua orientação, "se mostra pelo seguinte contrassenso de princípio: nas suas argumentações ele pressupõe implicitamente, como condições de possibilidade de sua validez, justo aquilo que ele nega em suas teses". (HUSSERL,2006, p.178). Comte objeta, como vimos, que o indivíduo não pode se desdobrar em dois, um que raciocina e outro que vê raciocinar. Ao expressá-lo, ele está assumindo explicitamente que o ser humano raciocina e implicitamente que ele mesmo raciocina. Mas como Comte descobriu que ele raciocina? Será que alguém teve que avisá-lo? O mesmo com o caso de alguém que coloca a seguinte objeção: "eu duvido da importância cognitiva da reflexão", tal sujeito, sem que percebesse exprimiu um contrassenso. Pois ao expressar sua dúvida ele refletiu, pois está exprimindo um "estado de consciência", a sua dúvida. Se afirmou algo verdadeiro, que duvida verdadeiramente da possibilidade de reflexão, significa que ele sabe verdadeiramente acerca de sua dúvida, o que implica que a reflexão possui valor cognitivo. Segundo Husserl, todo aquele que enuncia uma posição cética em relação à reflexão está refletido irrefletidamente. $\mathrm{E}$ por estarem refletindo irrefletidamente, não notam nem sabem que estão refletindo.

Uma segunda objeção à reflexão poderia se expressa do seguinte modo. Para que uma ciência seja verdadeira, ela não pode ser ciência do singular. Ainda que a introspecção seja possível para o conhecimento que o indivíduo tenha de si mesmo, ela não pode servir de base para uma psicologia científica. A única possibilidade de fazer com que o relato individual que um indivíduo faça de si mesmo assuma um caráter científico seria comparando seu relato com o de outros indivíduos, de modo que, por indução, se tire as leis gerais.

Essa objeção é falsa no caso da reflexão transcendental fenomenológica. Porque apesar de termos acesso apenas a nossa vida de consciência, os vividos intencionais possuem essências e leis essenciais. Aquilo que é válido na essência é válido para qualquer objeto singular que a represente. As ciências de essências não são feitas pelos métodos indutivos, um matemático, por exemplo, não prova um teorema por indução. Não se chega à essência de uma coisa por indução. Para que haja intuição de essência, um único exemplar pode ser 
suficiente. Temos intuição originária apenas de nossa consciência. Contudo, a lei: toda consciência é consciência de alguma coisa é válida para qualquer consciência, pois é uma lei apriorística.

Uma terceira objeção poder ser assim formulada: "A única forma de se fazer ciência é que seu objeto seja mensurável”.

Isso é evidentemente falso. Ciências qualitativas, embora muitas vezes não sejam ciências exatas, podem ser rigorosas. Os objetos lógicos não são mensuráveis. Um silogismo não é mensurável, nem um axioma. E seria ridículo dizer que a lógica, por isso, não é rigorosa. A linguagem matemática é importante e válida, mas nem todo fenômeno permite ser exaustivamente descrito em termos numéricos. A possibilidade de usar uma linguagem matemática depende da essência do objeto e da possibilidade de se estabelecer uma unidade de medida. Querer expressar em termos matemáticos um objeto que não comporta uma descrição matemática é desfigurá-lo. Entretanto, embora seja possível descrever rigorosamente a essência de um fenômeno sem usar a matemática, se essa descrição for feita em linguagem cotidiana, há sempre o risco de equívocos. Husserl, por questões de rigor, tenta usar termos técnicos, usando muitas vezes termos gregos em desuso para evitar uma interpretação equivocada pelo leitor.

Quarta objeção: a vaidade, o orgulho, e outras motivações atrapalham a autoobservação. Toda análise que uma pessoa faz de si mesma é viciada. Por maior que seja a honestidade intelectual de uma pessoa, ela pode ser enganada por desejos inconscientes.

Resposta: se partirmos dessa tese, podemos duvidar não apenas da reflexão, mas também de todo conhecimento. Se eu digo: eu sei que eu sou, digo uma verdade absoluta, uma verdade que tenho evidência apodíctica. Seria risível considerar que, na verdade, eu só digo que existo porque seria muito desagradável para mim dizer que não sou. Trata-se de um contrassenso, pois a condição de ser desagradável é eu ser ${ }^{213}$. É preciso notar: o que está em questão na fenomenologia não é a consciência do indivíduo em seus traços singulares ${ }^{214}$ o que está em questão na fenomenologia pura é a essência da consciência.

Por princípio, as conclusões que a fenomenologia chega são válidas para qualquer consciência. E por isso, pelo menos em princípio, tomando a risca o método tal como Husserl formulou, as conclusões de sua aplicação deve ser compartilhadas e válidas por todos aqueles

\footnotetext{
${ }^{213}$ Não usamos, aqui, o termo ser com o sentido de ser real.

${ }^{214}$ Como veremos, a objeção tem um fundo de razão quando o assunto é o conhecimento que a pessoa tem de si. Conhecer as vivências é distinto de conhecer os traços de caráter, as tendências, as fraquezas, em suma as propriedades, as qualidades do sujeito psíquico real. Neste caso, muitos fatores como a vaidade pode atrapalhar a auto-percepção do individuo, mas isso é algo muito distinto da análise da estrutura das vivências.
} 
que, partindo dos mesmos princípios e dos mesmos métodos, investigam a vida da consciência. Entretanto, a exploração cognitiva da própria personalidade, das qualidades singulares e pessoais de um indivíduo, embora impliquem atos reflexivos, não dizem respeito à atitude transcendental. Todavia, a fenomenologia pode dar um suporte conceitual $e$ metodológico a esse tipo de reflexão, que tem como escopo o estudo do ser singular em seus traços individuais. ${ }^{215}$ Estudaremos isso ao final desta tese.

\subsubsection{Classificação das intuições entre presentificação e apresentação}

Os vividos intencionais de consciência são de dois tipos. Ou são originários ou presentificações. Uma intuição originária é aquela no qual o objeto está presente em "carne e osso", isto é, no qual os objetos são apresentados (Gegenwärtigung). Quando os objetos são apresentados, mas não em "carne e osso", temos a presentificação (Gegenwärtigung). O que caracteriza as presentificações é que a consciência faz, por assim dizer, o objeto estar presente para ela. Por exemplo, recordamos um objeto que outrora foi percebido. Trata-se de um ato intuitivo (a recordação) no qual um objeto é dado "ele mesmo", embora não seja dado ele mesmo em "carne e osso", originariamente, tal como ocorre em uma intuição doadora originária (percepção) ${ }^{216}$.

Há um conexão essencial entre a intuição originária e intuição não-originária. $O$ objeto presentificado em uma intuição traz em si referência à vida originária da consciência. Toda imaginação, como vimos atrás, é intuição. Pela imaginação eu posso representar um ser individual de uma essência. Posso imaginar muitas casas individuais, mas sou incapaz de imaginar a própria essência casa. Sou apenas capaz de intui-la em "visão de essência".

Como observamos atrás, a imaginação é uma "quase percepção". Se imagino um gato qualquer e vejo na tela da minha consciência um gato, esse gato imaginado deverá estar e algum perfil. Embora nunca tenha sido vivido originariamente por mim, ele pode, por uma necessidade de essência, ser vivido originariamente por $\operatorname{mim}^{217}$. Poderia percebê-lo tal como imaginei.

\footnotetext{
215 Como já observamos, um dos objetivos de Husserl é fazer as ontologias regionais, que estudariam as essências e as leis essenciais de cada uma das regiões do ser. Uma ciência apriorística acerca da psique, sem dúvida, serviria de base para a construção de uma ciência de fatos.

216 As presentificações podem ser intuitivas ou não. A única necessidade aqui é que a apresentação ou presentação seja intuitiva e originariamente intuitiva.

${ }^{217}$ Edith Stein (2001) "Na fantasia o vivido presentificado não é posto como realidade passada ou futura e por isso não necessita de uma demonstração posterior. O conteúdo referido na fantasia diz apenas que seria possível
} 
A título de ilustração, é fácil perceber que qualquer criatura imaginada poderia ser percebida por mim. Isso não significa que seja realmente possível, ou fatidicamente possível, mas poderia ser percebida, por essência. Se eu imagino um macaco do tamanho de um prédio, sabemos que, fisicamente, não poderia percebê-lo, mas nada impede, em essência, que não possa percebê-lo: um gênio maligno poderia criar um. Do mesmo modo, posso imaginar um ser alienígena, uma espécie de coisa, que vive no espaço. Do ponto de vista físico, supomos com razão, que isso é insustentável. Mas é, em essência, possível. Um gênio maligno poderia criar tal ser que quebre as leis fáticas e tire a energia com a qual se movimenta de si mesmo, já um quadrado redondo, gênio maligno algum poderia fazê-lo.

A livre fantasia, como já havíamos observado, é o que abre o reino do possível, afinal tudo o que é imaginado é intuitivo e é essencialmente possível de ser dado originariamente, por mais estapafúrdio e por mais esquisito que seja a fantasia. Só podemos imaginar o que é concebível. A imaginação é uma "quase experiência". De fato, ninguém é capaz de imaginar um quadrado-redondo ou de conceber um. Portanto, trata-se de uma impossibilidade. Do mesmo modo, ninguém consegue imaginar um corpo material sem absolutamente nenhuma extensão. No entanto, é possível imaginar corpos materiais sólidos os quais não possuem peso. Toda a antecipação de uma situação pertence ao reino do possível, do concebível e tem como traço o fato de que o que é antecipado poderia vir a ser dado originariamente. Por isso, a imaginação, como Husserl diz, nos oferece uma natureza possível. É possível que um carrinho, deslocando em uma superfície plana e sem atrito, nunca deixe de se afastar em relação a um observador fixo em relação à superfície? Sim, é possível, mas como Einstein nota, não tal experimento não é realizável.

Quando alguém nos afirma: "a xícara de café está em cima da mesa" e eu compreendo a afirmação, sei o que aquilo quer dizer. Não há necessidade de imaginar a situação para compreendê-la. Mas, se quiser, posso imaginá-la. Em livre fantasia, posso imaginar inúmeros representantes individuais possíveis ao estado de essência. Por exemplo, imagino uma xícara no canto da mesa, imagino uma xícara no centro da mesa. Imagino uma xícara azul na borda de uma mesa amarela. Posso imaginar a xícara de porcelana, de cerâmica, de vidro. Cada uma dessas imaginações representam individualizações das possibilidades implicadas no estado de essência.

Há, como já havíamos estudado ao tratar de essência, uma relação entre intuição singular e intuição de essência geral. Cada uma das imaginações que faço a respeito do estado 
de essências anunciado pelo juízo representa uma das possibilidades desse estado de essência. Por outro lado, o juízo "a xícara está em cima da mesa” contém impossibilidades. De fato, posso imaginar inúmeras situações em que a xícara está em cima da mesa, mas o estado de essência anunciado e compreendido não me permite imaginar um elefante numa floresta, pois este estado de coisas imaginado não corresponde ao estado de essências enunciado pelo juízo.

\subsubsection{Atos de consciência atuais e inatuais}

Cogito no sentido forte da expressão, significa: eu tenho consciência de algo. E isso equivale a dizer: "eu efetuo um ato de consciência", "eu estou com o olhar espiritual dirigido ao objeto", "tenho consciência explícita do objeto no "estar voltado para atual". O fluxo dessas vivências intencionais cujos objetos estão diante do espírito são sempre puras atualidades as quais determinam o sentido forte da expressão cogito. Trata-se do eu que, ao pensar, tem diante do espírito, o pensado; ao perceber, tem diante do espírito, o percebido. Em um ato do cogito, o eu lança um raio de consciência em direção ao objeto intencional.

Quando meu olhar espiritual está voltado para um objeto, temos uma vivência intencional atual. Todavia, trata-se do único tipo de vivência possível? Minha consciência se resume a isso? O que há, em minha consciência, em um determinado instante, é apenas esse ato intencional atual?

Embora as vivências intencionais tenham como característica o fato de estarmos com o olhar espírito dirigido para o objeto intencional, temos simultaneamente nesse mesmo fluxo um halo de vivências inatuais. Para ilustrar, Husserl usa como exemplo uma percepção no qual estamos dirigidos para um papel em cima da mesa. Embora tenhamos o olhar do espírito dirigido para o papel:

Em torno ao papel estão livros, canetas, tinteiro, etc., de certo modo também "percebidos", perceptivamente ali, no "campo intuitivo", mas enquanto se está voltado para o papel, não há nenhuma apreensão, mesmo secundária, voltada para eles. Eles apareciam e, não obstante, não eram realçados, postos por si. Toda percepção de coisa tem, assim, um halo de intuições de fundo (ou de visões de fundo, caso já se compreenda no intuir o "estar voltado para"), e este também é um "vivido de consciência" ou, mais brevemente consciência, e mesmo consciência "de" tudo aquilo que está contido no "fundo" objetivo co-intuído. (HUSSERL, 2006, p.87).

O que está no halo de fundo também é percebido, intuído. Mas é importante notar que cada coisa que está "implicitamente consciente" pode vir se tornar explicitamente consciente. A consciência implícita, inatual pode se tornar consciência explícita, no modo do "estar 
voltado para" atual. "Pelo que foi dito acima, contudo, é da essência do fluxo de vivido de um eu desperto que a cadeia continuamente em curso das cogitationes seja constantemente circundada por um meio de inatualidade, assim como, inversamente, a atualidade está sempre prestes a passar à inatualidade.” (HUSSERL, 2006, p.89)

Portanto, cada uma dessas vivências inatuais implícitas pode, por necessidade de essência, sofrer uma modificação, de modo que o que era implícito na consciência pode vir a ser explicitado pela consciência, tão logo dirijamos para essa vivência implícita o "olhar do espírito". Daí que podemos considerar que a consciência inatual forma um campo potencial posto que cada uma dessas vivências inatuais pode ser explicitada, realçada, posta à luz, tornando-se atual, permanecendo diante do olhar do espírito ${ }^{218}$. Essa consciência potencial corresponde a um campo sempre possível de ser atualizado, e, por isso, forma o campo de liberdade da consciência.

Todas as sensações, presente em todos os campos sensoriais (auditivo, visual, sensações de fome, sede, olfativas etc.), são vividos de consciência. Não posso prestar atenção, no meu pé, na minha nunca, na música que vem da casa do vizinho, nos rumores da rua, nos cantos dos pássaros, no leve cheiro da camiseta, a um só tempo. ${ }^{219}$

Essa discussão se tornará mais clara ao analisarmos a distinção entre os momentos hiléticos e noéticos da consciência. Por enquanto o que importa notar é que para perceber algo em primeiro plano, é preciso que o olhar da mente para aí esteja dirigido e mais especificamente, da apreensão atencional ${ }^{220}$.

$* * *$

Agostinho aborda de certo modo essa característica da mente, quando afirma que, para que possamos perceber algo, é necessário a intentio animi. Usa como exemplo o de alguém que fala conosco sem que "escutemos", sem que prestemos atenção, o que significa que a nossa vontade não estava dirigida para a fala da pessoa, daí ele usar também o termo intentio voluntatis. O que ocorre neste caso, afirma Agostinho, é que as palavras proferidas pelo outro

\footnotetext{
${ }^{218}$ Ainda aqui, podemos notar a semelhança com o pensamento de Agostinho, quando este dizia que: Isso chama nossa atenção para o fato de possuirmos nos refolhos da alma conhecimentos de certas realidades que de algum modo vêm à superfície da mente e se põem como que mais abertamente à luz, na presença da mente, quando nelas ela pensa" (trinit., XIV, 5, 9; 2005, p.450).

Hinc admonemur esse nobis in abdito mentis quarundam rerum quasdam notitias, et tunc quodam modo procedere in medium atque in conspectu mentis uelut apertius constitui quando cogitantur

${ }^{219}$ A gestalt, a psicologia da forma, usou deste mesmo conceito de figura e fundo tirado da fenomenologia.

${ }^{220}$ A esse respeito, ver apêndice D.
} 
não informam o olhar do espírito, pois a atenção (intentio) não se aplicou aos sentidos. Agostinho diz metaforicamente que as palavras escutadas apenas "escorregam pelos sentidos”, mas não penetram a mente, para informar o olhar do espírito. Assim, para que reconheçamos o que alguém disse não basta que escutemos, mas é necessária a participação da mente, do extrato superior da alma humana, pois a vontade pertence à mente ${ }^{221}$. Assim que a atenção se voltar aos sentidos, o homem entenderá o que o outro está dizendo.

Como vimos, Agostinho fala da corrente de cogitationes, que se caracteriza pela sucessão constante dos objetos que desfilam diante do olhar do espírito. A intentio caracteriza-se por colocar objetos diante do olhar da mente para informá-lo, de modo que, ao dirigir-se a um novo conteúdo, deixa para trás o conteúdo antigo. A intentio voluntatis o que o que movimenta a corrente de "trindades", a corrente de cogitationes.

Para Husserl, semelhante processo é fazer o que era consciência implícita tornar-se consciência explícita. É por essa razão que o fluxo de vividos jamais pode consistir de puras atualidades, porque ao voltar o olhar do espírito para aquilo que era implícito abandonamos aquilo que era explícito. Como já dissemos, para Husserl, os vividos inatuais formam o campo de liberdade do espírito, pois tudo o que é inatual pode vir a ser atual. De fato, por mais concentrado que estejamos na atividade de escrever, se um escorpião aparecer em nosso campo visual, é muito provável que a atenção se desloque e percebamos o escorpião em primeiro plano, que o eu puro lance um raio de consciência a esse objeto, de modo que a percepção do escorpião torne-se um vivido intencional atual.

\footnotetext{
${ }^{221}$ E é notável observar que uma das melhores traduções de mens em latim é nous, termo usado por Husserl, para se referir à função noética.
} 


\subsection{A percepção}

\subsubsection{Introdução}

Ao colocarmos em suspensão a tese de existência real de um mundo real, não perdemos o mundo. Nós ganhamos um mundo-fenômeno, o mundo que se mostra à consciência, um mundo que é para mim e tira de minha consciência todo o seu sentido. Pela epoché, os fenômenos sofrem uma modificação e se tornam fenômenos purificados transcendentalmente, isto é, fenômenos que são irrealidades. O intuito é descrever deles a essência sem, para isso, partir do pressuposto que são reais. Analisar e descrever os fenômenos sem fazer uso da tese de realidade do mundo não é tarefa fácil.

A redução transcendental colocou-nos na seguinte situação. A análise da essência da consciência revelou-nos que é inerente à vida da consciência a estrutura: ego-cogitocogitatum. $\mathrm{O}$ mundo e os objetos do mundo entram como cogitata ou objetos intencionais.

Havíamos dito que, de algum modo, o objeto intencional, mais especificamente, o objeto percebido, está na consciência como "correlato". Resta, entretanto, elucidar como o objeto intencional está na consciência. Já sabemos que um objeto real não pode estar dentro da consciência, por outro lado, não podemos ver algo que está plenamente fora da consciência, pois se estivesse plenamente fora, não teríamos consciência de vê-lo.

A questão, portanto, é: como o objeto percebido adquire o sentido de estar fora de minha consciência? Porque o que vejo tem sentido de estar fora de minha consciência?

É preciso que mantenhamos na epoché para investigar a questão. Mantendo-nos na epoché, mesmo que o mundo que vejo seja um sonho coerente, as investigações não se tornam invalidadas.

\subsubsection{A percepção é um fluxo temporal}

A condição de possibilidade para que conheçamos um transcendente é que ele esteja, de algum modo, na consciência, sem que esteja "realmente" na consciência. Vejamos o exemplo seguinte. Percebo uma mesa. A mesa é o objeto intencional de uma percepção. Na "percepção da mesa" está presente o eu, o ato de percepção e o objeto intencional percebido. Mas devemos observar que a percepção de algo material ocorre um fluxo cambiante:

A percepção da mesa, porém, é uma percepção que se altera constantemente, é uma continuidade de percepções cambiantes. Fecho os olhos. Meus demais sentidos estão fora de relação com a mesa. Não tenho agora nenhuma percepção dela. Abro os olhos e volto a ter percepção. A 
percepção? Sejamos mais precisos, ao retornar, ela não é em nenhuma circunstância individualmente a mesma. (HUSSERL, 2006, p.98)

Se analisarmos a percepção que temos de uma mesa, ela não é como uma foto, pois a percepção se dá em um fluxo. No momento em que fecho os olhos e volto a abri-los não posso dizer que tenho a mesmíssima percepção, pois a percepção é um fluxo, e todo fluxo é mutável. Para facilitar a visualização, tome-se o seguinte exemplo. Se giro em torno da mesa, a "mesma mesa" se mostra a mim em diferentes perfis. Olhando bem para ela, vejo que, dependendo de como a luz incide, suas tonalidades variam. Se olho para a mesa contra a janela, vejo sobre sua superfície reflexos esbranquiçados, se mudo a perspectiva, vejo efetivamente apenas três de seus pés, enquanto o quarto pé permanece escondido. Dependendo do ângulo pelo qual a vejo, vejo apenas dois dos pés da mesa, de modo que os dois outros pés estão "escondidos". "Escondidos dos olhos", mas sei faz parte da mesa que percebo agora. O objeto intencional ultrapassa cada uma das aparências individualmente. Ele se mostra por um perfil, mas ele mesmo pode se oferecer por outros perfis. Diferentes e múltiplos perfis são entendidos como diferentes aparências de uma mesma mesa.

Minha consciência entende, sem muito esforço, cada um desses perfis como perfis da mesma mesa. E isso já começa a revelar algo: a mesa que permanece a mesma existe intencionalmente, apesar do fluxo perceptivo e das múltiplas aparências.

Fecho os olhos, abro novamente e vejo outra vez mesa, trata-se de "outra percepção", afinal, não é identicamente à mesma mesa percepção que eu tive anteriormente. Contudo, ainda assim, creio que vejo a "mesma mesa". Ao fechar os olhos, eu interrompo o fluxo de percepção. Ao abri-lo, tenho novamente a percepção da mesa e essa mesa que percebo agora é "mesma mesa" daquele outro fluxo perceptivo que eu tinha antes. Quem me informa que a mesa que vejo é a mesma mesa que eu havia percebido antes? É a minha memória: ela ligou um fluxo de percepção a outro, me fazendo crer que se trata da "mesma mesa".

O que está implicado neste "perceber uma mesma mesa" é a capacidade de identificação sintética inerente à consciência; é em virtude desta síntese que cada um dos perfis é "interpretado" como perfis da "mesma mesa". Girando ao redor da mesa, sei que cada fase perceptiva desta percepção de mesa é distinta da anterior. Em cada uma delas a pura aparência da mesa se altera, pois as luzes incidem de outro modo, alterando sua aparência, em vários aspectos, como a tonalidade da cores; dependendo da perspectiva que a vejo, as aparências de forma também variam, a mesa vista de cima parece um retângulo, vista na altura dela, parece-me muito mais "fina". Mas o que ocorre é que a consciência ligou todas essas fases entre si de tal modo que, ao longo das diferentes fases perceptivas, temos 
consciência de uma "mesma mesa". Em outros termos, a consciência liga cada um dos perfis como perfis da "mesma mesa". Tenho, no espírito a essência mesa e conheço sua estrutura esquemática de aparições.

\subsubsection{Perfil é vivido de consciência. O que se perfila (perfilado) não}

A “mesma mesa", que se perfila, não é um vivido de consciência, não está em cada uma das fases perceptivas como elemento real da percepção, pois cada uma das fases da percepção de mesa é diferente da anterior. De certo modo, não temos nem mesmo algo como vários perfis de uma mesma mesa, o que temos é a "crença automática", acompanhada de uma "interpretação" automática que executa a consciência segundo a qual cada um daqueles conglomerados cromáticos variáveis são perfis de uma única e "mesma mesa". Minha consciência só pode ter consciência de uma "mesma mesa" devido a uma síntese da consciência que liga diferentes modos de consciência, como consciência de uma unidade.

Enquanto a coisa é a unidade intencional, a identidade-unidade daquilo de que se é consciente no transcurso contínuo e regrado das multiplicidades perceptivas que se entremesclam umas nas outras, estas continuam tendo uma composição descritiva determinada, subordinada, por essência, àquela unidade. (HUSSERL, 2006, p.99)

Se analisarmos a vivência intencional da mesa, fica claro que o perfil e aquilo que se perfila (o perfilado) estão presentes na "percepção da mesa", porém de modos distintos. Em uma única fase perceptiva, vejo um único perfil. Mas não entendo que a mesa se limite àquele único perfil. Ela é algo que se perfila (objeto intencional), isto é, que poderia mostrar-me por outros perfis e de outros modos. Mas esses "outros perfis possíveis" não são dados em uma única fase perceptiva. Eu simplesmente "sei" que poderia vê-la por outros perfis, antes mesmo de vê-los. Em um dado instante, o que está "dentro" de minha consciência é um único perfil, é apenas aquela dada aparência. Mas o objeto não é aquela única aparência dada naquele único instante. Ele é mais do que isso.

O perfil, embora denominado da mesma maneira, não é, por princípio, do mesmo gênero que o perfilado. Perfil é vivido e se sustenta nas sensações cromáticas da mesa (se vejo a mesa, o perfil é um conglomerado de sensações recortadas do campo visual). Por ser “composto" por sensações, o perfil é vivido de consciência; está na consciência assim como as sensações estão na consciência. Porém, as sensações e o vivido só são possíveis como vivido e não como algo no espaço. $\mathrm{O}$ mesmo não se diz daquilo que é perfilado. $O$ perfilado só é possível como algo no espaço. O perfil de um cubo, em um determinado instante, é 
considerado por mim como um dos perfis de um "cubo" que, por sua essência, traz a possibilidade de se mostrar à minha consciência por outros perfis. Estes outros perfis, que pertencem ao objeto visto, e que poderiam ser visto por mim, estão "fora" de minha consciência. Entretanto, poderiam ser efetivamente vividos por mim. Todo o objeto intencional que possui o sentido de ser uma coisa no espaço se mostra para mim por perfis.

Aqui, podemos questionar sobre o que é a essência ou o sentido da coisa material. Questionar sobre o que é a essência da coisa material não significa, como já discutimos antes, procurar aquilo que ela a coisa é por dentro; por exemplo, ser coisa material é ser uma coisa composta de átomos. Perguntar sobre a essência de tal fenômeno é perguntar sobre as condições sem as quais não poderíamos ter o sentido intuitivo da coisa material. Assim, podemos compreender que a coisa material, por sua essência, é justamente dar-se por perfis.

A essência é o próprio modo pela qual a coisa se mostra. Se não fosse assim, não conseguiríamos conceber uma coisa material. Ora, a coisa material adquire para a consciência o sentido de coisa transcendente justamente pelo fato de que ela se oferece à consciência por perfis, nunca, porém, se mostrando por todos os perfis ao mesmo tempo. Nunca posso ver, ao mesmo tempo, todos os perfis de um cubo. Mesmo um som se mostra por perfis. O som do violino pode ser escutado de perto ou de longe. O mesmo não ocorre com uma vontade. A vontade não se mostra por lados.

As ligações dos perfis são feitas por uma síntese passiva, que faz com que tenhamos diante do olho do espírito um objeto intencional, que está se mostrando por lados. Temos consciência de uma unidade que está presente efetivamente por perfis. O objeto intencional é correlato da consciência, uma unidade de sentido, já o perfil está presente na consciência como vivido. O vivido não tem extensão, peso, etc. Mas se vejo um elefante, embora tenha na minha consciência o perfil de um elefante, o elefante enquanto correlato de minha consciência, enquanto perfilado, tem o sentido de coisa real, animal, cinza, com uma forma determinada. Digo que o elefante, correlato de minha consciência, o ser que se perfila é cinza. Mas também a cor cinza do elefante não me é dada de modo absoluto, mas sim por perfis de cor, conforme incide a luz. Digo que o elefante tem uma forma. Mas a forma do elefante também me é dada por perfis de forma. Os perfis são cambiantes e múltiplos. Mas qual a tonalidade de cinza é a verdadeira tonalidade de cinza do elefante? Qual o perfil de forma é o 
verdadeiro perfil? Segundo Husserl, não podemos dizer que exista um perfil correto, um perfil verdadeiro, mas que alguns perfis são os perfis normais ${ }^{222}$.

Percebo uma folha de papel, vejo-a de perfil e ela parece-me uma linha no meu campo visual. Começo a girar essa folha e o que antes era quase um fio mostra-se agora como um retângulo largo. Observei a folha por duas perspectivas diversas. Mas o que fez com que a folha vista nesta perspectiva fosse compreendida como a mesma que a folha vista pela outra perspectiva? Foi o meu "eu transcendental", que, na consciência imanente do tempo, sintetizou as perspectivas, como perspectivas de uma única e mesma folha. É por isso que se pode dizer que o eu puro, elucidado pela redução transcendental, é um eu transcendental, porque esse eu transcendental é a condição de possibilidade para que a folha seja uma folha para mim. Faz parte da essência da folha dar-se por vários perfis, segundo uma estrutura típica. Se eu não fosse capaz, por uma síntese passiva, de "ligar" as várias perspectivas por meio das quais uma mesma coisa se manifesta, essa coisa nem sequer seria vista como um objeto, nem seríamos capazes de falar das várias perspectivas de uma mesma coisa.

Oliver Sacks narra o caso de um cego de nascença que, já em idade adulta, mediante uma operação, recuperou a visão. Embora a tenha recuperado, não conseguia perceber objetos. Não conseguia diferenciar na massa de sensações cromáticas objetos determinados, não recortava, por assim dizer, conglomerados de sensações, animando-os de modo a ver o perfil de um objeto. Logos após a cirurgia, quando recuperou a "visão":

Depois ele me disse que, nesse primeiro momento, não fazia a menor ideia do que estava vendo. Havia luz, movimento e cor, tudo misturado, sem sentido, um borrão. E então, do meio da nódoa veio uma voz que dizia: "Então?". Foi nesse instante, e somente nesse instante, ele disse, que finalmente se deu conta de que aquele caos de luz e sombra era um rosto - e, na realidade, o rosto de seu cirurgião. (1995, SACKS)

O ponto é que para que vejamos o perfil de um objeto e entendamos aquilo como perfil de um objeto é necessário co-intuir os lados não vistos. O que o homem que acabara de recuperar a visão via era uma massa caótica de sensações. Não uma massa caótica em si, mas caótica porque ele era incapaz de organizá-la. Sua consciência estava aprendendo a organizar, estava constituindo os esquemas de aparições visuais das coisas. E mesmo quando começou a

\footnotetext{
${ }^{222}$ As antigas pinturas egípcias não respeitavam a leis da perspectiva, pintavam os olhos de frente, os pés de lado, eles davam de cada coisa o perfil no qual podemos identificar a coisa mais facilmente. O cubismo, ao perceber que o corpo é uma multiplicidade de perfis, procurou sintetizar em um único instante, sucessões de perfis de um mesmo objeto. Ao ver o quadro de uma tourada de Pablo Picasso, nossa impressão é que vemos o touro por todos os lados que veríamos se o touro tivesse dado uma chifrada no pano do toureador, como se ele sintetizasse numa pintura os múltiplos perfis que só podem se oferecer com o transcorrer do fluxo perceptivo.
} 
aprender a perceber objetos, confundia as distâncias, a profundidade, e não conseguia, muitas vezes, identificar um objeto visto de lado, com o mesmo objeto visto de frente.

\subsubsection{A “constituição" dos sentidos objetuais}

Nós aprendemos a perceber objetos por meio de sínteses de consciência. Já não precisamos aprender a ter sensações.

No momento em que bato o olho em uma folha de papel, minha consciência já recortou de meu campo visual global sensações cromáticas, um determinado conglomerado de sensações, correspondente à folha de papel, reconheceu aquele conglomerado como uma unidade, uma folha de papel. Justamente por ser entendido como uma folha de papel, minha consciência terá o "preconceito" de que esse algo que reconheço como folha de papel pode dar por outros perfis, mas estes outros perfis estão limitados pelo eidos "folha de papel". E esse eidos implica um estilo pré-traçado de exibição. Caso a unidade que eu entendia como sendo uma folha de papel se mostrar fora deste estilo pré-traçado, eu apenas considerarei que cometi um engano, que não era uma folha de papel.

Perceber implica reconhecer e reconhecer é “impor" um estilo pré-traçado mais ou menos determinado de aparições e exibições. Ao ver um dos lados de algo, só compreendo que é o lado de algo, porque já vi algo semelhante ${ }^{223}$. Se eu já tive a percepção visual de um ser humano, ao ver um, eu já antecipo "automaticamente" suas futuras possibilidades de manifestação. E cada fase perceptiva concordará ou negará o sentido.

No momento em que eu percebo um conglomerado de sensações como um perfil de uma folha de papel, eu estou tendo uma espécie de "preconceito". Pois na verdade, não olhei todos os perfis do objeto para saber se era realmente uma folha de papel. $\mathrm{O}$ ex-cego, que recuperou a visão é um caso de alguém com poucos "preconceitos visuais", mas isso não é vantagem alguma. Ele não constituiu intuitivamente estruturas típicas de aparição.

Os "sentidos", ou as "essências" são constituídos com a experiência, através de associações e sínteses de consciência.

Uma das dificuldades do pensamento fenomenológico é a "constituição intuitiva de objetos".

Os maiores problemas, todavia, são os problemas funcionais, isto é, os problemas da 'constituição das objetividades da consciência'. Eles dizem respeito ao modo como, em relação, por exemplo, à natureza, as noeses,

\footnotetext{
${ }^{223}$ Talvez não reconheça como nada de determinado, mas ainda assim a reconhecerei como "coisa" e, como toda coisa, poderia ver o lado de trás e vê-la por outros ângulos.
} 
animando o material e entrelaçando-se em contínuos e sínteses da multiplicidade da unidade, produzem consciência de algo, de tal modo que a unidade objetiva da objetividade possa 'se anunciar', se 'atestar' com coerência ali e ser determinada 'racionalmente'. (HUSSERL, 2006, p.197)

Tomamos consciência de objetos porque a consciência constitui intuitivamente os objetos por meio de sínteses passivas. Aprendemos a perceber objetos pela experiência. Mas isso não quer dizer que a consciência cria os objetos, assim como não é a consciência que cria as sensações. Para compreendermos, basta um esforço de se colocar na mente de um bebê. É bem provável que o bebê nos primeiros dias não tenha consciência do objeto "mãe". Ele começa aos poucos a ter consciência de uma zona de conforto, calor, de cheiros. À medida que suas experiências vão progredindo ele pode ter consciência do bico do seio, e constituir o primeiro objeto visual. Aos poucos, devido às sínteses de consciência, o bebê irá reconhecer o bico do seio de longe, de perto, e até mesmo de lado. Depois pode ter consciência de sua mãe como um todo e do seio como uma parte de sua mãe. Então, reconhecerá a mãe de longe, de perto, de lado, de cima, etc. A essa estrutura de aparições visuais, se somará estruturas de objetos com uma estrutura de aparições mais complexas, envolvendo diferentes sentidos.

Para a consciência, o objeto percebido como coisa no espaço é uma unidade sintética de uma multiplicidade de modos de consciência. Multiplicidade de modos de consciência ou de perfis? Tanto faz, pois o perfil é um vivido de consciência. Se considerar que esse mundo que é dado a mim seja uma ilusão coerente, isso não altera em nada a essência da coisa material. Esta continua sendo a mesma, pois a essência é a condição de possibilidade de a coisa ser o que é; e a condição de possibilidade está no modo de manifestação, no modo de ser para mim, e não numa suposta realidade em si. Se aquilo que se manifesta for um sonho, isso não alteraria as condições de possibilidade. Para que compreendamos determinada coisa como uma coisa material, a ilusão deve satisfazer algumas condições:. uma boa ilusão de gato deve parecer um gato, deve ter perfis de gato, deve miar como um gato, etc. e tal.

\subsubsection{Perceber não é ter sensações}

Perceber não é ter sensações. Toda percepção é percepção de um objeto. E um objeto percebido não se resume a um único conglomerado de sensações. Pelo contrário, a consciência recorta no campo visual, determinado conglomerados de sensações, colocando-os no espaço e compreendendo-os como um dos lados de um objeto, que se poderia apresentar por outros lados. 
Perceber visualmente um objeto é um processo que ocorre como se a consciência interpretasse a todo instante os diferentes dados de sensações cromáticas recortadas do campo visual, como diferentes perfis de um único objeto. Mas esse único objeto "ultrapassa" cada um desses perfis. O que há é que a consciência é capaz de ver objeto idêntico no múltiplo. Como já observamos, ela sintetiza passivamente as múltiplas fases perceptivas, tomando-as como diferentes perfis de um único objeto, condição essa sem a qual nenhuma objetividade perceptiva seria possível. Mas, a consciência aprende a ver o uno no múltiplo. A consciência constitui esquemas de aparições, esquemas esses que não são absolutamente rígidos, mas razoavelmente determinados, razoavelmente elásticas, de modo a abraçar possíveis manifestações. Vejo algo que nunca antes vi e, ainda assim, reconheço como sendo um serrote $^{224}$. O eidos, embora limitado, possui graus de elasticidade, justamente por ele corresponder a possibilidades e impossibilidades. Vejo algo que nunca antes vi, mais ainda assim, enquadro aquilo como "coisa no espaço". Minha consciência, automaticamente, já me "diz" a distância que está do meu corpo. Aquilo apenas representa uma individualização do eidos "coisa material".

Tomemos o seguinte exemplo. O homem está com fome, abre a geladeira e vê ali uma bela gelatina, num ato de molecagem enfia o dedo na gelatina e subitamente se dá conta que era óleo, para sua decepção. Aquele pote com óleo foi anteriormente percebido como sendo uma gelatina, a essência "gelatina" fazia parte da essência do percebido; no entanto no momento em que ele enfiou o dedo naquilo que ele havia percebido como sendo uma "gelatina", o sentido é "explodido" e ele se dá conta que era óleo. A nova evidência é discordante com o sentido que estava imbricado na percepção anterior.

$\mathrm{O}$ fato de ele perceber que aquilo não era gelatina, não altera a essência gelatina, pois a essência gelatina diz respeito a uma estrutura determinada de aparições, uma estrutura que contém um grau de elasticidade. Ao perceber um objeto, a consciência muitas vezes é apressada e vê no objeto singular uma essência, isto é, um conjunto de possibilidades e impossibilidades e uma estrutura "regrada" de aparições. Mas essa intuição de essência não é fortuita, pois encontra seu suporte nas sensações. De fato, um homem poderia confundir a tigela com óleo com uma gelatina, mas dificilmente confundiria aquilo com um maço de cigarros. A sensação não se altera, o que se altera é a "interpretação automática" que faço das sensações, pela qual percebo algo como sendo algo, isto é, como possuindo uma essência.

\footnotetext{
${ }^{224}$ Agostinho, ao chega perto dessa ideia, quando diz de "imagens genéricas".
} 


\subsubsection{Os momentos do ato intencional}

Até o momento, apresentamos a percepção usando o mínimo possível os termos técnicos empregados por Husserl. Mas agora que já se tem a primeiras noções, é possível dar um passo adiante e compreender mais precisamente a estrutura do ato intencional através do qual percebemos objetos, generalizando para outros tipos de percepções.

Havíamos dito que perceber é perceber objetos e isto é distinto de ter sensações. Para compreendermos melhor a relação entre o ato perceptivo e sensações, é necessário observarmos três momentos que Husserl distingue na vivência intencional.

1) A hylé sensível ou matéria sensível, como dados de cor, dados sonoros, de tato, de sabor.

2) A morphé intencional ou noese, nas quais se encontram as operações de perceber, sintetizar, explicitar, abarcar, relacionar.

3) O noema, ou sentido, que é o objeto visado; no caso da percepção: o objeto percebido enquanto percebido. "Todo noema tem um "conteúdo", isto é, seu "sentido", e se refere, por meio dele, a "seu" objeto." (HUSSERL, 2006, p.287)

Havíamos dito que o perfil é vivido de consciência, e se distingue do perfilado, que é correlato. Dentre deste novo quadro, mais preciso, Husserl distingue a noese e a hylé, revelando que se tratam momentos reais da percepção. É a função noética pertencente ao nous $^{225}$ que a anima, que "interpreta" essas sensações. Já o objeto visado, a unidade que mantém sua identidade consigo mesma, não se resume às sensações. O noema, unidade de sentido, é algo que se contrapõe à consciência, e, portanto, não é um momento que está realmente contido na consciência.

Ao analisarmos a percepção de um cubo, observamos que não podemos ter na consciência todos os perfis do cubo a um só tempo. O que ocorre aqui é que o perfil do cubo dado em um determinado instante é, se analisarmos os momentos reais desse vivido, um conjunto de sensações cromáticas. Esse conjunto de sensações cromáticas, seria, neste caso, é o que Husserl denomina hylé, ou matéria sensível, que é o suporte da função noética, pelo qual essas sensações cromáticas são "animadas" ou "interpretadas" de modo que a consciência entenda aquele conglomerado de sensações cambiantes como diferentes perfis de um mesmo objeto intencional. Para ilustramos essa relação, podemos usar, como exemplo, a figura que se segue:

\footnotetext{
${ }^{225}$ Husserl usa o termo grego Nous, geralmente traduzido por intelecto ou mente. Aristóteles o considerava a parte superior da psyché, distinguindo-o da psyche sensitiva.
} 


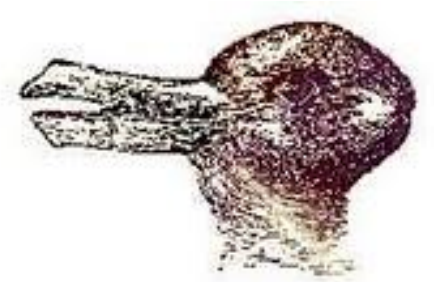

Em um momento, a pessoa pode ver a figura de um pato, mas subitamente, ela pode ver um outro objeto, isto é, a figura de um coelho. As sensações cromáticas não se alteraram, o que se alterou foi é o modo pelo qual a consciência entende, "interpreta" ou como Husserl diz: anima ou dá forma essas sensações de modo que reconheçamos algo.

O exemplo supracitado é uma figura em duas dimensões. Precisaríamos, para ser mais rigorosos, fazer um esforço de imaginação para compreender como, pelos dados sensíveis, a consciência dá uma "forma" a essas sensações, de modo que ela perceba objetos e os organize no espaço em que vivemos, no espaço intuído, que tem o eu como centro. Mesmo a pessoa que possui um único olho é capaz de impor uma forma aos dados brutos das sensações, vendo perfis de objetos próximos e distantes. Este processo evidentemente possui um grau de perfeição. Às vezes uma pequena sujeira nos óculos pode ser "interpretada" como algo que está distante, mas pode ocorrer que subitamente nos damos conta que era uma sujeira e a percepção é corrigida. Os dados de sensações foram os mesmos, mas o modo como a função noética deu forma à matéria sensível se modifica. Algo semelhante ocorre com uma pessoa que, ao entrar numa loja, "não vê" um enorme vidro em sua frente e tromba neste vidro, ao trombar ele se dá conta que o vidro já estava ali. Isto é, a matéria bruta das sensações já lhe fornecia dados suficientes para que percebesse o vidro.

Como já havíamos dito, a sensação, por si só, não implica percepção, pois a percepção implica a função de "organizar" a matéria sensível, "recortando", dentro do campo sensorial, certos conglomerados de sensações e entendendo-os como perfis de objetos no espaço, cada qual com uma distância do corpo. De certo modo, a função noética "monta" o espaço circunstante, cujo centro é o corpo, colocando cada um dos objetos a uma distância desse centro. Tomemos o seguinte exemplo. Uma pessoa está em um recinto que ela entende-o como um recinto amplo. Subitamente ela se dá conta que no fundo o que há é um grande espelho, instantaneamente a consciência "fecha" o espaço, perdendo-se parcialmente o sentido de "espaço amplo".

Mas os três momentos do ato intencional não ocorrem apenas na percepção visual, mas em qualquer percepção. Quando escutamos alguém falar em nossa língua nativa, a matéria sensível auditiva é posta em forma pela função noética, de modo que a consciência reconhece 
na matéria bruta auditiva as palavras que são ditas e frases. Mesmo que essas palavras sejam ditas pela metade ou numa má dicção, essa função noética é capaz de co-intuir e "complementar" o que está falho, como que corrigindo o que escutamos, de forma que apreendemos o sentido, ${ }^{226}$ por exemplo, de uma frase.

\subsubsection{Generalização dos três momentos na percepção para diferentes vivências}

Ao analisarmos os elementos reais do vivido intencional da percepção visual, facilmente percebemos que o perfil de um objeto percebido é efeito da função noética sobre as sensações visuais. Essa operação da consciência pelo qual determinado conglomerado de sensações é entendido como perfil de um objeto que pode se revelar em novos perfis diz respeito ao que Husserl denomina morphé intencional ou noese. Vale notar, que o termo hylé designa, em grego, matéria, enquanto morphé é forma. A matéria sensual é passiva e não diz respeito ao que há de intencional no vivido. É o momento noético que dá forma a essa matéria bruta, ao entendê-la como perfil de um objeto. Os dados sensíveis nada mais são do que matérias que servem de base para formações intencionais ou doações de sentido de diferentes níveis.

Perceber objetos é algo que o ser humano vai aprendendo aos poucos desde o momento do nascimento. Uma palavra, por exemplo, pode ser entendida como um objeto. Se escuto um chinês falando, sou incapaz de perceber palavras como unidades in tencionais. Perceber, como já foi exposto, é algo que se aprende. Do mesmo modo, aprendemos com a experiência, em sínteses passivas, que uma folha de papel vista sob determinado perfil, assemelha-se a uma linha, visto sob outro, assemelha-se a um retângulo. Vista sob determinada luz, parece amarelada, vista por outra, torna-se branca; vista na distância parece "pequena". Perceber implica reconhecer o mesmo em múltiplos modos. Por isso, somos capazes, apenas com o uso da fantasia, de girar uma folha de papel em nossa imaginação.

A mesma estrutura se encontra, por exemplo, quando alguém come algo com os olhos vendados e sem que digam o que é. A pessoa sentirá o gosto, e fundamentando-se neste dado de sensação, procurará reconhecer do que é aquele gosto. Pode dizer que parece carne de frango, mas que, ainda assim, tem algumas dúvidas, porque tem algo estranho ali. Ainda aqui a estrutura se repete: as sensações do paladar servem de suporte a uma intencionalidade noética, de modo que as sensações gustativas tornam-se o gosto de "algo". Que aquilo, para

\footnotetext{
${ }^{226}$ Nota-se neste caso que aquele que escuta a sucessões de fonemas que constituem uma palavra, deve usar sua memória, isto é, sua capacidade de retenção, pois em cada instante, o novo fonema escutado é sintetizado com o fonema anteriormente escutado, de forma que a consciência reconhece ali uma unidade de sentido que é a palavra.
} 
ela, tem sabor que parece carne de frango, é tão indubitável quanto ao fato que ela sente sabor. E ela pode dizer até mesmo que achou gostosa aquela carne. Todavia se aquele que lhe deu a carne a informar que era carne de cobra, é possível que a pessoa sinta nojo, mas os dados de sensação não se alteram.

Até o momento usamos apenas como base para a exposição os dados de sensações ligados aos cinco sentidos. Mas existem outras sensações, como prazer, a dor, e sensações oriundas de instintos sexuais, sensações de movimento, sensações intra-corporais. Todas elas estão sujeitas à função noética que lhes dá forma, imprimindo-lhes sentidos objetuais. Aquele que sente vontade de comer uma maçã tem como objeto da vontade a maçã. Mas essa vontade, que tem como objeto a maçã, poderia ter como matéria sensível à fome. O puro impulso, mesmo o sexual, não traz embutido em si mesmo o objeto, tudo aquilo que se relaciona com a vida intencional, isto é, com atos que pressuponham um "objeto visado", uma representação, uma objetualidade de qualquer nível, só ocorre em virtude de um momento noético. "Com efeito, esses conceitos de matéria e forma se impõem a nós quando nos presentificamos quaisquer intuições claras ou valorações claramente efetuadas, atos de prazer, volições etc.” (HUSSERL, 2006, p.194)

\subsubsection{A função noética}

É possível que façamos uma análise dos componentes reais do vivido intencional. Usemos, a fim de ilustração, o vivido intencional "percepção de árvore". Há, nele, dois momentos reais: o momento noético, que diz respeito à intencionalidade e o momento hilético. A percepção de árvore, como já observamos, não ocorre como uma "fotografia", mas em um fluxo: enquanto percebemos a árvore, podemos observar suas folhas levemente sendo balançada pelo vento. Pela análise real dessa vivência intencional, o que temos são dados sensíveis em fluxo, os quais são entendidos como perfis que a cada instante são dados. Mas esses não são os únicos momentos reais dessa vivência intencional perceptiva de árvore. Enquanto percebo aquela árvore, eu poderia, numa operação puramente espiritual, prestar atenção na coloração do tronco, ou nas formas de suas folhas, ou nas ramificações de seus galhos, tudo isso modifica minha percepção de árvore, mas não modifica o objeto intencional, o correlato de consciência, que é a árvore. Husserl (2006, p. 203) aponta como exemplos de momentos noéticos:

1. Os direcionamentos do olhar do eu puro para o objeto "visado" 
2. Apreensão e conservação do objeto enquanto o olhar se dirige para outros objetos que entram no "visado". Enquanto voltamos nossa atenção para os troncos ou para a coloração, não deixamos de ter a árvore como visado.

3. Operações de explicitar, abarcar, relacionar, sintetizar.

4. As diversas tomadas de posição: crer, supor, valorar. Por exemplo, se eu suponho que aquela árvore que percebo é uma macieira. Essa suposição não altera o percebido de árvore em quanto tal. Lógico que toda suposição tem o objeto suposto. Neste caso, o objeto suposto é macieira. Mas o ser macieira é fundado no percebido enquanto tal.

\subsubsection{O noema}

Uma vez que tenhamos claro o que são os momentos noéticos e hiléticos da percepção, podemos agora abordar o noema, diz respeito a esse "algo" que está implicado em todo ato intencional. Toda consciência é consciência de algo. Mas como este algo está na percepção? O objeto visado é a um só tempo imanente e transcendente, ele é vivido de consciência enquanto perfil, mas como ele não se resume a um único perfil, o seu sentido extrapola o que é atualmente dado. Por isso os momentos reais do vivido apontam para algo que transcendem o vivido, pois o noema, pelo seu sentido, poderia dar-se por outros perfis que não são atualmente dados; outros perfis que não estão contidos realmente em cada fase perceptiva. “Conquanto essa série de momentos aponte para componentes reais dos vividos, ela também aponta para componentes não-reais, a saber, mediante aquilo que se encontra sob a designação de "sentido". (HUSSERL, 2006, p. 203)

Ao percebermos um cubo, e analisando esse vivido em seus componentes reais, constatamos: cada fase perceptiva nunca é efetivamente idêntica à fase perceptiva anterior. Analisando "realmente" essa sucessão de dados sensíveis não encontramos identidade alguma, unidade alguma. O que há é uma multiplicidade de estados de consciência que se sucedem no tempo enquanto a unidade que se mantém em sua identidade é uma unidade de sentido para a qual a consciência está voltada e que não é um componente real do vivido, mas um correlato. E tendo em mira esse sentido objetivo, as diferentes exibições tornam-se diferentes perfis desse objeto intencionado, núcleo de sentido objetivo, sem o qual percepção alguma seria possível, mas apenas um caos infinitamente variado e mutável de sensações. Esse algo que se sustenta sua identidade consigo mesmo é o sentido objetivo, é o noema. No caso da percepção do cubo, o que ocorre, segundo Husserl, é: 
O cubo não está contido na consciência na qualidade de elemento real, ele o está "idealmente" como objeto intencional, como o que aparece, ou, em outras palavras, como seu "senso objetivo" imanente. O objeto da consciência, que mantém sua identidade "consigo mesmo" enquanto transcorre a vida psíquica, não lhe vem de fora. (HUSSERL, 2001, p.60)

Assim, para se saber o que é a visão não basta sustentar-se nas sensações. A análise dos dados reais imanentes ao vivido, especialmente no vivido de percepção, não irá revelar a essência do perceber. Pois perceber é não é ver sensações de cores, mas objetos coloridos. Os componentes reais e ideais se combinam nos atos perceptivos. Todo aquele que vê, vê mais do que o atualmente o dado. Vê não apenas um bando de cores, mas um lado de algo que potencialmente pode mostrar-se de outros modos.

Diante de tudo isso, é também absolutamente indubitável que aqui "unidade" e "multiplicidade" pertencem a dimensões totalmente distintas, e que, com efeito, tudo o que é hilético entra como componente real no vivido concreto, ao passo que o que se "exibe", "se perfila" nele, como múltiplo, entra no noema. (HUSSERL, 2006, p.225)

Devemos observar que esse objeto intencional também pode ser predicado. Por exemplo, dizemos que o cubo é azul. Mas do mesmo modo como o cubo é um polo com relação ao qual ligamos as multiplicidades de estados de consciência, o próprio azul também tem um sentido objetivo, pois ele próprio se manifesta na pluralidade de modos de consciência. De fato, a cor que predica o noema, assim como o próprio noema, não é um componente real do vivido. Porque do mesmo modo que o cubo se dá por múltiplos perfis, também o azul que predica o cubo se dá por múltiplos perfis de azul, conforme a luz incide de um jeito ou de outro, etc ${ }^{227}$.

Os momentos hiléticos, mas também as apreensões que os animam fazem parte da composição real do vivido. Mas o correlato, o noema, justamente por não ser um momento real, sustenta o sentido de coisa transcendente.

A designação "transcendental" aplicada à redução fenomenológica e, igualmente, à pura esfera de vivido se baseia precisamente no seguinte:

\footnotetext{
${ }^{227}$ É interessante observar que nem sempre a intenção se volta para esses múltiplos perfis pelos quais um mesmo objeto intencional se mostra. Como já observamos os antigos egípcios pintavam o homem colocando cada parte de seu corpo no perfil mais facilmente reconhecível. O nariz mostra de perfil, os olhos de frente, os pés de lado, etc. A ideia de se fazer uma pintura realista levou o homem a tentar perceber como os objetos "realmente" se mostravam. Às pinturas chapadas Bizantinas, contrapõem-se os corpos pintados com volume pelo renascimento. Até então, embora julgando realistas, os pintores não haviam notado que uma pintura realista deveria levar em consideração a origem da fonte luminosa. Se a luz estivesse a direita, o lado direito das figuras deveriam estar mais iluminados. No impressionismo, alguns pintores vão ao campo e começam a pintar uma mesma paisagem em diversas horas do dia, a paisagem, ao meio dia mostra-se distinta da paisagem ao por do sol. A água do mar, ao por do sol, não se mostra azul, mas com tonalidades vermelha. No cubismo, como já observamos um mesmo objeto é pintado por vários perfis distintos, como se congelasse um fluxo em um instante. Não queremos dizer com isso de forma alguma que a história da pintura se resume a pintar as coisas tais como efetivamente se mostram, mas sim revelar como o poder analítico das distinções entre hylé, noema, morphé.
} 
encontramos na redução uma esfera absoluta de matérias e formas noéticas, cujo tipo preciso de entrelaçamento implica, em necessidade eidética imanente, o prodigioso ter consciência de algo determinado ou determinável, dado desta ou de outra maneira, que está para a consciência mesma como algo contraposto a ela, como algo outro, irreal, transcendente por princípio. (HUSSERL, 2006, p.226)

O "ter consciência de algo" é ter consciência de algo determinado ou determinável, que se contrapõe à consciência. De fato, essa unidade de sentido é o polo para onde a consciência se dirige sem que este polo esteja totalmente presente "dentro dela", mas apenas um perfil é vivido a cada momento. Esse algo determinado não é real, mas irreal (uma unidade de sentido não é uma coisa real, e não é um momento real da consciência). $\mathrm{O}$ noema não é nem um momento hilético, nem mesmo uma apreensão que o anima. Assim, fica claro que quando percebemos um elefante, não temos o próprio elefante na consciência. Pelo contrário, é correlato da consciência. Temos, realmente, um perfil do próprio elefante na consciência, mas o próprio elefante, que é "objeto visado", é algo contraposto à consciência como uma unidade de sentido irreal, "transcendente por princípio".

Se o elefante estivesse totalmente na consciência, todos os perfis deveriam estar simultaneamente na consciência, como consequência o sentido da transcendência se perderia. Mas intuímos atualmente um perfil do objeto, um lado, uma aparência. E por isso: "A despeito de sua inteira transcendência, a coisa que vemos no espaço é um percebido, algo que se dá em carne e osso para a consciência. No lugar dela, não está uma imagem ou um signo.” (HUSSERL, 2006, p.102).

O noema, a unidade de sentido, é condição de possibilidade para que haja "consciência de algo no espaço".

Pela redução transcendental, chegamos ao noema, o correlato da consciência. Não precisamos fazer uso da tese de realidade do mundo para que o alcancemos. Partindo da consciência, e tomando-a como ser absoluto, é possível, pelo conceito de noema, furar a bolha solipsista. O sentido objetivo está contraposto à consciência, mas não está realmente na consciência. O ser de um objeto intencional, correlato da consciência, é uma verdade indubitável, válida até mesmo na hipótese deste mundo que eu percebo ser um sonho coerente. Se percebemos uma árvore, a árvore percebida, dentro da redução transcendental, nada mais é do que um noema. E o noema enquanto noema, o percebido enquanto percebido, apesar de ser "transcendente por princípio", não se confunde com o objeto real.

A árvore pura e simples, a coisa na natureza, é tudo menos esse percebido de árvore como tal, que, como sentido perceptivo, pertence inseparavelmente à percepção. A árvore pura e simples pode pegar fogo, pode ser dissolvida em seus elementos químicos, etc. Mas o sentido - o sentido desta percepção, 
que é algo inerente à essência dela - não pode pegar fogo, não possui elementos químicos, nem forças, nem qualidades reais. (HUSSERL, 2006, p.206)

E ainda:

Tal como na percepção, todo vivido intencional possui - e é justamente isto que constitui o ponto fundamental da intencionalidade - seu "objeto intencional", isto é, seu sentido objetivo. Tão-somente noutras palavras: ter sentido ou "estar com o sentido voltado para" algo é o caráter fundamental da consciência, que, por isso, não é apenas vivido, mas vivido que tem sentido, vivido "noético". (HUSSERL, 2006, p.206)

\subsubsection{Elementos autênticos e inautênticos da percepção}

Havíamos dito, no começo desta apresentação, que a verdade de um juízo é dada pela evidência ou pela intuição. Mas, naquela ocasião, havíamos dito que era preciso estudar e investigar o alcance e o grau de perfeição das intuições, para que soubéssemos até que ponto as coisas são mostradas em si mesmas. Dissemos que a percepção é uma intuição doadora originária, pois o objeto visado está ele mesmo presente em "carne e osso". Contudo, observamos nos capítulos anteriores que o intuído originariamente em percepção dirigida ao transcendente, isto é, o que se mostra a cada momento, não é o objeto como um todo. Portanto, é preciso ter claro que, na intuição perceptiva dirigida para o transcendente, o efetivamente dado em carne e osso são os perfis do objeto. Com isso, começa a esclarecer a questão sobre até que ponto as coisas são mostradas à consciência, isto é, o alcance da evidência ou intuição.

Se repararmos com atenção, cada um desses lados efetivamente vistos não diz nada a respeito dos lados não vistos, os quais não são efetivamente intuídos, mas co-intuídos. Portanto, a vivência intencional dirigida para um objeto, que mantém a identidade consigo mesmo, é formada por uma mescla de consciência intuitiva e não intuitiva. (cf. HUSSERL, 2001, p.60). Daí Husserl afirmar que o efetivamente dado na intuição é envolto um por um horizonte de "dados concomitantes" inautênticos.

É um horizonte intencional, cuja característica é remeter a potencialidades da consciência que pertencem a esse mesmo horizonte. Assim, por exemplo, em toda percepção exterior, os lados do objeto que são "realmente percebidos" remetem aos que ainda não o são e que somente são antecipados na expectativa de maneira não intuitiva como aspectos "que estão por vir" na percepção. Essa é um protensão continua que para cada nova fase perceptiva, assume um novo sentido. (HUSSERL, 2001, p.62). 
De fato, suponhamos que, ao girar o cubo, vejo que um dos lados não é igual aos demais. Com isso, aquilo que foi antecipado de maneira não-intuitiva é contrariado pela nova evidência. Tudo isso é feito de "modo automático". A evidência perfeita, que daria a coisa percebida em todos os lados, encontra-se apenas no limite ideal. O máximo que pode ocorrer é que, a cada nova experiência que temos da coisa, a intenção se preencha mais e mais. É o que Husserl chama de "experiência concordante". Mas sempre o correlato que possui o sentido de coisa transcendente terá um horizonte de indeterminação.

Está aí a origem, por exemplo, dos erros de julgamento e das ilusões. Vemos apenas um lado de um cubo e automaticamente julgamos como sendo um cubo. Ao visarmos aquilo como um cubo, imputamos ao atualmente percebido um sentido vai além do intuitivamente dado. O significado de um cubo prescreve uma estrutura típica de aparições ao objeto ${ }^{228}$. $\mathrm{O}$ "sentido" forma um horizonte de componentes não-intuitivos que poderiam vir a ser preenchidos. Esse horizonte é composto por um "eu posso" ligado ao cubo. Vejo um dos lados, mas já o significo como um cubo material, e, em seu horizonte, está incluído o fato de que "eu posso tocá-lo se quisesse". No momento em que vejo minha mão tocar no cubo, tenho sensações táteis, que, em virtude da função noética, serão animadas como "sentir o cubo". Os conglomerados de sensações táteis estão ligados aos conglomerados de sensações visuais, fazem parte dos modos de manifestação do noema em questão. Assim, o mesmo cubo oferece perfis táteis e perfis visuais e prescreve novos perfis os quais são presentificados de modo não intuitivo, formando expectativas de novos preenchimentos intuitivos.

Portanto, em todo estado atual da consciência estão implícitas potencialidades: o efetivamente intuído, pelo seu sentido, prescreve um horizonte de possibilidades da unidade intencional se mostrar intuitivamente. Mas este horizonte é apenas co-intuído. Por isso Husserl aponta que o trabalho original da fenomenologia é:

(...) o de revelar as potencialidades "implicadas" nas atualidades (estados atuais) da consciência. E é por aí que irá se dar, do ponto de vista noemático, a explicação, a precisão e a elucidação daquilo que é significado pela consciência, ou seja, de seu sentido objetivo. (HUSSERL, 2001, p.64).

A explicação fenomenológica consiste em elucidar o que está implicado pelo sentido do cogitatum. "A explicação fenomenológica elucida o que está "implicado" pelo sentido do cogitatum, sem ser intuitivamente dado (por exemplo, o "avesso" do objeto), representando-se as percepções potenciais que tornariam o não-visível visível.” (HUSSERL, 2001, p.66)

\footnotetext{
${ }^{228} \mathrm{Na}$ linguagem vulgar diríamos que teríamos um preconceito do objeto ou um prejulgamento.
} 


\subsubsection{Retenção}

Como já vínhamos observando, toda percepção é um fluxo composto de fases temporais distintas, nas quais uma unidade de sentido se sustenta e mantém a identidade. Faz parte da estrutura universal e apodíctica da experiência do eu a forma imanente da corrente de consciência; Enquanto giro uma folha de papel há um transcorrer de fases perceptivas. A percepção terminará quando eu deixar de perceber a folha de papel e perceber outra coisa. Mas se refletirmos sobre essa percepção da folha de papel, sabemos que ela possui uma duração, composta por fases perceptivas. A lei da retenção é: as fases transcorridas são sintetizadas com a fase atual. Em outros termos, podemos dizer que em cada fase atual de um vivido intencional perceptivo referido a um objeto, a fase que acabou de transcorrer está ligada à fase atual. Sem essa síntese de consciência não haveria sequer percepção de objeto.

A titulo de ilustração, imaginemos a percepção de uma melodia simples: uma sucessão de notas simples com intervalos entre as notas. Em cada instante escutamos uma única nota, ou o silêncio. Imaginemos um homem que não possua a capacidade de reter no espírito as notas que acabaram de transcorrer. Tal homem não conseguiria perceber a melodia, pois para perceber a melodia é preciso que a consciência faça a ligação entre a nota já transcorrida com a nota atualmente percebida. Uma melodia só é melodia em virtude da relação de sucessão e do intervalo de tempo entre as notas. Uma pessoa totalmente mergulhada no presente, sem nenhuma memória, não conseguiria perceber relação nenhuma entre a nota atual e a nota que acabou de ser tocada. Não conseguiria sequer ter noção de "duração", pois a apreensão da duração exige a "memória". O mesmo é válido, como já mencionamos, para a percepção de uma palavra, cada fonema é "ligado" ao fonema imediatamente transcorrido. Mas essa lei pode ser estendida para qualquer percepção.

O fato é que em todo vivido intencional: o agora que acabou de passar continua por assim dizer, ainda vivo no presente. O imediatamente presente é ligado ao imediatamente passado de modo ordenado. Sem isso, não conseguiríamos sequer entender uma frase, uma melodia, e mais, não conseguiríamos perceber objeto algum.

O que Husserl denomina retenção é essa capacidade de manter "vivo" na consciência o imediatamente passado. Diferencia-se do ato de recordar, pois este é um ato pelo qual sujeito presentifica algo. Por retenção também não deve se entender o fato de que tenho "retido" na memória o que escutei ontem. A retenção é um passado imediato que ainda se mantém "vivo", pois embora não seja efetivamente intuído atualmente, participa da intuição atual. Se faço girar uma moeda na minha frente, em cada fase perceptiva, a moeda se dará por um 
perfil. Mas o perfil, que atualmente se exibe e é intuído, é sintetizado com perfis que acabaram de ser intuídos. Devido a essa síntese de consciência, é possível ver, por exemplo, uma moeda em rotação. Essas fases perceptivas não estão simplesmente sintetizadas em um conjunto desordenado, mas são ligadas em sua ordenação temporal.

Entretanto, à medida que a vivência se prolonga, as fases imediatamente passadas vão se distanciando das atuais, de modo que essas fases vão se esfumando até passarem para a inatualidade. No que concerne à escuta musical, é de se esperar que a capacidade de retenção de um grande músico erudito seja maior do que a de alguém que apenas começou a escutar esse tipo de música. Um músico pode coordenar e perceber uma longa melodia e ter ainda fresca a melodia anterior e "perceber" que essa melodia é uma "resposta" à melodia anterior. Ele não precisa, para isso, relembrar a melodia anterior e compará-las, ele simplesmente percebe que essa melodia é uma complementação daquela e que dá equilíbrio à música.

Já observamos que toda vivência intencional possui uma duração e que o estado vivido possui fases. No caso da percepção do cubo, embora cada fase o cubo se mostre por um perfil, o objeto intencional, o "cubo visado" permanece o "mesmo", um polo de identidade. No entanto, a própria percepção do cubo, enquanto dura, também é uma unidade. No entanto trata-se de uma "unidade sintética" das múltiplas fases perceptivas, que vão desde o momento em que começamos a perceber o cubo até o momento em que deixamos de percebê-lo. $\mathrm{O}$ noema é unidade de sentido. Já a unidade da percepção do cubo é uma unidade sintética. Ao discorrer sobre a unidade de percepção do cubo, Husserl escreve:

Sua unidade é a de uma síntese. Ela não é uma simples ligação continua de cogitationes, por assim dizer, exteriormente unidas umas às outras, mas sim uma unidade de consciência una, e nessa consciência se constitui a unidade de uma entidade intencional, precisamente como o mesmo das diversas e múltiplas maneiras. (HUSSERL, 2001, p.59).

\subsubsection{Expectativa}

Para que uma vivência intencional ocorra, é necessária essa síntese de consciência, isto é, que os estados de consciências apenas transcorridos estejam ligados com o estado de consciência atual. Mas há um segundo aspecto de grande importância, que diz respeito ao fato de que o vivido atual contém elementos de antecipação. O que ocorre é que as fases transcorridas remetem para as fases que estão por vir, as quais são antecipadas de modo não intuitivo. $\mathrm{O}$ fato de que o intuído originariamente esteja sintetizado com as fases anteriores da vivência dirigida a um mesmo objeto, acaba gerando uma antecipação das fases que estão por vir segundo o estilo prescrito pelo que já se mostrou. Ao girarmos um cubo, os lados que 
virão já estão antecipados, dado o sentido do próprio objeto. Os lados do objeto que são "realmente percebidos" remetem aos que ainda não o são.

Imaginemos que vemos apenas um lado de um objeto que reconhecemos como um “cubo azul". Não vi dele todos os lados, ao girá-lo, terei a antecipação de que ele será azul também na parte de trás. Não que, nesse processo, eu imagine conscientemente a parte de trás do cubo, essa antecipação, já está prescrita tanto pelo estilo das fases transcorridas, quanto pelo "sentido" do próprio noema.

O objeto é por assim dizer um pólo de identidade, apresentado sempre com um "sentido" "preconcebido" e "a ser" realizado. Ele é, em cada momento da consciência indicador de uma intencionalidade noética que lhe pertence por seu sentido, intencionalidade que podemos pesquisar e que pode ser explicada. (HUSSERL, 2001, p.63)

Essa antecipação, a qual possui um nome técnico de protensão está presente em toda intuição originária. O realmente intuído é sempre acompanhado daquilo que é co-intuído, que nada mais é do que um sentido preconcebido a ser realizado. ${ }^{229}$

Podemos perceber a antecipação na própria música. A cada nota que vai se sucedendo observarmos que se encaixa, como se a ordem de notas e dos intervalos anteriores "pedisse" a nova nota que vem. $\mathrm{O}$ estilo presente nas fases transcorridas abria um campo de resoluções possíveis que estão dentro daquele estilo. Tanto isso é verdade que podemos reconhecer, ao escutar uma música em um aparelho de som, ruídos estranhos à música, como os ruídos da vitrola. Sabemos disso porque o ruído quebra o estilo, não cabe ali naquela música. Por outro lado, um dos traços da genialidade de um músico é justamente quando ele "quebra" nosso campo de expectativas com algo que não podíamos esperar e que foi melhor do que esperávamos $^{230}$.

No ato de percepção de um objeto material, aquilo que a intuição havia originariamente intuído nas fases anteriores continua ainda consciente de modo não-intuitivo, bem como o que é antecipado está presente de modo não intuitivo, como um sentido pré-concebido a se realizar. Justamente por isso toda "percepção exterior" é uma sucessão de fases, onde cada novo mostrar-se do objeto pode concordar com esse sentido preconcebido ou riscá-lo. Quando há experiências concordantes, nas quais expectativas são preenchidas de acordo com o

\footnotetext{
${ }^{229}$ Por exemplo, se vejo um objeto projetado em minha direção e logo reconheço como um tijolo eu desviarei automaticamente, eu antecipo e desvio meu corpo. Suponhamos que em um momento seguinte eu descubra que aquilo não era verdadeiramente um tijolo, mas apenas uma espuma que parecia um tijolo. Com isso, as experiências que sucederam não confirmaram o "sentido" implicado no ato perceptivo, sentido em virtude do qual, gerou determinadas expectativas e outros atos.

${ }^{230}$ No humor e mais precisamente no chiste, isso é constante. Por exemplo, na definição de Ambrose Bierce: "egoísta é algo que pensa mais em si mesmo do que em mim", o final dessa sentença quebra com as antecipações de um modo inteligente.
} 
sentido pré-concebido, esse mesmo sentido é fortalecido. Caso seja riscado, a unidade de sentido se altera, como numa correção. Contudo, apenas as novas evidências do objeto podem riscar, de modo racional, as evidências anteriores. Por isso, se é verdade que pelas evidências temos a experiência de um ser e de seu modo de ser, isso não significa que essa evidência seja perfeita, isto é, adequada, o que só poderia ocorrer se intenção significativa fosse completamente preenchida intuitivamente.

Ora, todas são mais ou menos perfeitas. Aqui, imperfeição quer dizer, em regra geral, insuficiência. As evidências imperfeitas são unilaterais, relativamente obscuras, indistintas quanto à maneira pela qual as coisas ou os fatos são aí mostrados em si. A experiência no caso é, portanto, viciada por elementos de intenção significantes não preenchidos ainda por uma intuição correspondente. $\mathrm{O}$ aperfeiçoamento dá-se, então, numa progressão sintética de experiências concordantes, em que essas intenções significantes chegam ao estado da experiência real, que os confirma e preenche. A ideia correspondente de perfeição seria a de evidência adequada, sem que pesquisemos se, em princípio, essa ideia está ou não situada no infinito. (HUSSERL, 2001, p.33). 


\subsection{O cogito}

\subsubsection{A síntese universal do tempo transcendental}

Heráclito dizia, ao contrário de Parmênides, que o que há é o devir. No Cosmos, tudo está em constante mutação. O ser de Parmênides, em certo sentido, joga de escanteio a evidência do fluxo cósmico, dado aos sentidos. Parmênides chega ao ser pelo puro pensamento teórico, e chega à noção de um ser imutável, pois toda mutação exige que o que é deixe de ser. Mas o ser não pode deixar de ser, pois ele é. E assim, conclui Parmênides: o "ser é e não pode não ser". Trata-se da pura identidade do ser consigo mesmo. Em Heráclito o ser não pode ter identidade consigo mesmo, pois o que há é o devir.

Esse quadro pode ser trazido para a consciência, sem que precisemos levar em consideração a tese de existência do mundo. A consciência é transcorrer, nenhum estado de consciência é igual ao estado anterior. Neste sentido, a consciência é devir. No entanto, dentro deste devir, a consciência é consciência de algo, ela possui um caráter intencional, de modo que todo vivido intencional é dirigido para um objeto. É condição a priori, para que um objeto seja um objeto para a consciência, que ele mantenha, durante algum tempo, a identidade. Aliás, a essência do objeto é a identidade; um objeto, para que seja objeto, deve "vencer" o fluxo de consciência, no qual um estado nunca é exatamente igual ao estado seguinte. Por isso, o objeto, enquanto unidade de sentido, não é ele mesmo um estado de consciência, mas o correlato de múltiplos estados de consciência sintetizados. O objeto intencional é polo em virtude do qual esses múltiplos estados de consciência são sintetizados, como múltiplos estados de um "mesmo". Ele é o "elemento comum" das varias e distintas fases da percepção, não está realmente presente na consciência, mas "idealmente", imanente em múltiplos e diversos estados de consciência, os quais são sintetizados no tempo, constituindo assim, por exemplo, a percepção de um objeto.

O noemático é o campo das unidades, o noético, o campo das multiplicidades "constituintes". Com efeito, a consciência que unifica "funcionalmente" o múltiplo e, ao mesmo tempo, constitui a unidade jamais mostra identidade onde a identidade do "objeto" está dada no correlato noemático. Onde, por exemplo, diferentes intervalos de uma percepção contínua, constitutiva de unidade de coisa, mostram um idêntico, esta árvore não alterada no sentido desta percepção - idêntico que se dá ora nesta orientação, ora naquela, ora visto de frente, ora de trás, primeiro de maneira indistinta e indefinida, mas depois de maneira distinta e definida, em virtude das propriedades visualmente apreendidas de algum ponto etc. -, aí o objeto encontrado no noema vem a consciência como um objeto idêntico no sentido literal do termo, a consciência dele, no entanto, é uma consciência nãoidêntica nos diferentes intervalos de sua duração imanente, é tão só uma consciência interligada, continuamente unida. (HUSSERL, 2006, p.228) 
Como já observamos nos capítulos anteriores, um vivido intencional implica uma síntese identificação que resiste ao fluxo temporal imanente à consciência. As diferentes fases perceptivas que se fundem como consciência de um mesmo. Essa síntese é uma síntese de identificação, pois cada fase, embora distinta, possui entre si, a identidade do noema, desse polo de sentido, o idêntico, que é correlato do múltiplo. Não é, portanto, uma síntese fortuita, é uma síntese cujo nó que as liga é a unidade de "sentido".

Contudo, esse operar sintético da consciência não ocorre apenas internamente a um vivido intencional. Existe também outra espécie de síntese, uma síntese universal que amarra todos os vividos intencionais de consciência. O "eu" é o componente comum a todos os vividos de consciência. Afinal, todos os vividos de consciência estão referidos ao eu e foram vividos pelo eu.

A consequência mais importante disso é que uma vivência intencional atual pode ter como objeto intencional uma vivência intencional que pertence ao próprio fluxo. É o que ocorre, por exemplo, quando eu me lembro de uma percepção que tive ontem. $\mathrm{O}$ ato de recordar tem como recordado a própria percepção de algo. Isso só é possível porque o eu que percebeu ontem é o mesmo eu que se lembra agora. Terminada a percepção de um gato, posso, sem percebê-lo atualmente, lembrar-me do gato que outrora foi percebido originariamente. Antes o gato individual era objeto percebido; agora "o mesmo" gato é objeto lembrado, objeto intencional do meu ato de recordar. $\mathrm{O}$ fato é que a consciência identifica gato lembrado com o gato outrora percebido. Quando percebia o gato, o noema era o "mesmo", que mantinha a identidade consigo mesmo, apesar de uma multiplicidade de aparições. Do mesmo modo, agora é o "mesmo objeto" visado por dois tipos de atos distintos. O "lembrar-se do gato" é um estado de consciência "isolado temporalmente" daquele estado de consciência pertencente ao meu fluxo de consciência relativo à percepção do gato. Mas ambos os estados estão ligados.

Mesmo não percebendo o cubo, posso lembrá-lo e o sentido implicado no objeto lembrado é identificado com o "cubo percebido". Aquele mesmo cubo que era objeto percebido é agora objeto lembrado. Antes o cubo, ele mesmo, se dava originariamente na percepção, agora esse "mesmo cubo", essa mesma unidade de sentido, se oferece, ele mesmo, em um ato de recordação. Há, neste caso, uma síntese entre a vivência perceptiva do cubo, com este novo estado de consciência, a recordação do cubo.

Mas o mesmo cubo - o mesmo para a consciência - pode estar presente na consciência (ao mesmo tempo ou sucessivamente), porém, em modos separados e muito diferentes, por exemplo, nas percepções, lembranças 
expectativas, julgamentos de valor, etc., isolados uns dos outros. No caso, também se trata ainda de uma síntese que realiza a consciência, ultrapassando e envolvendo seus estados isolados, e torna assim possível todo conhecimento da identidade. (HUSSERL, 2001, p.60)

A recordação é uma forma de intuição, porque o objeto intuído, o recordado, se mostra à consciência "ele mesmo", embora não originariamente, pois não se mostra presente em "carne e osso". Na intuição originária o objeto é apresentado, na recordação ele é presentificado. Mas em ambos os casos, o objeto se mostra "ele mesmo". Podemos observar, ademais, que assim como a vivência de percepção de um objeto possui uma duração e é composta por fases, do mesmo modo a vivência intencional de se lembrar do cubo possui também uma duração e também é composta por fases. O cubo recordado também aparece por perfis. Se eu lembro de um gato que vi ontem, os perfis pelo qual o gato se ofereceu, agora se oferecem na recordação - dificilmente iria lembrar-me do gato em perspectivas bizarras como, por exemplo, o gato visto de baixo para cima, tal como o veríamos se fôssemos do tamanho de uma formiga. A recordação é uma modificação do vivido de percepção. Presentificar é fazer com o objeto se torne "ele próprio" novamente presente, embora de modo não originário.

Essa identificação intencional, pela qual o "mesmo objeto" se mostra em atos distintos é uma condição de possibilidade da consciência para que a consciência seja o que é. Imaginemos a seguinte situação. Eu penso comigo mesmo: "direi para aquela pessoa que ela é uma autoritária". Está implicado aí que aquela pessoa com quem tive várias experiências originárias é agora o objeto sobre o qual recai um juízo: "Ela é autoritária". E mais, quando eu penso que direi para ela que ela é autoritária, significa que o ato da vontade tem como objeto da vontade um estado de coisas a ser realizado no qual aquela pessoa está contida. O objeto da vontade é: "falar para pessoa que ela é autoritária". Portanto é um objeto intencional complexo. Finalmente encontro-me com aquela pessoa e a percebo em "carne e osso". Aquela pessoa percebida é a "mesma" pessoa que antes foi objeto do meu pensamento e da minha decisão. Eu sou capaz de sintetizar aquela pessoa vista com a pessoa que, antes, presentifica va e era alvo do meu juízo e que estava implicada no estado de coisas da minha vontade. Então aproveito a oportunidade e digo para ela: "você é uma pessoa autoritária". Todo esse processo só foi possível devido a essas sínteses de identificação. 


\subsubsection{A verdade como juízo preenchido intuitivamente: a correlação entre a unidade de sentido no juízo e a unidade de sentido na percepção}

Já observamos que um juízo, antes de sua confirmação em evidência, nada mais é do que uma presunção de que um objeto ou estado de coisas é ou é de tal e tal modo. Aquele que anuncia um juízo usa palavras, mas o que está em questão não são as palavras, mas sim aquilo que ele quer significar com as palavras: o estado de coisas intencionado pelo juízo. O juízo é verdadeiro se estado de coisas anunciado estiver em conformidade com o próprio juízo. E saberemos se está em conformidade se obtivermos alguma confirmação do estado de coisas em uma intuição originária.

Havíamos já observado que a verdade não é uma crença subjetiva, pois a verdade não está na relação entre sujeito que julga e juízo, mas na relação entre o juízo e a "realidade". Poderíamos até mesmo dizer que a verdade é adaequatio intellectus et rei. Mas como é possível que o juízo, que é um objeto do pensamento, um objeto do nous, possua uma correspondência com o "real"? Afinal, como comparar um objeto do pensamento com um objeto real? Ao que parece só seria possível se o real fosse composto por ideias? E ainda, se o real é transcendente à consciência, como é possível encontrar essa correspondência?

A resposta do problema se resolve se levarmos em consideração o que já vínhamos observando. $\mathrm{O}$ ato perceptivo dirigido para a transcendência tem como correlato uma unidade de sentido. O noema está "idealmente" contido na percepção, e ele possui um sentido, uma essência. Nem o noema, nem as essências implicadas nesta unidade de sentido são "reais", são unidades de sentido, a princípio transcendentes, que mantém a identidade consigo mesmas. Terminada a percepção, essa unidade de sentido pode ser ela mesma objeto de um ato de juízo.

Imaginemos a seguinte experiência possível. Estou na cozinha e percebo, tendo como suporte conglomerados de sensações animados pela função noética, unidades de sentido, digamos: “a xícara em cima da mesa”. Essa unidade de sentido, terminada a percepção, continua sendo a "mesma", ainda que seja objeto de atos de outro tipo, como o juízo que faço a respeito dela. Se enuncio este juízo: "a xícara está em cima da mesa" o que faço é anunciar a essência das unidades de sentido daquilo que foi percebido. Suponhamos que eu saia da cozinha e vá ao quarto dizer a uma pessoa que: "a xícara está em cima da mesa". Dividamos, em momentos, para facilitar a análise. Eu chego ao quarto e recordo da xícara de café em cima da mesa. Há aqui uma presentificação do originalmente vivido, as unidades de sentido "xícara" e "mesa" são intuídas no ato da lembrança, elas se mostram "elas mesmas", embora de modo não originário, tal como no instante em que percebi. Esses objetos e a configuração 
espacial são intuídos e possuem o mesmo núcleo de sentido antes dado pela percepção. $\mathrm{O}$ estado de percepção, que já terminou, é sintetizado com estado de recordação, de modo que está sendo recordado é o mesmo que o que foi percebido, apenas não se mostra em "carne e osso". A recordação é uma intuição, um objeto me é dado e possui uma essência. Tomando a xícara recordada como exemplo, ela é, por sua essência, uma xícara de porcelana branca, utensílio, objeto material, etc. Ao recordar o "estado de coisas" sei tudo isso e mais um pouco: sei, por exemplo, que a xícara está no canto da mesa. No entanto, quando anuncio, anuncio apenas algumas das essências pertencentes ao recordado. A afirmação "a xícara está em cima da mesa" não diz nada a respeito do fato de que a xícara está no canto da mesa, nem que a xícara é de porcelana.

A pessoa que está no quarto e entende o meu juízo entenderá um estado de essências, razoavelmente elástico, que se refere a um conjunto de possibilidades e impossibilidades. Contudo, uma coisa é entender, outra coisa é crer. No momento em que o ouvinte crê no juízo, ele crê que esse estado de essências presumido pode ser dado em evidência, em intuição originária. Tal pessoa crê que este estado de essências intencionado pelo juízo pode "ele mesmo" vir a ser percebido, em "carne e osso". Suponhamos que, em virtude do fato de ela crer em minha palavra, ela vá até a cozinha. Por ser uma pessoa dotada de nous, sua função noética anime as matérias brutas e cambiantes dadas em sensação, de modo que ela e veja objetos, os quais, pelos seus sentidos, possuem esta ou aquela essência. Perceberá objetos, cada qual é uma coisa, e dentre estes objetos perceberá um que é uma xícara, e, portanto, possui a essência xícara, perceberá um outro que é uma mesa, e perceberá que a relação entre a xícara e a mesa é conforme ao estado de essências anunciado. Com isso, a intenção significativa se preenche intuitivamente. O estado de essências que antes era apenas compreendido, presumido e crido é identificado, é preenchido intuitivamente.

Algo aí deve ser notado. O que há não é uma comparação entre a "imagem mental" que tal pessoa formou ao escutar o juízo e a "imagem mental" percebida. Para que ela comparasse, seria necessário que ela imaginasse uma "xícara de café em cima da mesa" antes de vê-la somente neste caso sim ela poderia comparar a imagem formada em imaginação e o percebido. Neste caso, dificilmente seria a mesma. Se ela imagina a xícara de café em cima da mesa, ela necessariamente deverá colocar, na tela da imaginação, a xícara em algum dos cantos da mesa e provavelmente irá errar. O que há isso sim é que a pessoa simplesmente entende o estado de coisas anunciado pelo juízo. Ao ver a xícara em cima da mesa o que ocorre não é uma adequação da imaginação com a imagem do percebido, mas sim que um conjunto de possibilidades e impossibilidades eidéticas intencionado pelo juízo é preenchido 
por uma intuição originária, que mostra um representante individual de uma generalidade eidética.

Neste exemplo, podemos discernir o ato de julgar e o juízo. O juízo pode ser expresso de maneiras distintas. O que procuro exprimir não é o meu ato subjetivo de julgar, nem meu estado subjetivo de recordar a xícara em cima da mesa. Exprimo um o juízo que afirma um estado de essências objetivo. Como havíamos observado, toda percepção singular é acompanhada por uma intuição eidética. É em virtude dela que todo o processo foi possível: desde o momento em que percebi determinados objetos, recordei-os, exprimi um juízo acerca de um estado de essências embutidas no que vi, de modo que o ouvinte entendeu o estado de essência, creu no estado presumido e, em seguida, o confirmou por uma intuição originária. Aquele que percebe, não percebe objetos singulares absolutamente únicos, mas também essências e relações entre essas essências.

Contudo, devemos notar o seguinte. Nem sempre é possível encontrarmos "verdades absolutas" quando o objeto julgado possui o sentido de ser transcendente ${ }^{231}$. Conhecemos o objeto por uma progressão de experiências que podem concordar ou discordar com o sentido; mas sempre o objeto pode ser visto por novas perspectivas. Essa insuficiência no mostrar do objeto é válida também para os atos de recordação. Posso recordar da face de uma pessoa com mais ou menos nitidez; talvez lembre que era nariguda, que tinha os olhos pequenos, mas não exatamente o formato da boca. Se eu digo: "tal pessoa é nariguda", eu não estou intencionalmente dirigido à minha imagem mental, mas quero afirmar algo a respeito da "própria pessoa", que poderia ser percebida em carne e osso. Predico o noema, o núcleo de sentido que pode se mostrar em diferentes atos, e não a imagem mental ${ }^{232}$.

\footnotetext{
${ }^{231}$ Isso porque as evidências perceptivas dirigidas para a transcendência são sempre insuficientes e nunca plenamente adequadas, como já discutimos suficientemente nos capítulos anteriores. O que é dado originariamente do objeto são perfis enquanto os demais perfis são apenas co-intuídos em antecipações prescritas pelo seu sentido e pelo seu estilo. Percebo, ao andar na rua, objeto e entendo aquilo como sendo ouro. Pego o objeto em minhas mãos e percebo que ele é muito leve. O sentido imanente àquela percepção foi cancelado, porque o objeto não se mostrou tal como o ouro deve se mostrar. Para que algo seja realmente ouro, ele deve se mostrar tal como o ouro se mostra e faz parte da essência ouro ser denso. O percebido enquanto percebido não perde com isso sua identidade, continua sendo o "mesmo", embora o sentido que este "pólo de identidade tem para mim" tenha sido alterado. Toda a intenção voltada, por exemplo, para as coisas materiais possuem componentes não-intuitivos e objeto intuído é mais ou menos distinto, mais ou menos claro. E isso não ocorre apenas na percepção exterior. Lembrar é intuir.

${ }^{232}$ São duas coisas distintas. Uma coisa é dizer, "vejo na minha memória que fulano é narigudo", outra coisa é dizer, apoiado na memória: "fulano é narigudo". No primeiro caso, não posso me enganar. No segundo caso, uma evidência originária pode mostrar que estou errado: fulano fez uma plástica e eu não sabia.
} 


\subsection{O eu puro}

\subsubsection{Os modos de se comportar do eu}

O eu é um polo idêntico que, nas palavras de Husserl, lança um raio de consciência ao objeto. Em toda vivência existe o eu e o objeto visado e entre eles o ato de consciência. Assim, em todo fantasiar existe um fantasiado, em todo pensar existe um pensado, etc e tal.

O eu está referido aos objetos em modos muitos diversos, segundo gênero do ato que ele realiza. Em um certo sentido, voltando um mesmo objeto ele é sempre livre; por outro lado, a imagem do "dirigir-se para" a manifestação é utilizável apenas em parte. Em certo sentido, muito geral, o eu se dirige sempre em direção a um objeto, mas em sentido particular, do eu puro procedem raios egológicos que tendem em direção ao objeto, e no mesmo tempo do objeto emanam raios em direção contrária. Assim, quando desejo qualquer coisa, me sinto atraído ao objeto desejado, sou girado em sua direção, de modo tal a tender em direção a ele, sem, no entanto, alcançá-lo apenas no meu desejo. (HUSSERL, 2008, p.535, tradução nossa)

É, de fato, indubitável que o eu sente-se atraído e repugnado em suas relações com os objetos. Contudo, é igualmente indubitável que, mesmo atraído por um objeto, o eu não necessariamente cederá a essa atração. Um cogitatum, digamos um objeto do desejo, como um doce, pode atrair o eu, até mesmo "roubar" a atenção do eu, convidando-o a comê-lo, o que não significa que o eu irá aceitar o convite. Esse ser atraído significa que há também uma passividade do eu, que o eu não é um puro agente. A resistência à atração do objeto revela um eu que é ativo, mas o ser atraído revela o eu que é também passivo.

A atração que um objeto exerce no eu ao "lançar raios sobre ele" cria uma tendência, mas o eu pode, em linha de essência, resistir à atração. Contudo, podemos ir mais longe e observar que existe um comportamento do eu, isto é, como ele se comporta em seus atos. Às vezes o eu puro está agitado e às vezes está em um estado de passividade e torpor, como uma pessoa que se entrega ao luto e não querer fazer nenhum tipo de esforço, por exemplo, o do pensamento teórico, ou as atividades práticas. $\mathrm{O}$ eu pode, ao contrário, ter um comportamento movimentado, saltar ativamente de objeto em objeto, numa espécie de frenesi, como quem está imerso e empenhado em uma atividade muito urgente que precisa terminar logo. Obtemos esses dados apenas pela auto-observação da vida da consciência. Esses modos de se comportar do eu são válidos ainda que o mundo em que vivo seja um sonho coerente.

Como vimos, ao lado das vivências atuais, existe um halo de vivências inatuais, que formam o campo de fundo da consciência. Nesse momento em que escrevo, estou com a atenção dirigida para o tema da escrita, mas os vividos envolvidos no ato de escrever e pensar não são os únicos vividos, escuto a todo instante o barulho da rua, são vividos de percepção 
inatuais; meu o olhar espiritual não está para aí dirigido. Caso comece uma gritaria na rua, o olho do espírito irá para aí se dirigir. É possível que eu fique curioso para saber o que está acontecendo e talvez eu vá a janela para ver o que é.

O eu puro não vive apenas os atos singulares, enquanto os realiza, enquanto é ativo, enquanto os sofre passivamente; livre e, todavia objetivamente atraído, o eu puro procede de ato em ato, sofre estímulos provenientes dos objetos que constituem o "fundo"; sem obedecê-los imediatamente, os deixa intensificar, deixa que eles batam na porta da consciência, cede a eles e eventualmente cede prontamente, passando de um objeto a outro. (HUSSERL, 2008, p.535, tradução nossa)

Um outro traço é que os modos de se comportar do eu puro estão relacionados com o tipo de objeto e o tipo de ato. Lidar com determinados objetos implica em um modo próprio de se comportar do eu puro. Quando o eu puro está em sua atividade de teorizar, ele deve predicar, relacionar um objeto a outro, etc. O modo como ele se relaciona com os objetos lógicos diferencia-se, por exemplo, do modo com os quais se relaciona com de diferentes com objetos de outros domínios, por exemplo, quando o eu está empenhado em jogar pinguepongue.

\subsubsection{O eu substrato do habitus}

Tudo aquilo que eu entendo como pertencente ao "mundo" se dá em virtude das minhas experiências, passadas e presentes. Se eu penso que atrás dessa parede existem carros, pessoas, ruas, cidades, isso significa que carros, pessoas, ruas, cidades são objetos que foram constituídos intuitivamente para o meu eu. No caso, minha consciência entende que tais objetos são coisas reais no espaço. Uma criança de dois anos de idade tem um "mundo" distinto do meu, embora haja "intersecções", unidades de sentido em comum entre eu e ela. No mundo dela não existem tesouras, nem livros, pois objetos como tesouras e livros não adquiriram sentido para ela. A cada novo objeto que eu "descubro", isto é, que eu constituo intuitivamente, seja por experiência direta, seja por experiência intersubjetiva, o meu mundo se expande, isto é, expande a minha mônada ${ }^{233}$.

Quando a criança entende o que é um livro, ela passa agora a viver em um mundo no qual existem livros. Uma criança de dois anos de idade talvez possa rabiscar um livro, mas ela, mesmo rabiscando-o, não entende o que é um livro. Ela não intuiu a essência livro, do

\footnotetext{
${ }^{233}$ No entanto, como veremos, isso não significa que o homem seja uma mônada fechada sob si mesma, pois existe uma intercomunidade das mônadas além dos dados brutos da sensação.
} 
mesmo modo como um animal doméstico pode ver um livro e ainda assim não entender o que é um livro. A compreensão do que é um livro exige a compreensão do que é a escrita.

No fluxo monádico de consciência se encontram várias unidades distintas. Dentre elas encontram-se propriedades do eu, dentre as quais aquilo que Husserl denomina "opiniões intencionais" ou de "habitus" do eu. E por habitus não devemos entender o sentido usual no qual se fala de "costume". Os habitus são posicionamentos do eu perante objetos intencionais. $\mathrm{O}$ eu puro caracteriza-se não apenas por ser um polo idêntico ligado a qualquer vivência que ele viva, está também no fato de que o eu se posiciona perante os noemas. Cada um dos posicionamentos perante isso ou aquilo determina e singulariza o eu. As opiniões intencionais caracterizam o eu puro, mas essa determinação não é intrínseca, não faz parte da estrutura do eu. As opiniões intencionais, os habitus são, como dissemos, propriedades do eu, e elas são instauradas em virtude das relações entre o eu, que é um polo idêntico, e seus noemas. $^{234}$

É preciso notar, no entanto, que esse eu central não é um pólo de identidade vazia (não mais do que qualquer outro objeto); com qualquer ato que ele efetue e que tem um sentido objetivo novo, o eu - em virtude das leis da "gênese transcendental" - adquire uma nova propriedade permanente. Se eu me decido, por exemplo, pela primeira vez, num ato de julgamento, pela existência de um ser e por esta ou aquela determinação deste ser esse ato passa, mas eu sou e permaneço daqui por diante um eu que decidiu desta ou daquela maneira, "tenho uma convicção correspondente" (HUSSERL, 2001, p.83).

Toda e qualquer decisão me pertence como habitus. Não apenas as decisões sobre a existência real de objetos ou sobre determinações de objetos, mas também decisões de ações que resolvo tomar. Se eu me decido realizar uma ação, mesmo que eu não pense a todo instante na decisão que tomei, ainda assim, ela perdura. Trata-se de minha decisão. E feita essa decisão, torno-me um eu que se convenceu e por isso, a decisão influencia a minha vida intencional. Isso não significa que a minha convicção não possa, após algum tempo, ser riscada. Mas enquanto não tenho motivo algum para riscá-la, ela permanece. Certo, posso perder a convicção, mas ela havia se mantido, até então, minha convicção. Agora ela é minha ex-convicção.

O posicionar perante as coisas significa manter de modo estável um determinado tipo de relação com um determinado correlato de consciência. Cada nova posição perante um noema,

\footnotetext{
234 A distinção aristotélica entre predicados essenciais e predicados relativos poderia ser mencionada para facilitar a visualização. O ser pai não é um predicado relativo, pois não é uma qualidade intrínseca, pois ele é o que é em virtude de algo que não é ele. Contudo, a comparação tem limites, pois o predicado de relação ocorre entre duas substâncias e o eu puro não é uma substância real, tal como compreende Aristóteles. O que importa é que essas propriedades não são intrínsecas ao eu puro, elas ocorrem em virtude das relações entre o eu puro e os cogitata, como iremos melhor examinar.
} 
cria uma "opinião intencional permanente". Essa opinião intencional pode referir-se a um querer, um juízo, um valor.

Uma das características das opiniões intencionais é a sua permanência em relação à corrente do cogito. O eu, no mês passado e este eu agora, possuem uma propriedade em comum: ambos mantêm a decisão de finalizar o doutorado. Os vividos transcorreram, tive nesse último mês, muitas vivências, no entanto, a decisão de terminar o doutorado permaneceu. A decisão é uma propriedade do eu, é um habitus, uma opinião intencional que não se perde com o transcorrer do fluxo. Neste caso, a decisão "terminar o doutorado" diz respeito à minha vontade. Mas mesmo um valor pode ser uma opinião intencional. Por exemplo: terminar o doutorado é, tanto antes quanto agora, um valor.

Mas uma opinião intencional pode ser uma decisão quanto à existência real de um objeto. Suponhamos que, no último mês, passei a acreditar na existência de demônios. A crença em demônios é um tema do meu juízo: “demônios existem realmente”.

O que é importante notar é que essas opiniões intencionais não são fortuitas. Se eu me decido pela existência real de algo, eu decidi por algum motivo, seja por motivos racionais, seja por motivos psíquicos ${ }^{235}$. É por isso que Husserl escreve:

A minha tese, a minha tomada de posição, o meu decidir em base a certos motivos (compreendido o caso zero) são meus. Se eu sou identicamente aquele que sou, a tomada de posição não pode fazer outra coisa que permanecer tal como é, e eu não posso fazer outra coisa que mantê-la: posso modificá-la apenas se os motivos se tornem outros. (2008, p.549, tradução nossa)

Minha crença em demônios pode ter sido motivada por muitas razões. Posso ter acreditado devido ao relato de uma pessoa em que eu confio. Mas posso acreditar em um demônio porque certo dia eu vi, com meus olhos, um demônio. O ato de percepção, neste caso, foi o ato que motivou o meu posicionamento diante deste objeto intencional. Meu posicionamento é de crença diante do juízo: "demônios existem".

Mas por que se fala de posicionamento e não de constituição intuitiva? Se falamos de "posicionamento" é porque o que muda, quando passo a crer na existência real de demônios não é propriamente a essência demônio. Demônios já existiam para mim antes que eu acreditasse, existiam como unidade de sentido, como criaturas meramente imaginárias e lendárias. Ao ver um demônio, essa evidência me leva a mudar meu posicionamento perante o objeto intencional, passo a crer que demônios existem no "mundo real". Perceber um demônio é uma evidência adequada. E essa evidência pode prosseguir em experiências concordantes.

\footnotetext{
${ }^{235}$ Uma discussão mais detalhada sobre motivos e motivação será feita posteriormente.
} 
Vejo um demônio, não consigo acreditar no que estou vendo e, para me certificar, resolvo tocá-lo. Se, ao tocá-lo, sinto-o com minhas mãos, a evidência adequada ganha peso e força, me motivando racionalmente à minha crença, minha "convicção" ou "opinião intencional", no caso, a de que demônios realmente existem no mundo real.

Se me decido pela existência de demônios e passo a ser alguém convencido desta existência, a minha convicção influencia a vida intencional do o meu eu. A partir desse momento o meu "mundo real" será um mundo com tesouras, mesas, átomos, homens e demônios, etc. A minha decisão em acreditar em demônios foi fundamentada em uma evidência, não foi fortuita: acredito porque vi e toquei. Por isso, por fundamentar-se em uma evidência adequada, fui motivado racionalmente a acreditar em demônios. Ora, é racional acreditar na realidade daquilo que se percebe e que se mostra em experiências concordantes.

Na medida em que sou um ser racional, um eu que toma posição em base a um conhecimento evidente; posso decidir-me apenas de um modo, no modo racional, então a minha decisão é idêntica a de qualquer outro sujeito racional que tenha a mesma evidência: ou, se um outro não pode ter os mesmos motivos, pode compreender os meus e pode valorar a minha decisão de modo racional e compreensivo. (HUSSERL, 2008, p.549, tradução nossa)

Um outro sujeito racional pode não ter a mesma experiência que eu, a de ver um demônio, e, em virtude disso, é provável que não acredite. Mas, por ser racional, ainda que não acredite, tal pessoa pode entender os motivos racionais que me motivaram à crença. Um outro aspecto a ser observado é que a crença em demônios, por ser uma opinião intencional, influenciará a minha vida intencional. Se eu sinto um desejo de fazer o mal, posso considerar que isso acontece devido à influência maligna de algum demônio (neste caso de um demônio invisível). Dado que eu acredite nisso, é racional levantar a hipótese de que meu desejo foi decorrência de influxos malignos no meu espírito. Da mesma forma, a constituição de um objeto como tesoura para uma criança afeta sua vida intencional. Se ela quer cortar um pedaço de papel com precisão, é possível que pense em uma tesoura. O ato de querer cortar o papel com precisão possui uma ligação com o ato de ela pensar onde pode conseguir uma tesoura para cortá-lo. Se ela não houvesse constituído intuitivamente o sentido "instrumento tesoura", pondo-o como coisa real, não haveria associação entre o querer cortar o papel com precisão e a tesoura $^{236}$.

236 . Podemos imaginar a cena em que um homem das cavernas está esfregando uma pedra na outra para acender uma fogueira quando cai do céu, ao lado dele, uma caixa de fósforos. Isso em nada lhe serviria, mesmo que ele veja aquele objeto, para ele aquilo não é uma caixa de fósforos, é apenas um objeto estranho que caiu do céu. A caixa de fósforos não existe como correlato de sua consciência e, portanto, ele continuaria procurando acender a 
Em suma, o eu puro não é um polo de identidade vazio, cada eu puro possui suas crenças, seus valores, suas convicções, dentre elas a convicção de que o mundo é real, de que o sol nascerá amanhã, de que possui um corpo real, uma psique real, de que existem extraterrestres ou não. Essas opiniões intencionais se constituem em virtude de determinados motivos e muitas vezes se mantém e perduram porque se confirmam com experiências concordantes, em evidências adequadas ou por vários outros motivos que não convém, no momento, examinar. Estas convicções são constituídas no fluxo e permanecem apesar do fluxo, o que não impede que eu as mude:

O fato, isto é, que eu mantenho uma tomada de posição interna e atual e que, através de atos repetidos, conheço-a e assumo-a como minha. A lei, portanto, é essa: que cada opinião intencional é uma instauração (stiftung), que permanece é uma propriedade do sujeito até o momento que se apresentem motivações que exigem uma "troca" da tomada de posição, uma renúncia à velha opinião, ou um abandono parcial de alguns de seus componentes, uma modificação no conjunto. Cada opinião intencional de um único e mesmo eu permanece necessariamente na cadeia das rememorações, até o momento que vem cancelada em virtude de certos motivos. (Husserl, 2008, p.522, tradução nossa)

Essa unidade instaurada, a opinião intencional, não é qualquer coisa de abstrato, não se trata de uma pura ideia. Uma tomada de posição é "uma unidade concreta de vivido".

É preciso distinguir o juízo da opinião intencional. A opinião intencional, no momento em que é instaurada, tem uma duração imanente e, logo em seguida, o eu se ocupa com outra coisa. Contudo, embora não esteja pensando mais nela, a convicção permanece.

As questões relativas ao posicionamento perante os noemas também são válidas em relação ao juízo. Uma coisa é o juízo, outra coisa é a crença no juízo ou a convicção que o juízo é verdadeiro. O juízo, entendido como noema pode ser ligado a vários outros atos noéticos. $\mathrm{O}$ ato de julgar, pelo qual eu coloco para mim determinado juízo passa, já o juízo, enquanto objeto ideal, permanece. No caso da lei de Kepler, aquele que pensa duas vezes na lei, pensa no mesmo objeto, porque o juízo é um objeto atemporal e não ocupa lugar no espaço. Contudo, é possível que essa pessoa tenha acreditado na lei de Kepler quando no segundo colegial. E pode, após alguns anos, pensar na mesmíssima lei de Kepler e não mais crer nela. A lei de Kepler é a mesma, mas o seu posicionamento perante a lei muda.

De modo específico, também uma convicção do tipo "farei isso" é um habitus, é um posicionamento e me determina. No entanto, nem sempre os juízos nos quais acreditamos tem origem em evidências originárias. Posso acreditar que gnomos existem porque alguém me

fogueira com as pedras. Se esse homem das cavernas ao explorar aquele objeto e descobrir que riscando o palito, ele pega fogo: aquele "objeto estranho", terá para ele um novo sentido. 
disse que viu e eu ponho fé nessa pessoa. Posso acreditar porque a sociedade como um todo acredita. Posso acreditar que fumar faz mal porque o meu médico falou. Acreditar em um juízo porque uma autoridade médica o emitiu é um motivo racional para se crer, entretanto, é racional no sentido fraco do termo. Essas diferenças entre as espécies de motivos racionais serão analisadas posteriormente, quando investigarmos as diferenças entre os tipos de nexos entre uma vivência e outra, que podem ser nexos necessários ou adequadamente evidentes.

Se eu lembrar duas vezes da convicção, isto é, se eu me lembrar dela agora e daqui duas horas, ou daqui trinta dias, ela será a mesma convicção. Mas a identidade da convicção não é uma identidade ideal, como o é no caso da uma proposição. Se eu penso em uma proposição agora e daqui trinta dias, a proposição também será a mesma, mas ela será a mesma em virtude do fato de que a proposição é um objeto ideal, já a identidade da convicção não é dada pela idealidade do juízo, que tem o caráter objetivo. A convicção é a mesma apenas enquanto meu posicionamento for o mesmo.

A globalidade de nossas opiniões intencionais me singulariza. Cada "eu" possui diferentes propriedades, diferentes posicionamentos e diferentes convicções.

Aqui não se trata do estatuto, em qualquer lugar idêntico, da convicção enquanto unidade ideal, mas sim do estatuto enquanto idêntica para o sujeito, em quanto qualquer coisa que lhe é próprio, que ele adquiriu através de atos precedentes, mas que não ultrapassa o conjunto desses atos, e é inerente ao sujeito que dura como qualquer coisa, durando, permanece para ele. (2008, p.553, tradução nossa)

A convicção instaurada, portanto, nasce no fluxo e é constituída no fluxo em virtude de certos motivos. A convicção possui o caráter tético, ela implica em uma crença ${ }^{237}$.

\footnotetext{
${ }^{237}$ Contudo, se o tempo passa, pode ocorrer a seguinte situação. Posso lembrar-me da convicção sem me lembre nem de quando ela foi instaura e nem dos motivos que me levaram àquela convicção.
} 


\subsection{As experiências concordantes e o sentido do real}

Para Husserl, a consciência é o ser primeiro e, se ela entende determinados objetos como sendo reais, é porque os objetos se mostram dentro de determinados padrões que levam a consciência o ato dóxico os "põe" como reais, quando a consciência posiciona-se perante um noema de modo a crer em sua realidade, essa crença nunca é dada de modo apodíctico, mas sempre por evidências adequadas, ou seja por uma sucessão de experiências que podem concordar com o sentido prévio ou riscá-lo.

Por outro lado, todo o mundo espaço-temporal, no qual o homem e o eu humano se incluem como realidades individuais subordinadas, é, segundo seu sentido, mero ser intencional, portanto, tal que tem o sentido meramente secundário, relativo, de um ser para a consciência. Ele é um ser de que a consciência põe a existência em suas experiências, que por princípio só é intuível e determinável como o idêntico de multiplicidades de aparições motivadas de modo coerente - mas, além disso, um nada. (HUSSERL, 2006, p.116)

O mundo é o idêntico de multiplicidades de aparições, que, em virtude de experiências concordantes, me motivam considerá-lo real.

Como a fenomenologia se propõe ser uma ciência absolutamente fundamentada, não podemos simplesmente considerar o mundo como real apenas porque isso é muito evidente. Certo, trata-se de algo evidente. Mas quais são estas evidências? Quais os atos intuitivos pelos quais eu constituí o sentido de "ser real". Para que um objeto que se manifesta seja considerado real é necessário que o objeto se manifeste à consciência em modos determinados. Ou seja, em "evidências concordantes ou experiências concordantes.

É o conceito de experiências concordantes que está a chave para a compreensão do sentido do real. Para ilustrar essas evidências concordantes, partamos do seguinte exemplo.

Estou escutando, por exemplo, uma música. Creio que mú sica vem do rádio e creio que se trata de uma música real. Depois de um determinado tempo percebo que a música que escuto não vem do rádio. Como sei que a música não vem do rádio? Sei pois ponho a mão no rádio para ver se ele está vibrando e nada. E, além disso, percebo que o cabo de energia não está na tomada. Tampo os ouvidos e, mesmo assim, a música continua com o mesmo volume. Algo é absolutamente certo, não posso duvidar que eu "escuto" uma música. Tento cantar interiormente outra música para ver se a música sai da minha mente e nada. Refletindo, estou plenamente seguro que tenho uma vivência intencional, percepção de um som, de uma música. Entretanto, creio que eu estou alucinando. Em outras palavras, nem minha percepção é real nem a música terá, para mim, o sentido de uma música real. Contudo, o que é 
indubitável é que "algo" se mostra para mim como sendo uma música e como sendo som, embora, me posicione perante o fenômeno como sendo uma ilusão.

O ponto central é o seguinte: eu sei que posiciono-me perante ao fenômeno como sendo uma alucinação de um som porque o modo de doação do fenômeno sonoro não corresponde ao modo de doação daquilo que chamamos som real. Para que o som que eu escuto tenha o sentido de ser "real" é necessária uma concordância de vários níveis de experiência:

1) com o afastar-se da fonte sonora deveria diminuir a intensidade do som que eu escuto;

2) a fonte sonora deveria vibrar. Se o volume estiver alto, meu corpo deveria vibrar.

3) Posso usar um gravador e, em seguida, dar play para se ele gravou o som que havia escutado. Mas, além disso, posso também perguntar para a pessoa ao lado se ela está também escutando o som.

4) Para que seja real, a pessoa que está do meu lado (que não seja surda) também deve escutá-lo.

O noema é correlato da consciência. E para alguns correlatos de consciência, a nossa consciência dá o sentido de coisa "independente da consciência", devido às experiências concordantes. As experiências podem concordar ou negar o sentido implicado naquilo que se manifesta. Se as experiências vão concordando com o sentido prévio, o sentido da coisa vai se "fortalecendo". Por outro lado, as experiências podem riscá-lo. Percebo uma xícara com café em cima da mesa, "automaticamente, a xícara vem percebida como coisa real, o que implica que faz parte do seu sentido, o fato de que eu poderia pegá-la e que poderia ser vista por outras pessoas. Se eu levo a minha mão até a xícara e a pego, sentindo em minhas mãos a sua solidez, o sentido "preconcebido" se confirma numa experiência concordante. E se levo o café a até a boca e bebo, sinto agora o gosto amargo do café, o que constitui mais uma experiência concordante. Contudo, se, ao pegar a xícara, minha mão a atravessasse, consideraria uma ilusão visual de uma xícara de café. "Uma xícara de café irreal”, pois as experiências concordantes refutariam o modo de aparição prescrito pelo sentido: "xícara real".

A consciência considerada em sua pureza é uma conexão fechada em si mesma e nada de real e material pode penetrá-la. Husserl afirma, de fato, que o mundo da res transcendente está inteiramente referido à consciência. Essa afirmação, que contém o sentido do idealismo husserliano, segundo Costa não significa:

(...) que o mundo exista dentro da consciência, nem que esse seja simplesmente minha representação subjetiva ou que não exista em si. Essa frase alude ao fato que tudo do que faz sentido falar entra no nosso campo de experiência possível, que tudo aquilo que é ser o é enquanto se anuncia em 
contexto fenomênico, e que não há sentido falar de ser onde não há manifestação ou possibilidade alguma de manifestação.

Assim, a mesa que me está diante não é um mero produto mental, ou uma ilusão subjetiva. E todavia, se eu digo que ela existe em si e que, na sua objetividade, é irredutível aos meus atos de consciência, esta posição de realidade possui sentido apenas na medida em que, na minha experiência, existem razões que me sugerem esta posição de existência, (...) (2010, p.35)

Já observamos que uma dessas razões que levam a colocação de mundo real em si, pela consciência, é o fato de que temos experiências concordantes. Aquilo que é pura expectativa quase sempre se confirma dentro de um sentido prévio. Toda vez que eu abro a geladeira, vejo as prateleiras. Isso me leva a confiar que toda vez que abrir a geladeira eu encontrarei as prateleiras.

Então, poderíamos dizer que átomos, neurônios, ondas eletromagnéticas, tudo isso só adquire sentido em virtude da consciência, já que a consciência é o ser absoluto, ao qual tudo está referido? O real é contigente? Não se trata de uma inversão do "bom senso"? Afinal, se destruirmos o cérebro, a consciência não seria destruída?

De fato, experiências concordantes me levam a crer que a unidade de sentido "meu cérebro real", pelo seu sentido, uma vez destruído ou parcialmente destruído, implicaria problemas em meu fluxo de consciência. Mas o ponto é que os conceitos científicos não caem do céu, todos os conceitos físicos, químicos e todos os objetos do mundo estão referidos a uma consciência. Lógico que a consciência uma vez que chega a esses conceitos e objetos tende a considerá-los como algo "em si”" em virtude de suas motivações racionais. Mas sem essas experiências e essas motivações racionais, não haveria, para a consciência científica, tais objetos, os quais estão, portanto, em referência à consciência. Em virtude dessa interconexão essencial, tudo aquilo que possui o sentido de ser em si e ser real é também para a consciência. Por isso, Husserl afirma "todas as unidades reais são unidades de sentido" (2006, p.129). E uma realidade em si, absolutamente fora de qualquer relação possível com a consciência, é tão lógico quanto um quadrado redondo. E isso não significa que o fato de todo objeto estar em referência à consciência implique, segundo Husserl, que a "ordo et connexio rerum tivesse que se orientar pela ordo e connexio idearum" (2006, p.117). De fato, o suporte pelo qual os objetos visíveis são constituídos encontra-se nas sensações, sobre as quais o nous exerce sua função de animar esses dados, obtendo assim, os sentido objetuais. Os dados sensíveis limitam as possibilidades noéticas. Posso confundir um homem com um manequim, mas dificilmente o confundiria com uma moeda de ouro. A constituição dos objetos materiais e, de modo geral, do mundo, tem origem na ação do nous sobre a matéria prima dos dados sensíveis. Por isso, a percepção é o ato cognitivo fundante. Mas essa matéria prima não se 
resume à matéria sensível, há também o que Husserl denomina sensações de sentimento, a fome, a sede, as pulsões sexuais, as dores corporais. Elas também fornecem a matéria prima para atos intencionais. Sinto fome de alguma coisa, a dor é "dor de uma espinha de peixe atravessada na garganta". O desejo é desejo por alguém.

Essa discussão sobre o sentido do ser real para mim trata-se de uma etapa fundamental para os capítulos seguintes, nos quais iremos tratar a "essência do eu real". Os estudos não mais se concentrarão no eu puro, mas no eu da pessoa real, dotada de uma psique real. A questão, portanto, será: quais as evidências adequadas e concordantes sem as quais não haveria a noção de psique real? Para que um eu seja, basta que ele viva as vivências. Mas é preciso mais do que isto para que seja um eu real. Do mesmo modo, como já observamos, o simples fato de escutar um som já me dá a certeza de que escuto um som, mas para que este som que escuto seja real, é preciso que ele seja dado em evidências concordantes. 


\subsection{Ontologia regional da psique}

\subsubsection{A psique é real}

Em Ideias para uma fenomenologia pura e para uma filosofia fenomenológica, ou como abreviadamente se diz Ideias 1, Husserl tem como escopo central conhecer a essência da consciência e, para isso, vale-se da reflexão transcendental fenomenológica, que põe a tese de existência real do mundo entre parênteses. Seu objetivo é conhecer a estrutura apodíctica deste ser absoluto: a consciência e as vivências intencionais. Como a consciência, cujo ser, por essência, não pode ser penetrado por um real, pode, ainda assim, ter consciência de um ser “transcendente"? O que é o ser real? Todas essas discussões são feitas partindo do ser absoluto e da evidência apodíctica, indestrutível, que o eu tem de si mesmo. O real é, por essência, contingente, o que não significa nem que ele não seja real, nem que o fenomenólogo o negue. Pelo contrário, Husserl propõe-se a investigá-lo. Em Ideias 2, na segunda sessão do livro, Husserl apresenta a ordem dos temas que ele irá expor:

A nós importa aqui antes de tudo a unidade do eu puro (transcendental), depois a unidade do eu psíquico real, isto é, do sujeito empírico, do sujeito inerente à psique, onde a psique é constituída como uma realidade conexa ou entrelaçada com a realidade do corpo vivo. Uma particular analise será requerida para o corpo vivo; se trata de ver se as suas determinações essenciais sejam simplesmente aquela de uma coisa material particular ou se ele comporta um estrato constitutivo novo, extramaterial, que não possa ainda ser designado de estrato psíquico em sentido pregnante. Sobre o título, que será esclarecido, de "eu-empírico", encontraremos a unidade do "euhomem" aquele eu o qual não apenas se atribui os próprios vividos enquanto estados psíquicos, as suas noções, as suas peculiaridades de caráter e todas as outras características permanentes que se manifestam nos vividos, mas que define "suas" e, portanto, faz entrar na esfera do eu também suas características corporais (HUSSERL, 2008, p.529, tradução nossa)

O que Husserl coloca em questão é: "qual o modo de doação à consciência das unidades de sentido "psique real" e do “corpo real?" " Em sentido amplo, como é constituído intuitivamente o "eu-homem"? Quais são os traços que fazem com que eles se mostrem como reais? Quais são as experiências pelas quais o eu se apercebe como um eu real?

Já se entrevê nestas questões que objetivo de Husserl não é investigar um real em si, um suposto real totalmente irrelacionado da consciência. Já sabemos que isso é contrassenso. Trata-se de dar continuidade ao projeto já elucidado em Ideias 1: em primeiro lugar, investigar o ser da consciência. Em segundo lugar começar a fazer as ontologias regionais. $\mathrm{Na}$ 
segunda sessão de Ideias 2, o foco de Husserl está dirigido para a constituição intuitiva da psique e mais propriamente da pessoa humana.

São etapas metodológicas. Em virtude de Ideias 1 ter sido publicada em 1913 e de Ideias 2 ter permanecido na gaveta até a morte de Husserl 1938 e apenas publicado em 1952, é provável que isso tenha contribuído, em alguns autores, para um má interpretação da obra do pensador, considerando-o um puro idealista, desinteressado no real.

O segundo volume de Ideias é o trabalho de muitas mãos. O primeiro rascunho foi escrito por Husserl em 1912, imediatamente após o manuscrito do primeiro volume de Ideias 1 ter sido completado. Como Husserl afirma, Ideias 2 é a continuação do projeto, a aplicação do método fenomenológico a determinadas regiões ontológicas. Entretanto, é provável que Husserl esteve insatisfeito com os resultados do manuscrito e tenha resolvido corrigi-lo antes de publicá-lo. Em 1915, Husserl retomou o rascunho de 1912 e acrescentou material, deixando aos cuidados de sua assitente Edith Stein, que o havia acompanhado em sua mudança de Gottingen para Freiburg. Stein transcreveu o trabalho de taquigrafia de Husserl em 1916 e, durante os dois anos seguinte, procurou organizar os manuscritos em três partes, intitulando-as como atualmente vem intitulada as sessões da obra. 1)A constituição da natureza material, 2) A constituição da natureza animal, 3) A constituição do mundo espiritual. Entretanto, devido a evolução de seu pensamento, Husserl novamente abstem-se de publiar a obra. Outro assistente, Ludwig Landgrebe, trabalhou no texto durante os anos que vão de 1923-1925. Em 1928, Landgrebe, juntamente com Husserl, editaram a obra, deixandoa pronta para publicação. Entretanto, a obra só foi efetivamente publicada postumamente em 1952.

Interessante notar que Ideias 1 já havia sido polêmica. Muitos dos lógicos que apreciaram as Investigações Lógicas por ela ser uma resposta da lógica ao psicologismo, separando-lhe os domínios, dado que as leis da lógica não eram leis psicológicas, não aceitaram Ideias 1, ao observarem que ele retomava em sua obra o argumento cartesiano, declarando sua filosofia de "transcendental". Aos olhos de muitos críticos, Ideias 1 era uma espécie de paroxismo do subjetivismo, o que parecia contrapor a ideia de ciências objetivas. Entretanto, Husserl havia notado que via transcendental, fundamentada no sujeito, constituía uma espécie de princípio absoluto. Tanto Descartes e antes dele Agostinho já haviam observado que se tratava do argumento decisivo a fim de se provar que existem verdades absolutas, que não podem ser contestadas pelos céticos. Esse é um dos pontos em comum entre os três pensadores: superar o argumento cético, combater o relativismo. Contudo, o que 
pareceu aos críticos é que, partir da subjetividade para se construir uma ciência objetiva que desse suporte às demais ciências objetivas, tratava-se de tarefa impossível. Uma coisa é a subjetividade; outra são as ciências objetivas. Todavia, há um elo que une indissoluvelmente subjetividade e objetividade: a intencionalidade da consciência. Todo objeto é objeto para a consciência e toda consciência é consciência de um objeto. Husserl, ao contrário dos demais pensadores, percebe que a consciência pode ser explorada em sua pureza, sem usar a tese ingênua da existência de um real em si. Por isso, a ideia de fenomenologia pura.

Embora sem o rigor metodológico de Husserl, Agostinho também explora consciência e chega conclusões rigorosas, como a implicação mútua entre inteligência, vontade e memória. Ademais, o bispo de Hipona já havia percebido - tema que Husserl irá aprofundar - que a memória, atenção e expectativa constituem a condição sem a qual não teríamos a noção de temporalidade e duração. Agostinho percebe a distinção entre o tempo cósmico e o tempo do espírito. Só o espírito pode dar sentido ao tempo. Mesmo que não haja essas palavras, as investigações de Agostinho acerca de temas como o tempo, o pensamento, a percepção e tantos outros aspectos do espírito, tem como premissa às vezes oculta ou às vezes explícita que a mente é uma região privilegiada da realidade.

Husserl, por um princípio metodológico, entende a consciência como uma esfera do ser distinta da esfera do real. Agostinho, por seu turno, não distingue. Para Husserl, os objetos são dados à consciência e tiram o seu sentido da consciência, ainda que este sentido seja o sentido de ser real; isso porque todo real é real para o eu. Se nós supomos que o mundo é real e existe "independente" de nós é porque encontramos boas razões para isso, mas estas razões foram tiradas, conscientemente ou inconscientemente, de nós mesmos.

Portanto, a investigação do ser absoluto da consciência é, por razões metodológicas, anterior a exploração das ontologias regionais. Husserl, ao tentar elaborar essas ontologias regionais, diz explicitamente que está investigando o real. Mas não o real em si, mas o real tal qual é possível para a consciência. Nega apenas uma concepção de real enquanto ser absoluto, irrelacionado com a consciência

Sabemos também que só podemos estar seguros de ser real por meio da síntese de confirmação verificadora, a única que nos apresenta a realidade verdadeira. Fica claro que só se pode extrair a noção da verdade ou da realidade verdadeira dos objetos a partir da evidência; é graças apenas a ela que a designação de um objeto como realmente existente, verdadeiro, legitimamente válido - seja qual for sua forma ou espécie - adquire para nós um sentido, e o mesmo se dá em relação a todas as determinações que para nós - lhe pertencem verdadeiramente. Qualquer justificação provém da evidência e, em consequência, encontra sua fonte em nossa própria subjetividade transcendental. (HUSSERL, 2001, p.76) 
Em Ideias 2, Husserl afirma que o real se distingue em duas regiões ontológicas supremas: a do psíquico e a do material. A psique e mais propriamente o sujeito psíquico, não coincide com o eu puro. O eu puro é transcendental. A psique é real e é, em certa medida, transcendente à consciência, pois é algo que se mostra à consciência. Essa ideia, aliás, sempre acompanhou Husserl, por razões, como veremos, muito evidentes ${ }^{238}$.

O eu pessoal, pelo seu sentido, é algo real. Portanto, devemos entender quais são as experiências, as evidências, que levaram ao eu entender-se e aperceber-se como um ser real em um mundo real. Quais experiências sem as quais isso não seria possível? A questão não será, portanto, o que é meu corpo do ponto de vista físico-químico, mas uma questão anterior a essa. Uma condição sem a qual não haveria sequer investigação da química corporal, pois antes de se investigar a composição físico-química do corpo, a consciência deve ter uma noção do que é o corpo. Um homem que não tenha a noção pré-científica do que é um corpo não pode investigar os aspectos físico-químicos de um corpo. Como essa noção pré-reflexiva é constituída intuitivamente e quais as suas condições de possibilidade será o tema das investigações seguintes.

Conhecer as impossibilidades e as possibilidades inerentes ao psíquico é a condição básica para se procurar construir uma ciência de fatos psíquicos. Nada garante, em linha de princípio, que o método causal ou princípios mecânicos sejam adequados à esfera do psíquico. Caso se aplique, devemos entender o como, o porquê, e os eventuais limites de sua aplicação.

Por isso, bem compreendido o sentido de real, fica claro que motivações racionais nos levam a tomar os vividos de consciência não mais como vividos puros, irreais, mas como estados reais de uma psique real. Considerar os vividos como reais não é o resultado de uma evidência apodíctica, mas o resultado de evidências adequadas que nos motivam a assim considerá-los, fundamentando-nos em intuições originalmente doadoras ${ }^{239}$.

\footnotetext{
${ }^{238}$ Mesmo em Meditações Cartesianas, Husserl escreve:

Esse eu e sua vida psíquica, que mantenho necessariamente apesar da epoché, não são uma parte do mundo; e se esse eu diz: "Eu sou, ego cogito", isso não mais quer dizer: "Eu, como esse homem, sou. "Eu" não é mais o homem que se percebe na intuição natural de si considerado como homem natural, nem tampouco o homem que, limitado pela abstração aos dados puros da experiência "interna" e puramente psicológica, capta seu próprio mens sive animus sive intellectus, nem mesmo a alma, ela própria, tomada separadamente. (HUSSERL, 2001, p.42)

${ }^{239}$ Conforme foi citado anteriormente: "só podemos estar seguros de ser real por meio da síntese de confirmação verificadora, a única que nos apresenta a realidade verdadeira. Fica claro que só se pode extrair a noção da verdade ou da realidade verdadeira dos objetos a partir da evidência"
} 


\subsubsection{Os vários sentidos do eu}

A psique possui propriedades reais. Afirmar que a psique possui a propriedades reais, como o olfato apurado, pode ser convertido em se dizer: "eu tenho o olfato apurado". A linguagem cotidiana apresenta certas dificuldades para uma investigação do eu. Isso porque o termo "eu" é usado, de modo geral, para se referir ao eu-homem, em todos seus estratos. Por isso, podemos dizer coisas como: eu peso 85 quilos, eu sinto uma dor no meu pé, eu sou corporal, eu tenho um corpo, o fogo me queimou, eu danço, eu estive doente, eu sou bom de matemática, eu sinto uma tristeza, eu estou triste, etc. $\mathrm{O}$ eu-homem na sua auto-percepção compreende-se como um eu real que tem um corpo, que pensa, que tem impulsos, sentimentos e qualidades:

Cada homem, na "autopercepção" colhe a si mesmo, e assim, conhecendo por experiência um outro homem, colhe este outro homem. Cada um, falando em primeira pessoa, fala dos próprios atos e dos próprios estados nesta forma: "Eu percebo, eu julgo, eu sinto, eu quero" e assim na forma do "eu sou feito assim e assim", fala também de suas características pessoais, das suas disposições de caráter inatas ou adquiridas, das suas capacidades, das suas disposições transitórias ou relativamente permanentes. A mesma coisa vale para os outros. Nós dizemos que alguém é um homem de caráter, é um homem virtuoso, é alegre, melancólico, que tem um temperamento colérico, que está apaixonado, etc. Mas contemporaneamente se diz também que ele dança, que faz ginástica, que come, que escreve cartas, que possui certas faculdades psicofísicas, que é um bom dançarino, um ginasta discreto, do mesmo modo alguém pode dizer: ele é foi golpeado, tocado (...) Nós dizemos que alguém está sujo se tem, por exemplo, os dedos sujos, dizemos que abstêmio, pletórico, fraco de coração, doente do estômago. (HUSSERL, 2008, p.530, tradução nossa)

Em suma, o discurso normal sobre o homem "abraça o inteiro homem, alma e corpo. Por isso se diz: eu não sou o meu corpo, mas tenho um corpo, eu não sou a minha alma, mas tenho uma alma". (HUSSERL, 2008, p.530, tradução nossa). Devemos dizer, portanto, que a unidade do "homem" engloba as duas realidades, psique e corpo, não como duas realidades ligadas exteriormente uma à outra, mas internamente emaranhadas, uma penetrando na outra, ambas presentes no "Eu-homem".

O conceito de psíquico tem prioridade sobre o de corpo. Essa prioridade reside no fato de que o conceito de psique é determinante para o conceito de eu-homem. Em outras palavras, a psique é condição necessária para o eu real. Se a psique vem subtraída de um corpo material, a intuição de "eu real" é cancelada. Um cadáver não é intuído empaticamente como possuindo um "eu" em plena atividade. Não podemos dizer, aliás, que o cadáver possui qualidades psíquicas; seria um contrassenso dizer que o cadáver é bom em cálculo ou que tem 
o olfato apurado ${ }^{240}$, mas não é contrassenso dizer que determinado cadáver tem barbas e veste paletó preto. Se eu digo que "eu sou moreno", esse "ser moreno" é uma propriedade realmaterial do meu corpo. Se eu digo "eu sou uma pessoa melancólica", refiro-me à psique; se eu digo "eu percebo uma mesa", refiro-me ao eu, enquanto polo essencial de todas as vivências reais e possíveis. Contudo, se eu digo "tenho uma percepção real de um homem que me parece real", refiro-me ao meu eu real. O eu-homem, portanto, possui estratos emaranhados uns nos outros ${ }^{241}$.

O eu-homem real pressupõe tanto um corpo material real quanto o eu-psíquico real. Nós nos percebemos assim em experiências concordantes. O homem sem psique não é homem, é cadáver. Contudo, o "eu homem" implica a existência de "eu psíquico" e também de um "eu puro". Isso se revela na linguagem cotidiana pelo fato de dizermos "eu tenho um corpo" e não "sou um corpo" e "eu tenho uma psique" e não "sou uma psique".

A psique, como dissemos, está conexa ao corpo. Depois de uma atividade corpórea pesada posso sentir-me casado. O cansaço não sou eu, é algo que se mostra a mim e que está em mim, o cansaço é o meu cansaço. O cansaço que sinto é algo indubitável, mas que esse cansaço provenha das atividades físicas exercidas pelo meu corpo, isso é dado pelas experiências concordantes, afinal "só podemos estar seguros de ser real por meio da síntese de confirmação verificadora, a única que nos apresenta a realidade verdadeira". E a psique, por ser real, me é dada pelas experiências concordantes. E mais, esse cansaço, o qual é compreendido como um estado psíquico, pode afetar a vida intencional do meu eu. Por exemplo, o cansaço atrapalha minha atividade intelectual, a consciência torna-se mais fraca, os objetos mostram sem muitos realces.

Por outro lado, toda vez que estamos falando de um eu que vive seus vividos, estamos falando do eu puro. $\mathrm{O}$ eu puro enquanto polo dos vividos é algo que não muda, permanece sempre idêntico. Ele é simplesmente o "eu" que vive as vivências, quaisquer que sejam estas

\footnotetext{
${ }^{240}$ Poderíamos dizer aqui, com Aristóteles, que a psique está para o corpo, assim como a visão está para o olho. A visão não se identifica com o olho. A intuição da visão, tal qual se manifesta, se dá de tal forma que os olhos são como puros orifícios, janelas abertas, mas que podem ser fechadas pelas pálpebras. Por outro lado, se giro os olhos tenho sensações localizadas nas órbitas oculares. Por outro lado, tenho dois olhos e uma única visão. Não tenho duas visões, como seria de se esperar de quem tem dois olhos. Não tenho a percepção fenomenológica que são meus olhos que veem, porque ao girar o olho tenho micro-sensações táteis das órbitas oculares, as quais sempre coincidem com o campo visual. Em outras palavras, quem vê sou eu, e não o meu olho. Sei factualmente que sem meus olhos eu não veria, mas fenomenologicamente falando, os olhos são uma espécie de janela por onde o espírito vê o mundo.

${ }^{241}$ Observamos, portanto, que a investigação a respeito do eu é extremamente complexa. Seria por que há uma plurivocidade de sentidos no próprio eu? Na verdade não é uma plurivocidade do significado do eu. Mas uma estratificação do eu. E dentro desta estratificação, existe uma ordem de fundação do eu. De fato, é impensável um eu que seja apenas corpo de um homem vivo normal que não possua um sujeito "dentro" daquele corpo.
} 
vivências e qualquer que seja o conteúdo. De fato, esteja eu triste ou feliz, isso em nada afeta a identidade do eu enquanto sujeito que vive a vivência. Portanto, seja lá qual for o tipo de vivência e o conteúdo desta vivência, o eu, no que se refere estritamente ao fato de viver as vivências é exatamente idêntico, pois não é nada além do que o eu que vive as vivências, seja essas vivências tomadas como vivências reais ou irreais.

\subsubsection{A intuição empática da psique como princípio animador dos corpos}

Ao aplicar o método fenomenológico sobre a psique, o que devemos perguntar é: quais são as experiências fundantes da psique, isto é, como ela é constituída intuitivamente para mim e quais são as condições a priori da psique, condições sem as quais o sentido "psique" seria impossível. É nesse segundo sentido que Husserl, ao investigar a psique, questiona-se se é pensável uma psique sem um corpo vivo. Certo, factualmente sabemos, devido a experiências concordantes e por intuições adequadas, que não é possível, mas trata-se de uma impossibilidade factual ou essencial?

Para sabermos se é uma necessidade de essência que a psique tenha um corpo devemos aplicar o método da redução eidética. Investiguemos, portanto, em nossa livre fantasia se é possível, isto é, se é concebível uma psique sem um corpo vivo material.

Em primeiro lugar, Husserl parte da questão: é concebível um corpo vivo espacial sem materialidade? A resposta apresentada por ele é sim. Com efeito, podemos, por exemplo, imaginar um fantasma. De fato, ninguém negaria que, do ponto de vista da pura possibilidade, um fantasma é algo concebível. Diz respeito simplesmente a algo que seja visto como dotado de forma, extensão, cores, mas que não tenha matéria. O mesmo valeria para um holograma ou para quem vê cinema 3D. Neste último caso ocorre o seguinte fenômeno: o percebido enquanto tal é percebido como algo espacial e dotado de volume, mas não como coisa material. Não importa os processos factuais para se gerar a ilusão de ótica, o que importa é que seja concebível. O fantasma é algo concebível e, por sua essência, o fantasma não deve ser coisa material ${ }^{242}$. Mas o fantasma não é uma alucinação ou ilusão de ótica? Ora, dizer que o fantasma percebido seja uma alucinação implica uma interpretação de ordem factual ${ }^{243}$.

Se um fenômeno dessa espécie ocorresse com alguém, o mais provável é que novos atos intencionais e certos posicionamentos iriam se dirigir ao objeto percebido. Algumas pessoas

\footnotetext{
${ }^{242}$ Toda coisa material se mostra por perfis, mas nem tudo o que se mostra por perfis é coisa material.

${ }^{243}$ Nada garantiria, a priori, que seja uma alucinação. O que importa para o método é simplesmente que é possível fantasiarmo-nos percebendo um corpo imaterial.
} 
tomariam aquilo que aparece como uma "assombração"; o juízo dóxico poderia ser expresso na seguinte proposição: “isso que vejo é uma assombração", talvez alguém da religião espírita o consideraria um "espírito de luz"; um católico talvez julgasse aquilo "um demônio". Um psicólogo poderia ver no fantasma um sinal de que está alucinando e se tornando esquizofrênico. Não importa neste momento que seja possível formular diferentes juízos e posicionamentos a respeito de um objeto percebido. O que interessa é que o fenômeno da percepção de um fantasma é imaginável e, portanto, pertence à esfera do possível. Se pertence à esfera do factual, isso é bem discutível, mas trata-se de uma outra questão muito diversa da que estamos investigando. Um fenomenólogo, ao fazer a redução eidética está tão interessado nas leis de fato quanto um matemático que estuda um espaço de n-dimensões está em saber se esse espaço é real ou não.

Estabelecido a possibilidade do fantasma, podemos encarar a próxima questão: É possível imaginar um fantasma dotado de uma psique? Em outras palavras, é possível imaginar um fantasma que se manifeste de tal forma que pareça possuir uma psique? Sim, o fantasma, por exemplo, mostra-se um fantasma brincalhão e começa a fazer macaquices, intuiremos que ali há uma psique, que ali dentro há um eu. O ser brincalhão é um atributo psíquico, o qual eu atribuo ao fantasma por intuição empática. Dificilmente eu conseguiria atribuir esse predicado a uma pedra. O objeto percebido, o fantasma, caso se mostre como brincalhão é intuído por mim não como uma mera coisa percebida, mas como "fantasma brincalhão", e, portanto, como dotado de uma psique.

$\mathrm{O}$ ato intuitivo empático é fundado no ato perceptivo. Por exemplo, eu colho empaticamente o ser brincalhão do fantasma, percebendo-o. Todavia, o "ser brincalhão" não é algo que pertence ao percebido enquanto percebido, como ser espacial em movimento, dotado de cores, extensão. O fantasma é compreendido por mim como corpo vivo (embora imaterial) justamente porque, por um ato empático, eu colhi um estrato do ser pertencente ao objeto intencional que não é o próprio percebido enquanto tal. Ele é mais do que um "ser visual", é, isto sim, um ser brincalhão. Ser brincalhão não é uma qualidade visual, mas uma qualidade psíquica. Em outros termos, o percebido enquanto tal torna-se o suporte no qual uma nova objetividade intencional é constituída, o corpo vivo. E o corpo vivo tem como necessidade de essência que ele seja corpo vivo animado por uma psique. Que ele seja o corpo vivo de uma psique é algo que intuo empaticamente, pois o corpo vivo é o meio de expressão do ser psíquico. Em outras palavras, se o fantasma fosse absolutamente estático, não o compreenderia como dotado de um corpo imaterial vivo, isto é, como tendo um "eu" ali dentro. 
Não estamos considerando as condições para o fantasma ser brincalhão em si, o que estamos analisando são as condições sem as quais o fantasma não poderia aparentar-se brincalhão. O simples fato de que ele me parece brincalhão já exige um conjunto de condições apriorísticas.

Não basta que o corpo material se movimente para considerá-lo um corpo vivo. Se o fantasma fosse uma espécie de imagem "congelada" girando ao redor do eixo em giro constante, ou em movimentos estereotipados, não me pareceria dotado de vida. Ele deve se movimentar dentro de determinado estilo. Mas não só. Uma outra condição para que eu intua aquilo como um ser dotado de uma psique é que o fantasma se relacione comigo. Eu o afeto e ele me afeta. E não se trata de uma relação mecânica, por exemplo, eu levanto o braço e o fantasma faz determinada careta. O fantasma deve relacionar-se com um certo grau de espontaneidade e imprevisibilidade. E mais, deve haver uma concordância de sentido entre o que eu quero significar com meus gestos e sua resposta, de modo que eu intua que o fantasma entende o que eu quero dizer, entende o meu corpo vivo, percebe-me empaticamente. Trata-se de mais uma condição de possibilidade sem a qual eu não posso vivenciar aquilo como ser psíquico dotado da propriedade "brincalhão". Por outro lado, a psique que eu colho empaticamente como um estrato "interior" do fantasma deve necessariamente estar ligada ao fantasma percebido enquanto tal, de forma que o corpo percebido expressa o psíquico.

Em virtude disso Husserl (2008) afirma "Se o ser psíquico pode ter uma existência objetiva, deve satisfazer as condições de possibilidade de uma doação intersubjetiva" (p.532; tradução nossa). A condição de a psique existir objetivamente é ela se dar, intersubjetivamente: "Para ser objetivamente passível de ser experienciado o espírito deve ser o fator animante de um corpo vivo objetivo (mas não necessariamente, a priori, de um corpo vivo material)". (ibid, p.532; tradução nossa)

Isso não quer dizer que todo corpo vivo, isto é, todo corpo experimentado como corpo vivo, tenha necessariamente uma psique real e que tenha um eu psíquico e consciência. É imaginável uma situação na qual uma pessoa encontrou um androide sem saber que é um androide. Se ele for um androide sofisticado, ele satisfará as condições de possibilidade para que haja a intuição empática, com a qual eu entendo o outro não como mera coisa, mas como um corpo vivo de um sujeito dotado de uma vida mental como eu.

Como já afirmamos, o que Husserl está buscando conhecer são as condições de possibilidade sem as quais uma psique alheia não poderia dar-se, manifestar-se e, portanto, sem as quais não poderia ser intuída. Trata-se de condições necessárias para que eu perceba no outro uma psique, mas não de condições suficientes para que o percebido tenha realmente 
uma psique. O conhecimento dessas condições é importante para conhecermos qual o sentido de "psíquico", isto é, as condições sem as quais a psique alheia não poderia dar-se para mim. Isso não significa dizer que a psique alheia é dada de modo apodíctico, nem mesmo de modo direto. Ademais, por necessidade de essência, a intuição empática deve ser fundada em um ato perceptivo e deve dar-se em uma intuição adequada e não apodíctica. Se a consciência do outro apresentasse diretamente à minha consciência sem nenhuma mediação através do corpo, significaria dizer que o fluxo individual de uma outra pessoa faria parte do meu próprio fluxo de consciência. $\mathrm{O}$ resultado seria uma plena indistinção entre o eu e o outro. Se todas as vivências do outro fossem minhas vivências, significaria que eu teria duas percepções visíveis, terias duas vontades distintas, e com isso, anularíamos justamente, a percepção do outro $^{244}$.

\footnotetext{
${ }^{244}$ No entanto, é possível a priori que o eu puro saia do seu fluxo, esqueça de si mesmo e entre no outro e viva todo o que o outro viveu e tal como o outro viveu, durante, digamos, um dia, e no dia seguinte, ao acordar, tenha em si todas as memórias do passado e as memórias que teve enquanto esteve vivendo tudo identificado com o outro? Tal hipótese é possível.
} 


\subsection{0 corpo}

\subsubsection{O corpo próprio e seu modo de doação à consciência}

Uma coisa é o corpo vivo do outro e como captamos pela intuição empática a psique alheia. Outra questão distinta, mas correlata a essa é: como intuímos o nosso próprio corpo vivo?

Suponhamos o caso de um homem que, subitamente, perca os cinco sentidos, bem como as sensações corporais localizadas. Tal homem estará fechado dentro de si mesmo e terá apenas a sua própria vida de consciência para se relacionar. Mas esse homem poderia ter uma vida psíquica; por exemplo, ele poderia lembrar-se de seu passado, poderia, eventualmente, tentar resolver alguns problemas filosóficos ou matemáticos. Imaginemos que o seu corpo seja alimentado por via intravenosa. O que temos nesse caso são dois seres aparentemente irrelacionados, um espírito sem um "corpo próprio". Contudo, esse eu trancado dentro de si mesmo, pode ter dormido mal, por exemplo. Podemos supor, talvez, que a enfermeira tenha se esquecido de alimentá-lo e que isso tenha gerado a esse homem trancado dentro de si mesmo uma sensação de mal estar, embora talvez ele não tenha muita noção de onde tenha vindo aquele mal estar. O que importa observar é que, podemos formular esse experimento imaginário. Subtraindo todas as sensações ligadas ao corpo, isso não significa que seja anulada a vida de consciência. Entretanto, tal homem não terá a intuição originária de um corpo próprio $^{245}$.

Para analisarmos o corpo próprio, duas questões devem ser feitas. 1) O que me leva a crer que o corpo é meu? Em outras palavras, como se dá a intuição constitutiva do corpo próprio e quais as condições apriorísticas sem as quais não poderia intui-lo. 2) A segunda questão é: $\mathrm{O}$ que leva a consciência a posicionar em relação ao corpo próprio entendendo-o como um corpo real?

Como iremos procurar mostrar: as intuições que levam à constituição do corpo próprio como corpo real provem de experiências concordantes.

Para facilitar essa intuição, podemos pensar no caso do sábio chinês que sonhou que era uma borboleta e, ao acordar, questionou-se se, na verdade, ele não seria uma borboleta sonhando que era um sábio chinês. Partamos da hipótese de que eu sou uma borboleta que estou sonhando que sou um homem. Por mais improvável que seja, o corpo que percebo como

\footnotetext{
${ }^{245}$ Poderia, é verdade, ter um corpo próprio fantasma, tal como ocorre com quem perdeu um braço. Neste caso é possível até mesmo que este homem, tenha, neste nível, um corpo próprio. Contudo, desconsideramos essa possibilidade para facilitar o exemplo.
} 
sendo meu corpo real é algo que pode ser posto em dúvida. No entanto, algo é absolutamente certo. 1) não posso duvidar acerca da existência de um eu cogito, que eu duvido, penso, eu existo enquanto pensamento. 2) Não posso duvidar que possuo dúvidas a respeito da realidade de meu corpo. 3) Também não posso duvidar que eu tenho percepções de um corpo próprio. Mas não tenho certeza absoluta se esse corpo que percebo seja real, pois talvez o meu corpo real seja o da borboleta e não esse, que se manifesta a mim, neste momento.

Em outras palavras, não posso duvidar que tenho vivências perceptivas de um algo que se mostra como sendo "meu corpo", ainda que isto que esteja vivendo neste momento seja um sonho. Se sinto uma dor no pé, posso duvidar se essa dor no pé é uma dor em um "pé real”, ou se é uma dor em um "pé ilusório", mas não posso duvidar que eu, enquanto puro sujeito, sinto aquela dor como sendo uma dor no "pé fenomênico". Não tenho certeza absoluta de que meu corpo seja real ou ilusão. Mas o eu puro e suas vivências e seus objetos intencionais são irremediavelmente algo que é para mim. Nesse sentido, eu, em minha pureza, existo enquanto o puro sujeito das vivências, como puro ser a quem "objetos" se manifestam. Do mesmo modo que eu tenho percepção uma mesa na minha frente, eu tenho a percepção deste meu corpo. Se a mesa que eu percebo pode ser uma ilusão, isso não é menos verdade para meu corpo. Entretanto, posso afirmar que, pelo fato de eu perceber uma mesa, a mesa existe enquanto percebida; do mesmo modo, posso dizer que meu corpo existe, para a minha consciência, enquanto percebido. O percebido enquanto percebido é absolutamente certo. Mas algo deve ser notado, o corpo próprio é percebido de modo distinto do modo como a mesa é percebida. E posso falar da essência do corpo percebido, do corpo intuído.

Tudo isso é dado em evidência apodíctica, mas agora investiguemos as evidências concordantes. Percebo, por evidências concordantes, que esse meu corpo é tão material quanto as demais coisas materiais. Contudo, há algo peculiar no corpo próprio, pois se por um lado, intuições me revelam que meu corpo compartilha com os demais corpos materiais uma essência em comum, por outro lado ele se mostra também de modos distintos das coisas materiais. O corpo próprio se dá por uma dupla doação à consciência, como uma coisa material, mas também se mostra como uma coisa que não é meramente material ${ }^{246}$, porque

\footnotetext{
${ }^{246}$ Ortega y Gasset, a esse respeito, escreve:

Porque o corpo do homem é o único objeto do qual temos uma dupla consciência, formada por notícias de ordem totalmente diversa. $\mathrm{O}$ conhecemos, com efeito, do exterior, como uma árvore, como um cisne, como uma estrela; porém se junta a isso, que cada um percebe o seu corpo do interior, dele tem uma apresentação ou vista interior. (...) Não valeria a pena analisar, descrever com alguma precisão como é para cada um o seu corpo, visto de dentro, qual é a paisagem interna que se oferece? Por enquanto, isto que eu chamei nos meus cursos universitários de intracorpo não possui nem cores, nem forma bem definida, como o extracorpo; não é, com efeito, um objeto visível. Ao contrário, é constituído por sensações de movimento ou táteis das vísceras e dos músculos, das impressões das dilatações e compressões dos vasos sanguíneos, das sutis percepções do sangue
} 
meu corpo, ao contrário das coisas materiais "exteriores" é dado à minha intuição como algo que obedece à minha vontade e que é o suporte de sensações localizadas.

\subsubsection{O corpo como órgão da vontade}

Não posso mover com a força do pensamento uma xícara que está na minha frente. Por mais que eu queira que a xícara se mova, ela permanece parada. Contudo, para eu mover minhas mãos, basta eu querer. Só consigo mover as coisas materiais usando meu corpo.

O papel privilegiado do corpo vivo como campo de localização é o pressuposto das outras caraterísticas particulares do corpo vivo com relação à coisa material, em particular esta: que esse, já tomado como corpo vivo (isto é como aquela coisa que há um estrato de sensações localizadas), é órgão do querer, único objeto que a vontade do meu eu puro pode mover livremente e espontaneamente e que é uma mio para produzir movimento espontâneo e mediato de outras coisas. Por exemplo: a minha mão empurra, agarra, ergue. (HUSSERL, 2008, p.586, tradução nossa).

Se eu perdesse todo o contato com o meu corpo, isso é, se o meu corpo deixasse de obedecer à minha vontade e adquirisse vida própria e independente do meu eu, eu deixaria de considerar aquele corpo o meu corpo $^{247}$. Seria um corpo humano, mas não o meu corpo.

Usemos mais uma vez o método da livre fantasia. Façamos o seguinte experimento imaginário. Neste experimento, passo a imaginar o caso de meu corpo começar a falar coisas que não quero falar, ir a lugares onde não quero ir, isto é, se comportar de modo que eu não quero; em suma o corpo começa agir autonomamente independente de mim. Entretanto, neste experimento, eu compartilharei as sensações ligadas aos cinco sentidos com o corpo.. Passado um tempo, o corpo começa a me envergonhar, a agir de modo reprovável na relação com as outras pessoas. Como compartilho as sensações cromáticas com ele, posso ver a cara de espanto das a cara de espanto e de desaprovação das pessoas, como se elas dissessem pela expressão, “eu não acredito que você está fazendo isso". É possível que, em um primeiro momento, em virtude do hábito, atribua a mim o mau juízo que as pessoas teriam do meu corpo, embora eu não seja responsável. Ficaria, de fato, desesperado, pois não teria como avisá-las que não controlo mais o meu corpo, ou o que julgava ser meu corpo. Depois de um tempo iria me conformar com a situação. Ficaria a meu critério decidir em que campo de sensação eu prestaria mais atenção, por exemplo, se na visão, na audição, etc.

escorrer pelas veias e artérias, das sensações de dor, prazer, etc. (ORTEGA Y GASSET, 1963, p.462, tradução nossa.)

${ }^{247} \mathrm{O}$ filme, eu queria ser John Malkovich ilustra bem essa possibilidade, embora de modo limitado. Nesse filme uma consciência pessoal entra no corpo de John Malkovich e passa a ver o mundo com os olhos de Malkovich, embora não seja capaz de controlá-lo. 
Intuiria empaticamente àquele corpo possuindo um eu que não sou eu; um eu que presta atenção em coisas diferentes de mim. Em determinado momento o corpo está escrevendo uma carta, eu de outro lado, aproveito para escutar a música que vem do quarto ao lado e relaxar um pouco daquela situação desesperadora. Nem prestaria atenção no que aquele corpo está escrevendo, embora, caso queira, pudesse fazê-lo, pois bastaria querer, dirigindo minha atenção para o campo visual. Se fosse eu mesmo a escrever a carta com minhas próprias mãos, deveria necessariamente estar concentrado no ato de escrever ${ }^{248}$.

Com esse experimento imaginário queremos mostrar que ser órgão da vontade é condição apriorística para a constituição intuitiva do corpo próprio. No ato de escrever, por exemplo, o olhar do espírito, embora esteja dirigido ao texto, o corpo próprio está plenamente envolvido. Se o corpo não fosse o órgão da vontade, não haveria o sentido que tem para nós de corpo próprio. O estudo da relação da vontade com o corpo próprio constitui um vasto campo para ser explorado fenomenologicamente, apenas limitamos a mostrá-lo, na medida em que o corpo próprio faz parte da estrutura do ser humano e é dado em evidência.

\subsubsection{O corpo como órgão de sensações localizadas}

No exemplo, anterior, o de um corpo totalmente desobediente, não teríamos como falar de um corpo próprio. Para usar uma metáfora clássica na antiguidade, a alma seria prisioneira de um corpo, ao menos uma prisão com janelas, diferente do caso já observado no qual o homem perde todas as suas sensações. É possível notar que um homem sem propriocepção e sem tato, apenas dotado de visão, tenha não só um corpo ao qual considere seu, como seja capaz de movê-lo, embora necessite olhar para ele para conseguir ${ }^{249}$. O corpo continua sendo o meio pelo qual ele age no mundo material e o órgão da sua vontade. Nesse caso, no entanto, o corpo é tão corpo quanto uma perna mecânica é para quem tem uma.

Mas e se eu estendesse os neurônios sensitivos à perna mecânica? Para uma análise fenomenológica o que interessa é observar como aquela perna percebida até então como

\footnotetext{
${ }^{248}$ Segundo alguns relatos, algo semelhante por acontecer com médiuns. Alguns autores diferenciam médiuns conscientes e médiuns inconscientes. Os médiuns consciente mantém a consciência e observam o corpo possuído pelo espírito.

${ }^{249}$ Existem até mesmo relatos de tais casos. Oliver Sacks(1997) narra a respeito de uma paciente que havia perdido a propriocepção. Oliver Sacks recomenda que ela tente mover seu corpo olhando para ele. Veja-se o relato da mulher: "Então o que devo fazer é usar a visão, usar meus olhos, em toda a situação na qual antes eu usava a propriocepção. Já notei que posso "perder" os meus braços (...) A tal da propriocepção é como os olhos do corpo, o modo como o corpo se vê. E quando ele desaparece, como desapareceu para mim, é como se o corpo estivesse cego. Meu corpo não consegue "enxergar" a si mesmo se perdeu seus olhos, certo? Por isso preciso olhar para ele - ser os olhos do meu corpo, certo?" (SACKS, 1997, p.64)
} 
insensível passará a ser percebida após estendermos os neurônios a ela. A questão que importa, do ponto de vista fenomenológico, é o modo como a consciência vivenciará a operação médica. Devemos, portanto, observar o modo de doação à consciência da "perna mecânica" ${ }^{250}$. Podemos fazê-lo em imaginação, a prestar atenção na minha perna eu a sinto como coisa no espaço. Talvez os cientistas digam que o cérebro e as redes neurais precisam aprender a interpretar aqueles novos sinais neurais. Suponhamos que os neurônios sensitivos que tinham as terminações nervosas na parte de traz da perna passem ser colocados na parte da frente da perna. É de se esperar que a hora que a pessoa tocar na parte da frente da perna, ela sentirá como se alguém estivesse tocando a parte de trás de perna dela. Com o tempo, já que o cérebro é maleável, a pessoa passe a sentir corretamente a perna. Estamos no âmbito do discurso científico. O cientista só saberá se a pessoa passou a interpretar "corretamente" a perna se a pessoa disser. E a pessoa só poderá dizer se ela observar seus estados interiores, isto é, se a pessoa tiver uma vivência concordante da experiência da perna, de tal modo que, ao ver alguém tocando a parte da frente da perna, ela sinta a parte da frente da perna sendo tocada e não a parte de trás. Por mais que o cientista, numa situação ideal, fosse capaz de conhecer cada uma das sinapses, ele não teria como encontrar ali o vivido de consciência, segundo o qual a pessoa sente a parte da frente dela sendo tocada quando ela vê algo tocar a parte da frente da perna dela. Se um homem não for capaz de mover, pela vontade, seus membros, nem falar, o cientista não terá como saber qual a "sensação subjetiva que ela tem", depois de estender os neurônios à sua perna, poderá apenas supor, fundamentando-se em inferências ou outros métodos.

Pela minha visão, eu vejo o meu corpo. Para sermos precisos, só consigo olhar determinadas partes do meu corpo, não consigo, por exemplo, olhar diretamente a minha nuca. Percebo que o foco irradiador da visão está localizado no meu corpo e o meu "ver", para o espírito, ocorre como se existisse uma "abertura" mais ou menos indeterminada na parte frontal da minha cabeça. Vendo o meu corpo, tenho a intuição de que é uma coisa no espaço como outras coisas. Mas, ao contrário das outras coisas, o meu corpo é o centro a partir do qual ocorre a visão. Esse centro da visão está especialmente um pouco acima do nariz. Os dois olhos são uma espécie de "único buraco" através do qual espiamos o mundo. Sabe que se as pálpebras fecharem, a "janela" se fecha. Não vemos com os olhos, do mesmo modo como sentimos com as mãos.

\footnotetext{
${ }^{250}$ A ideia da perna mecânica como exemplo serve apenas para facilitar a imaginação, a questão não é fazer ciência de fato.
} 
Para o eu, o corpo é o aqui absoluto. Esse aqui absoluto, no entanto, não é um ponto. É um "aqui mais ou menos aqui”". Todo meu corpo é razoavelmente o ponto zero. A intuição da espacialidade ocorre também na propriocepção, eu percebo internamente minhas pernas, como localizadas em um sistema de referências espaciais, mesmo com os olhos fechados, percebo que minhas pernas estão abaixo da minha barriga. A propriocepção oferece o corpo por dentro, como coisa no espaço. Já o tato me revela os limites do meu corpo.

É interessante comparar o tato e a visão. Os objetos intuídos, tendo como suporte hilético as sensações táteis, são dados no contato com corpo. Embora saibamos factualmente que a visão ocorre por um encontrar dos raios luminosos no olho, não sentimos nenhum contato, não temos a sensação tátil dos raios luminosos tocando no olho, percebemos as coisas visuais como separadas do corpo, como longe de nós. Com o tato a coisa é diferente: se minha mão toca algo, sinto esse algo com minhas mãos ${ }^{251}$. Sinto simultaneamente o objeto tocado e a mão que toca. Todo mostrar-se das coisas pelo tato, mostra também o corpo próprio.

Encontramos uma notável diferença entre a esfera do visível e a esfera do tátil. No domínio tátil temos o objeto externo que se constitui em modo tátil e um segundo objeto, o corpo vivo, que, por sua vez, se constitui em modo tátil, por exemplo o dedo que apalpa; e temos também o caso no qual um dedo apalpa outro dedo. Temos uma dupla apreensão: a mesma sensação tátil apreendida como característica do objeto "externo" e, de outra parte, como uma sensação do objeto-corpo vivo. (...) Não temos nada de semelhante no caso objeto que se constitui de modo puramente visível.. (2008, p.582, tradução nossa).

Como já observamos a hylé são os dados de sensações. E, para que haja objetualidades, é preciso que a função noética se aplique à hylé, animando os dados de sensação. Mas algo interessante se revela. As sensações cromáticas, quando animadas pela função noética, formam objetualidades que pelo seu sentido, estão separadas do corpo - vejo ao longe um objeto colorido. Mas as sensações táteis pelo seu turno servem de suporte para a função noética de um modo distinto, pois quando o nous se aplica as sensações táteis, os sentidos objetuais exigem o corpo próprio. Podemos imaginar um eu, descarnado, que seja um "puro de vista" sobrevoando a superfície de um rio. Haverá sensações cromáticas e animaríamos essas sensações cromáticas, de modo que perceberíamos objetos. Entretanto, se falamos de sensações táteis, a coisa se distingue, pois a aplicação do nous às sensações cromáticas, só

\footnotetext{
251 , mas se vejo algo, não vejo com meus olhos, vejo através de meus olhos. O percebido visual está "longe”, o tocado está em contato.
} 
ocorre na duplicidade de um objeto que toca e um corpo que é tocado; ou um corpo que toca e um objeto que é tocado ${ }^{252}$..

Por isso, as sensações auditivas e visuais, apenas em segundo plano estão ligadas ao corpo vivo; já as sensações localizadas, as sensações táteis, a dor ${ }^{253}$, as sensações cinéticas ${ }^{254}$ estão ligadas diretamente à constituição do corpo próprio.

Evidentemente todas as análises fenomenológicas do corpo próprio poderiam se seguir em se tornaram cada vez mais complexas. O que nos importa é distinguir os modos de doação dos diferentes estratos da pessoa humana e o que há de apriorístico nestes estratos.

Como pudemos perceber, a constituição intuitiva do corpo próprio está ligada por determinadas classes de vivências intencionais. Não são quaisquer vivências que estão ligadas ao corpo próprio. Sujeito enquanto resolve uma equação matemática vive determinadas vivências que não estão diretamente ligadas ao corpo próprio. Já não é o caso de uma vivência pela qual percebemos a dor no pé, e qualquer outra percepção na qual estão envolvidos dados de sensações localizadas. É preciso notar, entretanto, que o corpo próprio não é dado em uma única vivência, em classes de vivências. Através dessas vivências concordantes o corpo próprio vai se anunciando e se constituindo. Mas como observarmos essa constituição do corpo vivo real pede exige que essas vivências sejam concordantes. Por exemplo, vejo minha mão tocar na mesa e, no instante em que ela toca a mesa, sinto, com minhas mãos a dureza da mesa, motiva-me a crer que minha mão é real. Do mesmo modo, posso sentir dor nos pés, uma dor que parece a dor de um espinho. Em vista disso, examino cuidadosamente meus pés, pela percepção visual, encontro ali um espinho, retiro-o com um pinça e sinto o alívio. Todas essas experiências estão relacionadas com o corpo próprio e, pela concordância, temos o sentido de ter um corpo próprio real. Mas, como no exemplo, atrás discutido, é possível que alguém, que tenha um dos pés amputado, sinta uma coceira no dedão, como ocorre nos membros fantasmas. Neste caso, não há uma síntese concordante de experiências. Determinadas vivências negam o sentido de realidade do dedão do pé. Tal pessoa sabe que tem um dedão do é fenomênico, mas não um dedão no pé real.

\footnotetext{
${ }^{252}$ Há, contudo uma diferença fenomenológica entre ter a mão tocada e a mão tocar algo. Se entrelaço minhas mãos uma com a outra, posso, direcionando adequadamente o olhar do espírito, sentir que a mão direita agarra a esquerda. Mudando o foco da atenção, sinto que a esquerda está agarrando a direita.

${ }^{253}$ Do mesmo modo, podemos falar em dores corporais localizadas. Não sinto simplesmente uma dor, mas sinto uma dor no braço, uma dor nos pés.

${ }^{254}$ A sensação cinética são as sensações que temos ao movimentar o corpo; se eu movo minha mão, não apenas vejo com meus olhos os movimentos de minha mão, mas também sinto dentro de minhas mãos e de meus braços o movimento.
} 


\subsection{A psique}

\subsubsection{Apresentação das investigações sobre a psique}

Vimos nos capítulos anteriores que o corpo próprio se anuncia em determinada classe de vivências e não em qualquer vivência. Do mesmo modo, ao estudarmos a psique, será necessário compreendermos quais as classes de vivências em que a psique se anuncia. Antes de mais nada convém observar que Husserl em Ideias 2 distingue o sujeito psíquico da psique. Entretanto, essa diferenciação é feita por Husserl somente depois de longas discussões. Optamos respeitar a ordem da exposição de Husserl, embora convenha, antes disso, já antecipar brevemente os resultados. A psique está, como vimos, estreitamente relacionada com o corpo material e está ligada fundamentalmente às sensações. Vimos que o corpo próprio se anuncia nas vivências ligadas às sensações localizadas e que é instrumento da vontade. A psique, por seu turno está vinculada a todas as sensações, que constituem os momentos não-intencionais das vivências intencionais; a hylé não carrega objetividade alguma, sem que haja uma apreensão noética. O noema dado no ato perceptivo resulta da aplicação do nous à hylé. No sujeito psíquico encontraremos tanto o eu da vida intencional do sujeito (nous), quanto os dados de sensação (hylé). Não é difícil observar que os dados de sensação possuem uma estreita relação com o corpo material; um aumento da temperatura exagerado gera dor. Há, até mesmo, uma espécie de relação causal entre o corpo material e os dados de sensação. A psicofísica revela bem que existe uma intercorrelação entre a força do estímulo físico e as sensações. Mesmo a sensação de fome e sede está ligada ao corpo material. É preciso ainda observar que não podemos confundir sensação com sentimento. Essa distinção sustenta-se no fato de que alguns sentimentos estão ligados à vida intencional do sujeito. Em Investigações lógicas, Husserl os denomina sentimentos intencionais.

O que importa observar é que existe uma relação causal, que pode ser apreendida em evidências adequadas, entre sensações (vivência não intencional) e materialidade do corpo próprio. Entretanto, a quadro se torna mais complexo quando nos questionamos se uma vivência intencional também é causada. Apenas para citar um exemplo: se a temperatura aumenta para 45 graus célsius, sinto calor. Mas se creio que este corpo que está na minha frente é real, o ato de crer na realidade do corpo é causado? Essa vivência intencional é causada? Como veremos, a vivência intencional não é causada, mas motivada. Essa distinção entre motivação e causalidade será discutida quando analisarmos a vida intencional do eu, isto é, o espírito. 
Em certo sentido, a distinção entre "sujeito psíquico" e "psique" faz lembrar a teoria Aristotélica dos estratos da psyche, na qual vem distinguindo: 1) alma vegetativa; 2) alma sensitiva; 3) intelecto, ou nous. Faz lembrar também a distinção agostiniana entre homem interior, mens (dotada de inteligência, vontade e memória), e o homem exterior, este último ligado aos apetites sensíveis e à anima. Husserl, como veremos, estava consciente dessa semelhança e considera que a antiga doutrina da teoria dos estratos da psique era correta, embora faltasse aos autores o método de investigar esses estratos tomando como base as vivências em que cada um desses estratos se anuncia.

Toda dificuldade da apresentação consiste fundamentalmente no fato de o corpo material estar ligado às sensações, as quais entram nos vividos intencionais, os quais, por seu turno, formam a vida espiritual do eu. Em outras palavras, os três níveis estão imbricados um no outro.

Iremos partir de um conceito amplo de psique para somente depois diferenciar a psique do espírito, lembrando que o sujeito psíquico envolve psique e espírito. E que o eu-homem envolve corpo vivo, corpo material, psique e espírito (e, portanto, sujeito psíquico).

\subsubsection{A psique enquanto realidade substancial-real distinta da natureza material}

O psíquico não é um simples conceito, pois ele é um conceito regional. Sua clarificação circunscreverá uma determinada região do ser. E assim, por necessidade eidética, o que é válido para o psíquico será válido para qualquer um desses objetos dessa região, tal como uma cadeira, que, por ser uma coisa material, terá as qualidades ontológicas de uma coisa material.

O ser real psíquico, assim como o ser real material, é uma substância real, o que significa que o ser real psíquico é um substrato de propriedades reais psíquicas, tal como a coisa material é um substrato de propriedades reais-materiais.

Inicialmente, é preciso demarcar a diferença fundamental entre a região ontológica da psique e a material. A psique é temporal e não-espacial, ao passo que a coisa material é temporal e espacial. Todos os objetos psíquicos, como sentimentos, estados psíquicos e mesmo as qualidades psíquicas têm uma certa duração, mas não ocupam lugar no espaço. Uma paixão que está viva e pulsante, passado algum tempo, se apaga; a boa visão que tenho pode se consumir, minha capacidade de fazer contas de cabeça, passado um tempo sem usá-la, vai se atrofiando; efetuo um pensamento e ele dura um único instante. Certo, é possível dizer que sinto a paixão na região do peito, sinto que a boa visão está nos olhos, mas essa espacialidade não é uma espacialidade tal com é a espacialidade de uma pedra, que se mostra 
por perfis. Basta dizer que uma vivência psíquica não é mais extensa do que a outra; não faz sentido dizer que um sentimento de uma criança, que tem caixa torácica menor, é menor do que o sentimento de um homem de dois metros de altura com uma caixa torácica enorme.

A psique não é o fluxo monádico pertencente ao corpo vivo, nem mesmo nada que seja um momento real do fluxo. É, isto sim, uma unidade relacionada ao fluxo, embora, de certo modo, transcenda o fluxo. A psique é o sujeito dotado de propriedades.

Ela é em referência com os vividos de consciência em modo tal que os possui, os vive e vive nesses; mas estes vividos não são suas propriedades, são simplesmente modos do seu comportamento e seus estados psíquicos. (HUSSERL; 2008, p.559, tradução nossa)

\section{Portanto:}

1) O eu psíquico não é a corrente de vividos, não é a consciência, não é o fluxo de consciência.

2) Vimos anteriormente Husserl afirmar que o eu puro vive as vivências. Agora ele está dizendo que o eu-psíquico vive as vivências. Existiriam dois eus que vivem as vivências? Um eu puro e um eu psíquico? A resposta é negativa; o eu puro é o resíduo do eu-psíquico, quando colocado entre parênteses. Colocamos o eu-homem real na epoché justamente para podermos encontrar a ossatura apodíctica do eu. Uma vez que encontramos o que é indubitável no eu, é preciso explorar as evidências não-apodícticas, isto é, as evidências concordantes, através das quais nós nos apreendemos como um eu real. O que era válido para o eu puro será válido para o sujeito psíquico, com a diferença que o eu psíquico será entendido como um sujeito real que vive estados psíquicos reais, ao passo que o eu puro não é uma parte real do mundo. Por isso, não é de se espantar que Husserl diz que o sujeito psíquico vive as vivências, mas não é suas próprias vivências. Do mesmo modo, o eu puro vive as vivências, está nelas, mas não é as vivências. O eu-psíquico é algo a mais em relação ao eupuro, pois possui propriedades reais.

3) Essas propriedades reais do eu-psíquico se anunciam nas vivências.

4) Como o eu psíquico é real, as vivências intencionais sofrem uma modificação, ou seja, as vivências intencionais serão apercebidas como estados psíquicos reais. Se colocarmos os estados psíquicos entre parênteses, o que encontramos serão vivências transcendentalmente purificadas, que são entendidas, dentro da epoché, como irrealidades puras.

5) Portanto, os estados psíquicos ou as vivências intencionais anunciam as propriedades psíquicas porque elas são modos de se comportar dessas propriedades. 
O eu puro não vai confundido com o eu da pessoa real, com o sujeito de um homem real; o eu puro não tem disposição de caráter, faculdades, disposições originárias ou adquirias, etc. $\mathrm{O}$ eu puro não está em referência mutável com circunstâncias mutáveis, não é dotado de propriedades reais e estados reais, e, portanto não é dado na ordem da manifestação em relação com circunstâncias fenomênicas. (HUSSERL, 2008, p.541, tradução nossa)

Tenho certas evidências adequadas (embora não apodíticas) de que sou mais do que um eu puro, pois tenho propriedades psíquicas, tenho preferências, gostos particulares, capacidades. Dizer que eu tenho um gosto ou uma preferência é dizer algo a mais do que simplesmente "sou um eu que vive as vivências". Dizer que eu tenho uma disposição é dizer algo que se anuncia nas vivências, isto é, nos estados psíquicos. $\mathrm{O}$ eu, apreendido em sua pureza apodíctica, é o puro sujeito que vive as vivências; o eu, apercebido como eu real, além de viver as vivências reais, tem disposições e qualidades psíquicas.

As qualidades psíquicas, como uma disposição de caráter, se anuncia nos estados psíquicos, nas vivências psíquicas. Mas é preciso notar: o estado no qual uma substância se encontra não é a própria substância. A água, por exemplo, pode ter como estado o ser gasoso, ser líquido, o ser sólido. Se água passa de um estado a outro, a água continua sendo a mesma, embora o estado tenha mudado. O mesmo ocorre com o clima. O clima de uma região é algo cujas propriedades reais se revelam na sucessão de seus estados. "Nublado" é um estado no qual o clima se encontra, mas não define a essência do clima. Isso porque, em outro momento, o clima pode estar frio e seco. Entretanto, o clima tem necessariamente um estado atual. $\mathrm{O}$ clima também não é a soma dos estados. O clima de uma dada região possui seus estados em constante mutação e se comporta em seus estados. As propriedades climáticas de uma região se revelam nas sucessões de seus estados. O clima mediterrânico, por exemplo, é tal que nos meses de dezembro e janeiro, usualmente, é frio e chuvoso. Trata-se de um modo determinado do clima mediterrânico se comportar. ${ }^{255}$ De modo semelhante, as propriedades psíquicas se anunciam através das vivências psíquicas, dos estados psíquicos. O meu vício ao fumo se anuncia nas frequentes vivências de desejos de fumar.

Existem, no entanto, diferenças entre o modo de ser do clima e o modo de ser do sujeito psíquico $^{256}$. Na psique, cada uma das vivências atuais, isto é, cada novo estado psíquico, ao

\footnotetext{
${ }^{255}$ Ser mediterrâneo é um acidente da substância clima, assim como ser músico é um acidente da substância homem. Ser músico não define o que é o homem, assim como ser mediterrâneo não define o que é o clima.

256 É interessante notar que Husserl usa uma terminologia aristotélica para descrever a psique e, com as ressalvas, devemos elucidar o sentido Aristotélico, na medida em que isso pode ser útil para a descrição da essência do fenômeno psíquico.

Aristóteles diz que existem três coisas na alma, faculdades, disposições e paixões. A paixão é a atualização de uma faculdade. A faculdade da visão existe mesmo no escuro, mas não é atualizada. Para que seja atualizada é
} 
atualizar uma faculdade, deixa traços, deixa uma marca. Uma pessoa que exercita sua faculdade auditiva, concentrando sua atenção na escuta musical, sempre atualizando sua faculdade auditiva, vai criando e fortalecendo suas disposições e se tornando capaz de perceber, com cada vez mais agudeza, as formas sonoras.

\subsubsection{Necessidade da reflexão para apreensão das propriedades psíquicas}

$\mathrm{O}$ eu psíquico possui faculdades e propriedades psíquicas que se anunciam nas vivências, isto é, nas vivências apercebidas como estados psíquicos reais. O modo como as propriedades psíquicas se anunciam guarda uma certa semelhança como o mostrar-se das coisas materiais. Uma cadeira se manifesta, na percepção, não em um único vivido, mas em uma multiplicidade de vividos de perfil, que se polarizam em torno de um mesmo objeto percebido, a unidade de sentido. As propriedades psíquicas, ao contrário, são conhecidas apenas pela reflexão sobre os estados psíquicos.

Para conhecermos a psique é preciso que voltemos a atenção para as próprias vivências, pois são as vivências que anunciam as propriedades e as qualidades da psique. E de fato, não basta observar um único estado psíquico para conhecer a psique, devemos observar a sucessão de vários estados psíquicos, pois isso é condição para que possamos compreender o modo de se comportar dessa psique. Para conhecermos, por experiência, o clima mediterrâneo é preciso atentar para os vários estados climáticos ao longo do ano; analogamente a psique possui modos de se comportar que só se revelam na sucessão de seus estados. Suas propriedades são transcendentes, não se manifestam elas mesmas. Refletindo tomamos consciência da vivência da ira. Mas essa única vivência não nos diz se somos irascíveis. Apenas a vivência intencional da ira é indubitavelmente dada à consciência, não à própria propriedade psíquica, a irascibilidade. ${ }^{257}$ Uma pessoa pode sentir frequentemente o desejo de comprar isso ou aquilo. Ela tem consciência de seus desejos, mas talvez não se considere dotada da propriedade psíquica "disposição ao consumo".

necessário que haja luz. Contudo, a boa vista é uma disposição. A disposição diz respeito ao modo pelo qual a força da paixão se dá, se ela se dá de modo forte ou fraco. Ser guloso é uma disposição na qual a comida a afeta de modo muito violento a alma. O covarde é aquele que diante de uma situação perigosa sente um medo muito violento. A faculdade da visão atualiza-se tanto no homem com má visão quanto no homem com boa visão, contudo naquele que tem boa visão se diz que o modo pelo qual a função implicada na faculdade de ver atinge um grau maior de perfeição.

${ }^{257}$ Embora no caso, apercebidos como real. 
Se sou uma pessoa gulosa, a gulodice é algo que se anuncia nos estados psíquicos. Sinto a todo instante desejo de comer, mesmo sem fome. Ao refletir sobre esses estados psíquicos frequentes, isto é, sobre o desejo de comer que me surge frequentemente, posso perceber que sou uma pessoa gulosa. Contudo, se não refletisse sobre estes estados e não os notasse que eles aparecem muito constantemente, talvez nem me considerasse guloso ${ }^{258}$. A tendência a sentir desejo de comer, portanto, poderia existir sem que eu percebesse essa tendência. Contudo, a consciência não percebe a própria disposição, o que ela efetivamente percebe é a constância com que emerge à consciência o desejo de comer, mesmo quando não sente fome. Ora, caso a pessoa reflita sobre o seu desejo, ela saberá que seu desejo é dado de modo absoluto, mas o "ser guloso" não. Talvez uma pessoa que quer comer o tempo todo pode julgar que não seja gulosa, mas a cada vez que sente desejo de comer e reflete sobre isso, não pode se enganar sobre o fato de que sente desejo.

\subsubsection{Relação entre propriedades psíquicas e os estados psíquicos}

Husserl define o eu psíquico como um sujeito que é substrato de propriedades. Estas propriedades que se anunciam nos estados psíquicos podem ser qualidades, disposições, estilos, tendências, capacidades etc. Husserl ilustra o que são essas propriedades:

Entre as propriedades psíquicas no sentido que ilustramos, entram todas as propriedades pessoais, o caráter intelectual do homem e todas as disposições intelectuais que ele nutre, o caráter afetivo, o caráter prático, todas as suas faculdades espirituais, as suas habilidades, os seus dotes matemáticos, a sua agudeza lógica, a sua generosidade, a sua abnegação, etc. também os seus sentidos, as disposições que são próprias e que o caracterizam no seu comportamento sensível, as disposições de sua imaginação e similares são propriedades psíquicas.(HUSSERL, 2008, p.560, tradução nossa)

Nessa descrição, o que pode causar um pouco de dificuldade é a distinção entre faculdade e disposição. Por disposição entende-se a maneira como a faculdade está disposta. Nesse sentido a disposição é uma propriedade de uma propriedade. A faculdade psíquica sensível "visão" é uma coisa, mas a "boa vista" é uma disposição desta faculdade. É uma propriedade (boa visão) de uma propriedade (faculdade de ver) da psique. A "boa vista" é uma propriedade que depende da existência de uma faculdade (propriedade).

Husserl (2008) alega que existem propriedades de grau superior que se constituem em propriedades de grau inferior, e nelas se atestam. Usa o seguinte exemplo, para ilustrar: "Para

\footnotetext{
${ }^{258}$ Se estou insatisfeito com o fato de ser obeso e resolvo fazer um regime, a minha tendência de comer muito é mais facilmente apercebida. Isso porque eu estou "policiando" meus desejos e, evidentemente, só posso policiálos eu percebê-los, se eu refleti-los, apreendendo com a atenção.
} 
tomar um exemplo na esfera sensível, a faculdade da vista, que muda segundo as circunstâncias, se anuncia aquela propriedade unitária e mutável que se diz "agudeza da vista" (p.559, tradução nossa). Esse exemplo serve para ilustrar em que sentido as propriedades espirituais se edificam em propriedades sensíveis inferiores.

Mas, como a coisa mesma, também a psique não é outra coisa que a unidade de suas propriedades e cada uma destas propriedades é um mero raio do seu ser. Podemos exprimir tudo isto também no modo seguinte: a psique é a unidade de suas faculdades "espirituais" que se edificam sobre as faculdades sensíveis inferiores (que por sua vez são graduadas), e nada mais. (HUSSERL, 2008, p.559, tradução nossa)

Primeiramente Husserl diz que: 1) a psique é "a unidade de suas propriedades"; 2) usa o termo "disposição" com sentido diverso de "faculdade" e considera a "disposição" pertencente à psique; 3) em seguida diz que a psique são apenas "faculdades espirituais" que se edificam em "faculdades sensíveis". Interpretamos da seguinte forma a passagem: o fato de a psique ser unidade de faculdades espirituais edificadas em faculdades sensíveis não implica que ela não possua outras propriedades, como já vimos anteriormente, como habilidades, disposições, tendências etc. Isso porque todas essas propriedades variáveis de indivíduo para indivíduo estão vinculadas às faculdades sensíveis ou espirituais. Essas propriedades não são as faculdades, mas estão ligadas a estas - são acidentes da substância e não definem o sujeito psíquico.

Dizer que a psique é a unidade das faculdades espirituais edificadas sobre as faculdades sensíveis é dizer aquilo que é essencial ${ }^{259}$. E podemos seguir dizendo que as diferentes faculdades e as disposições se anunciam dentro de determinados grupos de estados psíquicos. A qualidade "paladar apurado" se anuncia pelos vividos de percepção gustativos.

As qualidades disposicionais são propriedades variáveis. O que gera essa variabilidade é que os estados psíquicos exercem um influxo real sobre as disposições, modificando-as. Quanto mais uma pessoa provar vinhos, melhor será o paladar; a psique, assim como o corpo, pode se desenvolver. Aquele que está sempre a resolver problemas matemáticos desenvolve essa capacidade. Aqui, há um ponto importante: o desenvolvimento das faculdades sensíveis implica o mundo exterior; se não existisse mais nenhum tipo de luz no mundo, não poderia exercer minha capacidade visual. Contudo, um homem, mesmo perdendo a faculdade da vista, pode se tornar um grande matemático. Por outro lado, fatores, como a idade, modificam as

\footnotetext{
259 As qualidades podem ser acidentes. Tanto os acidentes (propriedades acidentais), quanto as propriedades essências (faculdades) são propriedades da psique, contudo são os acidentes que particulariza e distingue um homem do outro, uma psique da outra.
} 
prioridades psíquicas. No curso da vida, a acuidade auditiva tende a diminuir à medida que os cabelos brancos vão chegando.

\subsubsection{Dependência da psique do real material}

Até agora só esclarecemos a distinção entre o eu puro (não substancial) e a psique, que é uma realidade-substancial. Falta, no entanto, investigar mais claramente porque a psique é real e qual a relação entre a psique e a matéria. O que há em comum entre a matéria e a psique é que ambas são substâncias reais. Os conceitos de matéria e psique circunscrevem as duas regiões ontológicas do real. Os objetos reais são ou objetos psíquicos ou objetos materiais ${ }^{260}$. Portanto, antes de estudarmos propriamente as diferenças entre psique e matéria, é preciso compreender o que é a substância real.

No nível da generalidade formal o conceito de substância real (concretamente entendida no sentido mais amplo), de propriedade real, de estado real (comportamento real), de causalidade real, são conceitos que vão juntos por essência. Eu digo: causalidade real, porque, dados os estados, somos remetidos às circunstâncias reais, e isto na forma da dependência de um real a um outro real. (HUSSERL, 2008, p.562, tradução nossa)

O que caracteriza um objeto real é uma relação de dependência deste real com outros reais. Em outras palavras, todo objeto real relaciona-se com sua circunstância com algum grau de regularidade. Husserl procura, de fato, especificar melhor o conceito formal de realidade: “(..) a dependência na modificação de um real em suas propriedades depende da modificação de um outro real em suas propriedades" (HUSSERL, 2008, p.562, tradução nossa). Portanto, o conceito de realidade implica o conceito de causalidade e o conceito de dependência. Ser real é estar em uma relação regulamentada com suas circunstâncias. Um ser que não afeta nada, nem é afetado por nada, trata-se de um ser totalmente irrelacionado, não possui o sentido de ser real. Em outras palavras, todo objeto substancial real está em relação causal com outros reais.

Eu digo: causalidade real, porque, dados os estados, somos remetidos às circunstâncias reais, e tal nas formas da dependência de um real a outro real. As realidades são o que são apenas em relação com outras realidades reais ou possíveis, dentro do entrelaçar das causalidades substanciais. (HUSSERL, 2008, p.562, tradução nossa)

Essa é a essência que o ser real tem para a consciência. Se eu imagino um gnomo e não creio na existência de gnomos reais, isso significa, para mim, que o gnomo imaginado não

\footnotetext{
${ }^{260}$ Um campo eletromagnético, neste sentido, é um objeto material. Para que seja material basta que ocupe um lugar no espaço e que se inter-relacione com outros reais.
} 
afetará a natureza real e nem a natureza afetará o gnomo imaginado. Se eu creio que o gnomo é real, creio que o gnomo afete a matéria, afete a natureza, deixe pegadas no solo, produza ruídos, desloque o ar.

E como já observamos, o ser real não é uma propriedade intrínseca ao próprio percebido enquanto percebido. A árvore percebida, entendida apenas enquanto correlato da consciência, enquanto noema, não é confundida com a árvore real. Contudo, um ato posicional pode colocar a árvore percebida como real ou como ilusão. Se eu considero que a árvore percebida é uma ilusão, isso significa que considero que essa árvore não possui dependência causal com os objetos reais. Se minha ilusão de árvore cair na cabeça de um homem real, não afetará esse homem. Mas se considero a árvore real, isso significa que também creio que a árvore pode pegar fogo. A árvore percebida, enquanto noema, é o que se mostra. $\mathrm{O}$ ato posicional que a coloca como ilusão ou como coisa real é um ato de outra espécie. O que importa é observar que o estudo da essência do real é apenas o estudo das condições de possibilidade sem as quais algo não poderia ser real para a consciência.

Ao considerar que o "real é aquilo que depende, de modo regular, de outro real", a impressão é que não obtemos nenhuma resposta. Mas não é o caso, pois a psique adquire o sentido de substância real em virtude de sua relação causal e regulada com o real-material. Essa definição permite estabelecer a ponte entre o real material e a psique. Há, com efeito, uma relação de dependência entre minha psique e meu corpo, bem como uma relação de dependência entre meu corpo e as circunstâncias materiais em torno de meu corpo. Se me aproximo de uma lareira, sinto calor. A sensação de calor está relacionada com modificações na temperatura ambiente.

O que faz com que algo seja real é a relação com outros reais, uma relação funcional de dependência em que haja regularidade. Essa definição implica uma ampliação do conceito de causalidade, de modo que nem toda causalidade é causalidade mecânica. A causalidade mecânica é uma das possibilidades de relação de dependência regular entre um ser real e outro ser real.

Só temos a ganhar com essa ampliação da definição de real, que não exclui espécies possíveis de causalidade real. $\mathrm{O}$ fato de que existe uma dependência funcional e regular de um real a outro, de modo que as mudanças nas propriedades de um real estejam em relação com as mudanças nas propriedades de outro real, não implica na necessidade de que um elo causal 
possa ser descrito matematicamente ${ }^{261}$, embora em alguns casos seja possível. Podemos ter evidências de relações causais e descrevê-las conceitualmente. Pode-se dizer que mesmo no nível pré-científico percebemos elos causais. Existe, segundo Ales Bello, uma diferença entre

causalidade exata, que é a base da ciência física, e aquela pre-científica, que nos é presente no mundo físico. É a este ultimo tipo de causalidade que se pode referir para entender o que ocorre na psique. Se colocamos em paralelo com afirmações comuns do cotidiano: "estou tão cansado que não consigo ler um livro que me exige intelectualmente" e ainda "hoje está tão úmido que não é possível ter uma boa visibilidade", se nota que estas conexões não são determinadas de modo rígido, mas sim vaga, embora exprimindo um tipo de necessidade. (BELLO, 1999, p.13 apud STEIN, 1999)

Uma modificação na umidade do ar modificou a visibilidade, o cansaço do meu corpo real modificou minha capacidade intelectual. Como descrever matematicamente a causalidade existente entre esses reais dados no exemplo, entre o cansaço extremo e a incapacidade de se ler um livro que exige esforço intelectual? É evidente que existe uma relação de dependência entre esses eventos, mas essa relação só pode ser descrita e colhida no âmbito pré-científico (tomando aqui um sentido usual do termo ciência, como ciência exata ou naturalística). Esse gênero de causalidade será melhor observado logo adiante, ao observarmos a relação causal entre psique e o mundo natural.

A extensão do conceito de causalidade não afeta a causalidade tal como entendida pelas ciências naturais, mas abre caminho para a descrição rigorosa de causalidades que estão no plano pré-científico.

\subsubsection{Diferenças entre a substância real psíquica e a substância real material}

Tendo esclarecido o que é o conceito formal ontológico de realidade, o próximo passo é distinguir a diferença entre natureza material e natureza psíquica.

Já observamos que a definição que Husserl propõe de psique é "unidade de suas propriedades". A psique é uma transcendência cujas propriedades se anunciam em vivências que são apercebidas como estados psíquicos reais. Essas propriedades psíquicas são faculdades, disposições, tendências, traços de caráter, estilo etc. Husserl considera que a antiga psicologia tinha razão em se dizer uma psicologia das faculdades. O problema dessas psicologias era que não contavam com um método adequado para investigá-las, pois a

\footnotetext{
${ }^{261}$ Como ocorre no caso de um termômetro de mercúrio, quando a coluna de mercúrio sobe tantos centímetros diz-se que aumentou tantos graus. Há uma relação de dependência entre a temperatura e a coluna de mercúrio e essa relação de dependência pode ser descrita matematicamente.
} 
investigação das propriedades é feita observando cuidadosamente as vivências intencionais através das quais elas se anunciam.

Husserl aponta as seguintes diferenças entre a psique e a coisa material:

1) O estado psíquico, pelo seu sentido, é imanente; o estado da coisa material, pelo seu sentido, é transcendente.

2) A psique, os estados psíquicos e as propriedades psíquicas, por necessidade de essência, estão em constante fluxo, pois cada estado vai alterando as qualidades psíquicas, cada estado deixa traços na própria psique.

Para a psique, junto com a necessidade de mutações de estados, se dá a necessidade de modificações das propriedades psíquicas através das formações de novas disposições: cada vi vido deixa atrás certas disposições e cria uma certa novidade na realidade psíquica. Isso de tal modo que esta realidade se modifica constantemente. ${ }^{262}$ (HUSSERL, 2008, p.568, tradução nossa)

3) Infragmentabilidade da psique.

Alguns corpos materiais podem se fragmentar. Mas psique alguma pode se partir, de modo que teremos duas psiques. Um copo pode se quebrar, desfazendo-se em muitos cacos. Já a psique não pode quebrar, não pode separar-se. Se uma pedra se quebra, teremos duas pedrinhas. A psique, por seu turno, não pode fragmentar-se, pois ela "não conhece pontos, não conhece partes". (HUSSERL, 2008, p.568, tradução nossa)

Não é possível que uma única psique seja fragmentada em duas psiques. Pode ocorrer, no entanto, que o eu psíquico sofra uma brusca modificação em suas propriedades, como ocorre nos casos psicopatológicos de dupla personalidade. Mas isso não quer dizer que ela foi fragmentada, de modo que haverá duas psiques, descoladas e fluindo concomitantemente uma ao lado da outra. Segundo Husserl, no caso de dupla personalidade, quer o indivíduo esteja em uma personalidade, quer na outra, teremos, em todo caso, um único eu, o qual não pode viver simultaneamente dois fluxos de vividos separados. Trocando de personalidade, o sujeito psíquico permanece, ainda assim, vivendo um único fluxo monádico, embora com suas propriedades abruptamente modificadas.

Embora infragmentável, isso não quer dizer que não haja estratos psíquicos, os quais podem coexistir em um único fluxo. Por exemplo, posso ter a sensação de bem estar enquanto

\footnotetext{
${ }^{262}$ Isso não significa, no entanto, que a psique não posa articular-se com outras psiques sob uma forma da constância, subjacente às modificações. Essa forma da constância é inerente ao psíquico e à sua constituição, consiste na forma da comunidade social. Essa forma da comunidade social é fundada na somaticidade.
} 
dirijo o carro e faço uma conta de matemática. O termo "estratos" é cuidadosamente escolhido porque é concebível que os estratos superiores venham a ser subtraídos sem que o eu psíquico deixe de ser o que é. Se eu retiro, por exemplo, o estrato do pensamento teórico, ainda sobra a psique animal. $^{263}$

Portanto, a psique é um fluxo único de estados infragmentável, embora estratificado, nos quais se anunciam as propriedades que estão também em constantes modificações. As propriedades estão em constantes modificações pelo fato de que cada novo estado psíquico inaugura algo, alterando, assim, as propriedades, por exemplo, criando tendências, criando um novo traço de memória, criando uma nova "experiência de vida", desenvolvendo uma disposição etc. As propriedades psíquicas estão em relação tanto com a própria história dos estados psíquicos, quanto com os estados psíquicos atuais.

\section{4) Historicidade da psique}

Fica assim evidenciado que a psique, ao contrário da matéria, possui, segundo Husserl, uma história. O que isso quer dizer? O objeto físico é determinado pelo exterior. É possível que, dadas as mesmas circunstâncias exteriores, um mesmo corpo venha a agir do mesmo modo. Mas isso não ocorre com a psique.

A essência da realidade psíquica implica que por princípio essa não pode tornar ao mesmo e idêntico estado global: a realidade psíquica possui uma história. Dois ciclos limítrofes de circunstâncias externas agiriam do mesmo modo na mesma psique, mas na psique mesma o decurso psíquico dos estados não seria o mesmo, porque o estado precedente determina 0 sucessivo. (HUSSERL, 2008, p.572, tradução nossa)

\subsubsection{Os três níveis de dependência do sujeito psíquico}

Uma vez distinguida a psique da coisa material, podemos observar que a psique possui dois lados: 1) o lado psicofísico (dependência dos reais materiais); 2) o lado idiopsíquico (dependência da história). A esses dois lados, Husserl soma um terceiro, o qual iremos estudar mais adiante: 3 ) o estrato supranatural (dependência intersubjetiva).

1) O lado psicofísico.

O primeiro estrato diz respeito ao fato de a psique depender do corpo vivo e, portanto, da natureza física e das suas numerosas relações. A maior evidência deste estrato é dada pelas

\footnotetext{
263. É concebível que alguém com Alzheimer em estado muito avançado seja incapaz de pensamento teórico, mas ainda assim seja capaz de ver.
} 
sensações; por exemplo, é necessária a luz para que possamos ver; a visão é uma faculdade e possui estados de visão; contudo, a visão depende da natureza da luz etc. Mudando as circunstâncias luminosas ao nosso redor, muda-se a visão. As sensações visuais dependem da natureza física, o que não significa que se reduzem a ela. Em outras palavras, apercebemos intuitivamente, em experiências concordantes, que os dados de sensação estão entremeados por sua ligação com a matéria.

As sensações devem ser entendidas em sentido amplo. Por sensações Husserl também entende as sensações de sentimento e as sensações de instinto ${ }^{264}$. O cansaço, por exemplo, é uma sensação de sentimento, igualmente o prazer de comer uma comida gostosa. Há, portanto, uma relação entre as sensações e o corpo material e entre este último e as circunstâncias materiais. Essas relações de dependências são o que Husserl chama de relações fisiopsíquicas, "o organismo fisiológico investe em todos os processos de consciência".

\title{
2) O lado idiopsíquico
}

Diz respeito à historicidade da consciência, o que implica o fato de que a psique é dependente de si mesma. O estado de consciência, se é verdade que depende do corpo vivo e dos fatores fisiológicos, depende também de circunstâncias internas. Um estado global de consciência depende do estado global de consciência precedente. O modo como um estímulo vem acolhido na consciência é codeterminado pelo estado psíquico atual.

\begin{abstract}
A essência da psique comporta uma contínua reformação e uma contínua replasmação de disposições que vão sobre o título de novas associações, hábitos, memória, além de modificações sensoriais motivadas, modificação motivada das convicções, (disposição ou tomada de posição na ordem do sentimento ou correspondente abstenção), das direções da vontade, que certamente não podem vir reduzidas, para o sentido mesmo das apreensões, à mera associação. (HUSSERL, 2008, p.571, tradução nossa)
\end{abstract}

Se eu estou determinado a terminar um cálculo, o momento em que eu me decidi passa, mas essa vivência influencia o futuro, pois o estado sucessivo pode ser o de empenho e, como consequência, minha atenção volta-se para o cálculo, enquanto os sons que circundam meu espaço e até mesmo a fome não me abalam como me abalariam outras circunstâncias. Se uma vez eu vi uma aranha e senti medo, mas informo-me que aquela aranha não é nociva, é provável que, se eu vir outra vez aquela mesma espécie de aranha, não sinta tanto medo. Um estado de consciência não é totalmente determinado pelo corpo vivo e pelos estímulos materiais provenientes do exterior e que afetam esse corpo, é, isso sim, codeterminado por esses fatores. Isso valeria até mesmo para um animal. A psique de um cachorro não é

\footnotetext{
${ }^{264}$ Nem todo sentimento, entretanto, são sensações de sentimento.
} 
plenamente determinada de modo mecânico pelo exterior, pois é capaz de aprendizado, acumula experiência e age em dadas circunstâncias em correspondência com elas ${ }^{265}$

3) O estrato supranatural: o eu espiritual

Lembremos que Husserl define psique como a unidade de suas faculdades "espirituais" que se edificam sobre as faculdades sensíveis inferiores. Cremos que a psique é um ser real porque evidências concordantes nos levam a crer que mudanças nas propriedades circunstanciais reais-materiais causam alterações psíquicas. Estas alterações são mediadas pelo corpo ${ }^{266}$. Se eu bebo muito álcool sinto-me bêbado. Se fico muito tempo sem comer, sinto fome. Se já passou da hora de dormir, sinto sono. Contudo, essa relação de dependência tem seus limites. O fato de eu beber muito álcool não determina o que eu vou pensar. Sem dúvida que afeta o estilo de pensamento, mas não determina exatamente em que exatamente eu vou pensar. Se eu bebo álcool ou não, se estou cansado ou não, se estou nesta ou naquela situação material, tudo isso pode influenciar o sujeito psíquico e o seu modo de se comportar, mas não determina exatamente no que eu vou pensar ou prestar atenção, isto é, se vou pensar no meu trabalho ou sobre a infinitude do universo. Existe, como veremos, um estrato real da psique que não possui relações causais com os corpos materiais. Certo, para mantermos no método, devemos observar quais são as intuições através das quais tomamos consciência desse estrato, que é o estrato espiritual.

\footnotetext{
${ }^{265}$ A própria noção de condicionamento do behaviorismo deixa entrever esse aspecto histórico, embora tomando apenas no nível corpóreo, olhando apenas o histórico de reforço e punição. Skiner fala de pensamento condicionado. $\mathrm{O}$ pensamento condicionado diz respeito ao fato de quanto maior o número de reforço, maior a probabilidade de alguém fazer o mesmo comportamento. $\mathrm{O}$ reforço gera uma cadeia associativa e uma tendência a emitir o mesmo comportamento. Portanto, mesmo para Skiner, um animal não é determinado pelas circunstâncias imediatas. Não basta saber o conjunto de causalidade exteriores naturais, o conjunto de estímulos dado em um mesmo momento para saber como o animal vai agir, pois os animais possuem aprendizado. $\mathrm{O}$ aprendizado implica em uma modificação nos modos de agir perante a determinados estímulos. Só que cada estímulo gera novos aprendizados, fortalece ou enfraquece uma associação. Dizendo em termos de psique, um estado psíquico depende dos precedentes, assim como a determinação de um comportamento depende dos precedentes. No entanto, o fato de um estado global de consciência depender do precedente e das circunstâncias físicas pode assumir sentidos distintos. Devemos examinar em que nível e como se dá essa relação de um estado psíquico atual com o precedente. o histórico de reforços e punições. Qualquer animal dotado de alguma capacidade de aprendizado é determinado tanto pelo seu passado associativo quanto pelos estímulos materiais. Em outras palavras, o modo como os estímulos irão agir depende do histórico do animal. Em virtude de seu histórico, um cão de Pavlov saliva ao escutar a sineta, um cão no qual não se criou este reflexo condicionado, não.

${ }^{266}$ Devido a esse aspecto de dependência da psique e realidade material, a disciplina psicofísica investiga as relações de dependência entre percepção, intensidade de sensações e os estímulos materiais. Encontram-se, por exemplo, os limiares auditivos, as bandas de frequência visuais, sonoras, etc. A psicofísica não estuda a relação entre estímulos materiais e corpo material. Os raios infravermelhos apesar de não termos uma sensação correspondente, afetam materialmente tanto o olho quanto a pele, ainda que não tenhamos sensações correspondentes. Portanto, nem todo estímulo material que afeta o corpo material afeta o corpo vivo. Isso não impede, sem dúvida, que haja uma relação causal entre psique e mundo material e esta relação seja mediada pelo corpo.
} 
Temos motivos racionais suficientes para crer que um sentimento vital de cansaço é causado por modificações corpóreas. Afirmamos que é "causal” porque há uma dependência regular entre o excesso de atividade física e o sentimento de cansaço; mas se eu estou, além de cansado, pensando em um problema matemático, embora com certa dificuldade em virtude do cansaço, o estado psíquico particular "pensar em matemática" coexiste com o cansaço, mas não é determinado por ele. Seria até de se esperar o contrário, que, em virtude de meu cansaço, eu sinta uma inclinação a dormir ou ir descansar. Mas se tenho uma prova amanhã e preciso ir bem, posso lutar contra meu cansaço e contra minha inclinação de descansar. Se eu quiser entender esse estado psíquico em particular, "o pensar em matemática", que se dá simultaneamente com o estado psíquico de cansaço, devo entrar em uma outra esfera do sujeito psíquico, a região da intencionalidade. O pensar em matemática não é causado pelas sensações que tenho, mas decorre do fato de que sei que tenho uma prova amanhã. $\mathrm{O}$ fato de eu saber que tenho uma "prova amanhã", unido ao fato de eu sentir que seja para mim um valor ir bem na prova, me motiva a estudar matemática, mesmo que eu esteja cansado.

Por essas considerações voltamos à distinção que já outrora havíamos feito, entre nous e hylé. O nous, que é o responsável pela intencionalidade, pela função noética, intencional, e a hylé, os dados de sensação.

Se eu quiser entender porque resolvi ir dormir, é de se esperar que foi pelo meu cansaço. Mas o cansaço nada mais fez do que criar uma tendência: a tendência de ir dormir. Em último caso, a decisão de ceder a essa tendência é minha. Para sermos mais detalhados, seria necessário dizer que do estado vital de cansaço brota um impulso cego, o qual se transforma em uma tendência específica "ir para a cama dormir". Eu me sinto atraído para a cama, para o repouso. Se fosse para escolher, preferiria não sentir cansaço e continuar estudando matemática. Mas se o cansaço me abate de tal modo que começa a se tornar insuportável, pode ocorrer de eu desistir de lutar contra o cansaço e ceder a ele. E assim sigo minha tendência à qual se contrapõe a vontade que tenho de estudar matemática.

Certo, o fato de ser tarde da noite e já ter passado muito tempo da minha hora habitual de dormir causou o sono. Há entre esses dois eventos um nexo causal, uma relação de dependência. Mas o ato de pensar em matemática para ir bem na prova de matemática não é "causado" pelo meu querer ir bem na prova? E a minha vontade de ir bem na prova não é "causada" pelo fato de eu sentir o "ir bem na prova" como um valor? 
$\mathrm{O}$ sujeito psíquico é o eu real dotado de propriedades reais. $\mathrm{O}$ eu real, por viver as vivências, envolve tudo aquilo que havíamos observado do eu puro, os modos de se comportar, as convicções, ser ativo e ser passivo. Os estudos que fizemos sobre o eu puro foram estudos sobre a vida intencional do eu: como ele se posiciona com relação a seus correlatos, como ele constitui intuitivamente os objetos, como ele decide pelo ser real e, ao decidir-se, cria uma convicção, a qual influencia em sua vida intencional. Feito isso, começamos a investigar como o eu constitui-se intuitivamente a si mesmo como eu real e porque o eu posiciona-se a si mesmo como ser real. Começamos então procurar observar como as propriedades psíquicas se anunciam em seus estados e, posteriormente, quais são essas propriedades e, dentre estas, as variáveis e as essenciais que definem a psique. Foi quando observamos a definição proposta por Husserl: "Psique é a unidade de suas faculdades "espirituais" que se edificam sobre as faculdades sensiveis inferiores (que por sua vez são graduadas), e nada mais".

Agora, feito todo o percurso, e já tendo analisado a relação de dependência entre realidade da psique e as realidades materiais, fica claro que o que há de fundamental no nexo de dependência regular entre a realidade psíquica e as realidades materiais é dado fundamentalmente no campo das sensações. Mas já observamos que a hylé não diz respeito à vida intencional do sujeito. As sensações são vividos de consciência, mas esses vividos só adquirem sentido objetivo quando recai sobre eles a função noética. Em outras palavras, as sensações, por si só, não determinam nem o nous nem o noema, as unidades de sentido, embora seja verdade que as sensações limitam as possibilidades noéticas. Já observamos que a hylé é um momento real do vivido, assim como os momentos noéticos, ao passo que o noema não é consciência, mas um polo de identidade sintético para o qual a consciência está voltada.

Esse mesmo esquema nous-hylé está correlacionado com a distinção entre psique e espírito. Trata-se de dois estratos. Um estrato superior que se edifica sobre um estrato inferior.

Os estratos superiores podem ser subtraídos, então a psique muda de gênero, entrando em outro grau, e o caso, por exemplo, da psique constantemente dormente que não realiza nunca um ato do cogito. Ou a psique animal, na qual falta um estrato do pensamento teorético em sentido pregnante, etc. Através da fenomenologia é fácil convencer-se que a antiga doutrina das "partes da alma" e dos gêneros de alma contivessem problemas fenomenológicos efetivos: a fenomenologia permite de fato indagar por via intuitiva as possibilidades essenciais.

De todo modo, a estratificação mais importante se apresenta com a distinção entre psique e sujeito psíquico, este último entendido não como uma realidade, mas como uma realidade que entra na psique, uma realidade não autônoma respeito a essa mas que a abraça, uma unidade que domina 
prevalentemente o discurso comum sobre o sujeito humano e sobre o sujeito animal. (HUSSERL, 2008, p.570, tradução nossa).

Husserl escreve que um ato de consciência, pode ser entendido como um raio de consciência que o eu puro lança a um objeto. Entretanto, este raio pode ser mais forte ou menos forte. Vimos que o sujeito psíquico pode estar em um estado de frescor, ou vigor, quando a luz da consciência está acesa ao máximo; pode ocorrer desta luz estar meio fosca, o eu pode estar agitado, em frenesi, lançando rapidamente raios de consciência, saltando de objeto em objeto; é possível que o eu esteja passivo, quando é tomado, por exemplo, de torpor. Tudo isso observamos em sua descrição do eu puro e diz respeito à vida intencional do eu, a qual não é determinada pelas sensações, mas influenciada por elas. Ter a sensação de fome é uma coisa, mas querer comer algo é intencional. Neste caso, o ato intencional encontra seu suporte na sensação de fome. Mas o ato de querer comer algo não se resume à sensação. Não quererei comer algo que não conheço. A minha vontade de comer terá como objeto algo conhecido, algo a respeito do qual tenha a opinião intencional que é comestível. De todo modo, será um objeto constituído intuitivamente. Mas não só, se sinto fome e decido comer macarrão isso se dá em virtude de que macarrão é o único alimento que eu sei que tenho no meu armário. Mas essa vida intencional também é influenciada pelo corpo e níveis mais difíceis de se identificar. Se a pessoa bebe uma xícara de café o pensamento pode se tornar mais ágil. Isso influencia a vida intencional do eu, mas evidentemente não a determina por completo, pois, como já dissemos em outros exemplos, o café que bebo não determina no que eu vou pensar.

\subsubsection{Distinção entre sujeito psíquico e psique}

Em virtude dessas considerações fica compreensível porque Husserl distingue o sujeito psíquico e psique. Distinção a qual também havíamos evitado de fazer porque não tínhamos como justificá-la até agora. A psique fica entendida como um estrato do sujeito que está entremeado com o corpo vivo real e material e por isso possui uma relação causal com o mundo real material. $\mathrm{O}$ espírito se edifica nas faculdades sensíveis próprias à psique e nos dados de sensação, mas não é a psique. O espírito é o sujeito da vida intencional. Contudo, o espírito não é o eu puro, o espírito possui propriedades reais, se edifica nas faculdades sensíveis e no corpo vivo real. Ser bom em matemática é uma propriedade espiritual real, que se anuncia em determinado grupo de vivências intencionais. 
Podemos colocar da seguinte forma. O eu real é dotado de um corpo material, um corpo vivo, uma psique, um espírito. Esses quatro níveis estão posto em estratos e um exerce influxos sobre os outros, mas um não se reduz ao outro. Correspondem a diferentes modos de doação à consciência. 


\subsection{A vida do espírito}

\subsubsection{Vida intencional do espírito e os campos sensoriais}

Husserl afirma que a vida do espírito é a vida intencional do sujeito. As sensações dizem respeito à psique como um todo, mas não ao espírito. A psique é entremeada com o corpo vivo. Sua vitalidade se manifesta nas sensações, na nitidez das cores e dos sabores, no frescor corporal e mental, mas também na exaustão corporal, nas sensações de fome, no emergir das pulsões sexuais.

$\mathrm{O}$ espírito não tem sensações, mas se edifica sobre elas. $\mathrm{O}$ ato de ler não se confunde com ter sensações cromáticas do livro, mas exige a presença das sensações, sem as quais não haveria nada de concreto para que lêssemos. $\mathrm{O}$ ato de ler exige a percepção e a percepção exige a sensação. Mas são três coisas distintas; é possível ter sensações sem perceber, é possível perceber um livro sem ler, como ocorre com o analfabeto. A função noética caracteriza o espírito. Aliás, Husserl (2006), em Ideias 1, diz en passant que a função noética é do nous.

Aquilo que forma as matérias para vividos intencionais e introduz a
especificidade da intencionalidade é exatamente o mesmo que dá o sentido
específico àquela maneira de falar acerca da consciência, segundo a qual ela
aponta eo ipso para algo de que ela é consciência. (...) Essas noeses
constituem o específico do noûs, no sentido mais amplo da palavra, que nos
remete, segundo todas as suas formas atuais de vida, a cogitationes e vividos
intencionais em geral e, assim, abrange tudo aquilo (e no essencial somente
aquilo) que é pressuposição eidética da ideia de forma. Ao mesmo tempo
não nos é inconveniente que a palavra noûs lembre uma de suas
significações eminentes, a saber, a de "sentido", pois embora a "doação de
sentido" que se efetua nos momentos noéticos abranja diversos aspectos,
somente como fundamento ela é uma "doação de sentido" que se prende ao
conceito forte de sentido. (p.195)

O eu espiritual é aquilo que Descartes denomina cogito. Para Husserl, a estrutura central do cogito é a intencionalidade. Toda consciência, no sentido forte de cogito, é consciência de alguma coisa. O perceber, portanto, pertence ao eu espiritual. E quando percebemos em uma vivência atual, o olhar de nosso espírito está voltado para esse algo, o que não significa que não tenhamos concomitantemente outras vivências intencionais inatuais. Percebo, de modo inatual, muitas outras coisas que estão no campo visual, no halo de fundo da consciência. O eu espiritual tem uma vida intencional e está em sua vida intencional e vive a corrente de cogitationes do cogito. Mas a corrente do cogito está ligada aos dados de sensação. 
Embora tenhamos vários campos de sensações em fluxo, nossa atenção está a cada momento em determinado objeto, concomitantemente em alguns objetos ${ }^{267}$. E mais, podemos fazer atos corpóreos, como, por exemplo, coçar o queixo, ainda que com o olho do espírito dirigido a pensamentos teóricos. A pessoa que assim faz tem uma certa consciência de que está coçando o queixo, bem como de todas as suas sensações corporais, sem estar no modo do “estar com o olhar do espírito dirigido para". Mas isso não significa que esses estratos do sujeito psíquico estejam desvinculados: eles continuam emaranhados. Por exemplo, uma pessoa que esteja imersa em pensamentos metafísicos pode começar a pensar com mais dificuldade e, ainda assim, não se dar conta de que está mais lenta em virtude do seu cansaço, o qual se manifesta pela sensação de cansaço. Em determinado momento, entretanto, ela pode “cair em si" e perceber, com os olhos do espírito, a sensação de cansaço e, em seguida, notar que ela está pensando com maior dificuldade, que já não está num estado de frescor e vigor dos pensamentos. Nada mais dissemos o que já havíamos dito, que a psique influencia na vida do espírito.

\subsubsection{Atitude natural e atitude pessoal}

Para que possamos colher a essência do espírito é preciso elucidar a distinção proposta por Husserl entre duas atitudes ou orientações do eu frente ao mundo: a atitude naturalística e a atitude pessoal. Na atitude naturalística, as coisas perdem seus significados de utilidade, beleza, ressonância emotiva e tornam-se "meras coisas". O mundo naturalístico é um mundo reduzido às qualidades primárias, é um mundo reduzido à matéria. Trata-se de um modo particular de se orientar frente ao mundo, no qual se procura subtrair das coisas os predicados que não são de ordem físico-matemática. Há, nesta atitude, um distanciamento da minha atitude prática e cotidiana com o mundo. Na atitude pessoal, uma música, por exemplo, é algo que possui o predicado belo e valoroso ${ }^{268}$, não é pura e simplesmente uma sucessão de ondas

\footnotetext{
${ }^{267}$ Poderíamos estabelecer ainda aqui um outro nexo entre o olho do espírito e as sensações. Poderíamos dizer que se uma sensação torna-se extremamente violenta essa sensação tende a ser tornar alvo do olhar do espírito, um ato intencional irá recair sobra ela. Por outro lado, podemos ainda observar um outro aspecto. A percepção do mundo constitui-se um voltar para esses campos de sensações, o que não significa que percebamos as sensações, mas objetos coloridos, músicas, a voz de alguém, etc. Mas o pensamento teórico exige uma diferente direção do olhar do espírito, exige uma abstenção do mundo circundante atual. Pois embora vividos inatuais estejam sempre presentes, o olhar do espírito estará voltado, por exemplo, a questões metafísicas.

${ }^{268}$ Podemos construir teorias musicais, com as quais podemos construir algoritmos que um software possa executar. Já ensinaram computadores a compor música, por exemplo, ao estilo de Mozart. A ciência procura prever e dominar. E se ensinarem um computador a compor ao estilo de Mozart. Mas aqui um fato de impõe, um computador é incapaz de ter consciência daquilo como algo dotado de beleza, e será possível ensinar um computador a avaliar a qualidade e o valor estético de suas melodias. Será possível montar um algoritmo
} 
sonoras. Uma panela, na atitude pessoal, não é apenas um pedaço de alumínio com uma determinada forma côncava, é um objeto que comporta ele mesmo o predicado "útil”. Ser útil não é uma propriedade material. O sentido do "ser útil' não pode ser descrito em termos físico-químicos. Um objeto não é, em si, útil, mas o é para uma cultura, para uma sociedade, para uma pessoa. O predicado "utilidade" não existe para um tratamento naturalístico das coisas. De fato, predicados como dureza, os elementos químicos, o formato, tudo isso não diz nada sobre a utilidade. Contudo, não considero o fato de a panela ser "útil" um mero predicado subjetivo, idiossincrático, como se dissesse: "essa panela é um objeto que lembra minha infância". Neste caso, trata-se de um predicado que a panela possui exclusivamente para mim e que não creio que seja compartilhado por toda uma cultura. Mas o que importa notar é que "ser útil" é propriedade objetiva da panela, tão objetiva quanto sua dureza. E mais, o ser útil é um predicado essencial da "panela". Uma panela é panela porque serve para cozinhar. Seu sentido é tão dependente do sentido "cozinhar" quanto o "livro" é dependente do sentido "ler e escrever". Se não existisse o cozinhar, não existiria o sentido "panela". Existiria talvez aquele objeto convexo, duro, feito de metal,; as propriedades materiais do objeto permanecem, o sentido "panela" é extinto. Ou se quiser: o referente se mantém, o sentido não.

O mesmo ocorre com uma simples moeda. Imaginemos o seguinte exemplo: vou a uma cultura distinta da minha e descrevo uma moeda quanto a seus aspectos exteriores. Digo o material de que uma moeda é feita, o peso médio de uma moeda, mostro um exemplar de moeda para essas pessoas. Ensino-lhes posteriormente o nome do objeto "moeda". Assim, estarão aptos a reconhecer uma outra "moeda" e nomeá-la corretamente, de tal modo que, tanto para eles quanto para nós, o nome terá a mesma referência objetiva. Se uma pessoa da tribo encontrar uma moeda no chão, dirá que há uma moeda ali no chão. Embora a relação nome-referente seja idêntica, tanto para as pessoas da minha cultura quanto para essa outra suposta cultura, se eu não expliquei em momento algum a utilidade da moeda, o termo moeda, embora se refira ao mesmo objeto, tem para eles um sentido e significado totalmente diferente do que tem para mim e para minha cultura; em suma, eles não entenderam o que é uma moeda, o sentido, embora tenham o mesmo referente e saibam identificá-la.

Essas essências não são independentes da cultura. Pelo contrário, elas são constituídas intersubjetivamente. Dizer que as propriedades materiais, em virtude de seu sentido, existem

computacional que ensine o computador a fazer uma poesia que tenha como tema o sentido da precariedade da vida humana e sobre a dificuldade de lidar com a transitoriedade dos seres? E mais, a teoria musical é algo que prevê novos estilos musicais ou ela é uma formalização da intuição criadora. Conhecer a teoria musical é condição suficiente para se criar melodias maravilhosas? 
independentemente da cultura é algo de que temos evidências concordantes. A coisa material tem, para a consciência, o sentido de ser em si. O ponto é que dizer que as coisas singulares possuem uma essência não implica que essa essência seja um "em si” boiando num espaço abstrato. Toda essência necessita de um exemplar individual, ainda que esse exemplar seja dado em pura fantasia. Do mesmo modo, a essência "livro" não é algo real que está no mundo das ideias. A essência livro depende da relação entre o sujeito e o objeto, ou, em sentido mais amplo, da relação intersubjetiva da cultura e o objeto cultural. O que faz com que o livro seja livro não são as propriedades materiais do objeto, pois já observamos que o mesmo referente teria um sentido diverso em uma cultura letrada em relação a uma cultura que não sabe ler e não tem notícia da escrita. Para que livros existam é necessário que a cultura tenha constituído aquele sentido e que haja pessoas letradas que compreendam aquele determinado pedaço de matéria como livro. A essência do livro e da moeda só existe intersubjetivamente e essa essência não se resume a seus aspectos materiais. Essas essências só existem para o espírito quando levamos em consideração a atitude pessoal ou personalística.

Alguns sentidos exigem a intersubjetividade; se apenas eu considerasse uma moeda um objeto que possui valor de troca definido, de nada adiantaria e na verdade seria até mesmo um contrassenso, pois o sentido "valor de troca" exige que haja alguém para se trocar e que perceba tal sentido. Por outro lado, não é um capricho subjetivo considerar que tal coisa é um livro, assim como não é idiossincrasia tomar esse pedaço de metal como uma moeda.

A questão aqui é: não é possível entender a pessoa humana sem se levar em conta seu mundo circunstante espiritual, sem se levar em conta as unidades de sentido constituídas intuitivamente e intersubjetivamente. Eu, em minha vida cotidiana, não posso me manter na atitude naturalística, pois a vida humana em sua dimensão espiritual e intencional não pode ser descrita em termos lógico-matemáticos, em termos físico-químicos, em termos materiais. Para descrever uma cultura é necessário o uso de predicados que não se reduzem a predicados “científico-naturalistas". Se uma pessoa está andando pela rua e vê no chão uma moeda e a pega, o ato de pegar a moeda não foi determinado pelas características físicas materiais da moeda, nem pelas sensações cromáticas, mas pelo sentido que aquele objeto tem para a pessoa. Aquela moeda a atraiu não em razão do seu formato e de sua aspereza ou de seus elementos físico-químicos, a atraiu porque é compreendida como sendo um bem, um objeto de valor, e pode ser usada, por exemplo, para comprar um pedaço de pão. Em outras palavras, para entender o ser humano é necessário compreender o seu "mundo circunstante espiritual", o qual é constituído subjetivamente e intersubjetivamente. 
O que está em questão não é a negação das qualidades físico-químicas e qualidades primárias, o que está em questão é que não é possível fazer uma ciência do espírito orientando-nos pela atitude naturalística. $\mathrm{Na}$ atitude naturalística, as coisas perdem seus significados de utilidade, beleza, ressonância emotiva e tornam-se "meras coisas".

Isso porque, do ponto de vista do mundo pessoal, a atitude naturalística é uma abstração operada pelo cientista, de modo a fazer emergir uma natureza, na qual a agradabilidade, a utilidade, a adequação prática, os valores de uso, o ser bom para qualquer coisa são eliminados, tomados como "meras subjetividades". Mas essas "meras subjetividades" escondem todo um mundo, o mundo que o cientista vive. O carvão, por exemplo, é considerado apenas como uma matéria passível de combustão. Mas se quisermos entender o sentido do carvão pela atitude pessoal, o carvão é um objeto de valor, uma commoditie.

A atitude naturalística é, no entanto, uma atitude artificial, porque o cientista, ao deixar de fazer ciência, pega a foto da família, se penteia antes de ir a uma conferência, é membro de uma sociedade de tênis, ambiciona um reconhecimento social. $\mathrm{O}$ mundo circunstante, com o qual ele se relaciona, não é constituído de meros corpos se interconectando causalmente.

Nós deveríamos dizer que somos, em tal atitude natural, objetos físiopsíquicos ao invés de psicofísicos, pois seria mais apropriado à ordem de fundação. O que tem sido dito refere-se tanto aos nossos semelhantes quanto a nós mesmos, na medida em que nós consideramos a nós mesmos teoricamente nesta atitude natural: como corpos animados, objetos da natureza, temas da ciência natural. Mas é uma coisa muito diferente considerar a nós mesmos pela atitude personalística, a atitude na qual nós sempre estamos quando vivemos a vida uns com os outros, conversamos com outros, damos a mão a outras pessoas para cumprimentá-las, ou estamos relacionados uns com os outros no amor e na aversão, na disposição e na ação, nos discursos e na discussão. Do mesmo modo nós estamos nesta atitude quando consideramos as coisas ao redor precisamente como nosso mundo circunstante e não como "objeto" da natureza, isto é, o modo pelo qual são para a ciência natural. (HUSSERL, 2008, p.619. Tradução nossa)

Em outras palavras, a consciência, em seu viver pessoal, tem como correlato um mundo que não se identifica com o mundo enquanto correlato da consciência na atitude naturalística. Olhando o mundo pelos olhos das ciências naturais, o mundo circunstante "torna-se" um mundo exterior "físico-coisal" que emite estímulos ao nosso corpo físico, que é interpretado por um cérebro etc. No entanto, se quisermos colher o sentido e a ontologia regional do espírito, devemos colocar em evidência a atitude na qual essa ontologia aparece. Para chegarmos a essa atitude, não precisamos usar artifício algum, mas apenas entrar em nossa atitude espontânea e natural pela qual o mundo em que vivemos é um mundo no qual não existem apenas seres psicofísicos e coisas, mas também pessoas, obras de arte, paisagens que 
são belas, instrumentos úteis. O mundo circunstante é o nosso mundo, esse mundo em que vivemos cotidianamente, o mundo da vida.

Um incontável número de relações distintas entre sujeito e o mundo circunstante aqui também tem lugar, todas elas enraizadas no fato de que o homem "sabe" sobre ele mesmo e sobre seus colegas e sobre um mundo circunstante comum a todos eles. Este mundo circunstante não compreende apenas meras coisas, mas objetos de uso (roupas, utensílios, armas, ferramentas), obras de arte, produtos literários, instrumentos para atividades religiosas e jurídicas (selos, ornamentos oficiais, insígnias, símbolos eclesiásticos, etc). E está compreendido neste mundo não apenas pessoas individuais, mas sim pessoas enquanto membros de comunidades, membros de unidades pessoais de uma ordem mais alta, (..). Os membros da comunidade, do casamento e das famílias, da classe social, de sindicatos, da vila, etc, conhecem a si mesmos como seus membros, conscientemente percebem que eles são dependes delas, e talvez conscientemente reagem a elas. (HUSSERL, 2008, p.618, tradução nossa).

Se estivermos dirigindo em alta velocidade e formos surpreendidos por um policial, somos imediatamente abatidos no ânimo. E isso não ocorre devido aos estímulos luminosos provenientes do exterior. O aspecto físico aqui só é importante porque, mediante eles, percebemos ali, um "policial" e sabemos o que isso significa, sabemos o sentido. E esse sentido motiva em mim o receio de ser multado. Se quiser respeitar o fenômeno, tal como ele se manifesta à minha consciência, não posso dizer que é uma relação físico-causal. O receio que sinto só ocorre em virtude do sentido do ser policial. Os fótons não me dizem nada a respeito do fato que serei multado.

Esse objeto, "o ser policial", não é um mero ser subjetivo, ele irá nos multar "realmente". Trata-se de um sentido que, compartilhado pela cultura em que vivo, quase todos os membros da cultura sabem identificar. Quase todos sabem reconhecer um policial pelo seu uniforme. Não se trata de negar que o policial que me vem multar tenha um corpo físico, possua um peso, possua órgãos. Contudo, se ele é algo que tem um corpo, tem uma psique, ele também possui como predicado o ser policial. Esse predicado toma seu sentido dentro da atitude pessoal, e se quero analisar esse "sentido" tenho que recorrer à ontologia do espírito e investigá-lo, partindo de uma orientação pessoal. É um tanto descabido procurar o sentido de se saber o que é um policial analisando a estrutura neuronal correspondente. Dificilmente a análise dos complexos neuronais nos quais este "sentido" está contido me dirá tão claramente, quanto eu sei, que vou ser multado.

Todo esse discurso sobre a atitude pessoal é um discurso óbvio. Não precisaria ser reproduzido se não fosse o fato de a ciência da natureza procurar reduzir a dimensão espiritual a ela. Embora óbvia, tem como função delimitar dois campos ontológicos diversos, as 
ciências do espírito e as ciências da natureza. O mundo circunstante e o posicionamento pessoal não constituem o universo da física, mas constituem a nossa vida na sua integralidade. E dessa atitude pessoal podemos nos distanciar apenas por não muito tempo seguido. $\mathrm{O}$ cientista permanece em seu laboratório observando como tudo é feito de energia até às seis da tarde, quando se lembra do compromisso com a namorada, a qual, para ele, não apenas qualidades psicofísicas. Quando ele está com ela, está na sua orientação pessoal.

Para que nós compreendamos uma cultura diversa da nossa ou outro homem é necessário não apenas olhar para o próprio homem, mas tentar compreender o que é o seu mundo circunstante. $\mathrm{O}$ mundo circunstante de cada homem não é o mero mundo exterior “coisal" deste homem, mas é o mundo constituído intuitivamente por ele. É o mundo que existe para ele, tal como ele o vê e o entende. Uma vaca, para um ocidental, tem um sentido muito distinto do modo como uma vaca é vista por alguém que segue a religião hinduísta. Por isso, a compreensão de uma cultura não se resume apenas a compreender a interioridade daquele que vive aquela cultura, implica também em conhecer o sentido do mundo circunstante de quem vive aquela cultura. $\mathrm{O}$ mundo circunstante é constituído em diferentes níveis intuitivos, por intuições de valor, intuições perceptivas, sentidos sociais e experiências individuais com determinada classe de objetos. Tanto para um hindu, quanto para mim, a vaca possui peso e dá leite. Contudo, para quem vive naquela cultura, a vaca simboliza um ser sagrado, ao passo que para mim é um ser cuja carne é gostosa.

Não se compreende o sentido do luto resultante da morte de uma pessoa querida abrindo o cérebro de uma pessoa e procurando ali quais as estruturas cerebrais envolvidas. A questão aqui não é se existe ou não uma correspondência entre a consciência e as estruturas neuronais, o que importa é que a explicação de ordem neurológica em termos de sinapse, neurônios, neurotransmissores entre outros, não colhe o próprio sentido do fenômeno do luto; tal explicação neurológica está falando de "outra coisa", e não da minha experiência de consciência enquanto tal. A existência ontológica desse fenômeno "luto" só existe como correlato do meu eu pessoal. Querer compreender o luto como puro epifenômeno já pressupõe a tese implícita de que o real material transcendente à consciência é o ser absoluto e esta é apenas uma sucessão de ilusões subjetivas. Contudo, nós, por termos um espírito, podemos colher, em certos limites, o sentido da vivência do luto experienciado pelo outro, percebendo o que a atitude puramente naturalística não é capaz de colher: o sentido implicado na morte do amigo e as ressonâncias disso em nosso ser, o sentido da precariedade da vida, da 
inevitabilidade do tempo, a condição de estarmos conscientes de que a morte virá etc. Por isso, viver como pessoa significa colocar a si mesmo como pessoa.

E colocar a si mesmo como pessoa não significa negar que o fluxo de consciência esteja desvinculado do corpo material. Existem de fato relações causais entre psique e mundo físico. Ao ingerirmos álcool perdemos tanto a acuidade visual quanto a vergonha, ao tomarmos antidepressivos, sentimos menos dor psíquica, ou ao tomarmos estimulantes sentimos nossas faculdades intelectuais mais rápidas; ao tomarmos determinadas drogas, sentimos o mundo com uma sensibilidade empática acrescida. Uma coisa é dizer que em determinados casos o nível de seretonina sobe, outra coisa é analisar a experiência mística.

Uma coisa é o cérebro, a química cerebral, outra coisa são os fenômenos espirituais. Que o corpo e a psique afetam o espírito todos sabemos. No entanto, o espírito não se reduz ao psíquico. Seria no mínimo insensível tentar consolar uma pessoa que perdeu um filho dizendo para ela que, na verdade, ela está mal não porque o filho morreu, mas porque o nível de serotonina está baixo ${ }^{269}$, ou dizer que não é motivo para pranto o fato de que os átomos que compunham aquele corpo irão agora se desprender uns dos outros ${ }^{270}$. Alguém que enxergue o mundo por este viés, esse sim está "morto". Mas, o fato é que muitos homens vivem na prática justamente o que negam na teoria. O olho do espírito está aberto ao mundo do sentido, ao mundo circunstante, mas o olho teórico da atitude naturalística está fechado.

Dentro dessa ordem de ideias deve ser sublinhado que "eu", enquanto pessoa, posso ser afetado intencionalmente por objetos que sequer existem realmente. Quem crê em gnomos da floresta será levado a agir, quando na floresta, de um jeito diferente de quem não acredita. Em outras palavras, ao levar em consideração o espírito, aquilo que nos golpeia não são apenas os objetos reais, isto é, meras coisas, mas os objetos intencionais, unidades de sentido e o posicionamento perante essas unidades. E a relação do homem com os objetos intencionais geram ações reais. Uma pessoa que acredita em fantasmas, ao passar uma noite em uma casa de campo, pode ser tomada de medo e terror; ao passo que é de se esperar que alguém que não acredite em fantasmas viva a mesma situação de modo diverso. O que importa observar é que algo "irreal" pode motivar ações reais. Com isso, já se entrevê que, seja real ou não, para quem acredita no Deus cristão, o mundo circunstante será distinto daquele que não crê. A natureza será boa, obra do bem supremo, as ações cruéis serão pecaminosas, as antipatias gratuitas serão combatidas, haverá uma inclinação ao perdão. A verdadeira crença religiosa

\footnotetext{
${ }^{269}$ Mas isso não é verdade? De fato, é bem provável que seja verdade, que baixos níveis de determinados tipos de neurotransmissores estejam ligados à tristeza. Mas investigar a tristeza e descrevê-la e lidar com ela é distinto do modo como descrevemos, lidamos e manipulamos os níveis de neurotransmissores.

${ }^{270}$ Atitude digna de Simão Bacamarte, do conto "O alienista” de Machado de Assis
} 
afeta profundamente a vida intencional do sujeito e o mundo da vida do sujeito. Dentro dessa chave, é possível perceber todo o significado e a força no pensamento de Agostinho quando ele muda do maniqueísmo para o cristianismo. O corpo, que havia o sentido, de ser mal passa a ser tornar bom, porque feito por Deus. O mal, que antes tinha o sentido de ser substância, passa a ser algo do próprio espírito. Mudam-se as experiências, muda-se o mundo da vida, mudam-se os valores e muda-se o modo de se deixar motivar pelo mundo, pelas pessoas. Mudando as motivações, muda-se o modo de agir.

Isso significaria que há um nexo causal entre as unidades de sentidos e a materialidade do corpo? Para sermos exatos não há uma relação causal entre o mundo circunstante e o eu pessoal, a relação aqui é motivacional. O fato de uma pessoa acreditar que a lua seja uma deusa poderá motivá-la à prática de rituais. Mas isso não significa que haja uma determinação necessária e mecânica, entre a crença e a prática.

\subsubsection{Motivação}

Para compreender a vida intencional do espírito, ou seja, o modo de se comportar da atenção, da vontade, da percepção, do pensamento, do pensamento teórico, é preciso levar em consideração não apenas os influxos psíquicos, os quais têm origens causais, mas também as motivações. Portanto, ao analisar o espírito o que está em foco são as vivências intencionais, com seus correlatos, as unidades de sentido, que constituem o mundo circunstante espiritual, dado na orientação pessoal.

Ao tratar a motivação, não se pode pensar em causa, pois causa implica uma dependência regulada entre as modificações nas propriedades de um real e outro real. Um aumento na temperatura aumenta a coluna de mercúrio. Mas a dor da tortura não necessariamente causa a delação ${ }^{271}$.

A motivação diz respeito não à relação entre um real e outro real, mas acerca dos nexos entre um vivido intencional e outro(s) vivido(s). E não há uma relação de dependência regular e necessária entre eles. Percebo a árvore, e em virtude de percebê-la, creio que a árvore exista realmente. A percepção da árvore motivou minha crença na existência da árvore. Poderíamos dizer, portanto, que toda percepção motiva a crença? A resposta é negativa, pois isso não necessariamente ocorre: percebo um gnomo e não creio no que meus olhos veem, penso, por

${ }^{271}$ Ora, do ponto de vista do espírito, o que temos é uma relação entre o eu puro com um objeto intencional, o qual pode ser real ou não. A crença em um fantasma pode me motivar o medo, afetando fisicamente o meu corpo, acelerando o ritmo cardíaco. O meu medo não foi causado por estímulos exteriores; o que motivou o meu medo foi a minha crença. 
exemplo, que estou alucinando. O nexo existente entre o ato perceptivo e o ato da crença não ocorre por um nexo causal ${ }^{272}$.

A respeito da motivação Husserl(2008) escreve as seguintes palavras:

Todos os modos de comportamento espiritual são conectados "causalmente" através de relações motivacionais; por exemplo: eu suponho que A seja, porque sei que B, C... são. Sei que é fugido um leão, sei que o leão é um animal feroz, e portanto tenho medo de sair pela estrada. O servidor encontra seu chefe, e posto que o reconhece, o saúda com deferência. Anotamos sobre a nossa agenda o que devemos fazer amanhã: a consciência de um propósito, conectada com a consciência da nossa tendência ao esquecimento, motiva a nossa anotação. Em todos estes atos está contido o porquê da motivação. (p.665, tradução nossa).

Portanto, toda a nossa vida é atravessada por motivações, as quais muitas vezes passam despercebidas, não notadas. A notícia que me alerta que o leão escapou é juízo que se refere a um estado de coisas. Crer que é verdade o juízo "o leão escapou” é crer no estado de coisas correlativo. E a crença neste estado de coisas motiva o sentimento de medo de sair pelas ruas. Mas como Husserl nota, o medo é despertado porque sei que o leão é um animal perigoso. ${ }^{273}$

O outro exemplo usado por Husserl, ele diz que a consciência da tendência ao esquecimento pode nos motivar à anotação. Podemos distinguir aí o ato motivante e o ato motivado. A consciência da tendência ao esquecimento, somado à consciência de que se trata de um compromisso importante, são atos de consciência motivantes. Já a decisão de escrever na caderneta é motivado. Podemos ir mais longe e dizer que escrever na caderneta foi motivado racionalmente. Trata-se de uma motivação racional porque há, entre os atos motivantes e os atos motivados um nexo de evidência.

Mas é interessante notar que, neste caso, o conhecimento da tendência ao esquecimento é um conhecimento de uma qualidade psíquica a qual a pessoa tem de si mesma em sua unicidade. Para que ela anote, não basta ter a tendência ao esquecimento, mas também o conhecimento de sua tendência ao esquecimento. Não é a tendência ao esquecimento o ato motivante, mas sim o conhecimento da tendência, somando-se a isso o propósito de não esquecer.

\footnotetext{
${ }^{272}$ Sabemos que os cristãos foram obrigados pelo império romano a negar Deus. Alguns deles negaram, outros preferiram não negá-lo e sofrer a tortura. Neste caso, em alguns Cristãos, o ato de crer em Deus unido ao ato de sentir Deus como um valor motivou neles ato de decidir sofrer a tortura. Contudo, a tortura física causou uma dor corpórea e essa dor gera uma tendência espiritual de negar, perante os torturadores, a própria fé. A decisão final de manter-se em silêncio ou ceder à tendência é do próprio sujeito. Neste caso a pessoa tem liberdade para seguir sua motivação ou ceder à tortura. Tem a liberdade de decidir por uma coisa ou por outra.

${ }^{273}$ Alguém que está andando tranquilamente por um parque e encontra uma placa que alerta: "zona infectada por carrapato-estrela" pode não se preocupar com o aviso, caso não saiba acerca da nocividade do carrapato-estrela. Pode até saber que carrapato estrela é um tipo de carrapato e supor que o único perigo é que ele lhe cause coceira. Se soubesse que o carrapato estrela pode transmitir uma doença mortal, é provável que sua reação fosse outra. Enquanto estou nesse nível, estou em minha orientação pessoal ou orientação prática.
} 


\subsubsection{Motivações racionais}

Explorar nossa vida intencional significa perguntar o porquê, a "causa" de um determinado ato intencional. "O que me motivou este meu desejo?", "O que me motivou a minha decisão?", "O que motivou o meu sentimento"?, "O que me motivou à crença no juízo de que eu existo?".

Husserl (2008) distingue dois tipos de motivações a todo e qualquer ato intencional: racionais e as originadas de associações, de hábitos e, de modo amplo, da psique. Ou seja, todo ato intencional pertencente ao meu fluxo terá ou motivos racionais ou motivos psíquicos ou uma mescla de ambos.

Um ato intencional, motivado racionalmente, caracteriza-se pelo fato de que este ato é feito devido a outro(s) ato(s), de modo que o ato motivante exige o ato motivado. Neles há sempre um porquê. O nexo motivacional entre duas vivências não é um nexo causal. Segundo Husserl:

O porque não exprime de fato uma causalidade natural, real. Em quanto sujeito das "premissas das ações", eu não me apreendo em modo realindutivo como causa do eu enquanto sujeito das "conclusões das ações"; em outras palavras, eu, que me decido sobre a base destes e daqueles motivos, não concebo a decisão como efeito natural dos motivos ou dos vividos dos motivos, nem concebo eu mesmo como sujeito de uma decisão promovida pelo eu enquanto sujeito de vivido motivante. (HUSSERL, 2008, p.665, tradução nossa)

Um segundo traço dos atos motivados racionalmente é que, nelas, o eu é ativo. Isso significa que o eu efetua “(...) uma tomada de posição através de outra tomada de posição (tese ativa através de outra tese ativa)(...)"(p.657, Tradução nossa). Por tomada de posição devemos entender o posicionamento do sujeito frente ao objeto intencional. Não é o próprio ato da percepção que me motiva, em alguns casos, a posicionar-me perante o objeto percebido, de tal modo que o tome como real e não como ilusão. Sou "eu" que, em virtude de ter percebido, faço ativamente o ato da crença no objeto. Posto que eu vi tal objeto e ele me mostrou de determinado modo, eu creio. ${ }^{274}$ Justamente por isso, eu não acredito em tudo que

\footnotetext{
${ }^{274}$ Se vejo uma mulher dentro de uma caixa, sendo serrada por um mágico, não creio no que vejo. Não sou constrangido a efetuar o ato da crença. Do mesmo modo, se efetuo a epoché, abstenho-me, por motivos metodológicos racionais, de não tomar como certa a tese de existência do mundo real, independente de minha consciência. Certo, continuarei com minha crença espontânea da atitude natural, contudo, o meu eu filosófico não se colocará sobre o terreno da crença, para poder dar continuidade ao método
} 
vejo. Vejo um cinema 3D e não tomo como realidade material as figuras que saem da tela. Isso porque as experiências concordantes negam a realidade material do objeto visto. ${ }^{275}$

O que caracteriza, portanto, as motivações racionais é o fato de que as experienciamos como ato que eu efetuei em vista de determinadas razões. Por isso, essas motivações racionais podem ser compreendidas como pertencentes à estrutura do "posto $\mathrm{A}, \mathrm{B}, \mathrm{C}$ etc, portanto, $\mathrm{D}, \mathrm{E}$ etc". ${ }^{276}$ Como se vê há, nos atos motivados racionalmente um nexo de evidência. O ato de querer ficar em casa é efetuado porque sei que um leão está andando pelas ruas.

Husserl faz uma distinção entre dois, tipos de racionalidade. A razão plena, quando os nexos motivacionais são absolutamente evidentes; e quando são evidentes, mas não absolutamente evidentes (evidências adequadas).

1) Atos da razão pura: nexos puramente evidentes entre dois vividos intencionais.

O primeiro tipo de atos racionais é aquele do sujeito puramente lógico. Caracteriza-se pelo fato dos nexos entre um ato e outro possuírem o caráter da necessidade. É o caso, por exemplo, do silogismo. "A razão pode ser dita razão pura somente quando é motivada de modo evidente, totalmente evidente". (HUSSERL, 2008, p.657, tradução nossa). Se efetuo o ato " $a=b$ ", em seguida, o ato " $b=c$ ", o ato conclusivo será " $a=c$ ". Nas demonstrações de teoremas, nas provas lógicas, matemáticas e de outros gêneros estamos no âmbito da razão pura, porque os nexos entre os vividos são puramente evidentes. O juízo: “eu existo" é motivado racionalmente pelo juízo "eu duvido". O "eu duvido" motiva racionalmente a crença no juízo "eu penso", e este motiva racionalmente a crença no juízo "eu sou”. Há entre

\footnotetext{
${ }^{275}$ A percepção de um objeto distante pode motivar racionalmente à posicionar perante o objeto intencional no ato da dúvida. Percebo, ao longe, alguém que talvez seja um amigo. Vivo a incerteza, a dúvida se é isso ou é aquilo em determinado. Vejo ao longe alguém que me parece ser um amigo, aproximo-me para confirmar minha percepção; aquela percepção exige novas percepções para que eu confirme o juízo: "aquele lá é meu conhecido". Mas neste caso, a percepção sem nitidez motivou em mim uma tomada de posição na modalidade do possível, a qual vem vivida como dúvida. Em outras palavras, a modalidade da dúvida é motivada racionalmente pelo fato de eu "ver de longe". Em virtude disso, novas motivações podem surgir: por exemplo, decido me aproximar para "ver de perto", a fim de resolver a minha dúvida, confirmando ou negando a tese. A própria probabilidade me motiva: "É bem possível que aquele seja meu amigo e se realmente for quero cumprimentá-lo". Isso é o que me motiva a vontade de aproximar, quero me aproximar para me certificar. $\mathrm{O}$ ato de movimentar o corpo caminhando é fundamentado no ato da vontade. E esta vontade, por sua vez, é fundamentada pelo ato da dúvida e da vontade eliminar a dúvida. Todas essas motivações estão presentes, mas não são necessariamente advertidas, notadas, colocadas como objeto temático.

${ }^{276}$ Nem todo ato motivado racionalmente é da forma do silogismo. Creio em um juízo não apenas porque cria nas premissas, posso crer em um juízo acerca de um estado de coisas porque percebi este estado de coisas. Posso acreditar em um juízo porque outra pessoa me contou que ela viu aquele estado de coisas.
} 
tais atos de juízos um nexo de evidência absolutos. Não é possível que não seja assim. Tratase de nexos absolutamente necessários ${ }^{277}$.

2) Nexos de racionalidade fraca, os quais não são plenamente evidentes.

O segundo tipo são as motivações racionais em que o vivido intencional motivante e o vivido intencional motivado não possuem um nexo de evidência absolutamente necessário. De fato, nem sempre nos movemos no plano da pura evidência. Creio que a lua possui um outro lado, o qual nunca vi. Creio que esse computador é real. Como já observamos é racional considerar o que percebo em evidências concordantes seja algo real, embora o nexo entre o perceber e o tomar como real não seja absolutamente necessário. A crença, em tais casos, é motivada racionalmente. Embora não tenhamos evidência absoluta que as pessoas os pedestres que passam na rua não são androides, seria irracional considerá-las como tal. A crença, em tais casos, é motivada racionalmente. Decido passear em virtude de um desejo muito grande de ir passear, também agi racionalmente. Minha decisão é fundamentada no desejo.

Mas as motivações racionais não terminam aí. também a vida prática do sujeito moral pode se dar dentro de uma estrutura formal racional.

Mas se retenho verdadeiro qualquer coisa, se retenho ética uma exigência, se retenho isto é, que esta exigência emane de fontes adequadas, se abraço livremente a suposta verdade, ao bem ético que tenho em mira, sou racional, mas sou relativamente, posto que em tudo isso posso me enganar. (HUSSERL, 2008, p.657. Tradução nossa)

De fato, o homem pode se enganar, pois talvez não tenha percebido que os seus pressupostos estavam errados. “(...) não apenas aquilo que é necessário pode ser chamado de racional, também as conclusões errôneas vão sobre o título de racionais" (Ibid, p.657, tradução nossa). Um homem do século XVII pode sentir que a vida e a liberdade humana é um valor e, ainda assim, escravizar índios, posto que os julgue simples animais. Caso venha a conhecer pessoalmente um índio e perceba empaticamente que ele também é um homem como ele, o escravizador ou irá libertá-lo ou deve mudar os seus valores, para agir racionalmente.

Para Husserl, existem leis formais racionais do sujeito ético. Dentre estas leis está "fazer de acordo com o que julga melhor". Talvez sinta o desejo de dormir e não ir a um compromisso importantíssimo. Sei que é melhor eu ir no compromisso do que dormir. Seu eu

\footnotetext{
${ }^{277}$ Evidentemente ainda aqui podem ocorrer enganos. Um lógico pode pensar que determinados axiomas são absolutamente evidentes e um outro lógico mostrar que uma evidência de ordem mais alta nega a evidência. Isso ocorre, por exemplo, quando um lógico prova a incompletude ou a inconsistência de determinados axiomas.
} 
agir de acordo com o que considero melhor, agirei racionalmente. Caso ceda à tentação e vá dormir, agirei irracionalmente.

Portanto, mesmo sem levar em consideração quais os valores de uma pessoa, o sujeito ético também age de acordo com uma forma racional. A lei aqui é: todos querem o melhor, mas o que é melhor para essa ou aquela pessoa varia segundo os seus valores. Nesta perspectiva a culpa nada mais é do que trair a si mesmo, trair os próprios valores, advém da consciência que se fez o que era pior. Por isso, nada impede de um homem, que não tenha a honestidade como valor, se sentir culpado, com má consciência pelo fato de ele não ter aceitado um suborno, de modo que ele pensa "teria sido melhor se eu tivesse aceitado o suborno, afinal os riscos eram muito pequenos, eu não fiz a coisa certa, agir da pior forma".

\subsubsection{Motivação como associação e hábito}

Até o momento observamos que, para se entender a vida do espírito, como se dá a corrente de atos intencionais, é preciso, em primeiro lugar, observar "o mundo circunstante" da uma pessoa. Em segundo lugar, observar os nexos motivacionais racionais entre as vivências intencionais. Agora iremos olhar especificamente os vividos intencionais que possuem motivos a-racionais ou irracionais. ${ }^{278}$, dentre os quais as associações e os hábitos.

Além disso, é incluso neste âmbito todo o reino da associação e dos hábitos. Entre a consciência passada e a consciência sucessiva, sempre no âmbito da consciência egológica, se estabelecem certas relações. A motivação age na consciência "atual", isto é, na unidade daquele curso da consciência que se caracteriza como consciência atual do tempo (consciência originária). (HUSSERL, 2008, p.657, tradução nossa)

Investiguemos primeiro como o hábito pode motivar. Se, todas as noites, antes de dormir, tomo um copo de leite, é provável que esta noite antes de dormir, terei o desejo de tomar um copo de leite. Tenho a vontade de tomar o leite e me questiono: "por que tenho essa vontade?", a melhor resposta é: o que "causou" a vontade foi simplesmente meu hábito. Melhor dizendo, assim que encerro as atividades e me preparo para ir à cama, "virá à minha mente" a ideia de tomar leite. Isso ocorre de modo tão automático, que nem preciso parar para pensar no assunto. Simplesmente vou a geladeira e tomo leite. Não é preciso fazer uma "psicanálise" para se compreender essas vivências.

Contudo, outras vivências intencionais do fluxo podem estar ligadas por associações obscuras. Certo dia, escutando uma música, lembro-me de tal pessoa. O "lembrar-se daquela

\footnotetext{
${ }^{278}$ Existem também motivos a-racionais, os estímulos. A esse respeito, ver apêndice F.
} 
pessoa", a reminiscência, não é vivida como um ato realizado pelo eu. $\mathrm{Na}$ expressão quotidiana, essa diferença fenomenológica vem expressa como um "me veio à mente". Neste caso, o "Ato de recordar" não é realizado ativamente pelo eu, como ocorre no ato do "eu concluo", "eu decido". Por exemplo, o ato de tentar recordar o telefone de uma pessoa pode ter sido motivado pelo ato de querer ligar para uma pessoa. Neste caso, há um nexo de evidência entre uma vivência e outra.

Nestes nexos associativos algo deve ser observado. Nem sempre o sujeito egológico percebe conscientemente os nexos através dos quais um ato se conecta a outro ato. Por exemplo, pode acontecer que no momento em que tal pessoa me "vem à mente", eu não apenas saiba dizer por que razão me ocorreu pensar naquela pessoa, como também pode ocorrer de eu nem mesmo coloque a questão: "porque tal pessoa me veio à mente?". Ao colocar essa questão eu estou refletindo sobre a reminiscência. Talvez, ao me colocar a questão sobre o porquê tal pessoa me ocorreu, encontre alguma pista. Lembro, por exemplo, que a música que estou escutando agora na rádio é uma música que agradava muitíssimo aquela pessoa e julgo ter encontrado aí o "nexo secreto". De todo modo, não há, neste caso, uma ligação racional entre o lembrar-se da pessoa e o escutar a música. O nexo é associativo. Entretanto, pode-se somar a associação, motivos psíquicos ocultos:

Neste contexto o vivido singular é então motivado por um fundo obscuro, possui "motivos psíquicos", aos quais se pode interrogar: como me veio na mente essa coisa - que coisa me levou a tal? Que esta pergunta seja possível é um fato que caracteriza qualquer motivação em geral. Os "motivos" são muitas vezes escondidos na profundidade, mas podem vir colocados à luz por meio da "psicanálise". Um pensamento "me recorda" outro pensamento, me chama à memória um vivido passado. Em certos casos este nexo pode até vir a ser percebido. Mas na maior parte dos casos, embora a motivação esteja realmente presente na consciência, não chega a assumir um relevo, não vem notada, è inadvertida ("inconsciente"). (HUSSERL, 2008, p.658, tradução nossa)

A uma classe de vivências intencionais que possui motivos obscuros, psíquicos, difíceis de se compreender. ${ }^{279} \mathrm{~A}$ psicanálise, entendida como ciência de fatos, teria como objetivo, dentro deste quadro, investigar as motivações ocultas desta classe de vivências.

Quando esse nexo é racional temos a evidência do próprio nexo. O fundamento da vivência é dado em evidência. "Concluo isso fundado nisso e naquilo". Estudar é o meio que eu escolhi para se chegar a esse fim. Nesses casos, quando os nexos são evidentes, é o eu

\footnotetext{
${ }^{279}$ Husserl não pretende fazer essas psicologias de fatos, apenas distinguir regiões ontológicas e certas generalidades eidéticas. Fica claro que existem vivências cujos motivos estão na profundidade. A psicanálise é, neste sentido, uma ciência de fatos que investigue esses motivos obscuros. A vivência da obsessão, a emergência constante de ideias desagradáveis, tem motivos obscuros. Mas já outras vivências são motivadas por nexos evidentes ou mesmo por pura e simplesmente por hábitos.
} 
central, ativo, que realiza os atos. Ele faz um ato sob o fundamento de outro. $\mathrm{O}$ ato de estudar é motivado racionalmente pelo querer ir bem na prova; e o querer ir bem na prova é motivado por sentir que ir bem na prova é um valor. Já uma obsessão, por exemplo, não possui origem racional. $\mathrm{O}$ objeto da obsessão simplesmente emerge na tela da consciência, sem que o indivíduo muitas vezes saiba nem seu motivo, nem sua origem.

Todavia, os motivos psíquicos podem se fundir a motivações racionais. Do mesmo modo como me vem à mente a recordação de uma pessoa, me pode vir à mente o desejo de ir ao cinema. Existe algum fundamento para esse desejo? Se observarmos bem, o desejo pode ter multiplicidade de origens não facilmente identificáveis. $O$ desejo pode ter sido fundamentado pelo fato de eu ter escutado de uma amigo, em cujo gosto eu confio, que um filme era bom, pode ter motivado o meu desejo de ir ao cinema. Mas se, além disso, eu estou cansado de estudar, esse cansaço pode ter contribuído para o surgimento deste desejo repentino de ir ao cinema. Esse desejo é, em um primeiro momento, uma pura tendência. Refletindo sobre ela, posso me decidir se cedo a ela ou resisto. Caso me decida pela tendência, torna-se uma vontade de ir ao cinema. Se quero realmente ir ao cinema, devo realmente querer pegar o carro, devo querer levantar-me da cadeira, etc. Todas essas vontades são fundadas na vontade de querer ver o filme. Para que uma vontade seja vontade, é preciso também querer os meios. Desejo ir ao cinema ver o filme, mas, estando indisposto para pegar o carro e enfrentar o trânsito, opto por ficar em casa. Tenho desejo, mas não vontade. A vontade implica a decisão de realizá-la ${ }^{280}$.

\footnotetext{
${ }^{280}$ Uma tarefa de grande importância seria um estudo detalhado dessas motivações psíquicas. Vimos, por exemplo, que uma pessoa pode ter uma tendência ao esquecimento sem que saiba a que tenha. Para que a conheça é necessário perceber-se interiormente, por atos de reflexão; pois essas tendências, bem como as disposições psíquicas não se anunciam "em carne e osso", quem se mostra originalmente são as vivências intencionais. Do mesmo modo, uma pessoa pode ter um hábito sem que saiba que tenha um hábito. Por exemplo, a pessoa tem o costume de contrair a aba direita do nariz toda vez que suspeita de algo, ou pode passar coçar o queixo quando fica feliz. Talvez não tenha percebido este seu hábito. Não é recomendável que essa pessoa vá ao cassino jogar pôquer. Já se vê que o "outro" pode auxiliar a pessoa para que ela perceba seu hábito. Por outro lado, uma pessoa pode ter uma tendência a se apaixonar por homens mau-caráter e nem sequer perceber que tem essa tendência e muito menos que essa tendência tem motivos obscuros. Pode até mesmo ocorrer de uma pessoa estar cansada e, estar tão envolvida em um problema que nem sequer nota o seu cansaço, não percebe o seu estado interior, justamente porque para isso, ela deveria dirigir seu olhar interior para apreender, com atenção, o seu próprio cansaço.
} 


\subsubsection{Sensações de sentimento e sentimentos intencionais}

Ao estudarmos a motivação, observamos que o fato de eu sentir que passar em um exame é um valor, motiva minha decisão de estudar a matéria do exame. Neste caso, um ato de sentimento motivou um ato da vontade. Logo, para compreender como a vontade é motivada, é preciso entender os atos de sentimento.

Os sentimentos intencionais distinguem-se das sensações de sentimento. A distinção feita por Husserl, já em Investigações Lógicas, é derivada da psicologia descritiva de Brentano. Para este, o sentimento pode ser de dois tipos, ou fenômenos físicos ou psíquicos. O primeiro não é intencional, o segundo sim. Em outras palavras, os fenômenos físicos não carregam, em si mesmos, a representação; já os fenômenos psíquicos têm sua origem em uma representação e estão vinculados às representações. Se uma notícia me deixa alegre, o prazer é, neste caso, intencional, pois é fundado em uma representação. Por exemplo, tomo conhecimento que ganhei na loteria. O conhecimento motiva minha alegria. Sem o conhecimento do estado de coisas, não haveria a alegria, pois não haveria o "porquê" de minha alegria. Algo diferente se passa se sinto uma dor no pé, ou o mal estar da gripe. No caso da dor no pé, a própria dor é o dado bruto e nasce do próprio corpo e não de uma representação, por isso Brentano denominava tais tipos de sentimento de fenômenos físicos, tais como sensações cromáticas, auditivas, dores físicas, mal estar físico, pulsão sexual, etc. Nestes casos, a representação é apenas posterior à própria sensação. Já o prazer originado de receber uma notícia que me agrada seria, segundo Brentano, um fenômeno psíquico, pois esse prazer não ocorreria sem a representação, ele nasce a partir da representação.

Husserl nega a distinção feita Brentano entre fenômenos físicos e psíquicos, embora distinga a mesma classe de fenômenos. O que Brentano denominava fenômenos físicos, Husserl denomina: sensações de sentimento. E o que Brentano denominava fenômenos psíquicos, cujo traço é a intencionalidade, Husserl denominará: atos de sentimento. Estes últimos são fundados em representações e não em estados corpóreos. Em Ideias 1, Husserl muitas vezes preferirá denominar essas sensações de sentimento simplesmente de hylé, que é aquilo que fornece a matéria para a função noética, ocorrendo a vivência intencional. Uma dor "no pé”, enquanto sensação, pode servir de material para um ato intencional. Por outro lado, se vejo uma bela paisagem, o sentimento de prazer não tem origem em um estado corpóreo ${ }^{281}$, mas em uma representação. A alegria originada da contemplação da paisagem tem sua origem

\footnotetext{
${ }^{281}$ O que não significa que por não ter origem corpórea, não consequências corpóreas, o prazer de ver uma bela paisagem pode fazer alguém chorar de emoção, por exemplo.
} 
na própria paisagem, ou seja, na "imagem". O objeto percebido, fundado sobre uma representação, é a "fonte" do sentimento.

O ser agradável, e respectivamente o ter uma sensação de prazer, não pertence a esta paisagem como realidade física e nem mesmo como efeito físico, mas, na consciência de ato aqui em questão, pertence a esta paisagem enquanto esta se manifesta deste ou daquele modo, ou mesmo enquanto vem julgado assim e assim, recorda isto ou aquilo, etc. enquanto tal, a paisagem "solicita", "desperta" sentimentos desse gênero. (HUSSERL, 2005, p.180. Tradução nossa)

Husserl, nesta passagem de Investigações Lógicas aponta aquilo que já vínhamos discutindo em Ideias 1, a diferença entre a noese e a hylé e noema. Um momento não se confunde com o outro:

É verdade que, de certo modo, cada sentimento da sensibilidade, por exemplo, a dor de se cortar, se refere a qualquer coisa de objetual; de um lado, ao eu, e mais precisamente ao membro do corpo que se corta, do outro lado ao objeto que corta. Mas este é um outro aspecto que demonstra a homogeneidade entre estes sentimentos e as outras sensações. Exatamente o mesmo ocorre na sensação tátil, por exemplo, vem referidas ao membro do corpo vivo que toca e ao corpo material estranho que vem tocado. Se bem que este referimento venha efetuado em vividos intencionais, ninguém pensará todavia em indicar como vivido intencional a sensação mesma. (2005, p.181)

Essa distinção é fundamental para se compreender o sujeito psíquico. Isso porque as sensações de sentimento são estados psíquicos. E os estados psíquicos afetam o espírito é criando tendências ou inclinações, às quais não necessariamente serão seguidas. Um homem, ao ser torturado, não tem nenhuma escolha se vai sentir dor ou não, a dor é causada pelos maus-tratos físicos do corpo. As fortes sensações de dor criam, sem dúvida, uma tendência espiritual. Por exemplo, um prisioneiro político, torturado corporalmente, sentirá dor e, em virtude da dor, ele terá a inclinação de revelar o segredo ou dedurar os companheiros. Contudo, em virtude de seus valores éticos, os quais pertencem à dimensão espiritual, o homem pode resistir bravamente à tendência de origem psíquica e até mesmo ser torturado até a morte. É igualmente possível que um outro homem, com os mesmos valores espirituais, não resista e deixe se levar pela tendência, dedurando os amigos. Por outro lado, mesmo os instintos criam sensações corporais e podem criar tendências ${ }^{282}$.

\footnotetext{
${ }^{282}$ Atos de sentimento e sensações de sentimento, e tendências, algumas vezes estão emaranhados. A esse respeito, ver apêndice $\mathrm{G}-\mathrm{a}$ tentação.
} 


\subsubsection{0 valor e a motivação no sujeito moral}

Vimos acima que existem vivências intencionais com motivações mistas, nas quais se fundem motivos racionais com motivos psíquicos. Observamos que, para se compreender a vida do espírito, é preciso levar em conta o mundo da vida, o qual não possui apenas "meras coisas", mas diz respeito a todos os sentidos constituídos intuitivamente e intersubjetivamente. "A visão de mundo" de uma pessoa é constituída pelos seus valores, por suas crenças, pelas experiências religiosas, pelos modos de se deixar motivar pelos bens culturais, pelas suas relações sociais etc. O que iremos observar é o papel dos valores para a compreensão da vida do espírito. O ponto central é este: os valores são intuídos em atos de sentimento e os atos de sentimento motivam a vontade.

O estudo dos valores, axiologia, é uma área muito complexa. Ela se relaciona diretamente com a vida do espírito e com o sujeito ético. Os valores não são nada de "puramente subjetivo" ou "puramente psíquico". Eles constituem objetos, os quais ão intuídos em atos de sentimento. $\mathrm{O}$ quadro se torna mais complexo se observarmos que nem todos os valores e objetos de valor estão diretamente ligados ao nível psíquico, embora alguns estejam. Esta constatação é fundamental para a compreensão da vida intencional do sujeito.

Vejamos, em primeiro lugar, alguns valores associados ao nível psíquico. Se eu gosto muito de chocolates, o chocolate para mim é um objeto de valor. Mas porque é objeto de valor? É objeto de valor em virtude de ele ser saboroso. Seu valor está, neste caso, intrinsecamente ligado aos dados hiléticos. Quando o chocolate derrete em minha boca, sinto uma sensação de prazer. Mas um valor pode não estar ligado às sensações. Estudando geometria, percebo sublime beleza de um teorema. ${ }^{283}$ A beleza do teorema está ligado ao ato de sentimento, que é um ato intuitivo no qual o objeto-valor se mostra. Colher o valor é sentilo. Um violino, por exemplo, não é um mero objeto, é um objeto de valor. É constituído intuitivamente como objeto de valor em virtude dos atos de sentimento.

Quando eu escuto o tom de um violino, o prazer e a beleza são dados originalmente se o tom mexe com meus sentimentos originalmente e em uma maneira vívida, e a beleza como tal é dada originalmente precisamente junta com o prazer, similarmente é dado o valor mediato do violino como aquilo que é capaz de produzir tal tom. (HUSSERL, 2008, p.623, tradução nossa)

A música é algo de valor. Mas a música é um objeto de valor porque o homem é capaz de um sentimento intencional, por meio do qual, se intui o valor da música. A beleza da música mostra-se apenas a quem é capaz de intui-la. O valor não está nas puras sensações

\footnotetext{
${ }^{283}$ Outras pessoas, talvez, não sejam capazes de perceber a beleza das matemáticas.
} 
auditivas, mas no modo como os sons estão organizados, na composição. Mas um homem incapaz de sentir o valor de uma música, que não vê aí nada de belo, para esse homem a música não tem efetivamente valor. ${ }^{284}$

Esta discussão que fizemos acima diz respeito ao conteúdo dos valores, trata-se de uma discussão de "Ética material dos valores". Já a "Ética Formal dos Valores", como vínhamos observando ao estudar as motivações racionais, não diz respeito ao conteúdo de valor intuído, mas sim à forma apriorística do sujeito ético, ou seja, cada pessoa possui uma escala pessoal de valores ${ }^{285}$.

No nível individual, o sistema de valores de uma pessoa, aquilo que a pessoa efetivamente e originariamente sente como valor, constitui o seu caráter. No nível mais basal, os valores são constituídos por atos de sentimento. É a partir da aí que deve se investigar a materialidade dos valores. Entender quais são os valores de uma pessoa, ou seja, conhecer o seu caráter, é fundamental para se compreender a vida intencional do sujeito. Essa estrutura de valores de uma pessoa está intimamente ligada ao modo de se deixar motivar da vontade. Se, para uma pessoa, uma obra de arte é sentida como um valor, se faz mover seus sentimentos, tal pessoa terá a propensão a ir para museus. Se uma pessoa entender que o amor é um valor superior ao ódio, ela se esforçará por agir de acordo com o valor.

Para Agostinho, o maior dos valores é Deus. Mas, lendo as Confissões, observa-se que, para ele, Deus não é um valor por motivos puramente dogmático. Ninguém o obrigou a acreditar em Deus. Os rios de lágrimas que sua mãe havia chorado, durante muito tempo, de nada serviu. A conversão de Agostinho inicia quando ele começa sentir Deus e Cristo como um objeto de valor, um objeto de amor. Sentir Deus profundamente Deus como um valor e amá-lo profundamente não está ao alcance da razão, embora a razão possa ser importante neste processo. Agostinho mesmo se converte intelectualmente antes de se converter o coração. Por isso, já crendo em Deus, Agostinho pede que Deus the dê o amor para que ele O ame. Uma vez que Deus e os ensinamentos de Cristo sejam reconhecidos e experienciados

\footnotetext{
${ }^{284}$ Ou talvez a música tenha um valor inautêntico. Por exemplo, a pessoa não é capaz de sentir o valor de uma música clássica, mas vai a um concerto para se sentir culto. Do mesmo modo, para uma pessoa, obter o título de doutorado pode ser um valor; uma outra pessoa pode não sentir que o título de doutorado não é um valor. Para algumas pessoas sentam a honestidade é um valor, outras não. Uma pessoa pode querer ajudar o próximo porque ela sente que isso é um valor em si; outra pessoa, por seu turno, pode querer ajudar o próximo, esperando que este posteriormente retribua.

${ }^{285}$ Apenas para citar duas leis formais: “se efetivamente quero tal fim, devo querer os meios”. Já o puro desejo não é dessa forma. "Desejaria ser milionário, mas não tenho disposição para ficar indo atrás de dinheiro". Uma outra lei formal: "Entre alternativas possíveis de meu querer, escolherei a melhor". Como se vê, o que será melhor, para cada pessoa, depende do conteúdo, mas a forma é válida para todo sujeito racional.
} 
como valores a se seguir, o homem se motivará a agir de acordo com eles ${ }^{286}$ Por isso que Agostinho tanto valoriza a ação da graça. Para querer algo com intensidade é preciso amar esse algo com intensidade. E é a graça que tonifica o amor e a vontade.

\subsubsection{Vivências intencionais autônomas e vivências intencionais executadas pelo eu central}

Até o momento, observamos que a vida do espírito é caracterizada por motivações psíquicas e motivações racionais, o que não implica que toda vida do espírito seja livre. Observamos várias vivências intencionais nas quais o eu não tem o poder de não vivê-las, mesmo que queira não vivê-las. Ninguém escolhe se vai sentir desejo ou não, se vai sentir tal sentimento ou não. Por outro lado, observamos que as vivências motivadas racionalmente são experienciadas como efetuadas pelo próprio eu. "Supondo tal e tal, decido tal e tal"; "Eu vi e toquei tal coisa, decido acreditar na realidade de tal coisa, pois estou convencido". Ninguém me obrigou crer. Apenas "vi" que era assim. Se os motivos mudarem, mudarei minhas conclusões. Faço as equações e chego a tal resposta. Alguém me mostra que cometi um erro de sinal; percebo o erro e deixo de crer no resultado final. Ninguém me "forçou" a crer que estava errado; a pessoa simplesmente iluminou o meu erro. Curvo-me à evidência sem grandes dilemas. Quando o sujeito executa a conclusão de um silogismo, ele não vive o ato do juízo como algo que "emerge em seu espírito", como algo que está fora de seu poder. É o próprio "eu central" o responsável por concluir o silogismo porque tomou como certas as premissas.

Por outro lado, já observamos, há também uma espécie de espontaneidade na ligação de um ato a outro. Está fora de nosso alcance extinguir a vida espontânea do eu, constituída de atos ativos, mas também de atos passivos. Mesmo tendo o colesterol muito alto, a visão de um torresmo pode despertar em mim o desejo de comê-lo. Neste caso, podemos dizer que o desejo, embora seja um vivido intencional, e, portanto, "espiritual", afunda sua raiz no psíquico. Por outro lado, sei que comer o doce irá me fazer mal e luto contra o desejo. O desejo é meu; a vontade de não comê-lo também é minha. Entretanto, a vontade de não comêlo é mais minha do que o desejo, pois caso queira, posso abrir uma exceção e comer o torresmo. Mas, caso queira, não posso mudar o desejo.

\footnotetext{
${ }^{286}$ A ideia, por trás do argumento, é que há uma objetividade dos valores. Os valores não são frutos do capricho. A questão é uma questão de abertura do espírito aos valores. Os valores ligados à carne são facilmente reconhecíveis. Mas ainda aqui podem ser diferenciados, ligados ao tato, ao sexo, ao olfato, etc. Por outro lado, o poder é também um valor, existem valores ligados à vaidade; e assim por diante.
} 
Posso sentir antipatia por um determinado homem, embora sem aceitá-la, decidido não me deixar ser levado por ela, ${ }^{287}$ procurando agir de modo respeitoso com ele. Essa decisão de "não querer dar atenção à antipatia" é uma decisão efetuada pelo eu central, o qual é livre. O que importa é que este "querer não dar atenção à antipatia" é vivido como algo que está sob o meu poder. Se quisesse, poderia tratar mal aquela pessoa, mas não quero, "não considero correto", "não é o melhor". Infelizmente, não tenho o poder de não sentir a antipatia.

Inversamente, ao ver em um museu a obra de um autor nazista o qual reprovo moralmente, pode acontecer de eu me deleitar com ela, pois, por um ato de sentimento, intuo a beleza da obra. Ocorre aqui uma tomada de posição espontânea do sentimento. Sou tão incapaz de proibir-me de sentir o valor estético, quanto sou incapaz de crer honestamente que este computador que percebo é uma ilusão. No entanto, posso, em virtude de outros valores que estão acima daqueles em uma escala hierárquica estabelecida por mim, não dar espaço ao sentimento, não dar atenção a ele, deixá-lo de lado. Esse "deixar de lado o sentimento", não me deixar seduzir por ele, é vivido por mim como executado pelo eu central. Em outras palavras, existem determinados atos intencionais sobre os quais eu tenho o poder, e outros atos os quais estão fora de meu poder.

Dentro da vida do espírito, podemos distinguir, portanto, duas classes de vividos. Os vividos que são meus, mas não são realizados por mim, e os vividos que são meus e foram realizados por mim, ou seja, pelo "eu central". Essas duas espécies de vividos constituem toda a vida intencional do sujeito, a vida intencional do espírito, em senso lato. Mas a vida do espírito, em senso estrito, é apenas a vida intencional que diz respeito à segunda classe, aos atos efetuados pelo eu central, que é o espírito entendido como inteligência e vontade, ou seja, a mens, de que falava Agostinho.

\subsubsection{As tendências e os posicionamentos}

O que iremos observar agora é a tomada de posição espontânea e das opiniões intencionais. Já havíamos observado o eu puro se posiciona com relação aos noemas, que estes posicionamentos caracterizam o eu e influenciam sua vida intencional. Já observamos isso, em capítulo dedicado ao eu puro. Retomamos o argumento, pois as opiniões intencionais estão profundamente ligadas ao sistema motivacional do sujeito.

\footnotetext{
${ }^{287} \mathrm{O}$ ato intencional que colhe esse valor é sentido profundamente em minha alma e tomo-o como um valor que devo seguir e sobre o qual devo pautar a minha vida. No entanto, pode ocorrer que eu seja tomado de alegria ao escutar a notícia de que alguém, por quem alimento antipatia, foi despedido do trabalho. A "alegria sórdida" me invade sem o meu consentimento. E essa alegria foi motivada pelo ato cognitivo pelo qual eu tomei conhecimento de um estado de coisas. Também pode acontecer de eu ter antipatia por uma pessoa sem ter motivos para isso, sem que saiba dizer porquê. A antipatia, nesse caso, ocorre no nível psíquico.
} 
Husserl usa o termo "posicionamento" porque eles não alteram a representação. Existência possível, existência provável, existência real, existência duvidosa são posicionamentos do eu frente a uma representação. E esses posicionamentos, que constituem o habitus afetam minha vida prática, minha vida espiritual ${ }^{288}$.

Os posicionamentos podem gerar disposições e tendências. Posiciono-me perante o Deus Cristão como algo certo e creio que Deus está no meu íntimo e é capaz de observar meus pensamentos maus. Em virtude desse meu posicionamento, é possível que eu pense duas vezes não só antes de cometer um pecado, mas que esteja sempre atento à minha própria atenção, pois posso irrefletidamente estar pensando em algo mau. Os objetos constituídos intencionalmente, bem como os posicionamentos perante eles são elementos essenciais na constituição do meu mundo circunstante, do mundo que é para mim.

Muitas pessoas ouviram falar do "pé grande". Algumas se posicionam no modo do "muito provável"; outras no modo do "pouco provável”, outras apenas do "possível”. Tais posicionamentos não abalarão, entretanto, de modo significativo a vida intencional do sujeito. Contudo, os posicionamentos perante "teorias acerca do homem" 289 , sejam certas ou não, abalarão profundamente a vida intencional, assim como os posicionamentos perante Deus. Mas é preciso distinguir: uma coisa é o que a pessoa entende por Deus, outra coisa o posicionamento dela perante aquilo que ela entende por Deus.

Tomemos o seguinte juízo "O homem nada mais é do um animal instintivo, a razão nada mais é do que um mecanismo evolutivo". O sujeito pode crer nisso como coisa certa, como provável, como improvável, como absurdo. Caso creia plenamente, tal sujeito pode ser fortemente abalado em sua visão de mundo, de modo que terá, para si, que seus pensamentos, emoções, sentimentos, valores éticos, seus gostos artísticos tem, "no fundo" tem função evolutiva. Alguém que tenha a convicção de que reprimir as pulsões provocam patologias, pode ser levado a valorizar os desejos carnais. Analogamente, um sujeito que creia que tomar banho após beber café quente faz mal para os rins, evitará fazê-lo.

\footnotetext{
${ }^{288}$ Se tenho para mim que demônios existem, trata-se de algo que existe para mim no mundo circunstante e isso afeta minha vida em meu todo. Um desejo cruel que me advém pode ser entendido como uma influência demoníaca. Se me posiciono frente à teoria de Freud, "tal como entendo", como certa, o desejo cruel pode ser uma expressão das profundezas do inconsciente. E mais, qualquer homem que eu veja, será um homem dotado id, ego e supe-ego. Mas posso me posicionar perante o que conheço da teoria freudiana como algo provável, como algo possível, como algo impossível.

${ }^{289}$ Para um aprofundamento de como pode influenciar, ver apêndice E.
} 
Como se vê, as convicções afetam profundamente a vida intencional do espírito, pois as opiniões intencionais estão relacionadas ao que "eu sou" e ao que "o mundo é para mim"290. Criam tendências, modos de se comportar, criam, em alguns casos, disposições aos atos reflexivos, afetam até mesmo o sujeito ético responsável. Vimos que era justamente essa briga de Agostinho com o Maniqueísmo, quando seus seguidores afirmavam: "Não sou eu que cometo o mal, é meu corpo. E meu corpo não sou eu. Como irei me responsabilizar?”.

Em alguns casos, pode acontecer de duas pessoas ter os mesmos valores, mas opiniões intencionais muito distintas. Por exemplo, quatro pessoas podem querer viver uma sociedade em que haja menos pobreza e miséria. Contudo, um deles crê que, para isso, seria preciso extinguir o capitalismo, o outro crê que o melhor meio é ajustar o capitalismo. Um terceiro está convicto que, para erradicar de vez a pobreza, é melhor deixar o capitalismo solto. O quarto crê que não se deve mudar a sociedade, mas o coração dos homens, pois a mudança da sociedade vem naturalmente com a mudança dos valores morais. Os quatro homens tem, como valor, viver em uma sociedade sem miséria, mas discordam quanto aos meios, em virtude de suas opiniões intencionais.

\footnotetext{
${ }^{290}$ Em virtude das opiniões intencionais, alguns homens vivem em um mundo cheio de fantasmas, duendes, demônios etc. Outros vivem em um mundo cheio de átomos, campos, elétrons. Outros ainda vivem em um mundo no qual as pessoas são todas elas egoístas. A literatura bem revela esses diferentes mundos.
} 


\subsection{A vontade}

\subsubsection{Distinção entre diferentes concepções e momentos da vontade}

O termo vontade é escorregadio. Por isso, é conveniente distinguir entre esforço, vontade em senso estrito.

1) $\mathrm{O}$ esforço

No primeiro desses sentidos, a vontade é compreendida enquanto esforço. Diz respeito a um querer genérico, como o querer ser bom, o querer perdoar sempre, o querer se tornar uma pessoa importante. O que caracteriza esse querer enquanto esforço é que, aqui, o querer é compatível com o não poder. Neste caso, um dos aspectos que caracteriza o esforço é que ele é livre. É livre não no sentido que eu posso realizar aquilo que "quero ser", mas no sentido de que eu posso esforçar-me nesta ou naquela direção em virtude de uma decisão. Não me sinto forçado a querer ser uma pessoa boa. O esforço tem como alvo não a realização de um estado de coisas determinado, mas o próprio comportamento do sujeito, entendido não apenas como comportamento corpóreo, mas também espiritual. "Quero ser mais paciente”, "quero perdoar os outros com mais facilidade". Ninguém obriga alguém a querer algo na base da força. Não é possível obrigar uma pessoa a querer ser uma pessoa boa.

$\mathrm{O}$ esforço, portanto, é um querer posto ativamente pelo eu central e que se refere ao próprio sujeito volitivo. Trata-se de um ato livre, porque a direção do meu esforço, daquilo que eu quero me esforçar, daquilo que tenho vontade de ser, foi posta por mim e nada me obrigou exteriormente a fazê-lo. Aquilo para o qual se dirige o meu esforço foi experienciado como posto por mim. Não sou livre para perdoar uma pessoa no fundo do meu coração. Se meu coração é incapaz de perdoar, não posso fazer nada. Mas sou livre para me esforçar para não me deixar me levar por esse sentimento rancoroso. Sou livre para tentar não dar atenção a esse sentimento. Procuro permanecer em alerta para não deixar que o sentimento rancoroso sub-repticiamente domine o olhar do meu espírito de modo que comece a imaginar a cena da vingança. Logo que percebo o movimento, trato de espanar as imaginações. O esforço, em linhas gerais, implica atos reflexivos, pois o esforço tem como objeto o próprio sujeito. 


\subsubsection{A vontade, o propósito e o fiat}

A vontade, em sentido estrito, ao contrário do esforço, tem como fim um estado de coisas determinado, o qual estimo que esteja na medida de meu poder efetuá-lo. A vontade pode ser uma vontade espontânea e vitalizada, por exemplo, "quero ler um livro". Sinto esse querer vivo dentro de mim e pretendo realizá-lo. Mas a vontade pode ser uma vontade desvitalizada: "devo pagar uma conta no banco". Toda vontade desvitalizada ocorre na seguinte forma: "É necessário fazer tal coisa, e tal e coisa é possível de ser feita e, mesmo indisposto, irei fazê-la" ou ainda "Apesar de tudo, o melhor é fazer tal coisa".

O estado de coisas intencionado pela vontade deve ser posicionado como um estado de coisas possível de ser realizado pelo eu. Já o desejo não o exige. Por isso, posso desejar que chova amanhã, mas não posso querer que chova amanhã. Entretanto, posso querer terminar um trabalho.

Um outro traço da vontade é que elas são fundadas racionalmente. Portanto, todo querer autêntico é do tipo "quero algo por causa de algo.”. Esse algo que motiva a vontade é o valor. Os valores podem ser os mais diversos. Por exemplo, quero pagar a conta de luz, porque para mim, ter luz elétrica em casa é um valor. Posso querer dar um presente à namorada, porque é um valor para mim. Posso querer comer um chocolate, porque, para mim, matar o desejo é um valor.

$\mathrm{O}$ "eu posso" presente em toda a vontade é sempre referido a um "eu consigo superar as resistências, as dificuldades" para realizar o estado de coisas almejado. "Não posso querer uma coisa que não esteja diante os olhos da minha consciência, que não esteja em meu poder, que não entre na ordem das minhas capacidades”. (HUSSERL, 2008, p.690, tradução nossa).

Segundo Husserl, para que o eu posso venha à luz da consciência é necessário que haja uma consciência da resistência. "Antes da vontade implicando a tese ativa do fiat está o agir como agir instintivo: Pegar uma cigarro na mesa é involuntário”. (HUSSERL, 2008, p.691, tradução nossa).

De fato, eu enquanto estou escrevendo, minha atividade espiritual está voltada para atos teóricos, e, se imerso nos raciocínios, desejo fumar um cigarro, simplesmente pego-o e fumo, sem fazer do cigarro objeto temático, sem dirigir o olhar da atenção para este agir. Pegar o cigarro, acendê-lo e começar a fumar faz parte do "eu posso", mas justamente por ser um eu posso que não oferece resistência, o fumar o cigarro não se tornam "tema" de minha vontade. Para que uma vontade seja vontade é preciso um olhar espiritual dirigido para ela. Já não é caso de quando temos que decidir, dentre possibilidades práticas, qual é a melhor. "Posso 
decidir apenas dentre as diversas possibilidades práticas, apenas uma delas pode se tornar tema de minha vontade.” (HUSSERL, 2008, p.691, tradução nossa)

Para que a vontade se torne um tema do espírito é preciso, como exposto, que o estado de coisas almejado ofereça uma resistência ${ }^{291}$. É por isso que na vontade em sentido estrito, ocorre uma consciência de um poder que supera a resistência.

$\mathrm{Na}$ experiência se distinguem por seu caráter fenomenológico o "eu posso" e o "eu não posso". Existe um agir privado de resistência, e portanto a consciência de um poder que não encontra resistência, e, por outro lado, um agir que comporta a superação de uma resistência, um agir que há um próprio contra e que comporta a consciência de um poder que supera a resistência. (HUSSERL, 2008, p.691, tradução nossa)

Sempre nos confrontamos, em toda vontade a força de inércia da resistência, a qual possui graus. Se essa resistência se mostra insuperável, nos defrontamos com um "não posso". O "eu não posso" faz apagar a vontade, tornando-se um puro desejo. Há casos, entretanto, que é difícil decidir se podemos ou não podemos dar conta da resistência, e se vale a pena realizar o estado de coisas em virtude das dificuldades. Por exemplo, me proponho a resolver um cálculo, mas, pouco tempo depois de iniciá-lo, dou-me conta que não posso, não tenho conhecimentos suficientes para resolver aquele cálculo, ou não vale a pena o esforço.

As dificuldades para a realização da vontade são estimadas e avaliadas. Por isso toda vontade, para que seja vontade, é uma vontade que vale a pena. Uma vontade que não vale a pena, não é vontade. Partindo das definições de vontade observadas logo acima, uma sentença como a que se segue, não se mostra adequada: "tenho vontade de estudar de estudar física quântica, mas acho que não vale a pena o esforço". Neste caso, não há propriamente vontade, tenho um desejo. "Gostaria de saber física quântica". Entretanto, é diferente se disséssemos, tenho vontade de estudar física quântica, qualquer hora vou me dedicar.

A vontade tem como fim um estado de coisas que eu pretendo fazer. Contudo, posso ter uma vontade e não realizá-la imediatamente. Neste caso, eu guardo dentro de mim a vontade e mantenho o propósito de realizá-la, esperando a ocasião adequada de colocá-la em ação. O início da ação dirigida pela vontade é o que Husserl, denomina fiat, que é o que põe a vontade em movimento.

\footnotetext{
${ }^{291}$ Husserl afirma que mesmo movimentos simples podem se tornar tema da vontade. Se minha mão está dormente e ao movê-la sinto dificuldade, o movimento oferece uma resistência, o simples mover a mão torna-se tema da vontade, o olhar do meu espírito é dirigido para esse tema. $\mathrm{O}$ mesmo ocorreria se eu disser para mim mesmo, "vou mover minha mão" e a movo. Contudo, estamos movimentando as mãos a todo instante e nem sempre tematizamos esse movimento. Então, o que dizer dos movimentos involuntários: "mas e se eu movo a mão involuntariamente? Por que se move? Porque a posição era incômoda. Ou: "não sou bem porque", não me dei conta que a move, o motivo sempre entra na dimensão psíquica, dependendo dos seus estímulos e dos seus motivos obscuros.”. (2008, p.693, tradução nossa)
} 


\subsection{O espírito, a alma e o si mesmo: um estudo comparativo}

\subsubsection{Introdução}

Nos capítulos seguintes, começaremos o estudo comparativo entre Agostinho e Husserl, no que concerne à alma e ao conhecimento de "si mesmo". Para isso, usamos o pensamento de outros fenomenólogos como Edith Stein e Ortega y Gasset, os quais aprofundaram a questão da alma. Como verá, não se trata de fazer teoria, mas descrever o que se anuncia em evidências concordantes, quando refletimos sobre nossas vivências. As ideias serão necessárias para uma justa apresentação da pessoa humana.

\subsubsection{O espírito e a alma}

Até o momento, nesta terceira parte do trabalho, evitamos referir à alma, pois ainda não tínhamos ainda os dados suficientes. Em primeiro lugar, observamos que a psique está entremeada ao corpo, mas não constitui propriamente o que há de intencional do espírito. $\mathrm{O}$ eu puro está edificado sobre a psique. Esta interconexão entre espírito e psique revela-se na interconexão entre as apreensões do nous e os dados hiléticos. A vida hilética deve ser entendida em senso amplo. Ela está associada não apenas às sensações "ligadas aos cinco sentidos", mas também às sensações de sentimento, à vida instintiva do sujeito, à fome, à sede, os instintos sexuais e de sobrevivência, ao medo, à dor. Por isso, fica claro porque, alguns desejos, embora sejam atos de consciência, afundam sua raiz na dimensão psíquica. Sinto desejo de comer carne. É um desejo que emerge em mim, mas esse desejo está ligado à psique, a vitalidade animal. Mas a psique possui propriedades, tais como disposições. Se sou vegetariano a longos anos, dificilmente me virá o desejo de comer carne.

Analisamos também a distinção entre sensações de sentimento e sentimento intencional. O sentimento intencional é despertado por uma representação. O conhecimento de que ganhei na loteria é uma vivência motivante do ato de sentimento da felicidade. A felicidade não brota espontaneamente do corpo, advém com o conhecimento acerca de um estado de coisas o qual eu sinto como valoroso. Mas, em alguns casos, é possível que o sentimento intencional tenha sua raiz na psique. Ver alguém comer pipoca na televisão desperta meu desejo de comer pipoca. Uma coisa é um puro emergir do desejo de comer pipoca; outra coisa é o desejo “despertado" por uma representação. Há, neste caso, um nexo de compreensibilidade entre 
sentir desejo e o ato perceptivo. A percepção da pipoca, por si só, não é suficiente para que eu sinta desejo.

Os sistemas motivacionais são complexos, pois muitas vezes muitos níveis estão emaranhados. Ligo a um amigo para ir a uma festa. $\mathrm{O}$ ato de querer ir a festa com um amigo pode ter sido motivado pelo prazer de tomar cerveja, pelo prazer de conversar, pelo prazer de dançar, pelo prazer de escutar música, ver gente etc, paquerar (entra aqui o nível das pulsões sexuais). Não há razão nenhuma para se crer que é um único motivo. A alegria de conversar com um amigo não está ligada aos prazeres sensuais, aos órgãos genitais. Não tem uma raiz identificável na hylé. Poderíamos dizer que é um valor espiritual, distinto de comer bem.

Ao tratarmos da vida do sujeito psíquico, um importante fator foi omitido até aqui, pois ele apresenta algumas dificuldades. Husserl diz que existem atos intencionais atuais e inatuais e que nem todos os atos inatuais podem, a um só tempo, passarem à atualidade. O olhar do espírito está voltado para isso ou aquilo, para o objeto de um desejo, para um objeto da percepção ou pode estar voltado concomitantemente para isso e aquilo. De todo modo, não podemos prestar atenção em tudo ao mesmo tempo. Há, isto sim, uma sucessão temporal, um fluxo de consciência.

Pois bem, no caso dos sentimentos intencionais a coisa se complica. É justamente explorando esses sentimentos intencionais que poderemos encontrar uma classe de vivências muito particulares às quais anunciam a alma. Partamos do seguinte exemplo:

Se estou perdido em uma floresta e amedrontado, o sentimento intencional do medo tem o seu objeto, a situação de perigo em geral, os possíveis animais ferozes, a sede, a fome, a morte, a dor. Esse medo permanece, ainda que o olhar do meu espírito não esteja dirigido para ele ou para os objetos de que tenho medo. O medo não some porque o olhar do meu espírito esta ocupado em pensamentos sobre o melhor jeito de sair da floresta. O que importa notar é que $\mathrm{o}$ ato de pensamento, o ato de percepção, de imaginação são atos pontuais, de curta duração, ocorrem em um único instante e já no momento seguinte, o olhar do espírito se dirige a outra coisa. Comparativamente ao pensamento e à percepção, o sentimento intencional pode ter uma longa duração. Do mesmo modo, as opiniões intencionais. Vimos que elas podem permanecer, apesar do fluxo. Não perco uma convicção porque, no momento, não estou pensando nela.

Em outras palavras, a atenção do espírito é altamente móvel, mas, no plano de fundo do espírito, as decisões, as convicções, as vontades, os posicionamentos permanecem, assim como os sentimentos intencionais. Perdido na floresta e, ainda que o espírito esteja dirigido 
em busca de alimentos, a decisão de escapar dali permanece, assim como a ansiedade e o medo.

Uma das dificuldades é que a linguagem cotidiana não oferece conceitos precisos para descrever esse nível, o "plano de fundo" sobre o qual acontece a vida intencional atual do sujeito. A alma começa a se anunciar se observarmos que esse plano de fundo do espírito não se resume estritamente à psique. Se assim considero, estarei equivocado, pois em alguns caso, encontramos, neste fundo, sentimentos intencionais. Se, por outro lado, considerar puramente espiritual esse plano de fundo, também recaio em sérios problemas, pois alguns destes sentimentos intencionais estão ligados com a psique, como o medo. Para dificultar ainda mais as coisas, os sentimentos deste plano de fundo podem estar correlacionados com âmbitos distintos da psique. Por exemplo, estou desempregado. E estar desempregado, para mim, é algo que abala toda minha estrutura vital. "Sinto-me imprestável, sinto que minha existência não vale nada, sinto que minha vida não faz sentido". Neste "sentir-se imprestável" estão elementos de ordem não puramente psíquicos, estão elementos de ordem espiritual, existencial. Há um "crise de sentido", a qual pode acompanhar o homem por dias, meses ou anos. A Insatisfação com o trabalho, a vaidade ferida, a crise da meia idade, a angustia de saber-se mortal, em suma, "crises de sentido" às mais diversas. Tudo isso abala a eu do espírito de modo profundo.

Mas, como se vê, a opinião intencional está estreitamente correlacionada com esses sentimentos existenciais. Quem tem a convicção que todo desempregado é vagabundo, caso esteja desempregado, tenderá a se sentirá vagabundo. Do mesmo modo, quem tem a convicção de que, com a morte, o eu se diluirá no nada, pode sentir profundamente a angustia de saber-se mortal. Essa angustia pode acompanhá-lo durante anos. Já quem crê que o espírito sobreviverá, após a morte do corpo, e que, ao morrer, a vida será muitíssimo melhor, terá no fundo do espírito, um outro suporte e um outro "sentimento de fundo", que poderá acompanhá-lo durante anos.

Talvez o melhor conceito para expressar essa dimensão da estrutura humana seja “alma”, não entendida puramente como psique, mas como a atmosfera na qual o espírito está envolto.

A alma não é propriamente a vida intencional do eu, não se fala de um olho da alma. A alma é a morada do espírito. Ela é mais estável do que a vida atual do eu. Quando a alma está bem $^{292}$, o eu sente-se confortável, sente-se acomodado em sua própria casa. Mas por que

\footnotetext{
${ }^{292}$ Partindo do princípio que a psique, que a animalidade está bem.
} 
razão a alma não é a psique? A psique, como já foi exposto, manifesta-se pelas sensações ligadas ao corpo, que vão desde sensações cromáticas, sexuais, cansaço físico, etc. Mas a alma possui algo distinto, pois ela não está em relação causal com o corpo material; o espírito exerce influxos sobre a alma ${ }^{293}$. O ato pelo qual tomo consciência da morte de um amigo dura um único instante, mas a "dor", a "tristeza" me preenche. Para pensarmos em um exemplo mais feliz, suponhamos uma mulher, a qual tenho amado durante meses, aceitou meu pedido de namoro. $\mathrm{O}$ instante em que escuto sua resposta positiva dura poucos segundos. Passado algum tempo, ainda que não esteja pensando neste fato, mesmo que o olho do meu espírito esteja voltado para outra coisa, a alegria continua existindo no campo de fundo. Em virtude desse estado de animo, o próprio mundo mostra-se com cores vibrantes, com nitidez de contorno, os pássaros parecem sorrir. Meu estado de ânimo perdura, embora o olhar do meu espírito continue "saltando de objeto em objeto", lançando a luz de consciência ora a isso, ora àquilo, embora uma luz mais intensa e vibrante. Esse sentimento que permanece no fundo, embora afete meu estado vital, não se limita a um estado vital, pois ele não está em uma interconexão causal com o mundo material imediato. Esse estado, no caso, origina com a consciência que um valor foi realizado. No dia seguinte posso estar doente, com gripe, dores horríveis no corpo. Ainda assim co-existirá com o mal estar da gripe o estado a alegria. A alegria, em certo sentido, também é um estado vital, mas distinto do causado pela gripe. A alegria está entremeada com o espírito, com o mundo de sentido, advém da realização de um valor conquistado; já o mal estar da gripe, pelo seu próprio sentido, é causado pela ação do vírus sobre o corpo.

Ortega y Gasset, entendendo o espírito no sentido estrito, como vontade e intelecto dotado do "eu posso", diferencia-o da alma nos seguintes termos.

No entanto, existe uma outra característica que diferencia o espiritual da região a qual nos reservamos o nome de alma em sentido estrito. Os fenômenos espirituais ou mentais não duram; aqueles anímicos ocupam tempo. O compreender que $2+2-4$ se realiza em um instante. Pode custar muito tempo para compreender alguma coisa, porém se o compreendemos isto é, se o pensamos - o pensamento é puro instante. Rigorosamente falando, não se pode dizer que estamos pensando em alguma coisa mais ou menos tempo. "Estar pensando" se refere à série sucessiva de muitos atos de pensamento, cada um dos quais é um lampejo mental. Do mesmo modo, se quer, ou não quer, com um só golpe. A volição, que talvez demore a se formar, é um raio de atividade íntima que fulmina a sua decisão. Ao contrário, tudo o que pertence à esfera da alma, dura e se estende no tempo. Enquanto pensar e querer são atos, por assim dizer, em forma de pontos, desejos e sentimentos são linhas afluentes. "Se está" triste, "se está alegre",

${ }^{293}$ É preciso notar que também o espírito exerce influxos sobre a psique e o corpo próprio. Sei que ganhei na loto; meu coração bate mais forte. 
um momento, um dia, toda a vida. Quando se ama, o amor não é uma série de pontos descontínuos que se produzem em nós, mas uma corrente contínua na qual, sem interrupção, opera o sentimento. Bastava essa diferença para separar radicalmente a vida espiritual intelectual e volitiva, da região da alma, onde tudo é fluido, um prolongado descarregar, uma corrente atmosférica. (ORTEGA Y GASSET, 1963, p.465, tradução nossa.)

Edith Stein diferencia o eu puro da alma de modo muito semelhante a Ortega y Gasset. Para ela, a alma caracteriza-se por ser dotada de extensão e profundidade. Trata-se da casa do eu intencional que vive as vivências. Para ilustrar a relação entre o eu e a alma ela se vale de um aspecto fenomenológico evidente. $\mathrm{O}$ eu tem um foco de atenção, mas existem vividos de consciência para os quais nossa atenção não está dirigida. $\mathrm{O}$ eu puro é algo funcional, ele é um centro do qual um raio é emitido em direção a um objeto. Por exemplo, estou ocupado com um problema. No entanto, co-existe com essas vivências outras vivências que permanecem no fundo. "A atenção central do eu ao seu tema e apercepção "periférica" são modalidades diversas de consciência"(2000, p.131, tradução nossa) ${ }^{294}$.

A alma está sempre nessa "consciência periférica" e por isso diferencia-se do eu espiritual, que atua lançando raios de consciência. Se o eu pode estar com o olhar do espírito dirigido para um filme, enquanto, na consciência de fundo, habita uma preocupação. Essa preocupação, que é um estado de fundo da alma não é “inconsciente”, apenas não é apreendida atencionalmente. Caso o seja, ela não será uma surpresa, pois ela se dá à consciência como algo que já estava ali. O olhar do espírito não pode manter-se fixo nesta preocupação para viver.

A ideia de um fundo da alma coloca em evidência uma "espacialidade interior". Se existe uma espacialidade interior, essa espacialidade só pode pertencer à alma. A alma de fato possui extensão e profundidade, "ela pode ser preenchida, qualquer coisa pode penetrar nela. Nela eu estou em casa, em modo totalmente diverso de como eu estou no meu corpo vivente." (2000, p.132, tradução nossa).

A dimensão da alma é distinta da dimensão corporal. Uma preocupação que permanece no fundo da alma é motivada. Por exemplo, posso, embora esteja bem alimentado e tenha uma família que possa me sustentar, sentir-me mal comigo mesmo em vista de estar desempregado. O fato de a alma estar desarrumada acaba me afetando. Em minha "alma carnal" tudo pode estar indo bem, minha vida instintiva, minha alimentação, esporte

\footnotetext{
${ }^{294}$ Isso já analisado atrás, quando Husserl procura distinguir em Ideias 1, duas modalidades de consciência. Por um lado tem a consciência atual e, por outro lado a consciência inatual. Ora, um sentimento intencional perdura durante um determinado tempo, como já foi mostrado em exemplos.
} 
regulares, saúde. Mas esse mal estar de existencial continua me afligindo. Contudo, não será o único mal estar. A alma possui extensão e níveis. Ao lado dessa preocupação, um outro "sentimento da alma" pode me acompanhar, a própria angustia de ver a transitoriedade dos seres. Um sentimento de que tudo todo esforço é inútil, toda conquista é vã, o sentimento que todas as pessoas que eu amo deixarão de existir.

O próprio luto é um estado da alma. Fico sabendo da morte de uma pessoa amada e sou abatido no meu ânimo. Mesmo que eu procure me distrair, dirigindo o olhar do espírito vendo um filme, o sentimento se mantém. Mas ao lado disso, ainda há o sentimento de felicidade por ter pessoas que amo e por ser amado por elas, etc. Vejamos a descrição a bela e triste descrição da morte de seu amigo de juventude:

Com esta dor fez-se trevas o meu coração e tudo o que via era morte. E a pátria era para mim um suplício, e a casa paterna uma incrível infelicidade, e tudo aquilo, que com ele partilhara, sem ele se tornara num horrível tormento. De todos os lados, o esperavam os meus olhos, mas ele não aparecia; e eu odiava todas as coisas, porque não o tinham e já não me podiam dizer: "Ele vem aí", como quando estava vivo e se ausentava. Eu próprio me tornara para mim uma questão magna e perguntava a minha à minha alma porque estava triste e porque se perturbava tanto dentro de mim, e ela nada sabia responder-me. E se eu dizia: "Espera em Deus!", com razão ela não acedia, porque era mais real e melhor aquele homem, amigo caríssimo, que eu perdera, do que um fantasma em que a mandava esperar. Só as lágrimas me eram doces e substituíram o meu amigo nas delícias da minha alma. (animus: n.d.r). (Conf. IV, 4, 9; 2004, p.133)

Quo dolore contenebratum est cor meum, et quidquid aspiciebam mors erat. Et erat mihi patria supplicium, et paterna domus mira infelicitas, et quidquid cum illo conmunicaveram, sine illo in cruciatum inmanem verterat. expetebant eum undique oculi mei, et non dabatur: et oderam omnia, quod non haberent eum, nec mihi iam dicere poterant: ecce venit, sicut cum viveret, quando absens erat. factus eram ipse mihi magna quaestio, et interrogabam animam meam, quare tristis esset et quare conturbaret me valde, et nihil noverat respondere mihi. et si dicebam: spera in deum, iuste non obtemperabat, quia verior erat et melior homo, quem carissimum amiserat, quam phantasma, in quod sperare iubebatur. solus fletus erat dulcis mihi et successerat amico meo in deliciis animi mei. (Conf. IV, 4, 9; 2004, p.132)

E como podemos observar, o preenchimento da alma pela dor do luto faz com que a alma se torne um lugar difícil de morar. E mais, dissemos que a alma afeta a vida intencional, mas isso significa dizer que essa afecção não é apenas "interior", mas também "exterior". A final o "mundo circunstante" ou "mundo da vida". A pátria, torna-se "tormento". A casa paterna, que antes era motivo de alegria, torna-se motivo incrível de infelicidade. Aliás, e tudo o que Agostinho tivera em comum com o amigo morto tem o sentido alterado, servindo de estímulo para o despertar de dolorosas lembranças; Então, para tentar fugir de si mesmo, 
resolve ir para Cartago. Mas, pouco adianta: "Para onde fugiria de mim mesmo? Para onde o coração fugiria de si mesmo? Para onde eu não me seguiria? (Conf., IV, 7,12; 2006; p.99)".

E mesmo em Cartago, ele não sentia prazer em mais nada, nem nos bosques amenos, nem nos banquetes faustosos, nem nos prazeres do amor, tampouco nos livros e na poesia. Em outras palavras, era incapaz de extrair prazer de qualquer espécie: “Tudo me era insuportável, até a luz do dia. Tudo o que não era ele, era triste e odioso, exceto os gemidos e as lágrimas, pois somente nisso eu encontrava um pouco de paz". (Conf., IV , 7,12; 2006, p.98) ${ }^{295}$.

A psique, como vimos, possui impulsos obscuros, mas, para sermos mais exatos, deveríamos dizer que a própria alma também os possui. Muitas vezes desconhecemos os nossos próprios valores, desconhecemos aquilo que nos motiva, não prestamos atenção em nossa vida de fundo, a morada do eu intencional. ${ }^{296}$

\subsubsection{O conhecimento de si enquanto indivíduo singular}

A respeito da pessoa humana, podemos distinguir:

1) Constituir-se intuitivamente como pessoa. ( ocorre ao longo da vida, basta nasce e viver em uma sociedade)

2) O conhecimento da essência da pessoa. (ontologia regional, leis apriorísticas).

3) O conhecimento de factuais acerca da pessoa. (psicologia de fatos, conhecimentos indutivos, conhecimentos experimentais, estatatísticos; conhecimentos psicofísicos, medicina, antropologia, etc)

4) opiniões intencionais a respeito do que é a pessoa. (entra aí opiniões com nexos de evidência fracos ou fortes, opiniões motivadas por "argumento de autoridade", crendices religiosas, preconceitos, teorias de fatos mal fundadas sem nexos racionais, teorias verossímeis, etc)

5) Conhecimento pré-reflexivo das qualidades psíquicas. A pessoa pode conhecer suas qualidades ainda que não tenha trazido tal conhecimento à expressão predicativa, tal como um gato conhece sua capacidade de saltar até determinada altura sem que tenha refletido.

\footnotetext{
${ }^{295}$ Omnia et ipsa lux, et quidquid non erat quod ille erat, inprobum et taediosum erat, praeter gemitum et lacrimas: nam in eis solis aliquantula requies. (Conf., IV, 7,12)

296 Veja que a pobreza de nossa linguagem nos força a fazermos malabarismos com as palavras para poder descrever os fenômenos. A riqueza de termos e conceitos usados por Agostinho poderia nos favorecer nesta tarefa. Animus, mens, anima, spiritus, mens.
} 
6) Conhecimento reflexivo de nós mesmos em nossa singularidade. (experiências concordantes, dado em evidências adequadas e suscetíveis ao engano, e qualidades ligadas à intersubjetividade: se vivo em uma cultura onde todos trabalham 16 horas por dia, posso sentir-me preguiçoso por trabalhar "apenas" 14 horas)

Conhecer a nós mesmos em nossa individualidade é algo distinto de conhecermo-nos em nossa estrutura essencial. Um dos aspectos que podemos conhecer de nós mesmos são nossas qualidades psíquicas. Observamos que a psique possui qualidades psíquicas às quais se anunciam em determinadas classes de vivências. Uma análise de nossa individualidade ocorre no sentido de revelar quais nossos traços singulares, disposições, hábitos, dotes, gostos, nossas próprias peculiaridades, em desvelar os nossos motivos psíquicos ocultos, mas também nossos valores de modo clarearmos nossa própria hierarquia de valores. Do mesmo modo como conhecemos nossa estrutura essencial pela análise dos vividos de consciência, conhecemos a nós mesmos, em nossos traços individuais, pela reflexão. Esse aprendizado sobre si se dá pela percepção de nossa vida intencional irrefletida.

A auto-percepção é uma reflexão (reflexão do eu puro sobre si mesmo), e por essência pressupõe uma consciência irrefletida. A vida irrefletida do eu com qualquer tipo de objeto dado, com um mundo circunstante de coisas estranhas ao eu, com um mundo de bens, etc, assume uma forma de todo particular, exatamente aquela da reflexão sobre si mesmo, da percepção de si, a qual é então um modo particular do "eu vivo" no contexto geral da vida do eu. Considerada mais de perto, assume esta forma: eu percebo que percebi isto e isto outro e que continuo a perceber; que isto ou aquilo, embora não mais percebido, suscitava em mim certas apreensões, atraia minha atenção, e ainda atrai, que era movido e ainda sou movido por uma alegria, que tomei uma certa decisão e a mantenho, etc. Através símiles reflexões, eu sei da minha vida egologica irrefletida. (2008, p.681, tradução nossa)

Assim, enquanto estou refletindo, vou colhendo meus vividos na imanência, em uma contínua progressão:

Todavia, quando através estes atos viventes e irreflexos do refletir, me movo para o campo da reflexão (dentro da subjetividade objetivante), experiencio o meu modo de comportar-me nas diversas circunstâncias subjetivas isto é, em relação com a esfera das minhas singulares doações (do meu mundo circunstante em sentido amplo), e quando penetro no emaranhando das motivações do meu cogito, nas intencionalidades abertas e ocultadas das motivações, experiencio o modo no qual sou e uso ser motivado por essas, descubro quais peculiaridades de experiência possuo, em geral, enquanto sujeito motivacional destas circunstâncias motivantes: em outras palavras, qual sujeito pessoal sou. Tudo isso, primeiramente, sem uma fixação conceitual que a acompanha e sem "pensar" (sem "reflexão", em um sentido particular, no sentido de um comportamento constituído de pensamento e de enunciação). Distinguimos portanto da pura reflexão sobre o $e u$, da reflexão sobre o eu puro que é inerente por essência a qualquer cogito, a experiência reflexiva temática efetuada sobre base da apercepção da experiência já 
constituída, cujo objeto intencional é este eu empírico, o eu da intencionalidade empírica, a experiência de si do eu pessoal em relação com estes contextos da experiência no qual este eu pessoal (e portanto em referimento com os atos que ele realiza nas inerentes circunstâncias motivacionais) mostra as suas "peculiaridades pessoais", isto é, as suas propriedades de caráter. (HUSSERL, 2008, p.682, tradução nossa)

Husserl segue dizendo que a reflexão voltada para o interior não exclui, mas sim implica que o homem se apreenda como eu humano nas relações com outros homens.

Uma coisa, portanto, é constituir-se intuitivamente como pessoa, outra é conhecer-se a si mesmo reflexivamente enquanto homem singular, individual, sujeito empírico. Por isso, aos poucos, cada homem vai tomando consciência de si mesmo e sabendo como tende a se comportar em tais circunstâncias, conhecendo suas próprias fraquezas, qualidades, disposições, capacidades. Isso não significa que não possamos ainda desconhecer determinados traços de nós mesmos, que não tenhamos capacidades e propriedades latentes.

O eu pode ter "algo a mais" e pode ser diverso do eu como unidade aperceptiva. Pode ter capacidades latentes (disposições) que não são ainda manifestadas, que não são objetivadas aperceptivamente, tal como uma coisa pode possuir propriedades que não estão à luz em uma apercepção da coisa. (...) Um homem não se "conhece", não "sabe" que coisa é; aprende a conhecer-se. A experiência de si, a apercepção de si se amplia constantemente. $\mathrm{O}$ aprender a conhecer-se é a mesma coisa que o desenvolvimento da apercepção de si, da constituição do "Si", e esta última se realiza de modo unitário com o sujeito mesmo. (HUSSERL, 2008, p.685, tradução nossa)

A constituição intuitiva do eu homem distingue-se da constituição intuitiva do "si mesmo". Esta é uma constituição intuitiva feitas em atos de reflexivos, que, por meio de experiências concordantes, vão revelando modos de se comportar, gostos, inclinações etc. Justamente pelo fato das propriedades do sujeito psíquico serem transcendentes, o conhecimento de si enquanto indivíduo pode estar sujeito ao engano. Em virtude disso, um homem orgulhoso pode ver a si mesmo como modesto; um homem mesquinho pode ver-se a si mesmo como pródigo. Mas o conhecimento de si não diz respeito apenas às disposições das faculdades. Conhecer a si mesmo é conhecer àquilo que nos motiva, os nossos valores, assumir o nosso amor, o nosso ódio, nossas simpatias e antipatias. É possível que alguém sinta inveja e não saiba que a sente. Que sinta antipatia por determinada pessoa e nem pare para pensar que sua antipatia é infundada e se dá por motivos psíquicos ${ }^{297}$. E não há dúvidas

\footnotetext{
${ }^{297}$ O que não significa que devemos “desprezar” nossas antipatias e que elas são totalmente infundas, afinal é possível que esse não "ir com a cara do outro" seja fundamentado em intuição empática. A intuição empática não envolve sentimento; trata-se de um ato intuitivo pelo qual a vivência do outro é dada, embora de modo não originário. Trata-se de uma evidência adequada, cuja confirmação se dá em experiências concordantes. $\mathrm{O}$ ato empático é fundado na percepção do corpo vivo do outro. Vejo que o outro está sentido prazer sem que ele me
} 
de que as trocas intersubjetivas contribuem para constituição do Si. É nas experiências com os outros que, aos poucos, um homem vai se tornando ciente de sua propensão à inveja. Há, também o conhecimento das próprias fraquezas, das preferências, etc:

Tenho minhas valorações individuais, minhas preferências, as minhas tentações, minha capacidade de superar certos grupos de tentações e tenho outras tentações que me são perigosas. Existe, no entanto, um desenvolvimento do si, transformações derivantes das posições dos fins morais. (HUSSERL, 2008, p.687, 2008)

Segundo Agostinho, o animus é incapaz de conhecer determinados aspectos de si mesmo. Agostinho assume que ele não sabe exatamente como ela irá se comportar diante uma circunstância futura. Por isso, quanto a esse ponto, o homem conhece mais a Deus do que a si mesmo. O homem sabe que Deus é inviolável, mas o próprio homem é incapaz de conhecer, examinado a si mesmo, as tentações que poderá ou não resistir.

$\mathrm{Eu}$, porém, ainda que na tua presença me despreze e me considere terra e cinza, contudo sei de ti alguma coisa que de mim ignoro. É certo que agora vemos como por um espelho, em enigma e ainda não face a face; e, por isso, enquanto peregrino longe de ti, estou mais presente a mim do que a ti e, todavia, sei que tu de nenhum modo podes ser ultrajado; eu, porém desconheço a que tentações posso resistir e quais não posso." (Conf. X, 5, 7, 2004, p.447)

O homem não conhece, em muitos casos, as medidas de suas forças. Assim, Deus, conhece mais o homem do que o próprio homem. "Eu poderia esconder-te de mim, mas nunca esconder-me de ti”, confessa Agostinho. (2006, p.269) ${ }^{298}$.

Alguns capítulos adiante no livro $\mathrm{X}$ das Confissões, Agostinho comenta sobre as tentações referentes a cada um dos sentidos. Para isso, procura, por introspecção, examinar o poder que os prazeres de cada um dos sentidos exerce sobre ele. Ao examinar os prazeres do olfato, Agostinho diz não se preocupar, pois é pouco suscetível a eles. E julga a si mesmo preparado para se abster desses prazeres. Mas faz uma interessante ressalva:

diga que está sentido prazer. Pela percepção visual, vejo apenas o corpo, pela intuição empática, vejo o prazer do outro, colocando-me no lugar do outro. Caso o outro seja um inimigo, o prazer que percebo no outro me desagrada. Caso seja um amigo, ficarei feliz. Portanto, empatia não significa sentir o que o outro sente. $\mathrm{O}$ fenômeno do contagio emocional é de outra espécie, embora fundado no ato empático. O ato empático é um ato cognitivo. A dificuldade consiste em saber até que ponto a antipatia é fundada na percepção empática de que o outro é um mal elemento, até que ponto que essa antipatia não é fruto de motivações psíquicas. Por exemplo, associo inconscientemente o rosto de tal pessoa com o rosto de outra pessoa que é mal caráter.

${ }^{298}$ Et tibi quidem, domine, cuius oculis nuda est abyssus humanae conscientiae, quid occultum esset in me, etiamsi nollem confiteri tibi? te enim mihi absconderem, non me tibi. nunc autem quod gemitus meus testis est displicere me mihi, tu refulges et places et amaris et desideraris, ut erubescam de me et abiciam me atque eligam te, et nec tibi nec mihi placeam nisi de te. tibi ergo, domine, manifestus sum, quicumque sim. et quo fructu tibi confitear, dixi. neque id ago verbis carnis et vocibus, sed verbis animae et clamore cogitationis, quem novit auris tua. cum enim malus sum, nihil est aliud confiteri tibi quam displicere mihi; (Conf., X, 2, 2) 
Pelo menos assim me parece. Mas talvez me engane, pois sou envolvido por deploráveis trevas que me escondem as reais capacidades. Assim, quando o meu espírito se interroga sobre as próprias forças, ele julga que não pode confiar facilmente em si, pois o seu íntimo permanece muitas vezes desconhecido, se não o revela a experiência. E ninguém deve sentir-se seguro nesta vida, pois toda ela se chama tentação (Conf., X, 32, 48, 2004, p.307)

forsitan fallar. sunt enim et istae plangendae tenebrae, in quibus me latet facultas mea, quae in me est, ut animus meus de viribus suis ipse se interrogans non facile sibi credendum existimet, quia et quod inest plerumque occultum est, nisi experientia manifestetur, et nemo securus esse debet in ista vita, quae tota temptatio nominatur. (Conf., X, 32, 48).

Portanto, é necessário sempre cuidado com a introspecção. Ela pode fornecer conhecimentos seguros sobre a mente no que se refere à estrutura de sua atividade, quanto ao fato de que ela é sujeito dos atos. Mas no que concerne às outros aspectos dela própria, por exemplo, a medida de suas forças, ela corre o risco de se enganar. Embora conheçamos os nossos desejos, nossas vontades, não é tão fácil conhecer aquilo que se anuncia nestas vivências, ou seja, as qualidades. Por isso, se sinto um desejo pecaminoso, sei reconhecê-lo, mas não é tão fácil saber a que tentação eu possuo forças para resistir. Quando Agostinho diz que não conhece as medidas de sua força, ele está afirmando que existe um limite para o autoconhecimento das propriedades. Quanto a isso, o animus não pode estar tão certo quanto o fato de que ele vive. $\mathrm{O}$ conhecimento das próprias forças implica em estimar como iremos agir em tais e tais circunstâncias futuras. Agostinho narra nas Confissões que seu amigo Alípio, deixando-se arrastar ao circo por seus colegas, acreditava que iria resistir à tentação e não iria se entusiasmar com o espetáculo. Não é o que acontece. A experiência revela aquilo que a introspecção não havia lhe revelado. Sob este aspecto, apenas a experiência é, em última instância, a prova da verdade.

Mas, ainda assim, Agostinho percebe mesmo as experiências são, em alguns casos, difíceis de serem analisadas, no que diz respeito ao fator motivante. Muitas vezes não sabemos ao certo a origem de um sentimento ou de uma vontade. De fato, Agostinho confessa não saber identificar ao certo a origem da alegria que ele sentia ao ser louvado pelas boas ações que ele havia feito. Alegrava-se pela vaidade? Ou alegrava-se pelo fato de que suas ações haviam inspirado exemplos? Certo, seu estado de ânimo é claro, a dificuldade é saber o que o motivou:

Em ti, ó Verdade, compreendo que não é por mim, mas pelo bem do próximo, que devo alegrar-me com os louvores que me dirigem. Mas não sei se me comporto assim. Nesse ponto, eu me conheço menos do que te conheço a ti. Eu te peço, meu Deus, que me reveles a mim mesmo, a fim de que confesse aos meus irmãos, de quem espero orações, as feridas que em 
mim encontrar. Examinar-me-ei de novo, mais diligentemente. (Conf. X, 37, $62)^{299}$

${ }^{299}$ Ecce in te, veritas, video non me laudibus meis propter me, sed propter proximi utilitatem moveri oportere. et utrum ita sim, nescio. Minus mihi de hac re notus sum ipse quam tu. Obsecro te, deus meus, et me ipsum mihi indica, ut confitear oraturis pro me fratribus meis, quod in me saucium conperero. iterum me diligentius interrogem. si utilitate proximi moveor in laudibus meis, cur minus moveor, si quisquam alius iniuste vituperetur quam si ego? cur ea contumelia magis mordeor, quae in me quam quae in alium eadem iniquitate coram me iacitur? an et hoc nescio? etiamne id restat, ut ipse me seducam et verum non faciam coram te in corde et lingua mea? insaniam istam, domine, longe fac a me, ne oleum peccatoris mihi sit os mecum ad inpinguandum caput meum. (Conf. X, 37, 62) 
PARTE III: CONCLUSÃO 


\subsubsection{Husserl e Agostinho}

Em que sentido a descrição agostiniana coincide com a de Husserl? A conexão profunda que une os dois pensadores é o esforço de se obter conhecimentos seguros por meio do exame das próprias experiências. Em outras palavras, o uso dos atos reflexivos como método de conhecimento da essência do homem e mais propriamente do "si mesmo" em sua própria individualidade.

O que caracteriza o "eu" é a absoluta certeza com que ele mostra-se a si mesmo. Não é possível colocar em dúvida sua existência. Agostinho, como Husserl, usou esse argumento para rebater a crítica feita pelos céticos a respeito da possibilidade da verdade. Essa verdade absoluta, entretanto, é dada quando o eu se problematiza, colocando a si mesmo o problema de sua existência. Problematizando a si mesmo, o homem vê que in interiore homine habitat veritas.

Mas então vem a pergunta: o que é esse eu que não pode duvidar de si mesmo? Neste aspecto Husserl e Agostinho aparentemente se separam. Para Agostinho, esse “eu nuclear", indubitável, será a mens, para Husserl será o eu puro, o qual, segundo este autor, não pode ser entendido como o mens sive animus sive intellectus, porque estes são tomados como designando entidades reais, mas a evidência apodíctica do eu nos diz que o "eu" existe, que é um ser, mas não que seja real. O eu puro, para Husserl, é o eu entendido apenas em sua estrutura absolutamente indubitável.

Agostinho, por seu turno, entenderá a mente como uma realidade interior e incorporal. O traço central da mente é a sua capacidade de apreender-se a si mesma, isto é, a reflexividade. Trata-se de uma realidade íntima, capaz de ver os inteligíveis e as imagens provindas dos sentidos e que, não obstante, se relaciona com o corpo e, por meio deste, com o mundo. Para Agostinho, a mens está correlacionada com a anima, mas não se identifica com ela.

Husserl afirma que o eu apercebido como sujeito psíquico é uma realidade dotada de propriedades reais, inclinações, caráter, disposições. Isto implica uma certa dose de transcendência, algo além do eu puro, pois uma qualidade psíquica não se oferece em "carne e osso" à consciência, mas se anuncia em atos de consciência. O que é absolutamente dado são os atos de consciência, os quais, uma vez refletidos, podem revelar as qualidades psíquicas.

Contudo, isso não apresenta grandes dificuldades na comparação entre os dois autores porque a estrutura do eu puro está no sujeito psíquico. Agostinho, como observamos, se dá conta da indubitabilidade de um estado de consciência quando afirma que quem tem uma 
vontade, tem certeza absoluta de tê-la, não podendo nem duvidar de sua existência, nem do conteúdo de sua vontade. Ademais, Agostinho também encontra algumas das estruturas indubitáveis do eu, embora não diferencie com a precisão e a clareza de Husserl o que é dado em evidência apodíctica daquilo que é dado em "experiências concordantes" quando se estuda a essência da psique. Embora tais distinções não estejam claras em Agostinho, elas, não obstante, estão presentes.

De fato, Husserl procura encontrar as condições apriorísticas do eu, isto é, a essência do eu. Agostinho, ao seu modo, também o faz. Logo após observar que o eu é indubitável e que ele se mostra para si mesmo, o bispo de Hipona, para encontrar a substância da mente, adota o seguinte método: descartar todo aquilo que não seja necessário para que o eu seja um eu, deixando apenas aquilo sem o qual o eu não poderia subsistir. Em outras palavras, trata-se de uma investigação apriorística. A absoluta certeza que o eu tem a respeito de si mesmo implica a certeza absoluta que o eu possui vontade, intelecto e memória. Mas não só, pois a certeza que o eu tem de si mesmo exige, como condição de possibilidade, que ele tenha memória de si, inteligência de si, amor a si.

Para Husserl, o eu puro é o sujeito psíquico, compreendido dentro da epoché. A exploração do eu puro é uma etapa metodológica, cuja etapa seguinte é a exploração da essência do sujeito psíquico real. Em certo sentido, Agostinho, por não aplicar o método da redução transcendental, não distingue e elucida com precisão cada um dos passos tomados até se chegar ao sujeito psíquico, tal como Husserl o faz. Contudo, devido ao extremo cuidado com que Agostinho refletiu sobre si mesmo, ele foi levado a constatar aquilo que Husserl deixa claro: a "consciência" não pode ser confundida com "o sujeito psíquico", dotado de propriedades reais. Agostinho sabia que a certeza que o eu tem de si não significava que o eu se conhecesse de modo absoluto em todos os seus aspectos, em sua historicidade, em suas qualidades. A distinção entre consciência e psique, em Husserl, se manifesta em Agostinho pela distinção que este faz entre o olhar do animus e o próprio animus. Afirma que o olhar do animus não pode abarcar o inteiro animus com um só golpe de olhar. Poderíamos ter quatro níveis em que tal distinção se revela.

Primeiro, o animus não pode trazer, a um só tempo, todo conteúdo que está na memória do espírito para diante de seu espírito. Segundo, a atividade do animus não se resume às atividades atuais do animus, as quais ocorrem diante do olhar do espírito. Terceiro, os campos de sensações estão no animus, mas o olhar do espírito pode não estar dirigido para eles. Quarto, as qualidades e as fraquezas, isto é, qualidades do sujeito psíquico, não são 
plenamente transparentes; em muitos casos, apenas a experiência pode revelar se temos ou não certas qualidades que julgamos possuir.

1) O olhar do espírito e o cogito

Para Agostinho, o olhar do espírito, o cogito e a vontade estão estruturalmente ligados. A cogitatio é uma visão da alma (cogitatio visio est animi). Ocorre quando a vontade (intentio voluntatis) une o olhar do animus com um conteúdo, seja este conteúdo verbos interiores com os quais o homem pensa, um objeto sensível, uma experiência passada etc. De modo amplo, tudo aquilo que pode estar diante do olhar do espírito coincide com tudo aquilo de que podemos ter consciência, para dizer numa terminologia posterior. Como vimos, a tradução de cogito por pensamento é insuficiente. Pois ter o olhar do animus informado por um objeto sensível também é compreendido por cogito. A vontade é móvel e, por isso, há o fluxo de cogitationes. "Cedendo ac succedendo trinitates cogitationum."

O que está presente diante do olhar do espírito não coincide com aquilo que está presente no espírito. Em seus traços centrais, o modo como Agostinho entende o olhar do espírito está plenamente em concordância com Husserl, embora a descrição deste último abarque e enriqueça a descrição de Agostinho. Este, por exemplo, não fala de atos intencionais, mas diz que a percepção, a imaginação, a vontade, o entendimento caracterizamse pela participação da intentio voluntatis, que liga o olho da mente ao objeto, ao conteúdo, seja um conteúdo da memória, seja uma realidade sensível. O germe do conceito de intencionalidade já está presente em Agostinho.

2) O olhar do espírito e as qualidades psíquicas

Vimos que um dos motivos que leva Husserl a distinguir o sujeito psíquico da consciência é que as qualidades do sujeito psíquico não se mostram em "carne e osso" para a consciência; pelo contrário, elas se anunciam pelas experiências.

Nas Confissões, Agostinho nota que o animus, embora presente a si mesmo, não se conhece plenamente, pois não conhece suas fraquezas, não sabe ao certo as tentações a que ele conseguirá resistir. "Eu, porém, desconheço a que tentações posso resistir e a quais não posso" (Conf. X, 5, 7, 2004, p.447). Agostinho ainda afirma que é possível que o homem engane, crendo ter capacidades que não possui. Mas algo pode revelar ao homem se ele está enganado ou não em suas capacidades: a experiência. De fato, Agostinho afirma a respeito do 
animus que "o seu íntimo permanece muitas vezes desconhecido, se não o revela a experiência" (2006, p.307).

3) O olhar do espírito e a memória

A distinção entre o olhar do animus e o próprio animus também diz respeito à memória. Nem tudo aquilo que está na memória está diante do olhar do animus. "Mas como a visão da alma não pode abranger com um só olhar tudo o que está retido na memória, as trindades do pensamento se revezam, aproximando-se e retirando-se, alternadamente" (De trinit., XI, 8, 12b; 2005, p.355). Aliás, Agostinho aponta que é justamente por isso que Deus não pensa em si mesmo, pois, caso o fizesse, Deus seria mutável, pois o ato de pensar implica fluxo, o transcorrer dos pensamentos, o que não é possível para Deus.

É neste quadro que se deve entender a distinção entre pensar em si e conhecer a si. Como Agostinho diz, a mente de uma criança se conhece, mas não sabe que se conhece. Mas que conhecimento é esse? Observamos que, neste caso, não se trata do "conhecimento de si" relativo às qualidades, disposições, inclinações, caráter, história de vida. Trata-se, isto sim, de um puro conhecimento de si, o simples conhecimento de saber que se é uma presença de si para si, uma presença que acompanha toda a vida do eu. Havíamos visto que a certeza de existir leva à conclusão de que a mente ama a si, entende a si e tem memória de si e está sempre presente a si. E esse "conhecimento puro", por assim dizer, não é um conhecimento das capacidades, das disposições. É um conhecimento estrutural, que permanece e, sem o qual, o eu não poderia subsistir.

4) O olhar do espírito e o amor.

Nossas análises sobre este conhecimento puro que o espírito tem de si nos levou à questão seguinte: Como é possível que a mente ame a si mesma sem que este amor não esteja diante do olhar do espírito? É justamente aí que se evidencia que a vida e as atividades do animus ultrapassam as atividades que ocorrem diante do olhar do animus. Isso se mostrou muito significativo, pois fora do olhar do espírito não se encontram apenas conteúdos guardados na memória, mas atividades que estão vivas, ainda que o olhar do animus não lance a elas a luz da consciência. O amor não deixa de estar vivo quando o homem não presta atenção nele. Algumas vezes a vontade está viva, influenciando as direções do olhar, sem que o espírito a note. O homem não deixa de amar Deus apenas porque não está pensando nele. Embora o amor a Deus não possa sempre estar diante do olhar do espírito, basta que o homem 
volte seu olhar para ele e constate que o amor já estava ali. E, por outro lado, mesmo não tendo o olho do espírito para aí dirigido, o amor se faz presente, influenciando a vida do espírito em diversos níveis. E, do mesmo modo, o amor às coisas terrenas também influencia o homem. Aí está um dos pontos mais interessante do pensamento de Agostinho: intentio pode "escorregar" sutilmente para pensamentos maus, com os quais o homem se deleita, sem que seu senso crítico, num ato reflexivo, recrimine-os. $\mathrm{O}$ espírito tem uma propensão de não refletir e de se projetar para fora e "esquecer-se de si mesmo" e de seus próprios valores. A vontade carnal tem, por assim dizer, o poder de hipnotizar a atenção. De fato, a atenção está ligada à vontade. A vontade espiritual tem um forte caráter reflexivo, já a vontade carnal tem como traço o "projetar o eu para fora", "foras se nostra proicit intentio”. (De trinit., XI, 1, 1)

Amamos até mesmo sem perceber que amamos. O amor nos rouba a atenção, exige nossa atenção, exige que executemos planos para alcançá-lo. Por isso, não raro, a mente está ocupada com os meios para se conseguir aquilo que quer sem refletir, a fim de avaliar, o próprio querer. Nossa vida, a direção de nossos pensamentos, de nossa imaginação, de modo geral, são regidos pelo amor. Quem ama Deus ama o amor. Por outro lado, quando o amor está disperso, projetado no múltiplo, naquilo que não tem ordem e permanência, o espírito também está disperso e sem unidade. Se o homem não sabe ao certo o que amar, seu espírito está sujeito a se entregar mais facilmente ao ódio, à inveja e vingança, à crueldade, à lascívia, à gula, à vaidade, apegando-se facilmente a tudo o que seja simplesmente prazeroso. $\mathrm{O}$ amor sem estrutura desestrutura o espírito, retira-lhe a unidade.

5) O olhar do espírito e as sensações

Para Husserl, a percepção é diferente da sensação justamente pelo fato de que a percepção é um ato intencional e, por isso, espiritual, no qual o olhar do espírito lança um raio de consciência ao objeto ${ }^{300}$.

\footnotetext{
300 “Atenção da alma, que retém o sentido no objeto percebido e enlaça a ambos, não é apenas diferente desse objeto em sua natureza ( pois a atenção é espiritual e o objeto corporal). A atenção também é diversa do próprio sentido da visão. Pois a atenção é função apenas da alma, enquanto o sentido dos olhos recebe o nome de sentido corporal precisamente porque os olhos são partes do corpo. E embora um corpo sem vida não tenha sensações, alma, no então, unida ao corpo sente através de um instrumento corporal, instrumento esse chamado de sentido" (De trinit.,, XI, 2, 2; 2005, p. 338)
}

Itemque illa animi intentio quae in ea re quam uidemus sensum tenet atque utrumque coniungit non tantum ab ea re uisibili natura differt quandoquidem iste animus, illud corpus est, sed ab ipso quoque sensu atque uisione quoniam solius animi est haec intentio. Sensus autem oculorum non ob aliud sensus corporis dicitur nisi quia et ipsi oculi membra sunt corporis, et quamuis non sentiat corpus exanime, anima tamen commixta corpori per instrumentum sentit corporeum et idem instrumentum sensus uocatur. (De trinit., XI, 2, 2) 
Para Agostinho, a intentio animi é exclusiva do animus ou mens. A anima por seu turno é misturada ao corpo. “(...) anima tamen commixta corpori” (De trinit., XI, 2, 2) Apenas o homem é dotado de mens e animus, já os animais contam apenas com anima, o princípio vital, faltando-lhes o olho do espírito, que também pode ser denominado olhar da inteligência. Para Agostinho, como vimos, a atenção (intentio) é necessária para que haja a percepção. É ela que liga o olho do espírito à coisa vista.

No homem, a atenção está ligada à vontade, a qual está imbricada com a inteligência e a memória. Quando a atenção da vontade se lança ao mundo sensível, a memória e a inteligência para aí se dirigem. E o objeto no qual a atenção da vontade se aplica informa o olhar do espírito.

Mas, como observamos, o olhar do espírito pode estar "desligado" dos campos de sensações. O eu é um ser que está mergulhado no presente e, por isso, está envolto pelos campos de sensações, incluindo aí sensações como a dor. Mas isso não significa que o eu esteja, a todo instante, projetado nas sensações imediatas. Agostinho, em certas passagens, comenta que para que pensemos "as coisas ausentes" é necessária uma abstenção do mundo das sensações imediatas ${ }^{301}$. Para que a visão efetivamente ocorra é necessário que o olhar do espírito esteja dirigido para o mundo dos sentidos. Por outro lado, mesmo que o olhar do espírito não esteja aplicado ao mundo dos sentidos, isso não significa que os sentidos não estejam sendo informados pelas coisas corporais, significa apenas que a nossa vontade (intentio voluntatis) para aí não está dirigida. Agostinho usa o exemplo de alguém que fala conosco e, ainda assim, "não escutamos". Na verdade, afirma ele, escutamos sim, mas a fala apenas escorrega pelos sentidos, sem penetrar no espírito, pois a vontade para lá não estava dirigida. E, por isso, nossa mente não foi informada pelas sensações.

Há algo semelhante na descrição de Husserl, ${ }^{302}$ para quem o momento noético está relacionado com os diferentes direcionamentos do olhar do espírito. Essa coincidência não é de modo algum fortuita. Repousa na semelhança do ponto de partida adotado por ambos. O eu conhece-se a si mesmo por atos reflexivos. E quem não viveu a experiência de não prestar atenção quando alguém lhe dirige a palavra?

\footnotetext{
${ }^{301}$ E para isso, é preciso que as sensações estejam em um grau de conforto. Agostinho reclama que, em virtude de sua dor de dente, não conseguia aprender nada de novo.

302 Ora, faz parte dessa essência que certas modificações do vivido originário sejam possíveis, modificações que designamos como livre mudança do "olhar" - não exatamente e meramente do olhar físico, mas "do olhar espírito" -, do papel visto primeiro de modo originário para os objetos que antes já apareciam, objetos, portanto, de que se estava implicitamente consciente, os quais, após a mudança do olhar, se tornam explícitos para a consciência, são percebidos “com atenção" ou "notados concomitantemente”. (HUSSERL, 2006, p.87)
} 
Analisando a percepção em Agostinho, pudemos observar que ele, muitas vezes, é incapaz de articular a certeza da substância da mente com a realidade corporal exterior a esta. Há, em Agostinho, traços do que Husserl denomina "realismo ingênuo". Algumas vezes, Agostinho diz que a visão ocorre quando a vontade une o sentido à realidade sensível e enlaça a ambos. Mas tal explicação parece inapropriada, afinal: como a vontade "descobriu" no mundo real a coisa para informar os sentidos? Como a vontade é capaz de unir um real com os sentidos? Em outros momentos, Agostinho modifica os termos e afirma, o que parece mais apropriado, que é a intentio voluntatis que mantém o sentido no objeto. Em outros fragmentos, Agostinho afirma que a imagem do objeto no sentido é diferente da imagem do próprio objeto. Mas como ele sabe que a imagem tem um correspondente na realidade? Ele apenas nos diz que é a razão que nos informa. Ademais, ele não explica o dilema apresentado por Plotino: como a imagem vista do objeto parece distante do sujeito que vê. Como é possível que haja um espaço separando o objeto visto do sujeito que vê? Se a imagem estivesse no sentido, seria impossível que víssemos uma cosia ao longe. Em Husserl haverá uma espécie de síntese entre as concepções de Plotino e de Agostinho acerca da percepção.

Em algumas passagens, Agostinho descreve o animus como englobando a anima e a mens. Observamos que os sentidos estão presentes, mas o olhar da atenção pode não estar dirigido aos sentidos. Mas essa mesma estrutura é válida também para uma dor de dentes. Agostinho lamenta que, em virtude de sua dor de dentes, ele tinha dificuldade de se ocupar com o estudo, pois sua dor roubava-lhe a atenção constantemente, impedindo-o de aprender coisas novas. Todavia, mesmo quando ele não dirige o olhar de seu espírito para a dor, a dor não deixa de se encontrar presente no animus. É possível entrever aí a distinção entre o momentos noéticos e os momentos hiléticos, exposto por Husserl.

\section{6) A vontade e a reflexão}

Uma das consequências mais interessantes da vinculação entre o olhar do espírito e a vontade é que, a mente, para refletir, tem que querer refletir, tem que ser instigada a refletir. Pensar em si ocorre com a condição de querer pensar em si, afinal o cogito ocorre quando a vontade coloca um objeto diante do olhar da mente para informá-lo. Mas a vontade não é cega, pois está imbricada com a inteligência e a memória.

Havíamos dito que Husserl distingue o espírito em senso estrito, que é livre, do espírito em senso lato, que abrange toda a vida intencional do eu, incluindo os atos passivos que “emergem" em sua vida espontânea. Poderíamos encontrar algo semelhante em Agostinho? 
Lembremo-nos do capítulo VIII das Confissões, quando fala de duas vontades em conflito: uma espiritual e outra carnal. Ao contrário do maniqueísmo, Agostinho assume essas duas vontades como dele, como "suas vontades". Entende que o eu está em ambas, que não pode considerar a vontade carnal como exterior a si, o que exige que ele se responsabilize por ela. Justamente por isso, ele sofre. Sofre porque a vontade, fortalecida pelo hábito, havia se tornado "férrea". Entretanto, ele sente que o eu estava mais próximo da vontade que aprovava do que da vontade que desaprovava. Ora, não estava sob o poder da vontade espiritual extinguir a vontade carnal. Mas por que Agostinho considera que a vontade espiritual é "mais dele" do que a outra vontade, se ambas as vontades são dele? Como havíamos observado, a vontade carnal está ligada à carne e esta, por seu turno, exerce influxos sobre a vida intencional do eu. Já a vontade espiritual estava ligada a um valor que ele considerava mais alto. Em outras palavras, agir de acordo com a vontade carnal é agir incoerentemente com a escala de valores estabelecida pelo eu reflexivo, pelo "eu central", pelo eu racional.

Havíamos observado que Husserl entende que não está sob o poder do eu sentir ou não sentir um desejo que nasce, mas está ao poder do eu colocar-se contra o desejo autônomo. O desejo, embora seja um ato intencional e vivido pelo eu, afunda sua raiz na psique, em um estado vital, e, ademais, está ligado ao próprio hábito, que cria a disposição. Para Agostinho, a vontade carnal, embora pertença à mens, ao animus, tem sua raiz na carne, nas leis dos membros, fruto do pecado de Adão. Daí o termo aparentemente ambíguo usado por Agostinho: "vontade carnal". O próprio termo já diz que a "vontade" não deve ser entendida apenas como apetite racional, tal como concebia a tradição clássica. De fato, agir de acordo com essa "vontade carnal" resultaria em ferir os seus valores mais altos. Está em "seu poder" opor-se à vontade carnal, mas não necessariamente está em seu poder vencer a vontade carnal. A vontade espiritual é livre, a vontade carnal não. Entretanto, é a vontade que faz mover o corpo, seja a vontade espiritual, seja a vontade carnal.

Mas dizer que a vontade espiritual é livre não significa dizer que essa vontade seja imotivada. Pelo contrário, o que caracteriza o eu livre é que ele é motivado racionalmente.

Husserl nos fornece a chave para a compreensão quando ele aponta que, por racionalidade, não devemos entender apenas a racionalidade do sujeito lógico, mas também a racionalidade prática. Se a vontade fosse plenamente livre, isso significaria que a vontade não teria logos, seria errática, seria caótica, sem nenhuma lei. Tal situação é impossível. Em certo sentido, sou livre para escolher entre duas opções a pior delas, mas não faz sentido, é irracional escolher a que julgo pior. Sou livre para decepar as minhas mãos, mas evidentemente não irei fazê-lo, pois não há motivo algum para realizá-lo. A questão é que, em 
alguns casos, os motivos são irracionais, as tendências cegas nos induzem a fazer algo que consideramos que é pior. Os estudos de Husserl de lógica formal apontam que a culpa e a má consciência não são o resultado nefasto da moralidade cristã, mas sim o resultado de trair-se a si mesmo, trair e ferir aquilo que amamos e que damos mais valor em virtude de algo que amamos menos e damos menos valor. A culpa não é, neste sentido, um sentimento psíquico, mas um sentimento da alma, um sentimento existencial, por assim dizer. Quando agimos de acordo com a razão, sentimos que agimos livremente. Ninguém me obriga a concluir que eu existo; sou livre para afirmar aos outros que eu não existo, em princípio, sou livre para crer que eu não existo. Todavia, quando eu afirmo que eu existo, não faço isso como quem é forçado a admitir isso; constato de bom grado porque vejo que é assim. Do mesmo modo, ninguém me obriga a concluir que se $\mathrm{A}=\mathrm{B}$ e $\mathrm{B}=\mathrm{C}$, então $\mathrm{A}=\mathrm{C}$. Eu concluo porque "quero". É difícil não querer concluir isso, pois fui motivado racionalmente. Há uma forte ligação entre a vontade, a razão e a verdade. Quem conclui baseado em uma evidência, conclui livremente. Talvez alguém seja capaz de negar, para outras pessoas, algo dado em evidência, mas nesse caso terá a consciência de que está mentindo e mente porque quer, mas não pode forçar-se a se convencer de que fala a verdade. O eu não é capaz de negar, para si mesmo, a evidência, a não ser que seja por outra evidência ainda mais forte, ou por motivos psíquicos poderosos. A vontade espiritual, do eu central, está ligada à razão. Quando agimos com a consciência de que estamos fazendo o melhor porque "vemos" que é melhor, agimos de acordo com nós mesmos. Por outro lado, uma tendência pode ser violenta o suficiente para "nos arrastar", a tal ponto que, mesmo sabendo que ela é pior, agimos de acordo com ela. A vontade o desejo são meus, não se pode negar. Mas, neste caso, sentimos nossa impotência; não experienciamos que estamos agindo em nossa liberdade.

Agir de acordo com o que é melhor significa que agimos de acordo com o que julgamos que é melhor, o que não significa que, posteriormente, tomemos consciência de que estávamos enganados, que aquilo não era o melhor a se ter feito. E mais, não significa que o que é melhor para um seja melhor para outro. Mas a estrutura do agir de "acordo com o que é melhor" faz parte tanto de uma pessoa, quanto de outra, ou seja, faz parte do sujeito racional. E é essa vontade do espírito em senso estrito, do eu central, que se caracteriza pela liberdade. Não é difícil notar que esse agir livre implica, muitas vezes, o eu reflexivo, pois as escolhas e as decisões implicam avaliar as tendências da vida espontânea irrefletida do eu.

Muitas vezes a vontade espiritual, que visa ao que é melhor, choca-se com outras tendências oriundas do hábito e da psique. E como Agostinho faz notar, o conflito dilacera o eu, atormenta, tira a paz. 
Como vimos, Agostinho nega as colocações de Pelágio, o qual afirmava que a vontade é livre, no sentido de que está ao nosso alcance fazer aquilo que julgamos melhor, em conformidade com o eu reflexivo, racional e ético. Para Agostinho, a vontade do eu reflexivo, que avalia e julga conforme determinados valores estabelecidos, não é uma vontade toda poderosa. Por outro lado, o mesmo Agostinho afirma que não podemos dizer que a vontade não seja livre. O fato é que, para ele, ao lado de uma vontade livre existe também uma vontade que o arrasta a fazer aquilo que o eu reflexivo julga pior, de tal forma que ele faz querendo o que não quer fazer. Só resta ao homem pedir a Deus para que lhe dê amor para que $\mathrm{O}$ ame com mais intensidade, pois, quanto mais o homem amar Deus, mais sua vontade espiritual será fortalecida.

Interessante notar que o conflito entre a vontade carnal e a vontade espiritual é experimentado com toda intensidade logo após a conversão intelectual de Agostinho, quando ele começa a sentir a vida cristã como um valor. Sua vontade espiritual tem como escopo elevar-se a uma vida contemplativa, no qual se contempla a unidade, a sabedoria, a beleza, o bem. E toda a vida prática, para Agostinho, deve estar subordinada e deve ser referida à vida contemplativa, pois o fim último da vida é a felicidade.

O homem, tal como acontece com todo ser dotado de corpo, é transitório. Por outro lado, o homem poder ver, com os olhos da inteligência, as regras eternas, contemplando o bem supremo, repousando aí a vontade. E essa abertura a Deus revela que o homem vive, em si, a tensão oriunda de seu amor pelo eterno e pelo transitório, pela unidade e pela multiplicidade, projetando-se para fora e retornando para dentro e para o alto. Mas o amor pela criação não é, em si, um mal. O mal está na desordem do amor, na inversão da hierarquia dos objetos amados. A chave da vida é a "Ordo amoris". Estruturando o nosso amor, estruturamos a nossa vida. Tudo o que foi criado por Deus é digno de amor, desde que amado em sua justa medida. Aliás, esse é o problema: a criação é tão boa que esquecemos o criador. Todavia, só o amor pelo eterno pode estruturar o amor pelo que é transitório. A vontade só pode repousar naquilo que é o supremo bem, no que é eterno e imutável. Trata-se, em certo sentido, de uma concepção formal de ética: a vida só adquire unidade e estabilidade se nós amamos o que é eterno e o que nunca nos abandona. 


\subsubsection{Conclusão}

Ao longo desta tese procuramos mostrar, implícita ou explicitamente, a importância dos atos reflexivos para o conhecimento de si próprio. A reflexão é um método para a obtenção de conhecimentos seguros sobre o sujeito psíquico, caso seja usada adequadamente e sem extrapolar os seus limites. Os atos reflexivos fornecem como dado básico as próprias vivências. E é analisando-as que se inicia a exploração do sujeito psíquico. Como vimos, a tarefa é observar as diferentes classes de vividos: os vividos ligados à constituição do corpo próprio, os vividos ligados à psique e os vividos propriamente espirituais.

Um dos traços que marcam o pensamento de Agostinho é o de seu pensamento se sustentar em suas próprias experiências. Trata-se de uma filosofia feita em primeira pessoa e seu esforço, muitas vezes, consiste em procurar explorar o que está implícito em suas próprias experiências. Qual a distinção entre o modo como ele vive a vontade carnal do modo como ele vive a vontade espiritual? O que a experiência de uma dor de dente nos ensina? Como é possível escutarmos alguém e ainda assim não escutar? Como é possível querer conhecer o que se desconhece? O que a morte de seu amigo pode lhe ensinar? Como é possível que pensemos em ideias como números, forma, essência? Como é possível conhecer o esquecimento?

Como procuramos observar, o pensamento de Agostinho se sustenta em suas próprias experiências, aceitando-as tal como são dadas. Vimos até mesmo que Agostinho refuta Pelágio fundamentando-se em suas experiências pessoais, assumindo que ele havia vivido a mesma experiência de Paulo: sua impotência de seguir à risca a vontade espiritual. É com o coração dilacerado que ele constata, não por vias dedutivas, mas aceitando suas próprias experiências, que, algumas vezes, ele era incapaz de fazer aquilo que julgava melhor.

Ao focar e analisar suas próprias experiências em seu texto, Agostinho parece muito próximo a nós, apesar dos séculos. Os sistemas metafísicos variam, as crenças igualmente, mas algumas das experiências básicas humanas continuam: a dor, o medo, a ansiedade, a inveja, o amor, o desejo, o luto, a angustia diante da morte. Aceitar as próprias experiências, respeitá-las, descrevê-las tal como elas são vividas implica colocar-se como pessoa. O significado de colocar-se como pessoa é não só importante para a psicologia, mas para nós mesmos. É antes de tudo a pessoa de Agostinho que nos toca, seu esforço em desvendar e escrever a sua história, em suma, seu esforço de conhecer a si mesmo como pessoa. Isso vale ainda para nós, pois Agostinho, em certo sentido, nos ensina a respeitar nossas experiências, 
nos ensina que, quando o assunto é o eu, é preciso, como diz Husserl, estarmos em nossa orientação pessoal, e não em orientação naturalística.

Talvez uma das grandes vantagens do método reflexivo é que, tendo como objeto nossas próprias experiências, pauta-se em um grande respeito a nós mesmos. Isso porque o método nos revela que, embora soframos influxos psíquicos e tenhamos vivências intencionais vinculadas à psique, também vivemos em correlação ao mundo da vida, com todas as unidades de sentido constituídas intuitiva e intersubjetivamente. E nosso espírito, caracterizado pela intencionalidade, está sempre vinculado a um mundo que não é um mundo de "meras coisas", mas um mundo que é correlato do espírito, um mundo de sentido, com obras de arte, objetos de valores, no qual pertencemos a uma família, a uma sociedade, a uma comunidade. Como vimos, não é possível compreendermos o sujeito psíquico sem levar em consideração seus posicionamentos perante as unidades de sentido constituídas intuitivamente e que formam o seu mundo circunstante. Ademais, apreendemos a nós mesmos como sujeitos racionais, como sujeito ético, responsável pelos nossos próprios atos, mas também dotado de uma camada animal, fisiológica, psicofísica.

A análise reflexiva das experiências, feita por Husserl e por Agostinho, cada qual ao seu modo, talvez seja um dos pontos mais importantes que tais autores tenham a contribuir para a psicologia. Isso porque muitas teorias não são fundamentadas nas descrições das vivências, mas, pelo contrário, se sustentam em princípios que fecham a possibilidade de qualquer outro método que não o método experimental-indutivo. Assim, muitos psicólogos tomam como ponto de partida o determinismo; tomam como ponto de partida a preconcepção de que a razão é nada mais do que um mecanismo evolutivo, que o ser humano é uma máquina associativa, que a consciência é um epifenômeno. Qual o interesse em analisar um epifenômeno? Colocar-se a si mesmo como epifenômeno é negar a orientação pessoal. Não se trata de desqualificar os resultados que os cientistas alcançaram partindo destes outros princípios. O que importa, para nós, é mostrar que é possível se elaborar uma ciência que parte da consciência para explorar a constituição intuitiva do eu-pessoal. E, embora assuma que exista uma estrutura apriorística do eu, ela, por outro lado, revela que o eu pessoal não pode ser devidamente compreendido sem se levar em conta o mundo da vida do sujeito, no qual muitas das unidades de sentido são constituídas intersubjetivamente. Nesse sentido, a fenomenologia pode oferecer ferramentas para uma abordagem histórica das pessoas que viveram em diferentes tempos, em diferentes culturas.

Dentro desta perspectiva, suas investigações sobre o espírito foram motivadas em grande parte pelos seus valores e por suas crenças, sobretudo pelo fato de o cristianismo 
defender a realidade individual do espírito humano e pelo fato de Deus não estar no Cosmos, mas no fundo do espírito. Não há nada mais importante do que cuidar do próprio espírito, colocá-lo em sua direção correta, conhecê-lo para dominá-lo.

Nossas próprias experiências podem nos ensinar sobre nós mesmos. Dentro dessa chave, poderíamos até mesmo dizer que um dos papéis da psicoterapia seria o de auxilar o paciente a refletir adequadamente sobre si mesmo, pois, como Husserl afirma, constituir-se como pessoa é diferente de constituir-se como um "Si". A constituição do si é feita por atos reflexivos e o homem aprende a se conhecer.

Seguindo esta ordem de ideias, tomando como princípio a análise das vivências, a aceitação de que nossa vida psíquica em sua inteireza é "causada" implica que neguemos a nós mesmos, que não aceitemos as nossas próprias experiências. Para entender o caráter motivacional é preciso compreender o nosso mundo circunstante, nossa cultura, nossas opiniões, nossas crenças, nossos valores e até mesmo nossas experiências religiosas. E o mundo me motiva não pelos estímulos materiais, mas pelo significado que as coisas têm para $\operatorname{mim}$.

A fenomenologia permite articular e coordenar os diferentes estratos do ser humano. Uma pessoa é alguém que faz lógica, matemática, é um sujeito ético, um sujeito cultural, um homem que faz obras de arte e pertence a uma comunidade, mas que também é um animal, um corpo material.

A fenomenologia tem no horizonte um vasto projeto, o qual foi seguido por muitos outros filósofos depois de Husserl. Nunca é demais destacar que ela não visa à construção de uma "psicologia de fatos", mas apenas a clarear a essência do sujeito psíquico. Tem como intuito demarcar os territórios do eu pessoal, de modo a fornecer os alicerces para a construção das "psicologias de fatos". A idéia de Husserl era que o psicólogo saiba justificar absolutamente todos os passos e conheça, até a raiz intuitiva, os conceitos empregados, que tenha plenamente claros seus princípios, seus métodos e as fronteiras de seu domínio. Nossa vida pessoal se fundamenta nas unidades de sentido que constituímos intuitivamente. Uma coisa é conhecer a fisiologia do homem, outra coisa é conhecer como o sentido "eu-homem" é constituído intuitivamente.

E clarear esses sentidos nos permite evitar muitas confusões, dentre as quais a redução do sujeito moral aos instintos, a redução da lógica à psicologia, a redução da vida do espírito à fisiologia, a redução do espírito à psique. Clareando os diferentes estratos e as diferentes classes de vivências, a psicologia poderia, segundo Husserl, sustentar-se em alicerces mais 
sólidos, ou seja, em leis apriorísticas. Assim, a psicanálise teria o seu domínio de aplicação, bem como a psicofísica, a antropologia, o comportamentalismo, e mesmo o estudo da história da psicologia e da mentalidade. Cada uma dessas ciências são bem vindas, desde que respeitem a pessoa humana e suas experiências.

A dificuldade é que essas diferentes regiões ontológicas às quais o homem está ligado só podem ser articuladas por uma filosofia que tenha como escopo os princípios supremos do conhecimento e tenha como objeto "tudo quanto há". O projeto de Husserl, sem dúvida, é grandioso. Mas sua honestidade intelectual o levou a praticá-lo. É um defensor fervoroso da razão e da racionalidade. Mas o amor à razão e à verdade não é algo exclusivo de Husserl, pois, para ele, tal como apontou em Crise das ciências europeias e a fenomenologia transcendental, tais valores sempre estiveram no horizonte do Ocidente. As tragédias do século XX não revelaram a impotência da razão como quiseram alguns críticos, mas, pelo contrário, revelaram o poder que têm o mal uso da razão, a substituição da razão pela técnica, a redução do homem como uma peça dentro da engrenagem do estado, a redução da razão a um razão positivista, que não é autenticamente uma razão, mas seu aprisionamento e seu estreitamento.

Com esta tese procuramos resgatar e defender a tradição da reflexão como método para o conhecimento de si. Por outro lado, procuramos também mostrar que não é possível compreender o ser humano sem levar em conta o seu mundo circunstante espiritual, suas crenças, seus valores, suas opiniões, suas experiências pessoais. Por isso, embora tenhamos encontrado muitas semelhanças entre Husserl e Agostinho, também foram elucidadas diferenças fundamentais, sobretudo no que diz respeito às motivações de cada autor para a exploração das experiências. Procuramos observar como a maneira pela qual Agostinho analisa suas experiências está intimamente ligada às suas concepções sobre Deus como um ser espiritual, sobre a imortalidade do espírito, com a prática das confissões. No que diz respeito a Husserl, procuramos observar como as suas experiências de matemático e lógico foram decisivas na maneira como ele procurou abordar a psicologia, de modo a não querer reduzir o sujeito lógico ao nível psíquico, assim como a lógica não poderia ser reduzida à psique. 


\section{REFERÊNCIAS}

AGOSTINHO, S. Confissões. São Paulo: Paulus, 3 ed, 2006.

Confessioni, 4 vols. Edição bilíngüe latim; italiano. Trad. Gioacchino Chiarini. Milano: Arnaldo Mondadori, 1994.

Confissões. Tradução de J. Oliveira, SJ., e A. Ambrósio de Pina, S.J. São Paulo: Nova Cultural, 1999.

Confissões. Edição bilíngue latim; português. Tradução e notas de Arnaldo do Espírito Santo, João Beato e Maria Cristina de Castro-Maia de Sousa Pimentel. $2^{\mathrm{a}}$. ed. Lisboa: Imprensa nacional-casa da moeda, 2004.

. Solilóquios. Trad. Adaury Fiorotti. São Paulo: Paulus, 2007a.

. A vida feliz. Trad. Ir, Nair de Assis Oliveira. São Paulo: Paulus, 2007b.

. A Trindade. Tradução Agustinho Belmonte. 3. ed. São Paulo: Paulus, 2005.

. Obras completas de San Agustin (Bispo Hipona); Trad. de Santos Santamarta

Del Rio e Miguel Fuertes Lanero. 4. ed. Madrid : Católica, 1988.

. Sobre a Potencialidade da Alma. (De quantitate animae). Tradução de Aloysio Jansen de Faria. Petrópolis: Vozes, 2005.

.Santo Agostino, tutte le opere. 2009. Disponível em http://www.augustinus.it/italiano/trinita/index.htm. Retirado em 09 /10 /2010.

. O livre Arbítrio. Tradução Nair de Assis Oliveira. São Paulo: Paulus, 1995.

ABBAGNANO, Nicola. Dicionario de Filosofia. São Paulo: Martins Fontes, 2007.

Storia della Filosofia. Vol.1. Milano: UTET. Libreria. 2009.

ALASUUTARI, P. The discursive Construction of Personality. In: Amia Lieblich and Ruthellen Josselson (eds): The Narrative Study of Lives Vol. 5. Newbury Park, California: Sage, 1997, 1-20.

ARIÈS, P.; DUBY G, (Orgs.). História da vida privada. 5 vol. São Paulo: Companhia das Letras, 1991.

ARISTÓTELES. De Anima. Trad. e notas de Maria Cecília Gomes dos Reis. São Paulo: Editora 34, 2006.

ARISTÓTELES. Ética a Nicômaco. Trad. Pietro Nassetti. São Paulo: Martin Claret, 2007.

ARENDT, H. A vida do espírito. Trad. Antônio Augusto de Almeida, Antônio Abranches e Helena Martins. Rio de Janeiro: Civilização Brasileira, 2009. 
BACHELARD, Gaston. A Poética do Espaço. Traduzido por Joaquim José Moura Ramos. São Paulo: Abril Cultural, 1984.

BELLO, A.A. Fenomenologia e Ciências Humanas. Bauru, SP: EDUSC, 2004. . Culturas e Religiões: Uma leitura fenomenológica. Bauru, SP:EDUSC, 1998.

BERKElEy. G. Treatise Concerning the Principles of Human Knowledge. Chigago: Ecyclopedia Britannica, 1952.

BRETT, G. S. História de la psicología. Trad por D. A. Sampietro. Buenos Aires: Paidós, 1963.

BROWN, P. R. L. Agostinho: uma biografia. Trad. Vera Ribeiro. São Paulo: Record, 2000. Primeira edição 1967.

BROZEK, J; MASSIMI, M. De Animorum Medicamentis. Un testo significativo per la storia delle idee psicologiche del secolo XV. Teorie e Modelli. Bologna, v. 6, n. 3, p. 27-46, 2002.

BROZEK, J. e MASSIMI, M. (ed.). Curso de Introdução à Historiografia da Psicologia: Apontamentos para um Curso Breve. Memorandum, abril de 2002, 2, 103-109. Disponível em http://www.fafich.ufmg.br/ memorandum/artigos02/brozek02.htm. Retirado em 6/9/2006.

BRUSS, Elisabeth. Autobiographical acts: the changing situation of literay genre. Baltimore, John Hopkins University Press, 1976.

BURKE, Peter. Montaigne. São Paulo: Loyola, 2006.

CALLIGARIS, Contardo. Verdades autobiográficas e diários íntimos. Estudos históricos, Rio de Janeiro: FGV, vol. 11, n. 21, 1998. Disponível em: http://www.cpdoc.fgv.br/revista/asp/dsp_edicao.asp?cd_edi=39. Acesso em: 20 de outubro de 2006.

CAMPOS, J.A S. Introdução às Cartas a Lucílio. In: SÊNECA, L.A. Cartas a Lucílio. 2.ed, Lisboa: Fundação Calouste Gulbenkian, 2004. p.V-LIV.

CARPEUX, Otto Maria. História da Literatura Ocidental. 9. vol. Rio de Janeiro: O cruzeiro, 1959.

CHÂTEAU J. As grandes psicologias da Antigüidade. ( trad. A. Gonçalves.). Lisboa: Publicações Europa-América, 1978.

COSTA, V. Husserl. Roma: Carocci editore, 2010. 
CUNHA, Mariana Palozzi Sérvulo da. O movimento da alma: a invenção por Agostinho do conceito de vontade. Porto Alegre: EDIPUCRS, 2001.

DE CERTEAU, Michel. A invenção do cotidiano 1. Artes de Fazer. Petrópolis: Vozes, 1997.

DE MAN, Paul: Autobiography as de-facement. In:__. The rhetoric of Romanticism. New York: Seabury 1979. p.67-81.

DESCARTES, Discurso do método. In: O pensamento vivo de Descartes. Tradução. Maria de Lourdes Teixeira. Apresentado por Paul Valéry. São Paulo: Livraria Martins editora, 1975.

DILTHEY, W. Teoría de las concepciones del mundo. traducción del alemán y comentario de Julian Marías. Madrid: Revista de Occidente, 1944.

. Introducción a las ciencias del espíritu. Mexico: Cultura Economica, 1949.

Psicología y teoría del conocimiento. 2. ed. México: Fondo de Cultura Económica, 1951.

DURANT, Will. História da Civilização Ocidental. 20 vol. 2.ed, São Paulo: Companhia Editora Nacional, 1957.

EAKIN, Paul John. Fictions in autobiography: studies in the art of self-invention. Princeton: Princeton University Press, 1985.

EINSTEIN, A. INFELD. L. A Evolução da Física. Trad. Giasone Rebuá. Rio de Janeiro: Guanabara Koogan. S.A, 1988. Orinalmente publicado em 1938.

EDWARDS, Catharine. Self-scrutiny and Self-Transformation in Seneca's Letters. Greece \& Rome, vol. 44, No. 1. p. 23-38. abr., 1997.

EVANS, G.R. Agostinho: sobre o mal. São Paulo: Paulus, 1995.

FOUCAULT, M.. L’écriture de soi. Corps Écrit, vol.5. p.3-23, 1983.

. História da Sexualidade I. A vontade de saber. 5.ed. Rio de Janeiro: Graal, 1988.

FRANCASTEL, P. Histoire de la peinture française. vol.1. Paris: Elsevier, 1955.

ORTEGA Y GASSET, José. Que é filosofia?. Rio de Janeiro: Livro Ibero-americano, 1971.

Obras completas. Tomo II. Madri: Revista de Occidente, 1963.

GALIMBERTO, Humberto. Gli equivoci dell'anima. Milano: Feltrinelli, 2003.

GALlAGHER, S; ZAHAWI, D. A mente fenomenológica. Milano: Raffaelo Cortina Editore, 2009.

GIARDINA, A. et al. O homem romano. Lisboa: Editorial presença, 1992. 
GILSON, Étienne. Introdução ao estudo de Santo Agostinho. São Paulo: Paulus, 2006.

GUENON, R. Os Símbolos da Ciência Sagrada. São Paulo: Pensamentos, 1993. A Grande Tríade. São Paulo: Pensamentos, 1990;

GUSDORF, Georges. La découverte de soi. Paris: Presses universitaires de France, 1948.

Conditions and limits of autobiography. 1956. In: J. OLNEY, Autobiography:

Essays theoretical and critical. Princeton, NJ: Princeton University Press, 1980.

. Les sciences humaines et la pensee occidentale. 15 vol. Paris: Payot, 1985.

. Les écritures du moi: lignes de vie 1. Paris: Édition Odile Jacob, 1991a.

Auto-bio-graphie: lignes de vie 2. Paris: Édition Odile Jacob, 1991 b.

HUSSERL, Edmund. Idéias para uma Fenomenologia Pura e para uma Filosofia

Fenomenológica. Trad. Márcio Suzuki. Prefácio de C.A. Moura. SP: Ideias e Letras, 2006.

Idee per una fenomenologia pura e per una filosofía fenomenologica. Libro secondo: Ricerche sopra la costituzione. Milano: Mondadori, 2008a.

La Crisi delle Scieze Europee e la fenomenología trascenentale. Tradução de Enrico Filippini.Milano: Saggiatore, 2009.

Lições para uma fenomenologia da consciência interna do tempo; trad., introd. e notas Pedro M. S. Alves. Lisboa : Impr. Nac.-Casa da Moeda, 1994.

Meditações Cartesianas. Trad. Frank de Oliveira. São Paulo: Madras, 2001.

Conferências de Paris. Tradução de Antonio Fidalgo e Artur Morão.

Lisboa: Ed. 70, 1992.

. Fenomenologia e teoria della conoscenza. Ed. Com testo original e tradução para o italiano de Paolo Volonté. Milano: Bompiani, 2004.

Filosofia Prima: teoria della reduzine fenomenologica. Tradução Andrea Staiti. Soveria Mannelli(Catanzaro): Rubbettino, 2007. Originalmente publicado em 1924.

Introduzione all'etica: Lezione del semestre estivo 1920/1924. Trad. Nicola Zippe. Roma: Laterza, 2009.

Richerche logiche. Volume 2. Milano: Saggiatore, 2005.

FRANKL, V. Mans's search for meaning: the classic tribute to hope from the holocaust. London: Rider, 2004.

LEJEUNE, P. Le pacte autobiographique. 2. ed. Paris: Seuil, 1984.

Je est un autre. L'autobiographie, de la littérature aux medias. Paris: Seuil, 1980. 
MASSIMI, M. Historiography of Psychology: old and new paths. Cadernos Argentinos de História da Psicologia, v. 2, n. 1, p. 95-107, 1996.

. Conhecimento e dinamismo psíquico em dois sermões no Brasil colonial. Psicologia: Teoria e Pesquisa, Brasília, v. 21, n. 1, p. 061-067, 2005.

Considerações Gerais Sobre Historia e Psicologia. TEMAS EM PSICOLOGIA, v. 3, p. 19-26, 1994.

MATHEWS, Gareth B, Santo Agostinho: A vida e as ideias de um filósofo adiante de seu tempo. Rio de Janeiro: Zahar, 2007.

MAUSS, M. A category of human mind : the notion of person, the notion of "self". In: . Sociology and Psychology: Essays. London: Routledge \& Kegan Paul, 1979, p.57-94.

MIRAUX, J. P. L’autobiographie: Écriture de soi et sincérité. Paris: Nathan, 1996.

MISCH, Georg. A history of autobiography in Antiquity, 2 vol. Traduzido do alemão para o inglês em colaboração com o autor por E. W. Dickes. Londres: Routledge \& Kegan Paul LTD, 1950.

MONTAIGNE, M. Essais. 3 vol. Paris: Gallimard, 1965.

. Ensaios I, II, III. Traduzido por Sérgio Millet. São Paulo: Abril Cultural, 1972.

Ensaios I, II, III. Traduzido por Rosemary Costhek Abílio. São Paulo: Martins Fontes, 2000.

MORRIS, Colin. The discovery of the individual 1050-1200. New York: Harper. 1972.

MUELLER, Fernand-Lucien. História da Psicologia: Da Antiguidade aos dias de hoje. São Paulo: Companhia Editora Nacional, 1978.

OLNEY, James. Metaphors of the self: the meaning of autobiography. Princeton, Princeton University Press, 1972

OLIVEIRA, C.I.; Pires, A.C.; MACEDO, R.G. \& SIQUEIRA, A.T.E. A antropologia paulino-agostiniana: a criação do paradigma da ambivalência do eu-moral e a interpretação do binômio saúde-doença. $\quad$ Memorandum, $\quad$ 09-32. http://www.fafich.ufmg.br/ memorandum/a10/oliveira01.pdf. Acesso: 10/11/2006.

OLIVEIRA, R. M. C. Diários públicos, mundos privados: Diário íntimo como gênero discursivo e suas transformações na contemporaneidade. Universidade Federal da Bahia, 2006. Dissertação de Mestrado em Comunicação e Cultura Contemporâneas.

PACHECO, P. R. A; MASSIMI, M. O conhecimento de si nas Litterae Indipetae. Cadernos de Psicologia e Educação. Paideia, Ribeirão Preto, 2005. 
PENNA, A. G. História das Idéias Psicológicas. Rio de Janeiro: Zahar, 1980.

PERES, S.P; MASSIMI, M. Representações do conceito de inconsciente na obra de Machado de Assis. Memorandum, 2004, V.7, p.128-137. Disponível em http://www.fafich.ufmg.br/ memorandum/artigos07/peresmassimi01.htm. Retirado em 09 /02/2006.

PLATÃO. The Dialogs of Plato. Trad. Benjamin Jowett. Chigago: Ecyclopedia Britannica, 1952.

; O banquete. Tradução Albertino Pineiro. Bauru: EDIPRO, 1952.

PLOTINUS. The six enneads. Trad. Stephen MacKenna e B.S.Page. Chigago: Ecyclopedia Britannica, 1952.

REALE, A; ANTISERI. Historia da Filosofia, 3 vols. São Paulo: Paulus, 2003.

REALE; G. SINI, C. Agostino e la Scrittura dell'interiorità; San Paulo: Torino, 2006.

REUCHLIN, Maurice. Historia da psicologia. 2. ed, São Paulo: Difusão Européia do Livro, 1965.

RILEY, Patrick. Character and conversion in autobiography: Augustine, Montaigne, Descartes, Rousseau and Sartre. Charlottesville: University of Virginia Press, 2004.

ROSENFELD, A. O pensamento psicológico. São Paulo: Perspectiva, 1933.

ROUSSEAU, J. J. As confissões. São Paulo: Ediouro, 1994.

SACKS, O. O homem que confundiu sua mulher com um chapéu. São Paulo: Companhia das Letras, 1997.

SACKS, O. Um antropólogo em Marte. São Paulo: Companhia das Letras, 1995.

SÊNECA, L.A. Cartas a Lucílio. Traduzido do original latino por J.A. S. Campos, 2.ed, Lisboa: Fundação Calouste Gulbenkian, 2004.

. Sobre a tranqüilidade da alma. Tradução de J. R. Seabra, 2001.

Obras completas, 2a ed. Madrid: Aguilar, 1949.

Ad Lucilium epistulae morales, Edição bilíngue: latim-inglês. Cambridge,

Mass.; London: Harvard University Press: W. Heinemann, 1970.

SILVA, Paulo José de Carvalho da. O ideal da consolação e a paixão pela morte. Revista Latino-americana de Psicopatologia Fundamental, X, 1, março de 2006.

STEIN, E. Essere finito e essere eterno. Roma: Città nuova 1998 .

Psicologia e Scienze dello Spirito. Traduzione Ana Maria Pezzella. Roma: Città nuova, 1999.

La struttura della persona umana. Roma: Città nuova, 2000. 
. Introduzione alla filosofia. Traduzione Ana Maria Pezzella. Roma: Città nuova, 2001.

TAYLOR; Sources of the Self: The Making of the Modern Identity. Cambridge: United Kingdom, 2006.

TEIXEIRA, Leônia Cavalcante. Escrita autobiográfica e construção subjetiva. Psicologia USP. São Paulo, v. 14, n. 1, 2003. Disponível em: $<$ http://www.scielo.br/scielo.php?script=sci_arttext\&pid=S0103$65642003000100004 \& \operatorname{lng}=\mathrm{en} \& n \mathrm{~mm}=\mathrm{iso}>$. Acesso em: 22 Set 2006.

TRINCIA. S. Husserl, Freud e il problema dell'inconscio. Brescia: Morcelliana, 2008.

VANZAGO, L. Breve Storia dell'anima. Bologna: Mulino, 2009.

WEINTRAUB, K. J. The value of the individual: self and circumstance in autobiography. Chicago: University Press, 1978.

ZUBIRI, X. Sobre el sentimento y la volición. Madrid: Alianza editorial, 1993. 


\section{APÊNDICES}

\section{Apêndice A - Dificuldades terminológicos na tradução de Agostinho}

A compreensão da obra de Agostinho existe grande cuidado terminológico, sem o qual os próprios conceitos dificilmente podem ser apreendidos. Não apenas dezesseis séculos nos separam do autor, mas há uma barreira da própria língua original, o latim. Muitos dos termos latinos são traduzidos por termos que carregam uma grande dose de preconceitos implícitos à mentalidade moderna.

A primeira distinção a se fazer a fim de evitar confusões é a distinção entre alma (anima) de mente (mens). Para Agostinho, a alma é comum tanto aos homens quanto nos animais. Contudo, o homem possui a razão e inteligência. A razão está na alma humana, mais particularmente no estrato superior da alma, a mente. Portanto, tanto a mente quanto a razão e a inteligência são exclusivas dos homens.

Observamos logo atrás o que Agostinho entende por mente, essa realidade indubitável, essa presença que todos têm de si para si, dada por reflexão. Lógico que sendo a mente a parte superior da alma, tudo aquilo que é próprio da mente é próprio da alma humana. Portanto, se a mente é capaz de conhecer a si mesma, isso significa que, em alguma medida, a alma também é capaz de conhecer a si mesma e que o homem é, em alguma medida, capaz de conhecer a si mesmo. (Se considerássemos que o homem é parte do universo, deveríamos dizer que o universo, em certa medida é capaz de conhecer parte de si mesmo). Por outro lado, isso não significa que a mente, por ser capaz de conhecer determinados aspectos definidores si mesma, isto é, por conhecer sua substância, se conheça por completo em todos os seus atributos.

Mas é possível questionar-se: Agostinho não exclui da mente tudo aquilo que ela não tem certeza de não ser? Ou exclui da substância da mente tudo aquilo que ela não tem certeza de não ser, de modo que os demais atributos, sujeitos ao engano, possam entrar na mente como acidentes e propriedades, esta última definida como consequências da substância?

Agostinho, de fato, exclui da substância da mente tudo aquilo que ela não tem certeza de ser. No entanto, não exclui a possibilidade de que a mente possua atributos acidentais e propriedades. De fato, se definirmos o homem como animal racional, resultaria daí que o atributo "capaz de aprender gramática", é decorrência de sua substância, ao passo que ser negro ou não é acidente desta substância. Poderíamos considerar quer os atributos acidentais diferenciariam uma mente de outra? É o caso, Agostinho afirma que o poder da memória, da inteligência e da vontade varia de homem para homem. E poderíamos considerar que a capacidade de aprender gramática é uma propriedade da mente. 
Uma outra questão pode ser levantada, aquele que conhece a substância da mente, sabe que ela não átomos, fogo ou ar, ou fogo. Mas seriam possíveis acidentes da sua substância? A resposta é negativa. Pois se a substância da mente revela-se incorporal, ela não pode ter como acidente nenhuma qualidade corporal. Querer dar acidentes corporais a uma substância incorporal é como tentar pendurar roupas num cabide de ar.

A mente não tem extensão. Ora, mas se a mente está no corpo, seus limites não coincidem com o corpo? Embora a mente não tenha extensão, ela pode ter sensações do corpo, ela pode voltar sua atenção para partes do corpo, e ela que controla os movimentos voluntários do corpo, mas isso não significa que ela esteja difundida no corpo, como a água na esponja. Se o corpo possui partes, a mente também deveria possuir partes e ser dividia espacialmente, o que não é o caso, pois ela está sempre inteira. Não há como dividir uma pura presença, de modo que ela se tornaria meia presença, teria meias vontades.

A tradução corrente do termo animus é espírito, tanto na tradução italiana por nós consultadas quanto na portuguesa. Tudo isso pode gerar problemas. Seria melhor usar o termo animus como animus. Já vimos que Agostinho, na Trindade, tanto o animus quanto a mens são dotados de razão, aliás, o próprio homem é definido como uma substância racional, dotado de animus e corpo. Os animais não possuem animus nem mens, mas possuem anima. Mas o fato de mens ou animus estarem ligados à racionalidade não significa que sejam equivalentes. Se a mens é um estrato essencial do animus, resulta que o animus também o é. Ora, de fato, esse é o uso empregado por Agostinho. Contudo, tudo aquilo que afeta o animus, também afeta a mens, embora não a defina em sua substância. A mens não se define por suas afecções, pela sua passividade, mas por sua atividade, como princípio ativo de uma atividade espiritual, sujeito responsável, e não como puro efeito dos afetos.

Pelas razões mecionadas acima, raramente Agostinho irá dizer que a mente está triste; nestes casos preferiá dizer que o animus está triste. Isto é, a alma humana está triste como um todo, como nesta passagem: "Affectiones quoque animi mei eadem memoria continet non eo modo, quo eas habet ipse animus, cum patitur eas, sed alio multum diverso, sicut sese habet vis memoriae". (Conf., X, 14, 21). E em outros momentos usa pertubationes animi. (Conf., X, 14, 21). Mas nunca affectiones mentis ou pertubationes mentis, a não ser quando estas afecções forem afecções emocionais, mas de um outro nível, por exemplo, a apreensão do horror metafisico da transitoriedade dos seres. 
Nas Confissões, Agostinho afirma mesmo que Cristo possuía um corpo, uma alma e uma mente humana mutáveis ${ }^{303}$. Condena Alípio porque este cria erroneamente que os católicos pensavam que Cristo era apenas um Deus revestido de carne, sem alma e sem mente. Interessante notar aí que Agostinho diz que Cristo teve uma alma e uma mente e não animus, termo o qual ele parece usar unicamente para indicar o espírito humano.

A fim de evitar confusões, usaremos traduziremos animus por "alma humana" outras por "espírito" pressupondo no termo alma humana, por definição, a presença da mente. Em outros momentos, usaremos o próprio termo animus. Para o termo anima empregaremos o termo "alma", ou em outros momentos, o próprio termo latino, quando a situação exigir. E mens será traduzido mente.

Observando as traduções, algumas vezes o termo mens vem traduzido como pensamento, que é o uso corrente que faz Gilson (2007). Em algumas traduções o termo mens vem traduzido "inteligência", outras vezes por "espírito", outras ainda por "mens". Cada uma das traduções tem seus problemas. Isso porque o termo mente tal como compreendida pela atualmente não corresponde perfeitamente com ao sentido de mens, tal como empregado por Agostinho. Por outro lado, o uso do termo "pensamento" para traduzir mens é problemático, pois se assim o fizermos, com que termos traduziríamos o verbo cogitare seus correlatos, como cogitatio, cogito? Isso resultaria na mente do leitor uma confusão entre mens de cogito e, como consequência, graves equívocos: pois o próprio Agostinho distingue explicitamente um conceito do outro. E essa distinção é crucial para se compreender a diferença entre a mente conhecer a si mesma e ela pensar a si mesma, o que iremos examinar. Por ora, basta observar a passagem: "Nec sane cum sola cogitatione mens oblectatur inlicitis (...)";.A mente nesta passagem é o agente; pensamento (cogitatio) é uma ação da alma. A mens está implicada, como veremos nos atos de pensar, imaginar, recordar, entender (intelligere), e até mesmo deleitar-se com o ilícito. Deleitar-se com o ilícito não é uma "afecção sentimental" ou corporal, é algo que se coloca no plano da racionalidade e do orgulho, é um deleite espiritual, embora demoníaco, no qual o homem quer algo apenas pelo fato de não lhe ser permitido. É uma vontade diabólica de colocar-se contra tudo o que há de limite, mesmo quando esta lei é divina. O homem, ao comer a maça, exerce sua liberdade, comendo o fruto pró́bo apenas

\footnotetext{
303، tantum cognoveram ex his, quae de illo scripta traderentur, quia manducavit et bibit, dormivit, ambulavit, exhilaratus est, contristatus est, sermocinatus est, non haesisse carnem illam verbo tuo nisi cum anima et mente humana. novit hoc omnis, qui novit incommutabililatem verbi tui, quam ego iam noveram, quantum poteram, nec omnino quicquam inde dubitabam. etenim nunc movere membra corporis per voluntatem, nunc non movere; nunc aliquo affectu affici, nunc non affici; nunc proferre per signa sapientes sententias, nunc esse in silentio: propria sunt mutabilitatis animae et mentis." (Conf. VII, 19, 25, p.308).
} 
porque era proibido. E exercendo-a, se rebaixa, conhece o bem e o mal. Lúcifer, do mesmo modo, desobedece a Deus, colocando sua vontade acima da vontade divina, o que só poderia resultar na queda.

Mas o que caracteriza a mente é que ela, além de ela ser o sujeito das ações, tem a possiblidade de fazer a si mesma objeto dessas ações, como observamos na passagem, cogitat vivere se, et meminisse, et intellegere, et velle se. A alma pode pensar no fato que ela mesma vive, que ela entende a si mesma e quer a si mesma.

\section{Apêndice B - Aristóteles e a questão do Nous}

Aristóteles aponta principalmente em De anima que o nous (usualmente traduzido como intelecto), é a parte superior da psique, distinto da psique vegetativa e sensitiva. Trata-se do estrato superior da psique, responsável pelo pensamento teórico e conceitual; o nous pensa as formas sem as matérias. Aristóteles distingue, no homem, o nous passivo e o nous ativo. Afirma que este último, por si só, por pensar-se em si, subsiste separado e, portanto, é eterno. Há uma passagem na Metafísica em que Aristóteles identifica o Nous com o "motor imóvel". Essa identificação foi alvo de debates entre seus comentadores, bem como o que Aristóteles quer dizer com o nous ativo que existe separadamente.

O motor imóvel trata-se de um conceito chave para explicar o movimento. Todo movimento só é movimento devido a algo que faz mover. Se algo tem movimento é porque outro algo o move, afinal, o movimento não pode vir do nada. Contudo, se todo movimento é movido por algo, e esse algo por outro algo, e assim por diante, a série não teria fim. Para que tenha fim é preciso uma substância que dê início à série. Algo que faça mover e que permaneça ao mesmo tempo imóvel. E mais, se o movimento é eterno, este princípio, que é imóvel e que faz mover, deve ser eterno. Daí que, para Aristóteles, o motor imóvel é ato puro, do contrário, haveria potencialidade; se tivesse potencialidade, também ele poderia mover-se, pois toda passagem da potência para o ato é movimento. Portanto, se tivesse potencialidade, significaria que ele poderia se mover, o que é absurdo, pois é imóvel. Como não se movimenta, não pode ser movimentado e não pode se movimentar, logo é ato puro. Mas a matéria é potência; o ato, a forma. A matéria são possibilidades formais, é o que dá potencialidade à forma, mas o ato puro não pode ser distinto do que é, pois isso exigiria mudança, o que implica transformação e movimento. Logo o motor imóvel não pode ter 
matéria, pois se tivesse matéria, teria potência. E, neste sentido, está relacionado ao nous humano, que está separado da matéria. Isso porque toda matéria pode assumir uma forma.

Por isso, Deus é ato puro, sem matéria. Trata-se de uma forma que permanece idêntica a si sem se transformar, mas que, não obstante, faz mover o mundo, movendo os corpos celestes da mais alta esfera. Move estes corpos celestes não por empurrão, mas por atração. Portanto, o ato puro é imaterial. Mas, na metafísica, há uma estranha passagem, extremante sugestiva e que servirá de base para a interpretação de Plotino: "O Nous divino é o que há de mais excelente, pensa a si mesmo e o seu pensamento é pensamento do pensamento" (Met. XII, 9, 1074b, 34; ARISTÓTELES, 2009, p.577). E dado que a atividade do pensamento é o que há de mais excelente, a vida divina é a mais perfeita de todas. $\mathrm{O}$ intelecto humano é capaz de ser, pela forma, qualquer um dos objetos possíveis à percepção e ao intelecto. Acrescente a isso uma passagem no De anima:

Agora, resumindo o que foi dito a respeito da alma, digamos novamente que a alma de certo modo é todos os seres; pois os seres são ou perceptíveis ou inteligíveis, e a ciência de certo modo é os objetos cognoscíveis, e a percepção sensível, os perceptíveis; mas é preciso investigar de que modo isso se dá. (De anima. 431b20; ARISTÓTELES, 2006, p. 121)

Tudo o que o homem pode conhecer só pode conhecer porque já o conhece em potência. Mas por outro lado, essa potência é limitada pelas formas atuais. Todas as formas que existem atualizadas na matéria poderiam, em potência, ser formas atualmente no intelecto. Por isso todo ser material é inteligível em potência.

E, ao se referir ao intelecto do homem, Aristóteles afirma: "E ele próprio é inteligível tal como os objetos inteligíveis, pois no tocante ao que é sem matéria, o que pensa é o mesmo que o pensado. E, de fato, a ciência teórica e o assim cognoscível são o mesmo" (De anima. 430b28; 2006, p.116).

\section{Apêndice C - Distinção entre psicologia descritiva e fenomenologia}

A epoché fenomenológica limitou um campo de investigação, o ego cogito: o eu e suas vivências. Trata-se do mesmo domínio de investigação do psicólogo. No entanto, o psicólogo, por se mover na atitude natural, compreenderá esse mesmo domínio, “a vida psíquica", de uma maneira diferente do fenomenólogo, pois o primeiro entenderá a vida psíquica como a de um homem real no mundo, o segundo estudará a "vida psíquica" transcendentalmente reduzida. O foco de sua investigação será como essa vida de consciência constituiu 
intuitivamente os sentidos de mundo real, psique real, homem real etc. Portanto, embora tanto o psicólogo quanto o fenomenólogo tratem do mesmo objeto, a direção das pesquisas, como já afirmamos, são extremamente diversas. O primeiro estudará o que se passa na "cabeça de um homem", o segundo estudará o ser primeiro, o sujeito transcendental, a relação egocogito-cogitatum. O mundo, o homem, qualquer outro objeto possível são reduzidos transcendentalmente a cogitatum, a um correlato desse cogito. Já os "estados psíquicos" não serão apercebidos como estados psíquicos reais. Pois isso não é dado em evidência absoluta. Apenas para facilitar, consideremos que, do mesmo modo como não posso ter certeza absoluta que este computador é real, eu também não posso ter certeza absoluta que minha percepção é uma "percepção real". Para que minha percepção seja real, minha psique deve ser real. Percebo uma dor no estômago. Não tenho certeza absoluta de que meu estômago é real, afinal tudo poderia ser uma ilusão de estômago, uma dor fictícia. Se, "no fundo", eu sou uma borboleta sonhando que sou um homem percebendo uma dor no estômago, fica claro que minha percepção, neste caso, não é uma percepção real. Tenho certeza absoluta que percebo, mas não tenho certeza absoluta que minha percepção é real.

A fenomenologia não é a única ciência de essências. A geometria, a aritmética, a lógica também podem ser consideradas ciências de essências. Não se prova um teorema geométrico empiricamente. Ademais, os objetos geométricos não possuem sequer a pretensão de serem objetos reais. Seria um contrassenso dizer que um ponto, uma reta, um círculo, as formas do silogismo, ou mesmo os conceitos, são entidades reais, efetivas. São, isto sim, essências. Tradicionalmente, esses dois âmbitos foram distinguidos entre "ciências reais" e "ciências apriorísticas", ou "ciências ideais". Husserl, a fim de evitar confusão, procurará distinguir as ciências entre ciências de fatos e ciências de essências.

Distinguir com precisão estes dois âmbitos, como veremos, é fundamental. E Husserl insiste muito nesta distinção, pois muitos de seus críticos e outras pessoas que tomaram contato superficial com seu trabalho confundiram fenomenologia com psicologia descritiva. A confusão tem suas razões. O campo de investigação, tanto da psicologia descritiva quanto da fenomenologia transcendental coincidem. A fenomenologia transcendental tem como seu domínio a análise da essência da vida da consciência, os atos de consciência, ou ainda, as vivências intencionais e as demais vivências de consciência. Trata-se do mesmo objeto da psicologia descritiva. No entanto, existem diferenças. Isso devido à diferença de orientação do fenomenólogo com relação ao psicólogo. A psicologia tem como objeto a psique real de um indivíduo real, de modo que os "fenômenos psíquicos" são compreendidos como fenômenos reais de um homem real. A psicologia: 
(...) é uma ciência de realidades. Os "fenômenos" de que ela trata enquanto "fenomenologia" psicológica são eventos reais, que, como tais, se possuem existência efetiva, inserem-se, junto com os sujeitos reais a que pertencem, na omnitudo realitatis que é o mundo espaço temporal”. (HUSSERL, 2006, p.29)

Por outro lado, “(...) os fenômenos da fenomenologia transcendental serão caracterizados como irreais.” (2006, p.29). Logo após Husserl insiste:

Mostrar-se-á, além disso, que todos os vividos transcendentalmente purificados são irrealidades, estabelecidas fora de toda inserção no "mundo efetivo". A fenomenologia investiga justamente essas irrealidades, não como individualidades singulares, mas na "essência". (HUSSERL, 2006, p.29)

As essências, os conceitos, os juízos, os raciocínios lógicos, os números, equações são todos objetos ideais e não-reais. Do mesmo modo, como já observamos, aquele que pensa em dois momentos distintos sobre a segunda lei de Newton, pensa na mesma lei de Newton, embora em dois atos de pensar possam ser distinguidos.

Não é tarefa da "psicologia de fatos" estudar os fenômenos transcendentalmente reduzidos, isto é, sem fazer uso da tese de realidade. Esse estudo é o estudo da consciência pura. Por outro lado, os resultados obtidos com o estudo da consciência pura e das vivências transcendentalmente reduzidas servirão para a construção da psicologia eidética, cujo escopo é estudar a essência do sujeito psíquico real. E essa psicologia apriorística fornecerá a base, as leis de essência da região da psique, sobre a qual será(ão) construída(s) a(s) psicologia(s) de fatos.

A percepção de um gato será compreendida como a percepção real de um homem real que percebe um gato real. O fenomenólogo também poderá analisar a percepção de um gato, mas não fará uso da tese de existência real nem do gato, nem da percepção do gato. Por isso, na atitude transcendental, todos os fenômenos são tomados como irrealidades puras. $\mathrm{Na}$ atitude transcendental, iremos apenas analisar a percepção do eu puro do gato-fenômeno. E esse estudo é válido ainda que seja uma borboleta sonhando que sou um homem percebendo um gato.

É preciso insistir na distinção entre o ser para mim e o ser real. O ser para mim, do ponto de vista fenomenológico, é anterior ao "ser real". Pois se me posiciono perante o noema, de modo a considerá-lo como real, isso se dá por um série de motivos. A questão aqui é: o ser real exige um conjunto de condições maiores do que o ser para mim. Um objeto ilusório, por exemplo, é algo que "há" para mim, é um fenômeno que é para mim. Entretanto, não tem o sentido de ser real. Não tomo-o como sendo real porque o "ser real" exige que a 
coisa tenho o sentido, para mim, de existir "independentemente" de mim. Exige que a coisa ocupe um lugar no espaço, que esteja sujeita ao tempo, que se relacione e interaja realmente com outras coisas às quais têm para mim o sentido de serem reais e faça parte de um mundo que tenha o sentido de ser real.

O eidos, pela mesma razão, não é uma coisa real no mundo real, pois para que o fosse deveria ocupar um lugar no espaço, interagir e afetar objetos reais e ser temporal. Evidentemente isso não quer dizer que ele não exista para a consciência. Um espaço de ndimensões é algo que há, mas não é algo que seja real. Assim como um triângulo, uma reta são objetos que há, mas não são objetos reais.

\section{Apêndice D - A atenção e intencionalidade}

Toda discussão sobre atualidade e inatualidade parece sugerir que o objeto intencional de um ato intencional atual é um objeto ao qual nossa atenção está dirigida. Entretanto, a coisa não é assim tão simples, pois $\mathrm{O}$ 'estar-voltado-para', que distingue a atualidade, não coincide com a atenção.

De forma geral, é comum usar como sinônimos o "estar com o olho do espírito voltado para" e "atenção". Mas existem algumas distinções. A atenção apreensiva pode ser compreendida como "notar algo", "apreender". Nesse sentido, o atentar para algo não significa vivência intencional atual. Atentar é um modo particular de ato, é um modo no qual qualquer vivência intencional atual pode assumir. Se assume esse modo, ele não está apenas sob olhar do 'estar voltado para' espiritual, mas é objeto apreendido, notado. Segundo Husserl, não podemos estar dirigidos a uma coisa sem que seja no modo da apreensão. Em muitos casos, "voltar para", isto é, dirigir o olhar do espírito, é o mesmo que apreensão. De fato, a todo instante, a atenção está dirigida para algo. Mas a vivência intencional atual caracteriza-se pelo olhar do espírito estar dirigido para o correlato e não para a própria vivência. Mas nem todo vivido intencional que temos está no modo da atenção. Isso porque alguns objetos exigem uma dupla intencionalidade. É o caso do ato de valor e outros atos fundados.

No ato de valorar estamos direcionados para uma coisa, a direção para a coisa é um atentar para ela, um apreendê-la; mas também estamos "direcionados" para o valor - só que não no modo da apreensão. Não apenas a representação de coisa, também a valoração de coisa que a abrange possui modo da atualidade. (HUSSERL, 2006, p.91)

De fato, se estamos diante de um experimento de ótica, é possível que o fenômeno ótico seja objeto de um ato valorativo, pelo qual o sinto como belo. Contudo, embora esse ato esteja 
presente, embora seja um vivido intencional atual, ele não está no modo da atenção. Minha atenção está no experimento, mas não deixo de sentir a beleza, embora sem concentrar minha atenção nela. Mas se dissesse "este fenômeno é belo", isso nada mais seria do que um modo pelo qual o ato intencional valorativo colhe a beleza. A beleza do objeto é apreendida e notada. Do mesmo modo, eu posso estar querendo ver uma obra de arte. Só estou querendo vê-la em virtude de um ato valorativo que sente a obra um valor. Contudo, ao querer, o que tenho no olhar do espírito é a obra de arte e não o valor "ser belo" em virtude do qual minha vontade existe.

\section{Apêndice E - Fenomenologia e as filosofias da suspeita}

De todo modo, o que convém observar é que a fenomenologia não é uma "filosofia da suspeita”. Tais filosofias têm em comum o fato de que não partem das próprias vivências. Elas escondem, sempre, um "no fundo". Quero me casar, mas "no fundo" o que quero é reproduzir. Quero tornar-me padre, mas "no fundo" o quero apenas para compensar o ódio inconsciente ao meu próprio pai. Tenho paixão pela matemática, mas "no fundo" a paixão se origina de uma fixação anal. Angustio-me perante o problema da morte e da transitoriedade dos seres; no fundo, a morte simboliza a castração. Defendo o valor da "arte pela arte", a pura contemplação da beleza, mas, "no fundo", apenas estou defendendo uma ideologia burguesa. "No fundo", o espírito e a cultura são determinados pela economia, pela guerra de classes sociais.

Trata-se de uma redução da vida do espírito à vida psíquica. Não se trata de negá-la, mas observar que os influxos psíquicos têm limites. A ideia de que existe causas ocultas também está em Agostinho, mas de modo bastante diverso. Quando ele decide ir para a África para Roma, diz que, "no fundo", estava sob a mão invisível de Deus. O mesmo ocorre quando ele recebe os livros de Plotino.

O que importa notar é que a fenomenologia evitará conceitos de tipo. A ideia de Husserl é fundamentar-se e sustentar-se apenas naquilo que é dado e tal como é dado. O rigor é tão grande, como vimos, que nem mesmo a parte de trás do objeto pode ser considerada um dado absoluto; se vejo duas rodas de um carro, as duas outras rodas são apenas cointuídas. E mais, não se pode nem mesmo partir da evidência de que há um mundo, pois não é apodíctica. Mesmo a psique é transcendente à consciência, pois ela é, em última instância, real. Aliás, mesmos os vividos de consciência são apenas absolutos, caso não se considere que eles são reais. E todas as investigações sobre o real devem ser explicitadas, devem mostrar e deixar 
escancarado cada nexo de evidência. A ciência apriorística tem como horizonte não aceitar nada, absolutamente nada, que não seja dado em intuição originária. Toda e qualquer convicção deve ser remetida, em nexos de evidência, até as intuições originárias.

De acordo com o seu intuito, nada deve valer como realmente científico que não seja fundamentado mediante plena evidência, isto é, que não tenha de se legitimar pelo retorno às próprias coisas ou aos estados de coisas numa experiência e evidência originárias. Assim guiados, tomamos como princípio, enquanto filósofos principiantes, só julgar em evidência e examinar criticamente a própria evidência, e isto, claro está, também com evidência. (1992, p.4,)

Esse retorno aos próprios objetos e à evidência, entretanto, não tem como objetivo, como já frisamos, a confecção de ciências de fatos, mas ciências de essências, as quais, por seu turno, servem para apoiar possíveis ciências de fatos, criando, por assim dizer, uma matriz de possibilidades, mas também uma jurisdição, cujas violações devem ser expugnadas e refutadas tal como ocorrem modelos teóricos que sacrificam evidências. O erro, usualmente, provém dos princípios ocultos em tais modelos, em crenças irrefletidas, nas confusões entre os objetos e os domínios do ser, que resultam em reducionismos e contrabando de métodos de uma região para outra.

\section{Apêndice F - Atos motivantes e o "campo de possibilidade" dos atos motivados: O estímulo como motivo a-racional, porém não irracional.}

Vimos que, quando entre vividos motivantes e vividos motivados há uma nexo de evidência, os vividos motivados são racionais. Estes ocorrem em "consequência de", ou "devido a" tais e tais vividos motivantes. Mas existem nexos que não são dessa ordem, isto é, que não são nem plenamente evidentes, nem mesmo simplesmente evidentes.

Esses nexos entre um vivido e outros vividos podem ser a-racionais. Vejo em uma nuvem e percebo que ele tem a forma de um rinoceronte. Não é propriamente um ato racional. Mas perceber a forma tem seus motivos em "nexos associativos", em "nexos ocultos", em "nexos psíquicos" (alguém vê uma prancha de Rorschach e vê ali a "imagem da morte"). Essas espécies de nexos entre vividos são fundamentais para se compreender o fluxo espiritual, a corrente de cogitationes. Em outras palavras, o sujeito psíquico não é puramente racional. E não se entende o fluxo de vividos apelando apenas simplesmente aos nexos racionais, é preciso também encontrar os elos entre as vivências que não são plenamente no âmbito da racionalidade. Por outro lado, é incorreto desconsiderar os nexos racionais e considerar todos os nexos oriundos da psique, oriundos das pulsões. 
Antes de observarmos as motivações não-racionais, isto é, aquelas que não possuem um elo de evidência entre uma e outra, é preciso observar que o fluxo de consciência se dá de tal forma que um vivido "puxa" outro vivido, o qual "puxa" um outro vivido e assim por diante, formando uma cadeia desconexa com o mundo dado no instante atual. Isso porque o sujeito espiritual recebe influxos hiléticos. Podemos dizer que os estímulos "exteriores" também entram na vida do espírito. Para se compreender melhor a relação entre vividos intencionais, (os quais são sempre motivados) e o estímulo, apoiaremos na obra de Stein, Psicologia e Ciências Humanas. ${ }^{304}$ Em primeiro lugar, Edith Stein faz de fato, uma distinção entre motivação e motivo.

Se observamos a questão por este ponto de vista, parece dizer que, no curso da motivação, aquilo que motiva autenticamente não é a realização do ato de partida, mas sim o conteúdo de sentido de tal ato, para o qual mantemos, segundo o sentido comum, a denominação de "motivo": o relâmpago e não sua percepção do relâmpago, torna-se para mim o motivo da espera do trovão; motivo da alegria é a chegada da carta esperada, não o conhecimento de sua chegada. (STEIN, 1999, p.76)

Assim, podemos distinguir atos motivantes, atos motivados e motivo, este último referente ao conteúdo de sentido do ato. A distinção começa a se tornar importante se observarmos que "um estado de coisas pode entrar na conexão lógica as mais diversas e, portanto, permitir muitas conclusões" (1999, p.76). Dizendo de outro modo: um ato não necessariamente motiva apenas um único ato. Em determinados casos, o mais correto é dizer que um ato no qual se colhe um estado de coisas cria um campo possibilidade, e se o sujeito ultrapassa esse âmbito, se diz que agiu de modo irracional. "Do mesmo modo um valor pode delimitar possibilidades de tomadas de posição do sujeito que colhe o valor.” (1999, p.76). Um amigo fez um favor para mim, o que sinto como um valor. $\mathrm{O}$ ato pelo qual eu sento um valor pode me levar a realizar um certo número de atos. Este ato pode motivar o ato da vontade de agradecê-lo presenteando-o com um bom vinho, ou com um bom livro, posso, por outro lado, apenas sentir a gratidão e estar interiormente apto a ajudá-la caso note que ele precise. O vivido pelo qual eu colho o valor permite muitos atos possíveis, os quais estão conectados. Entretanto, é irracional, mesmo sentido o valor positivo do que ele fez para, xingá-lo e cortar relações com ele. Se eu o insulto, este insulto é motivado, mas não é

\footnotetext{
${ }^{304}$ Nesta obra, publicada por Stein pouco depois de ter sido assistente de Husserl, a própria autora, já no prefácio, afirma que não saberia dizer o que é dela, o que é de Husserl. No que concerne a esse tema em particular, "o estímulo", tudo o que a autora diz, em essência, está em Husserl, embora Stein tenha expos to de modo mais claro, tornando assim material apropriado à exposição. Aliás, não é nosso intuito expor o pensamento de Edith Stein, mas apenas esclarecer as questões referentes à motivação, que é um conceito chave, de suma importância, para se compreender, partindo dos princípios fenomenológicos, o sujeito psíquico.
} 
motivado racionalmente, mas apenas por motivos psíquicos, por exemplo, num surto de psicose.

Partindo dessas considerações, fica claro que podemos falar de motivos a-racionais, (porém não irracionais). Nestes casos, ocorre não nexo de evidência racional, mas um nexo de compreensibilidade, pois o ato motivado não é uma pura decorrência do ato motivante. $\mathrm{O}$ correto é dizer que o vivido permite determinados vividos.

O motivo vivido pode permitir um modo de comportamento, sem exigir nenhum em particular. Aqui também ocorre uma conexão de sentido entre motivo e motivado, o que equivale a dizer que um é compreensível a partir do outro; aqui, no entanto, não se apresenta uma relação de fundação racional" (STEIN, 1999, p.76)

Para ilustrar como isso é possível, Edith Stein usa o exemplo. Barulhos ocorrem na vizinhança, se minha atenção se foca nesses barulhos, o focar da minha atenção, que é um comportamento, tem como motivo os barulhos em minha vizinhança. Mas prestar atenção nestes barulhos não é racional, pois os barulhos não são motivos que exigem que minha atenção se foque neles. Um segundo exemplo que a autora usa é: o desejo de ir para um lugar onde eu creio que me sentirei bem não é nem racional, nem irracional. Nestes dois exemplos, as conexões entre os atos de consciência são compreensíveis, mas não se dão na forma do "tenho o ato A, portanto, tenho o ato B", tal como ocorre no silogismo, ou como ocorre no quero ir ao quarto, logo quero me levantar da cadeira. É simplesmente compreensível que eu preste atenção no barulho, como que eu queira ir para um lugar onde me sinta bem.

Nessa ordem de ideias, Edith Stein faz a seguinte distinção: entre motivos racionais e “estímulos", cujo nexo entre o estímulo a vivência não é racional, embora não seja irracional. Quando um vivido é fundado racionalmente em outro vivido, como ocorre no ato de concluir em virtude das premissas, ou no ato de eu crer porque eu percebi, no ato de querer algo em virtude de considerar o querido um valor, podemos falar de motivos racionais.

Husserl em Ideias 2, escreve que nem todo vivido é do tipo em consequência que:

Não é dito que na unidade do meu fluxo de vividos cada vivido seja necessário, necessariamente condicionado pelo vivido precedente e implícito naquele atual. Quando dizemos que cada vivido de um ato é motivado e está em um entrelaçamento motivacional, isto não implica que cada "dirigir-se a" seja tal "em consequência de". Quando percebo uma coisa, a tese implícita no perceber nem sempre é uma tese "em consequência de"; assim, quando no céu noturno vejo improvisamente brilhar um meteorito (...)" (HUSSERL, 2008, p.662, tradução nossa). 


\section{Apêndice G - A tentação}

Em alguns casos, a representação pode servir de estímulo a uma tendência de nível psíquico. Partamos do exemplo seguinte. Estou assistindo televisão e vejo um programa de viagem pelo mundo. Em virtude dessa representação, é despertado em mim o desejo de viajar. Tenho tempo livre e essa me parece uma boa opção. Por que não fazer uma viagem? Seria correto dizer que o desejo de fazer uma viagem, nesse caso, proveio de uma representação? $\mathrm{Na}$ verdade, não podemos dizer que proveio da representação, mas que o ato representativo, no caso um ato da percepção, despertou em mim a tendência, a inclinação, o desejo de viajar. Existe aqui uma conexão entre dois vividos. O vivido de percepção da viagem serviu de estímulo ao desejo de viajar. Mas não há um nexo evidente, um nexo racional, há um simples nexo compreensível. Não há uma relação de necessidade entre a entre a percepção da viagem e senti-la como um valor e o desejo de viajar. A conexão aqui não é uma conexão racional, nem irracional. Não há um nexo de exigência entre esses dois vividos, tal como as premissas exigem a conclusão.

O estímulo que desperta uma tendência é aquilo que poderíamos chamar de "tentação". Estou andando na rua, vejo uma carteira jogada no chão, abro a carteira, vejo que ela está com dinheiro, mas que tem o RG do dono - pode ser uma tentação para mim roubar o dinheiro. Essa tendência não nasceu em um estado vital. Nasceu a partir de uma representação, do objeto percebido. Mas se o objeto percebido não fosse um do objeto de valor, a representação, por si, não teria efeito algum. O objeto de valor é correlato de um ato de sentir o valor. $\mathrm{O}$ desejo que tenho de pegar o dinheiro não é uma decorrência necessária do perceber o dinheiro na carteira como objeto de valor. Talvez outra pessoa encontre a carteira e nem passe pela cabeça dela pegar o dinheiro (nesse caso, não há sequer a tentação). Entretanto, é compreensível que alguém que encontre uma carteira, queira pegar o dinheiro e não devolver ao dono. Neste caso, o ato de percepção atua como estímulo ou como tentação.

O estímulo e a tentação parecem aqui análogos à exigência sobre a qual se fundam os atos livres, como um apelo que reverbera em mim e que se torna eficaz apenas se o deixo entrar. A modalidade "despertar" de um vivido por meio de outro é o mesmo em ambos os casos, e se tomamos a motivação no sentido lato do termo, incluindo o despertar de um fazer espiritual privado de fundamento racional, ou o estímulo, parece justificado falar de motivação e de motivo também para a tendência. Ao contrário, se se aceita a motivação no sentido específico no qual, ao lado de uma determinada forma de despertar, se indica ao mesmo tempo também uma relação fundada racionalmente, de modo a se separar estímulo e motivo, não se deveria falar de motivo da tendência em todos os casos. (STEIN, 1999, p.101) 
Podemos, portanto, dizer que existem atos humanos cujos "motivos" (estímulo em sentido estrito) que não são nem racionais, nem totalmente originados na psique. De fato, se a vida intencional do sujeito é a vida espiritual, ocorre que o espírito, de modo amplo, não se resume à vontade e intelecto. Vontade e intelecto constitui para Husserl o espírito em sentido estrito. 